\title{
Operational costs induced by fluctuating wind power production in Germany and Scandinavia
}

\author{
Meibom, Peter; Weber, C.; Barth, R.; Brand, H.
}

Published in:

Energy solutions for sustainable development. Proceedings

Publication date:

2007

Document Version

Publisher's PDF, also known as Version of record

Link back to DTU Orbit

Citation (APA):

Meibom, P., Weber, C., Barth, R., \& Brand, H. (2007). Operational costs induced by fluctuating wind power production in Germany and Scandinavia. In L. Sønderberg Petersen, \& H. Larsen (Eds.), Energy solutions for sustainable development. Proceedings (pp. 196-205). Risø National Laboratory. Denmark. Forskningscenter Risoe. Risoe-R No. 1608(EN)

\section{General rights}

Copyright and moral rights for the publications made accessible in the public portal are retained by the authors and/or other copyright owners and it is a condition of accessing publications that users recognise and abide by the legal requirements associated with these rights.

- Users may download and print one copy of any publication from the public portal for the purpose of private study or research.

- You may not further distribute the material or use it for any profit-making activity or commercial gain

- You may freely distribute the URL identifying the publication in the public portal 


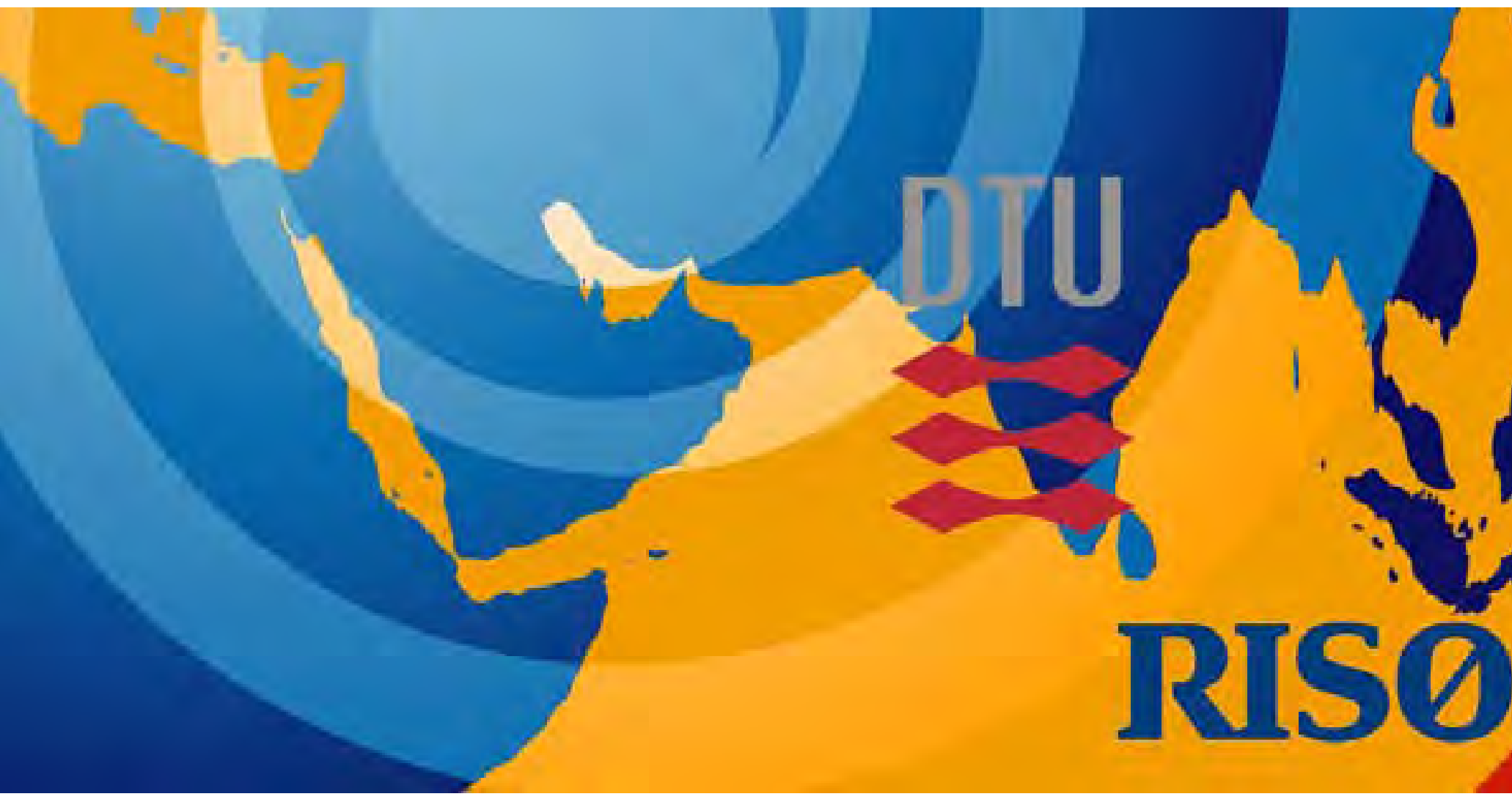

\section{Risø International Energy Conference 2007}

\section{Energy Solutions for Sustainable Development}

\section{Presentations}

\section{Session 1 - Future Global Development Options}

Energy Efficiency. Achieving more with less, Stefan Denig, Siemens AG

Energy Implications of Climate Mitigation Policies, Massimo Tavoni, FEEM

Promotion strategies for electricity from renewables in the EU-lessons learned, Reinhard Haas, Vienna University of Technology

\section{Session 2 - Scenarios and Policy Options}

Perspectives of the IDA Energy Year 2006 project, Per Nørgård, Risø National Laboratory, the Technical University of Denmark

Integrated European Energy RTD as part of the innovation chain to enhance renewable energy market breakthrough, Peter Lund, Helsinki University of Technology

Impacts of high energy prices on long-term energy-economic scenarios for Germany, Volker Krey, Dag Martinsen, Peter Markewitz, Research Centre Jülich, Institute of Energy Research - Systems Analysis and Technology, Evaluation (IEF-STE), Jülich, Germany 


\section{Session 3 - Clean Coal Technologies}

Polygeneration, Thomas Rostrup-Nielsen, HALDOR TOPSOE A/S

\section{Session 4 - Bioenergy}

Sustainable bioethanol production combining biorefinary principles and intercropping strategies, Mette Hedegaard Thomsen, Henrik Hauggaard-Nielsen, Anneli Petersson, Anne Belinda Thomsen, Erik Steen Jensen, Risø National Laboratory, the Technical University of Denmark

\section{Session 5 - Renewable Energy for the Transport Sector}

Co-ordination of Renewable Energy Support Schemes in the EU, Poul Erik Morthorst and Stine Grenaa Jensen, Risø National Laboratory, The Technical University of Denmark

Bioethanol. Second generation Bio-fuel - close to commercialization. Charles Nielsen, DONG Energy.

Long-term biofuels scenarios: preliminary results from REFUEL -A European Road Map for Biofuels, Henrik Duer, COWI A/S, Denmark

\section{Session 6 - Wind}

Upwind. A Wind Research Project under the 6th FrameworkProgramme, Peter Hjuler Jensen, Risø National Laboratory, the Technical University of Denmark

Wind Power Costs in Portugal, Carla Saleiro, Madalena Araújo, Paula Ferreira, Universidade do Minho

Economic and Financial Feasibility of Wind, Energy - Case Study of Philippines, Jyoti Prasad Painuly, UNEP Risø Centre, Risø National Laboratory, the Technical University of Denmark

\section{Session 7 - Solar and Wave Energy}

Wave Energy - challenges and possibilities, Per Resen Steenstrup, WaveStar Energy

\section{Session 8 - Systems with High Level of Renewable Energy}

Operational costs induced by fluctuating wind powerproduction in Germany and Scandinavia, Peter Meibom, Risø National Laboratory, Technical University of Denmark, Christoph Weber, University Duisburg-Essen, Rüdiger Barth \& Heike Brand, IER, University of Stuttgart

\section{Session 9 - End Use Technologies and Efficiency Improvements}

A cooling system for buildings using wind energy, Hamid Daiyan, Azad University-Semnan Branch, Iran

Energy Demand Patterns. The Effects Substitution and Productivity, Nico Bauer

Potsdam Institute for Climate Impact Research (PIK).

\section{Session 10 - Systems Aspects - Distributed Production}

STREAM: A Model for a Common Energy Future, Peter Markussen, DONG Energy

Vanadium redox-flow batteries -Installation at Risøfor characterisation measurements, Henrik Bindner, Risø National Laboratory, the Technical University of Denmark 
Centralised and decentralised control -a power system point of view, Oliver Gehrke and Stephanie Ropenus, Risø National Laboratory, the Technical University of Denmark, Philippe Venne (UQAR)

\section{Session 11 - Low Level $\mathrm{CO}_{2}$ Strategies for Developing Countries}

Assessing the Role of Energy in Development and Climate Policies in Large Developing Countries, Amit Garg and Kirsten Halsnæs, Risø National Laboratory, the Technical University of Denmark

Sustainable Transport Practices in Latin America, Jorge Rogat and Miriam Hinostroza, UNEP Risø Centre, Risø National Laboratory, the Technical University of Denmark

\section{Session 12 - Carbon Capture and Storage Contribution to Stabilization}

Environmental Analysis of Coal-based Power Production with Amine-based Carbon Capture, W.

Kuckshinrichs, J. Nazarko, A. Schreiber, P. Zapp, Institute of Energy Research, Systems Analysis and Technology Evaluation (IEF-STE), Fuel Cells (IEF3), Forschungszentrum Jülich GmbH

\section{Session 13 - Hydrogen Economy}

Solid Oxide Electrolysis for Fuel Production, Sune D. Ebbesen, Anne Hauch, Søren H. Jensen, and Mogens Mogensen, Risø National Laboratory, the Technical University of Denmark

\section{Session 14 - Fuel Cells}

Use of Alternative Fuels in Solid Oxide Fuel Cells, Anke Hagen, Risø National Laboratory

Fuel Cell - Shaft Power Packs, Frank Elefsen, Danish Technological Institute

\section{Session 15- R\&D Priorities}

Overview of U.S. DOE'sCoal RD\&D Programs, Scott M. Smouse, National Energy Technology Laboratory, Office of Fossil Energy, U.S. Department of Energy

The UK Energy Research Atlas: A Tool for Prioritising and Planning Energy R\&D, Jim Skea, Research Director, UKERC

European and global perspectives for CCS, Martine Uyterlinde, Heleen Groenenberg, Energy Research Centre of the Netherlands

Solar Energy, Status and Perspectives, Peter Ahm, Director, PA Energy A/S 


\section{Energy Efficiency Achieving more with less}

Risø International Energy Conference

Roskilde, 22 May 2007

Stefan Denig, Siemens AG 


\section{Challenges:}

\section{Climate change is a fact, threatening humans and biosphere}

\section{Climate change and impact}

\begin{tabular}{|l|l|l|}
\hline & $\begin{array}{l}\text { - Anthropogenic greenhouse gas emissions }{ }^{1)} \text { from } \\
\text { fossil fuel burning and land use shift the radiation } \\
\text { balance of the earth and cause warming }\end{array}$ \\
chimate & $\begin{array}{l}\text { Scientific consensus that doubling of } \mathrm{CO}_{2} \text { from pre- } \\
\text { industrial levels (280 ppm) by non-acting till } 2035 \\
\text { causes unacceptable global temperature increase } \\
\text { - Feedback amplifies warming }\end{array}$ & $\begin{array}{l}\text { Effect of greenhouse gases } \\
\text { Eangeat reflected } \\
\text { back to planet }\end{array}$ \\
\hline
\end{tabular}

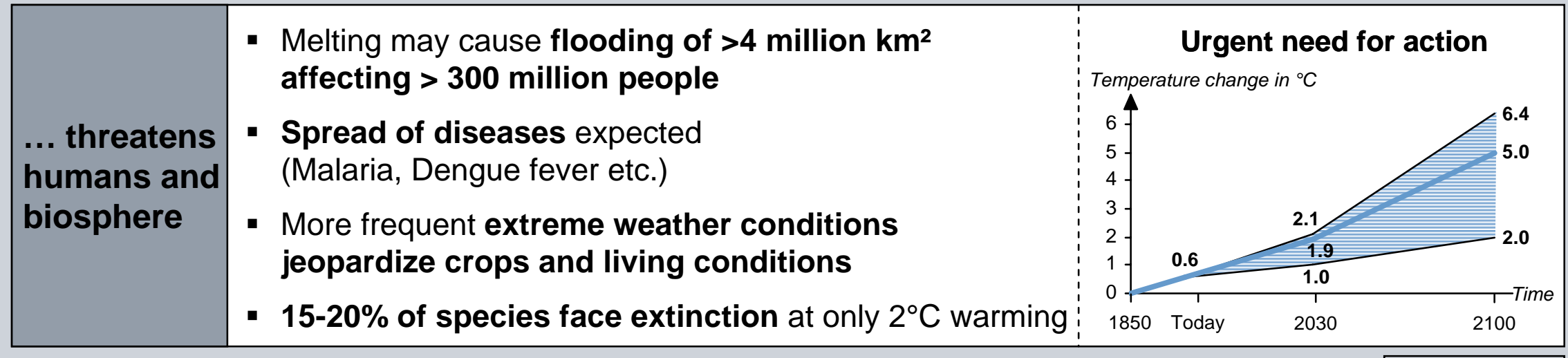

1) Carbon dioxide, methane, nitrous oxides, etc. 


\section{Challenges:}

\section{Business as usual will be more costly than action}

- Long-term cost of inaction (Business as usual) and action

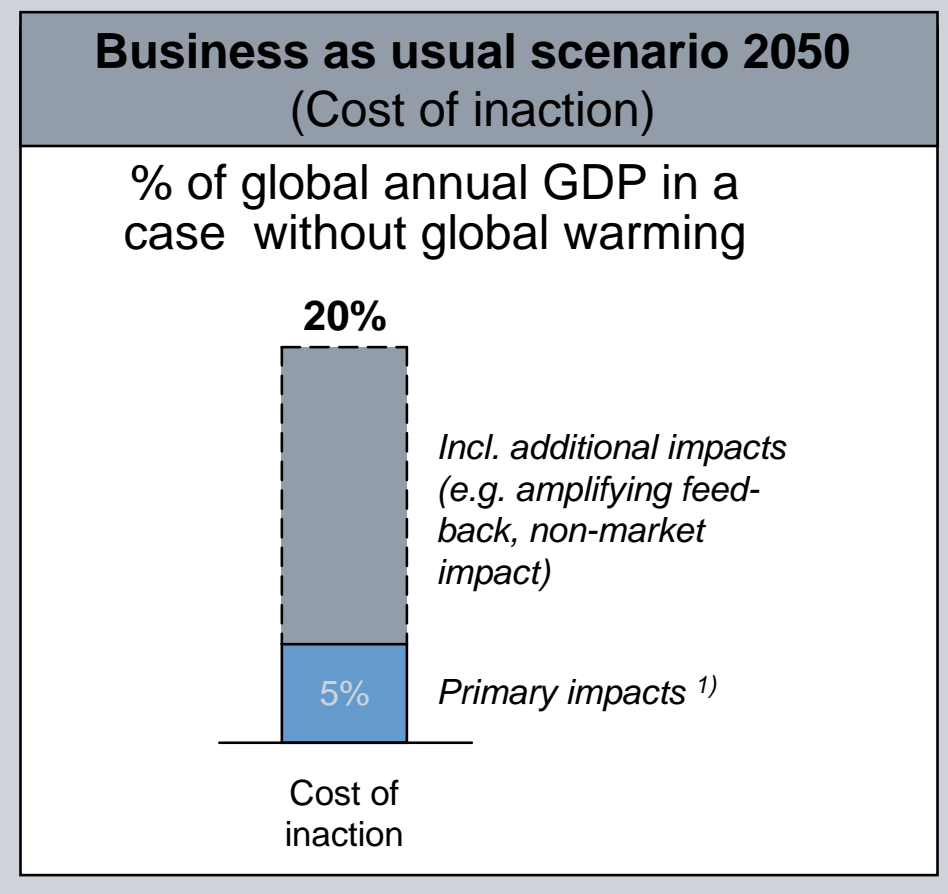

Climate change has serious impacts on growth and development

1) Assumes $5^{\circ} \mathrm{C}$ temperature increase by 2050

Source: Stern Review

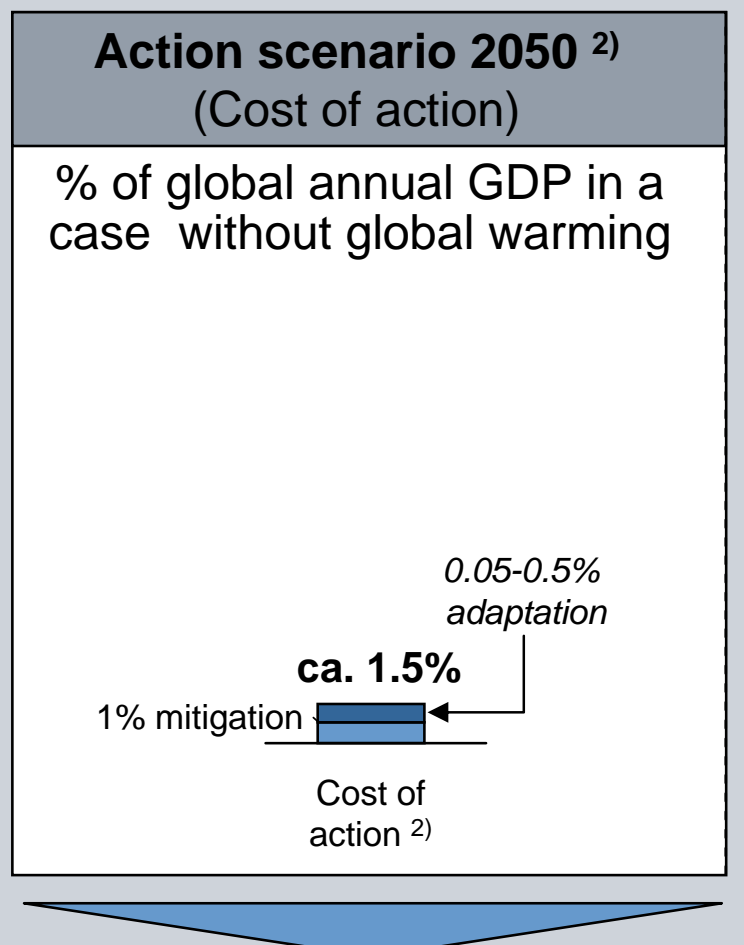

The costs of stabilizing the climate are significant but manageable

2) Keep GHG between 500 and $550 \mathrm{CO}_{2} \mathrm{e} \mathrm{ppm}$ 


\section{Challenges:}

\section{Highest $\mathrm{CO}_{2}$ emissions in North America and Asia}

Population size times average annual per capita emissions. The size of the circles indicates the product of these variables and therefore the region's total $\mathrm{CO}_{2}$ emissions in 2000 and 2020

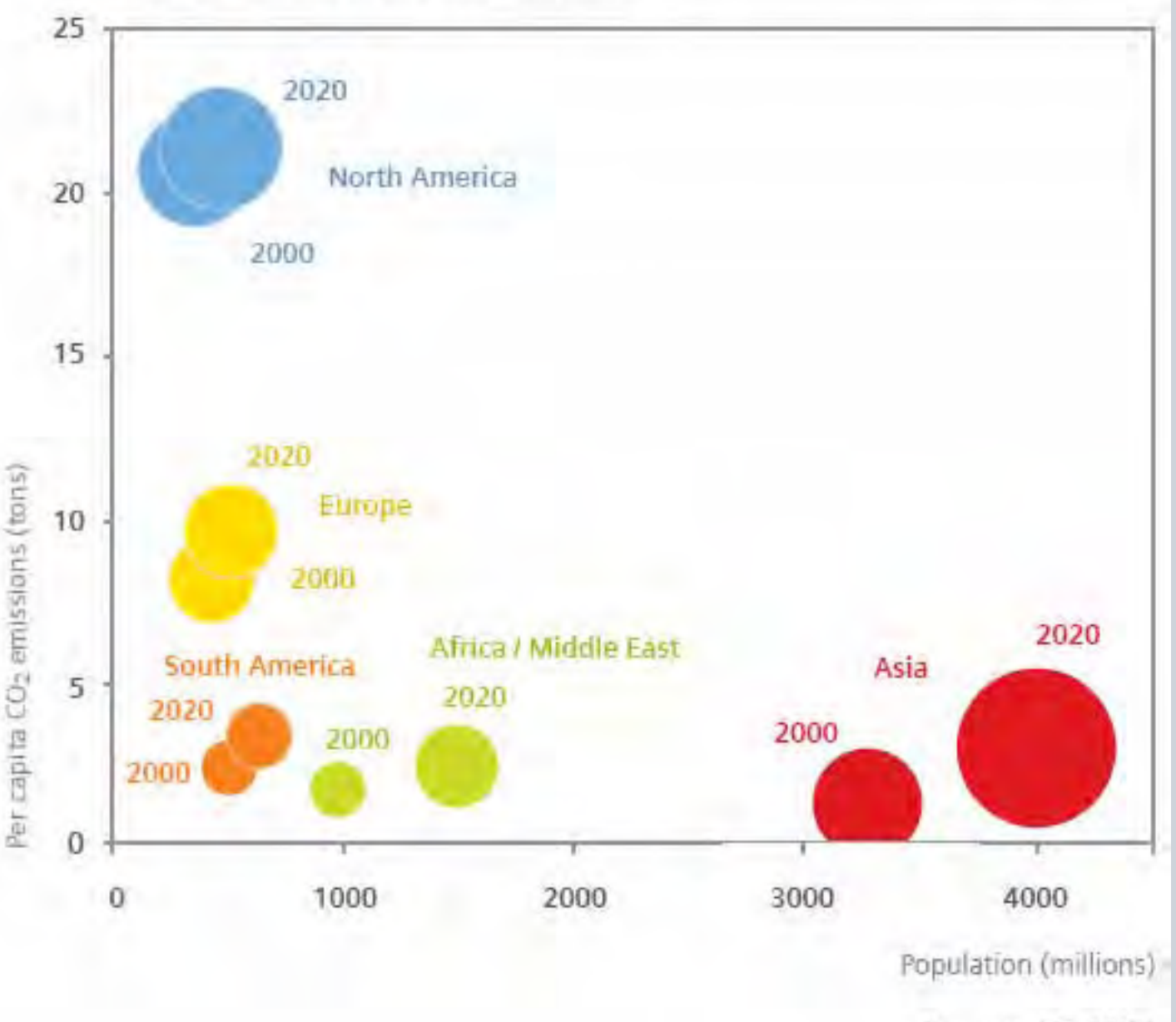

Source: EC 2003

\section{Development of $\mathrm{CO}_{2}$ emissions}

- GHG emissions - responsible for global warming - will increase

Level of GHG emissions will remain high in industrialized countries, but will increase particularly in emerging countries 


\section{Challenges:}

Rapidly increasing energy consumption, mainly in BRIC countries

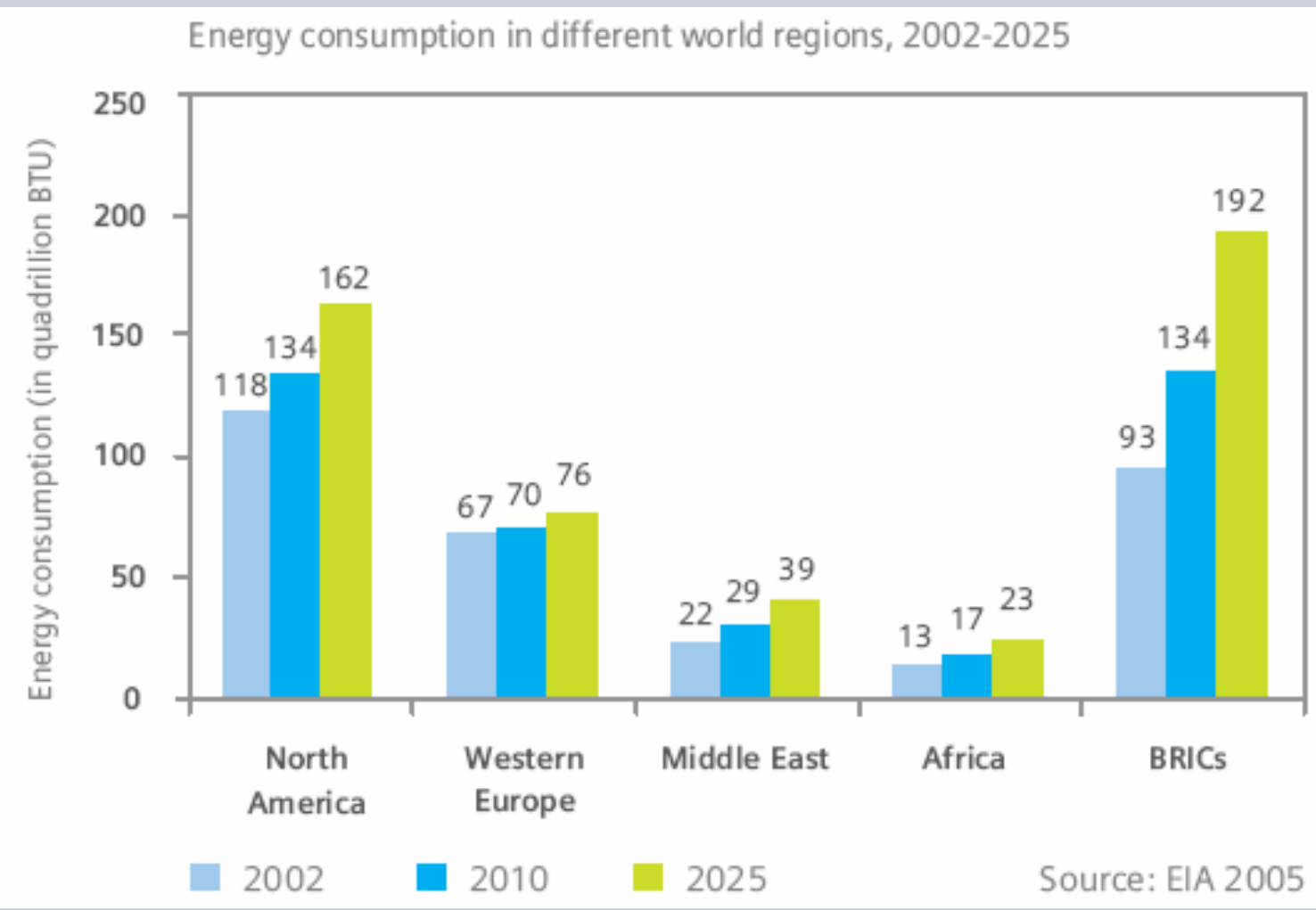

Most rapid growth expected in non-OECD countries

- Fastest growth evident in BRIC economies

- Growth driven by industrialization and rising per capita consumption, although per capita consumption remains at low level 


\section{Challenges:}

\section{Large growth of world final energy consumption}

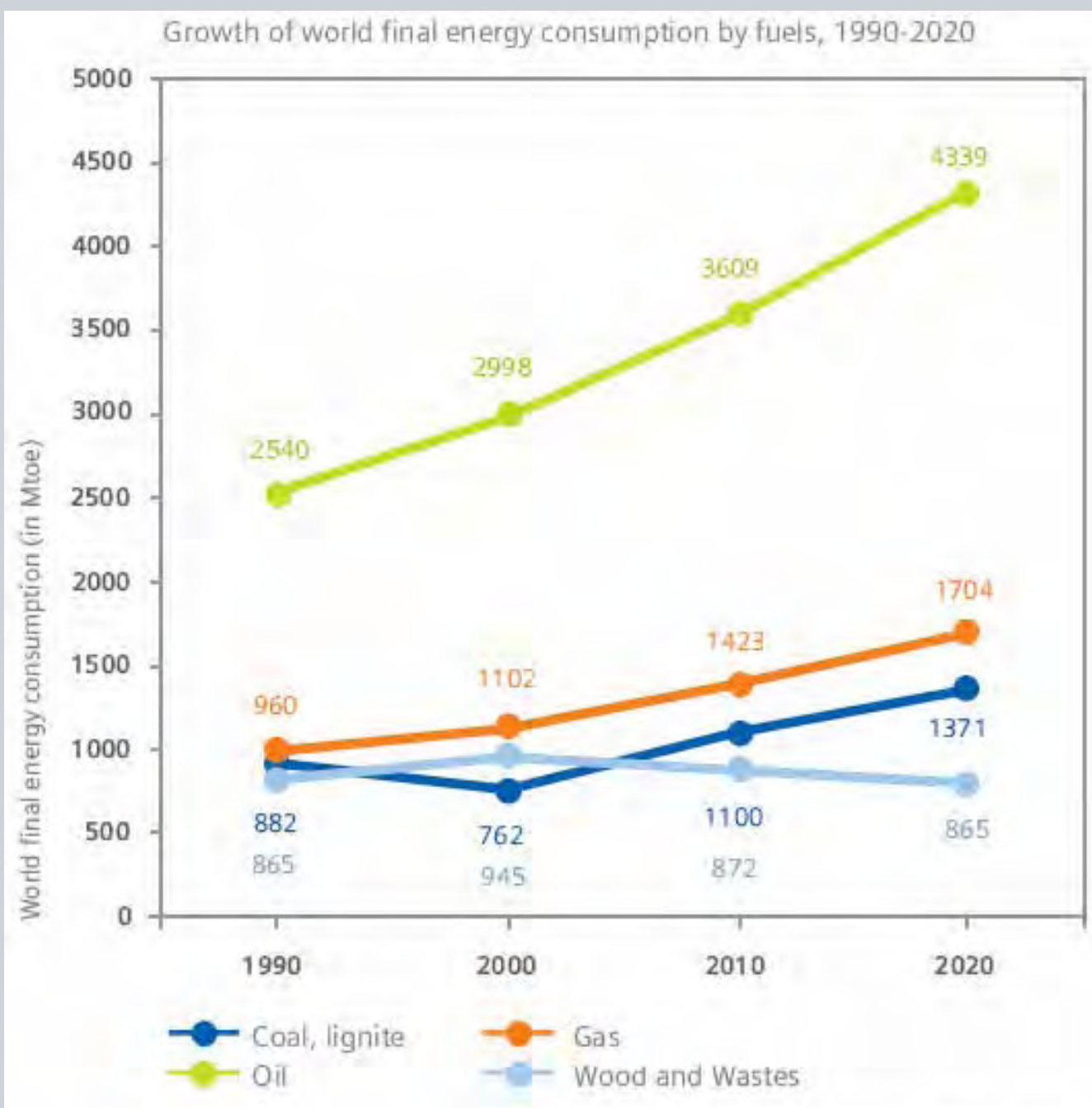

Growing consumption of natural resources

- Energy consumption is rising dramatically

- Fossil fuels to remain of vital importance

- Ongoing growth in the demand for oil, gas and coal 


\section{Challenges:}

Coal will last the longest

Statistical ranges of fossil and nuclear fuels

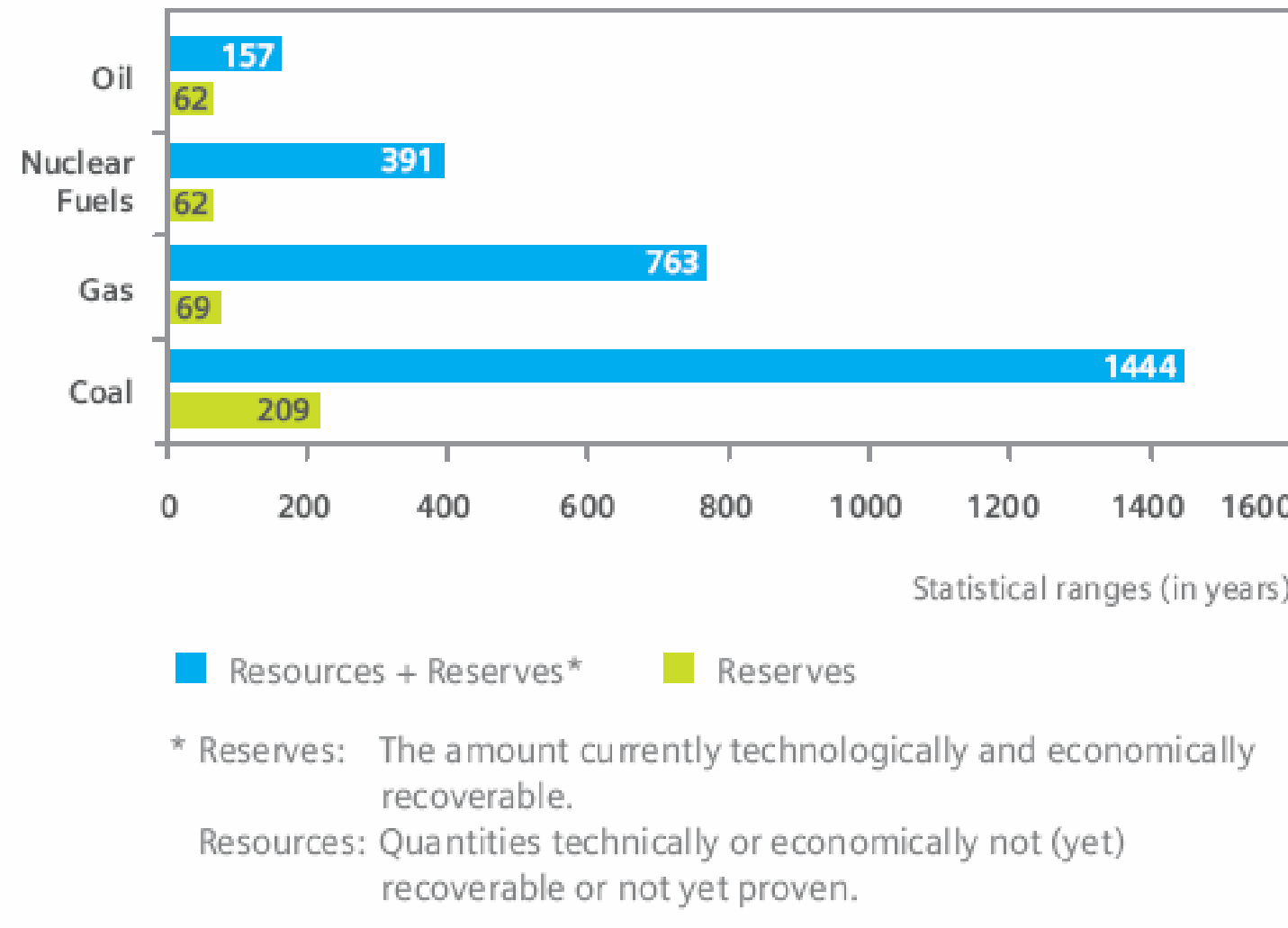

\section{Ensuring the supply of}

resources

- Improve production infrastructure in order to assure supply

- Manage political crisis

- Promote diversification in order to guarantee long-term supply

- Promote renewable energy use on individual level 


\section{Challenges:}

\section{Growing relevance of energy security}

\section{Political implications}

- Energy supply questions are entering the political agenda: Nationalization of energy industries (e.g. in Russia, Bolivia, Venezuela)

- China: Energy supply is vital for economic development (e.g. contracts with Iran to secure supply create dependencies and influence diplomatic behavior)

- Inter-regional trade of energy resources increasingly important (international attention will focus on maintaining the security of sea-lanes and pipelines)

\section{Managing political conflict}

- Challenge of fair resource supply needs to be addressed

- Conflicts have to be prevented

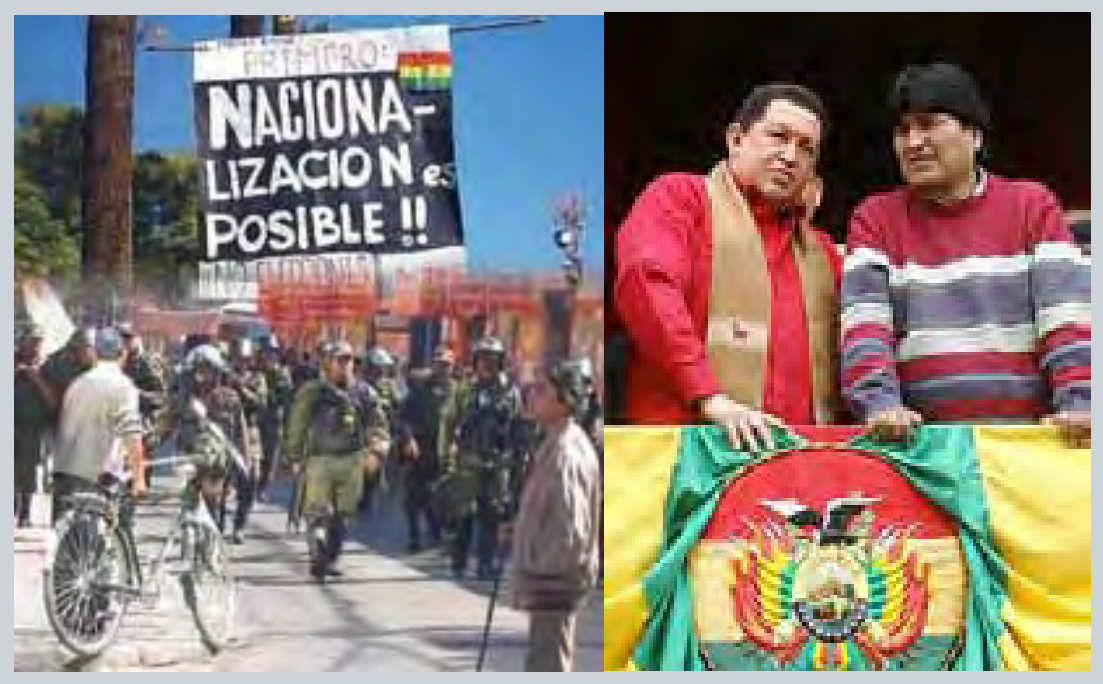




\section{Challenges:}

\section{Energy diversity will not change fundamentally in the next 10 years}

Growth of energy use and percentage shares of energy sources, 2002-2015

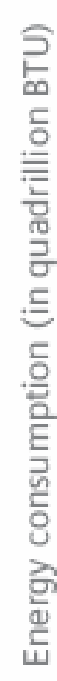

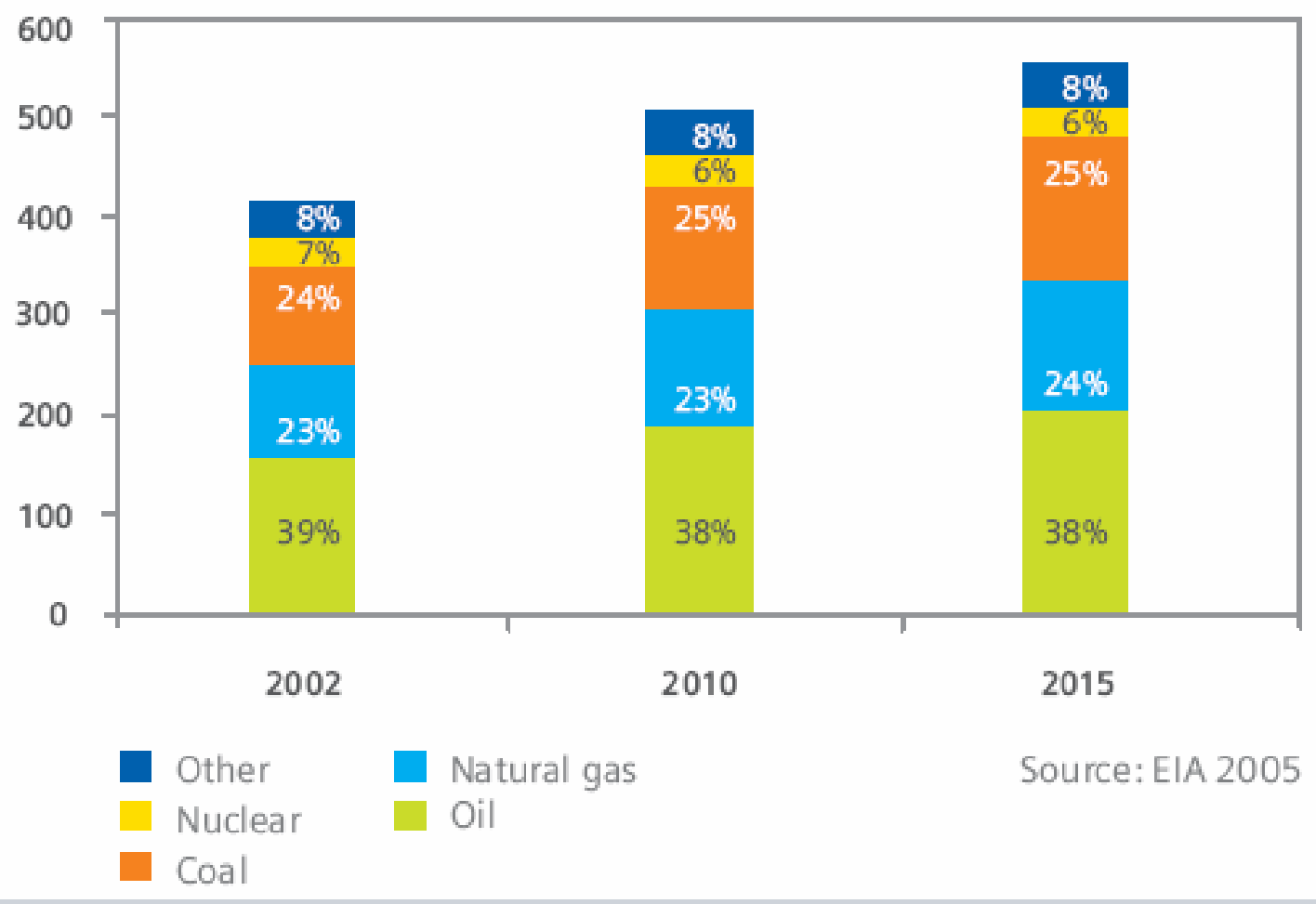

Increasing importance of energy diversity

- Energy diversity will have to be a more prominent issue on the political agenda

- Use of renewables to expand diversity of supply

- Development of other alternative energy sources 


\section{Solutions:}

Achieving more with less

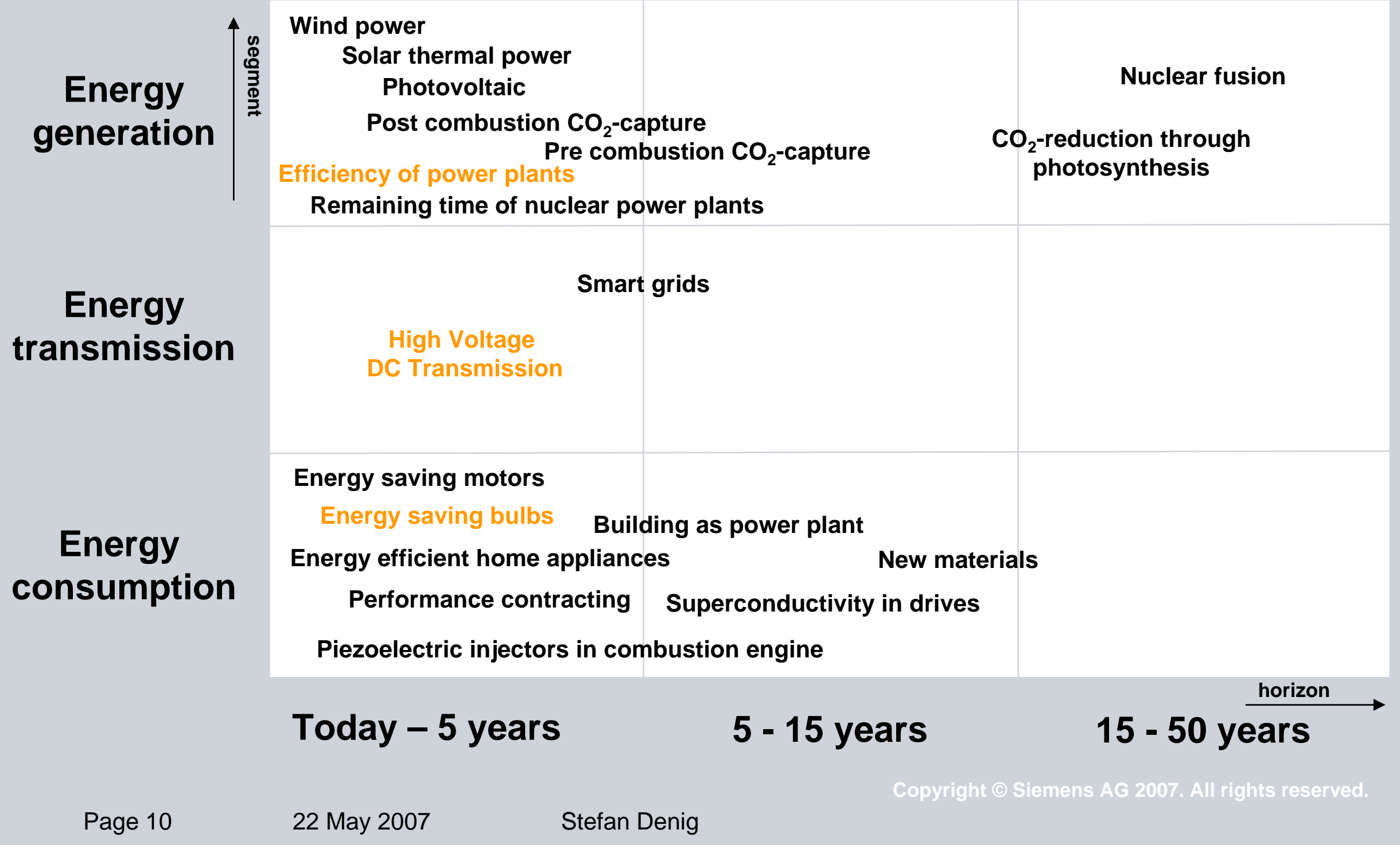




\section{Solutions:}

\section{Energy generation - Efficiency of up to $60 \%$ is possible}

\section{World's largest and most efficient gas turbine:}

- Can supply electricity to 620,000 three-person households or a city the size of Barcelona, Spain

- Combined-cycle power plant with this gas turbine will have an efficiency of over $60 \%$ - world record

- In comparison with a coal-fired power plant (average efficiency 38\%), it saves 2.8 million tons of $\mathrm{CO}_{2}$ per year - more than Siemens emits

\section{Shanghai - Efficient coal plant Waigaoqiao:}

- China's largest and most modern coal-fired power plant, two $900 \mathrm{MW}$ blocks installed, third in preparation

- Efficiency 42 percent (scheduled to rise to 45), highest of it's kind in China (average efficiency of black coal power plants in Germany: 37 percent)

- Sets also new standards in low-level nitrogen oxide and sulfur dioxide emissions 


\section{Solutions:}

\section{Energy transmission - HVDC enables use of remote sources}

\section{Low loss connection of remote power sources:}

- Low energy loss in long distance power transmission (e.g. coal and hydro power (e.g. China), offshore wind parks in Europe

- Opens up large renewable power potential worldwide

- Allows for decoupling of power generation and load centers

- Flexibility in power sourcing and trading

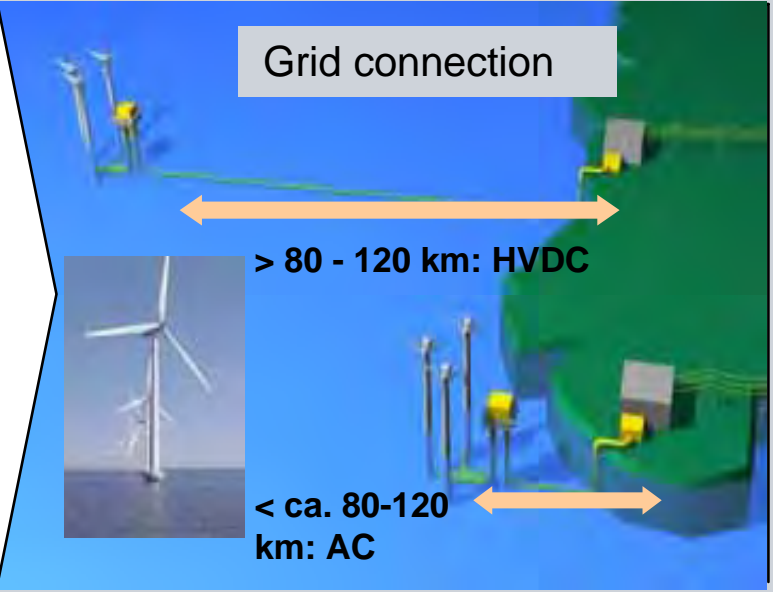




\section{Solutions:}

\section{Energy consumption - Huge potential for energy savings}

\section{New Siemens trains use $\mathbf{3 0} \%$ less energy than Oslo's current trains:}

- Less energy needed by feeding braking energy back into power grid and by using mostly aluminum for the lightweight body design

- Comprehensive disposal concept: $95 \%$ of each train can be utilized (85\% through recycling, 10\% through burning)

- Over their entire lifecycle the trains burden the environment with just 2.6 grams of $\mathrm{CO}_{2}$ per kilometer traveled and per ton of vehicle weight - a very low value for metros (2.0 grams for actual train operation, depending on energy mix)

\section{Energy saving bulbs use $\mathbf{8 0 \%}$ less electricity:}

- Lighting accounts for $19 \%$ of power demand worldwide

- Life of energy saving bulbs is up to 15 times longer than life of conventional bulbs; LED's life is up to 50 times longer

- Savings per energy saving bulb and LED: several hundred euros p.a. and 0.5 t of $\mathrm{CO}_{2}$

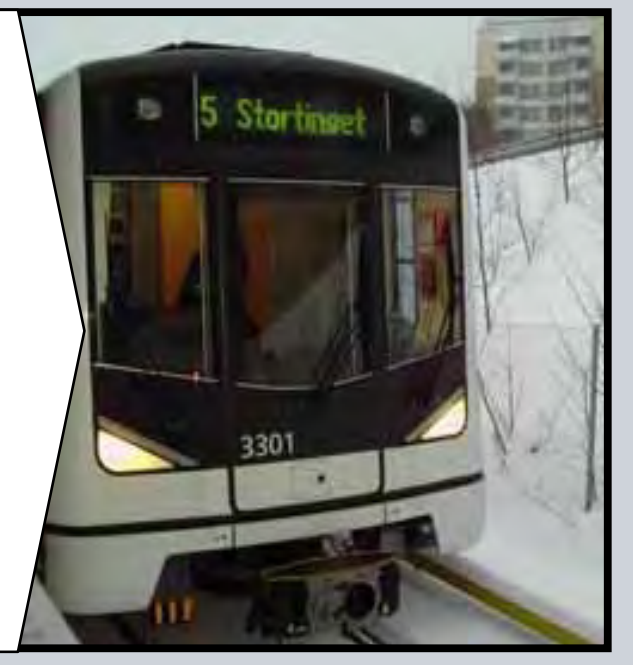$$
\text { . }
$$

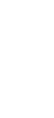




\section{Increasing awareness:}

Environment in top tier of megacities' infrastructure priorities

Need for Investment

Average \% of "Very High" Across All Cities (522 key decision makers in the 25 largest cities worldwide)

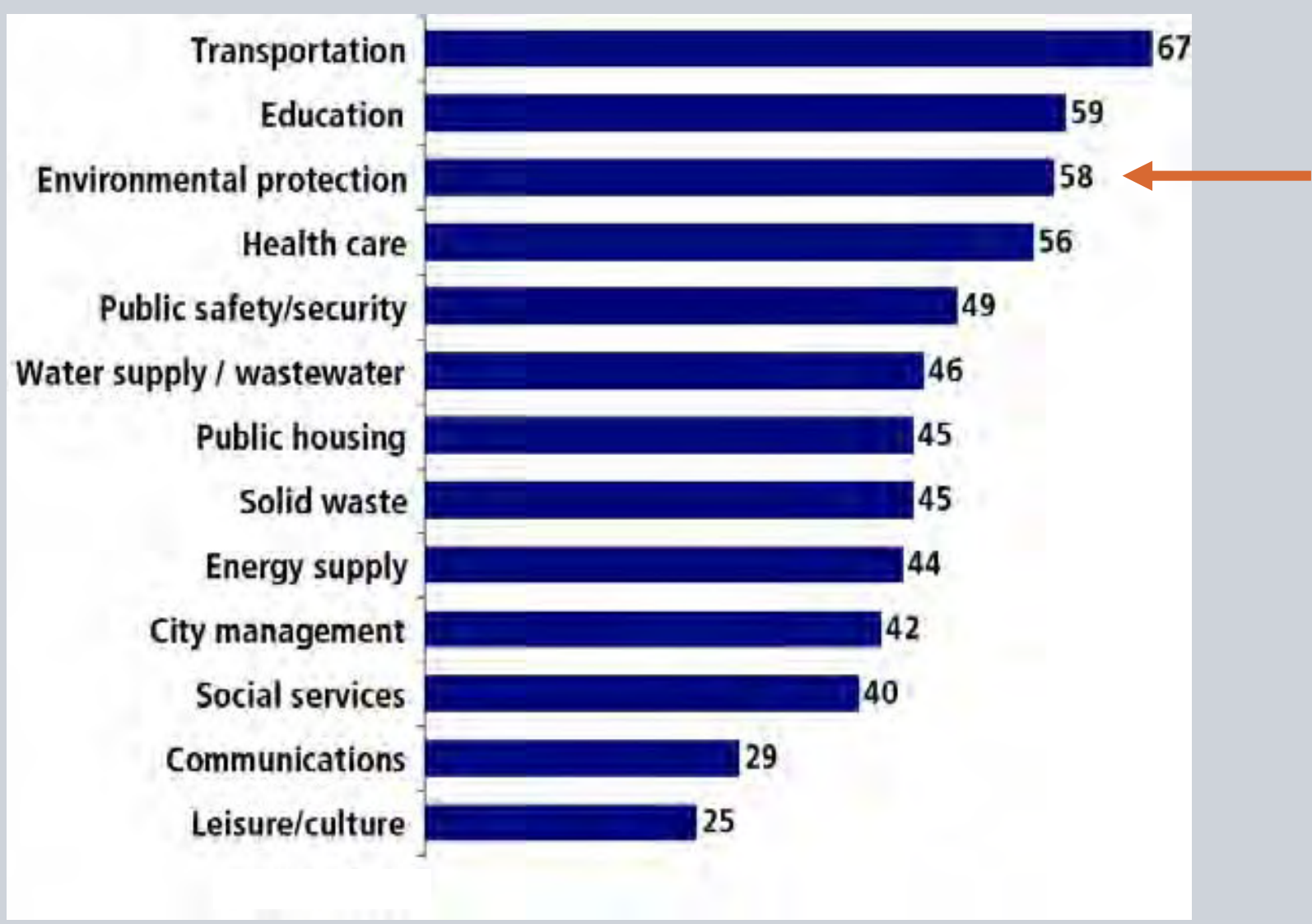

Source: Siemens Megacity Report 2007 


\section{Increasing awareness: Environment matters...}

Mass transit is the priority

Predicted by transport experts

\section{Individual motorized} transportation (29)

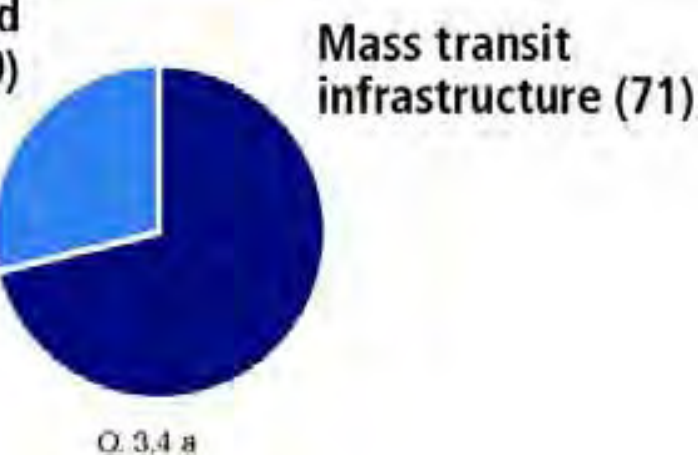

O. 3,4 a

Source: Siemens Megacity Report 2007
Strong role for renewables

Predicted by electricity experts

Fossil fuels (52)

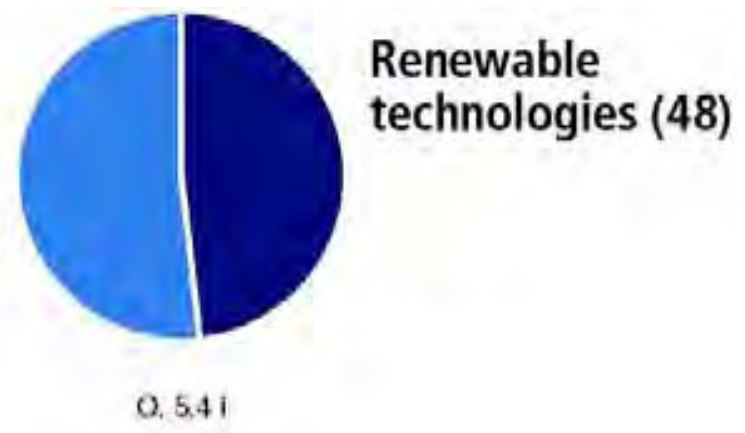




\section{Increasing awareness: \\ ... but may be sacrificed for growth}

Views of knowledgeable stakeholders

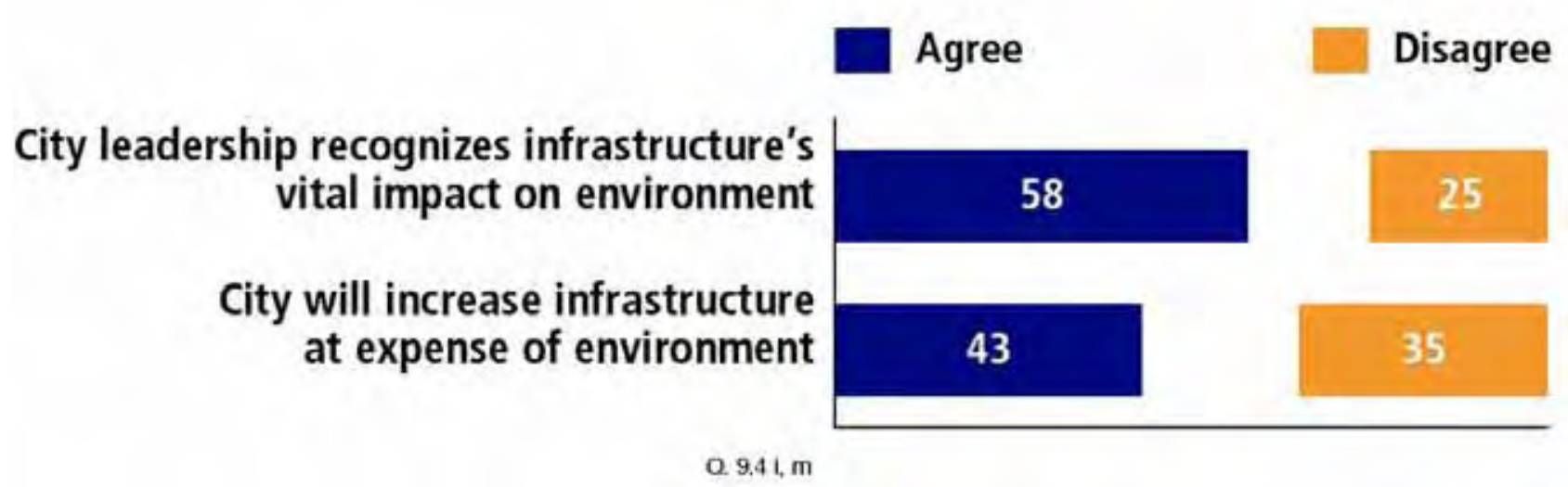

Source: Siemens Megacity Report 2007 
The efficiency champion: How to reduce megacities' energy consumption and $\mathrm{CO}_{2}$ emissions with technolog. innovations
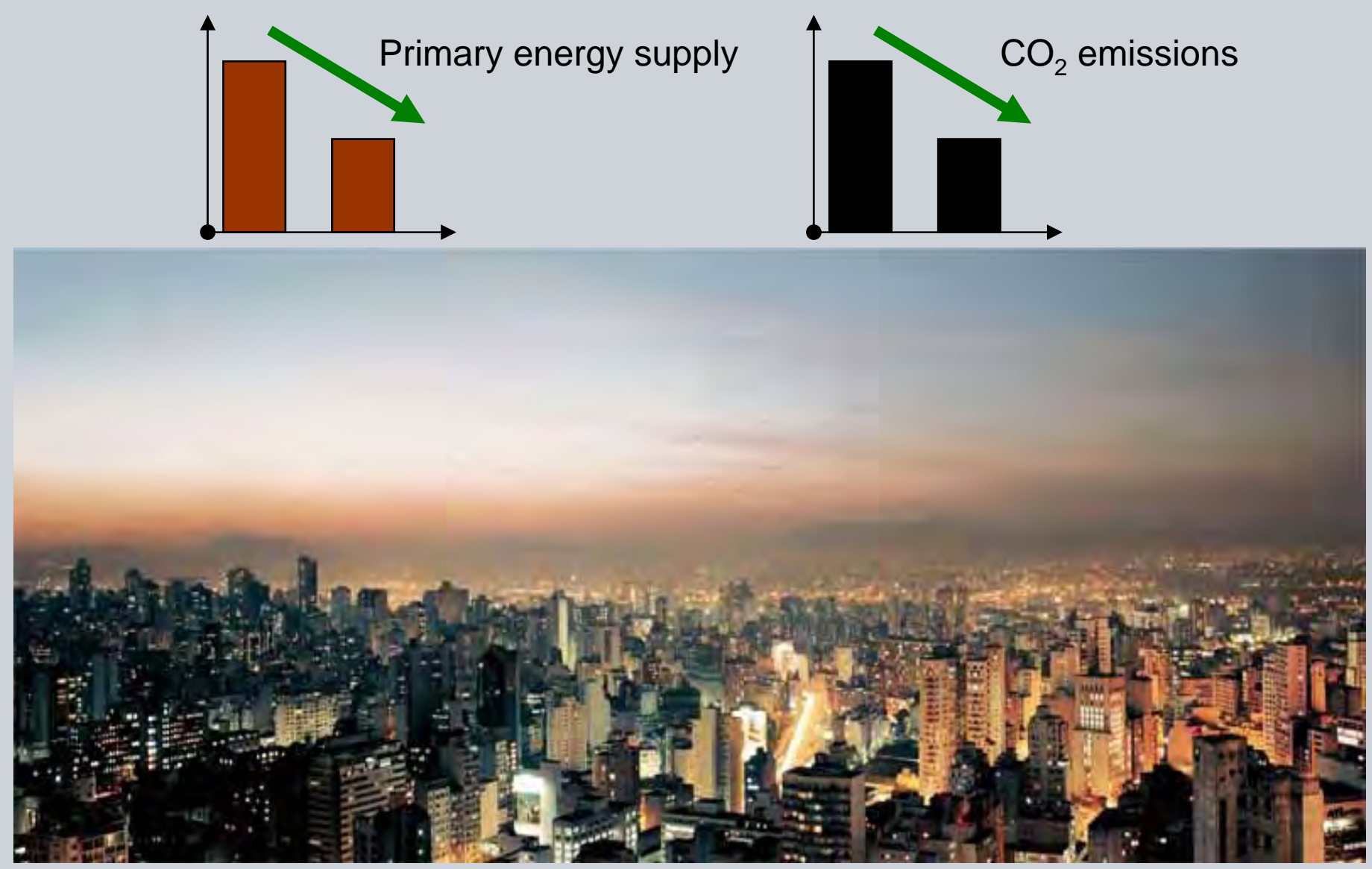
Energy-related $\mathrm{CO}_{2}$ emissions 106 million tons of $\mathrm{CO}_{2}$ per year

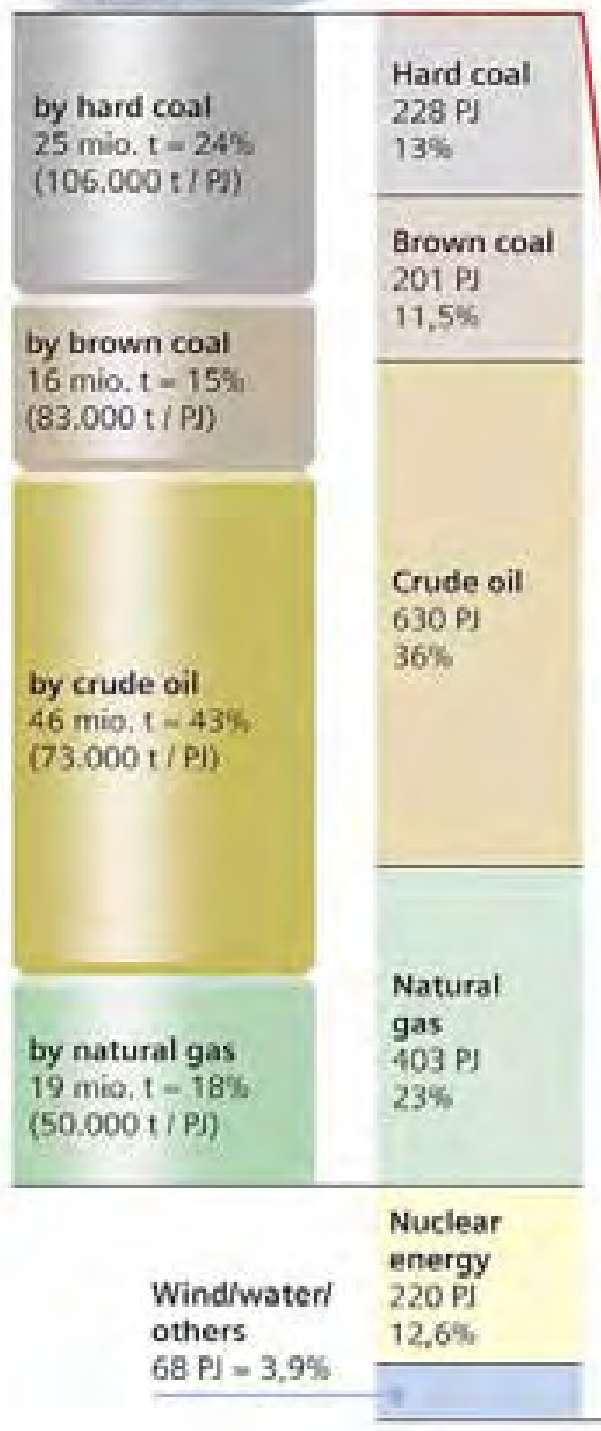

\section{Energy balance-sheet of a virtual German megacity - What are the levers to reduce energy consumption?}

Losses during energy

10 million inhabitants, energy data from 2004

generation and distribution

as well as consumption in

the energy supply chain:

$630 \mathrm{PJ}=36 \%$

Site energy consumption:

$1120 \mathrm{PJ}$ per year

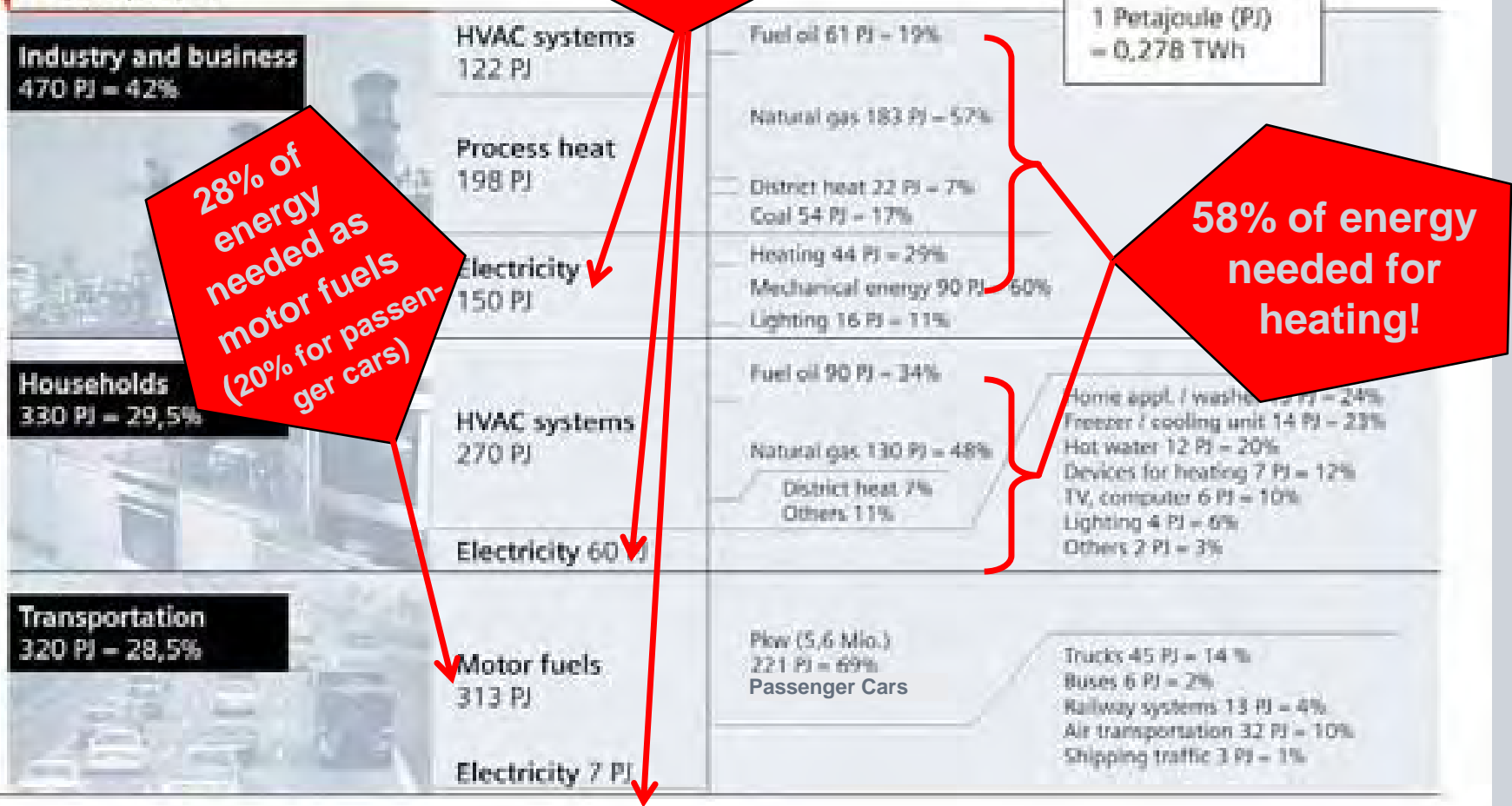

$20 \%$ of energy

needed as

electricity.

Equals $38 \%$ of

primary energy! 


\section{Possible scenario of tomorrow's megacity}

\section{Virtual German Megacity - tomorrow}

Many measures are realized regarding efficiency increase and energy savings

Site energy consumption today:

$1120 \mathrm{PJ}$ per year

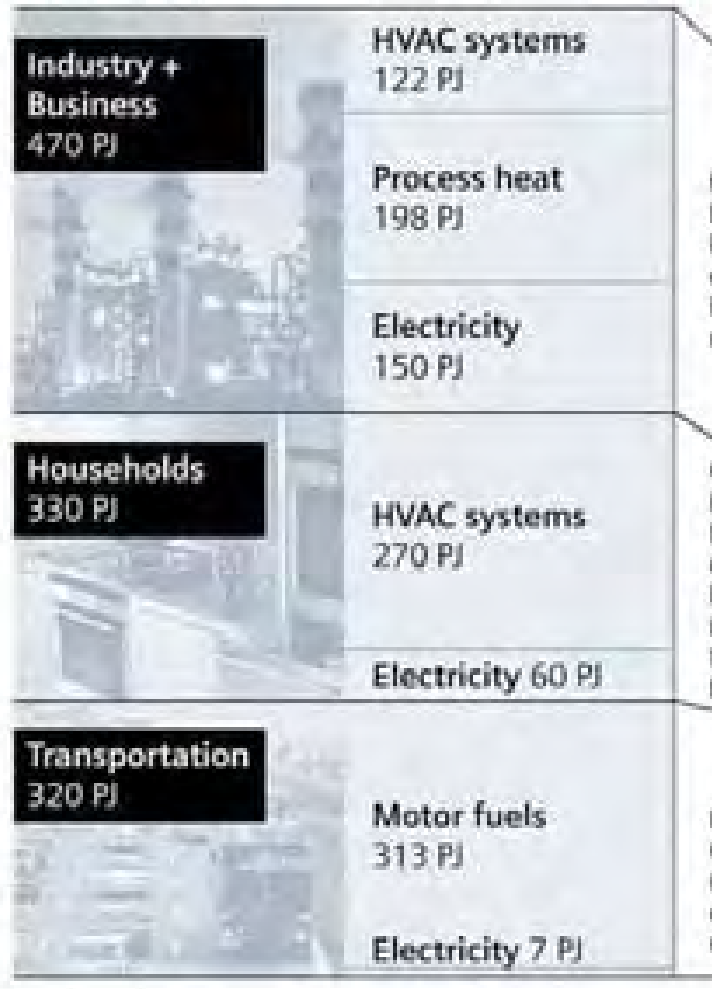

More efficient and

energy saving systems

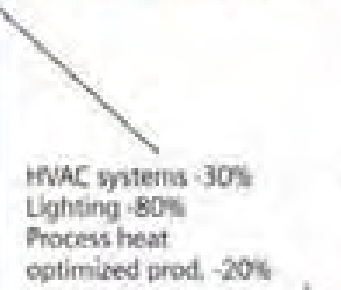

eptimined prod. $-20 \%$

Energy-saving

motors $20 \mathrm{~s}$

(2)

old building renowstion,

Heat insulation $-566^{\circ}$

New buildings as low

enengy or passive

houses $-70 \%$

tighteing - sos.

More efficient houne. hold appliances - $30 \%$

rences

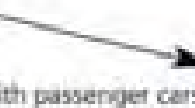

Less trips with passenger car

$(-305)$, but putic trancont

of trating energy $-20 \mathrm{~m}$.

more efficient trains $30 \%$
Site energy

consumption

tomorrow:

$710 \mathrm{PJ}$ per year

(minus 37\%)

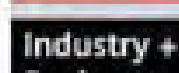

Business

$350 \mathrm{PJ}$

Process heat

160 PJ

Electricity

$110 \mathrm{PJ}$

HVAC syst. 105 P]

Households

$150 \mathrm{PJ}$

Transportation

Electricity $45 \mathrm{PJ}$

Motor fuels

200 PJ

Electricity $10 \mathrm{PJ}$

$210 \mathrm{PJ}$
51\% less primary

energy consumption, $51 \%$ less $\mathrm{CO}_{2}$ emissions

ver losses

Moce efficient power plants . coal-fired power plant 48x) and combined heat and power plants: cimized energy dis fribution solutions 
Fondazione

Eni

Enrico Mattei

Energy Implications of Climate Mitigation Policies

Riso International Energy Conference 2007, 22 May 2007

I Massimo Tavoni, FEEM 


\section{Outline}

- The WITCH model

- Cost-benefit glimpse

- Climate mitigation policies

- energy

- costs vs delaying

- uncertainty 


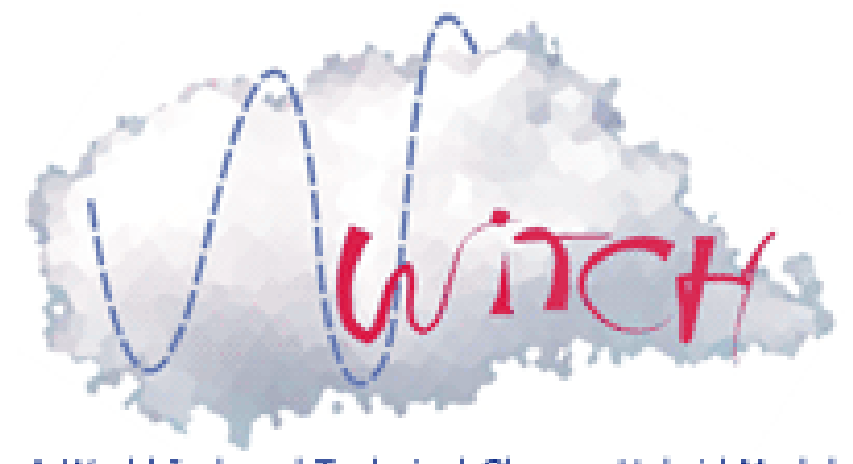

A World Induced Technical Change Hybrid Model

\section{World Induced Technical Change Hybrid model}




\section{The WITCH Model/1}

Hybrid I.A.M.:

- Economy: Top-down optimal growth (inter-temporal)

- Energy: Energy sector detail (technology scenarios)

- Climate: Damage feedback (global variable)

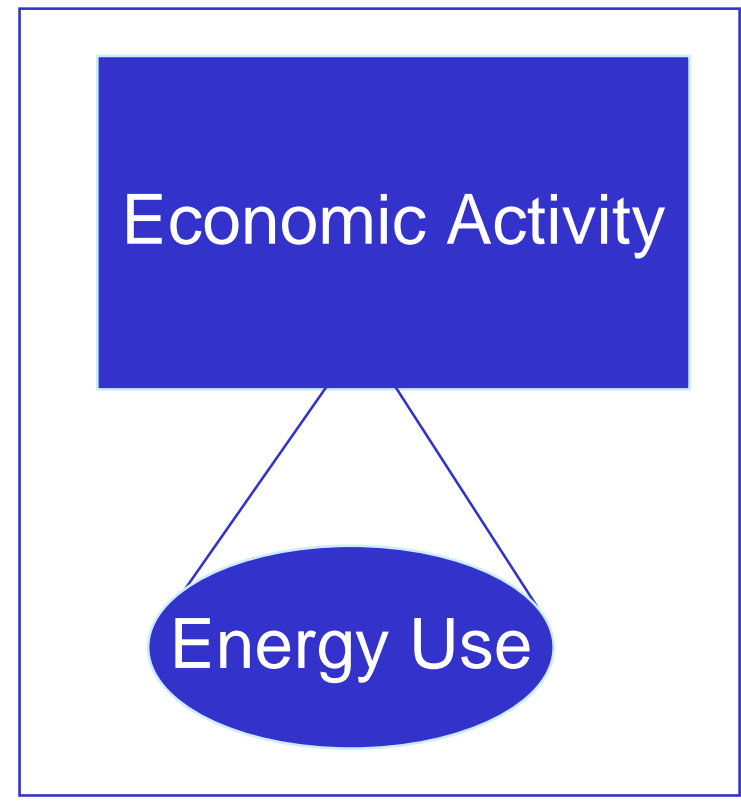

\section{Climate}

emissions

temperature 
Two solutions:

- Cooperative (world best)

- Non-cooperative (Nash), interactions among regions on:

- Environmental externality (carbon)

- Exhaustible resources (oil, gas, coal, uranium)

- Technological spillover

- Trade of emission permits 


\section{C.B.A. non-coop vs coop}




\section{World Carbon Emissions}

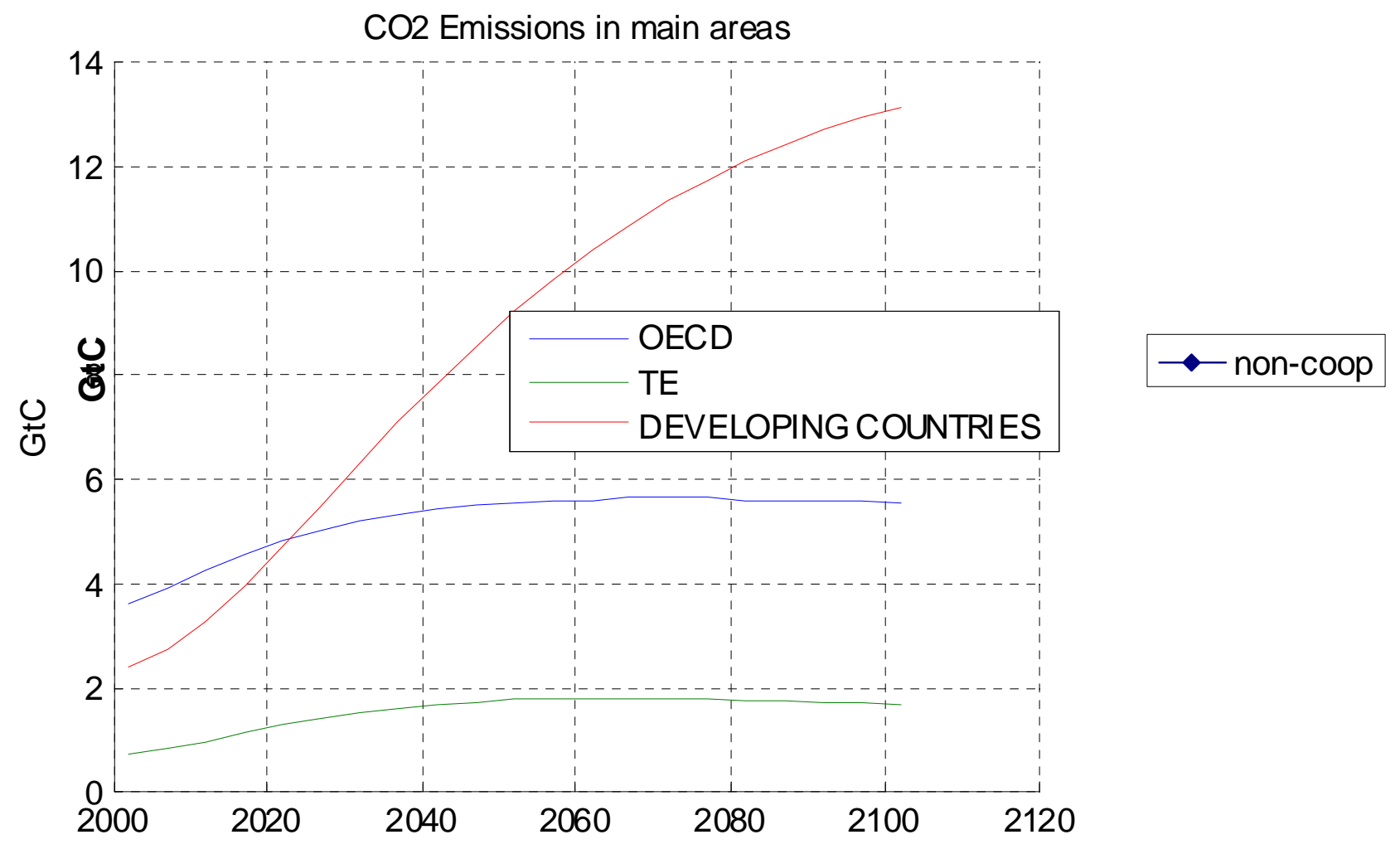

Fondazione

Eni

Enrico Mattei 


\section{World Carbon Emissions}

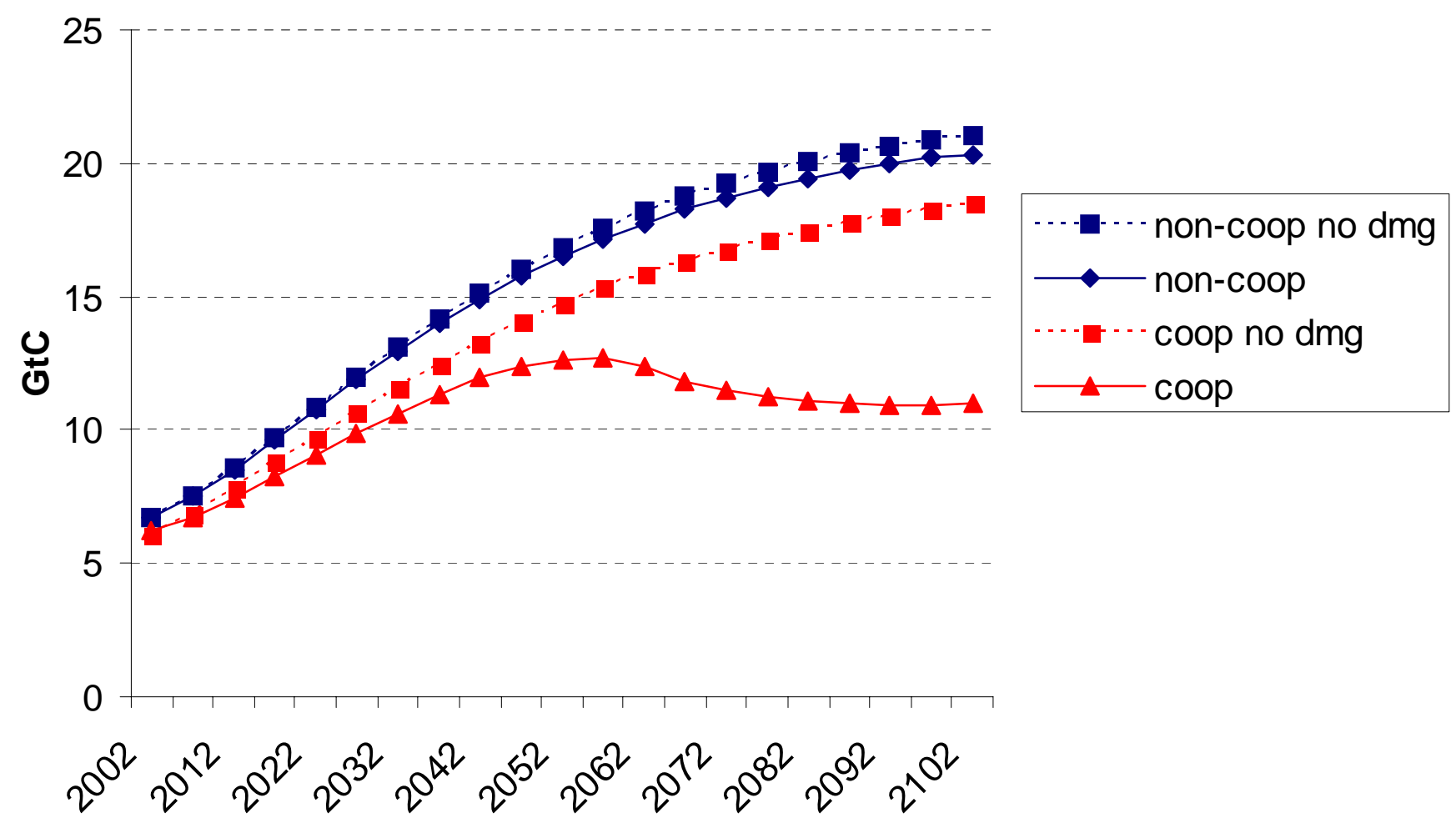




\section{$\mathrm{CO}_{2}$ Mitigation: C.E. Analysis}




\section{Mitigation Target: 450 and 550 ppmv}

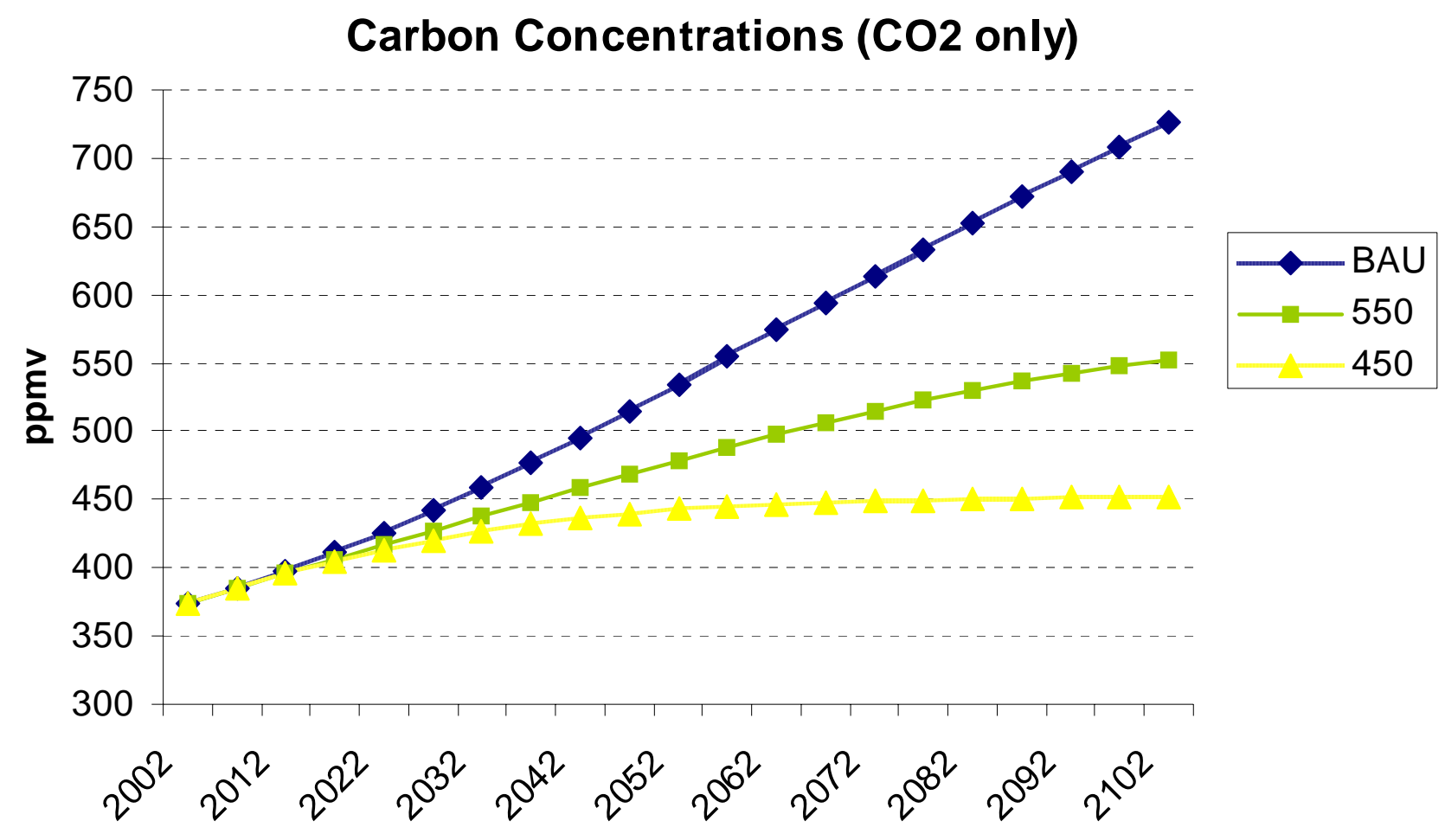




\section{Mitigation Target: 450 and 550 ppmv}

World Industrial Carbon Emissions (GtC)

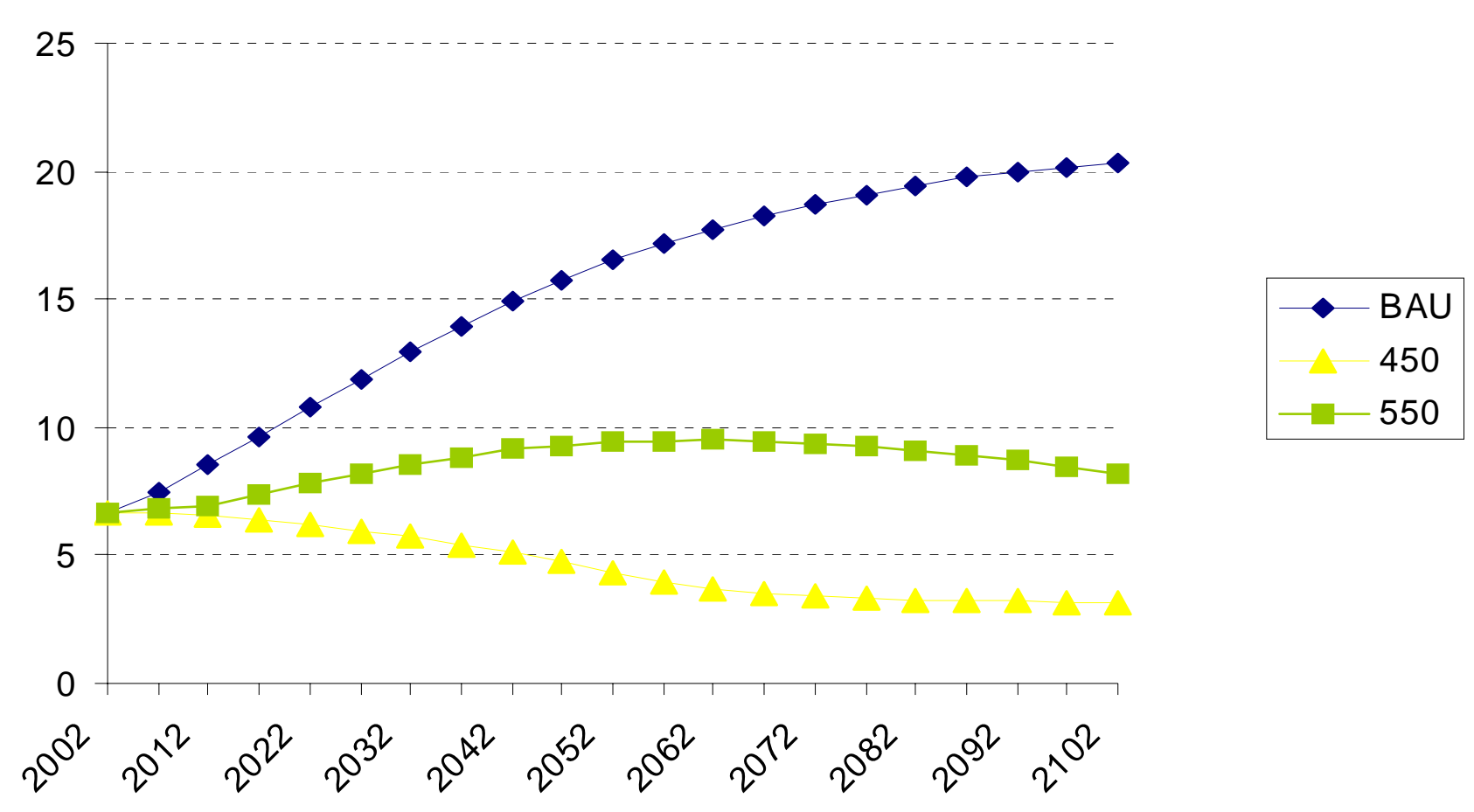




\section{Energy and Carbon Intensities}

Trajectories in the energy intensity/carbon intensity

wrt 2002

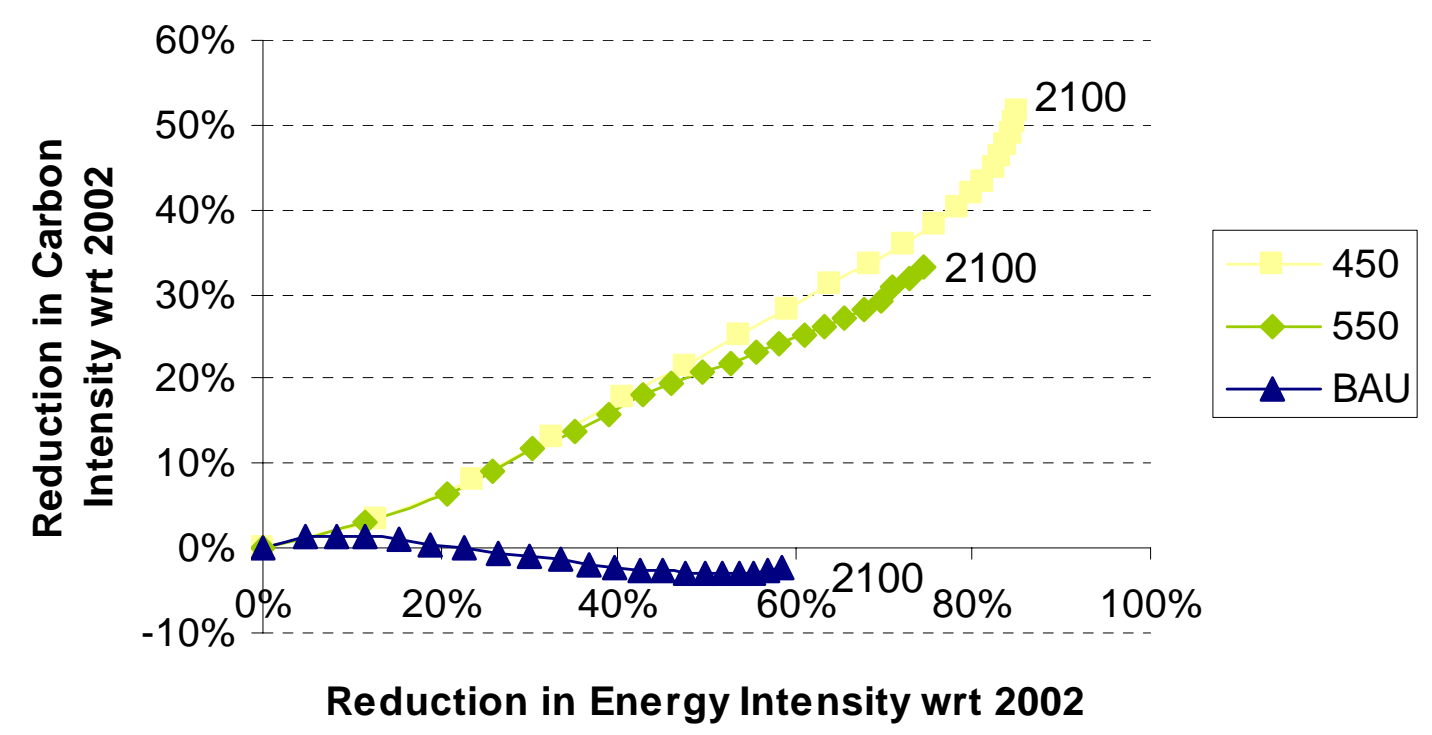




\section{Power generations mix}

\section{0ppmv}

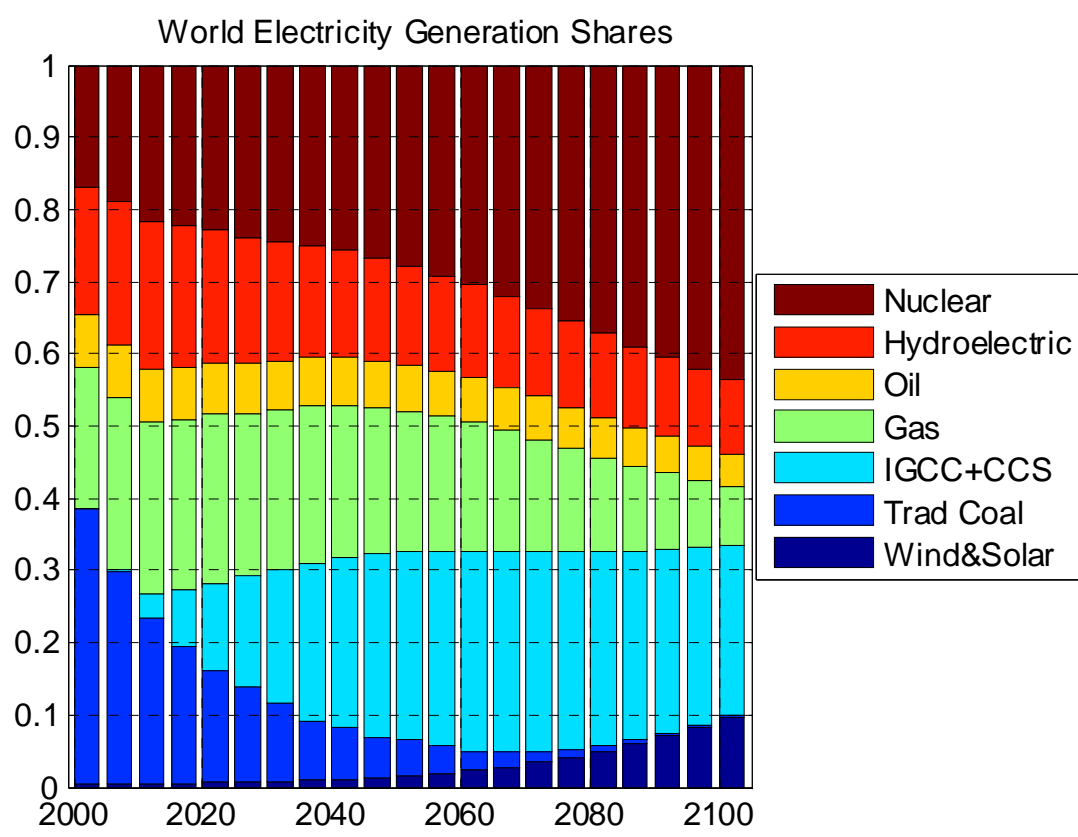

450pomv

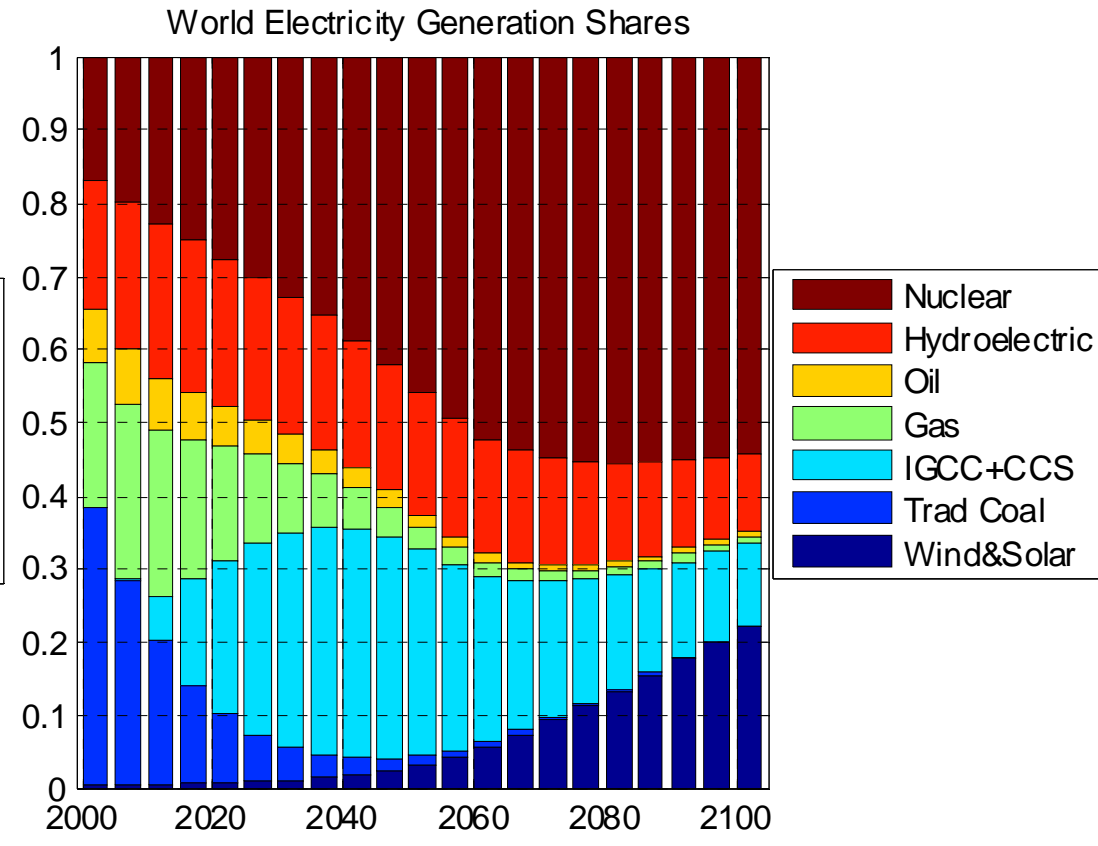

Fondazione

Eni

Enrico Mattei 


\section{Renewables: role of load factor}

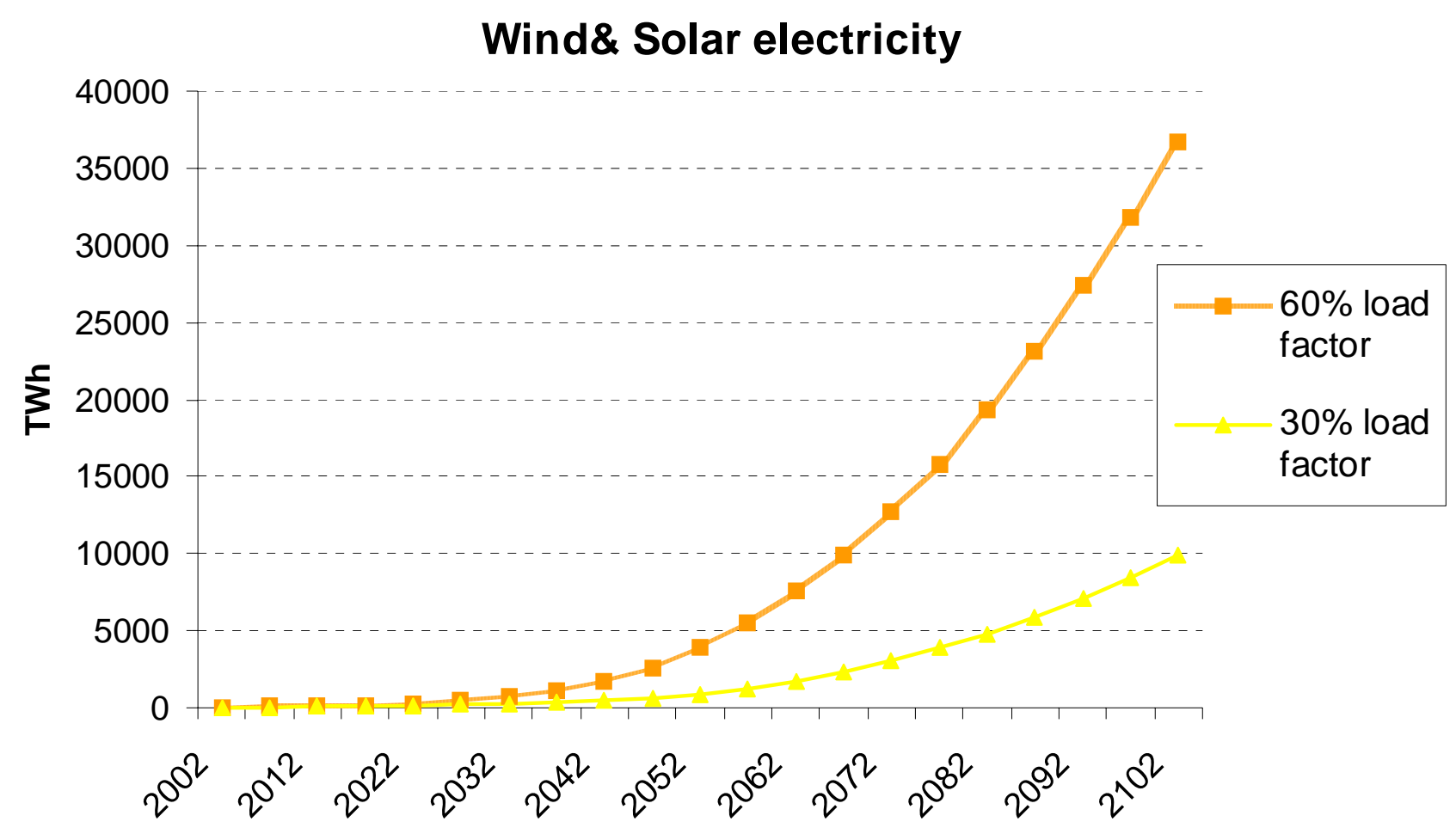




\section{CCS: quantities}

\section{Carbon sequestred}

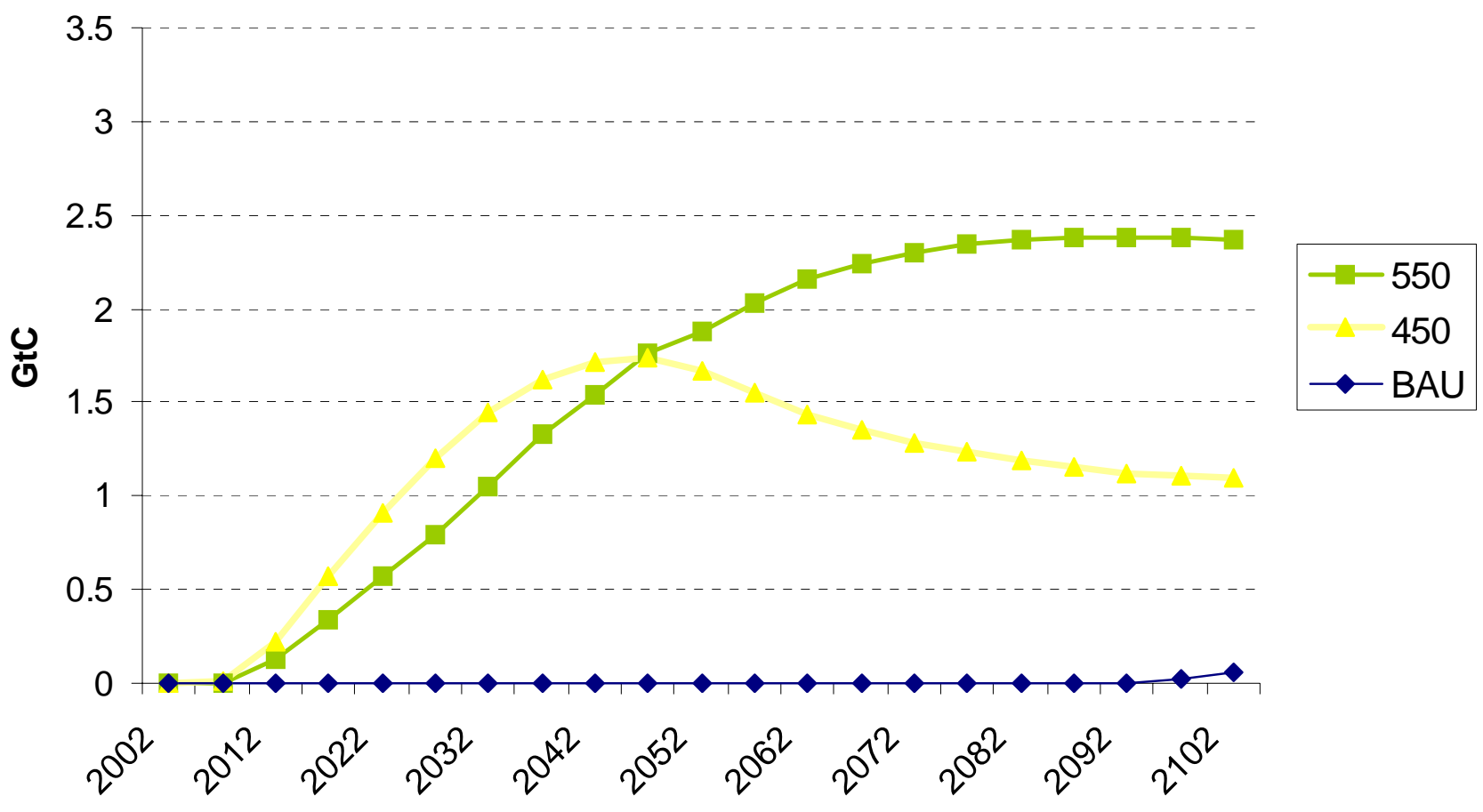




\section{CCS: effect of capture rate in a 450ppmv}

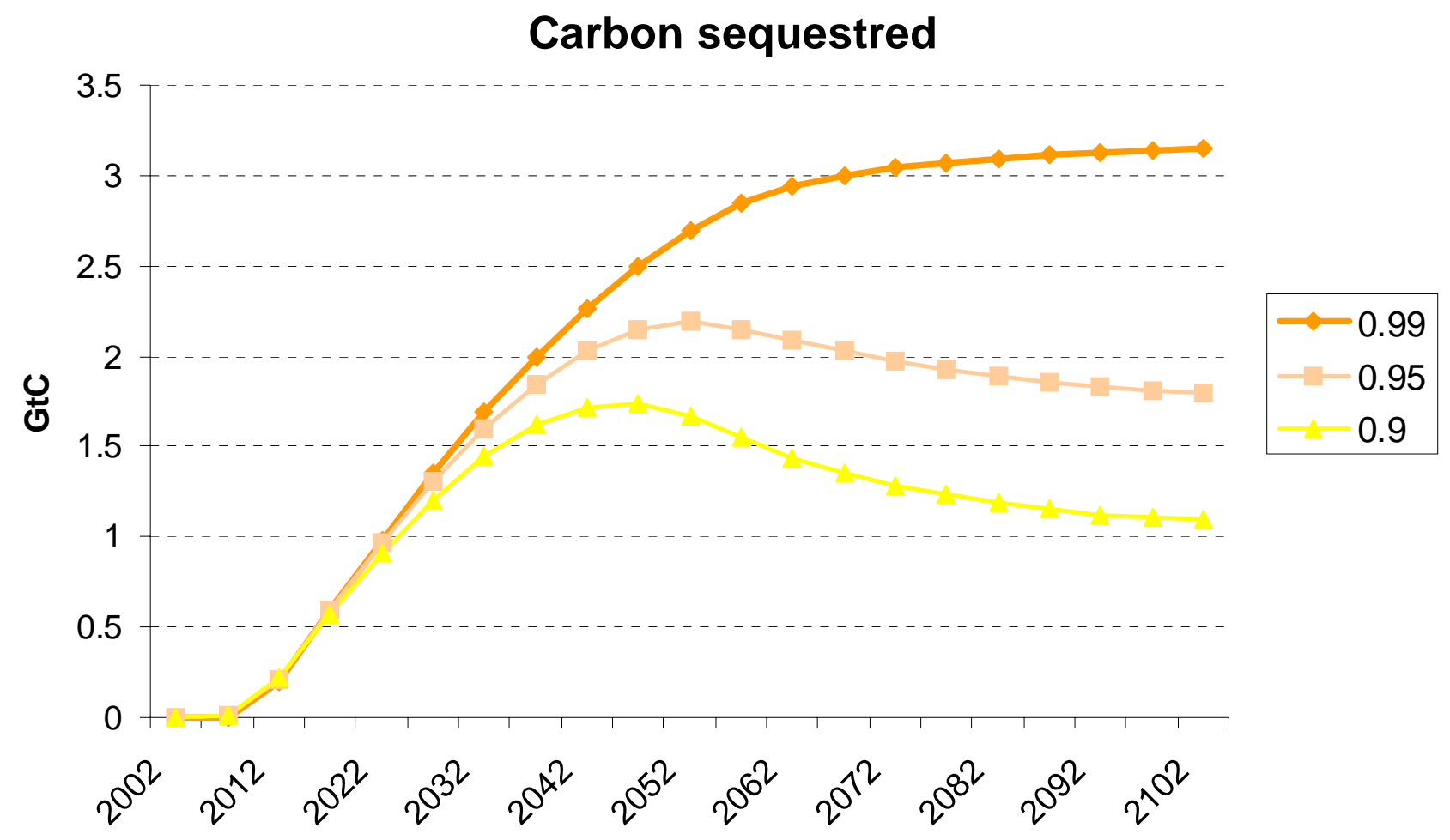

Fondazione

Eni

Enrico Mattei 


\section{CCS: effect of leakage rate in a 450ppmv}

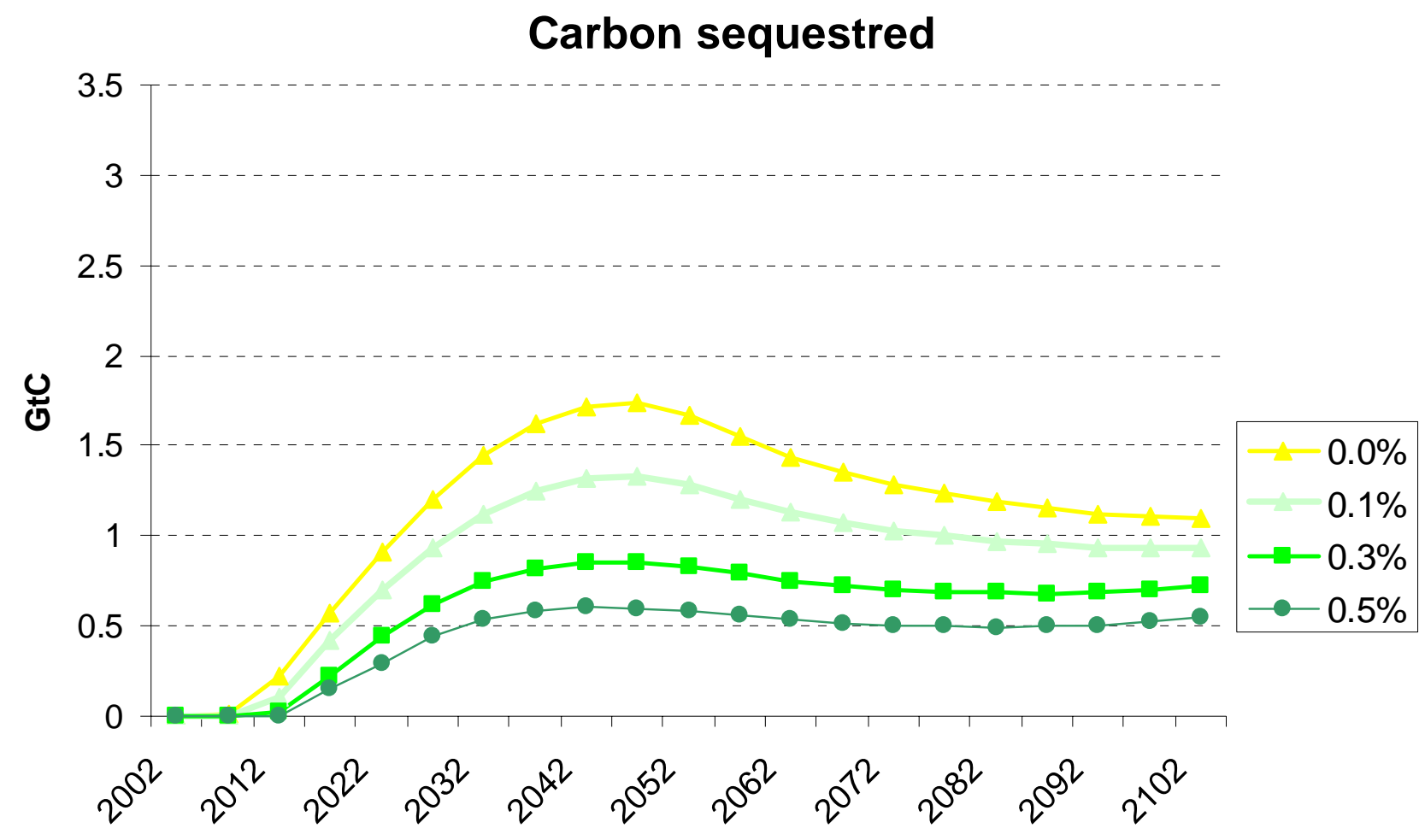

Fondazione

Eni

Enrico Mattei 


\section{Endogenous Technical Change}

LbD: Investment cost of wind\&solar plants wrt to BAU

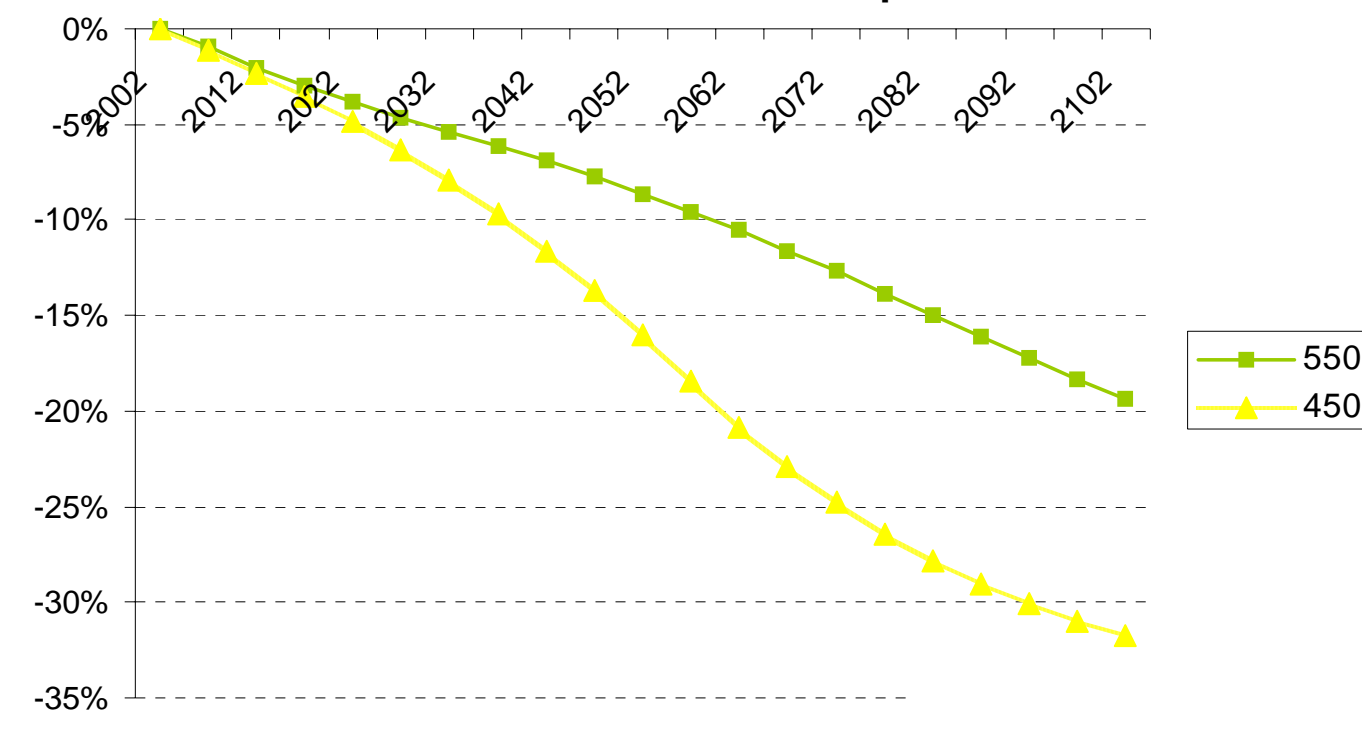

Energy R\&D investments

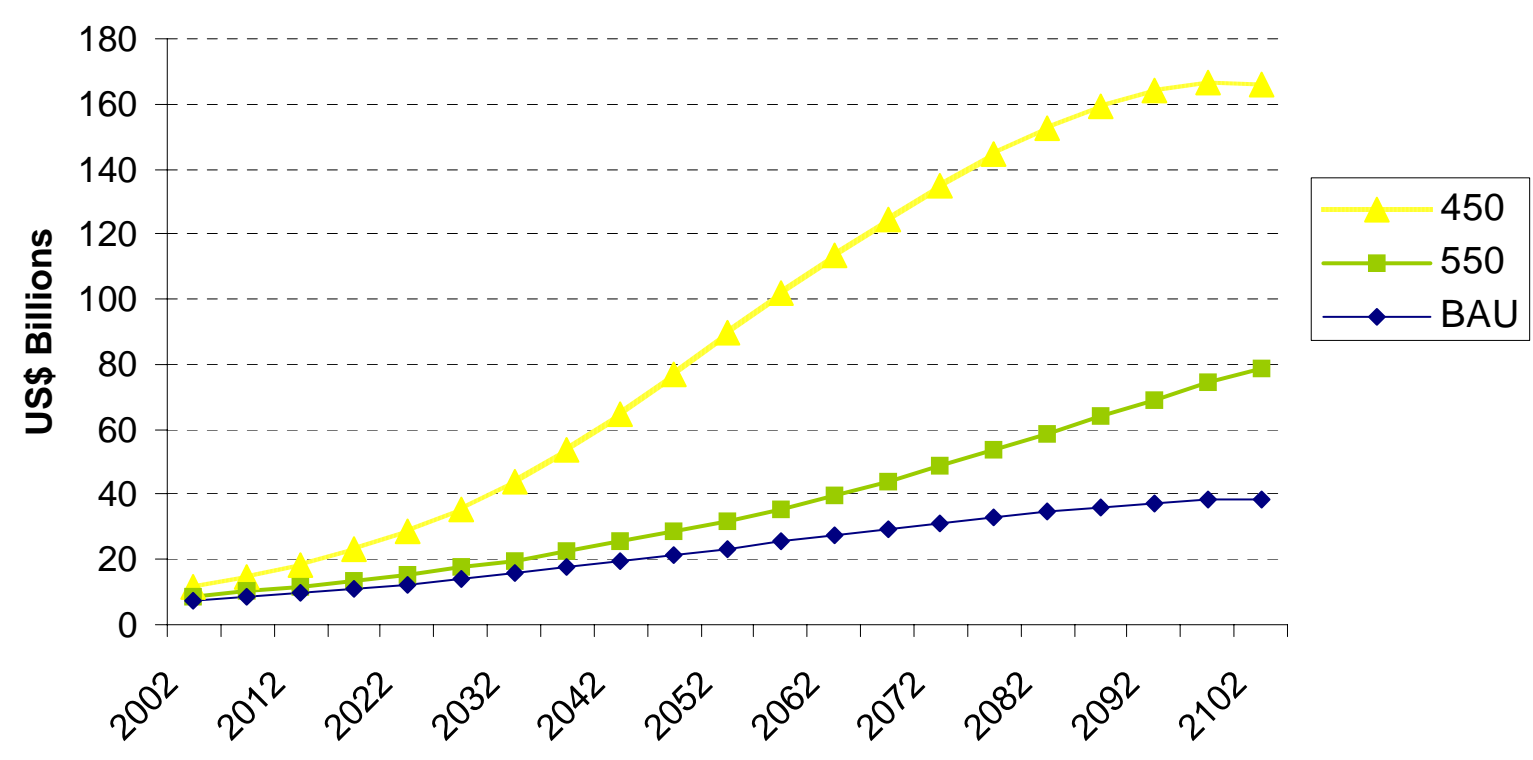




\section{Policy Costs}




\section{Costs and procrastination}

Costs of procrastination: $\mathbf{3} \%$ discounted

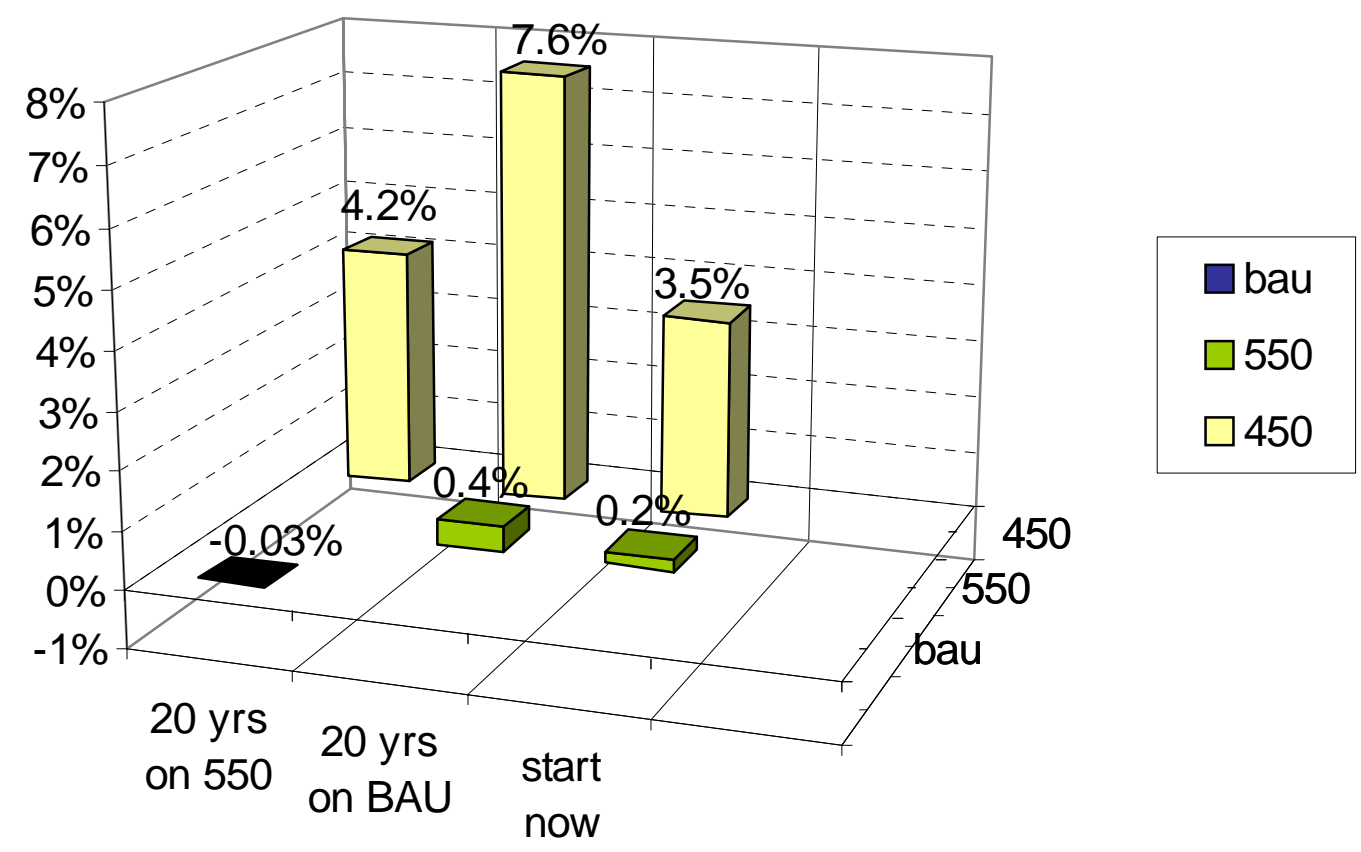




\section{Policy costs: "where" issue}

Regional Policy Costs

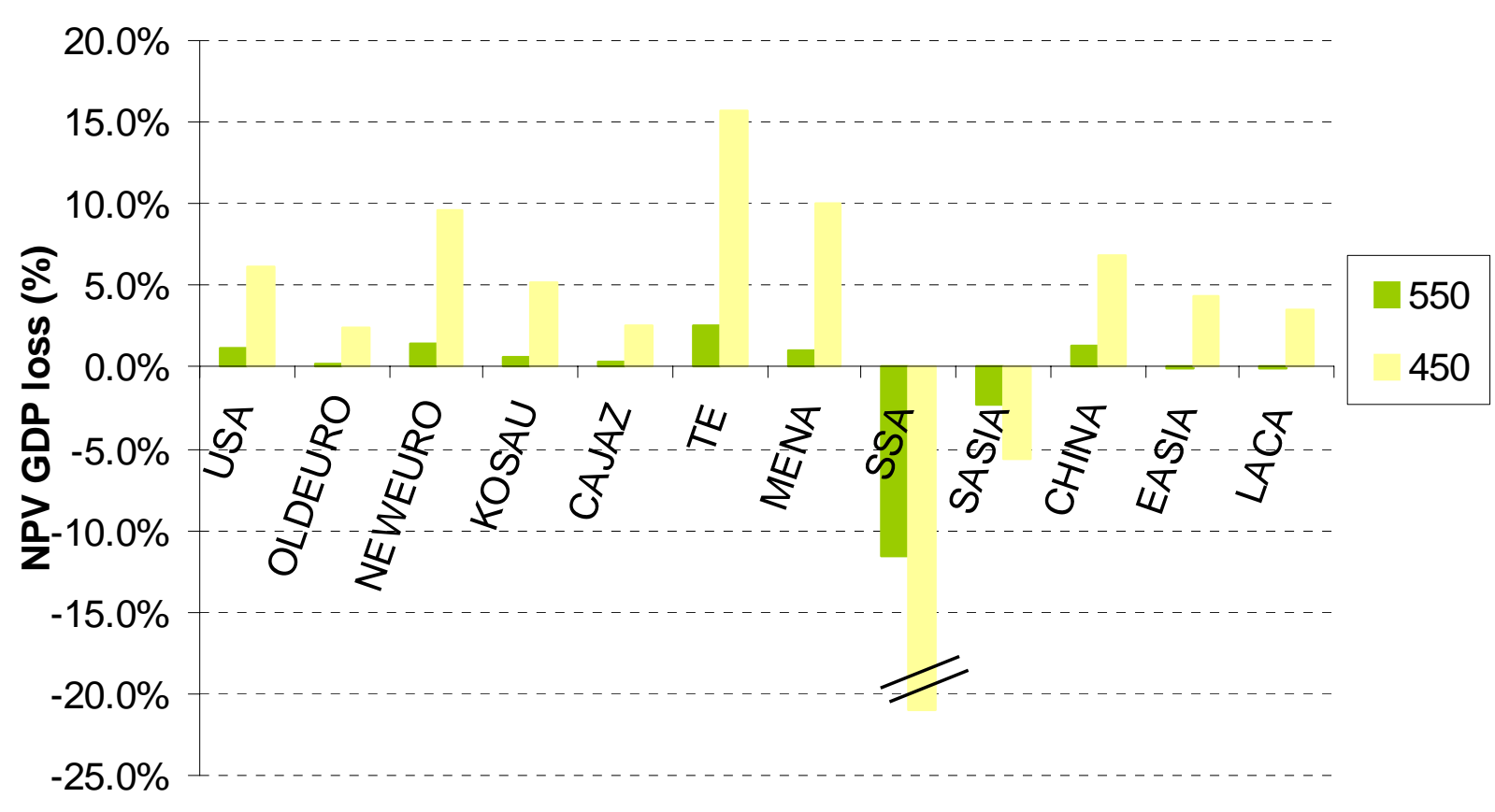




\section{Forestry in a 550ppmv}

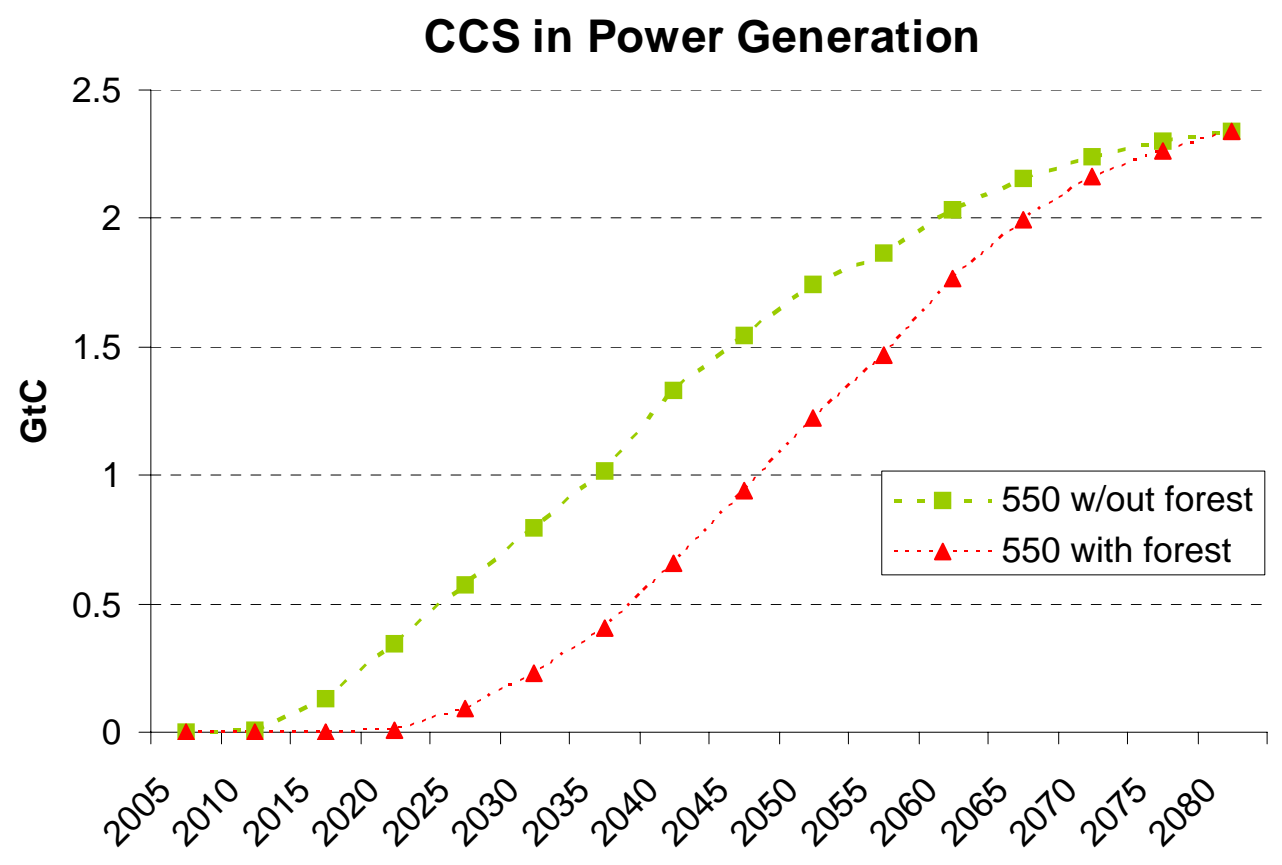

» halves 550ppmv policy costs

» achieves 50ppmv extra at no cost

» delay energy abatement 


\section{Uncertain concentration targets}

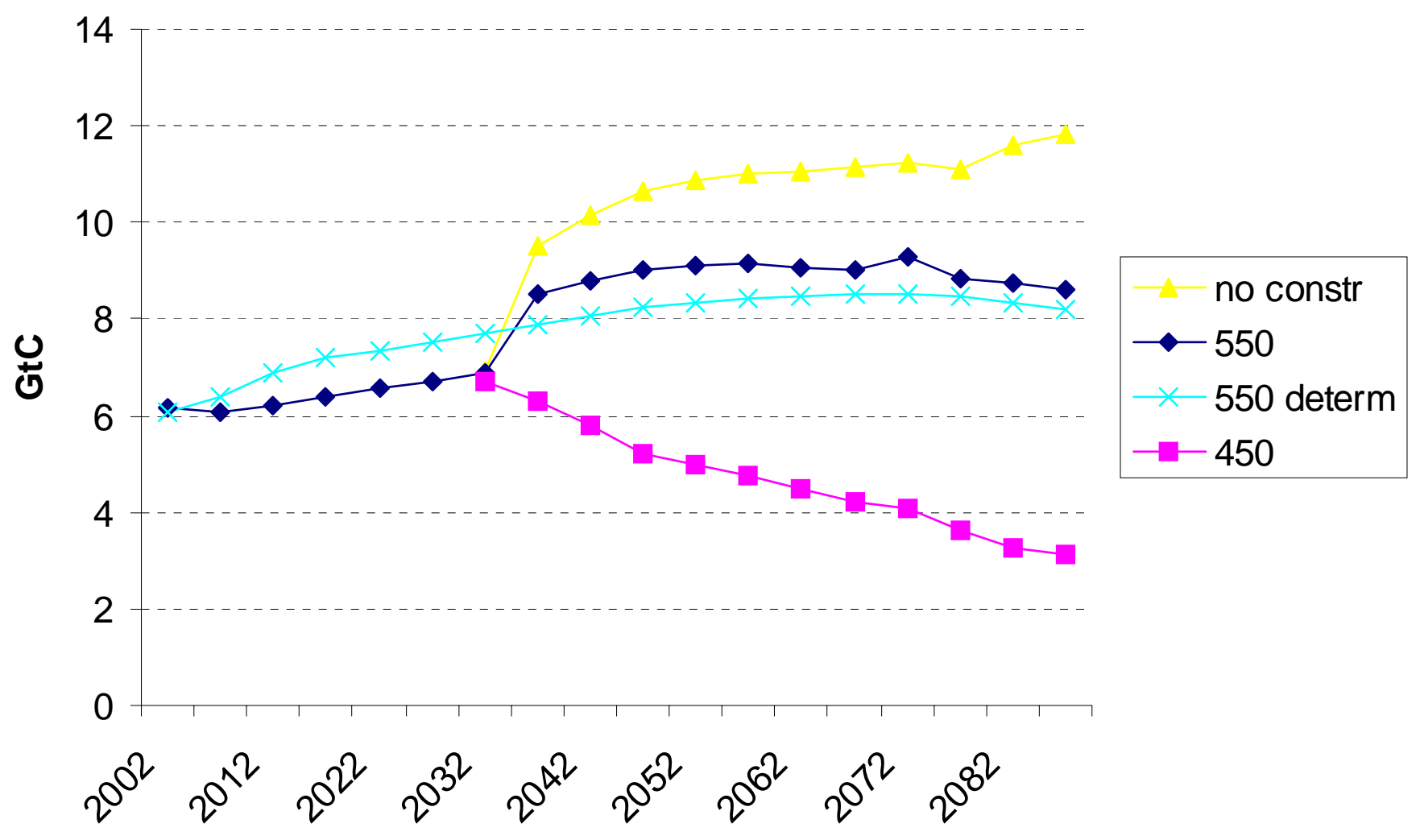

Endazione 


\section{Conclusions}

\section{Optimal abatement (CBA)}

- Coop CBA implies lower emissions (600 ppmv at 2100).

- Non-cooperative CBA does not suggest emission levels that scientists might like, mainly because of "global externality" nature of problem.

- Real issue is countries free-riding and how to induce cooperation

\section{Stabilization Policies (C.E.)}

- 550 "cheap" target, 450 tougher (real climate damages, tech. evolution)

- Power sector can do the job but needs Nuclear, CCS and Renewables

- Forestry important mitigation option with a bearing on carbon market/energ abat

- 550 no regret option, 20 yrs on BAU 450 is gone

- Climate uncertainties: more intermediate mitigation/interim conc. targets 


\section{massimo.tavoni@feem.it}

\section{www.feem-web.it/MITCH}

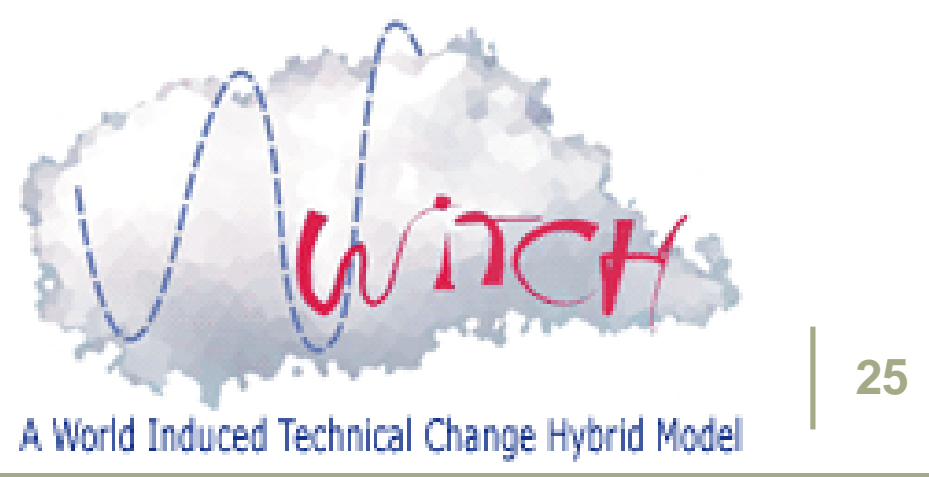




\section{0 costs: "when"}

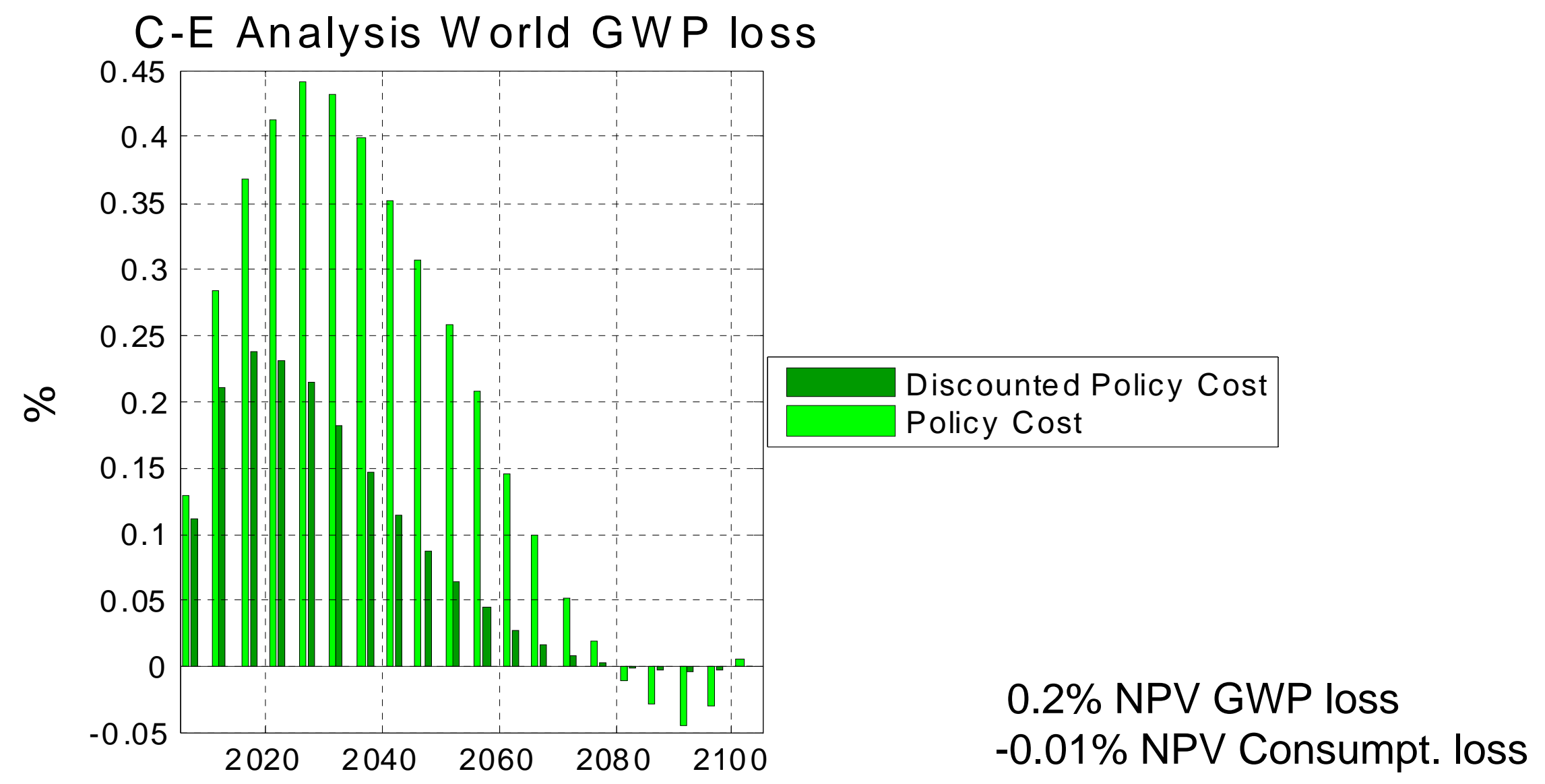

Fondazione
Eni
Enrico Mattei 


\section{The WITCH Model/2}

\section{Distinguishing Features}

- Focus on energy sector

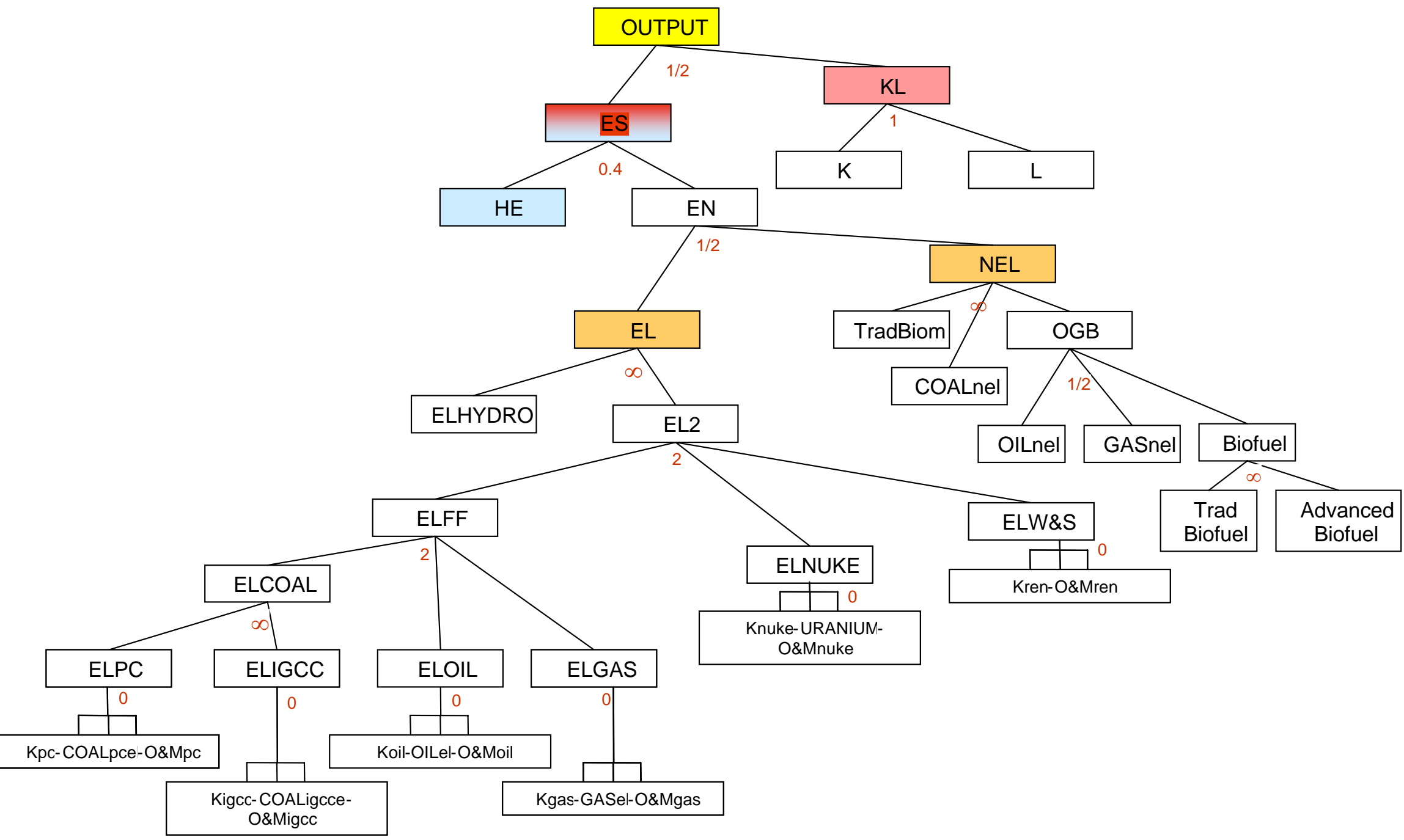




\section{Algorithm}

\section{Start}

\section{Nash \\ Main \\ Source}
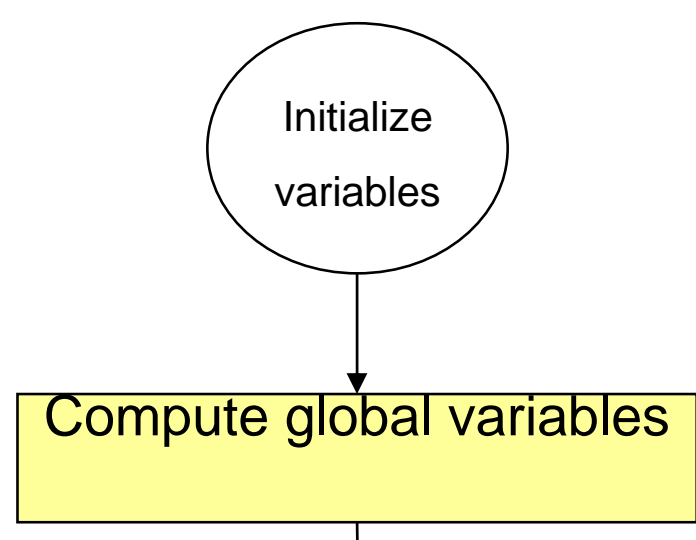

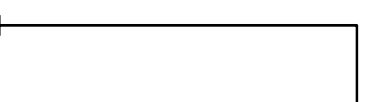

Fondazione Eni Enrico Mattei
To ease solution searching problem. Each region's problem solved assuming no interactions

To compute Temp, price of resources, W\&S capacity installed necessary in each regional optimization problem

$$
\forall \mathrm{n} \in \mathrm{N}
$$

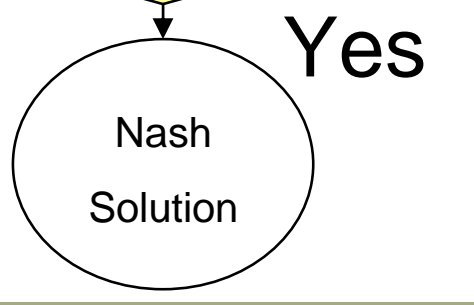

-The algorithm does not handle global constraints. 
Investigating the role of forestry as a stabilization option

Motivating Issue:

Missing analysis of carbon market response to forestry mgmt

\section{General idea:}

Coupling WITCH with a forestry model (Brent Sohngen, Ohio State Univ.)

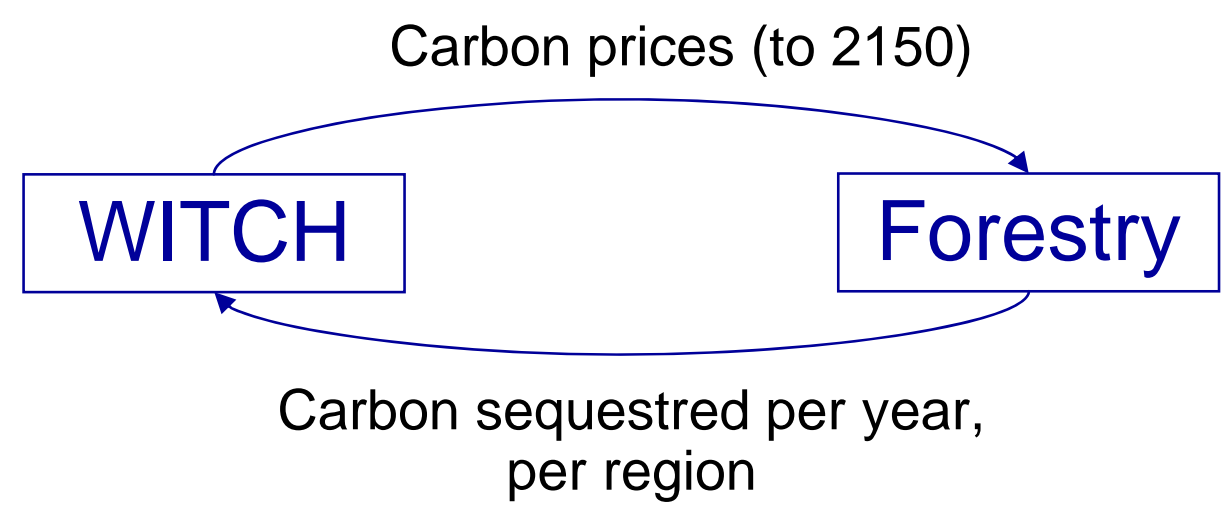




\section{Forestry Results}

PC

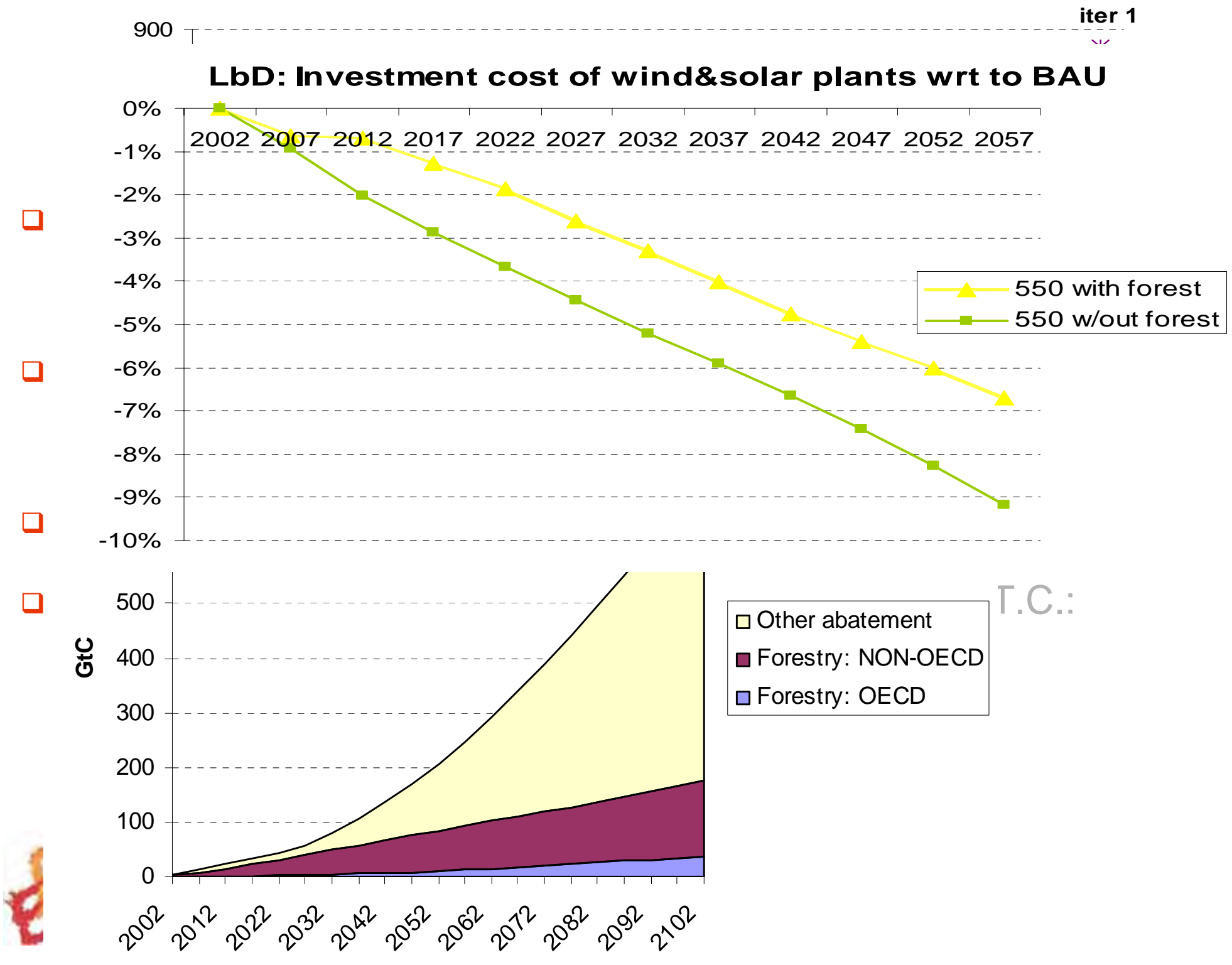


- Cost-Benefit Analysis

- Cost-effectiveness Analysis of climate policies

- Linking Forestry Management to Climate Change Policy

- Role of Uncertainty in Technological Change Processes

- Energy Technology Spillovers

- Role of Free Riding

- Role of Discounting 


\section{Uncertainty}

Investigating uncertain effectiveness of innovation in backstop technology

\section{Motivating Issues:}

Literature concentrates on uncertainty of climate damages and costs

1. Some preliminary research on uncertain future arrival of a backstop technology

2. Just few studies (Baker et al. 2006) on uncertain effectiveness of R\&D

\section{General idea:}

Develop a stochastic version of WITCH and analyze the effect of uncertainty on:

» optimal levels of investment in R\&D fostering the arrival of a carbon-free backstop technology

» the costs of a stringent climate policy 


\section{Uncertainty Results}
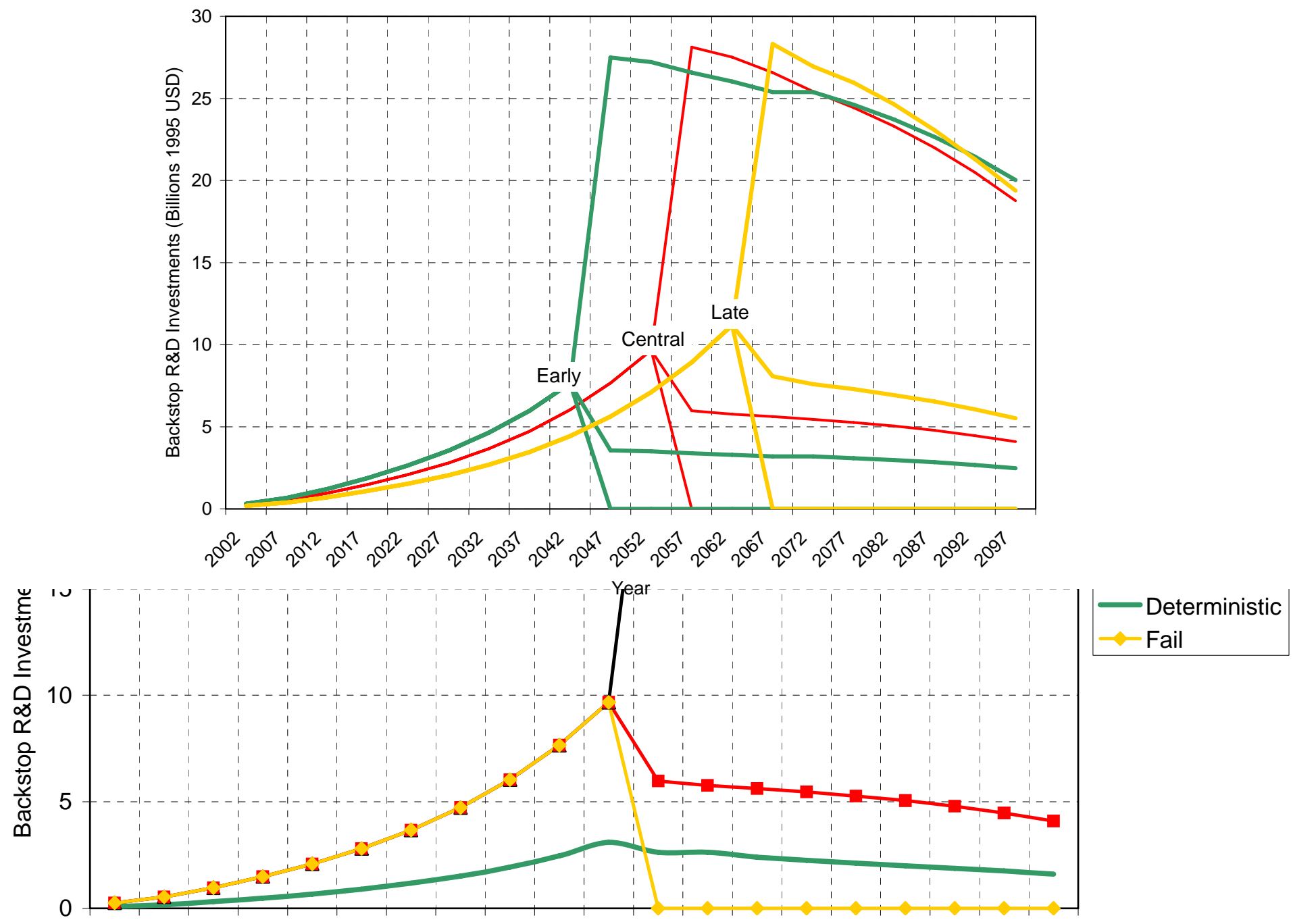

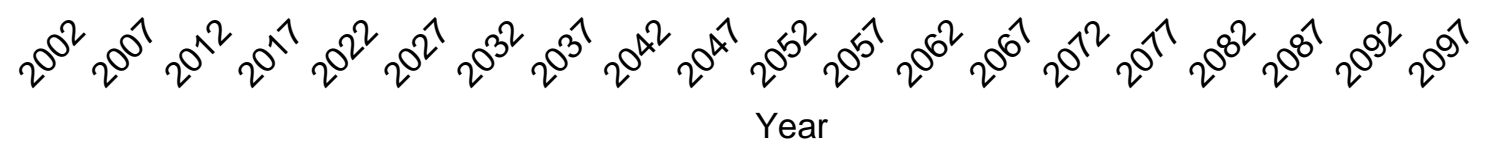




\section{Future Applications}

- Interactions between energy markets and climate policy

- Uncertainty of climate damages

- Spillovers and uncertain technological breakthroughs

- Linking land use management-forestry-energy and climate policy

- CDM and embodied technological spillover

- Accounting for non-cooperative behaviors in choosing the optimal climate policy instrument under uncertainty

- Mitigation vs Adaptation strategies 
*Bosetti V., C. Carraro, M. Galeotti, E. Massetti and M. Tavoni, (2006), "WITCH: A World Induced Technical Change Hybrid Model", The Energy Journal, Special Issue. Hybrid Modeling of Energy-Environment Policies: Reconciling Bottom-up and Top-down, 13-38.

*Valentina Bosetti, Carlo Carraro, Emanuele Massetti, Massimo Tavoni (2007) "Optimal Investment Strategies to stabilize GHG Atmospheric Concentrations" FEEM working paper

*M. Tavoni, B. Songhen and V. Bosetti (2007) "Forestry and the carbon market response to stabilize climate", FEEM working paper

*V. Bosetti, M. Tavoni (2007) "Uncertain R\&D, Backstop Technology and GHG

Stabilization", FEEM working paper

\section{www.feem-web.it/witch}

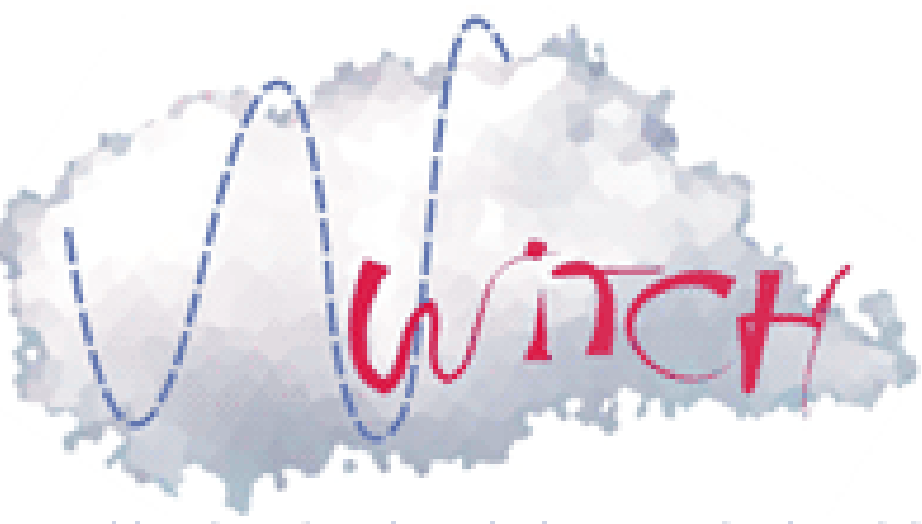

A World Induced Technical Change Hybrid Model 


\section{CO2, energy and income}

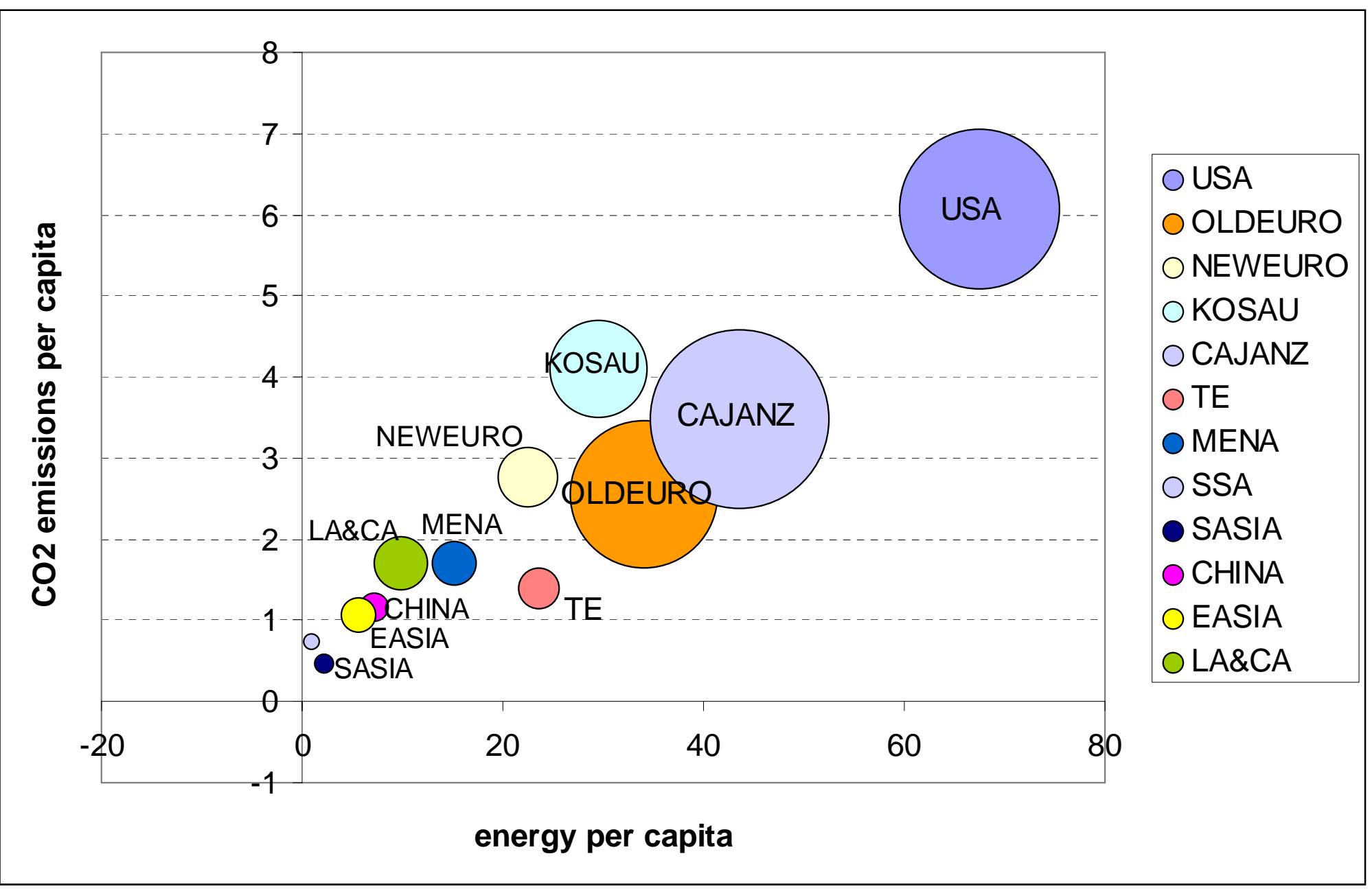

$2=\mid \begin{aligned} & \text { Fondazione } \\ & \text { Eni }\end{aligned}$ 


\section{Existing Models}

\section{TOP DOWN}

- DICE (Nordhaus) and Entice-BR (Popp) no energy detail nor regional disaggregation.

-DEMETER (Gerlagh), no regional disaggregation nor strategic choice of optimal investment profiles.

\section{BOTTOM UP}

- Energy system models (e.g., Markal, Message), no forward looking nor accounting for strategic behavior and related inefficiencies.

\section{HYBRID MODELS SOFT LINKED}

- MERGE (Richels et al.) stand-alone optimization nor accounting for strategic behavior and related inefficiencies.

\section{HYBRID MODELS HARD LINKED}

-MIND (Edenhofer et al.) no regional disaggregation nor strategic choice of optimal investment profiles. Single fuel.

- WITCH (World Induced Technical Change Hybrid model) 


\section{The Objective Function}

For each region $(n)$ forward-looking central planner maximizes present value of (log) per capita consumption (5-yr time steps):

(1) $W(n)=\sum_{t} L(n, t)\{\log [c(n, t)]\} R(t)$

choosing the optimal path of investment variables simultaneously and strategically with respect to the other decision makers.

Consumption of the single final good obeys to the economy budget constraint:

$$
\begin{aligned}
& \text { Final Energy } \\
& \text { R\&Ds } \\
& C(n, t)=Y(n, t)-I_{C}(n, t)-\sum_{j} I_{R \& D, j}(n, t)-\sum_{j} I_{j}(n, t)-\sum_{j} O \& \bar{M}_{j}(n, t) \\
& -\sum_{f} P_{\underline{f}}(n, t) X_{f}(n, t)-P_{C C S}(n, t) \operatorname{CCS}(n, t)
\end{aligned}
$$




\section{Output and Climate Damage}

Gross output produced via capital, labour (=population) and energy services.

(3) $Y(n, t)=\operatorname{TFP}(n, t)\left[\alpha(n) \cdot\left(K_{C}{ }^{1-\beta(n)}(n, t) L^{\beta(n)}(n, t)\right)^{\rho}+(1-\alpha(n)) \cdot E S(n, t)^{\rho}\right]^{1 / \rho} / \Omega(n, t)$

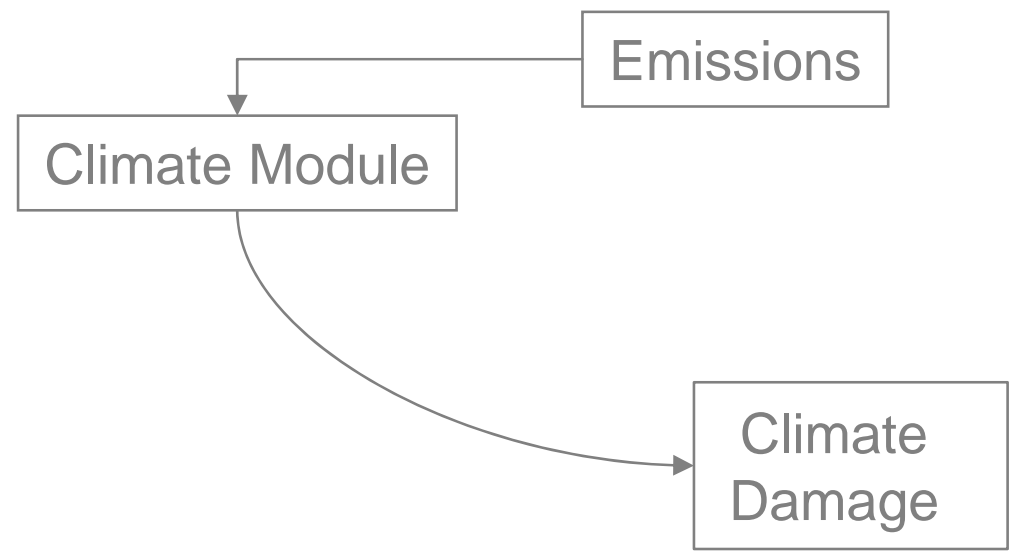




\section{The Energy Sector}

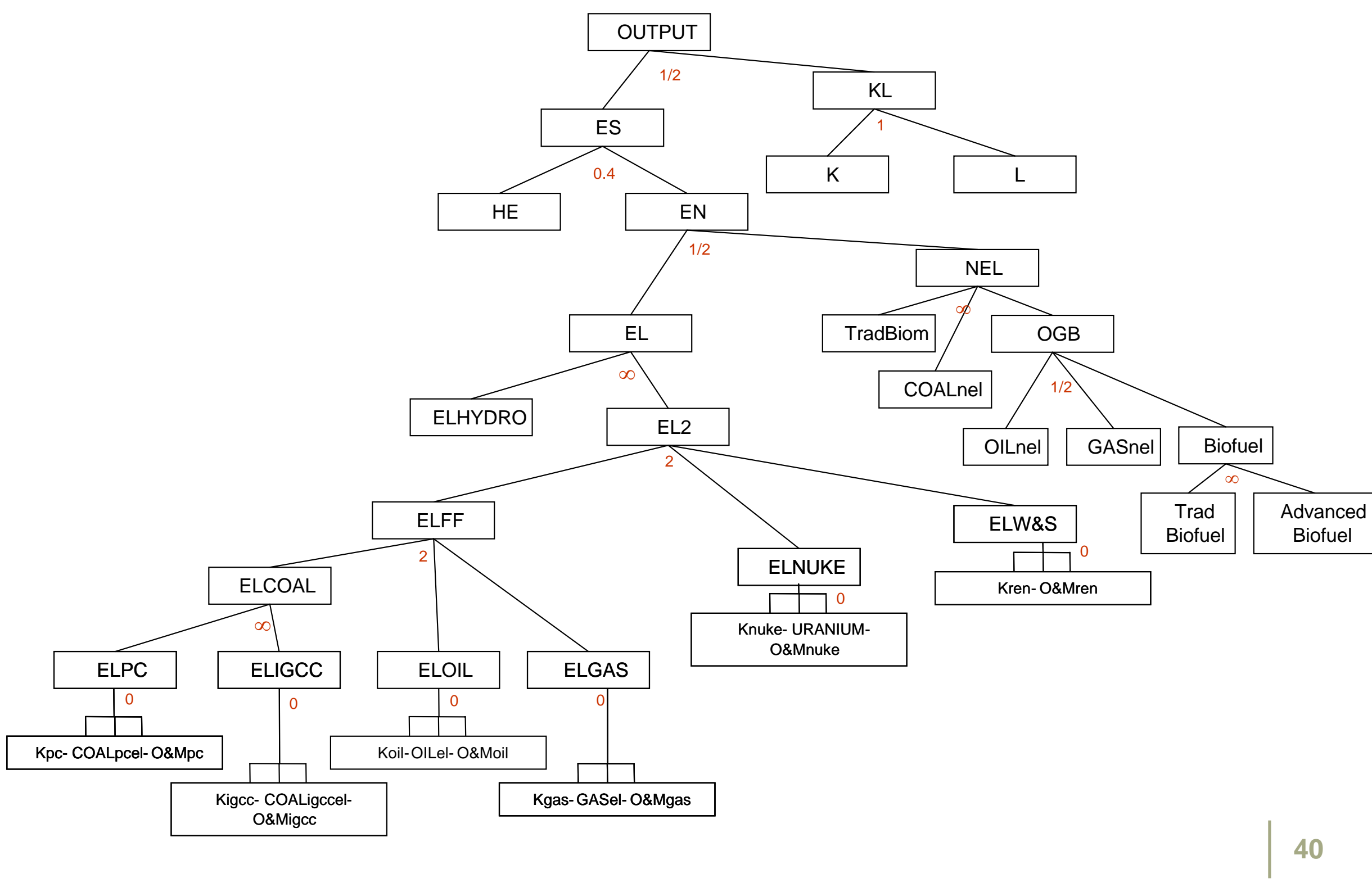




\section{Technical Change/1}

ETC is represented through both accumulation of experience and $R \& D$ investment:

i. Learning by Doing via experience curves in power plants investment cost

(4) $S C_{j}(n, t)=B_{j} \sum_{n} K_{j}(n, t-1)^{-\log _{2} P R_{j}}+\xi_{n}$

world learning, assume technology spillover

ii. Energy R\&D for increasing energy efficiency (Popp)

(5) $E S(n, t)=\left[\alpha_{H} H E(n, t)^{\rho}+\alpha_{E N} E N(n, t)^{\rho}\right]^{1 / \rho}$

(6) $H E(n, t+1)=a I_{R \& D}(n, t)^{b} H E(n, t)^{c}+H E(n, t)\left(1-\delta_{R \& D}\right)$ 


\section{PROMOTION STRATEGIES}

FOR ELECTRICITY FROM

RENEWABLES IN THE EU

LESSONS LEARNED

Reinhard Haas

Energy Economics Group, Vienna University of Technology 
1. Introduction

2. Additional costs for final customers

3. A comparison of the success

4. Achievements and prospects

5. The issue of competition

6. Conclusions

Thanks to the EC (DG RESEARCH, 


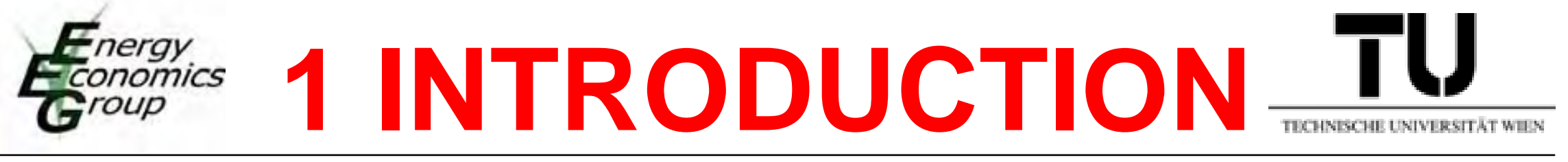

\section{CORE MOTIVATION:}

\section{Policy targets for an \\ INCREASE of RES-E!}

(e.g. currently discussed targets of $20 \%$ for 2020) 


\section{What is the problem?}

\section{SURVEY ON INSTRUMENTS TO PROMOTE ELECTRICITY FROM RENEWABLES}

\begin{tabular}{|c|c|c|c|}
\hline & & & VOLUNTARY \\
\hline \multirow{2}{*}{$\begin{array}{l}\text { Capacity- } \\
\text { driven } \\
\text { strategies }\end{array}$} & Generation-based & & - National generation targets \\
\hline & Investment focused & - Bidding/Tenderiı & $\begin{array}{l}\text { - National installation or capacity } \\
\text { targets } \\
\end{array}$ \\
\hline \multirow{2}{*}{$\begin{array}{l}\text { Price- } \\
\text { driven } \\
\text { strategies }\end{array}$} & Generation-based & - Net metering & $\begin{array}{l}\text { - Green Power Marketing } \\
\text { • Green tariffs } \\
\text { - Solar stock exchange }\end{array}$ \\
\hline & Investment focused & - Tax incentives & $\begin{array}{l}\text { • Contracting } \\
\text { - Shareholder progr. } \\
\text { • Contribution } \\
\text { • Bidding }\end{array}$ \\
\hline & Other & - & $\begin{array}{l}\text { - NGO-marketing } \\
\text { - Selling green buildings } \\
\text { • Retailer progr. } \\
\text { • Financing } \\
\text { - Public building prog. }\end{array}$ \\
\hline
\end{tabular}




\section{MAJOR PROBLEM:}

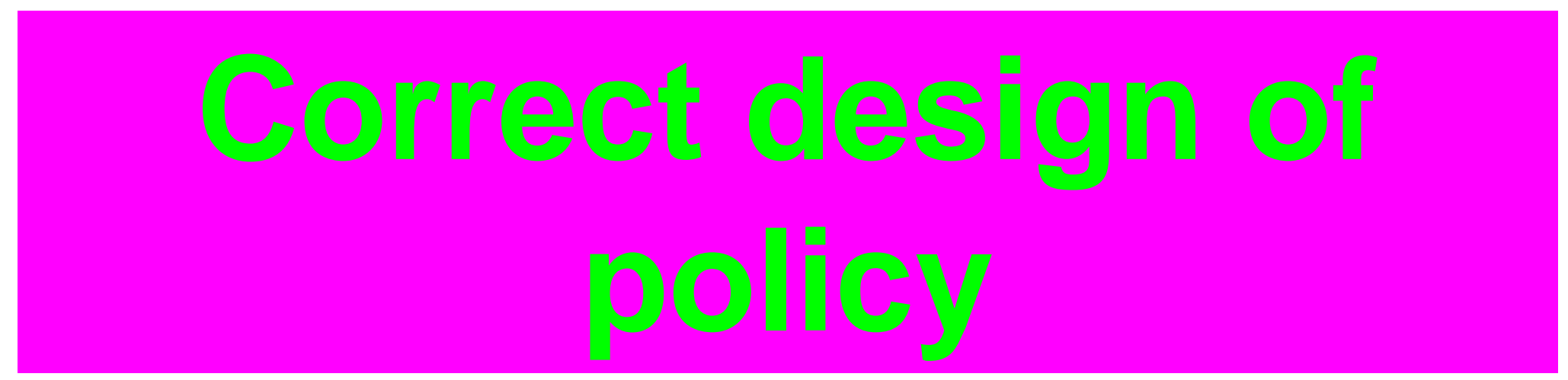

- with respect to: - renewable targets

- Financial incentives

- Credibility for investors

- Consideration of external costs? 
All regulatory promotion schemes (Quota-based TGC systems, tendering systems, Feed-in tariffs) create an

\section{artificial market}

\section{and cause}

transfer costs (additional costs) 
It is important to minimize these additional transfer costs. Why?

These additional costs have finally to be paid by the electricity customers

(regardless which promotion scheme is chosen) 


\section{Method of approach (EU-project GREEN-X)}

\section{STATIC COST RESOURCE CURVES}

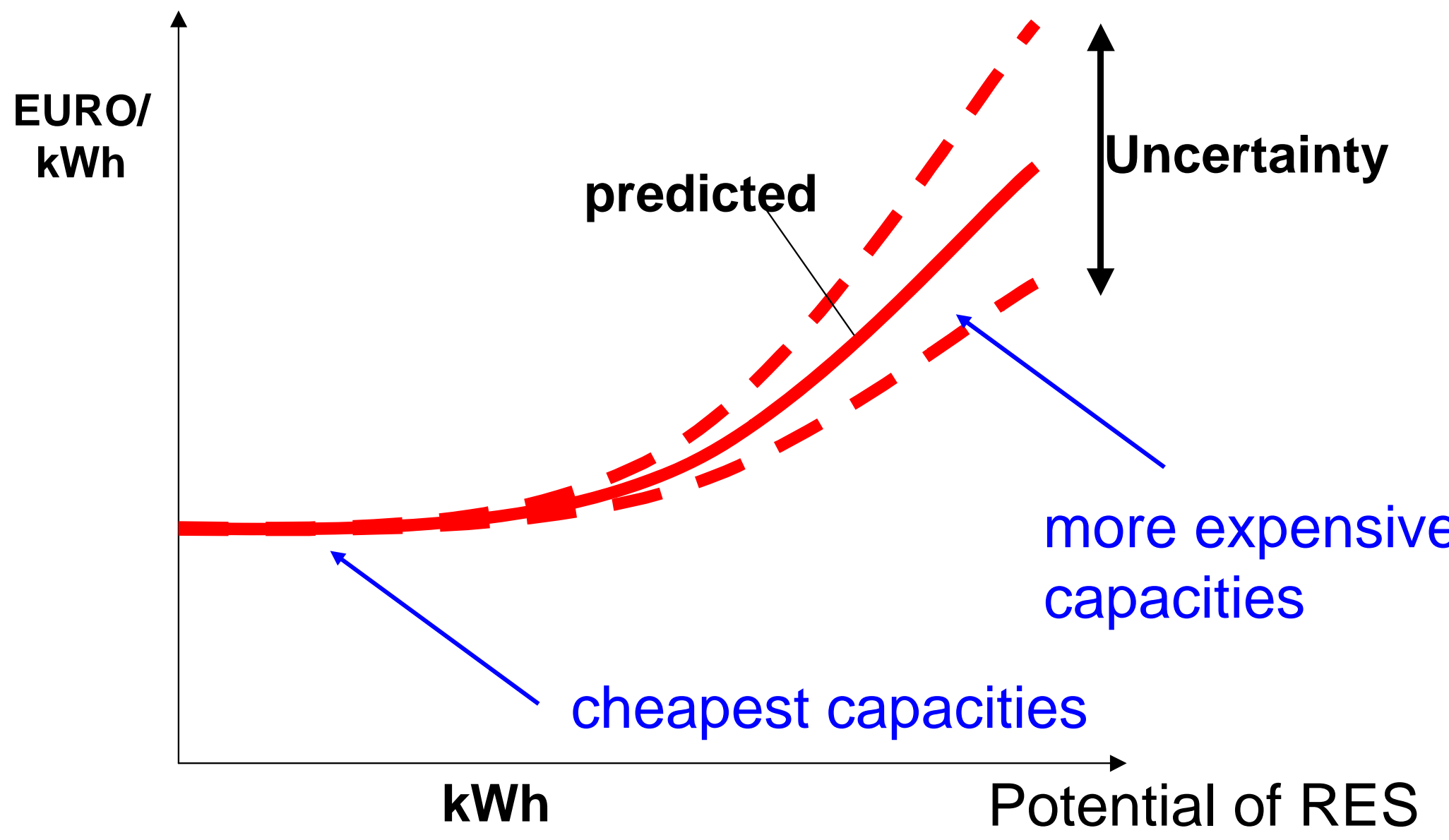




\section{Method of approach (EU-project GREEN-X)}

Minimise additional costs for consumers = Producer Surplus + Generation costs - Revenues electricity market

\section{Price, costs}

[Euro/MWh]

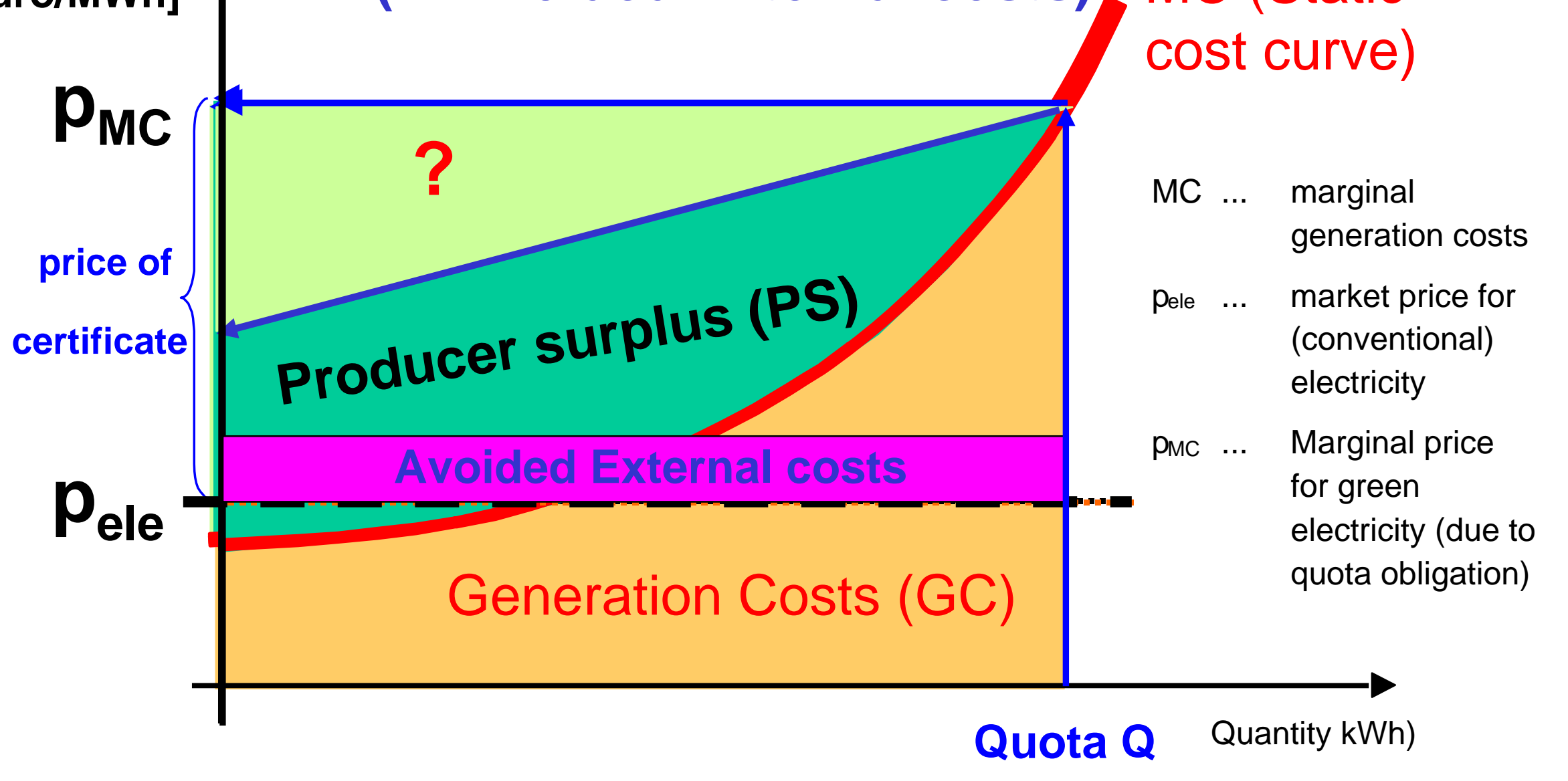

( - Avoided External costs) MC (Static cost curve)

$\begin{array}{lll}\text { MC } \quad \ldots \quad & \text { marginal } \\ & \text { generation costs }\end{array}$ market price for (conventional) Mrginal price for green electricity (due to quota obligation) 


\section{Transfer costs vs}

\section{avoided costs}

\section{Example: Promotion of wind in Germany 2005}

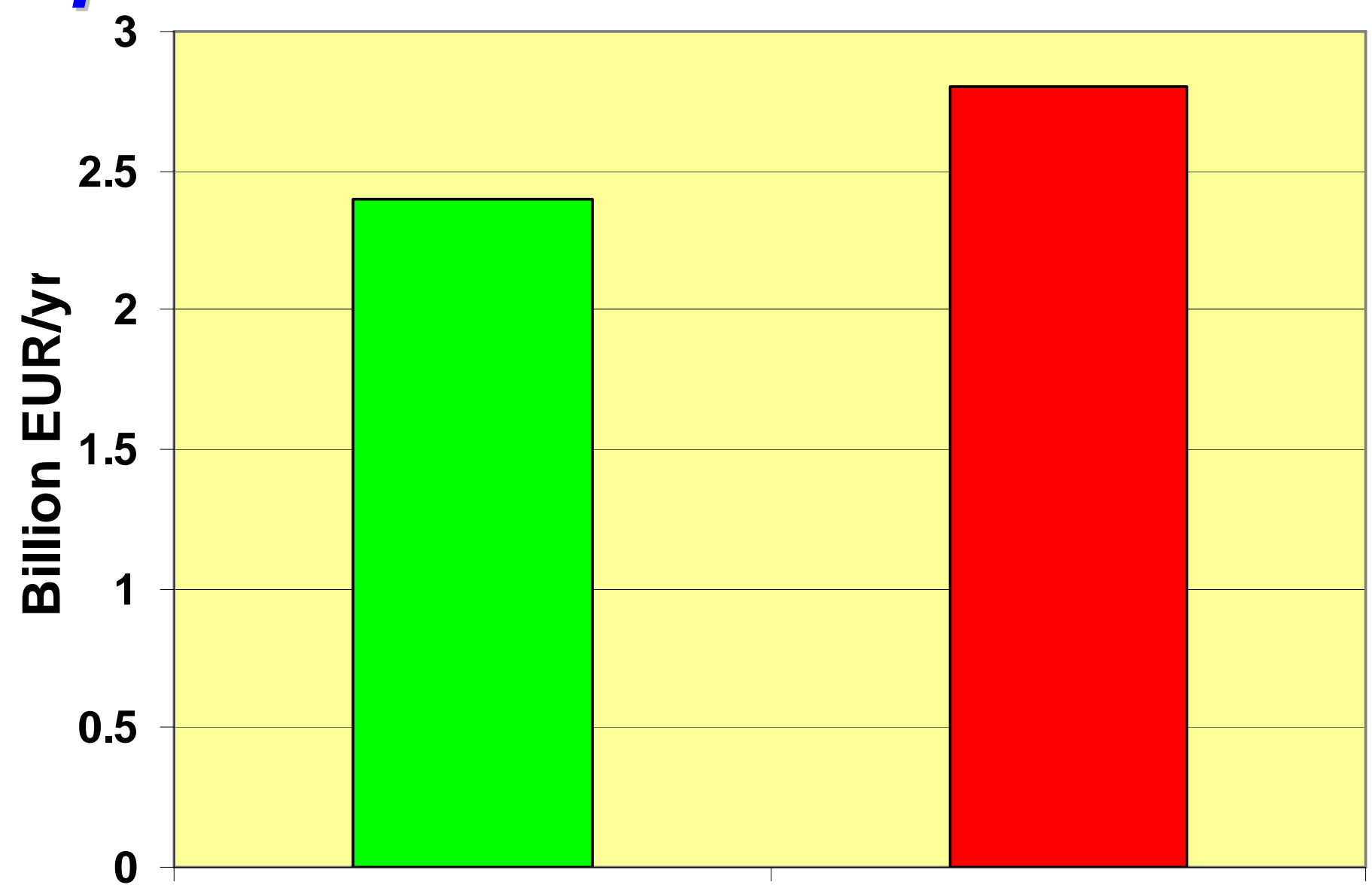

Transfer costs EEG

Avoided external costs

Source: Krewitt/Schlomann: Externe Kosten ...( 2006) 
The lower the additional costs (=transfer costs) are which have finally to be paid by electricity customers

the higher will be public acceptance

the larger will be the amount of additional electricity generated from RES. 
An example from the conventional electricity market:

in several countries (e.g. Germany, Belgium) customers are fed up with the high profits the large incumbent utilities make in the "free" market

they request a re-regulation of electricity prices! 


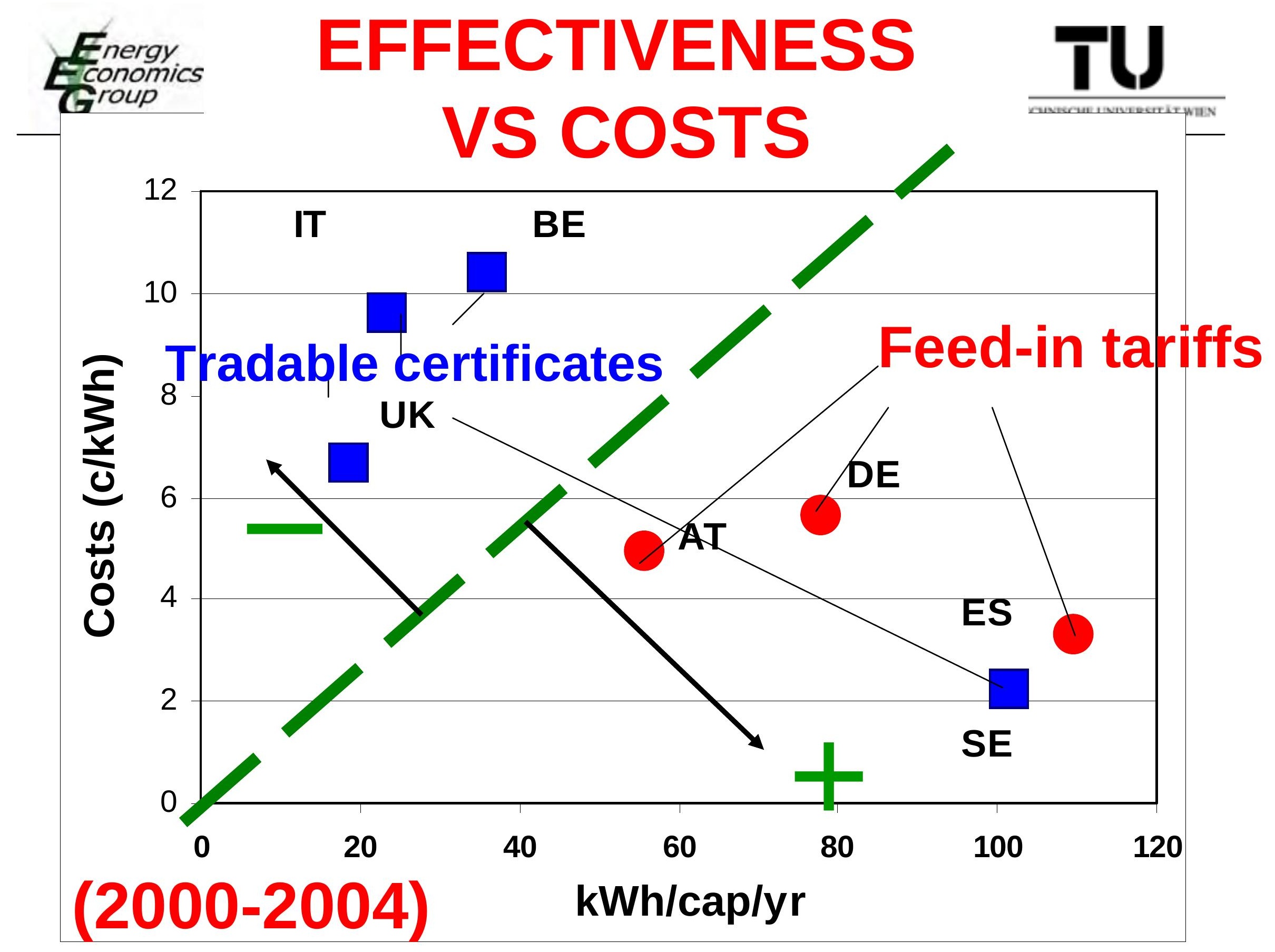




\section{Use a stepped FIT and calculate} starting values carefully

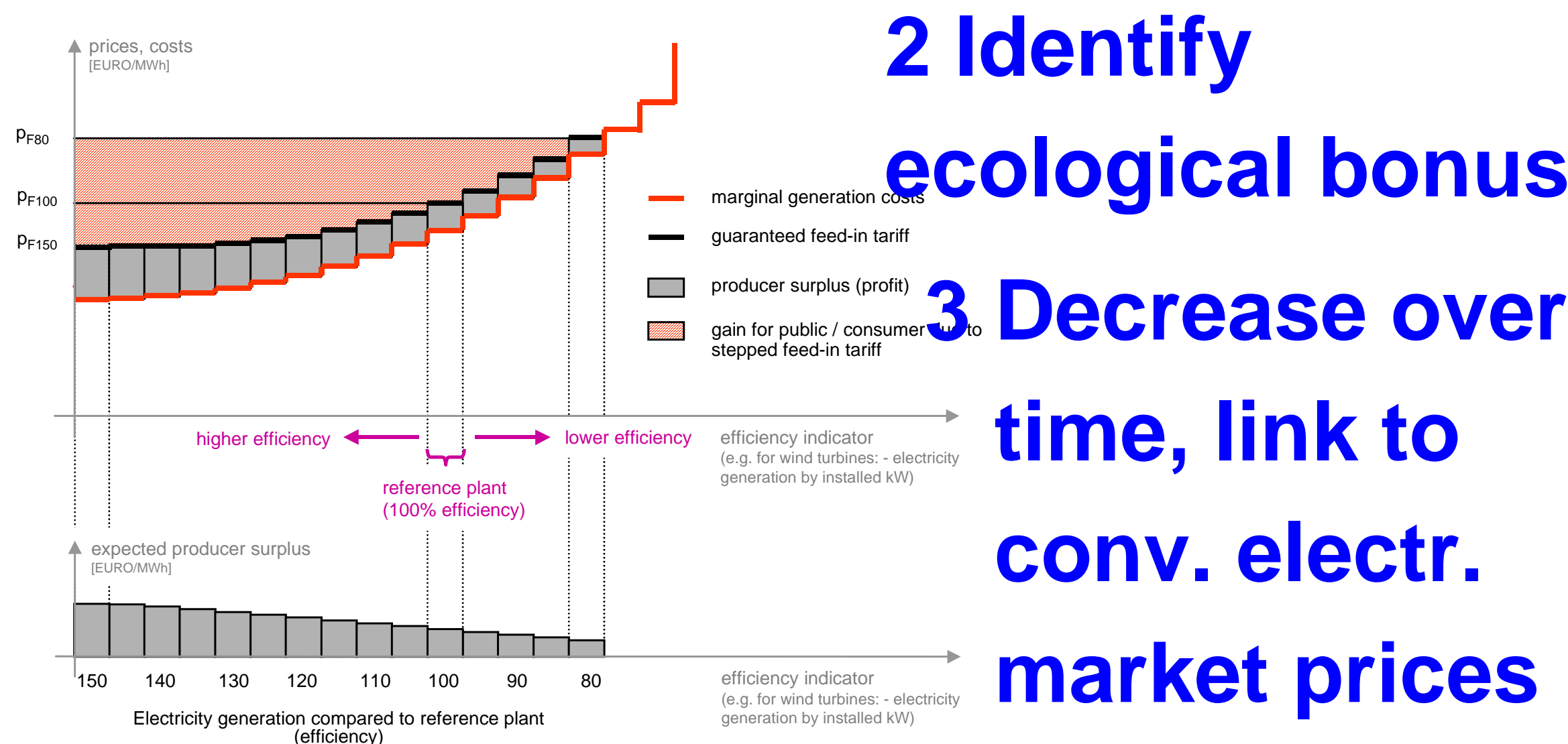



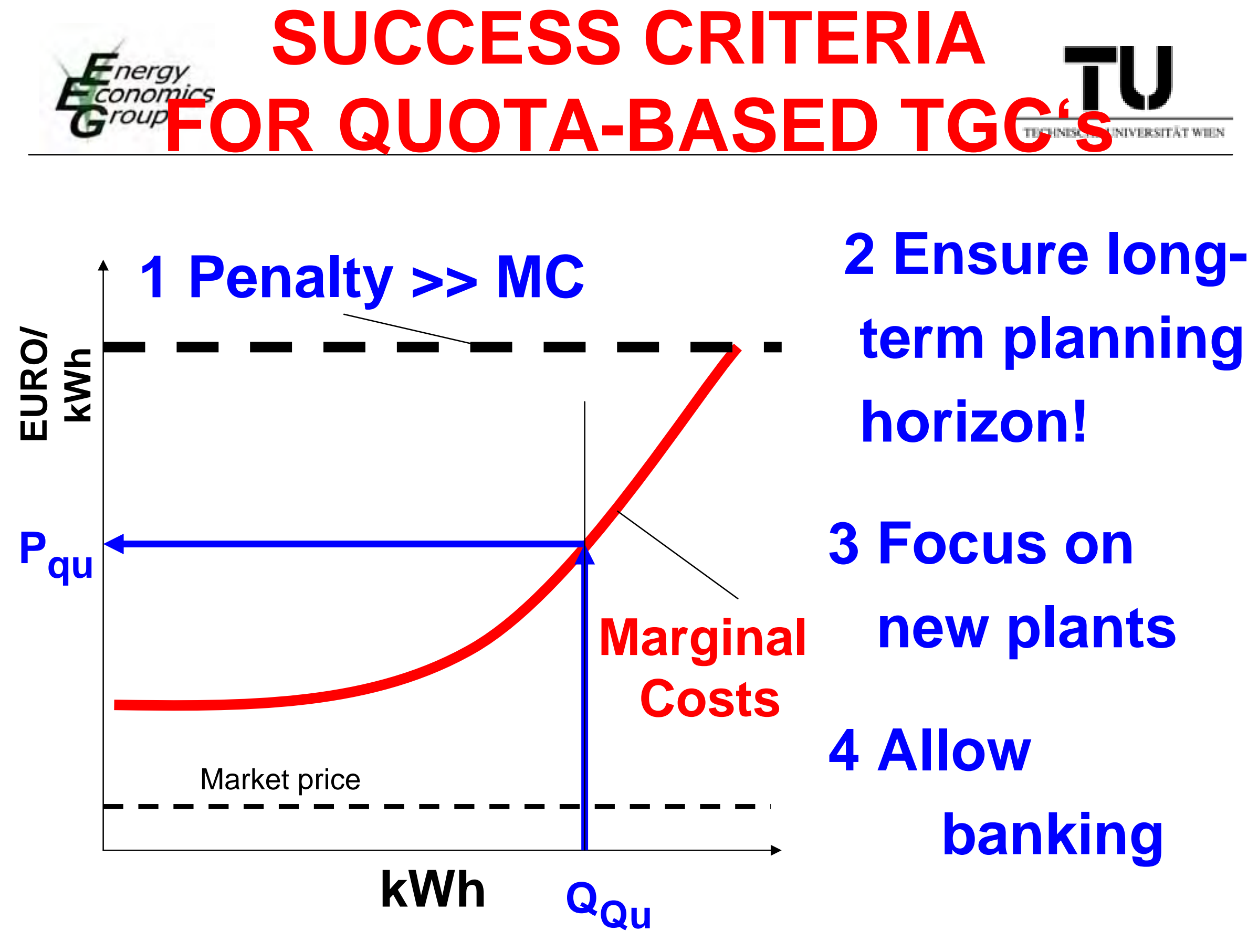
MAJOR PITFALLS FOR

1 Market to small: e.g. in a small country for one technology with very limited potential $->$ Non-Liquid because every single plant is known (e.g Flanders (BE))

2 Penalty is to low (e.g. UK)

3 Short planning horizon (e.g. UK 2003, Italy)

4 The problem of windfall profits for

(existing) capacities (e.g Flanders (BE),

Sweden) 
4. WHAT HAS BEEN ACHIEVED SO FAR AND WHAT CAN BE EXPECTED FOR THE FUTURE? 


\section{TOTAL ELECTRICITY}

\section{RENEWABLES IN EUROPE}

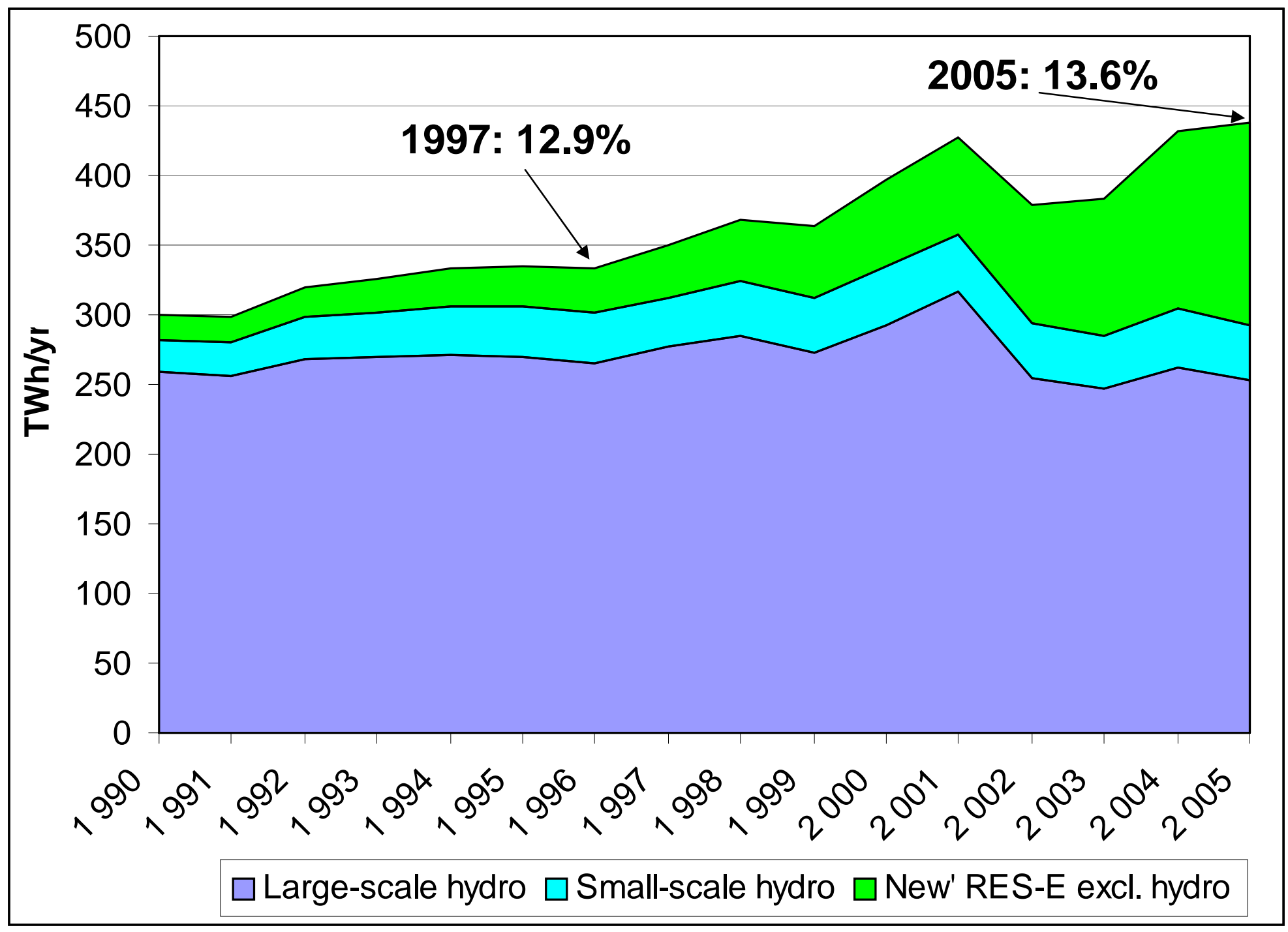


EEECTRICITY GENERATION TU
E EROM „NEW“ RENEWABLES IN EUROPE

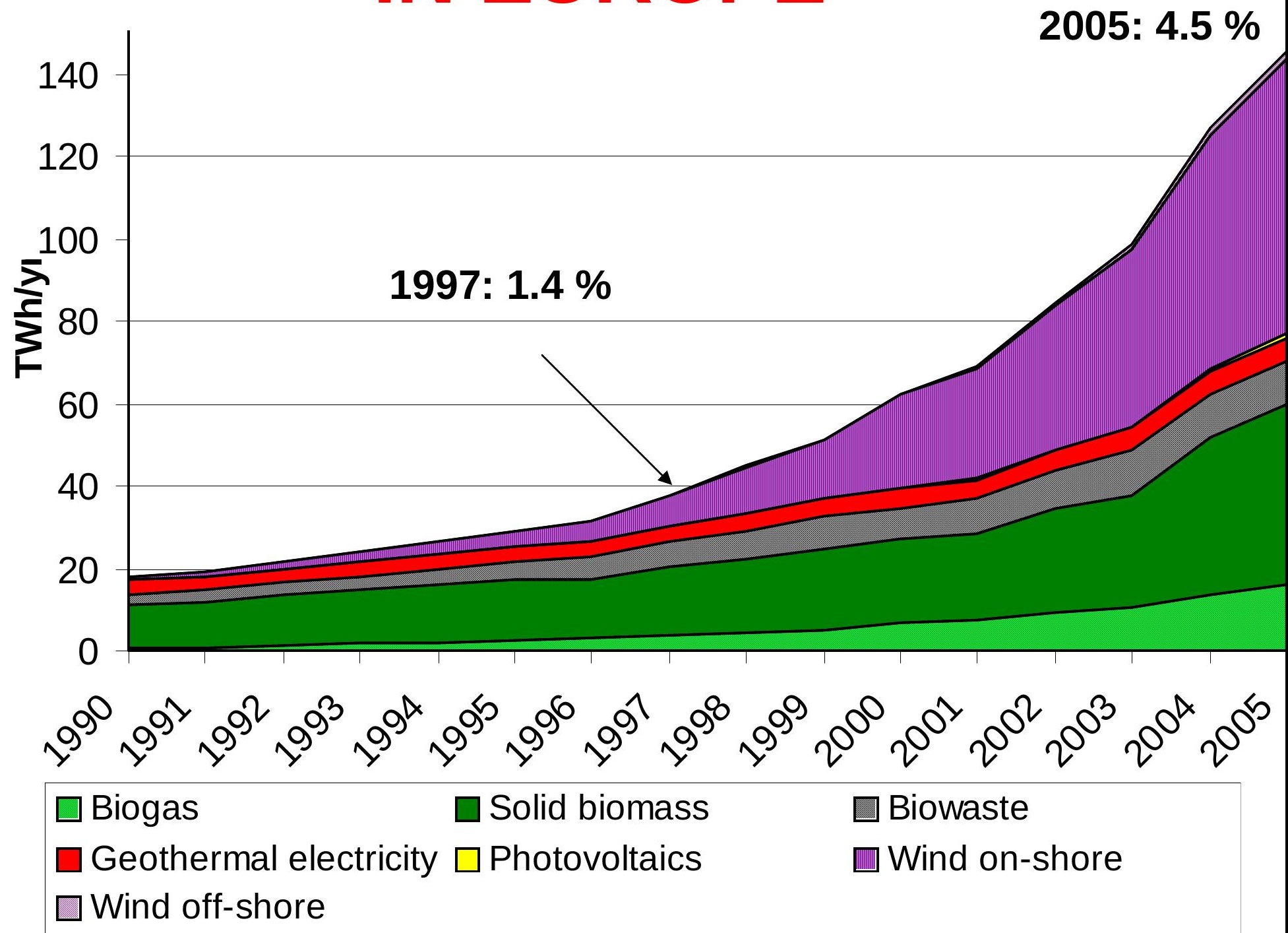




\section{GREEN-X: CASE STUDY 2020}

Lotalcurrent

electricity

consumption:

3200 TWh

\section{OPT \\ RES}

Investigated

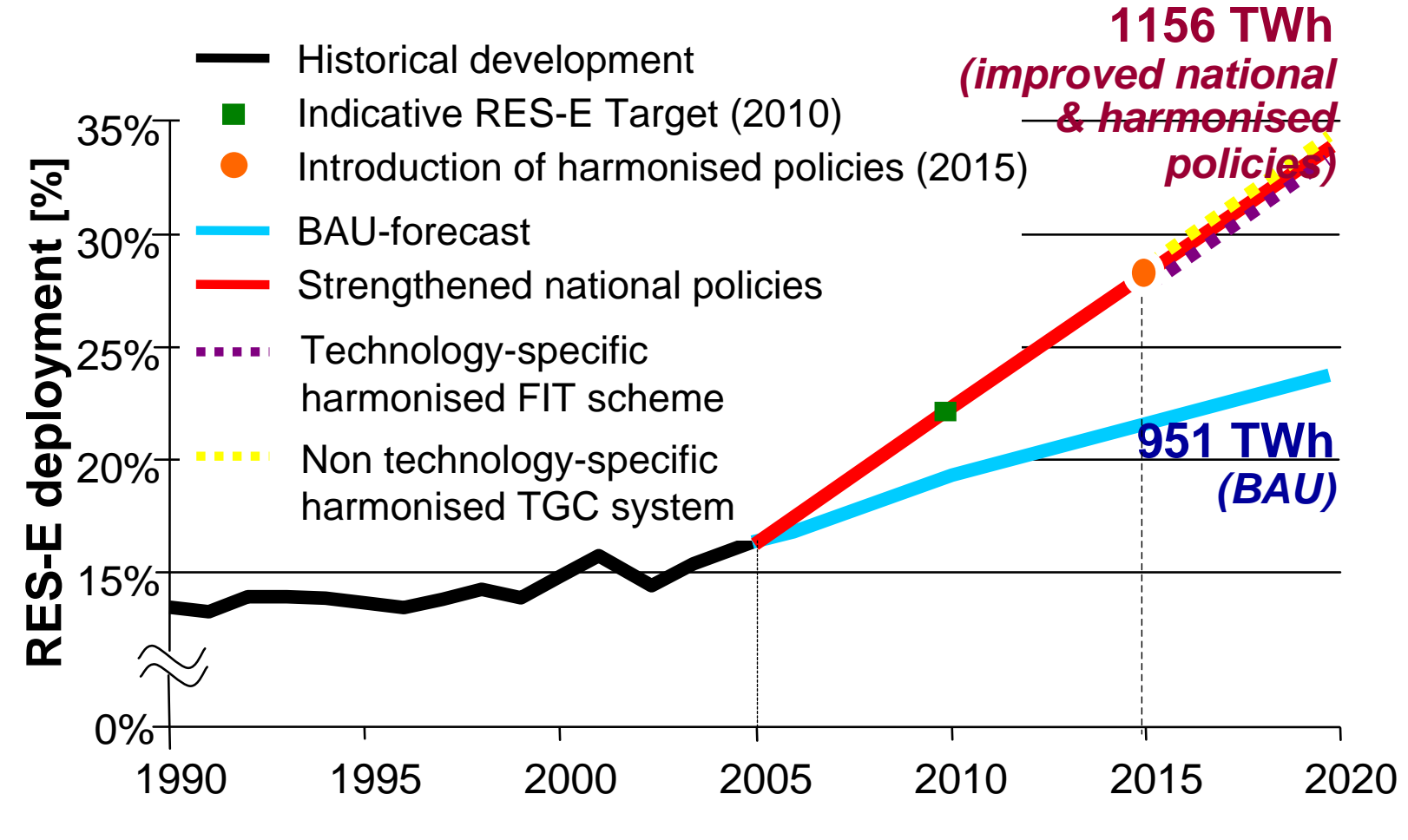

HARMONISATION IN 2015

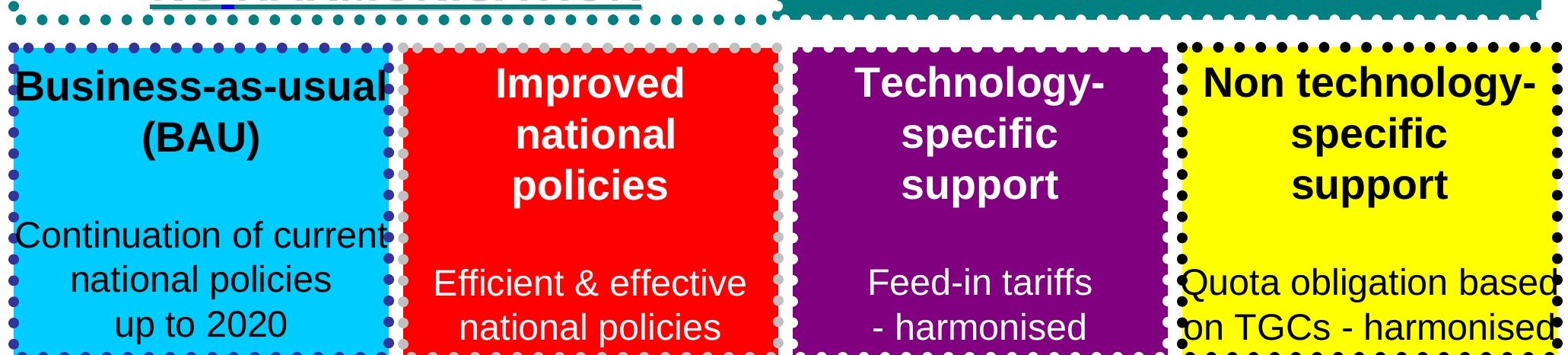

NO HARMONISATION

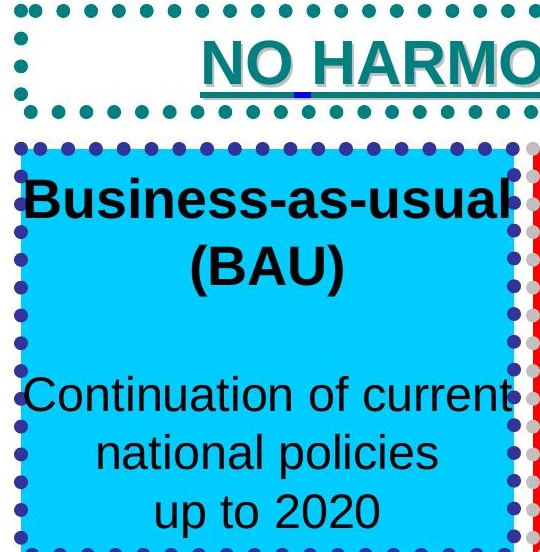

national policies
- harmonised cases: 
Total electricity generation from RES (EU25) as share of gross electricity de mand

BAU scenario ...kow far will we come with current RES policies?

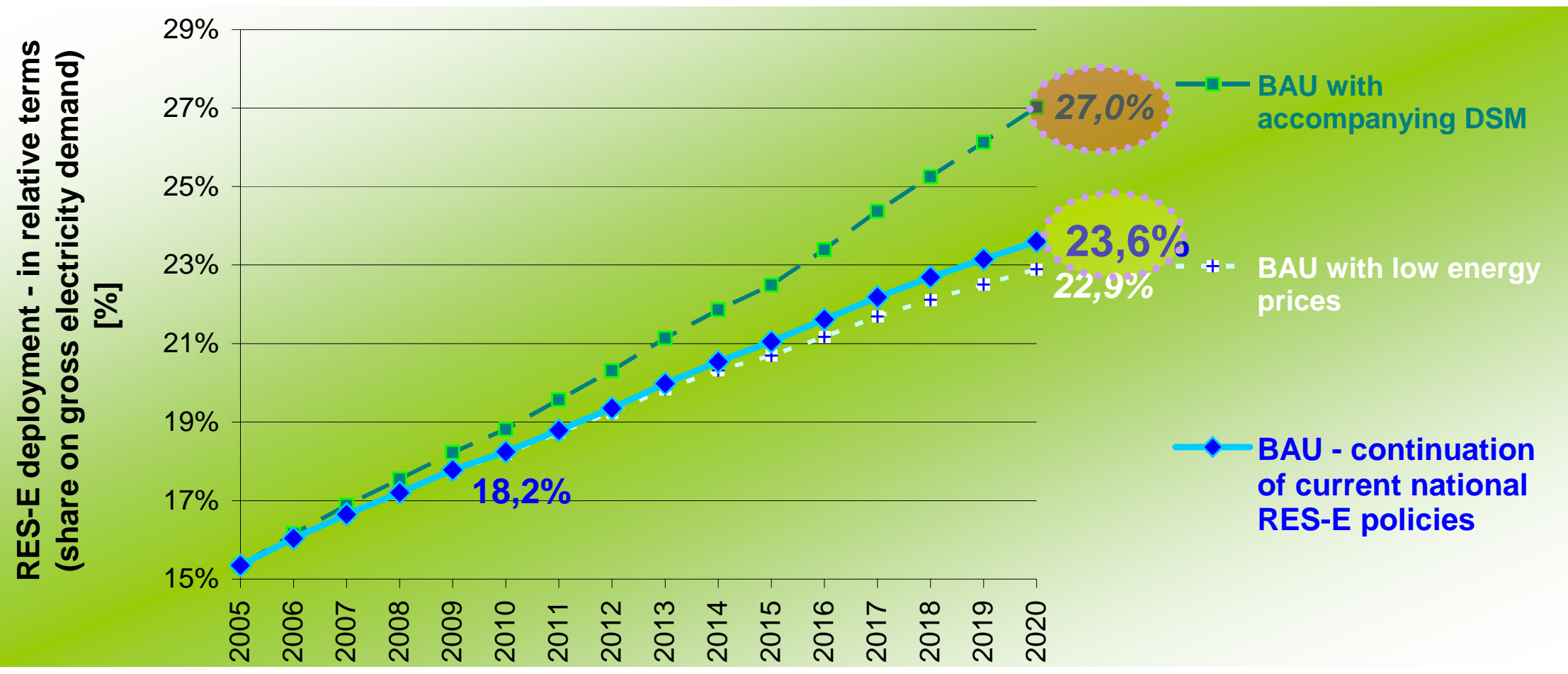

... the impact of an active DSM policy and: 
- conventional electricity market: To maximize profits utilities merge to avoid competition

- hard to imagine that a European-wide TGC market will work disconnected from these large incumbents

- TGC markets: Why should competition work if it does not in the conventional electricity market?

- Utilities/generators are in favour of TGC because they can make much more money and control the market, the construction of new plants much better 


\section{Ekgog Evans Group \\ 6. CONCLUSIONS (1)}

- We are far away from an optimal solution but we are on the way!

- Careful design of strategies:

by far the most important success criteria!

- There should be a clear focus on NEW capacities!

- To ensure significant RES-E deployment in the long-term, it is essential to promote a broad portfolio of different technologies

- Ensure credibility of the system! Avoid „stopand-go" approaches 


\section{Enoger Eamonins Group

- Currently, a well-designed (dynamic) FIT system nrovides a certain denlovment of RES-e fastest

IMPROVE THE CURRENT n SYSTEMS!

e.g. Feed-In-cooperation DE and ES -> vVny not a "Club" of TGC - countries (learning from SE)? 


\section{In the long run?}

- Re-regulation?

- Priority production from renewables should persist

- Ecological bonus of the magnitude of external cost relief could prevail "eternally" (at least as long as no environmental taxes are introduced)

- However, for sustainable policy -> parallel focus on demand-side conservation of high priority! 


\section{INTERESTED IN}

\section{FURTHER INFORMATION?}

- Download reports from:

www , eeg , tuwien . ac . at

www - green-x at

www . optres . fhg . de

- E-Mail to:

Reinhard.Haas@ @uwien.ac.at 


\section{Technical Change/2}

The cost of the cellulosic biofuels, $P_{A D V B I O}(n, t)$, is modeled as decreasing with investments in dedicated R\&D through a power formulation:

(7) $\quad P_{\text {ADVBIO }}(n, t)=P_{\text {ADVBIO }}(n, 0) \cdot\left(T_{O} T_{R \& D, A D V B I O}(n, t)\right)^{-\eta}$

where $\eta$ for the relationship between new knowledge and cost and $L A G=2$

(8)

$$
\operatorname{TOT}_{R \& D, A D V B I O}(n, t)=\sum_{n} K_{R \& D, A D V B I O}(n, t-L A G)+\sum_{\tau=t-1}^{t} I_{R \& D, A D V B I O}(n, \tau)
$$

Spillovers: different assumptions on completeness of spillovers (through lag time) 


\title{
Perspectives of the IDA Energy Year 2006 project
}

\author{
Per Nørgård \\ Risø DTU, Denmark
}

Henrik Lund and Brian Vad Mathiesen

Aalborg University, Denmark 


\section{The Danish Society} of Engineers Energy/Plan 2030 


\section{IDA Energy Year 2006 project}

\section{A one-year process}

- Involving 1600 professionals

2 conferences

- Jan 2006: Opening

- Dec 2006: Concluding

40 workshops

- knowledge workshops

- vision workshops

- roadmap workshops

Energy technologies in 2030

- performance

- price
7 themes:

- Buildings

- Transport

- Wind, sun \& waves

- Fuel cells, hydrogen, bio \& batteries

- Oil \& gas

- Industrial processes

- Energy systems 


\section{IDA objectives}

\section{by year 2030}

- environment

to reduce the $\mathrm{CO} 2$-emission by $50 \%$

- energy

to maintain the security of energy supply

- business

to increase the technology export by $200 \%$ 


\section{Danish Board of Technology - Energy Combi Scenario}

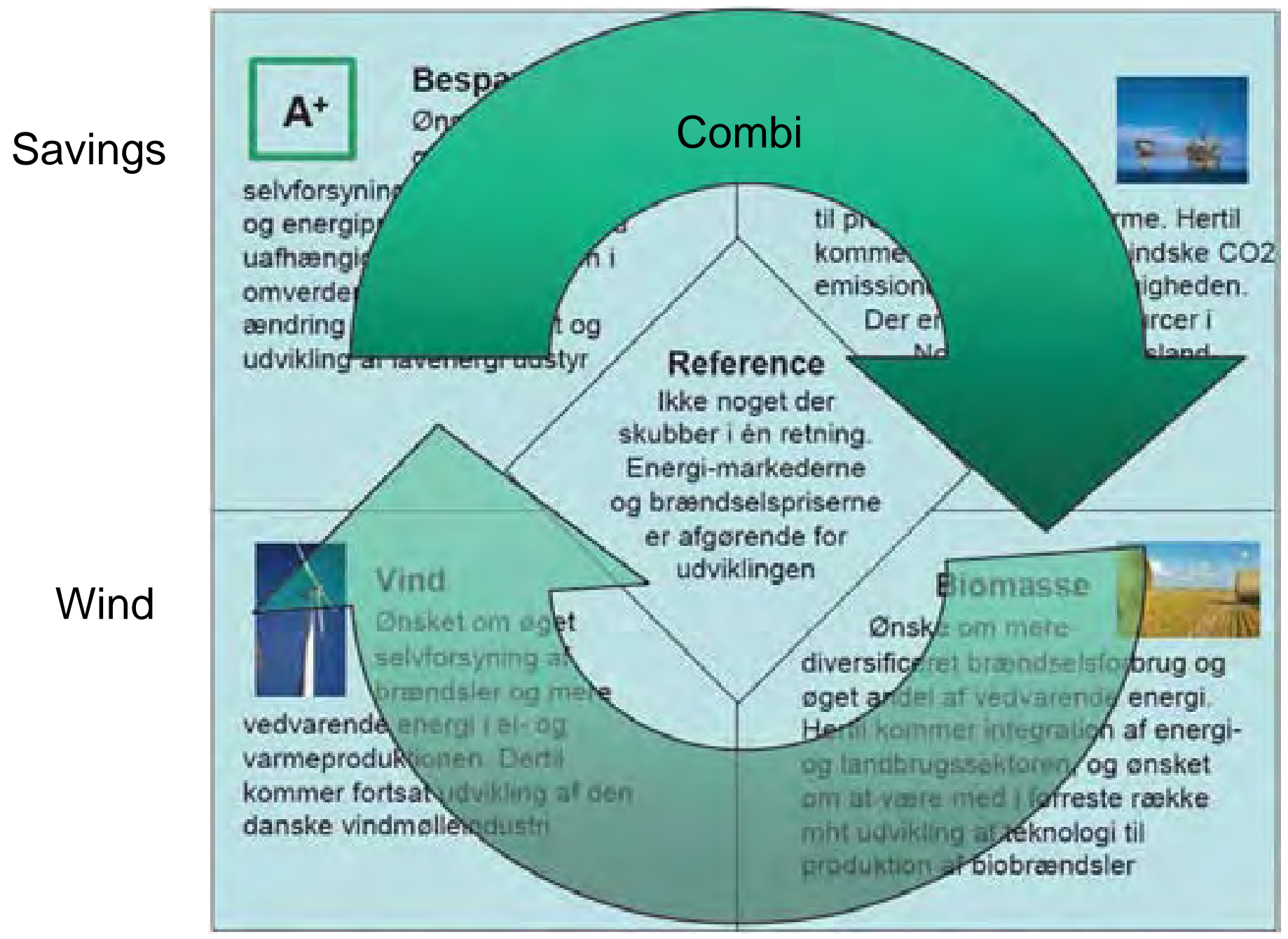

Energy+

Bio

Per Nørgård - Risø International Energy Conference, May 2007 


\section{Reference scenario}

\section{DK Energy Strategy 2025}

- by The Danish Energy Authority, for The Danish Ministry of Transport and Energy, 2005

- IDA: 2025 -> 2030

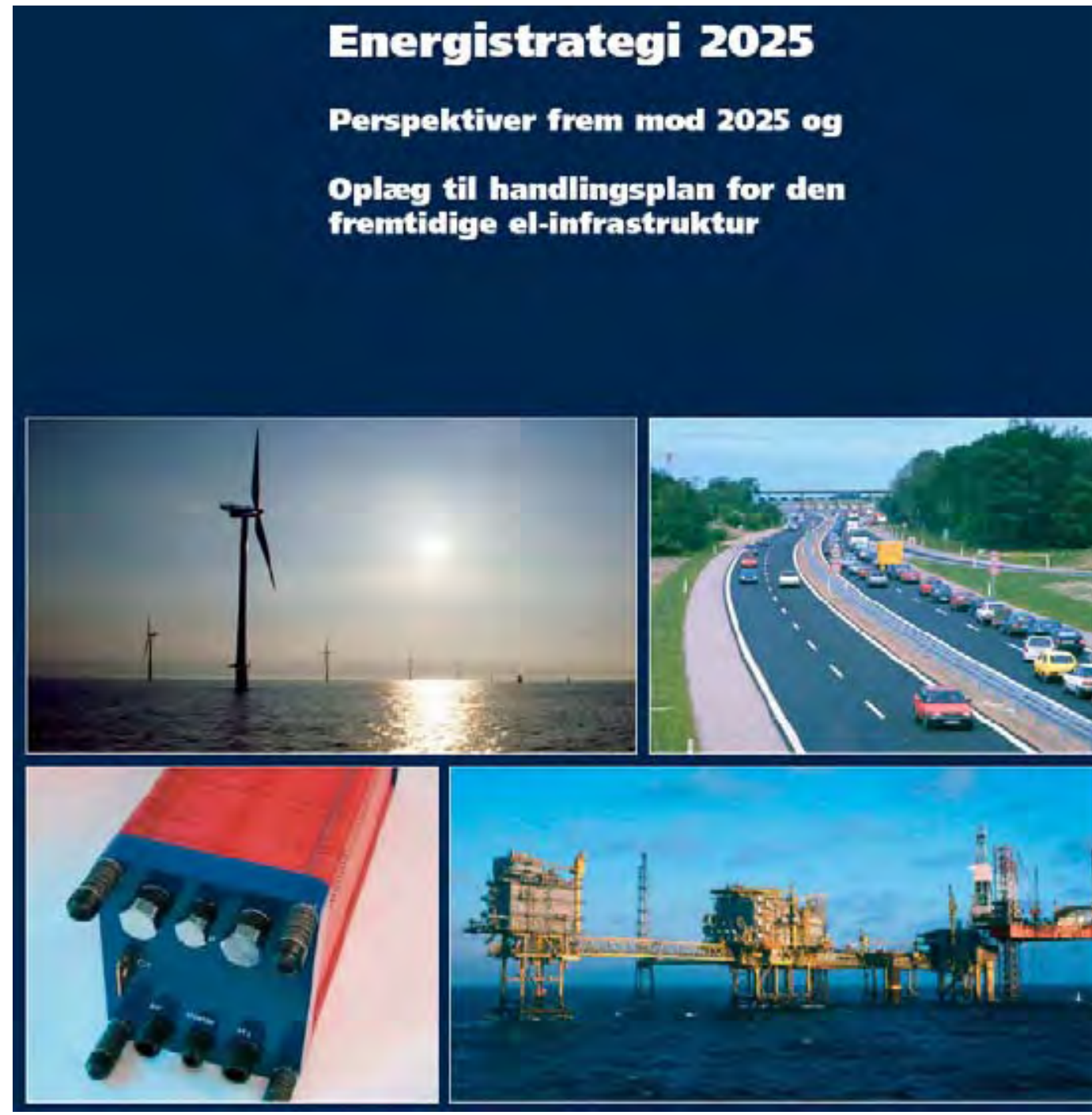

Oplaeg til handlingsplan for den fremtidige el-infrastruktur 


\section{Reference - DK oil and gas}

mia. $m^{3}$

$\begin{array}{llllllllllll}1980 & 1984 & 1988 & 1992 & 1996 & 2000 & 2004 & 2008 & 2012 & 2016 & 2020 & 2024\end{array}$ 


\section{EnergyPLAN - Energi System Analyse Model}

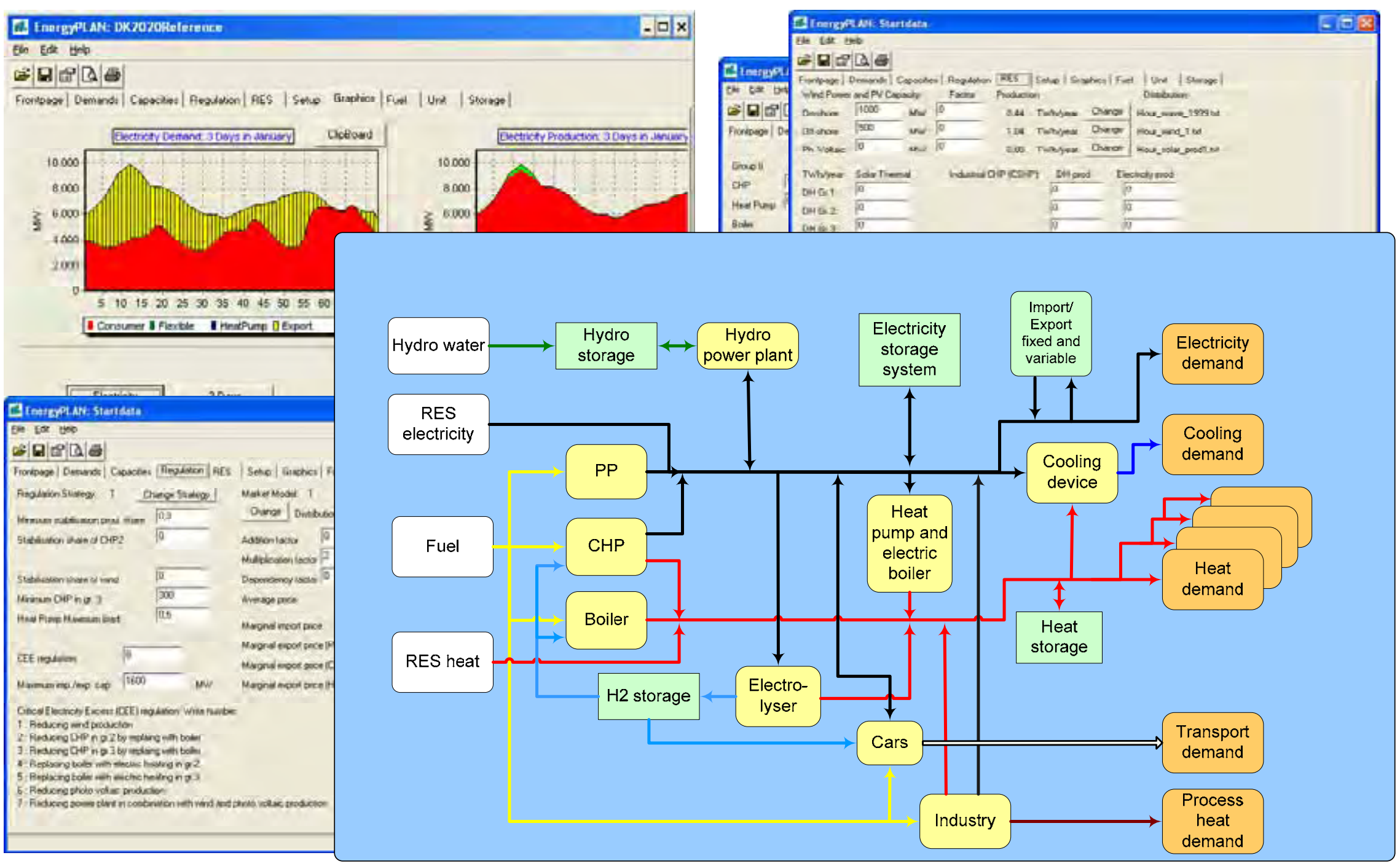

Per Nørgård - Risø International Energy Conference, May 2007 


\section{EnergyPLAN simulation}

\section{EnergyPLAN characteristics:}

- Time series analysis on hourly basis

- All energy exchange in one node

- Links between energy sectors

- Include energy storage

\section{EnergyPLAN simulations include:}

- Heat buffer capacity in district heating systems

- Conversion from electricity to heat by heat pumps

- Electricity buffering by electrical cars 


\section{Measures}

\section{Buildings}

- Energy for space heating: -50 \% relative to Ref 2030

- Solar heating: $30 \%$ of heating

- Electricity consumption: $-50 \%$ relative to Ref 2030

\section{Industry}

- Fuel consumption: $-40 \%$ relative to Ref 2030

- Electricity consumption: $-30 \%$ relative to Ref 2030

- Industrial CHP: $+20 \%$ electricity

- Biofuels: +80 PJ 


\section{Measures}

\section{Wind, sun, wave}

- Wind:

+3000 MW

- Wave:

$5 \%$ of electricity in 2030

- Photovoltaic:

$2 \%$ of electricity in 2030

\section{Oil \& gas}

- North Sea: -45 \% CO2 emission 


\section{Measures}

Transport

- Stabilising the total persontransport work

- Air traffic: 50\% -> 30\% increase (2005 - 2030)

- $20 \%$ transport work from road to rail and ship

- Energy efficiency: +30 \%

- Biofuels in 2030: $20 \%$

- Electricity in 2030: $20 \%$

\section{Biomass}

- In 2030: $30 \%$ of primary 


\section{Results - Primary energy supply}

Peta joule (PJ)

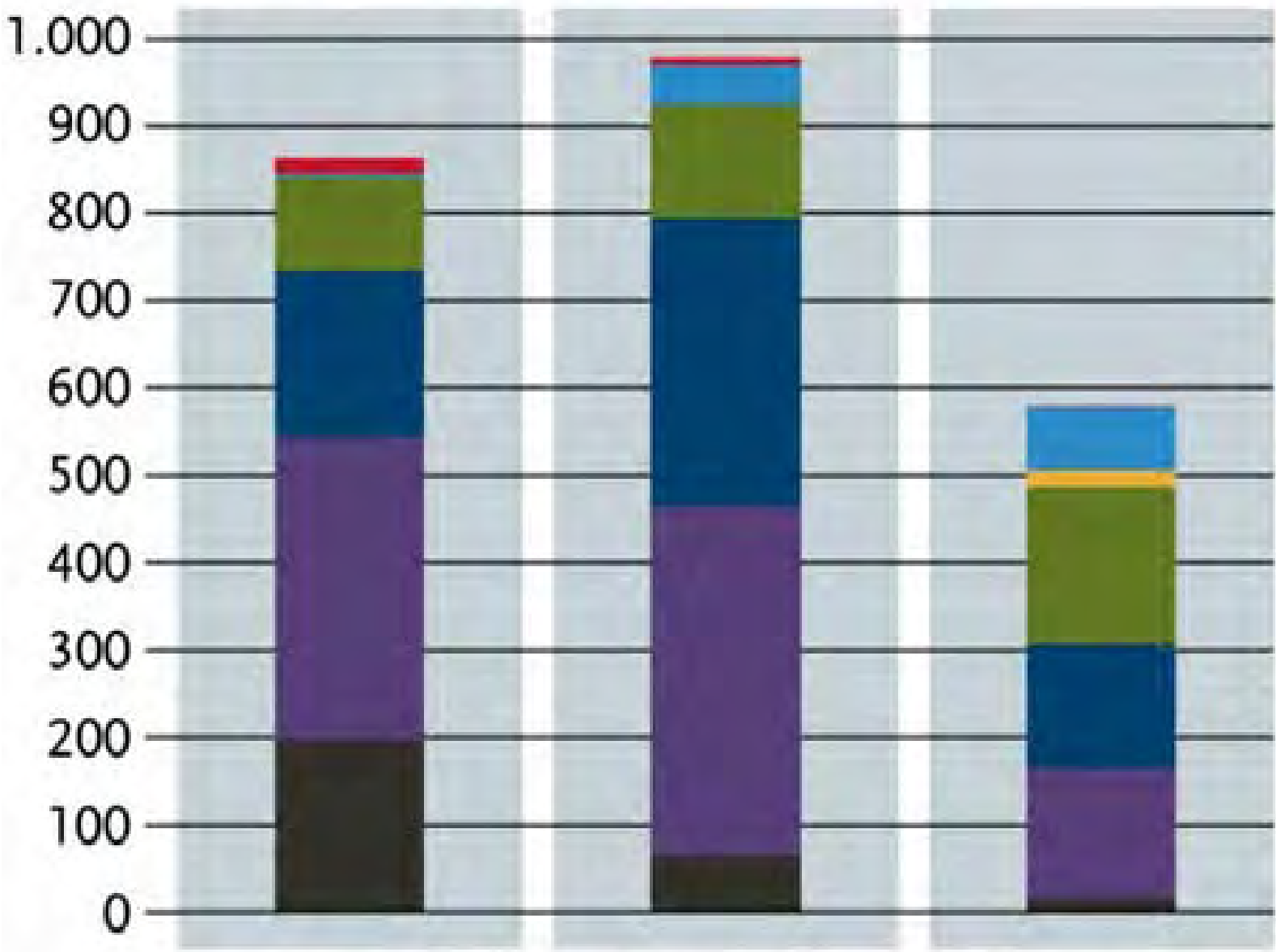

Export

RE electricity

Solar thermal

Biomass

Natural gas

Oil

Coal

2004

Ref. 2030

IDA 2030

Per Nørgård - Risø International Energy Conference, May 2007 


\section{Results - CO2 emissions}

\section{Million ton per year}

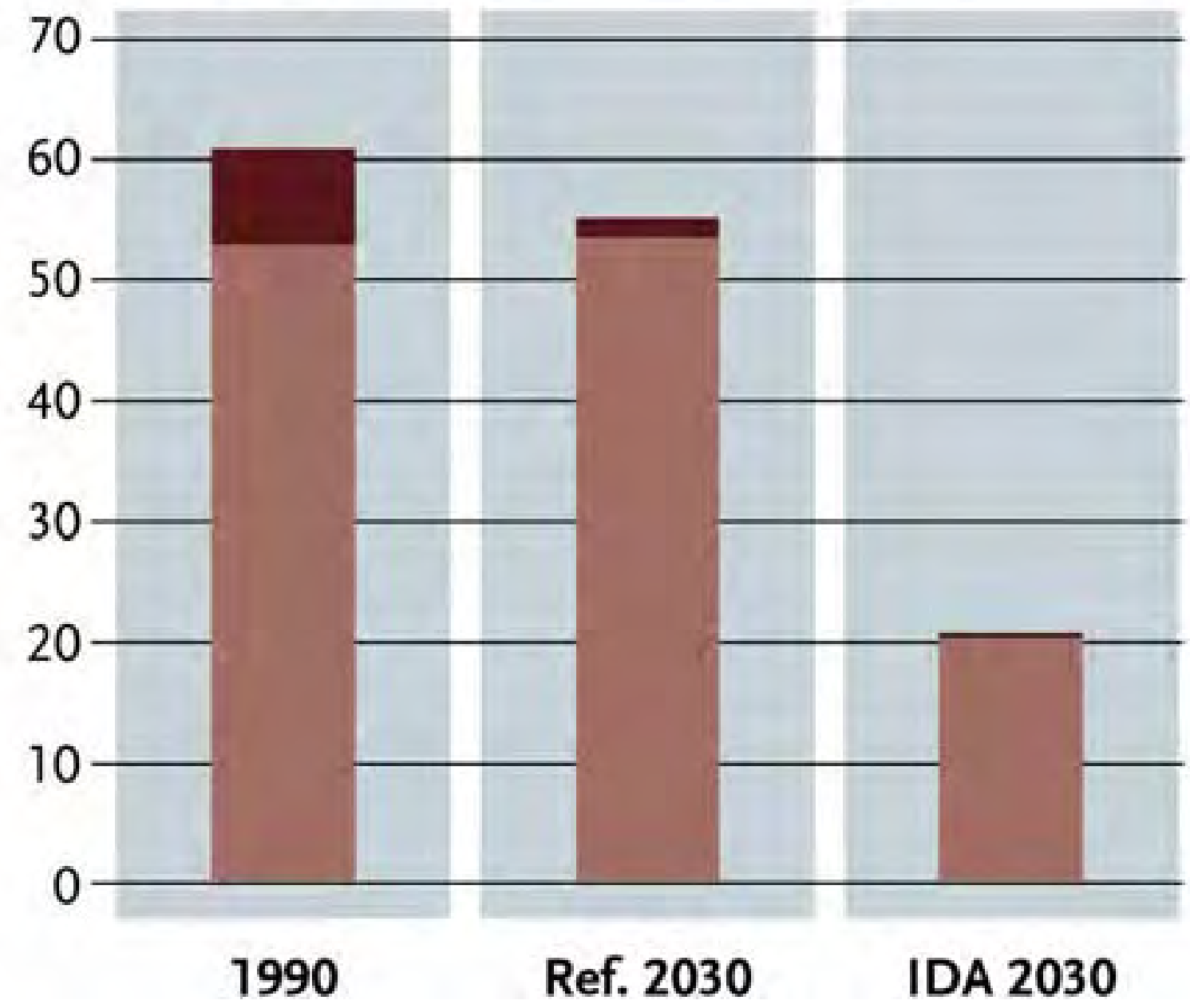

Export

Danish demand

Per Nørgård - Risø International Energy Conference, May 2007 


\section{Results - Business potential}

\section{Export in billion DKK per year}

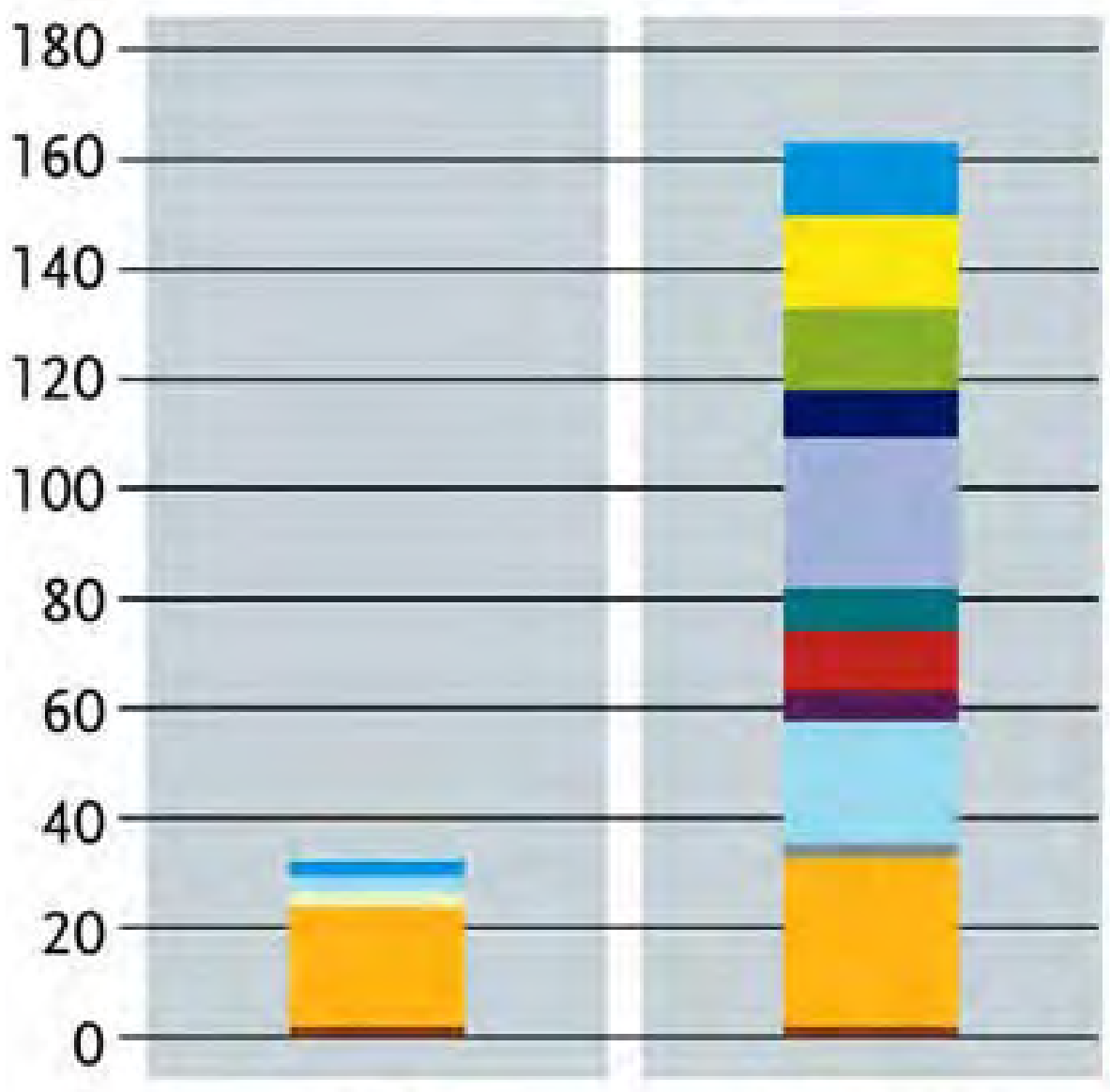

2004
Energy-efficient renovation

Biofuels

Bioethanol

Heat pumps

Fuel cells

Wave power

Solar thermal

Photovoltaics Management and measuring

Electricity, oil and gas management Wind power

District heating and CHP 


\section{Results - Economic costs}

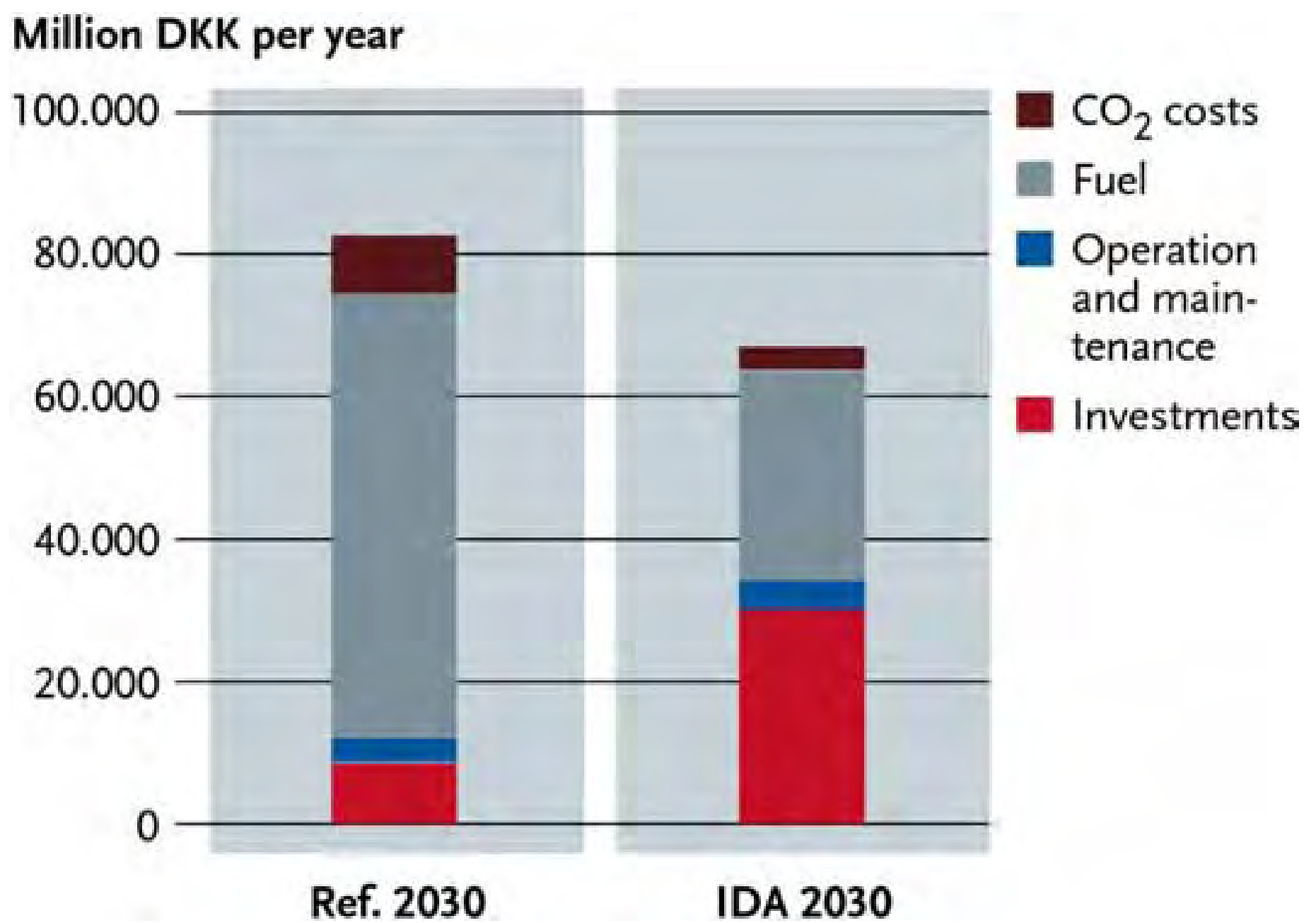




\section{Sensitivity analysis}

Fluctuating oil prices

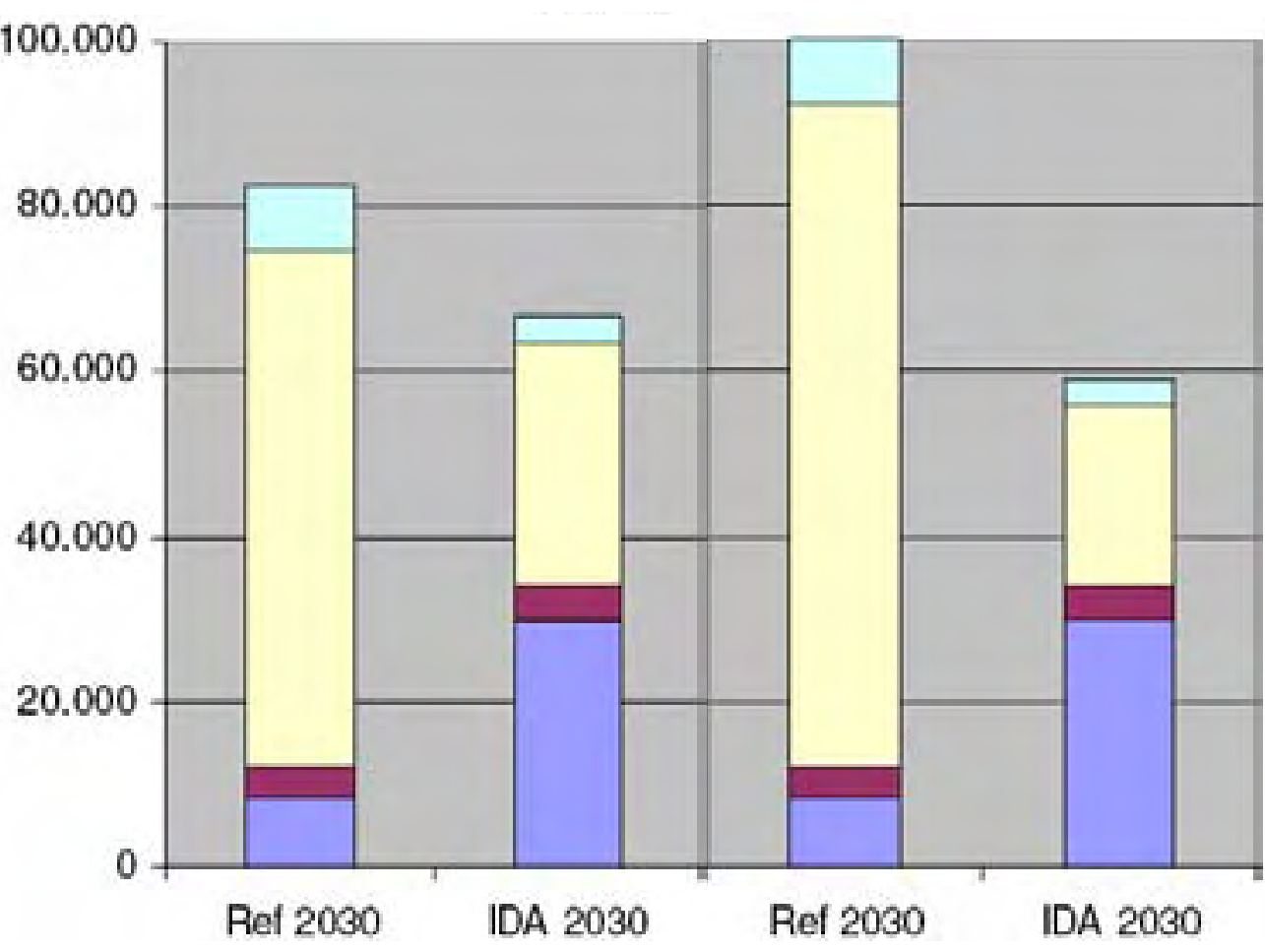

$+50 \%$ investment costs $6 \%$ interest rate

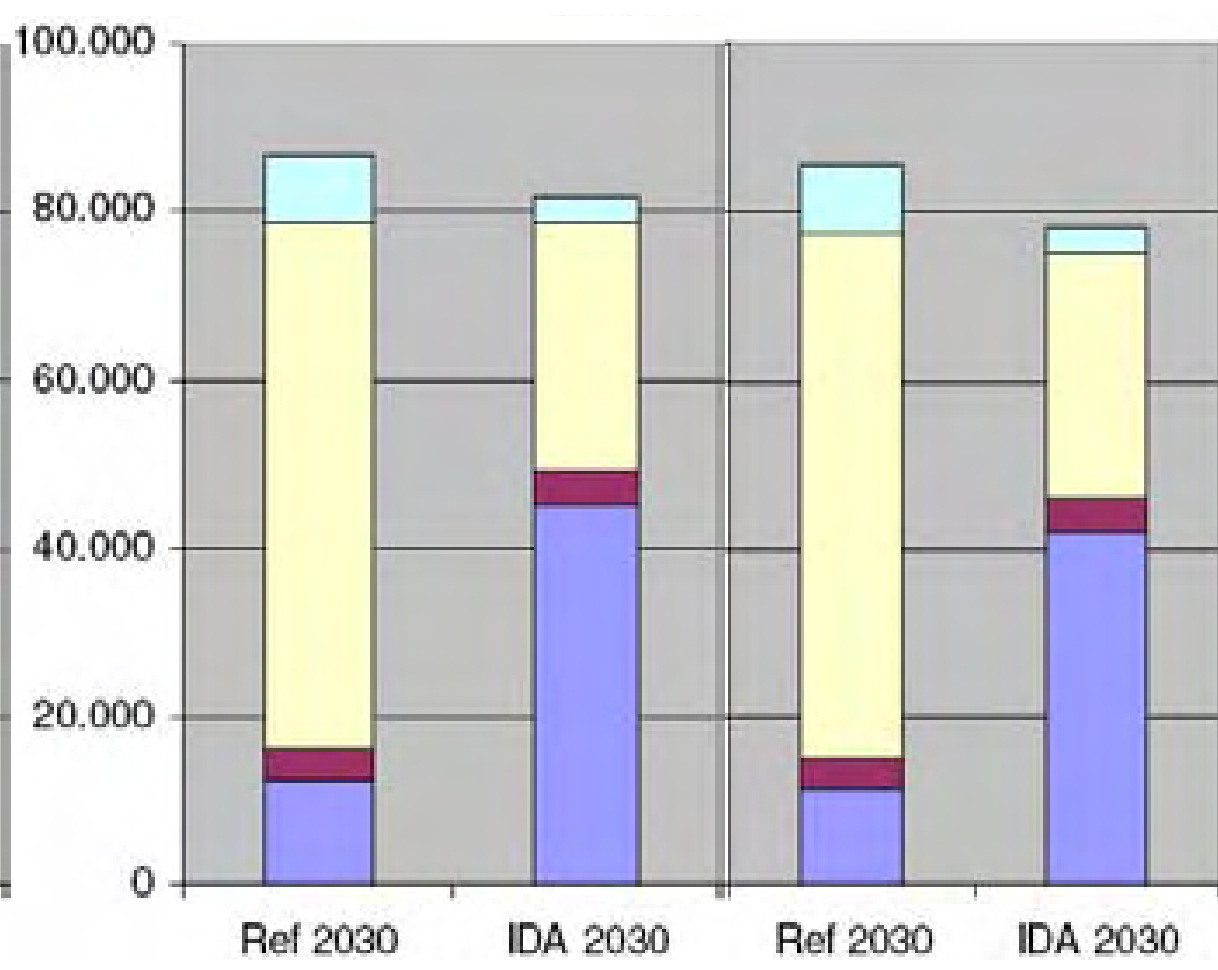

Per Nørgård - Risø International Energy Conference, May 2007 


\section{Conclusion}

The actual figures indicate:

- Energy: $-40 \%$

Ref 2030: $1000 \mathrm{PJ}$

IDA 2030: $600 \mathrm{PJ}$

- CO2 emission: -60 \%

1990: 50 mio ton

IDA 2030: 20 mio ton

- Fossil fuels: $-65 \%$

Ref 2030: $800 \mathrm{PJ}$

IDA 2030: $300 \mathrm{PJ}$

- Technology export: $+500 \%$

DKK 30 billion @ 2005

DKK 160 billion@ 02030

- Costs: $-20 \%$

Ref 2030: DKK 80 billion

IDA 2030: DKK 65 billion
It is both technical possible and economic feasible at the same time in $\mathbf{2 0 3 0}$ to achieve:

- less total energy consumption,

- less total CO2-emission,

- less fossil fuels consumption and

- increased technology export

- even at reduced economic costs.

Sustanable solution can only be achieved through:

- Energy conservation

- Energy efficiency

- System solutions

- Flexibility

- Couplings between energy sectors 
Elbesparelse i husholdningen Rumvarmebesp. i fjernvarmeområdet Rumvarmebesp. uden for fjernvarmeomr.

Solvarme, små individuelle

Solvarme, store i fjernvarmeområder

Elbesparelse i industrien Brændselsbesparelse $\mathrm{i}$ industrien

Biomasse $\mathrm{i}$ industrien Effektiviseringer på Nordsøen Nulvækst i persontransport Mindre vækst i luftfarten Kollektiv trafik Elbiler

Effektiv vejtransport Bioethanol i vejtransport Mikro brændselscelle kraftvarme Fjernvarmeudvidelse

Store brændselscelle kraftvarme Vindkraft Bølgekraft Solceller

Varmepumper i fjernvarmeomrảder Fleksibelt elforbrug
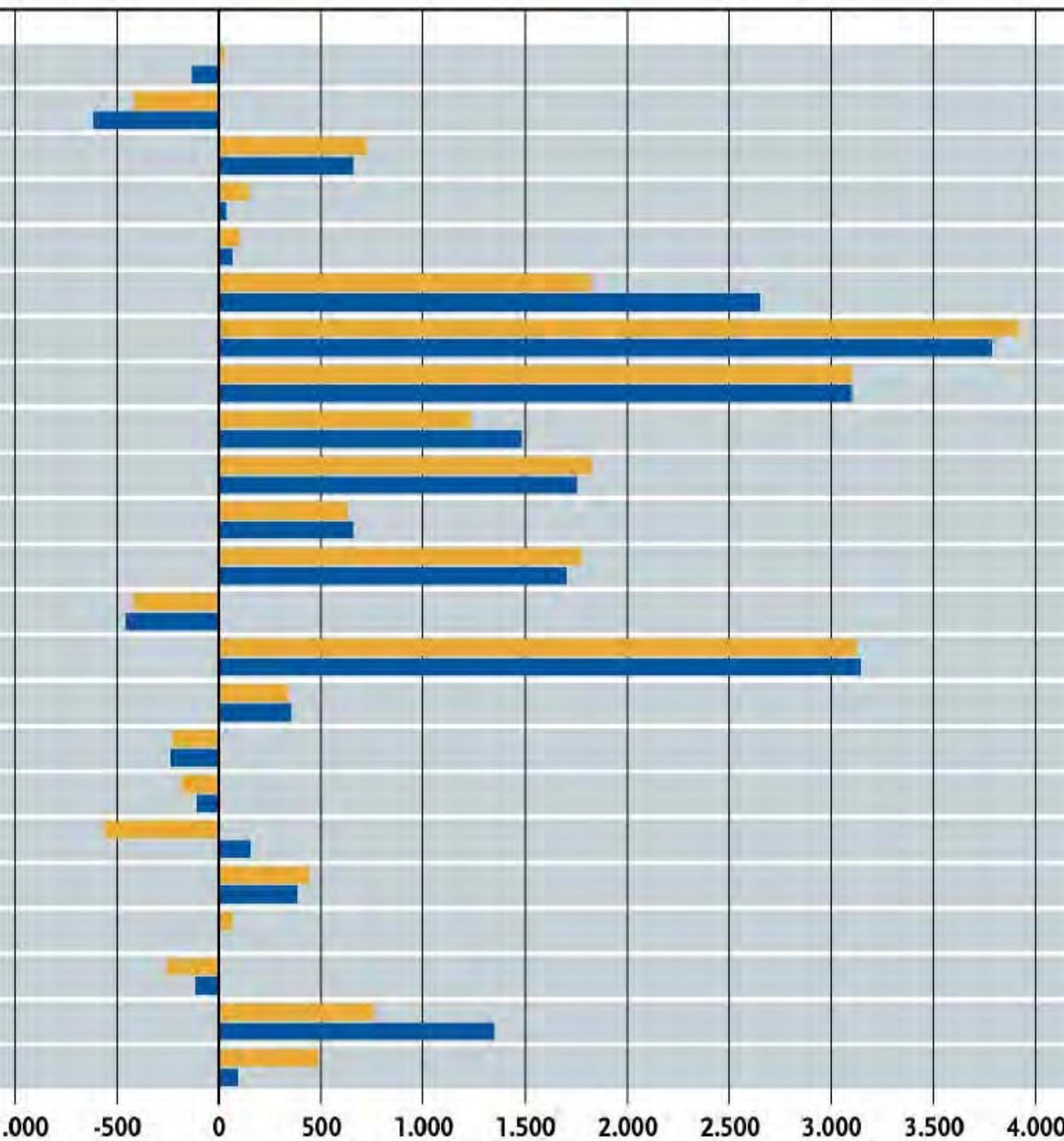


\section{Example: The IBUS bio-refinery concept}

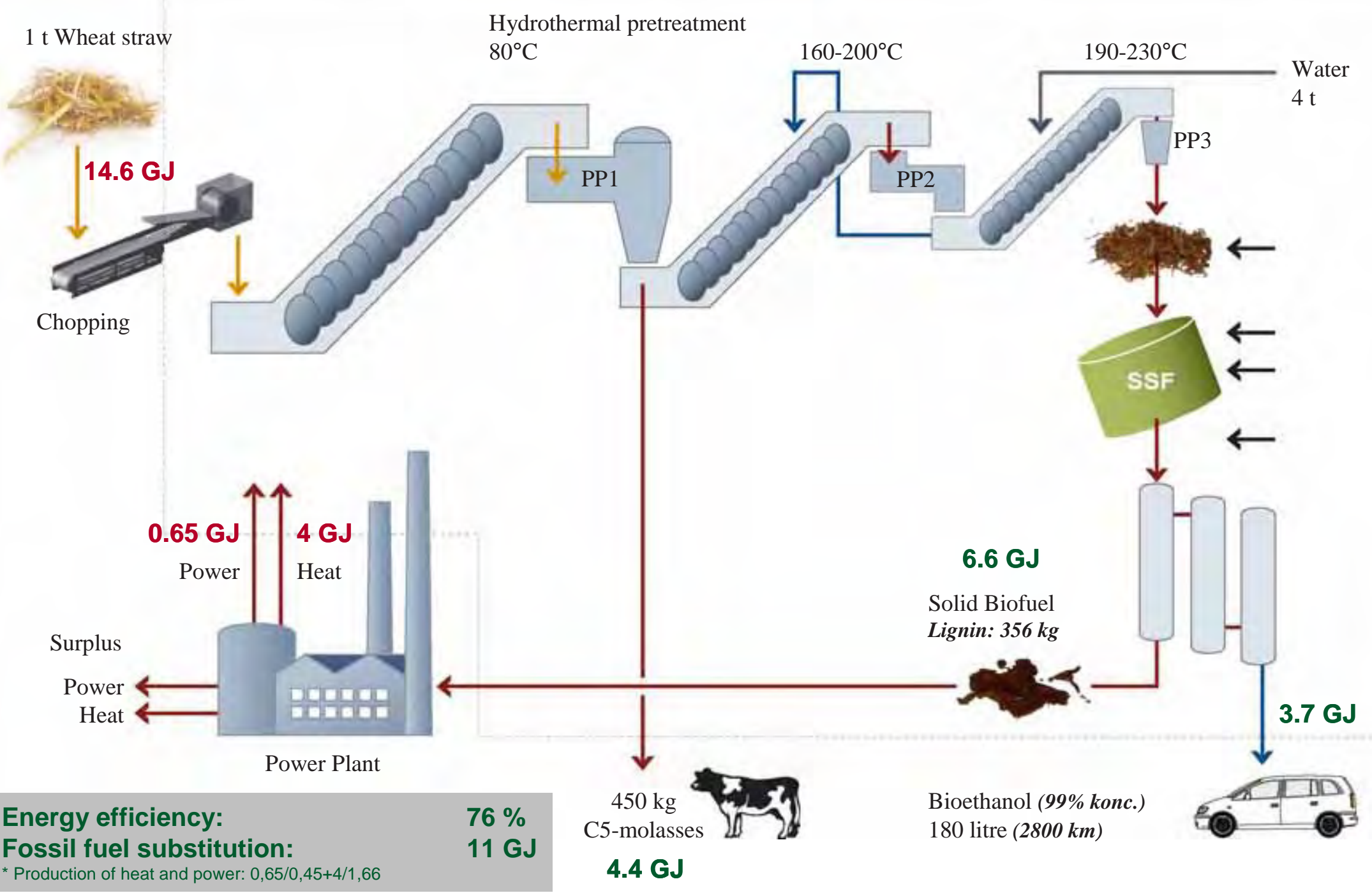

Per Nørgård - Risø International Energy Conference, May 2007 


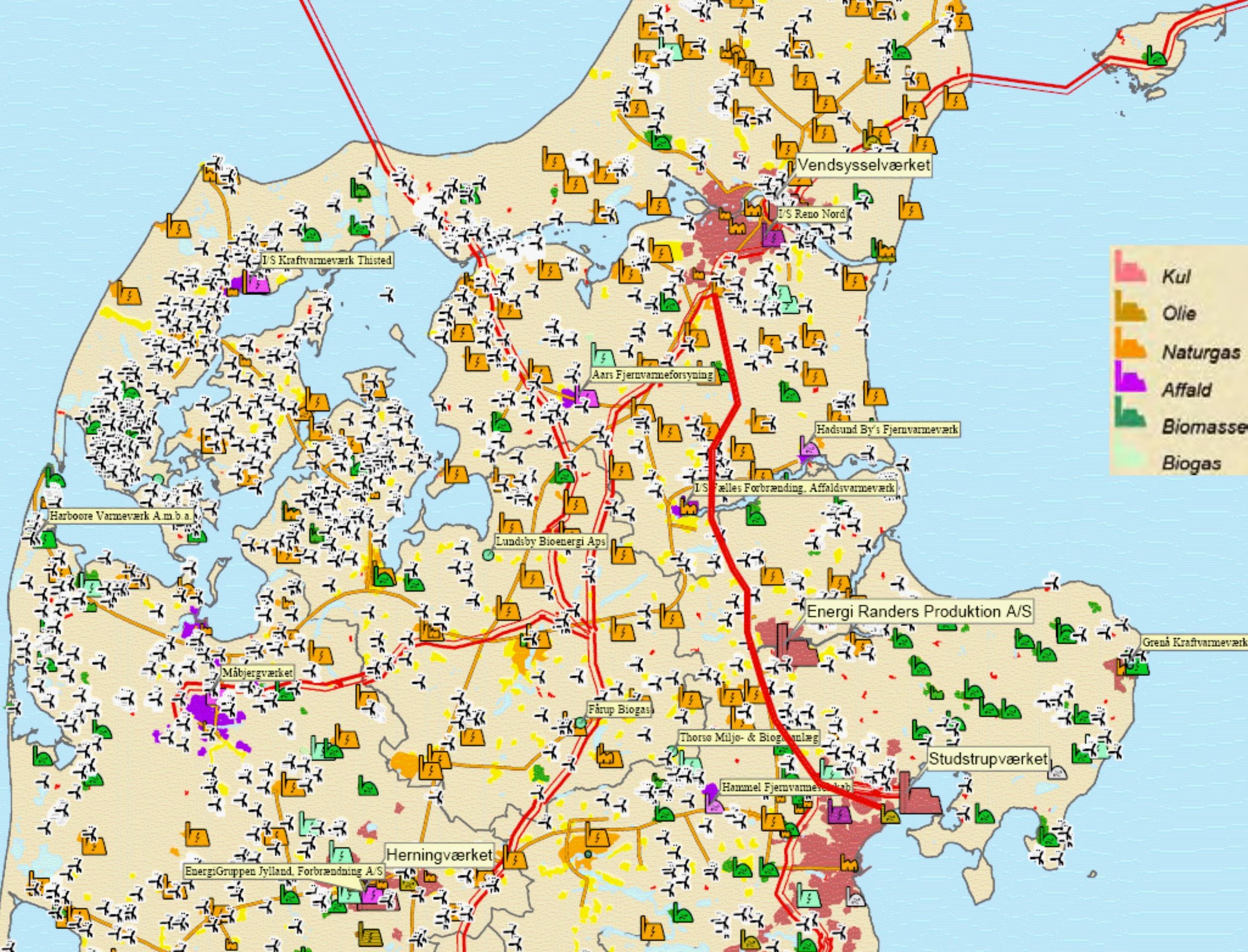




\section{Some of challenging discussions at IDA workshops}

\section{Buildings}

- New building energy standards - but $70 \%$ of the buildings in DK in 2030 are from before today

- District heating infrastructure in the future?

Biomass feedstock is a limited resource

- CO2-reduction: CHP

- Independency of oil: transport

- Business: bio fuels technologies

- Biomass for energy -> increased food prices

\section{Transport sector}

- Energy efficient technologies are present - but are not introduced!

- $-10 \%$ person road transport -> +50 \% rail transport

- Energy and CO2 related to international transport not included!

- International person transport: alternatives to fly? 


\section{IDA recommendations ( $€ 1.5$ billion / year)}

- The existing agreement on energy savings should be extended and continued (1.7\% annual reductions in energy consumption).

- An industry energy savings fund should be established ( $€ 100$ mio annually).

- A heat conservation fund should be established ( $€ 100$ mio annually).

- $€ 30$ billion should be invested in the Danish rail road system over the next 30 years.

- The Danish national funds for research, development and demonstration should be increased to $€ 100$ mio annually.
- Innovation markets for renewable energy technologies should be established by quotas in order to accelerate the development.

- All costs - including externalities - should be included in the market prices.

- Popular engagement in energy savings and renewable technologies should be supported.

- CO2 quotas should be sold through biddings.

- A thorough service control of all energy taxes and tariffs should be made.

- $100 \%$ renewable energy cities should be established in Denmark. 


\section{Follow-up}

ftri

Transport of

Enengiministerict

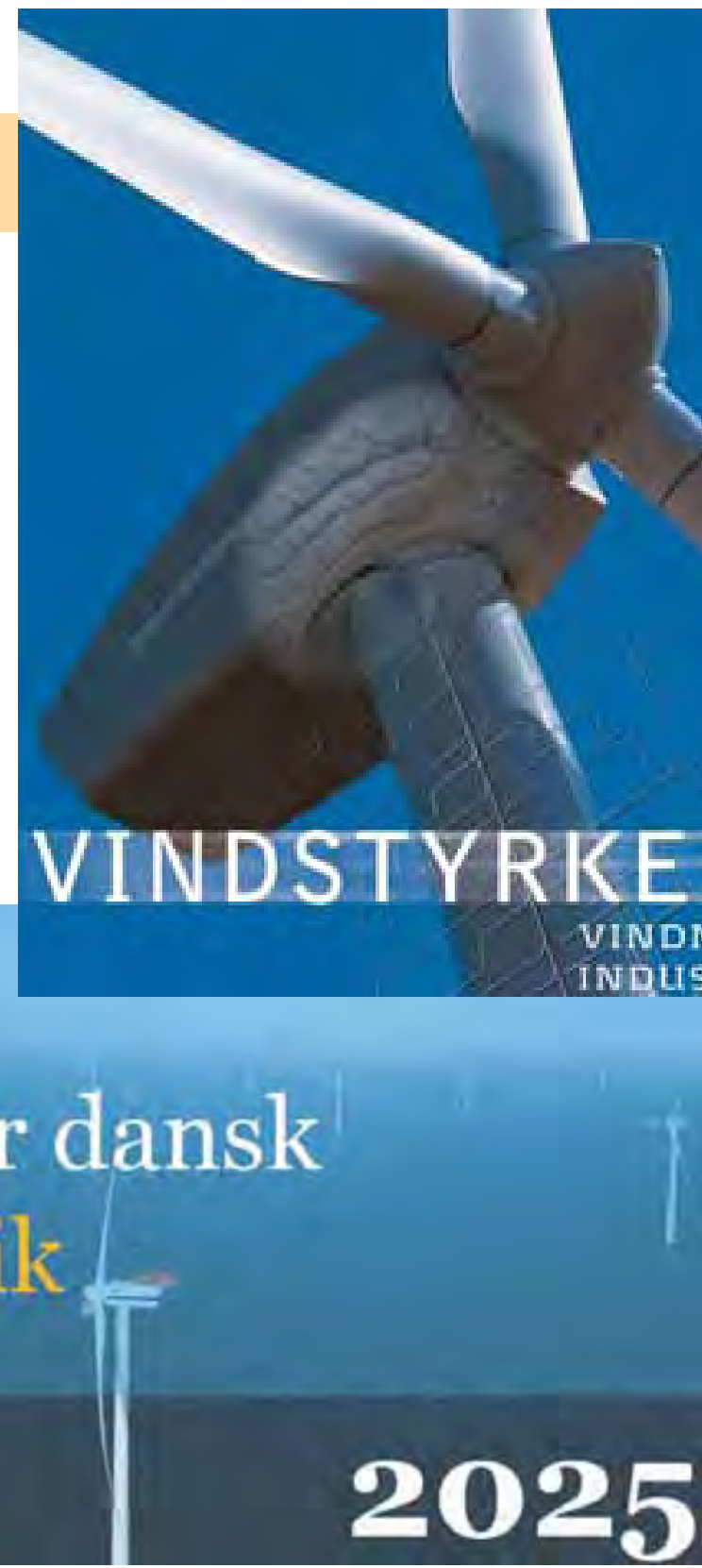

En visionær dansk energipolitik

Januar 2007

Per Nørgård - Risø International Energy Conference, May 2007
CLIMATE CHANGE 2001

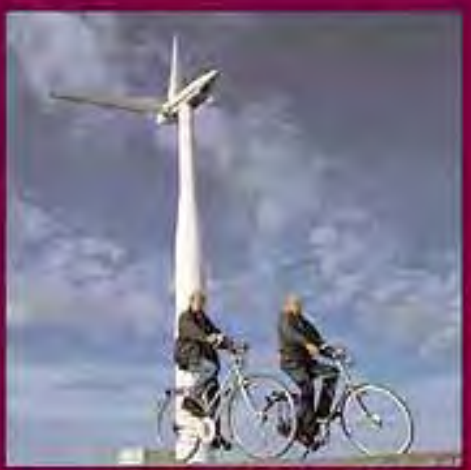

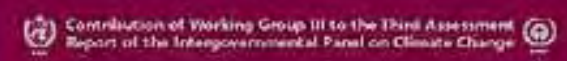
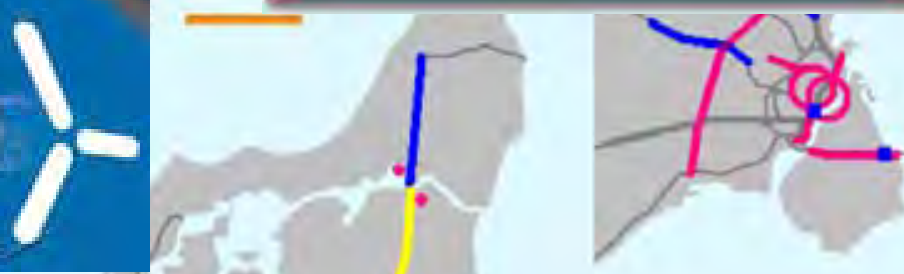


\section{Thanks}

\section{per.norgaard@risoe.dk}

http://ida.dk/Netvaerk/Energiaar+2006 

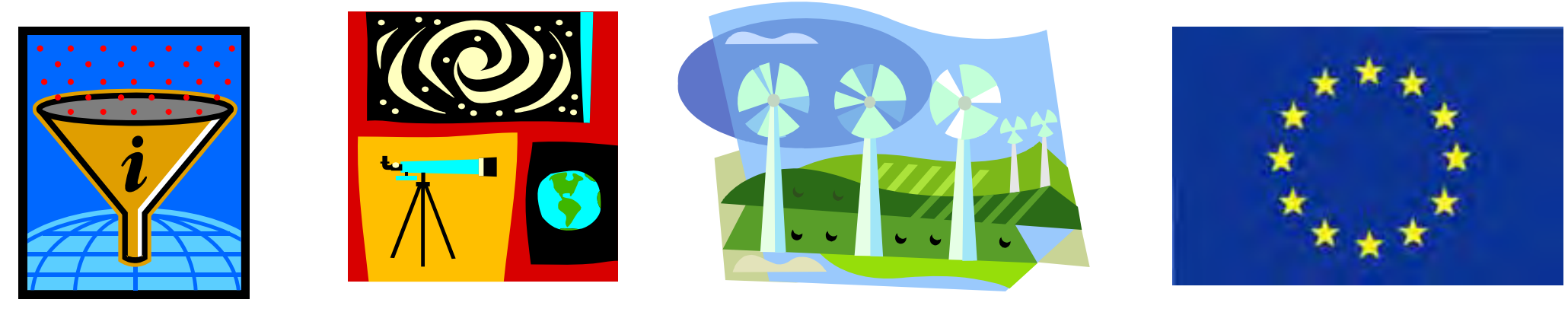

\section{Integrated European Energy $R \mathcal{T} \mathcal{D}$} as part of the innovation chain to enhance renewable energy market breakthrough

\section{Professor Peter Lund} Helsinki University of Technology, Finland peter.lund@tkk.fi

Risö I nternational Energy Conference 2007 22-24 May 2007 
Observations from the past on market penetration of new energy technologies

- It may take decades to reach a noteworthy share on world markets

- The public support required to bring a new major energy source into world-scale may be some fundred billion dollars in total

Figure. Penetration of selected energy technologies (MW).

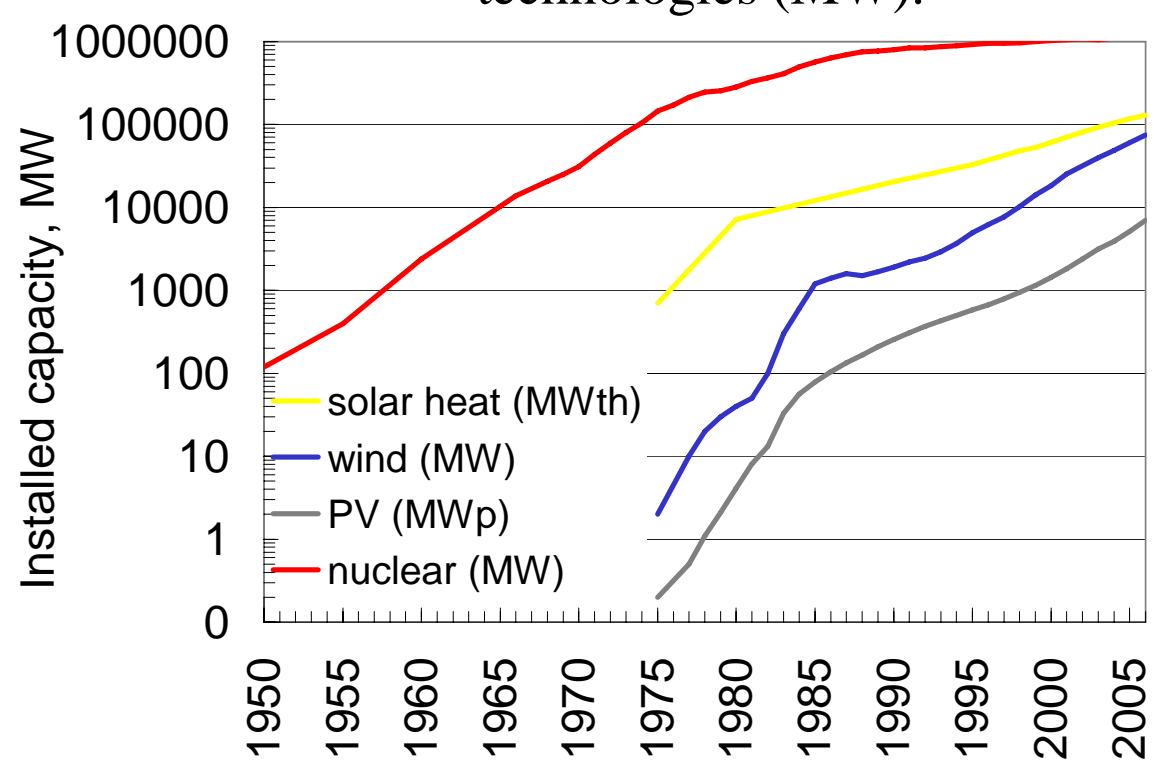

Table . Estimated public support to selected technologies in billion \$ (2003 prices).

\begin{tabular}{|c|c|c|c|c|}
\hline $\begin{array}{c}\text { Techno- } \\
\text { logy }\end{array}$ & $\begin{array}{c}\text { All } \\
\text { support } \\
1947-73\end{array}$ & $\begin{array}{c}\text { Market } \\
\text { deployment } \\
1974-2004\end{array}$ & $\begin{array}{c}\text { R\&D } \\
1974- \\
2004\end{array}$ & $\begin{array}{c}\text { Total } \\
1947- \\
2004\end{array}$ \\
\hline PV & 0 & 10.6 & 8.3 & 19.2 \\
\hline Solar th. & 0 & 10.3 & 3.4 & 13.7 \\
\hline Wind & 0 & 49.1 & 4.2 & 53.3 \\
\hline Nuclear & 176.6 & 0 & 157 & 333.6 \\
\hline
\end{tabular}


Public and private support to energy technology RoD fias dropped dramatically

- Public energy ReDD support of Member States is $<1 / 3$ of the 1980 's level; rene wables only a small share

- Energy companies invest " $0.5 \%$ of turnover in ReD

- Energy in EU's $7^{\text {th }} \mathcal{F P}$ is $45 \%$ of the 6udget; 20 years ago it was $50 \%$

- EU's Advisory Group on Energy (FP6) advised a $4 x$ increase in energy ReD funding

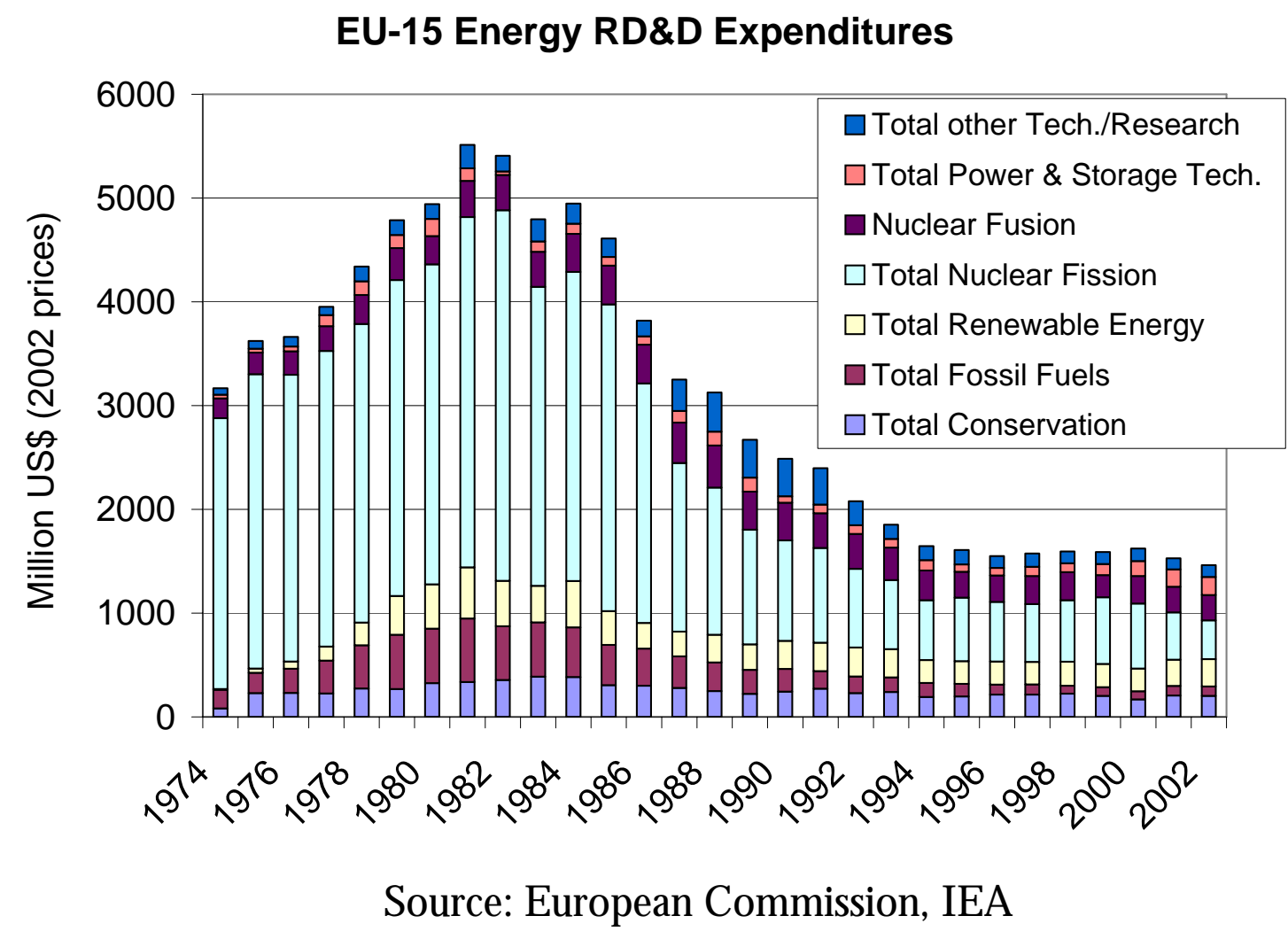




\section{European Strategic Energy Technology Plan}

- "The Europe an Strategic Energy Technology Plan (S ET-Plan) calls for a more integrated approach to match the most appropriate set of policy instruments to the needs of different technologies at different stages of the development and de ployment cycle". [An Energy Policy for Europe, Europe an Commission, $10 \mathrm{~g}$ an. $2007 \mathrm{~J}$

- Key objectives for energy technology: 1) to lower the cost of cle an energy, 2) to put EUl industry at forefront of low carbon technology

A vision to match the long term challenge competitively $\quad 2020 \quad 2030 \quad 2050$

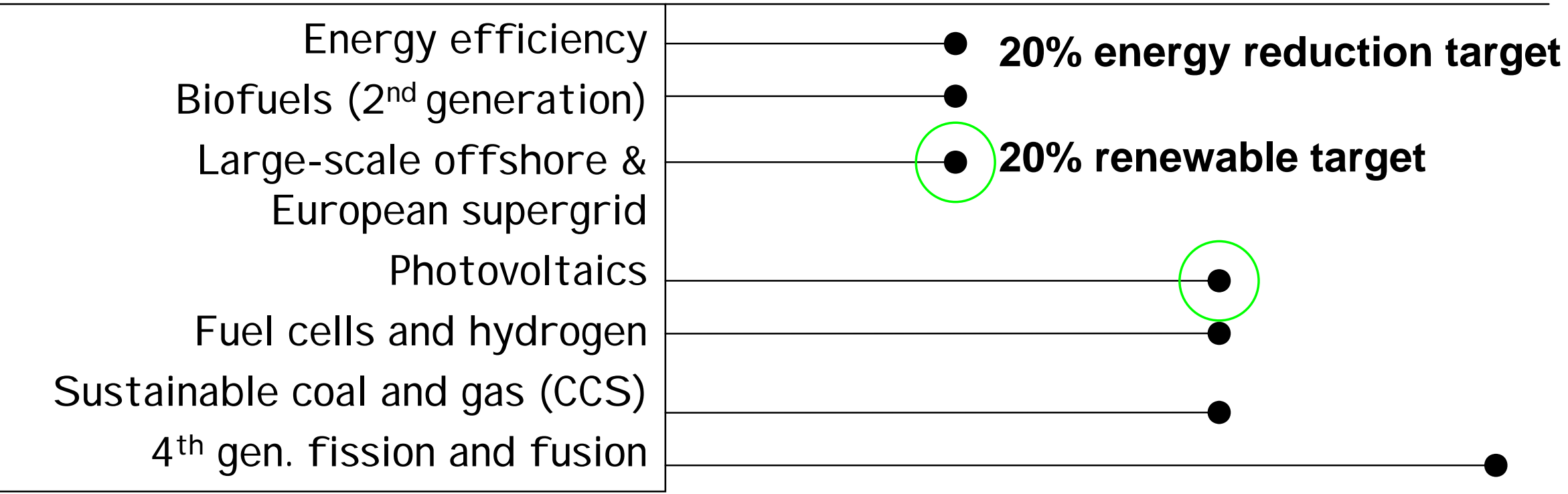




\section{Outline of the presentation}

- Starting point: Advisory Group of Energy's recommendations and concerns on energy RoD from 2006 and the EU's Energy Policy Communication from 2007

- Aim: Investigating future market breakthrough of renewable energy technologies ( $€$ and yrs); key parameter is cost. effectiveness

- Scope: matching policy measures (technology, market support) with specific technology needs over the whole innovation process

- Approach: modeling the commercialization process with links to policy measures 
Three important elements/aspects in an integrated $\mathcal{R T D}$ strategy

1. Commercialization process of new innovations or improvements of energy technologies

- precedes the more massive market penetration and is very development intensive and needs strong public support

2. Technology diffusion process

- describes the market share of the new technology over time once the 'takeoff' has occurred after market introduction and the new technology is becoming competitive against the prevailing ones;

3. Policies and instruments

- enhance above processes to enable full commercial market breakthrough

- includes also the overall policy needed to master the whole commercialization process. 


\section{Commercialization process}

- The commercialization process involves several stages (non-linear)

- Several endogenous and exogenous factors affect breakthrough

- Distance from market

- Incremental improvements for existing products $<<$ radical innovations without established markets

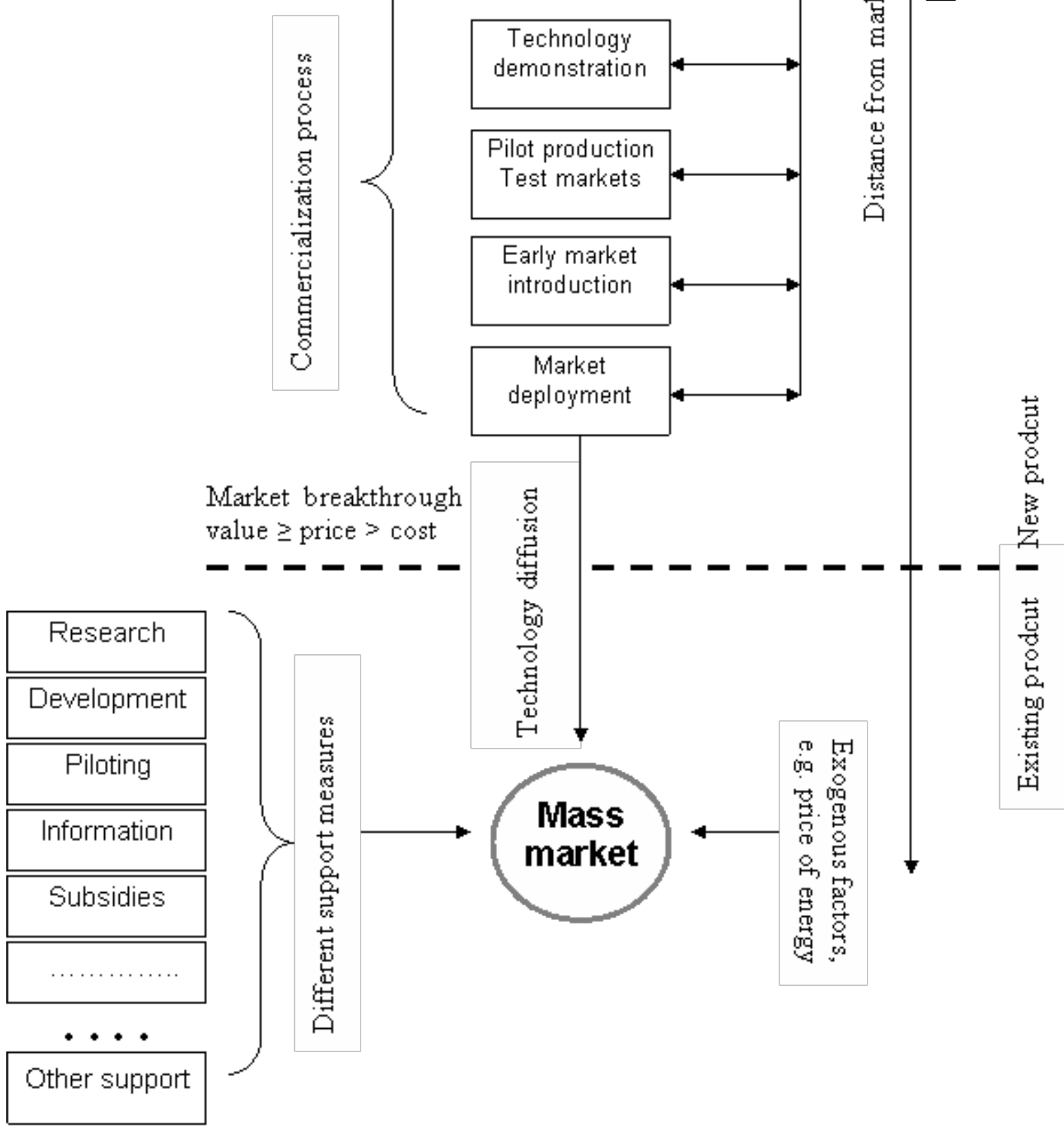




\section{Technology diffusion}

- Boundary between commercialization process and market penetration of ten overlapping

- Penetration described by diffusion (speed of penetration, inertia)

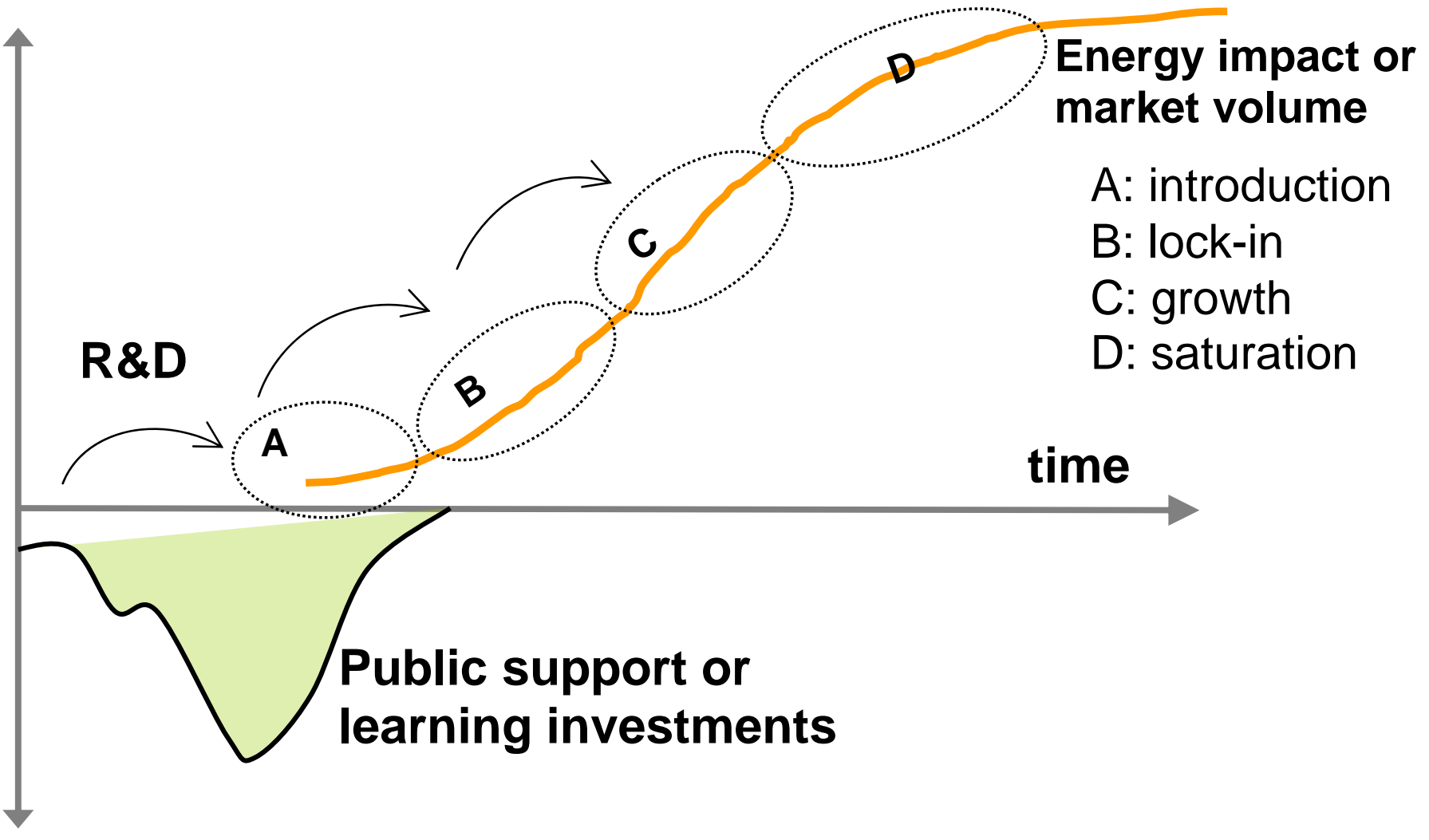




\section{Policy instruments in an integrated strategy}

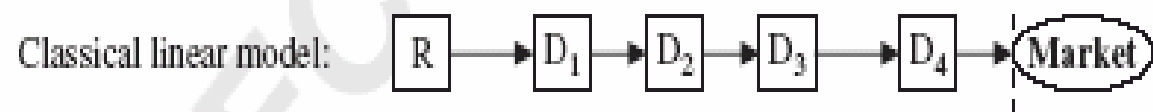

Non-linear model:

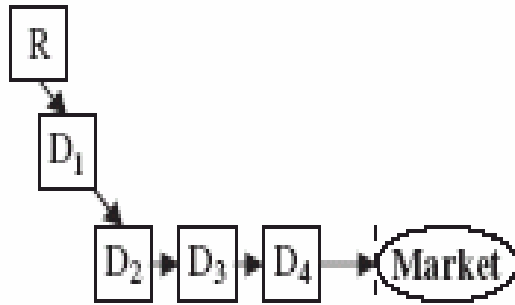

Concurrent radical model:
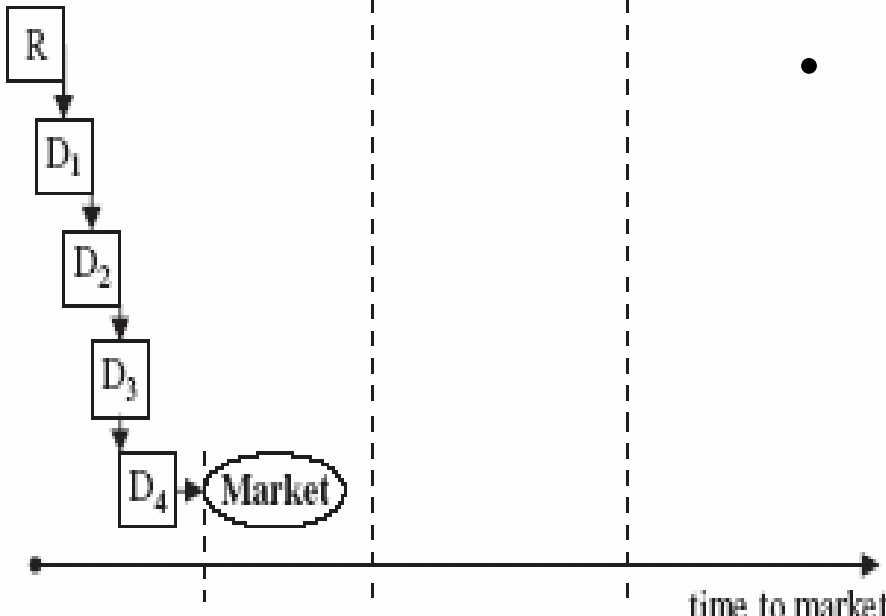

- Here policy instruments consider the whole commercialization process and aim at a full market breakthrough

- Technology pusf and market pull measures are interlinked and considered in parallel

- Catalyzing measures to boost the commercialization

- market forces and mechanisms (close cooperation between the different market players

Examples of different profiles of the innovation chain. $R=$ research, $D_{1}=$ development, $\mathrm{D}_{2}=$ demonstration (pilot production), $\mathrm{D}_{3}=$ dissemination, $\mathrm{D}_{4}=$ eleployment 


\section{Combined diffusion and learning model}

- The tool combines price. conditioned and segmented technology diffusion with an endogenous le arning model

- Three interlinked submodels: 1) calculation of the production cost of energy (C), 2) estimation of the market volume increase $\left(d \mathcal{V}_{t}\right)$ and 3) cost reduction $\left(d C_{v}\right)$

- The speed of market penetration is described by a diffusion model

- Cost reductions are described by endogenous le arning, i.e. le arning $6 y$ doing and by using and economies of scale.

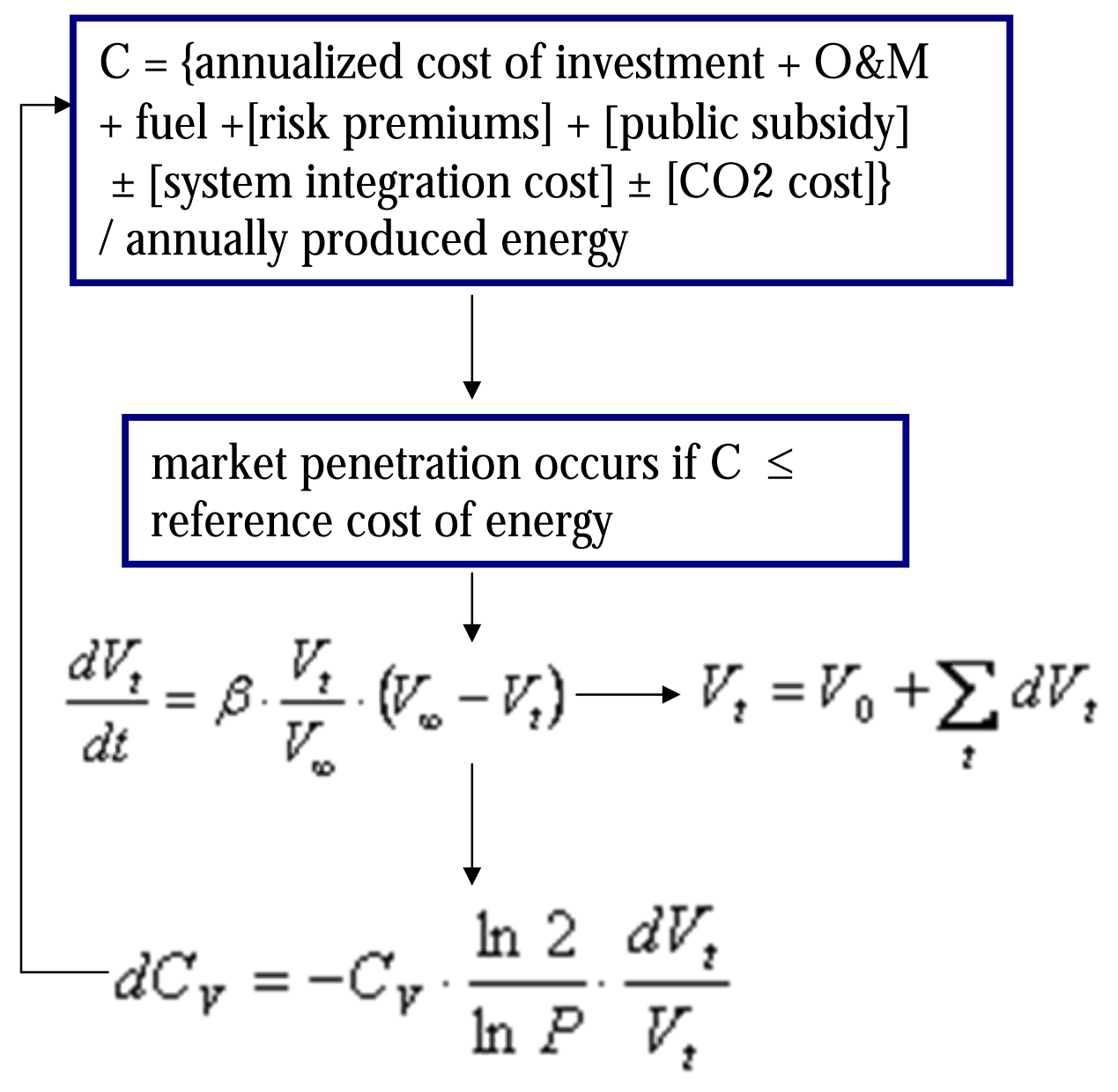




\section{Linking policies and strategies to the mode}

- Policy measures improve the economic competitiveness of the new technologies (C) and influence the penetration rate ( $\beta$ ) which leads to increased volume $(\mathcal{V})$

- Examples on how policies (both $R \mathcal{I D}$ and market de ployment) may influence the costs of the new technology (a-f)

- a: classical learning curve

- b: strong R\&D effort

- c: too high subsidies, low competition, bottlenecks

- d: c+ measures

- e: demand>supply, oversidized

- f: e+ measures

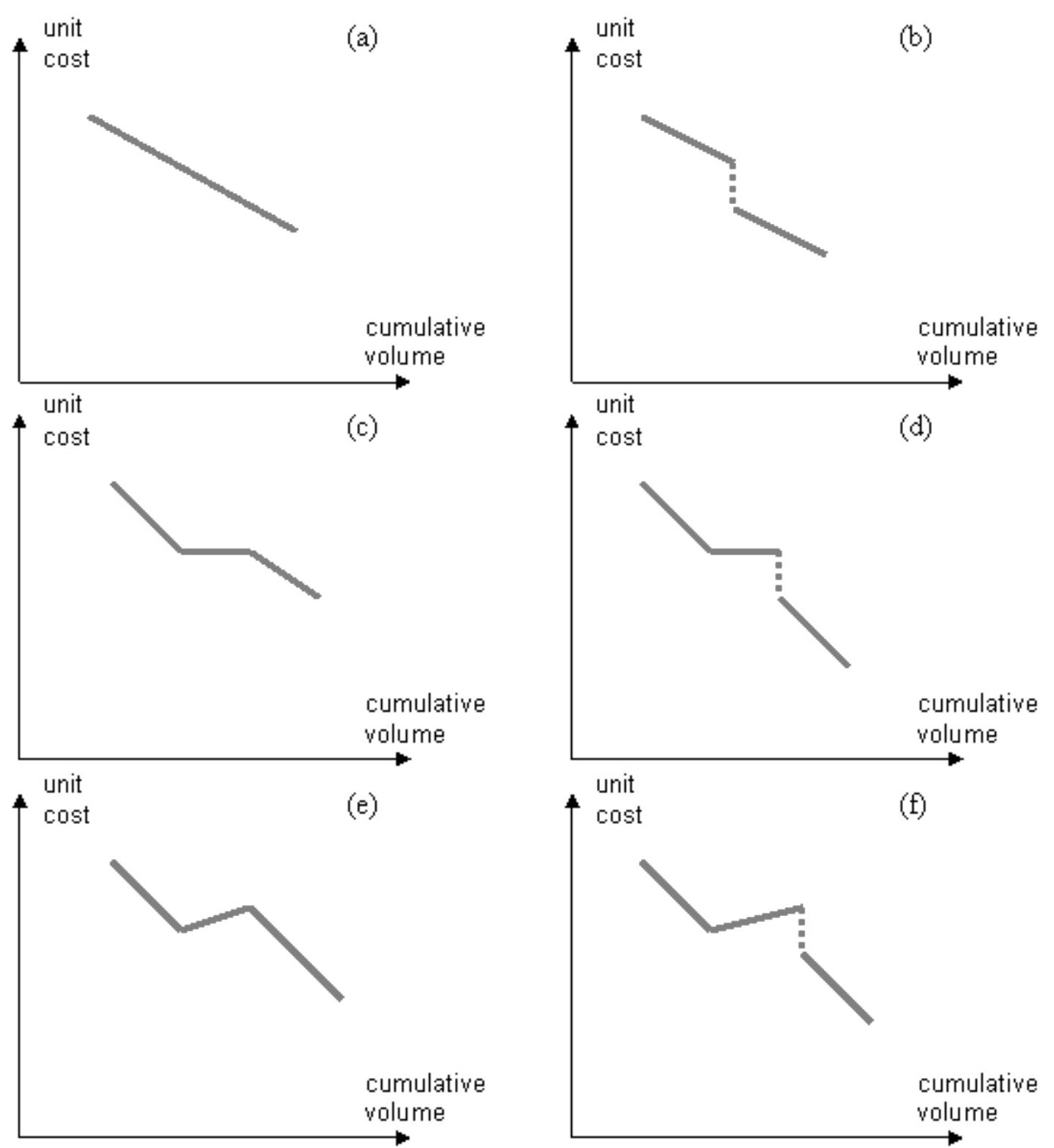


Examples of the use of the model

- Case: Photovoltaics - effects of a major Ród effort

- PV is marginal but growing fast, 2-4 $\mathrm{x}$ more expensive than consumer electricity

- Base case: feed-in-tariffs are used to ensure competitiveness; Hypothesis: a concerted RTD initiative (JTI) could be justified; a 30\% cost reduction possible in 10 years through stronger $R \& D$

- Case: Wind - impact of possible market disturbance

- Wind $>1 \%$ of world electricity and fast growing, marginally more expensive

- Base case: feed-in-tariffs are used to ensure competitiveness; Hypothesis: 1) demand for wind >> supply and could cause a short market disturbance, i.e. for 2 years costs a) stagnate and b) $+5 \% y r$ 2) in large investments the cost of capital becomes important 


\section{Case PV: penetration results}

- $P \mathcal{V} \sim 1 \%$ of world

electricity at $t=30 \mathrm{yrs}$

or around $400 \mathcal{T} \mathcal{W} h$

- $P V$ becomes fully

competitive at $t=20$

yrs in consumer

segments in $\mathcal{E U}$

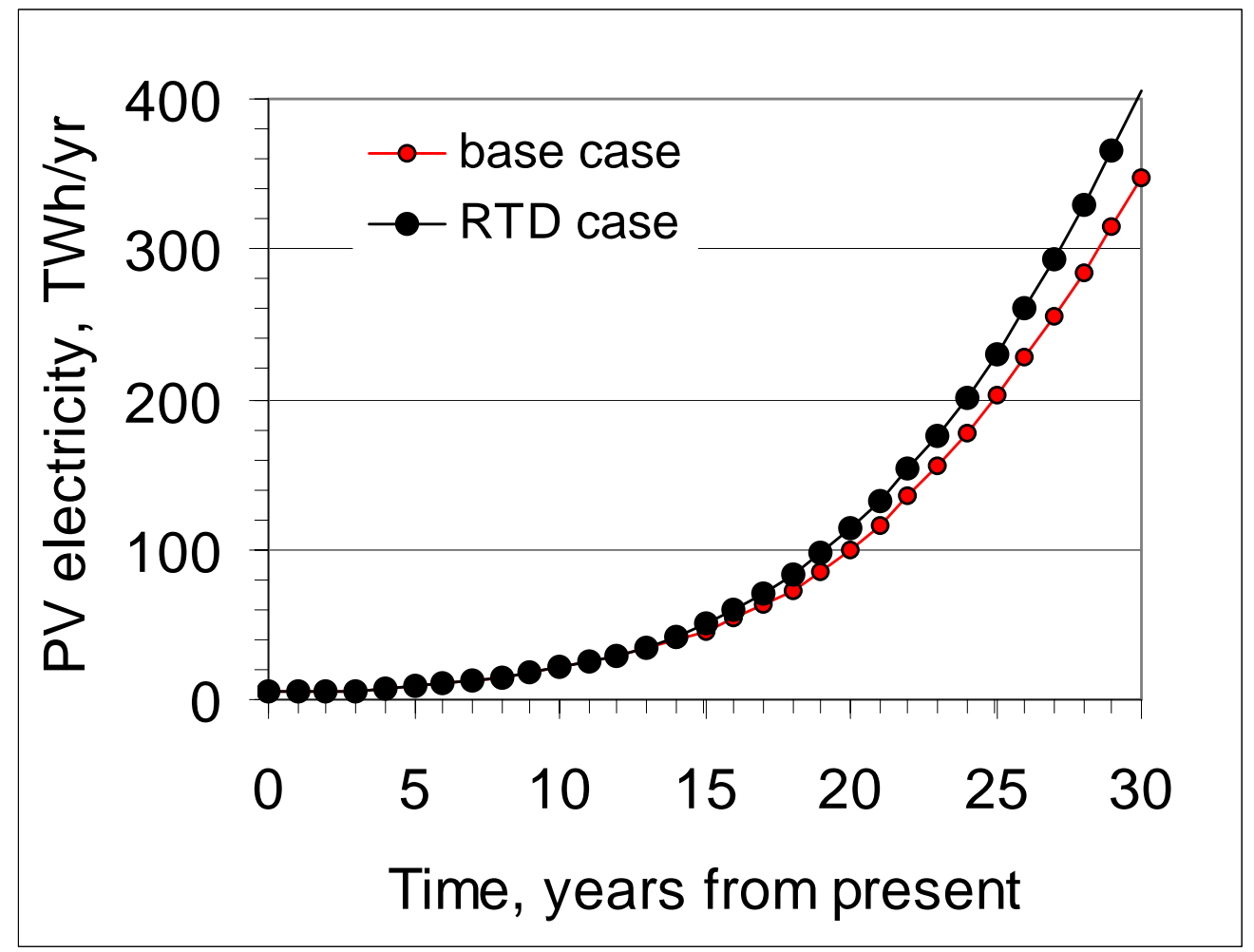




\section{PV (2): effects of technology jump}

- The concerted ReDD strategy case could save 150 billion $€$ in investment costs and 33 billion $€$ of public support in investments over the next 30 years

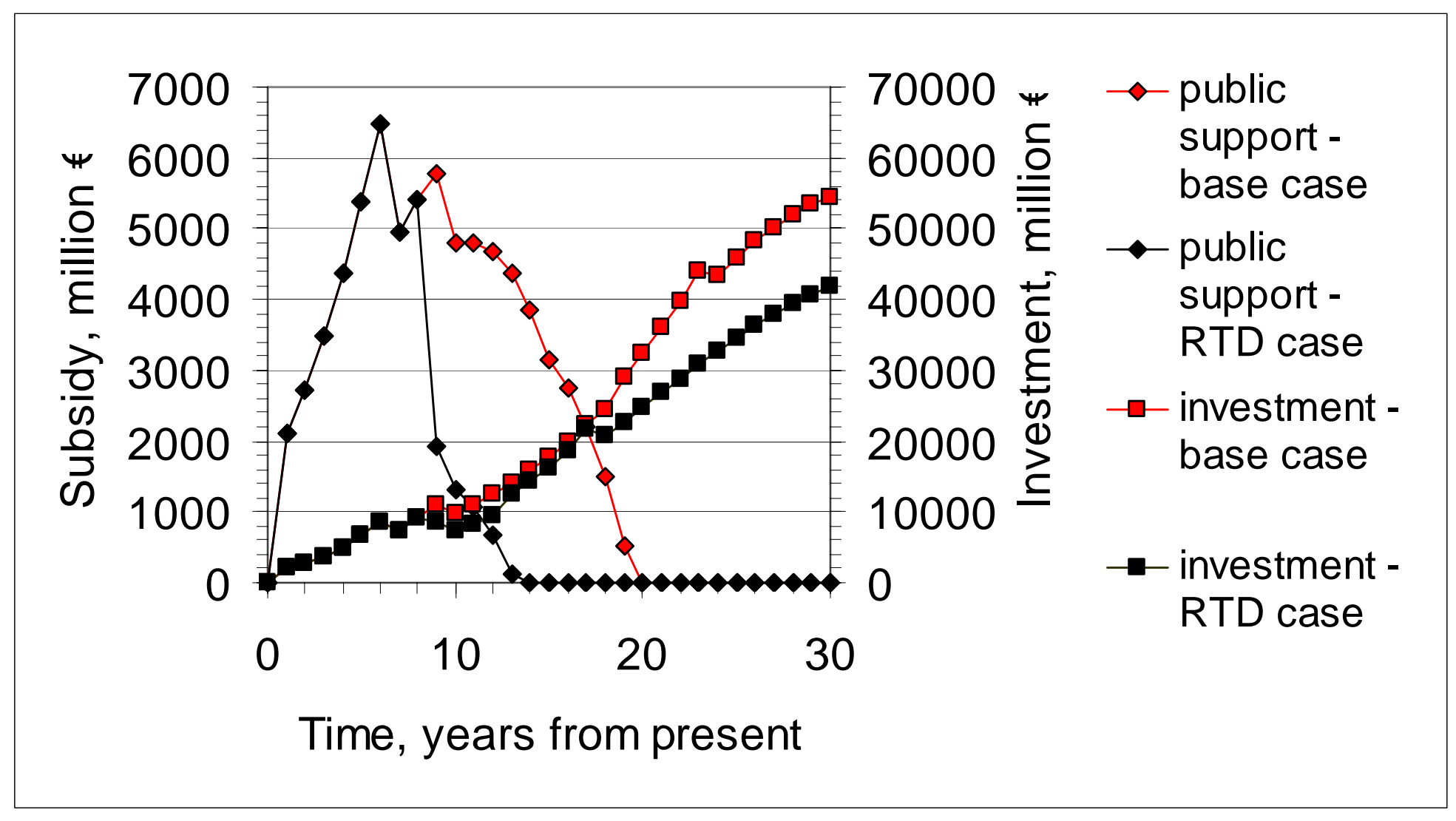




\section{Case wind: penetration results}

- Wind $10 \%$ of world electricity at $t=30 \mathrm{yrs} ; 20 \%$ in $\mathcal{E U}$

- The cost of wind-electricity is halved in 30 years

- Cost-effective (nonsubsidized) penetration starts at $t=10$ years in EUonshore and $t=20 \mathrm{yrs}$ in $\mathrm{EUl}$ -

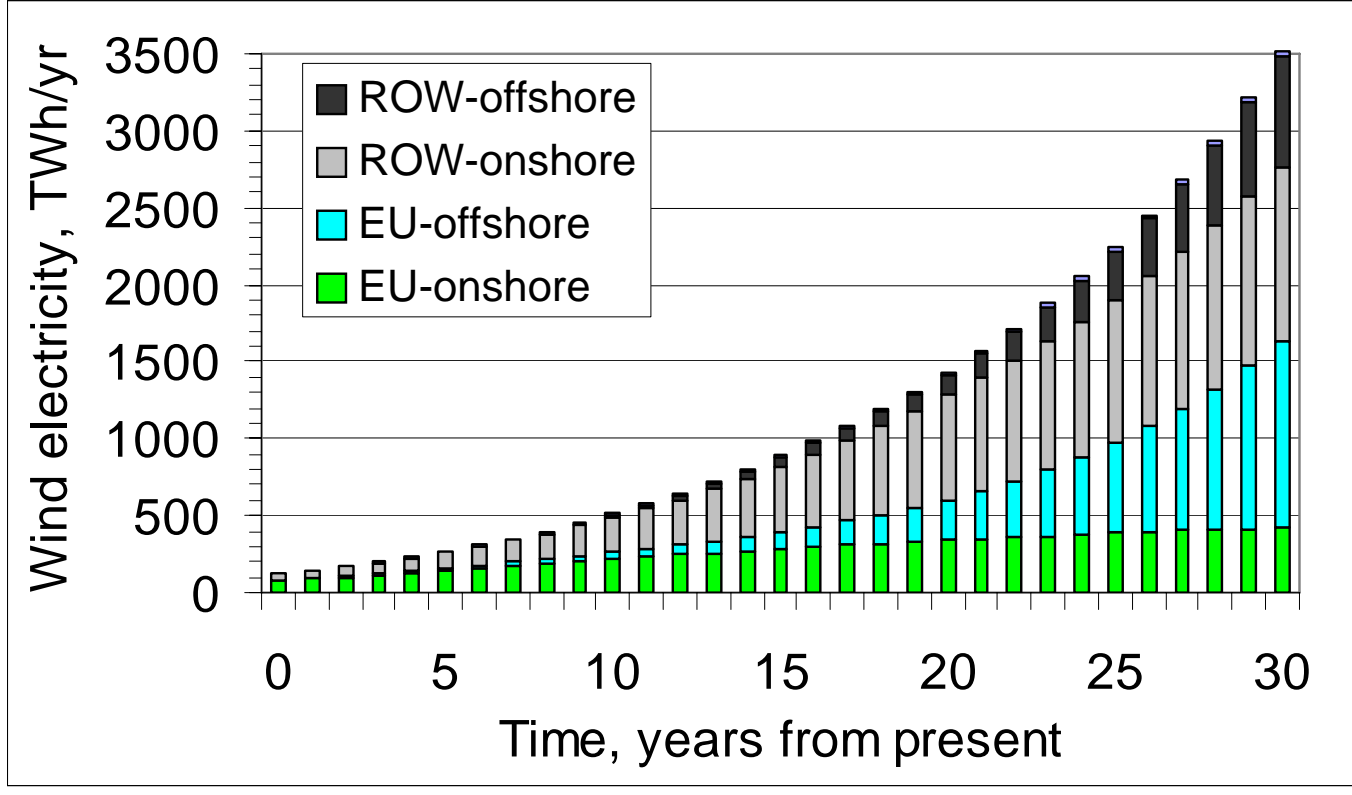
offshore segments

- Market saturation in some segments 


\section{Wind (2): effects of disturbances}

- $\mathcal{A}$ market disturbance of 2 years could mean 100 billion $€$ extra investment cost over 30 years; 30 billion $€$ (learning stagnation) -37 billion $€$ (cost disturbance) more public subsidies

- Advantageous loans could lower the public support needed by $85 \%$ and save 70 billion $€$ in the base case

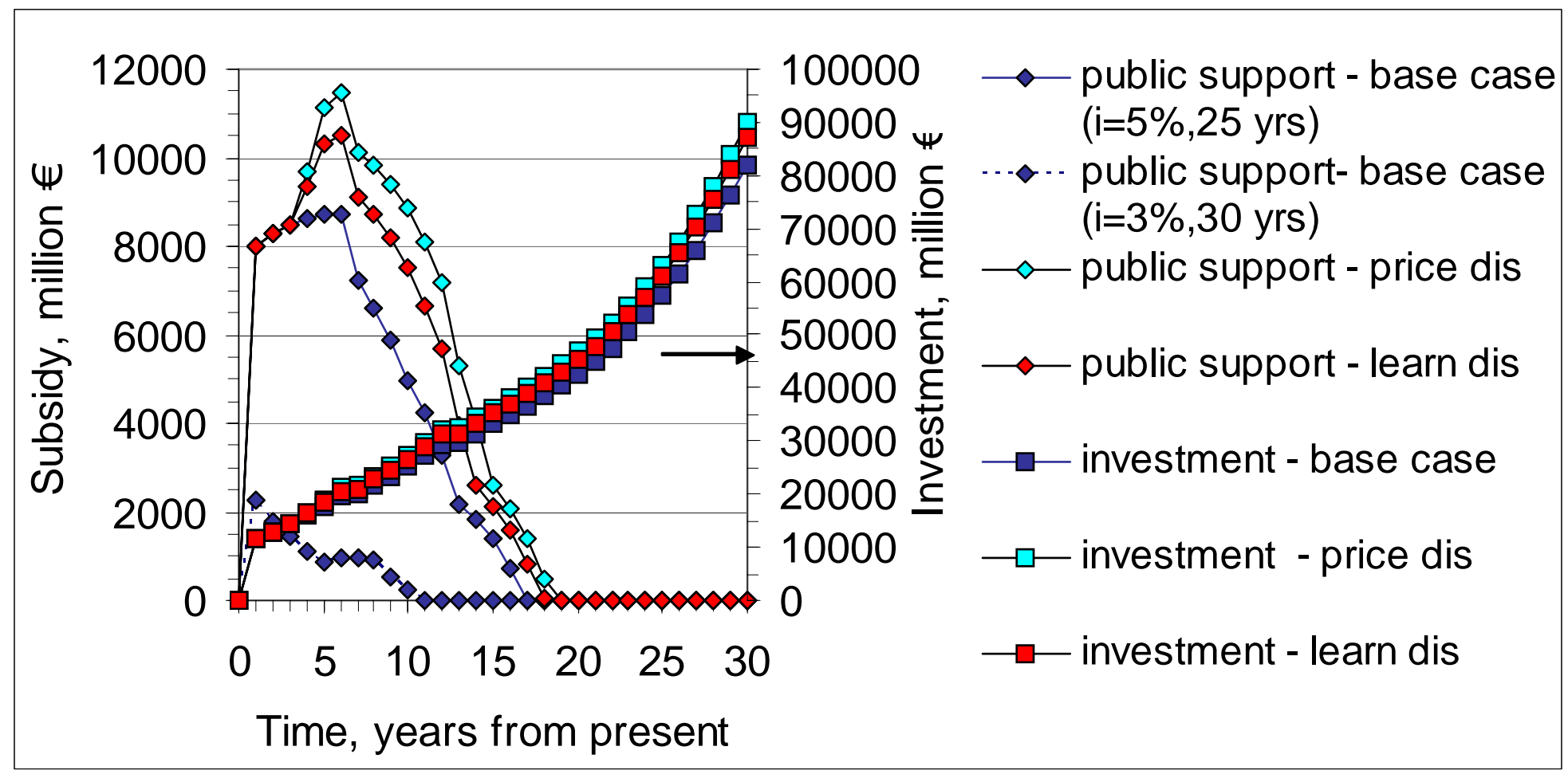




\section{Observations and conclusions (1)}

1. Distance from the cost breakeven point affects the optimal balance betwe en technology push and market pull actions

- if far away from the commercial breakthrough, focused R\&D efforts to enable technology jumps could be more effective than market deployment

- in case of PV the economic benefits from a strong joint European R\&D initiative would be highly motivated

2. When reaching higher volumes and exercising strong market pull measures to accelerate market growth even short disturbances in technology cost trends may turn out be costly

- careful planning of the subsidy levels to balance possible supply/demand bottlenecks is stressed

- in case of wind a planning of joint European policies could be highly motivated 


\section{Observations and conclusions (2)}

3. Full commercialization of newenergy technologies needs patient and continuous public support

- A long time horizon is most likely necessary (10-20 years), public support should be viewed as an investment with long pay-off

- Several factors may change the total financial support needed

- Involving European financing bodies in the investments could enable cheaper capital costs

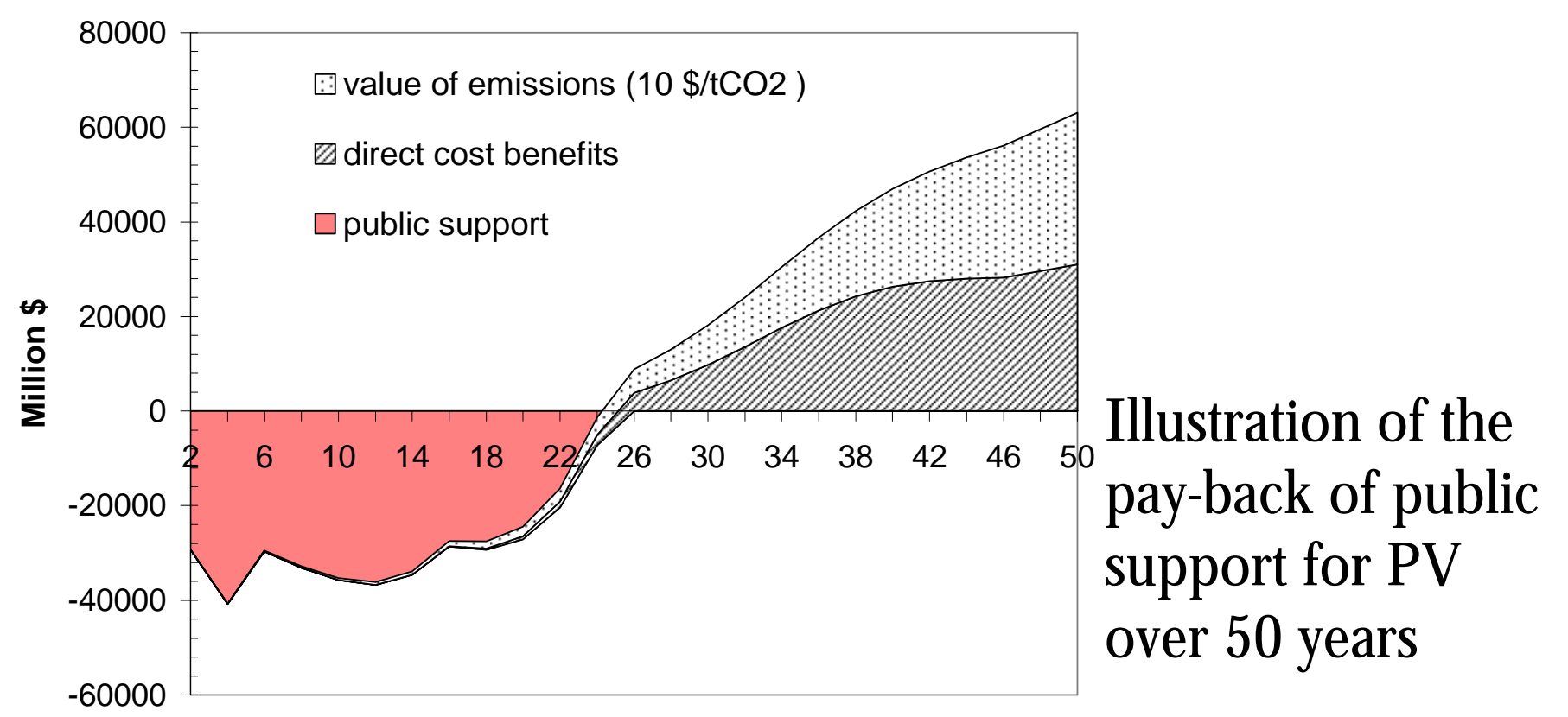




\section{Impacts of high energy prices \\ on long-term energy-economic scenarios for Germany}

Volker Krey, Dag Martinsen, Peter Markewitz

Research Centre Jülich, Institute of Energy Research - Systems Analysis and Technology

Evaluation (IEF-STE), Jülich, Germany

Manfred Horn

DIW Berlin, Berlin, Germany

Felix Chr. Matthes, Verena Graichen, Ralph O. Harthan, Julia Repenning

Öko-Institut, Berlin, Germany 


\section{Motivation}

- „new“ energy price levels since 2004

- energy-economic scenarios do/did not cover price levels

- compilation of adapted scenarios

- analysis of impacts:

- supply structures

- competiveness of energy-saving measures

- resulting $\mathrm{CO}_{2}$-emissions 


\section{Energy Price Scenarios}

\section{Reference Scenario}

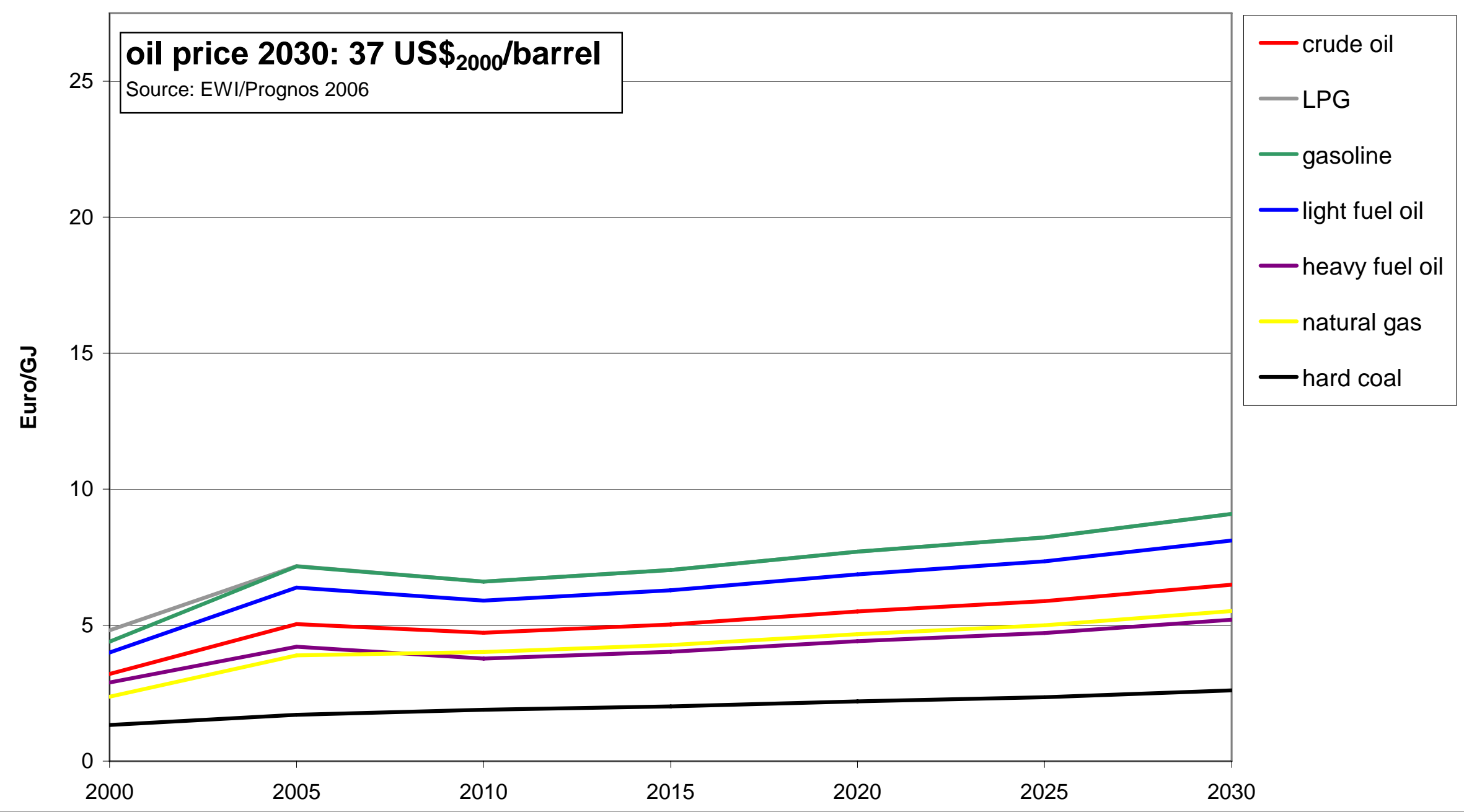

Institute of Energy Research - Systems Analysis and Technology Evaluation (IEF-STE) 


\section{Energy Price Scenarios}

\section{High Price Scenario}

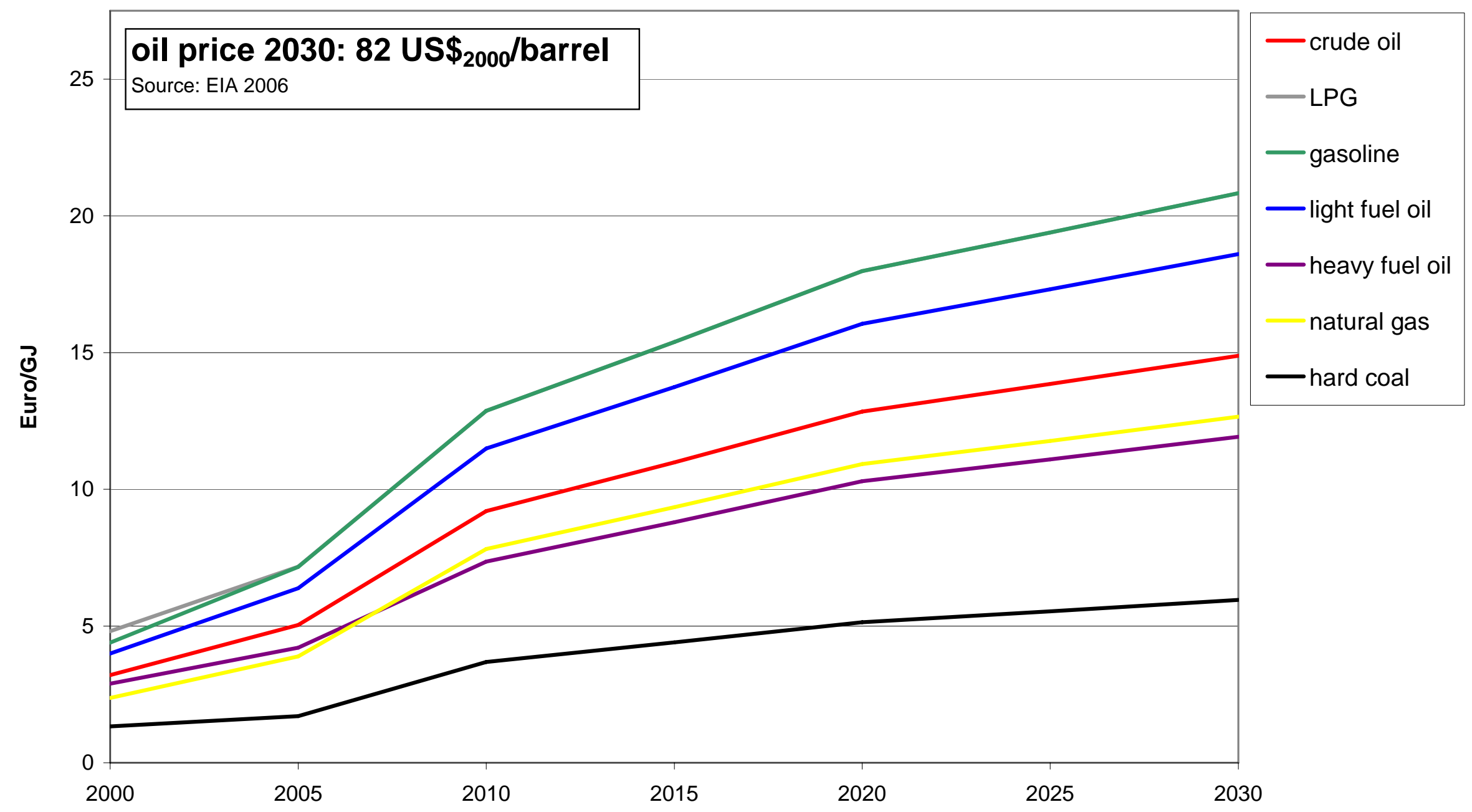

Institute of Energy Research - Systems Analysis and Technology Evaluation (IEF-STE) 


\section{Energy Price Scenarios}

\section{Price Spike Scenario}

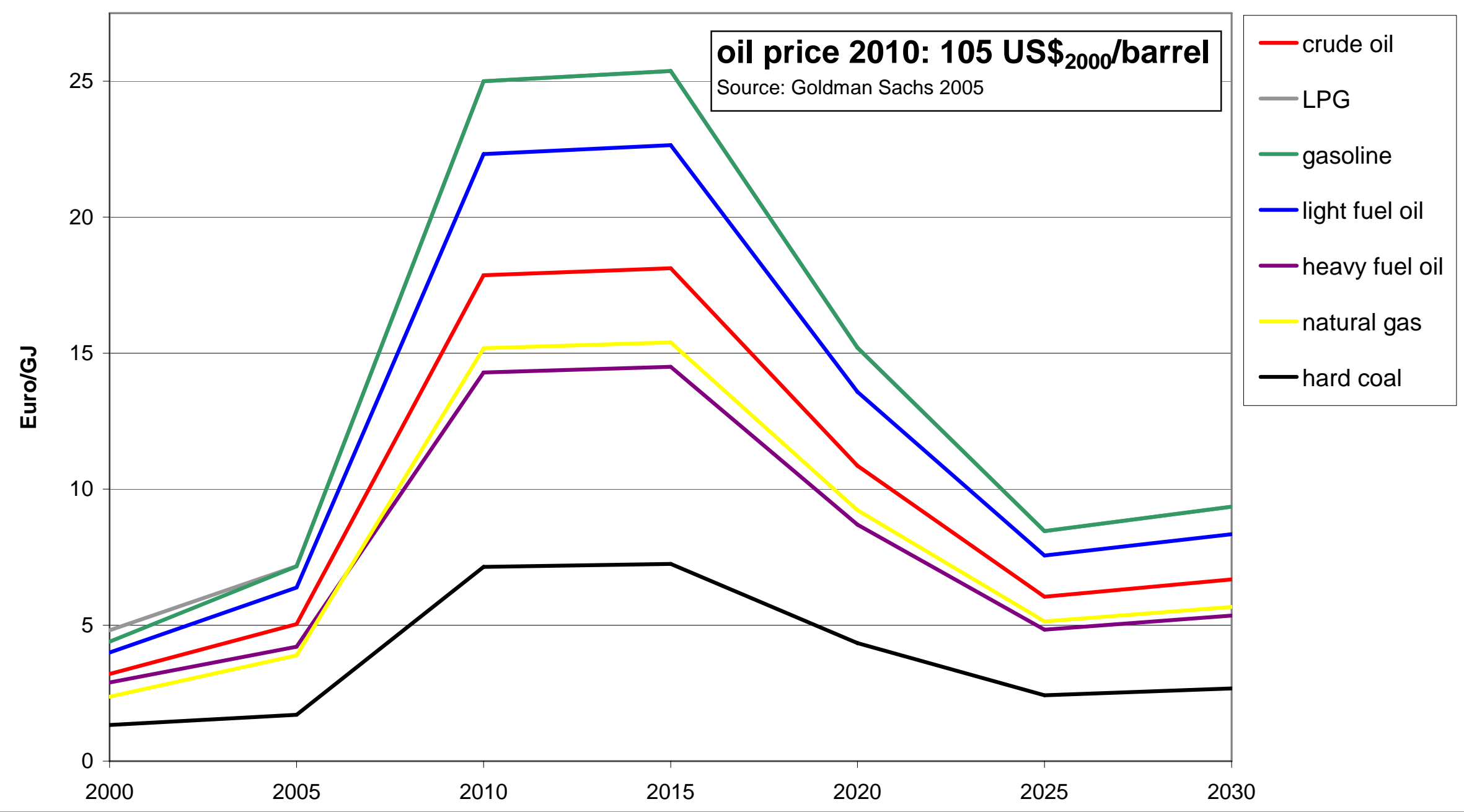

Institute of Energy Research - Systems Analysis and Technology Evaluation (IEF-STE) 


\section{Analysis}

- Energy Systems Model (IKARUS-LP):

- consistent scenarios

- impacts on whole energy system (supply and end-use sectors)

- Electricity Sector Model (ELIAS):

- detailed analysis of electricity generation

- interaction with carbon emissions trading 


\section{IKARUS-LP Model Structure}

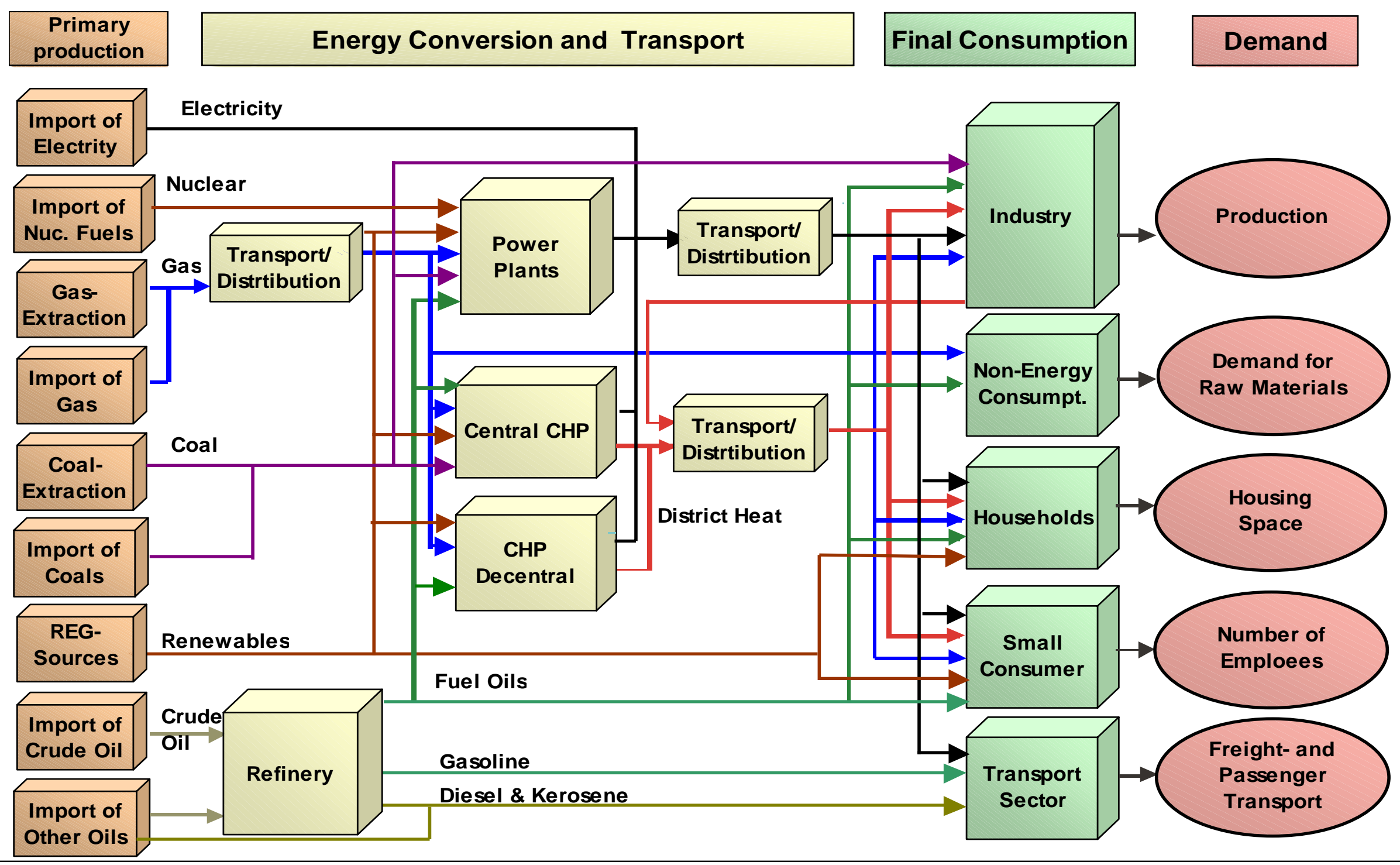




\section{Modeling Approach}

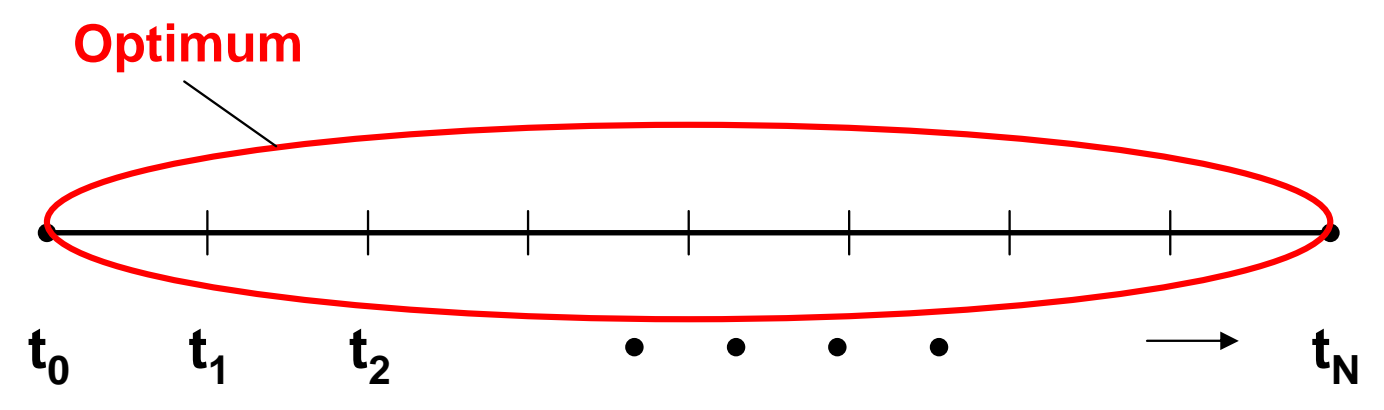

Perfect-Foresight

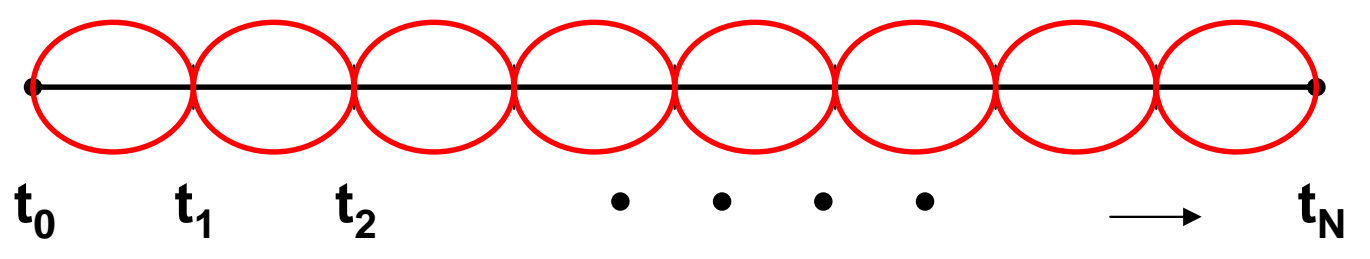

Time-Step (myopic)

e.g. energy consumption

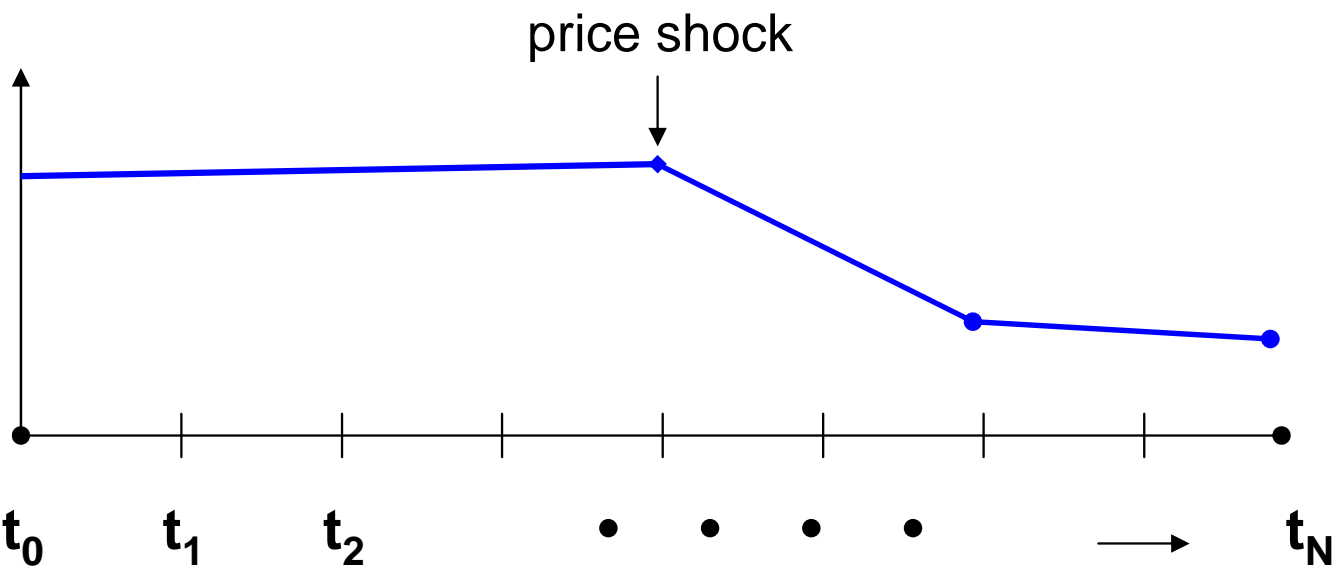




\section{Total Primary Energy Supply}

Reference Scenario

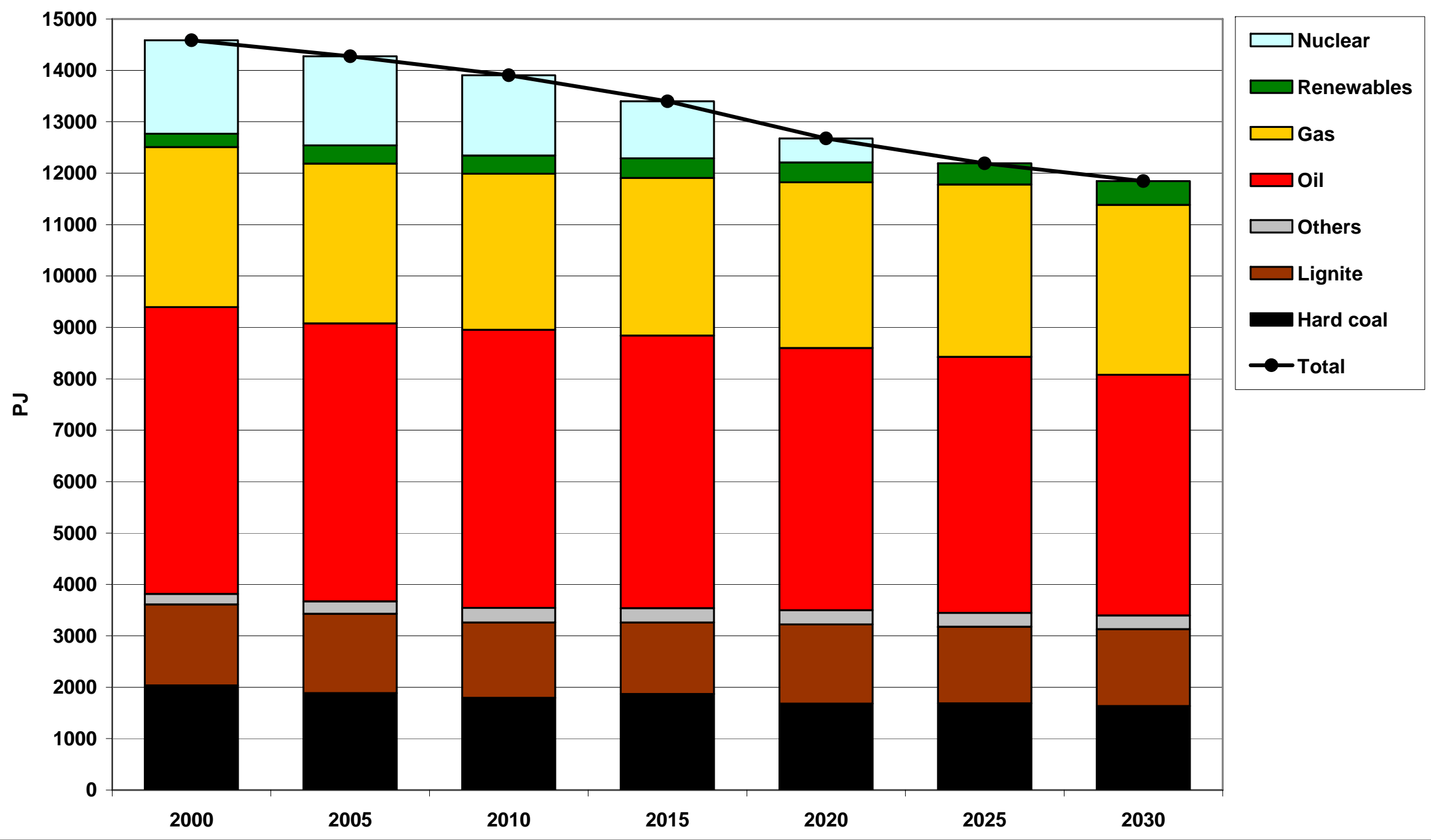




\section{Total Primary Energy Supply}

High Price Scenario

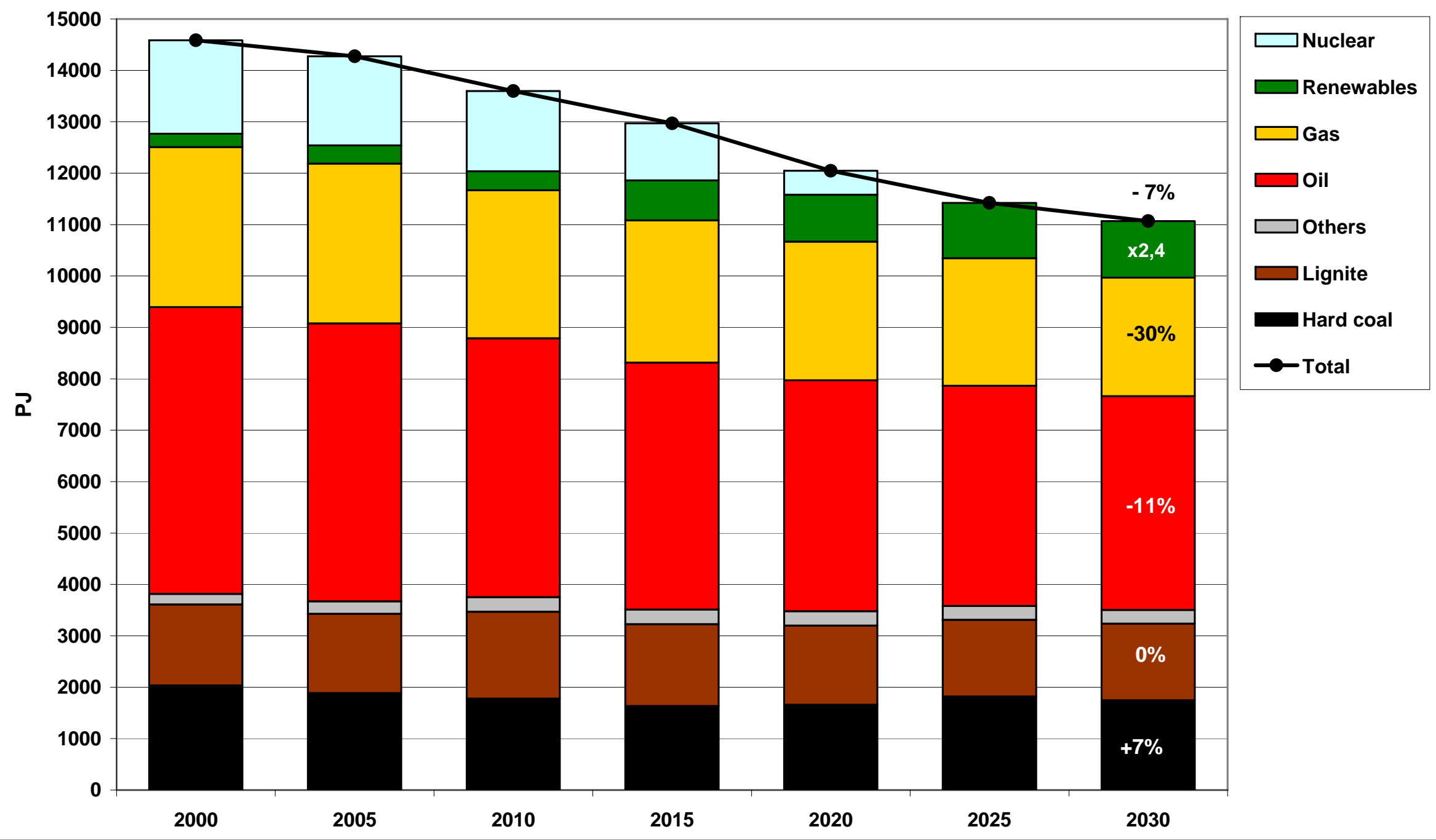

Institute of Energy Research - Systems Analysis and Technology Evaluation (IEF-STE) 


\section{Total Primary Energy Supply}

Price Spike Scenario

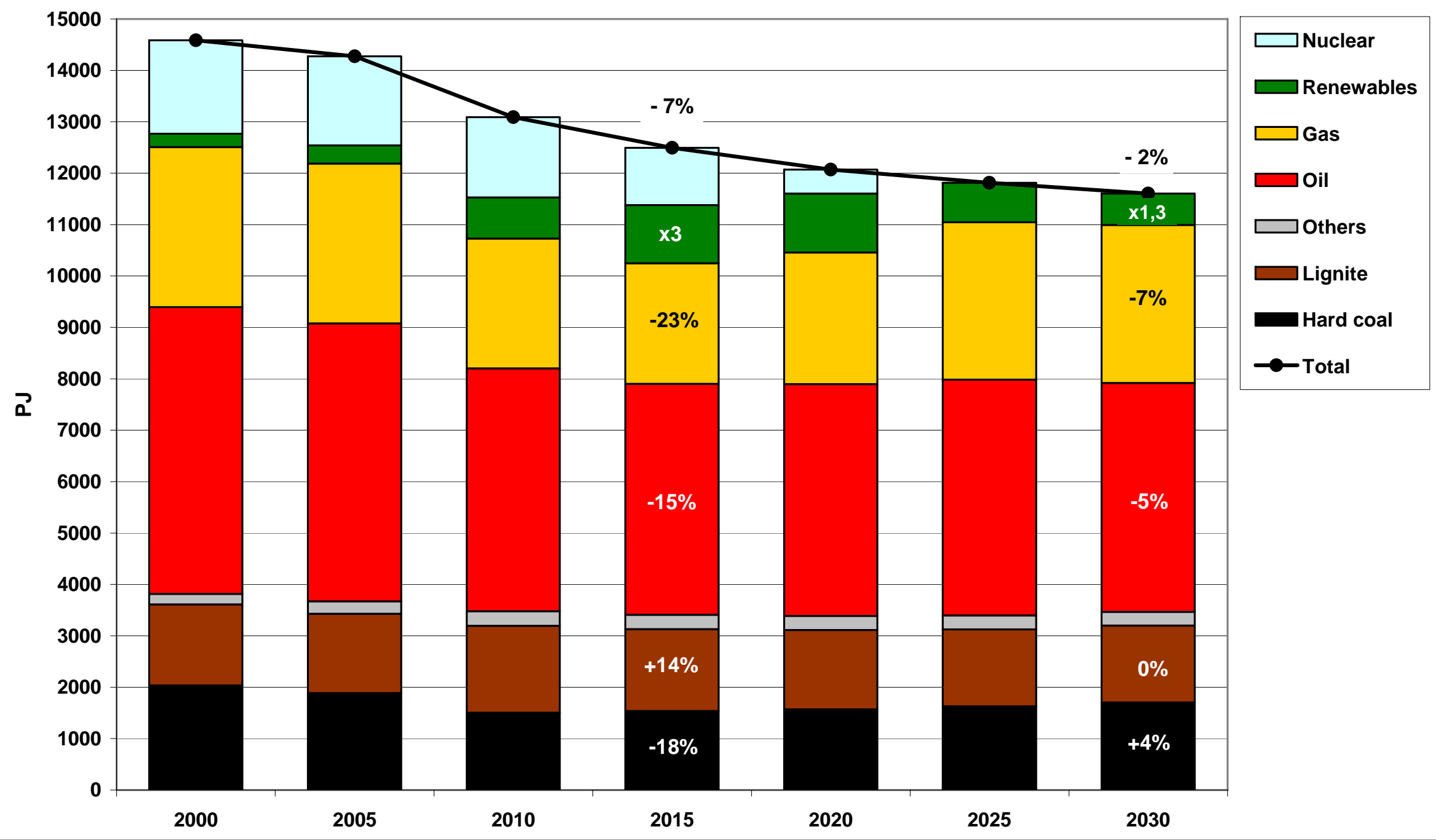




\section{$\mathrm{CO}_{2}$-Emissions \\ Reference Scenario}

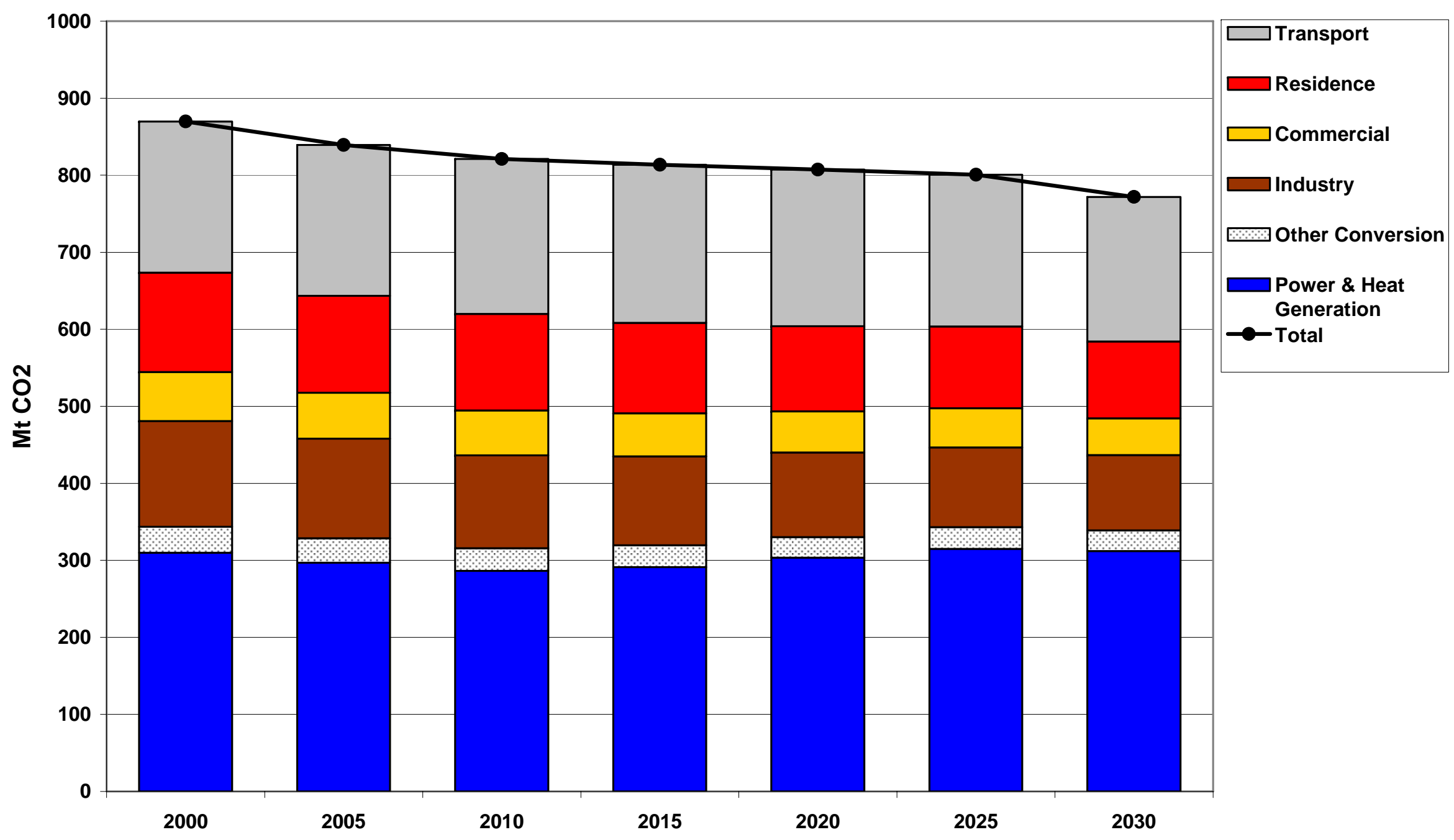

Institute of Energy Research - Systems Analysis and Technology Evaluation (IEF-STE) 


\section{$\mathrm{CO}_{2}$-Emissions}

High Price Scenario

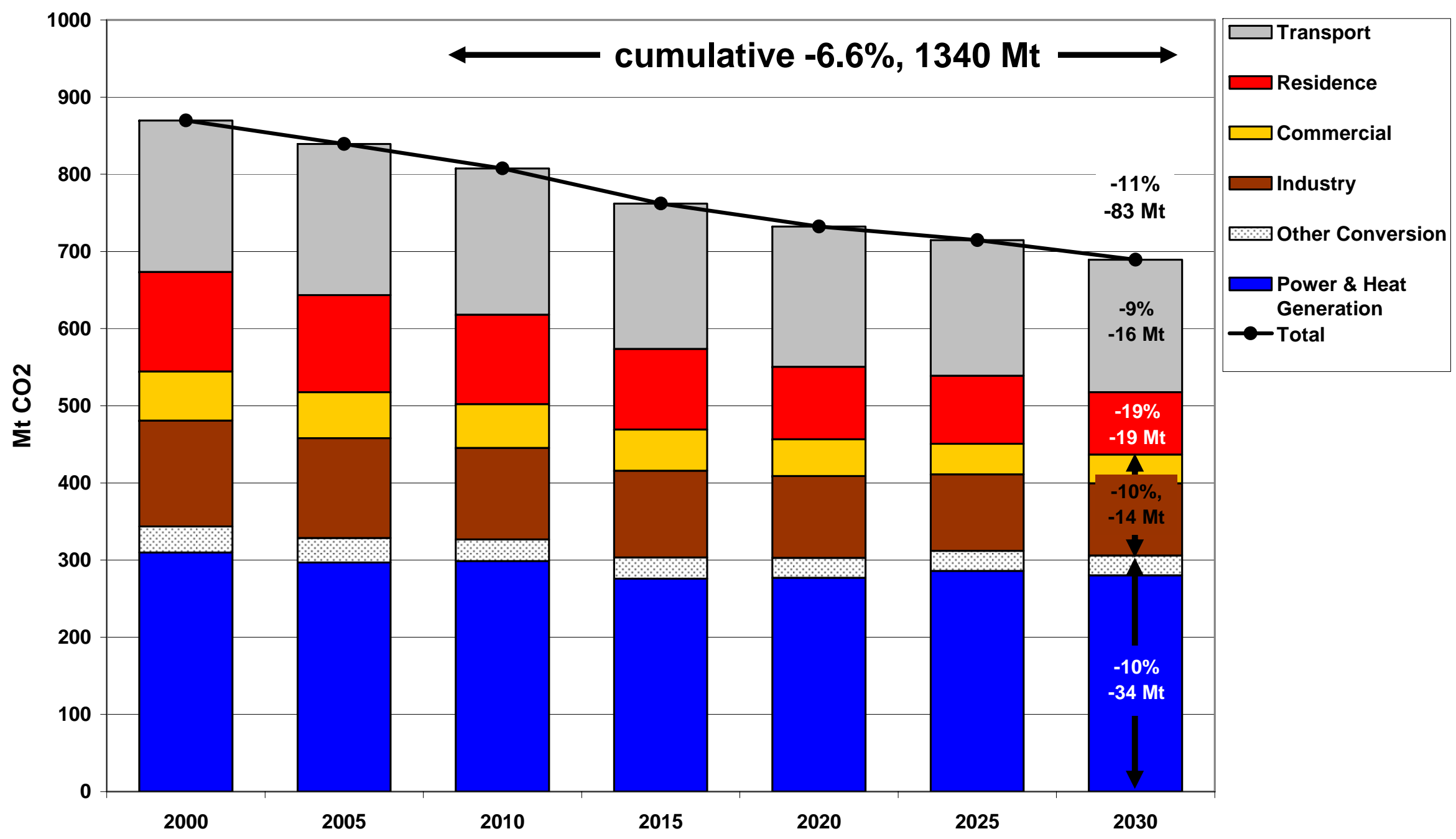

Institute of Energy Research - Systems Analysis and Technology Evaluation (IEF-STE) 


\section{$\mathrm{CO}_{2}$-Emissions \\ Price Spike Scenario}

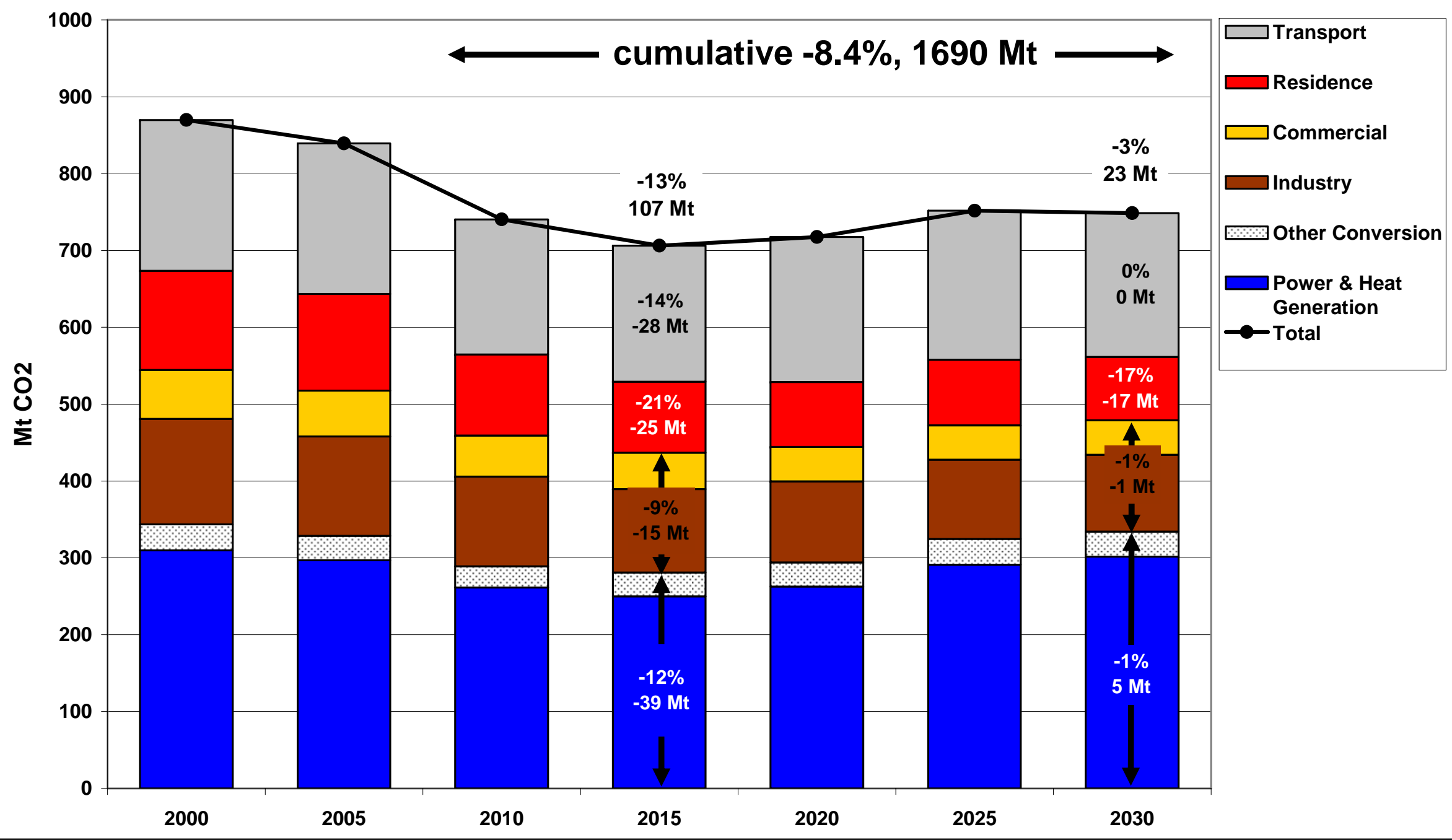

Institute of Energy Research - Systems Analysis and Technology Evaluation (IEF-STE) 


\section{Final Energy Consumption \\ Reference Scenario}

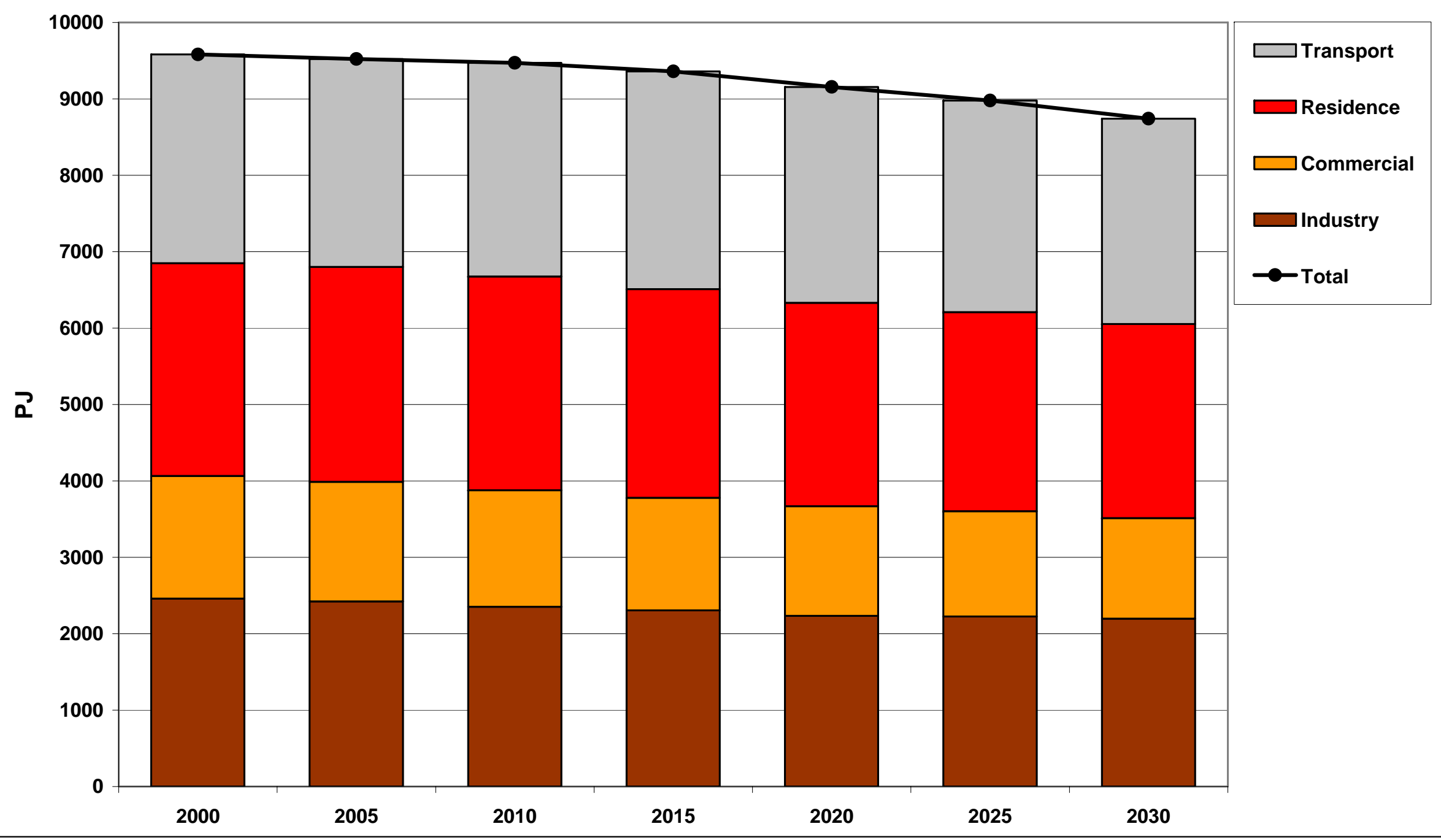

Institute of Energy Research - Systems Analysis and Technology Evaluation (IEF-STE) 


\section{Final Energy Consumption \\ High Price Scenario}

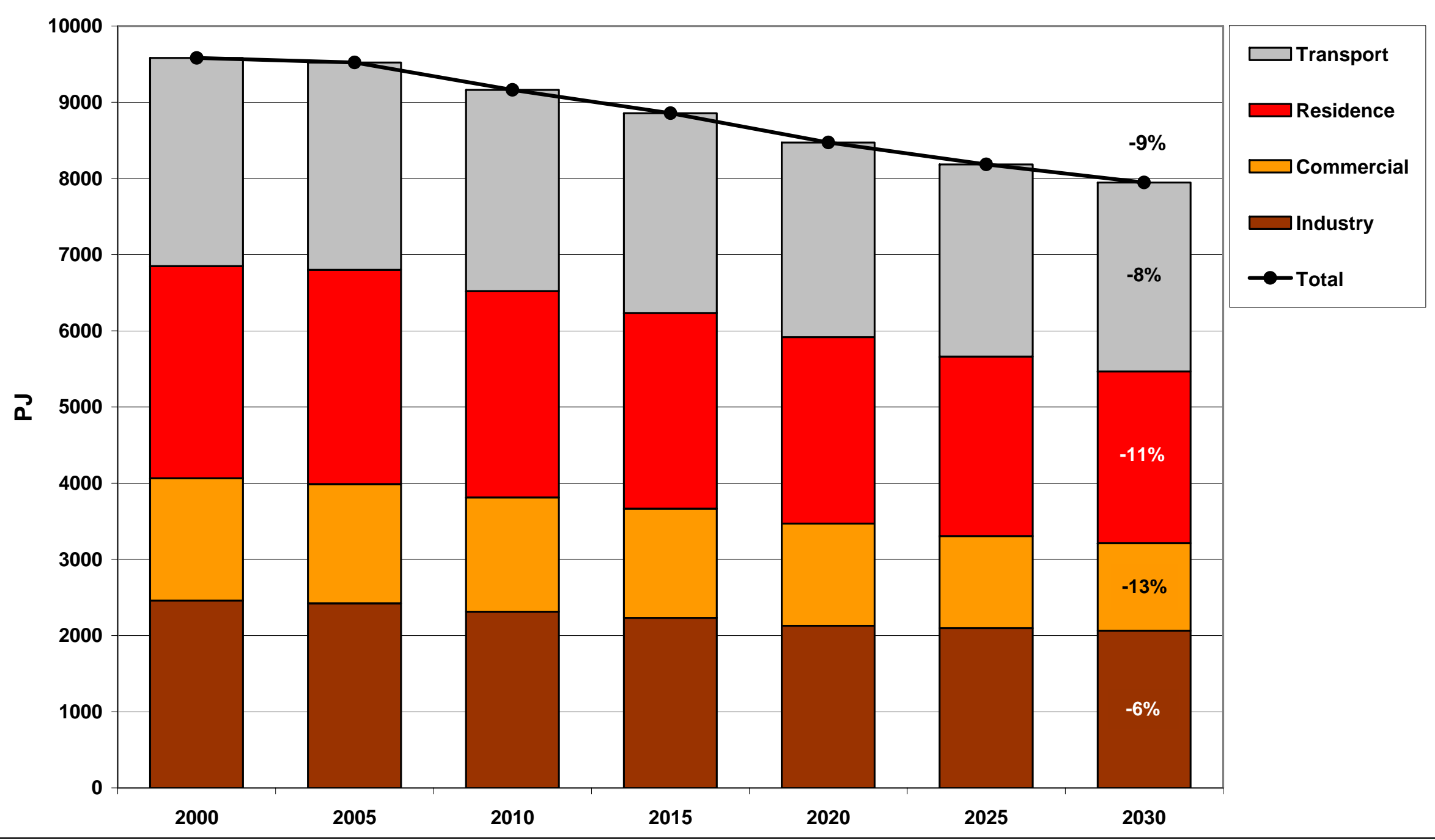

Institute of Energy Research - Systems Analysis and Technology Evaluation (IEF-STE) 


\section{Final Energy Consumption \\ Price Spike Scenario}

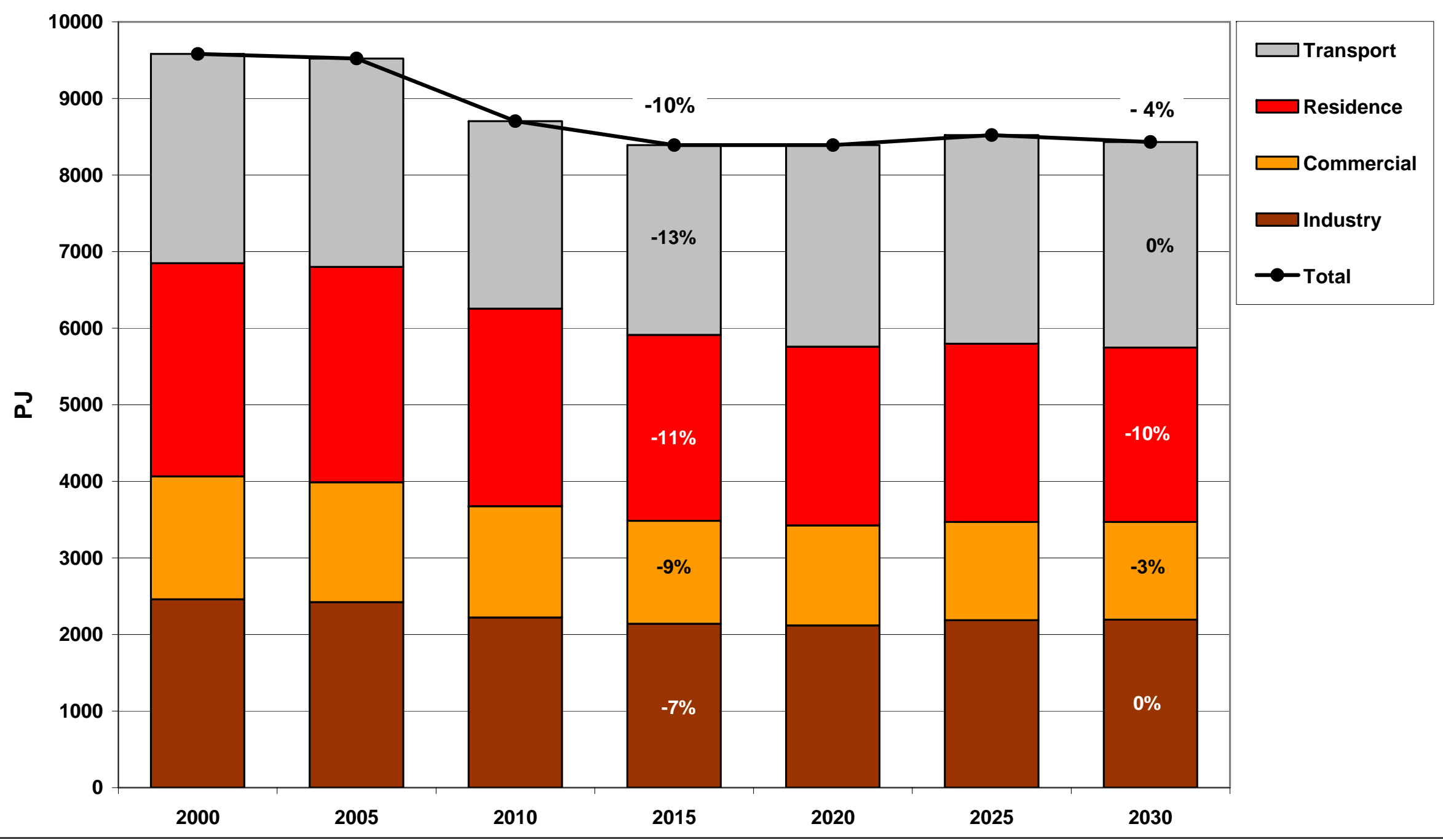

Institute of Energy Research - Systems Analysis and Technology Evaluation (IEF-STE) 


\section{ELIAS Model Approach}

- investments in power generation sector

- utility perspective

- political instruments:

- taxes

- feed-in-tariffs for renewables (EEG)

- promotion of CHP (KWKG)

- emissions trading scheme/allocation rules 


\section{ELIAS Model Approach}
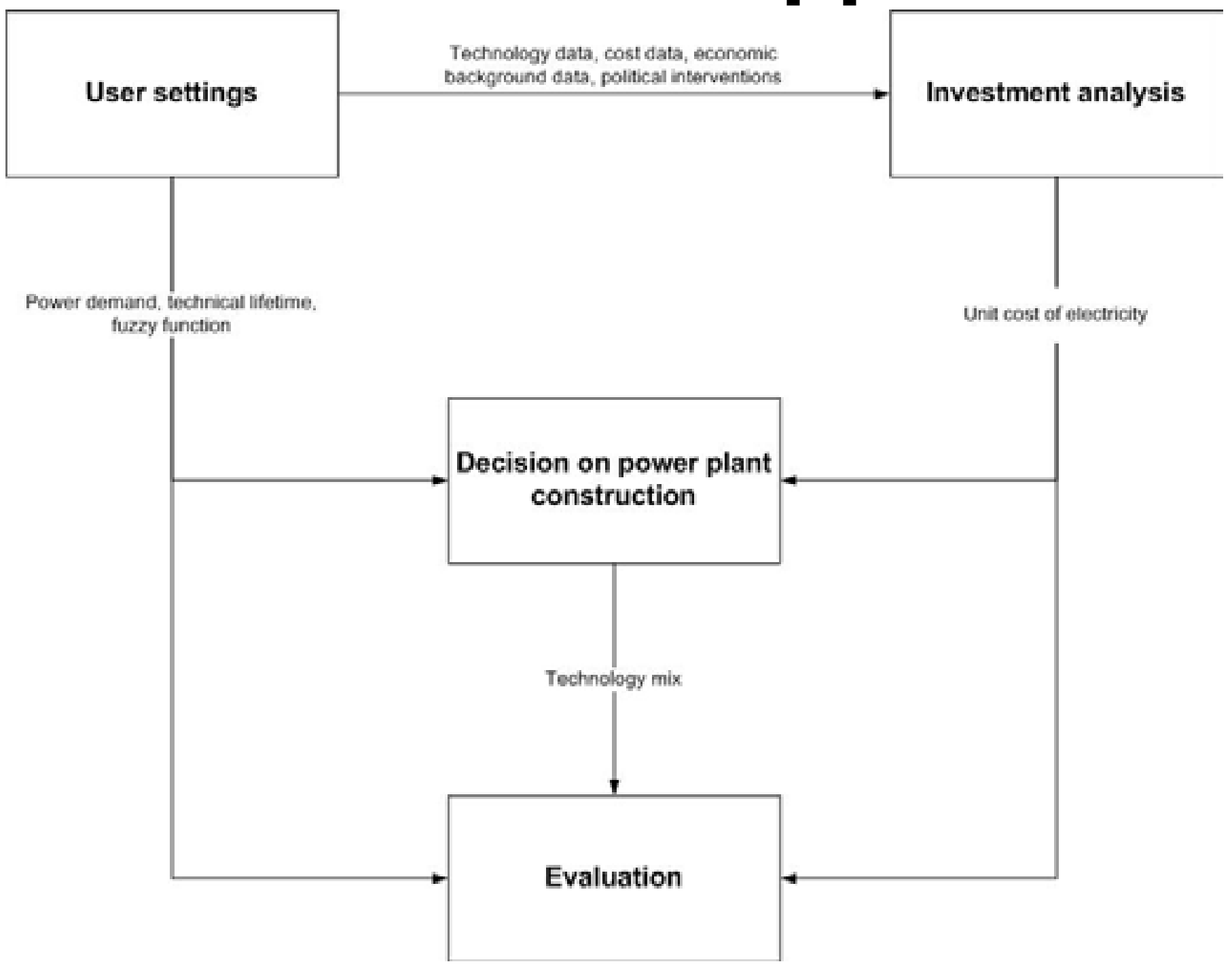


\section{Electricity Sector - Current Allocation}

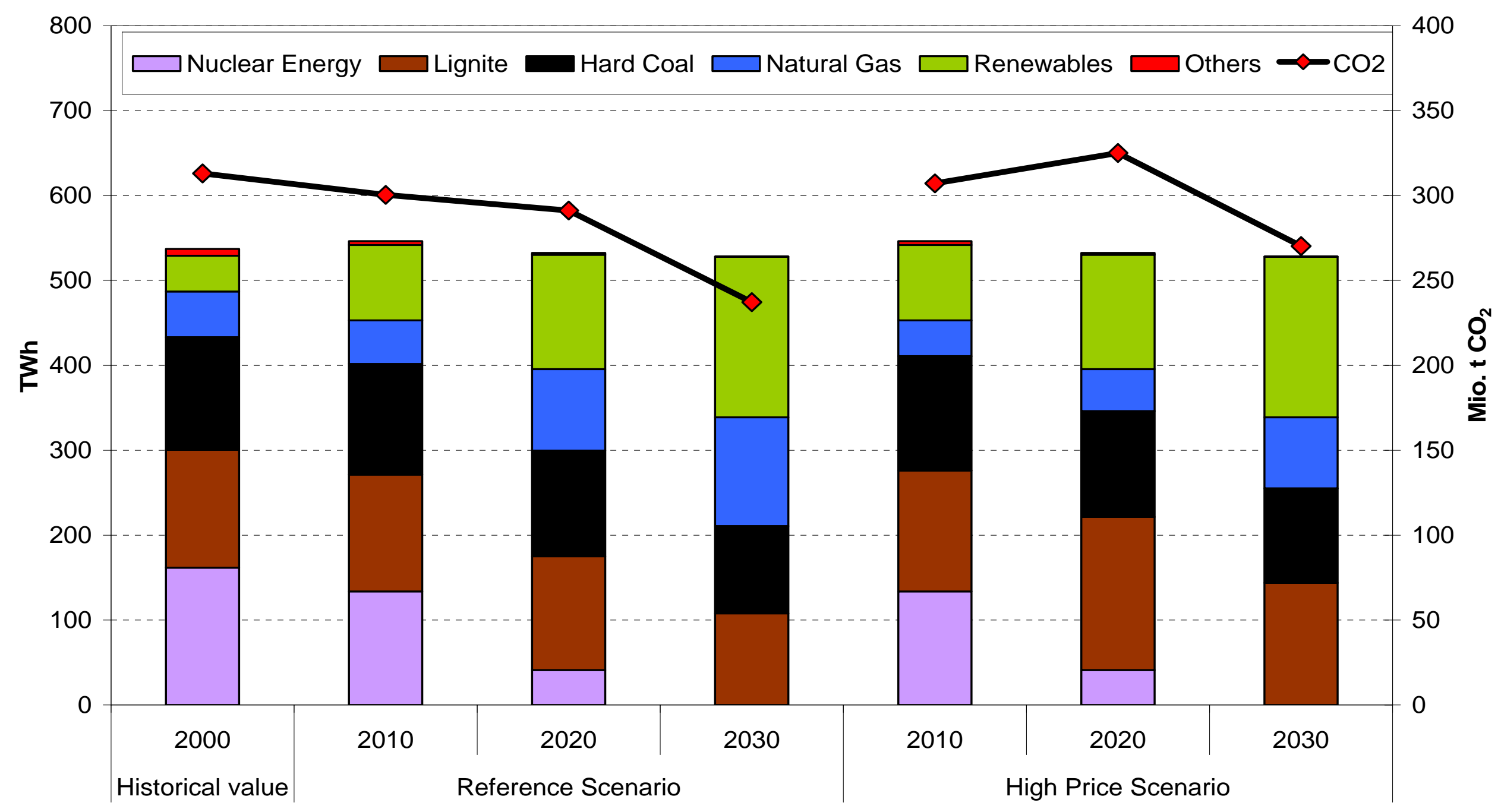




\section{Electricity Sector - Full Auctioning}

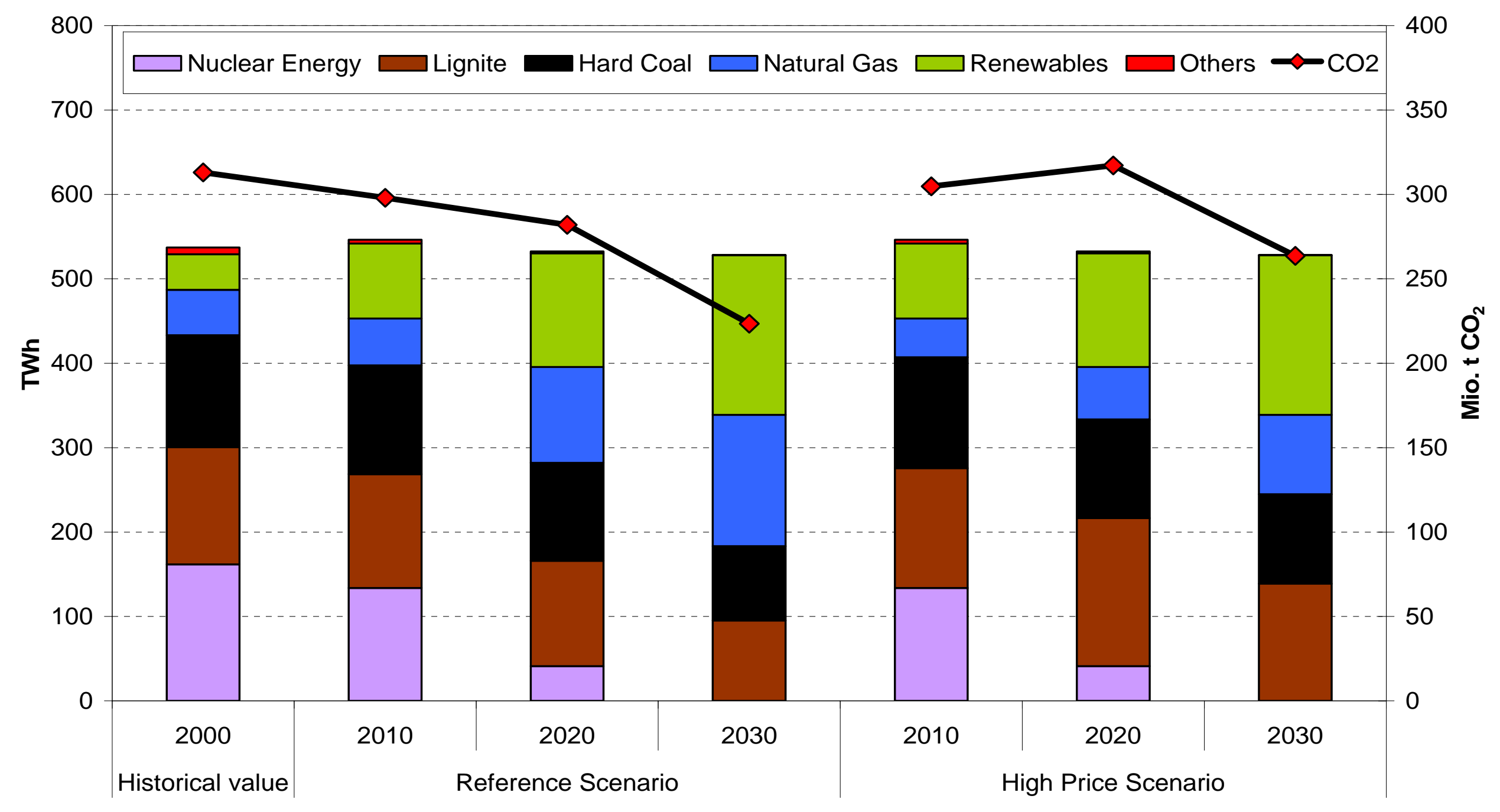




\section{Conclusions}

- energy-savings in end-use sectors but: relaxation effects in some sectors

- increased utilization of renewables

- electricity generation: natural gas vs. coal (strongly dependent on energy price levels and allocation rules)

- domestic hard coal competitive coal-to-liquids: > 55 US\$/barrel 


\section{Thank You!}




\title{
Polygeneration
}

Thomas Rostrup-Nielsen

\author{
HALDOR TOPSOE A/S
}

Haldor Topsøe A/S - Risø - May 232007 


\section{Outline}

- IGCC and Polygeneration

- TIGAS - Iopsoe's Integrated Gasoline Synthesis

- Integration of IGCC \& TIGAS

- Process performance

- Economics

- Options for $\mathrm{CO}_{2}$ abatement 
- IGCC and Polygeneration

- TIGAS - Iopsoe's Integrated Gasoline Synthesis

- Integration of IGCC \& TIGAS

- Process performance

- Economics

- Options for $\mathrm{CO} 2$ abatement 


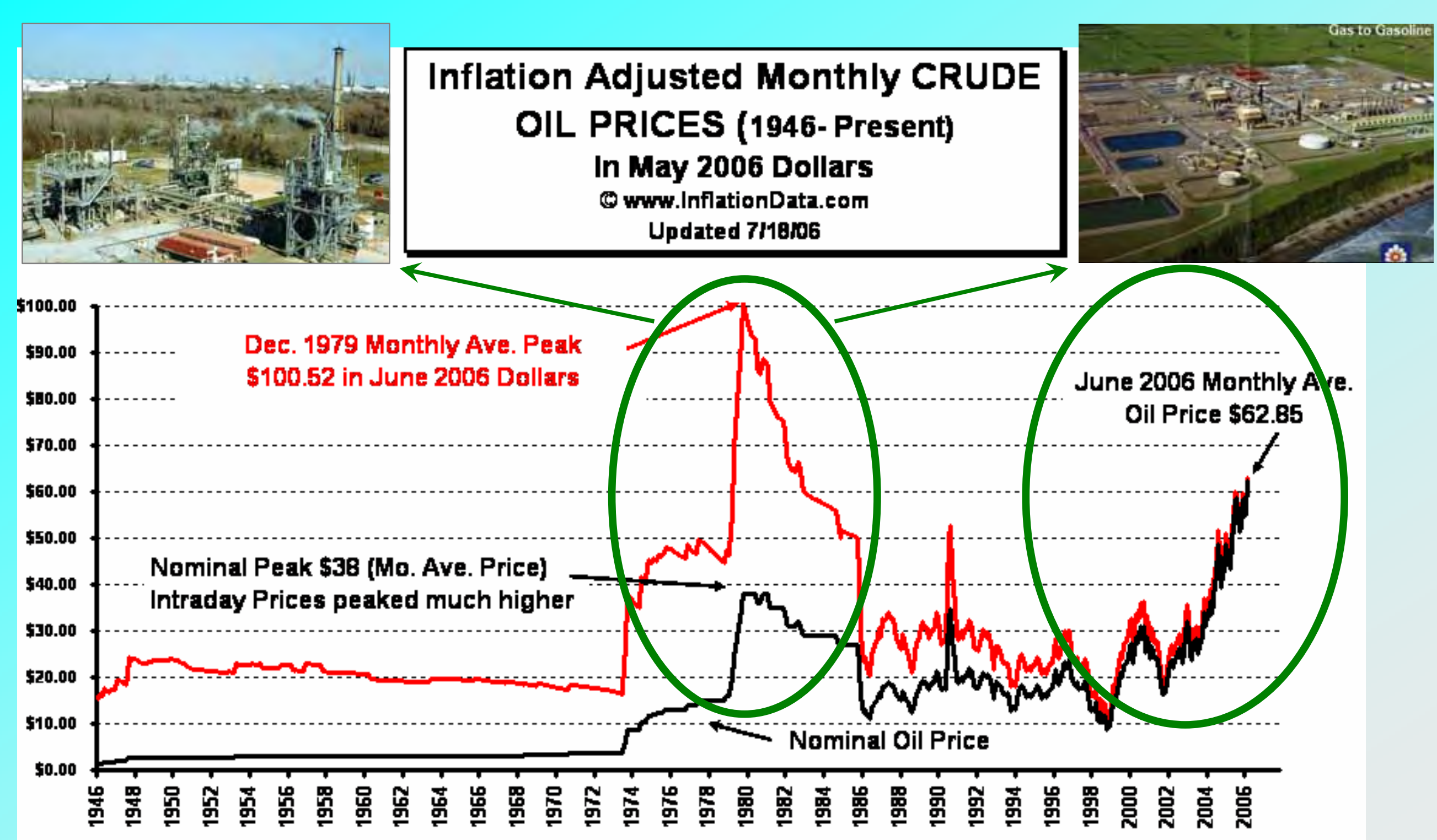

Nominal Monthly Ave. Oil Price

Inflation Adjusted Monthly Average Oil Price
Source of Data:

Illinois Basin Crude Prices- Wmm.ioga.com/Specialicrudeoil_Hist.htm CPI-U Inflation index- Wmw.bls.gov 


\section{Coal as a Raw Material}

- High oil prices \& Security of supply

- Interesting to generate power from coal

- if capable of dealing with $\mathrm{CO}_{2}$

- Interesting to generate chemicals otherwise obtained from oil from coal

- E.g. transportations fuels

- Interesting to use technology which can utilize renewable energy sources

- E.g. biomass 


\section{IGCC Plant}

Dirty synthesis gas

$$
\mathrm{CO}+\mathrm{H}_{2}+\mathrm{CO}_{2}
$$

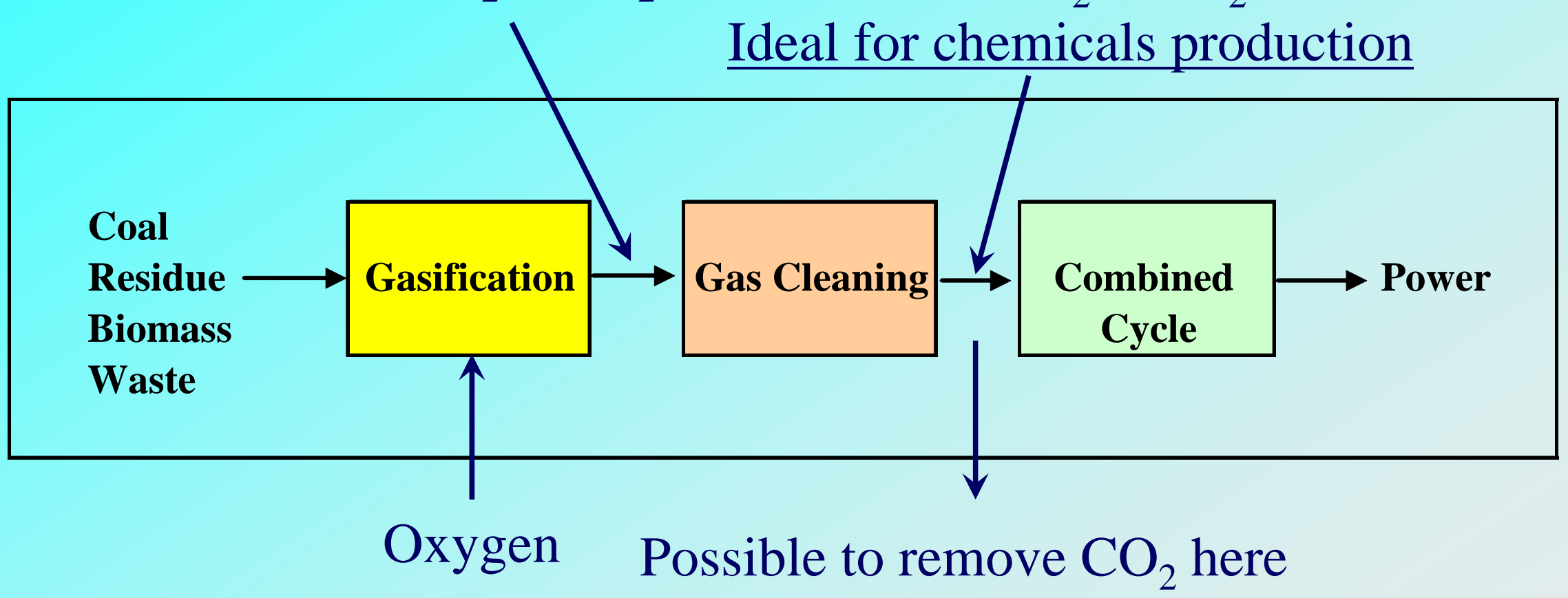

Clean synthesis gas

$$
\mathrm{CO}+\mathrm{H}_{2}+\mathrm{CO}_{2}
$$




\section{IGCC \& Chemicals Production Polygeneration}

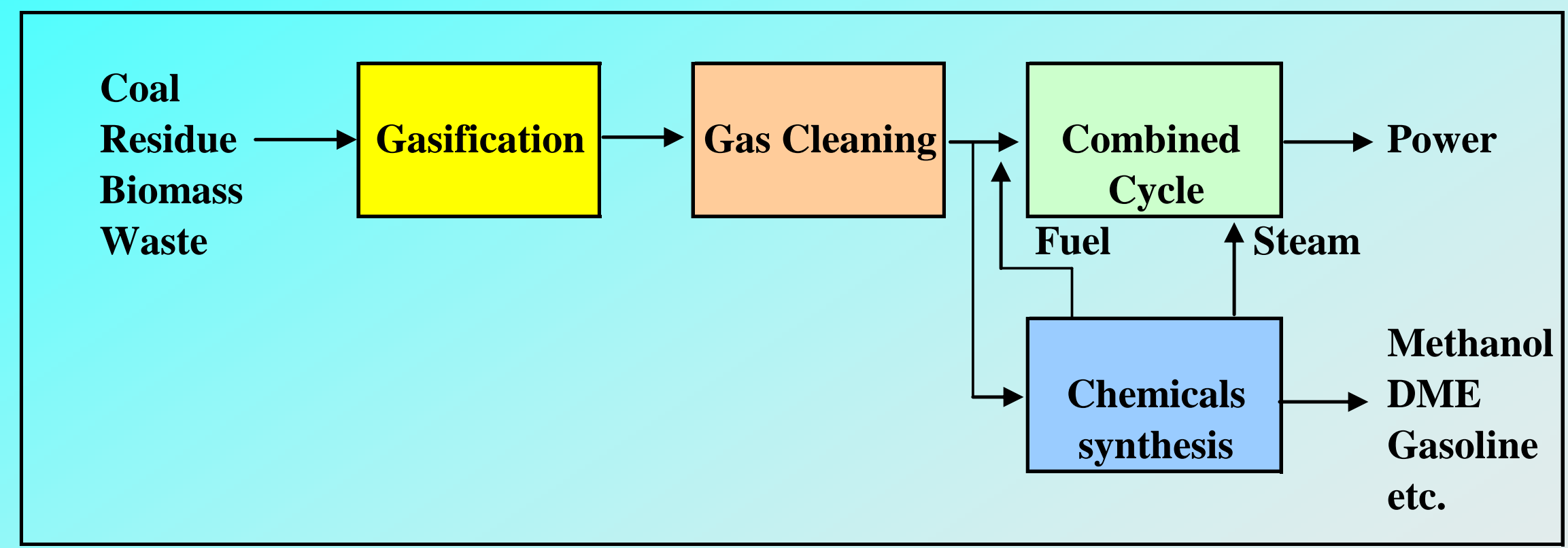


- IGCC and Polygeneration

- TIGAS - Iopsoe's Integrated Gasoline Synthesis

- Integration of IGCC \& TIGAS

- Process performance

- Economics

- Options for $\mathrm{CO} 2$ abatement 


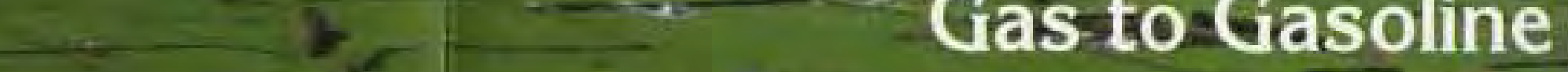

\section{Worlds first Gas to Gasoline Plant - New Zealand - 1986}

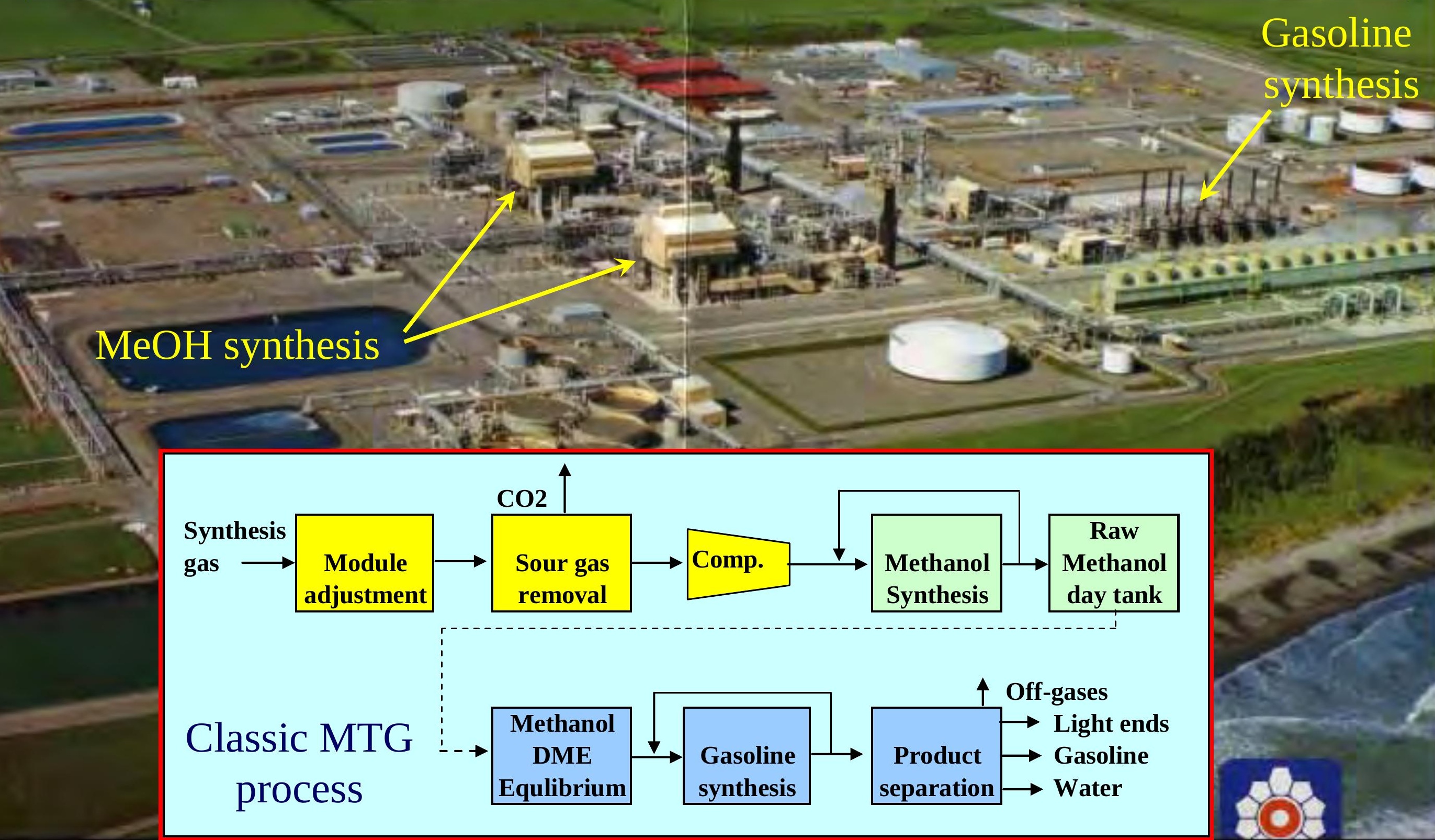




\section{TIGAS Process}

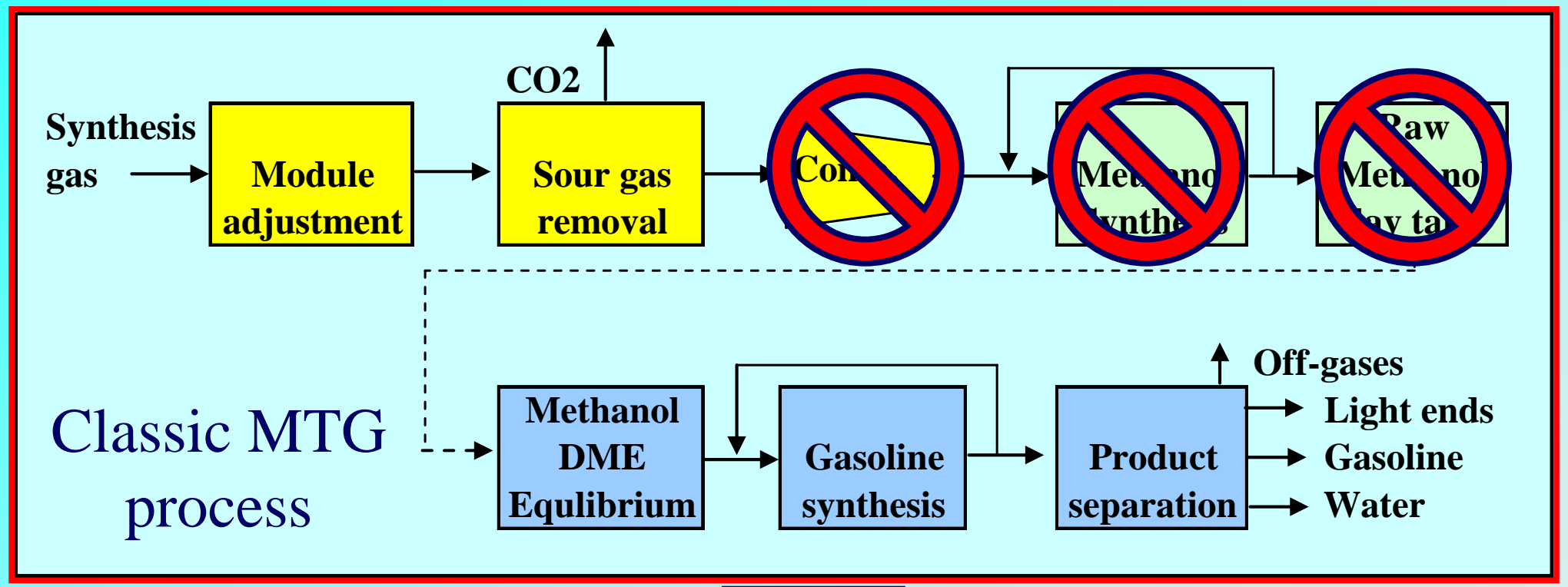

TIGAS Process
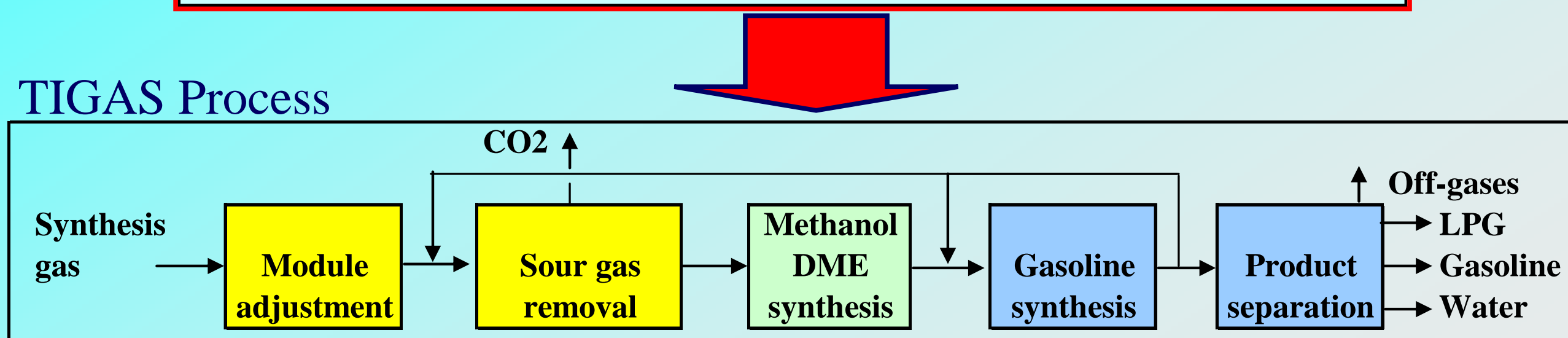

Haldor Topsøe A/S - Risø - May 232007 


\section{0 's Demonstrations from Natural Gas}

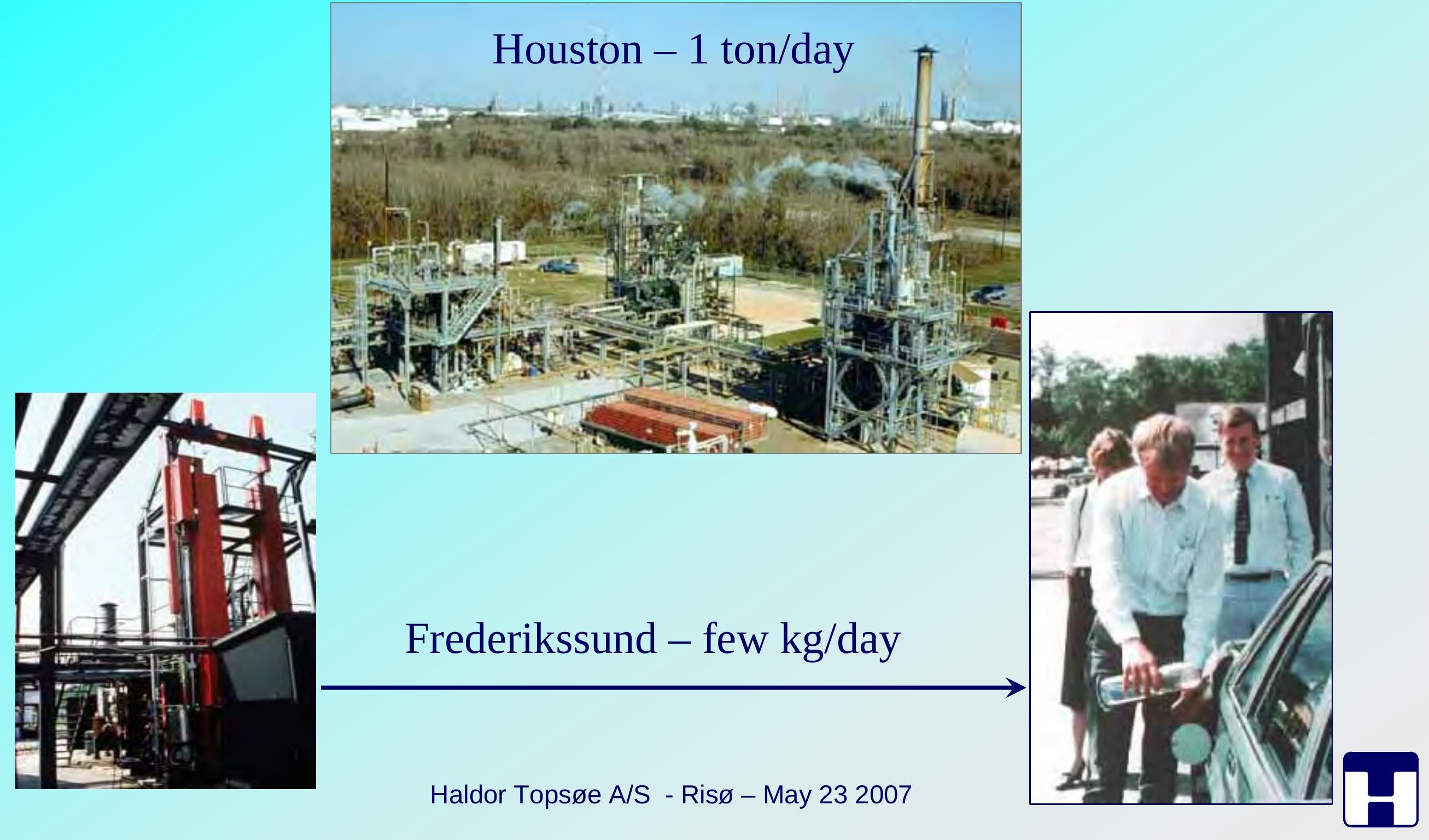


- IGCC and Polygeneration

- TIGAS - Iopsoe's Integrated Gasoline Synthesis

- Integration of IGCC \& TIGAS

- Process performance

- Economics

- Options for $\mathrm{CO}_{2}$ abatement 


\section{IGCC \& TIGAS}
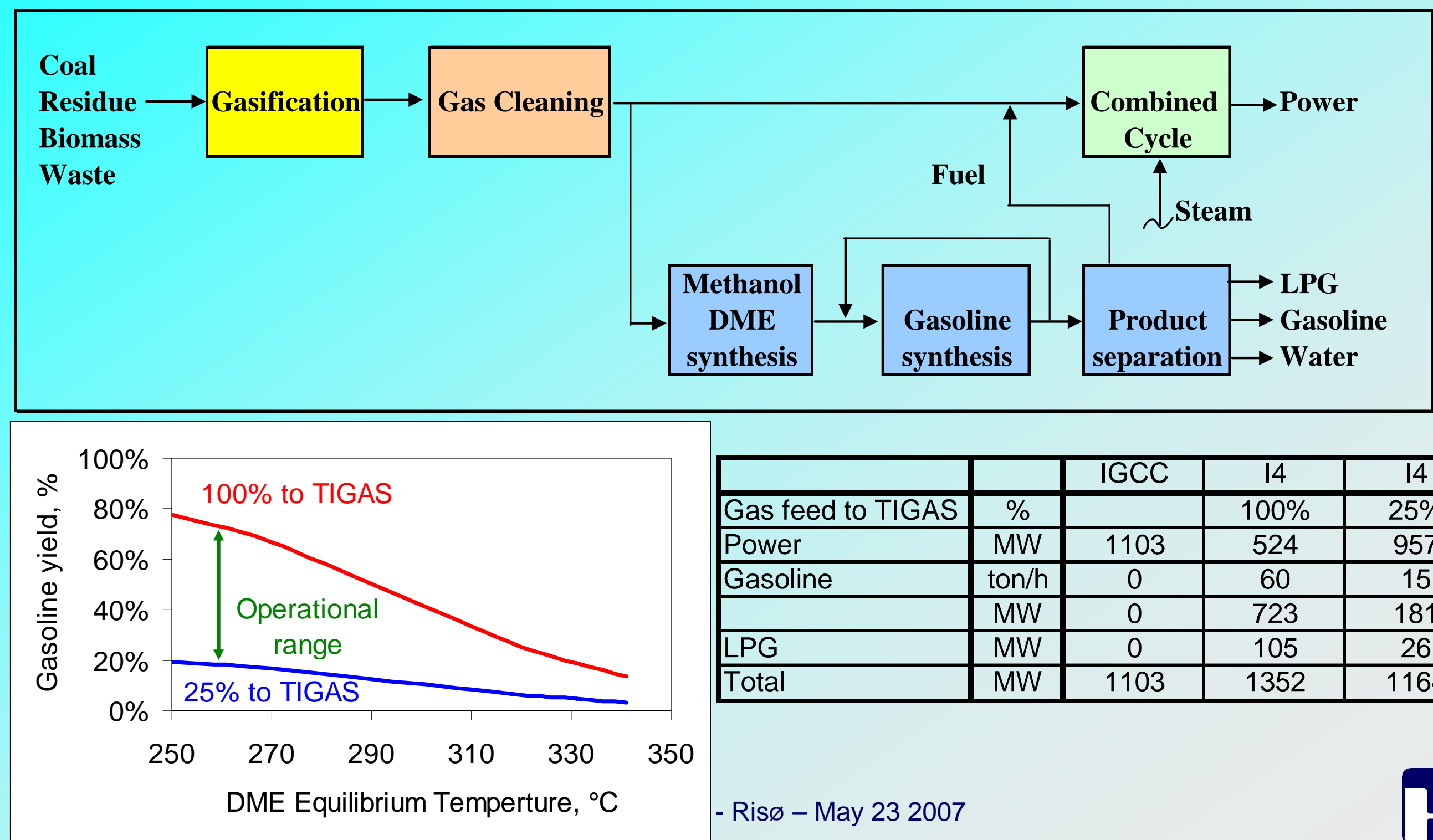

\begin{tabular}{|l|c|c|c|c|}
\hline & & IGCC & I4 & I4 \\
\hline Gas feed to TIGAS & $\%$ & & $100 \%$ & $25 \%$ \\
\hline Power & $\mathrm{MW}$ & 1103 & 524 & 957 \\
\hline Gasoline & ton/h & 0 & 60 & 15 \\
\hline & $\mathrm{MW}$ & 0 & 723 & 181 \\
\hline LPG & $\mathrm{MW}$ & 0 & 105 & 26 \\
\hline Total & $\mathrm{MW}$ & 1103 & 1352 & 1164 \\
\hline
\end{tabular}

- Risø - May 232007 
Efficiency
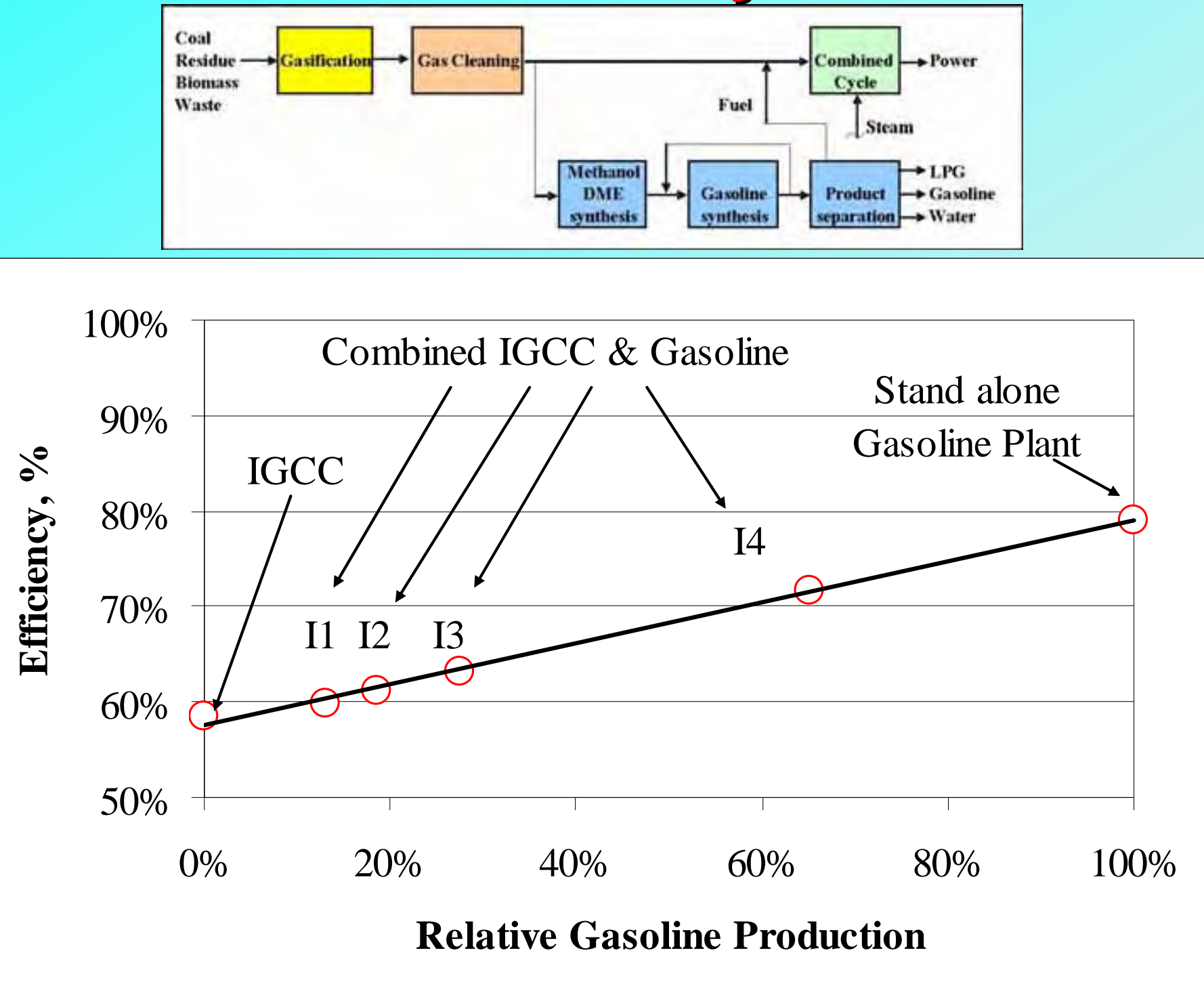


\section{Economics}

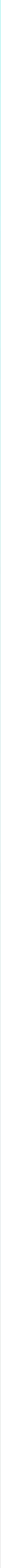




\section{How good an Investment?}

Assumed investment for TIGAS add-on 10,000 USD/bbl/d

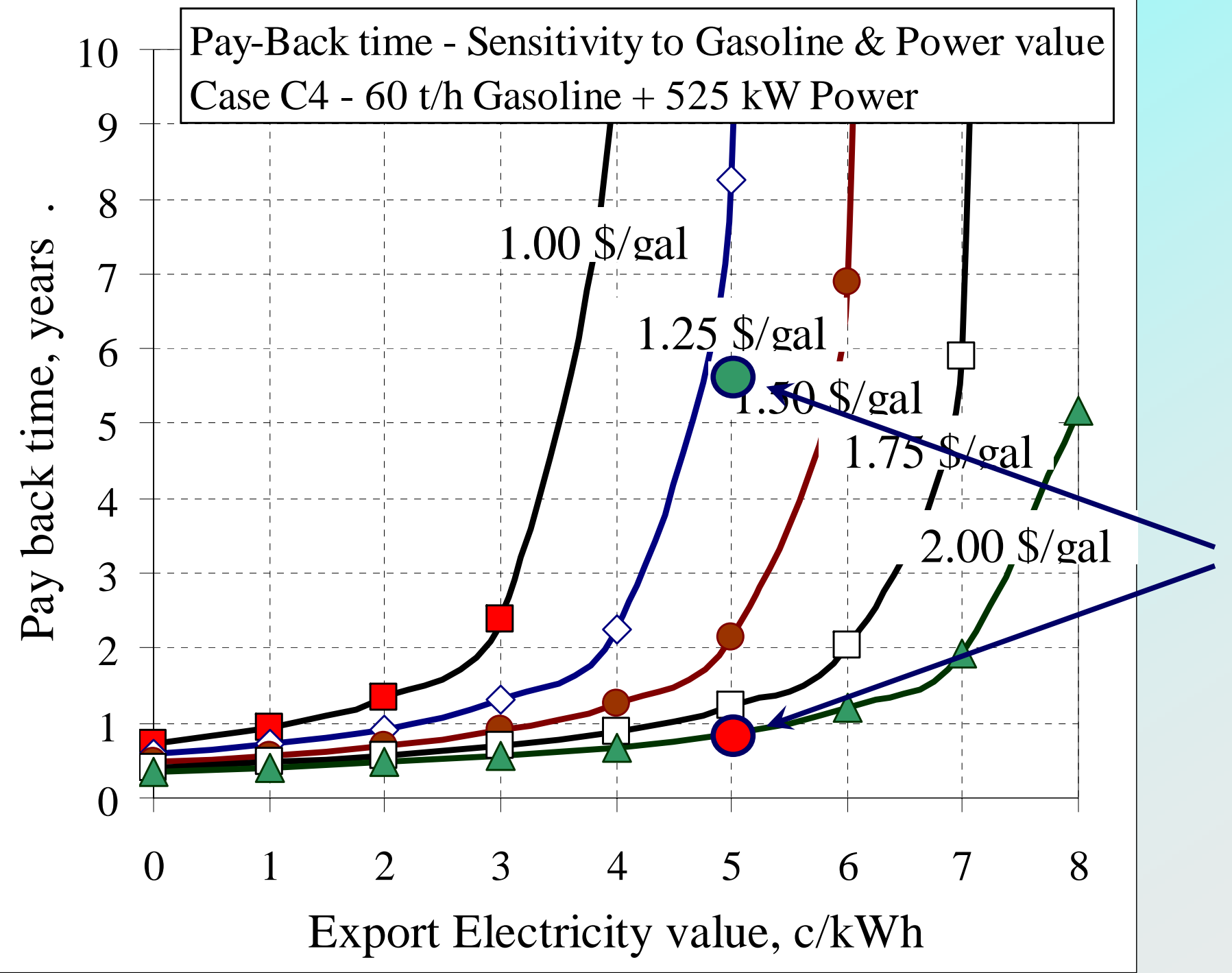

Operational flexibility 


\section{PSO Project}

- Project to demonstrate renewable technology for generation of Power and Gasoline

- HTAS, DONG, Novozymes

- Gasoline Pilot in connection with existing gasification plant

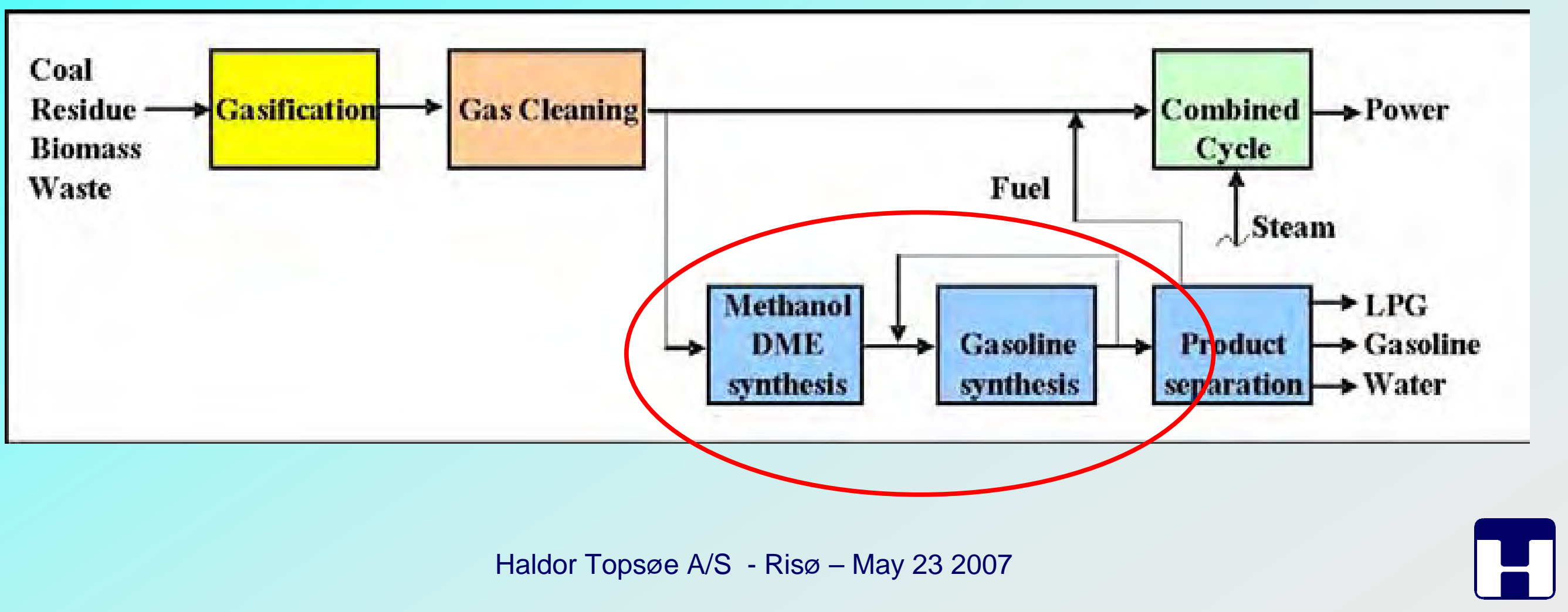




\section{$\mathrm{CO}_{2}$ abatement}

\section{- Power \& Gasoline with $\mathrm{CO}_{2}$ sequestration}

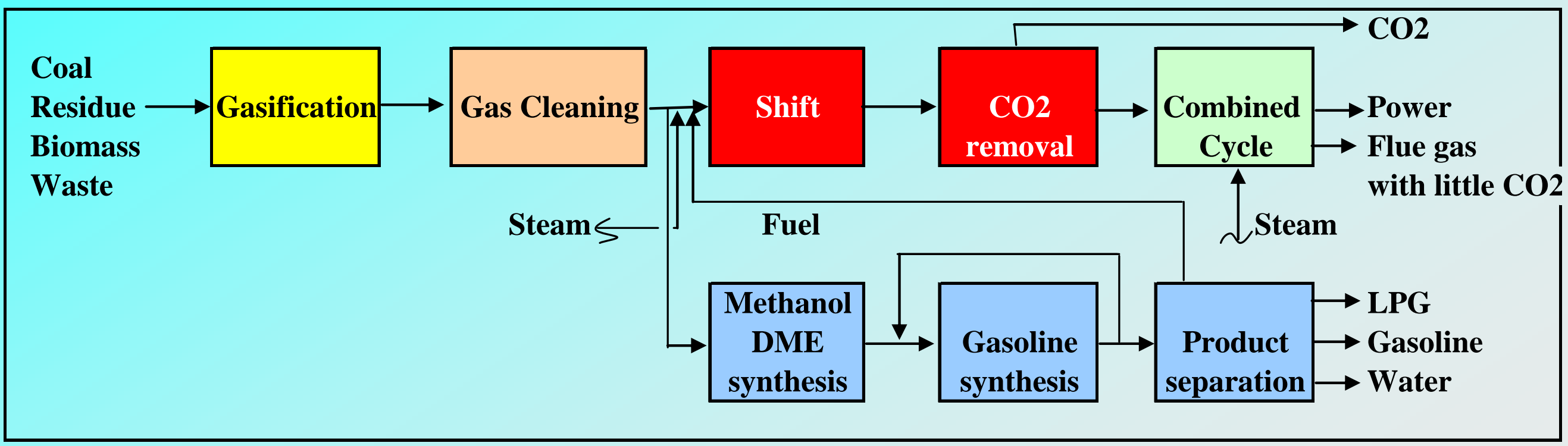




\section{Conclusions}

- Topsøe's TIGAS process is suitable for polygenration integrated with an IGCC plant

- Based on coal, waste, biomass

- Fast pay-back times are achieved for the TIGAS unit given realistic power and gasoline values

- Operational flexibility offers improved economics

- Topsøe is preparing to demonstrate an improved TIGAS process through a Danish government sponsored PSO project 


\section{$?$}
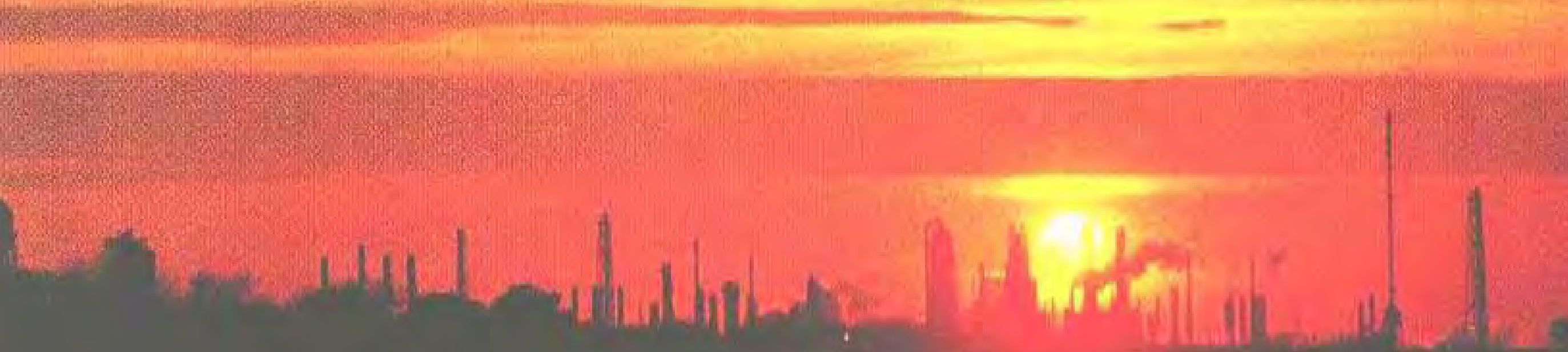
Risø International Energy Conference 2007, 22 - 24 May

Sustainable bioethanol production combining biorefinary principles and intercropping strategies

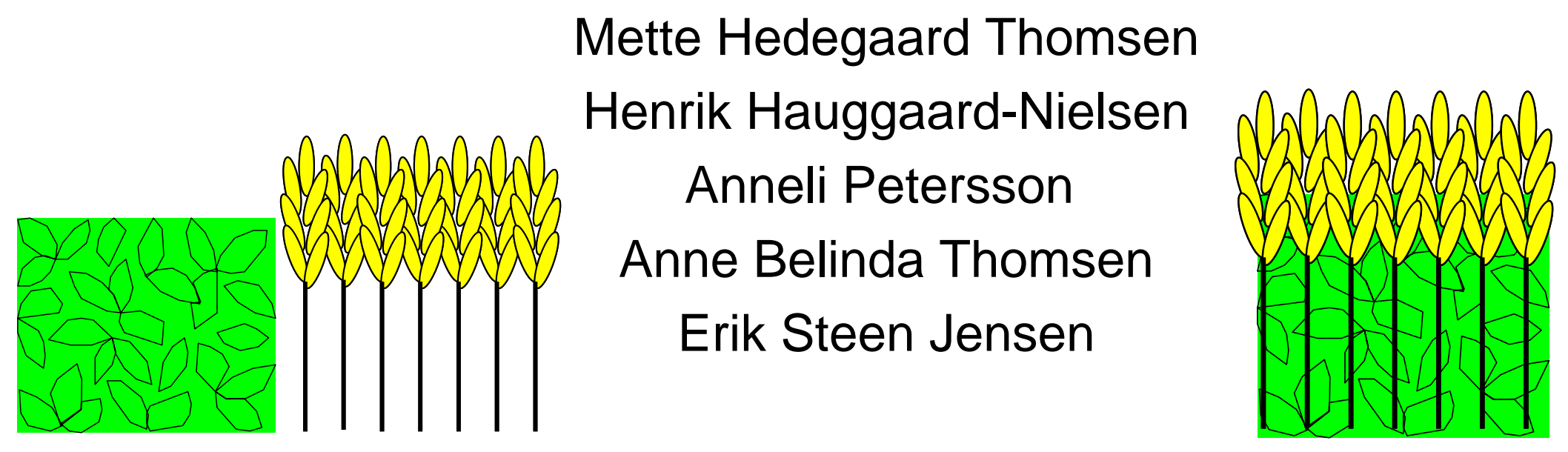




\section{Bioethanol}

\section{1. generation Bioethanol:}

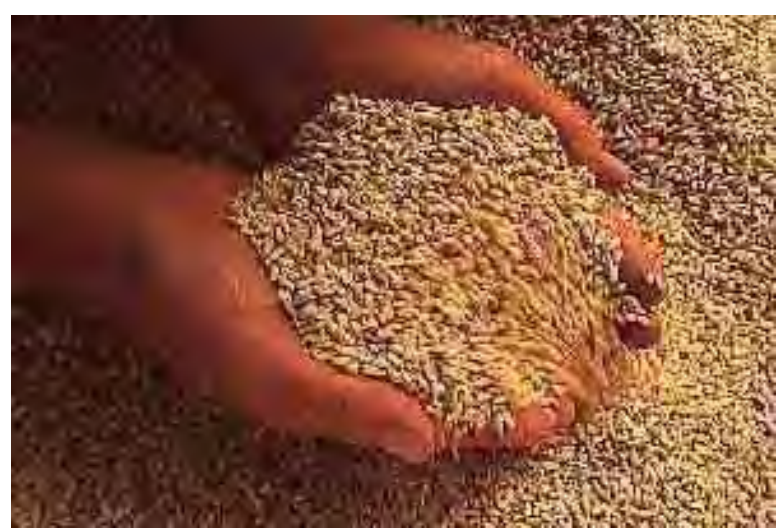

Substrate: Sugar (sucrose) from sugarcane and starch from corn or wheat.

No chemical/physical pretreatment of biomass before enzymatic hydrolysis.

Optimised, commercial enzymes available

\section{2. generation Bioethanol:}

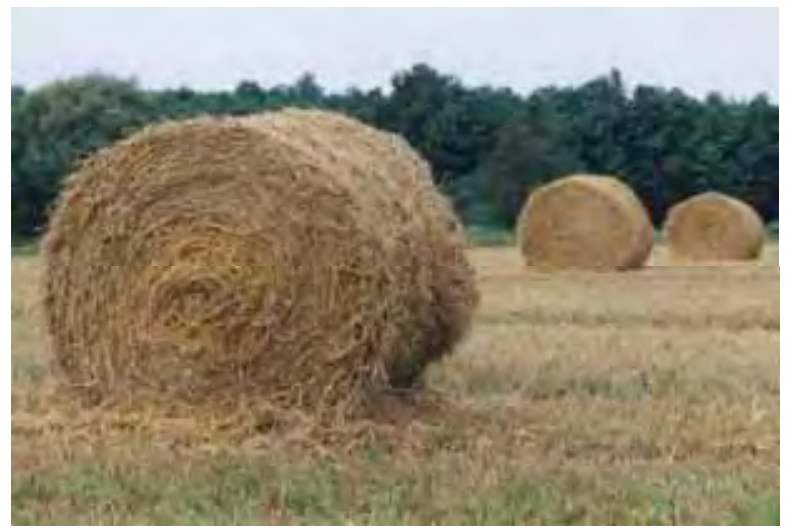

Substrate: Lignocellulosic materials (straw, corn stover, wood, waste)

Chemical/physical pretreatment necessary to facilitate enzymatic hydrolysis.

Expensive, non-commercial enzymes 


\section{2. generation Bioethanol production}

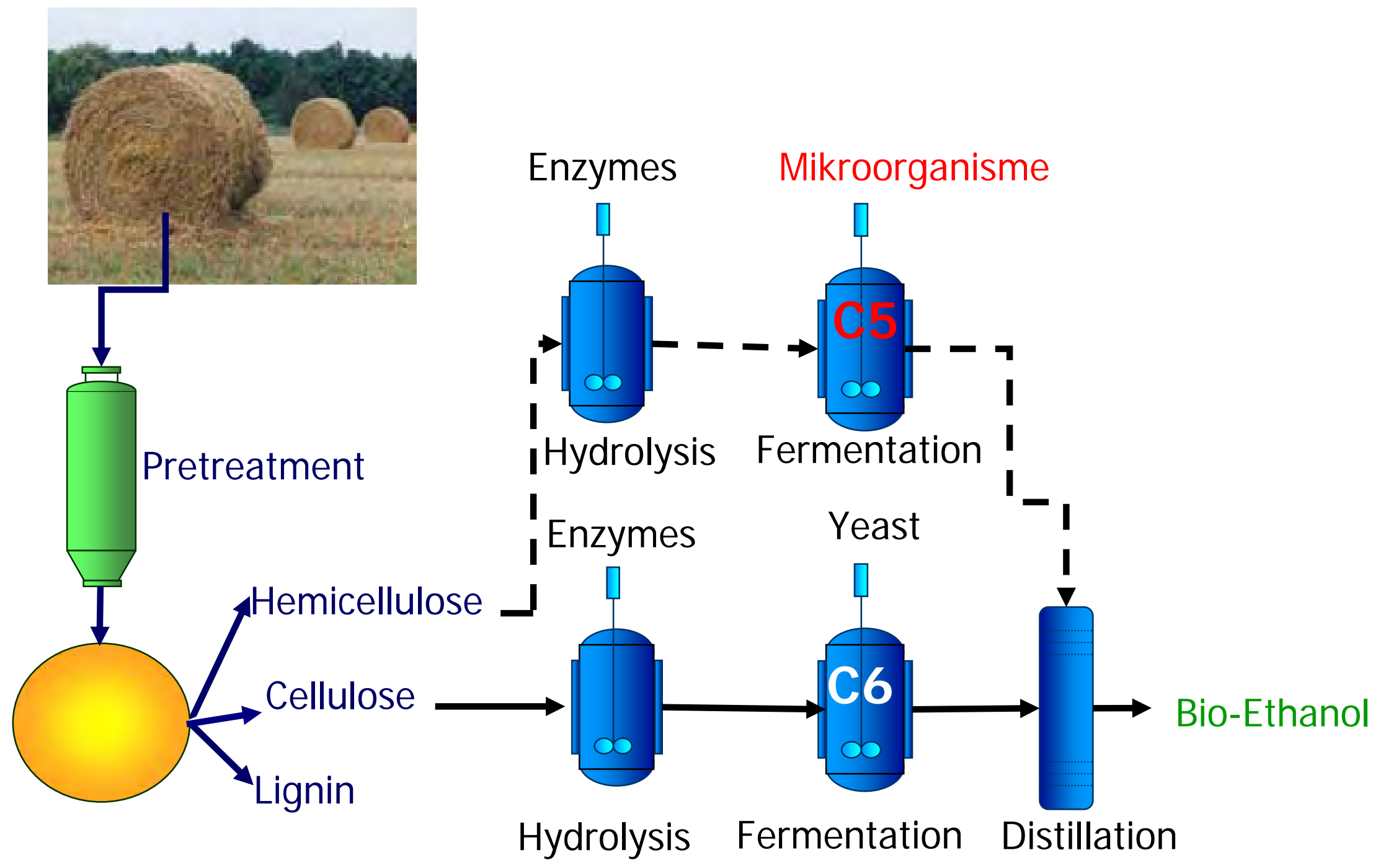




\section{Wet oxidation}

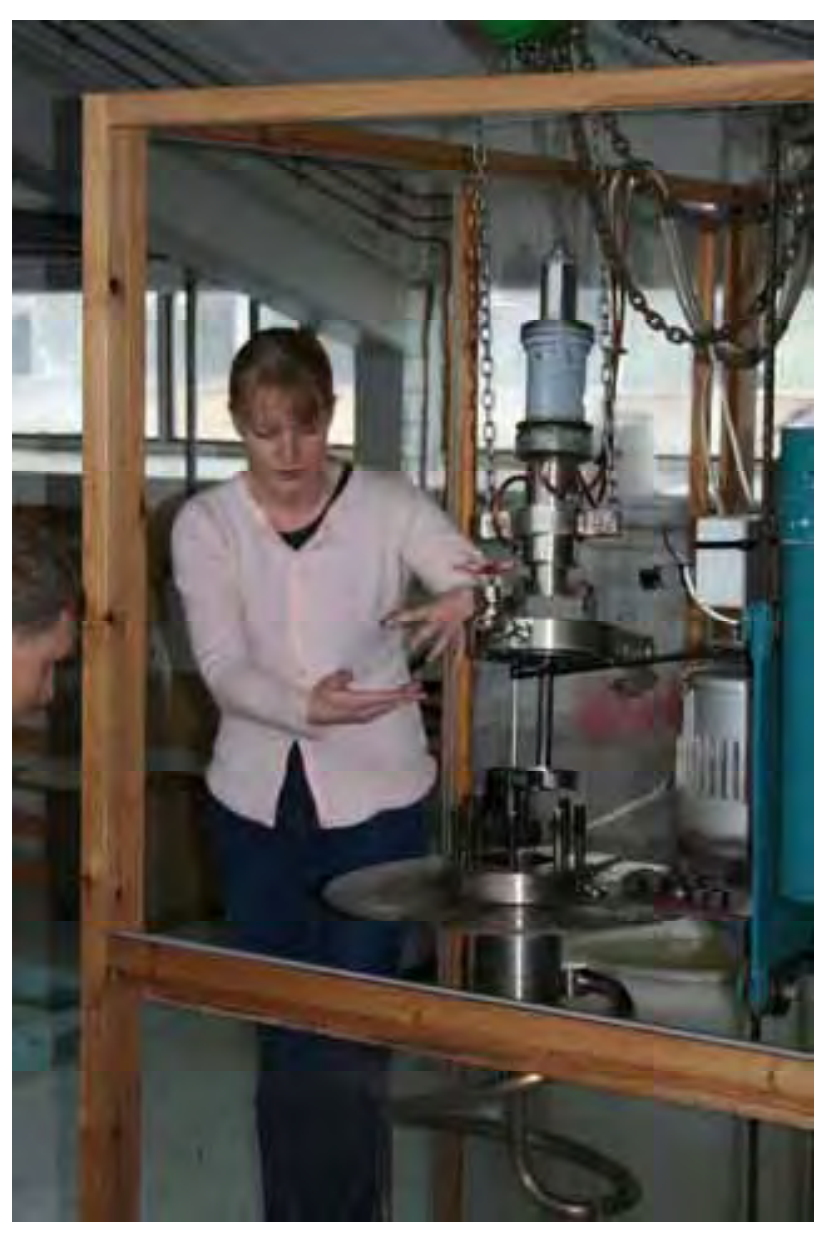

Pre-treatment method most suitable for annual crops such as wheat straw and corn stover.

Exothermic reaction:

- High temperature

- High pressure

- oxygen

- Reaction time 10-15 min.

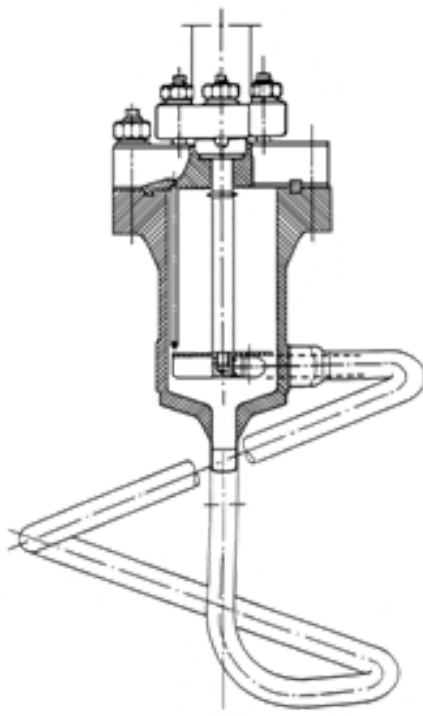

$-\mathrm{R}-+\mathrm{O}_{2} \rightarrow$ Products $+\mathrm{CO}_{2}+\mathrm{H}_{2} \mathrm{O}+$ Energy

Auto hydrolysis of hemicellulose sugars from the solid fraction because of production of carboxylic acids. 


\section{Choice of biomass resources}

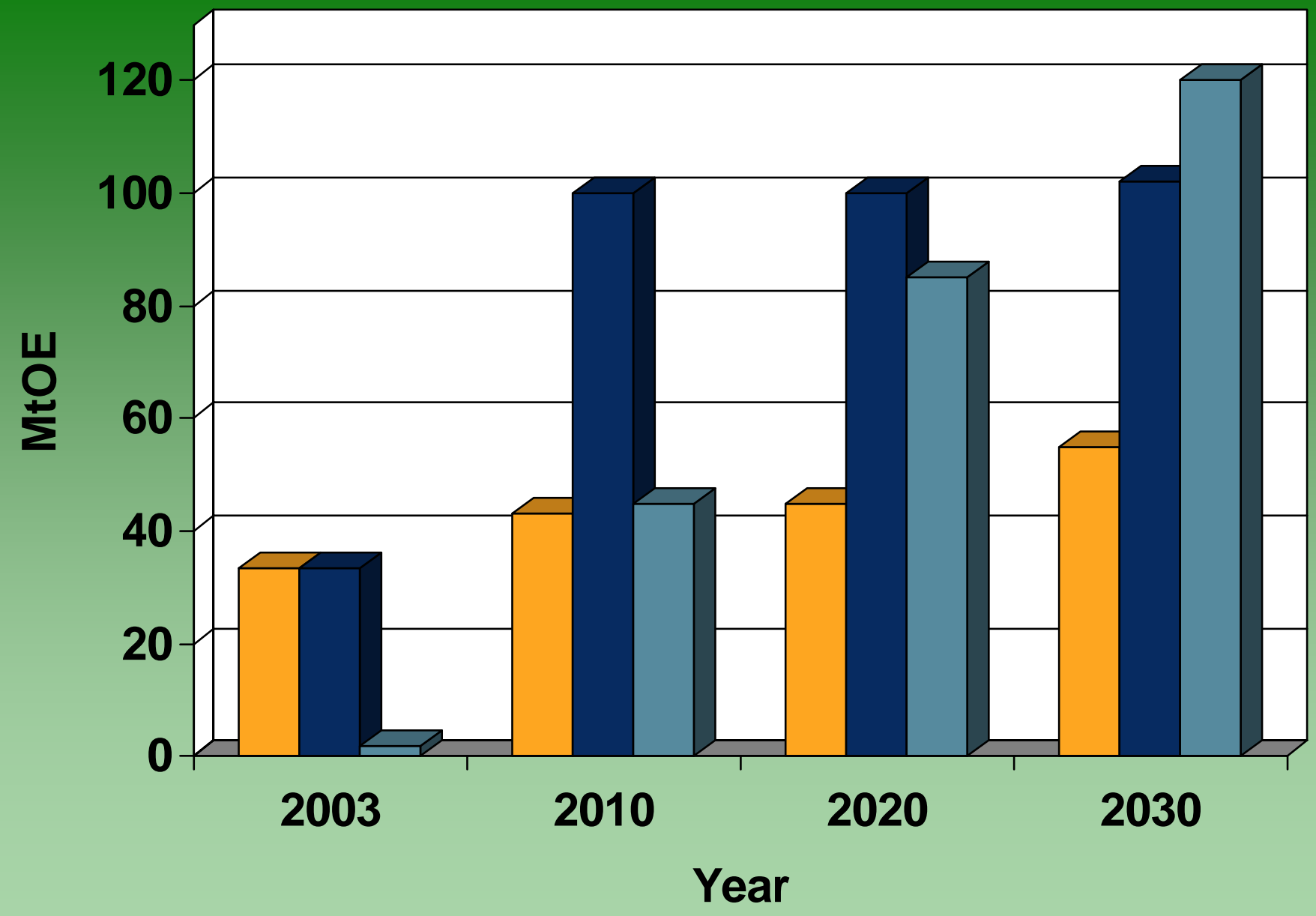

$\square$ Wood

Waste $\square$ Crops 
Choice of crop species and energy consumption

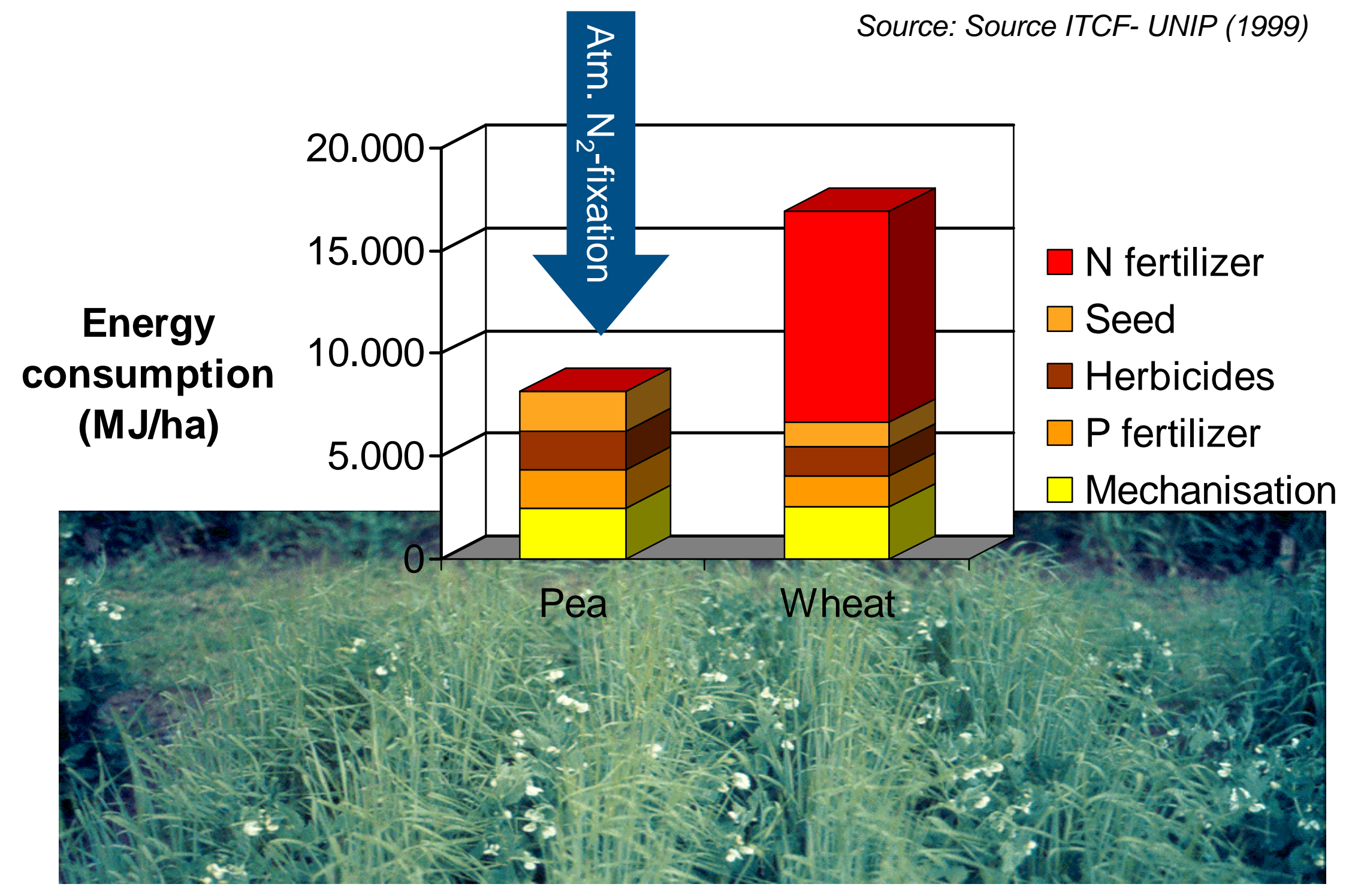




\section{Criteria to include when producing biomass}

- no effect on food production;

- no increase in pressure on biodiversity;

- no increase in environmental pressure;

- no ploughing of previously unploughed permanent grassland;

- a shift towards more environmentally friendly farming

- agroforestry - local integration and adoption of wood resources

- perennial energy crops

- environmental sensitive areas - e.g. groundwater protection

Source: http://ec.europa.eu/energy/res/biomass_action_plan

- It is required to design new cropping methods and multifunctional cropping systems when addressing a "new" issue - energy.

- low-input systems (energy and pesticides)

- harvest, storage and transportation

- Win-win solutions energy, environment, and recreation 
Intercropping as an alternative cropping strategy

- Intercropping is defined as the growing of two or more crops in the same piece of land and on the same time - planned crop diversity

- Associated interspecies interactions are tools for:

- improved utilization of resources (light, water nutrients),

- increased yield stability,

- control of nutritional quality of grains

- managing weeds, pest and diseases in low-input systems

- LEES NEED FOR PERSTI CI DES AND FERTI LI ZERS!!!

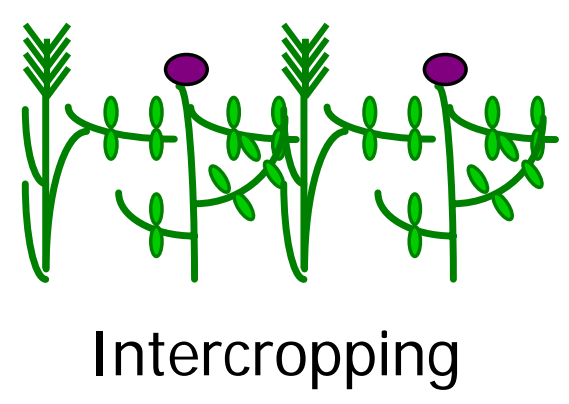




\section{Complementary use of resources}

- Complementarity is implemented in the crop stand when species utilize resources differently

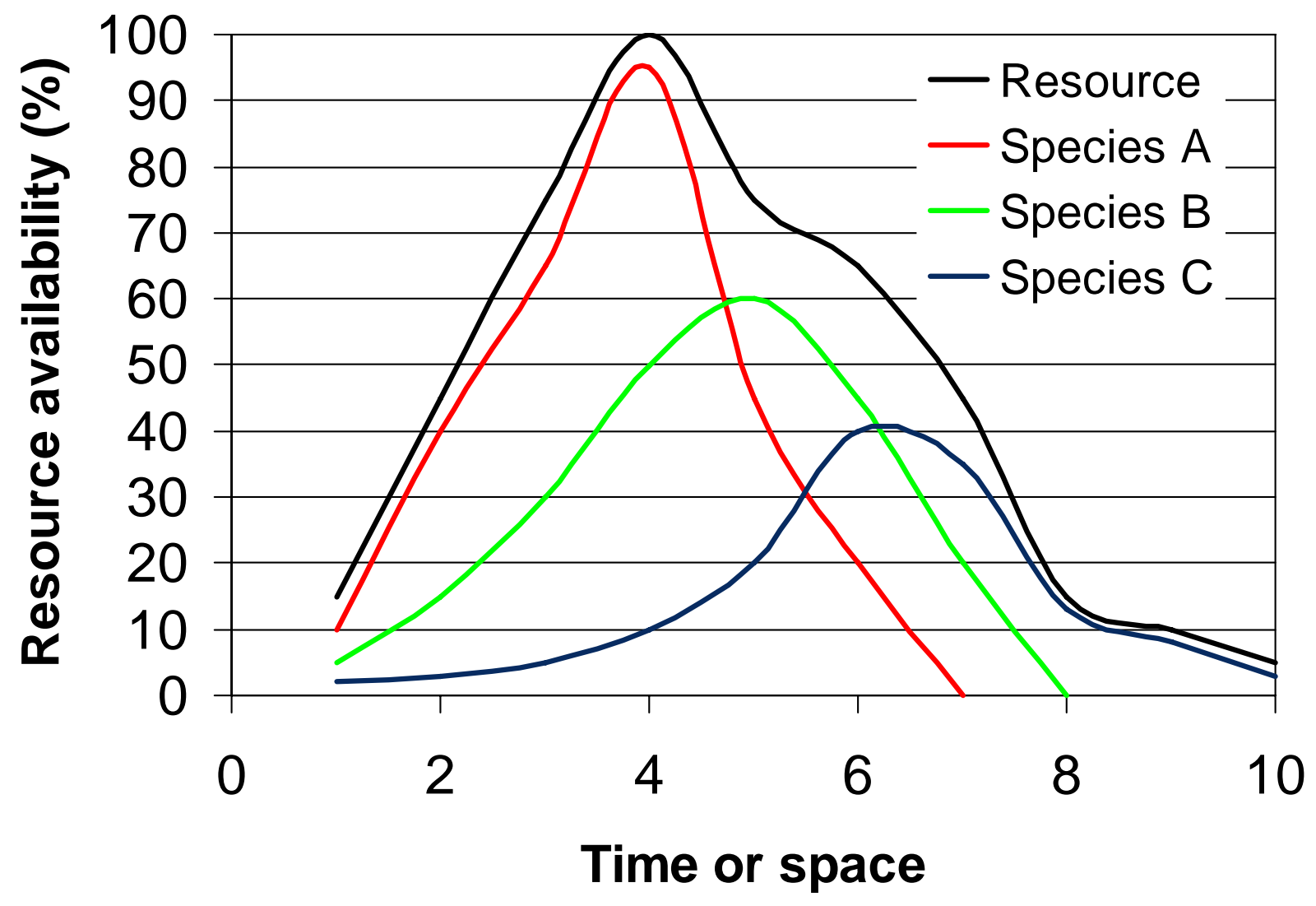


Clover grass pasture as a potential intercrop raw material

- A mix of white clover ( Trifolium repens L.) and ryegrass (Lolium perenne L.) are important in many agroecosystems today:

1. high quality feed for livestock

2. high productivity ( $>10 \mathrm{t} \mathrm{ha}^{-1} \mathrm{yr}^{-1}$ ) in unfertilized pastures, with 95\% of the $\mathrm{N}$ from $\mathrm{N}_{2}$ fixing clover (Høgh-J ensen and Schjørring, 1994)

3. their roots and stubble contain $60-110 \mathrm{~kg} \mathrm{~N} \mathrm{ha}^{-1}$ (HauggaardNielsen et al., 1998) reducing $\mathrm{N}$ requirements for succeeding crops

4. integration of pastures diversify the traditional cereal rich rotations

5. fields with clover grass pastures can be harvested several times a year and the green biomass can be collected and processed to ethanol throughout the year. 
Clover grass as raw material for bioethanol production

- Rich in carbohydrates:

cellulose and hemicellulose

- Rich in minerals, especially nitrogen $\Downarrow$

nutrients for yeast in fermentation
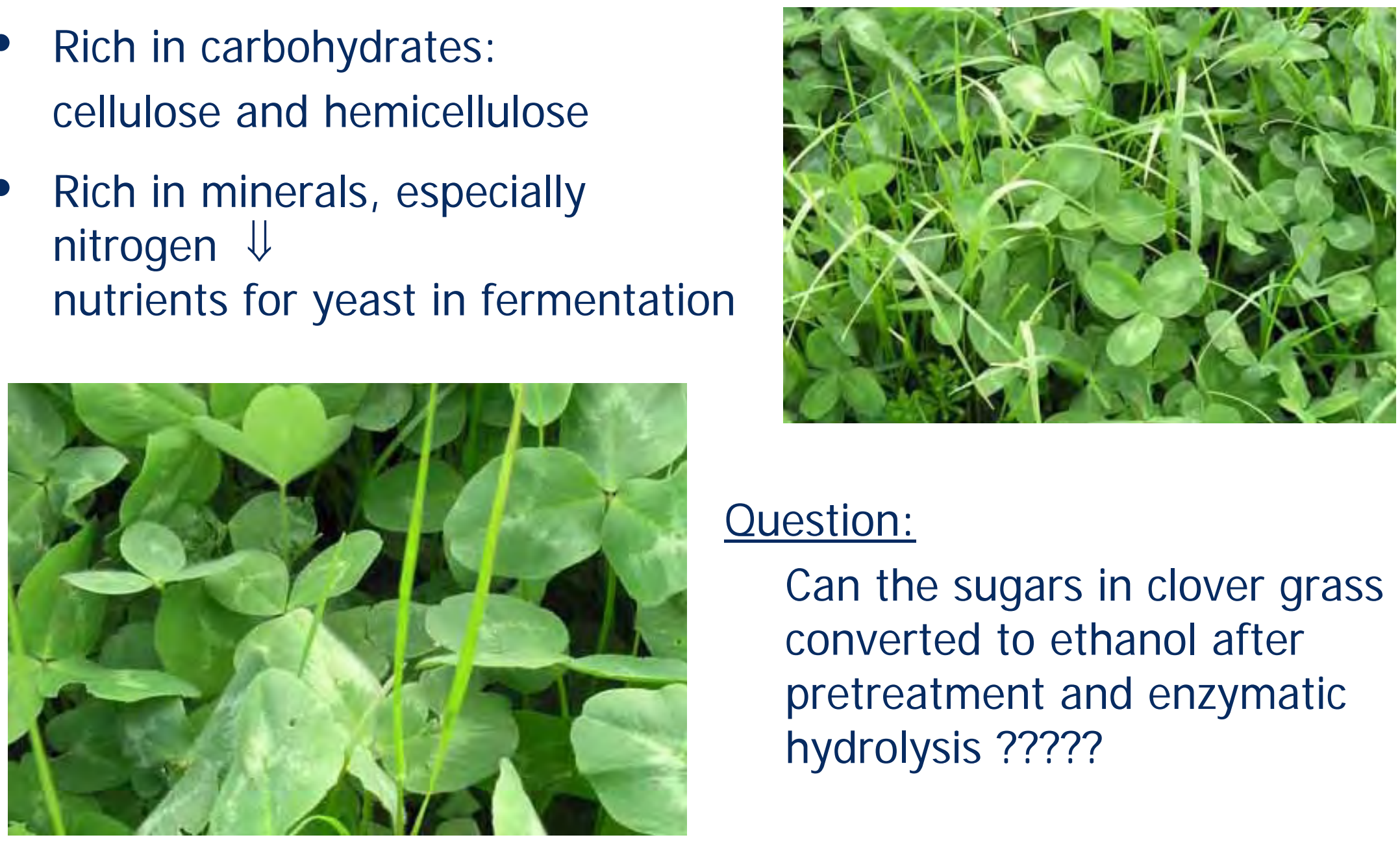

Question:

Can the sugars in clover grass be converted to ethanol after pretreatment and enzymatic hydrolysis ????? 


\section{Carbohydrate composition}

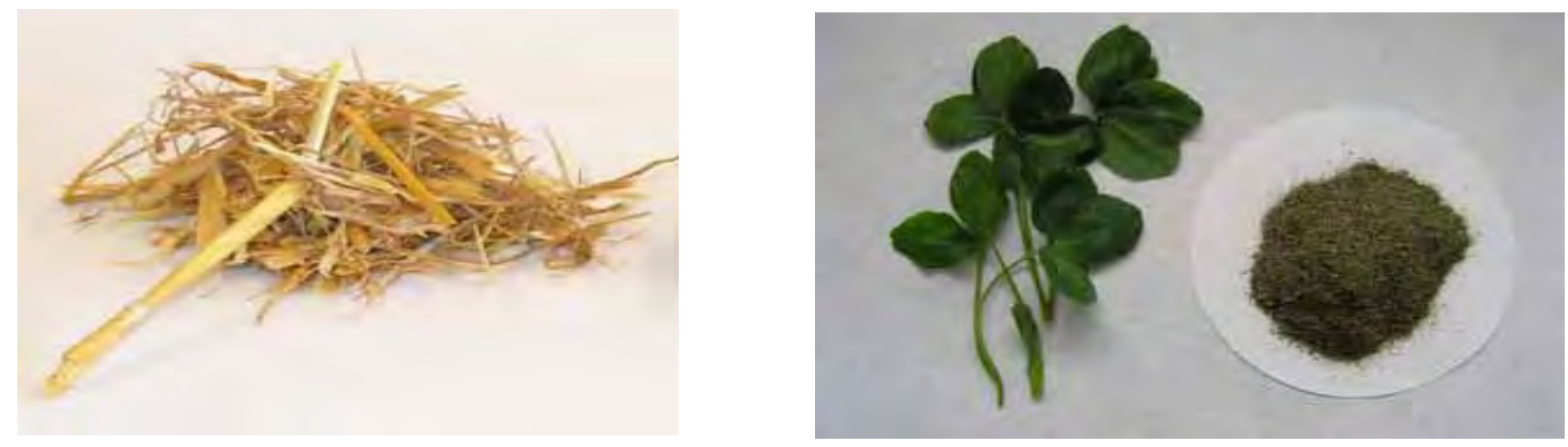

\begin{tabular}{|l|c|c|c|}
\hline Biomass & $\begin{array}{c}\text { Cellulose } \\
(\mathrm{g} / 100 \mathrm{~g} \mathrm{DM})\end{array}$ & $\begin{array}{c}\text { Hemicellulose } \\
(\mathrm{g} / 100 \mathrm{~g} \mathrm{DM})\end{array}$ & $\begin{array}{c}\text { Ligning } \\
(\mathrm{g} / 100 \mathrm{~g} \mathrm{DM})\end{array}$ \\
\hline Wheat straw & 33.9 & 23.0 & 19.1 \\
\hline Clover & 16.6 & 10.5 & 14.4 \\
\hline Grass & 23.9 & 17.5 & 12.8 \\
\hline
\end{tabular}


Clover grass - mineral composition
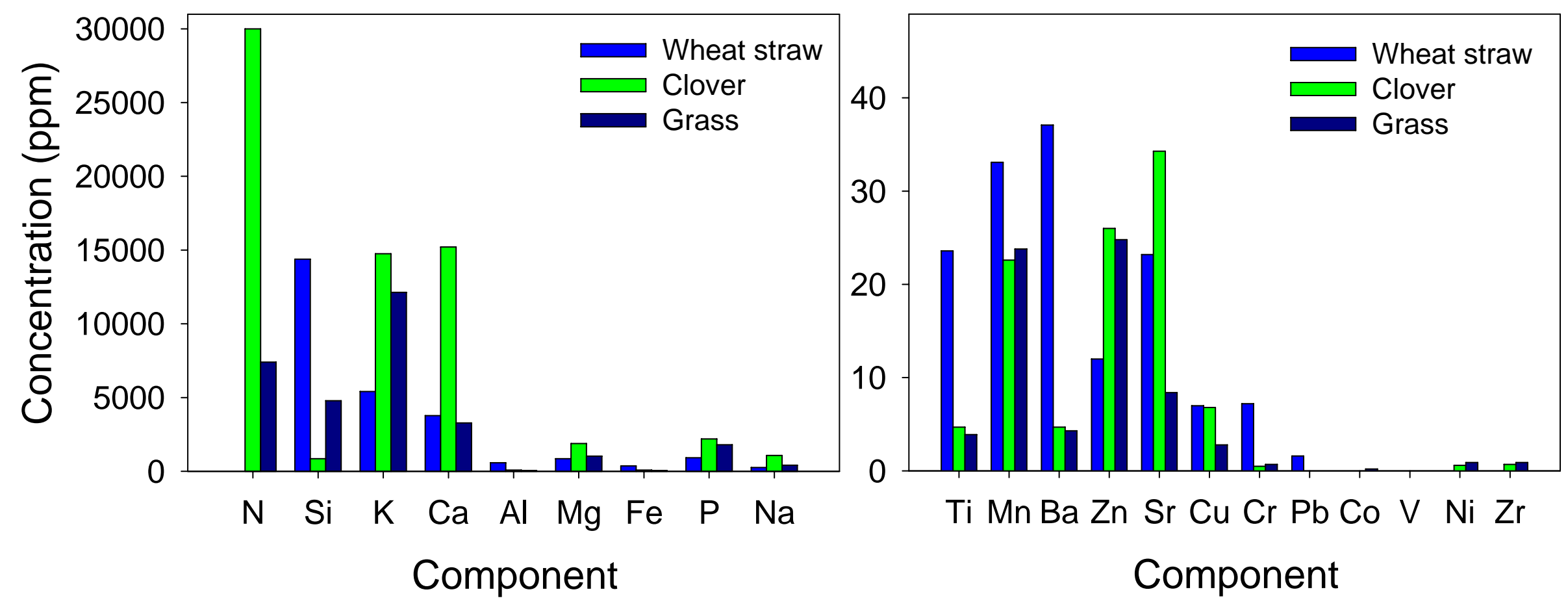

High mineral content $\Rightarrow$ sufficient nutrients for microbial fermentation $\Rightarrow$ less fossil energy input in ethanol process 


\section{Pretreatment conditions}

- Clover-grass mixture (1:1) were cultivated in the experimental fields of Risø National Laboratory, Denmark.

- Samples of pure clover and grass and 1:3 clover-grass mixture - was separated by hand.

- The samples were dried at $50 \circ \mathrm{C}$ to constant weight and milled to a size of less than $2 \mathrm{~mm}$ prior to pretreatment and further analysis.

- Wet oxidations were performed in the loop autoclave using $6 \%$ dry matter (DM) at different process parameters. The pretreated biomass was filtrated into a fiber fraction and a liquid fraction.

\begin{tabular}{|l|c|c|c|c|}
\hline Material & $\begin{array}{c}\text { Temp. } \\
\left({ }^{\circ} \mathrm{C}\right)\end{array}$ & $\begin{array}{c}\text { Time } \\
(\mathrm{min})\end{array}$ & $\begin{array}{c}\mathrm{O}_{2} \\
(\mathrm{bar})\end{array}$ & $\begin{array}{c}\mathrm{Na}_{2} \mathrm{CO}_{3} \\
(\mathrm{~g} / \mathrm{l})\end{array}$ \\
\hline Clover & 195 & 10 & 12 & 2 \\
\hline Grass & 195 & 10 & 12 & 2 \\
\hline CL-G (1:1) & 175 & 10 & 3 & \\
\hline CL-G (1:1) & 175 & 10 & 12 & 2 \\
\hline Cl-G (1:1) & 185 & 10 & 3 & \\
\hline Cl-G (1:1) & 185 & 10 & 12 & 2 \\
\hline CL-G (1:1) & 195 & 10 & 3 & 2 \\
\hline CI-G (1:1) & 195 & 10 & 12 & \\
\hline Cl-G (1:1) & 195 & 10 & 12 & 2 \\
\hline Cl-G (1:3) & 195 & 10 & 3 & 2 \\
\hline
\end{tabular}




\section{Pretreatment Yields}

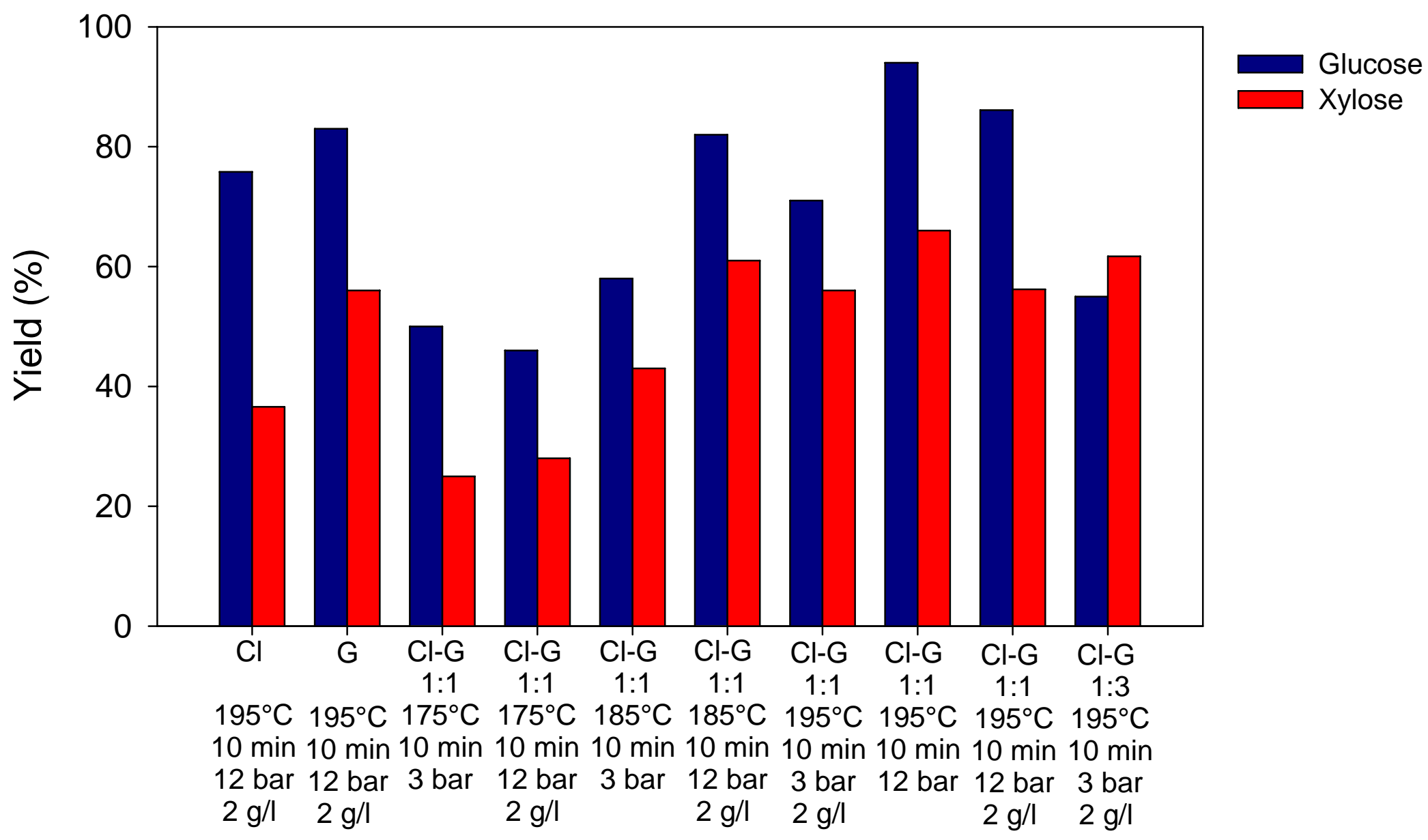

Material/Pretreatment conditions 
Fermentation of pretreated clover grass with Mucor indicus
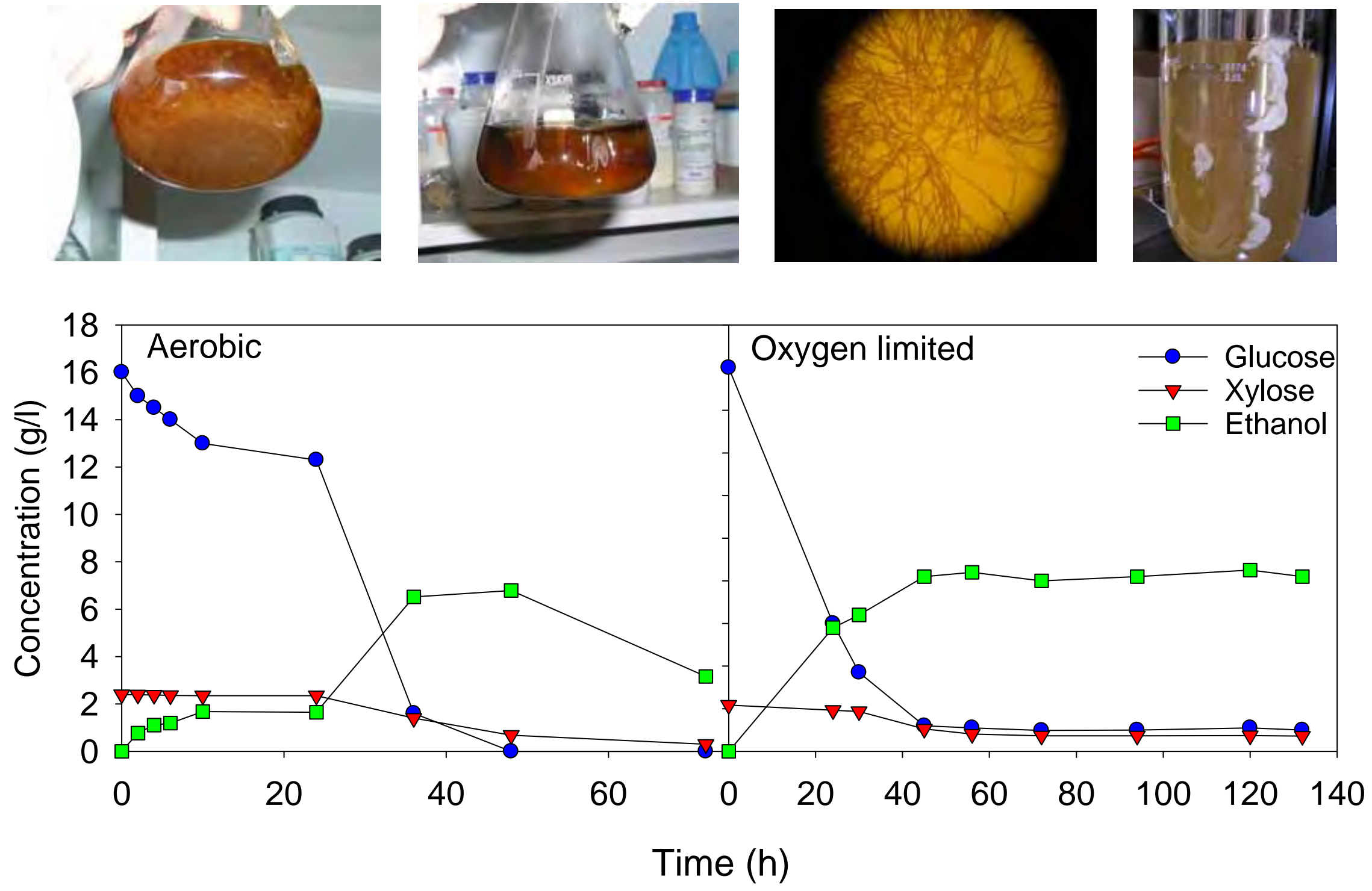


\section{Yeast fermentation of fresh clover grass}

Fructans are polymeric carbohydrates consisting of variable numbers of fructose molecules with terminal sucrose.

Grass and clover contains significant amount of fructans: Grass: 166 g/kg DM Clover: $111 \mathrm{~g} / \mathrm{kg}$ DM

Plant fructan hydrolases are active at $\mathrm{pH} 4.5$ - 5.5 and temp. $25-40^{\circ} \mathrm{C} \Rightarrow$ Activity during yeast fermentation at $32^{\circ} \mathrm{C}$ and $\mathrm{pH} 4-6$.
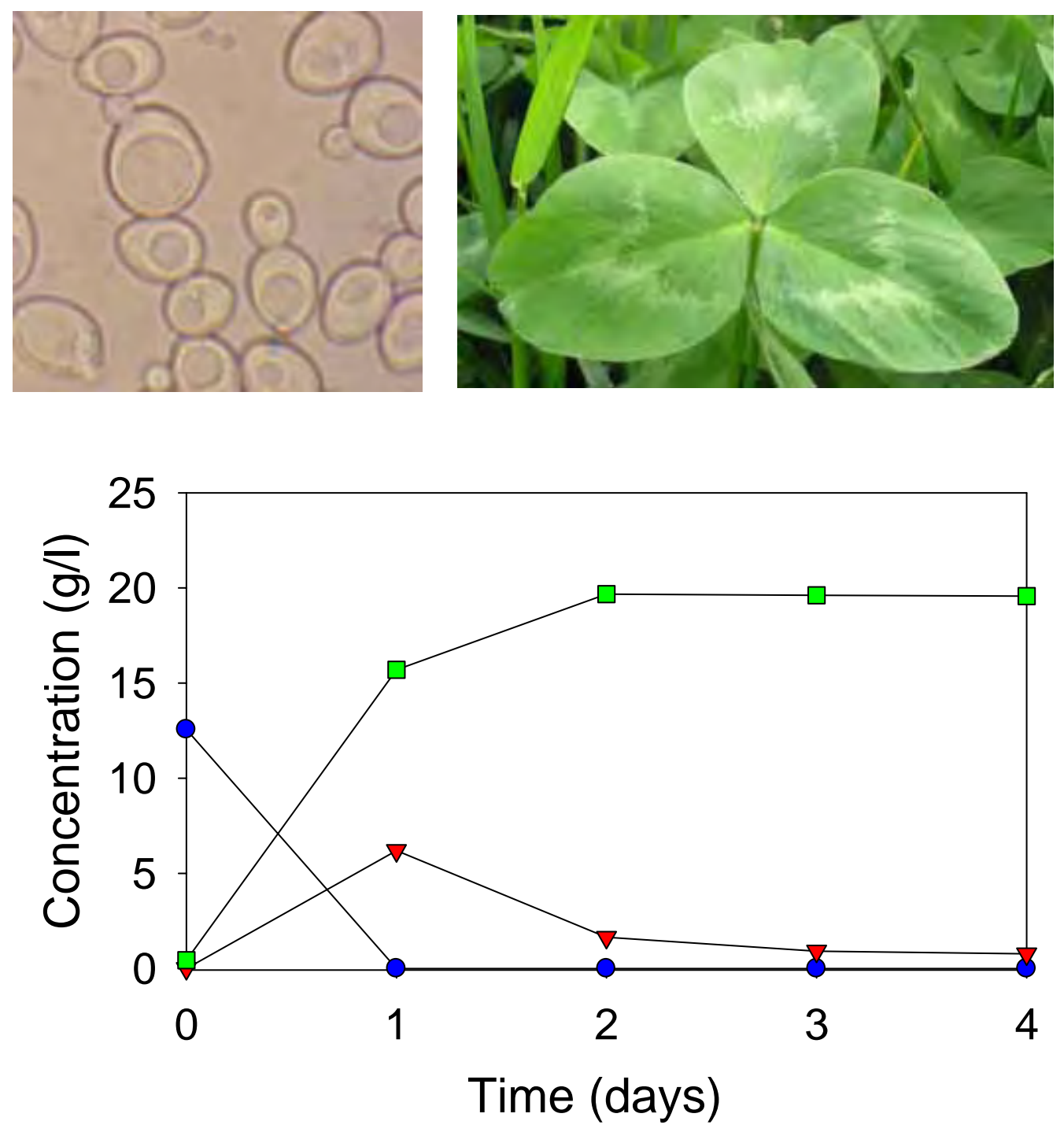


\section{Biorefinery concept}

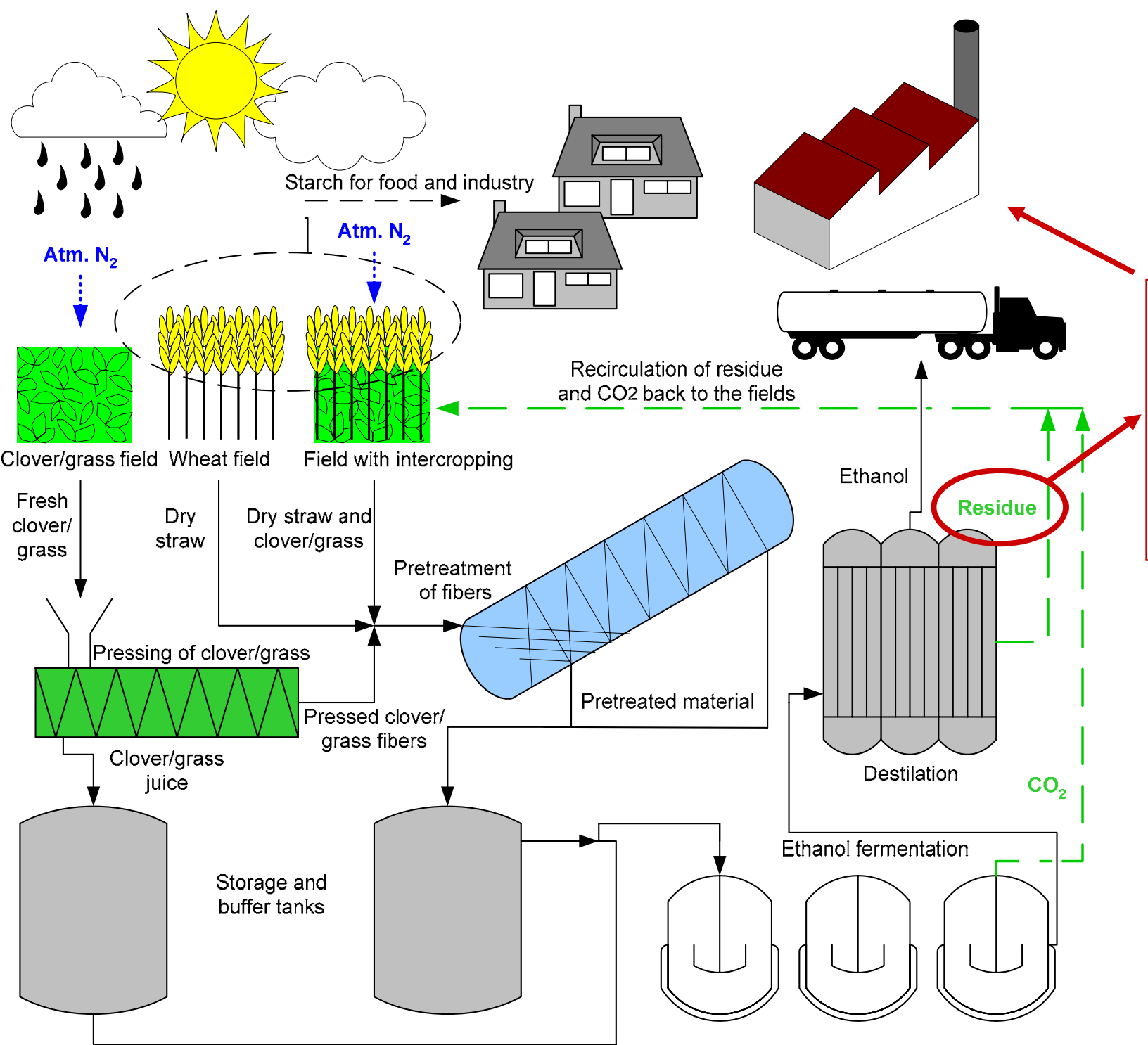

High value/protein rich feed product

Fertiliser rich in micro and macro nutrients 


\section{Theoretical ethanol production}

The highest sugar yields were obtained with clover grass pretreated at $195 \circ \mathrm{C}$ for 10 min. using 12 bar $\mathrm{O}_{2}$ and $\mathrm{no} \mathrm{Na}_{2} \mathrm{CO}_{3}$.

$Y_{\text {cellulose }}=94 \%$

$Y_{\text {hemicellulose }}=66 \%$

$203 \mathrm{~kg}$ cellulose/ton DM clover grass $\Rightarrow 107 \mathrm{~kg}$ ethanol/ton DM

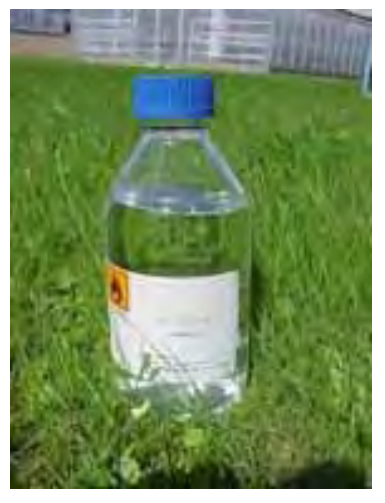

$140 \mathrm{~kg}$ hemicellulose/ton DM clover grass $\Rightarrow 63.5 \mathrm{~kg}$ ethanol/ton DM

$138 \mathrm{~kg}$ fructan/ton DM clover grass $\Rightarrow \sim 70.6 \mathrm{~kg}$ ethanol/ton DM (depending on yield)

Total: $241 \mathrm{~kg}$ ethanol/ ton DM 2.4 ton EtOH/ ha

Wheat straw: $\sim 250 \mathrm{~kg}$ ethanol/ton DM $\sim 1.25$ ton/ha (IBUS treatment)

Clover grass pasture undersown in wheat $\sim 964+125 \mathrm{~kg} \mathrm{EtOH} / \mathrm{ha}=2.2$ ton/ha + grain for feed 


\section{Conclusions}

- Starch is an important food source, lignocellulose should be the primary raw material for bio-fuel production

- Biomass for bioethanol production should be cultivated using the lowest possible input of fossil energy

- This can be archived by novel cropping strategies like intercropping combining crop species for food/feed and energy

- Clover grass is a promising raw material for bioethanol production e.g. in combination with wheat straw (Thorsted et al. 2006)

- The sugar yields after WO of clover grass were: $Y_{\text {cellulose }}=94 \%$, $Y_{\text {hemicellulose }}=66 \%$ - giving a theoretical ethanol production of 241 $\mathrm{kg} /$ ton DM

- All sugars in alternative raw materials like clover grass can be utilised by using the right biorefinery concept 


\section{Perspectives}

Biomass for energy is considered a key diversification strategy to improve energy supply security and mitigate GHG emissions. However, bioenergy systems are relatively complex, intersectoral and sitespecific. Therefore, solving problems is challenging and requires synergic contribution of various contributors from the agriculture, forestry, energy industry and environmental sectors to elucidate the most promising pathway for development. 


\section{Pretreatment of clover grass}

Carbohydrate composition of fiber fraction

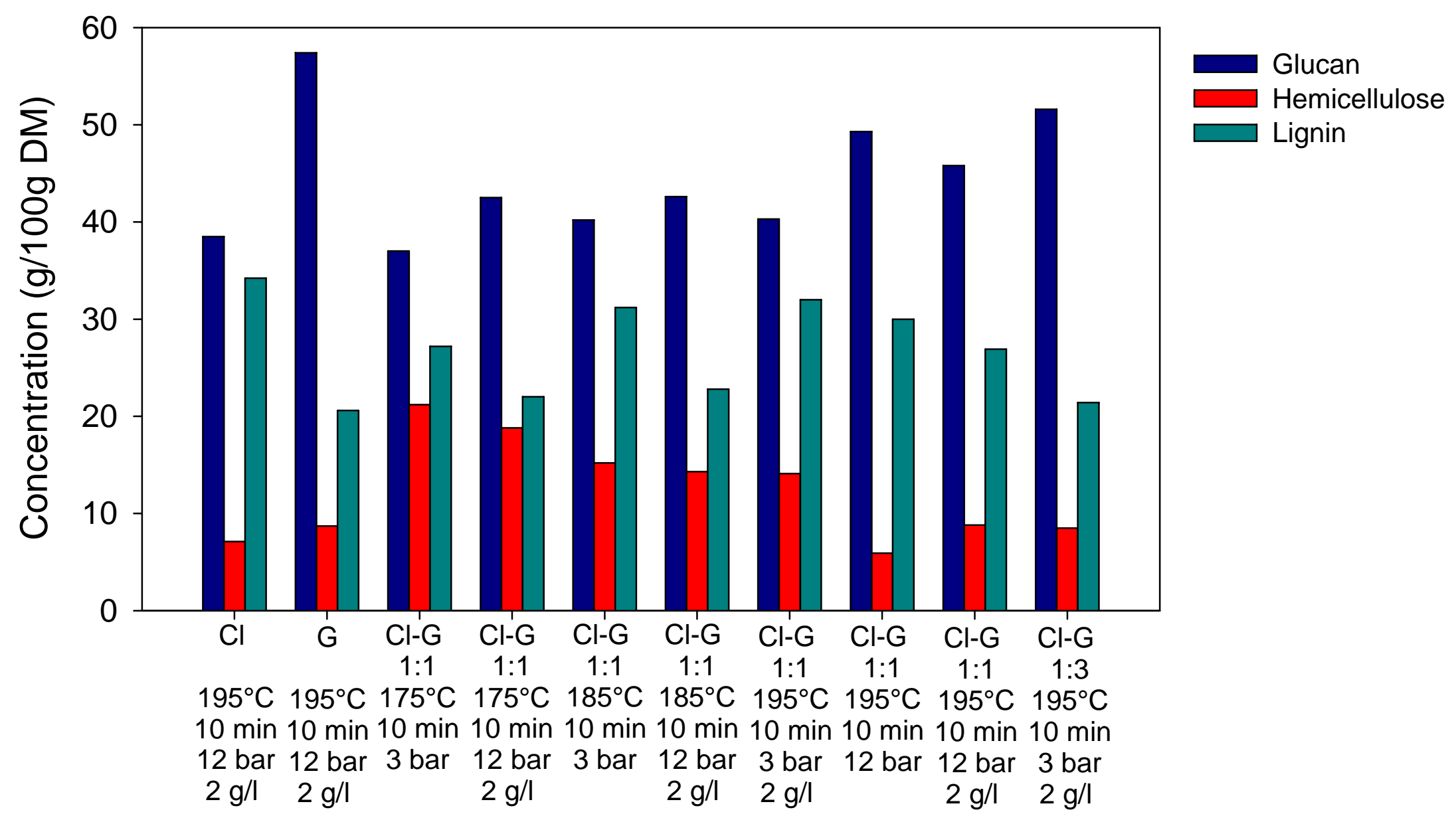

Material/Pretreatment conditions 


\section{Pretreatment of clover grass}

Carbohydrate composition of liquid fraction

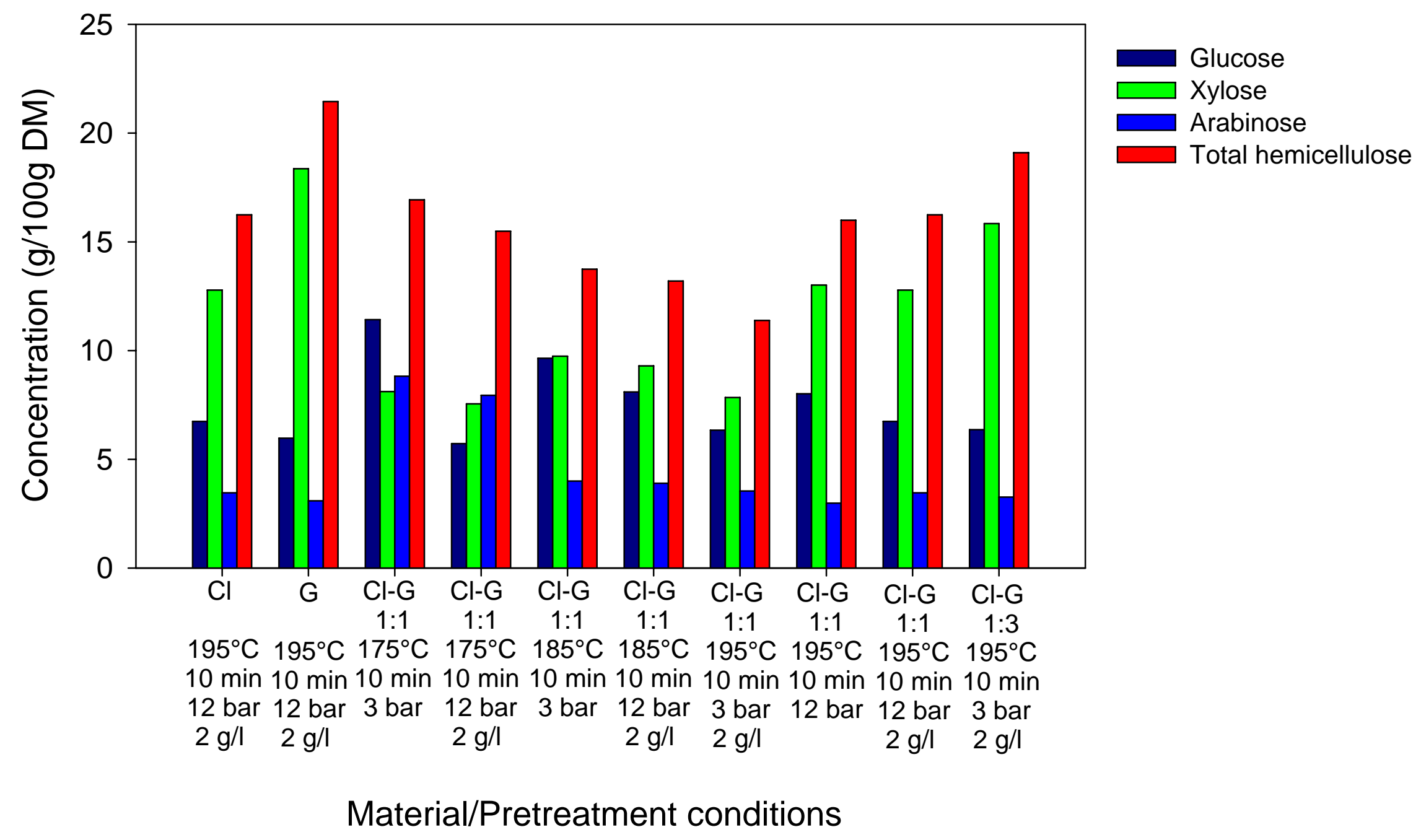




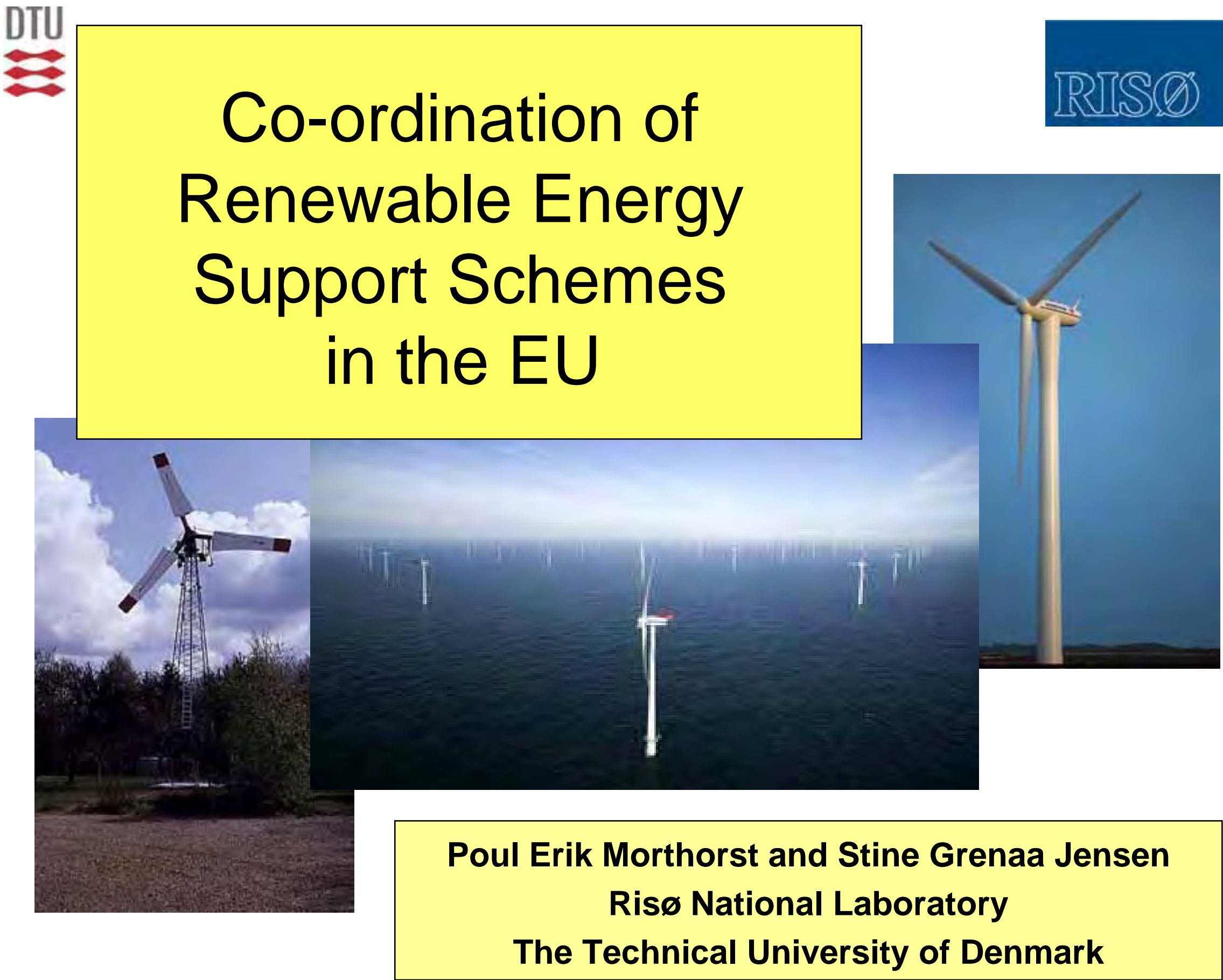




\section{Focus on Renewable Energy technologies}

- EU suggests binding targets

- Greenhouse gases has to be reduced by $20 \%$ compared to 1990

- Renewable energy has to cover $20 \%$ of gross energy consumption by 2020 - wind power is expected to have a significant role

- The existing target for renewable technologies was $12 \%$ by 2010 - a share of $8 \%$ is expected to be achieved by 2010 .

- Burden sharing is to be negotiated

- Ambitious?

- Anyhow, it is binding 


\section{What happens in Denmark?}

\section{Gross Energy Constimption by Fuel}

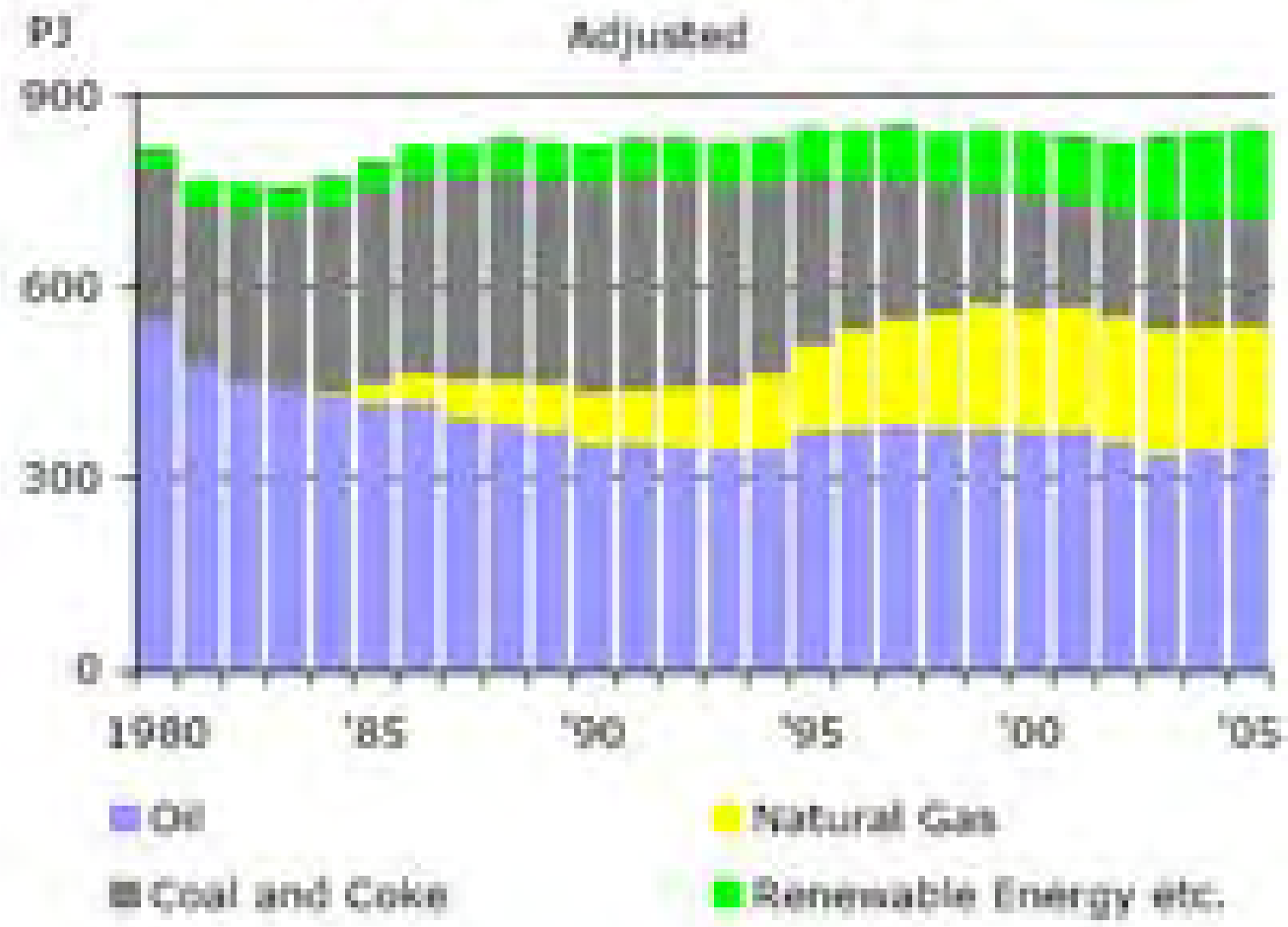




\section{Constant Energy Consumption in spite of strong growth in GDP}

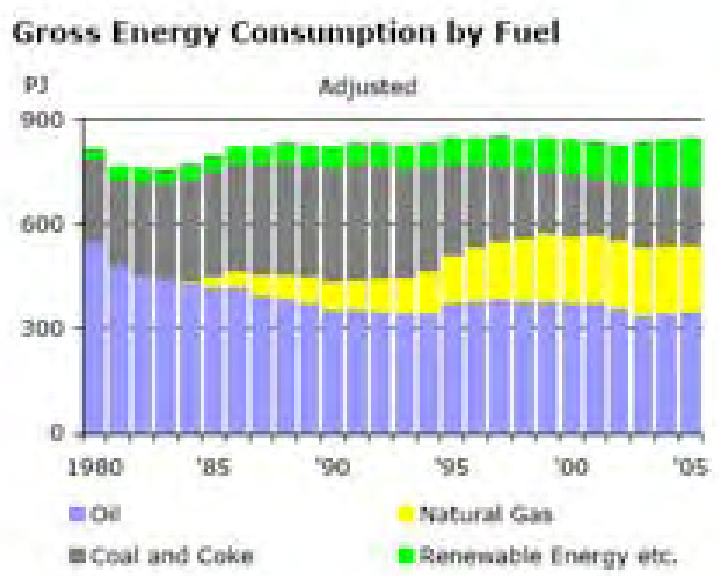

\section{GDP and Gross Energy Consumption}

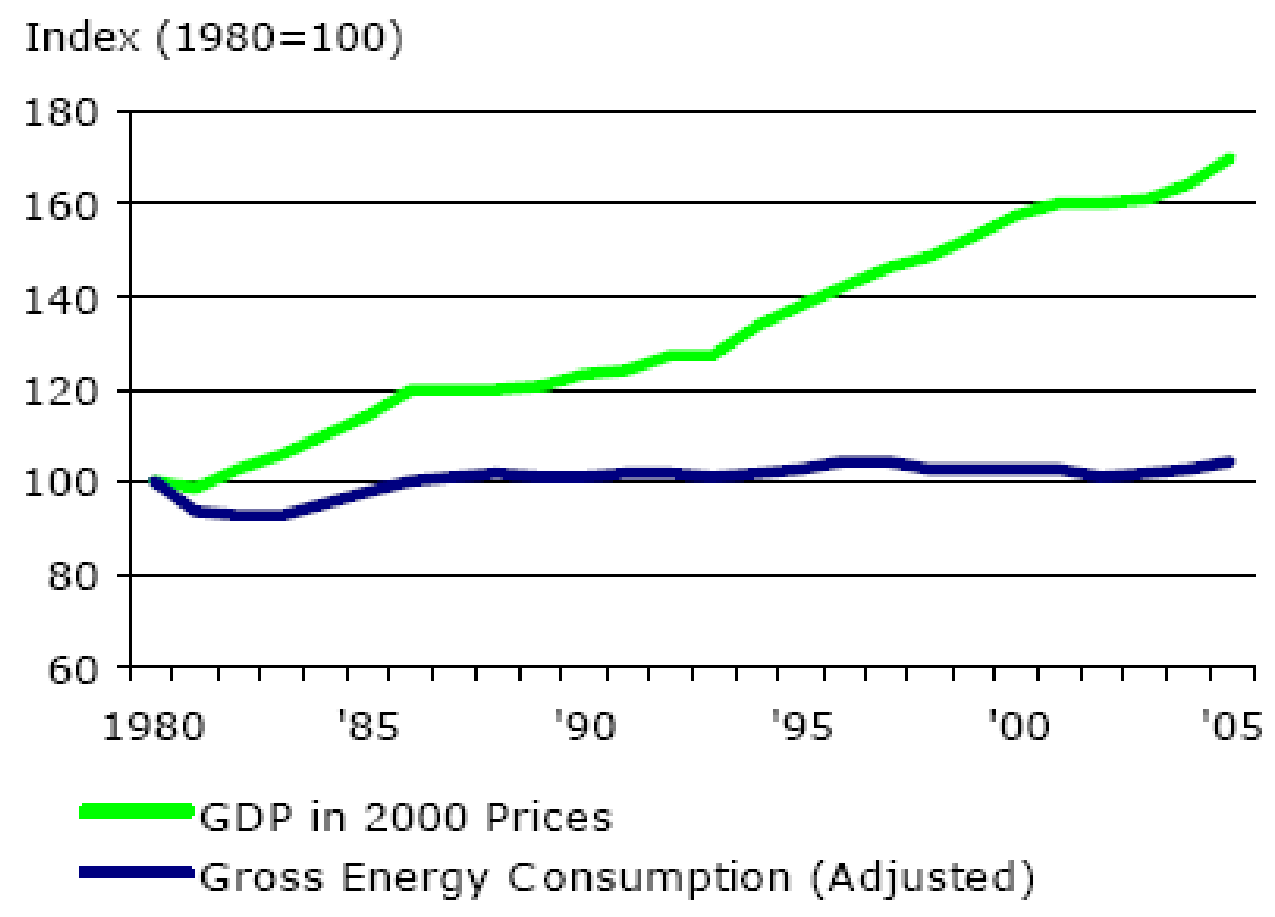




\section{Strong Increase in Renewables}

Gross Energy Consumption by Fuel

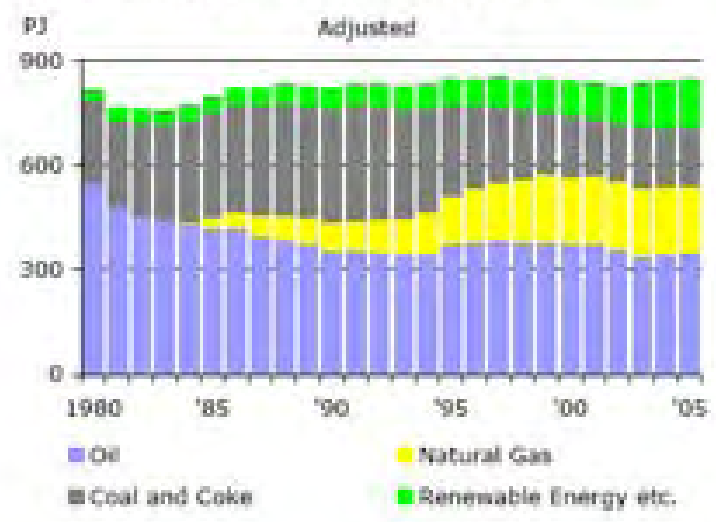

\section{Wind Power - Capacity and Share of} Domestic Electricity Supply

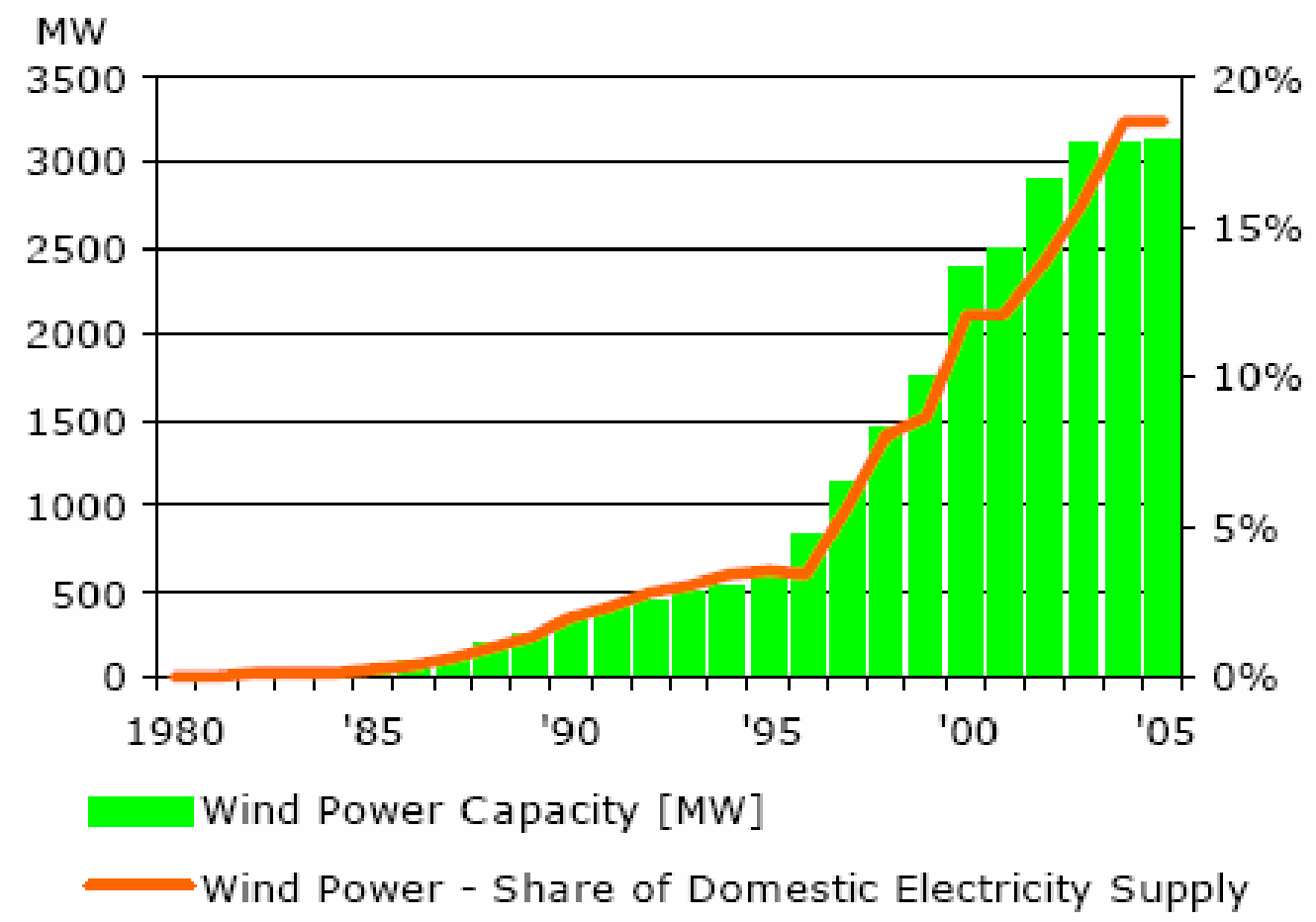




\section{Strong Increase in Renewables}

\section{Wind Power covered approx. $44 \%$ of Power consumption in January in Western Denmark}

Wind Power - Capacity and Share of Domestic Electricity Supply

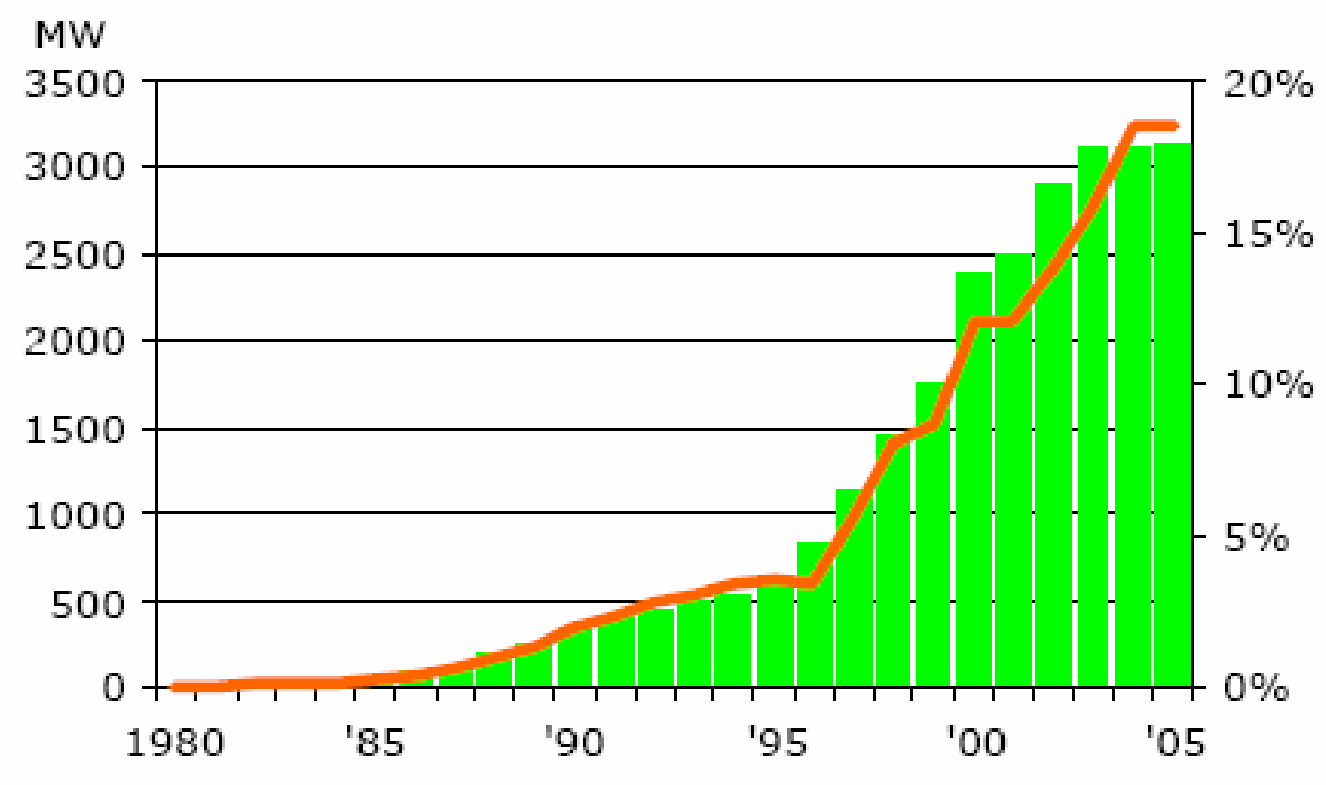

Wind Power Capacity [MW]

Wind Power - Share of Domestic Electricity Supply 


\section{Strong Increase in Renewables}

\section{Wind Power covered approx. $44 \%$ of Power consumption in January in Western Denmark}

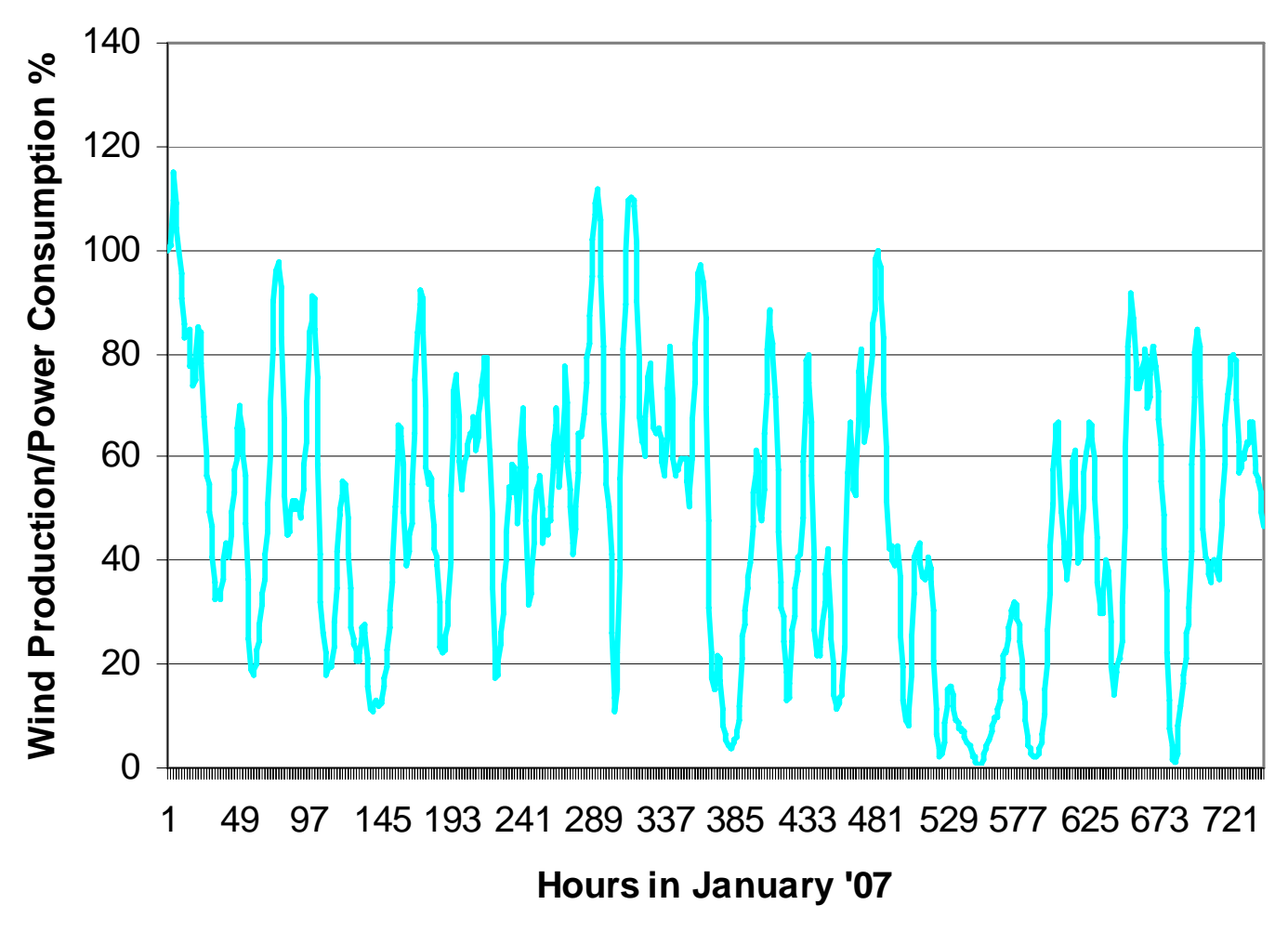


The New Energy Plan

- Renewables to cover 30\% of Gross Energy Consumption in 2025

- The share is approx. $15 \%$ today

- Energy conservation and development of new Energy Technologies

- Wind Power could cover 50\% of Danish Power Consumption in 2025 


\section{The New Energy Plan}

- Renewables to cover 30\% of Gross Energy Consumption in 2025

- The share is approx. 15\% today

- Energy conservation Energy Technologies

- Wind Power could co Consumption in 2025

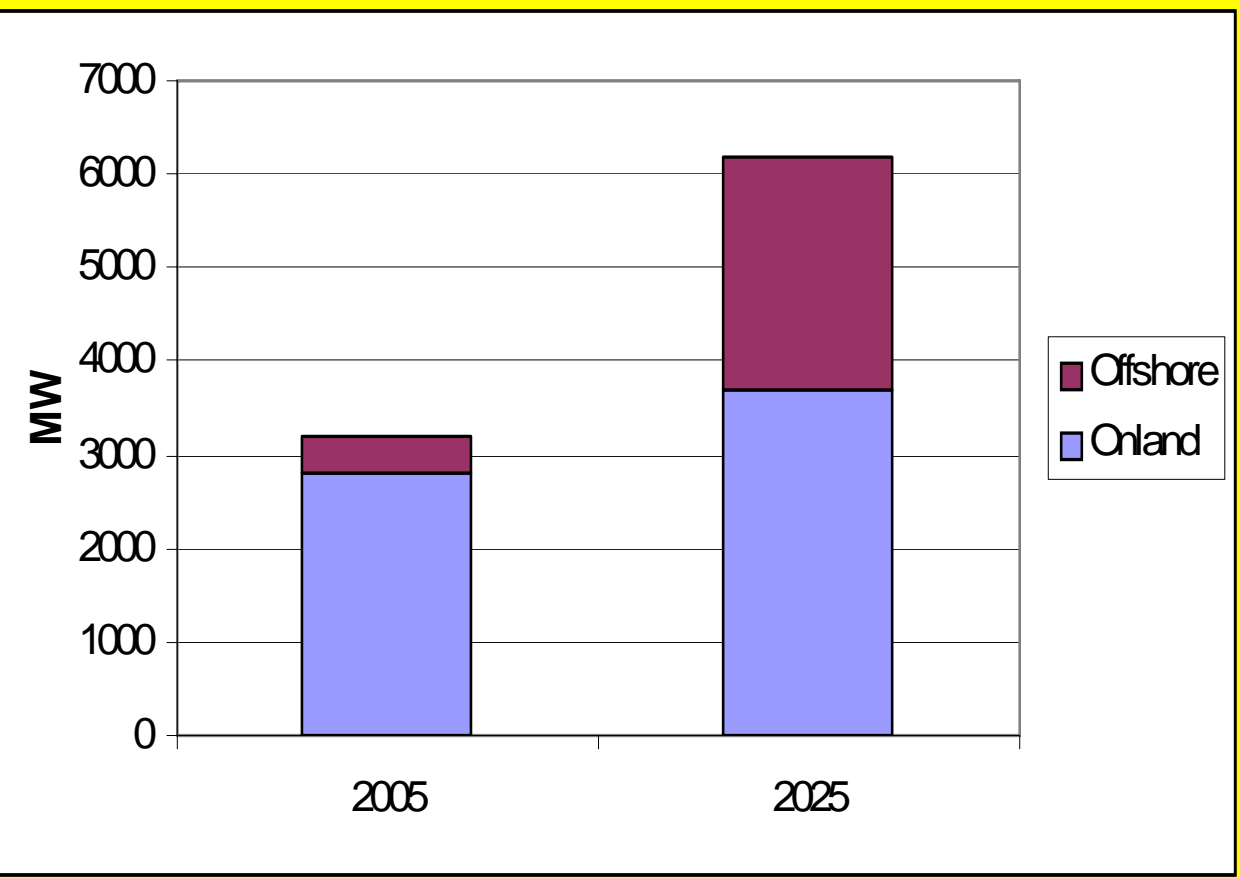




\section{Support Systems in EU}

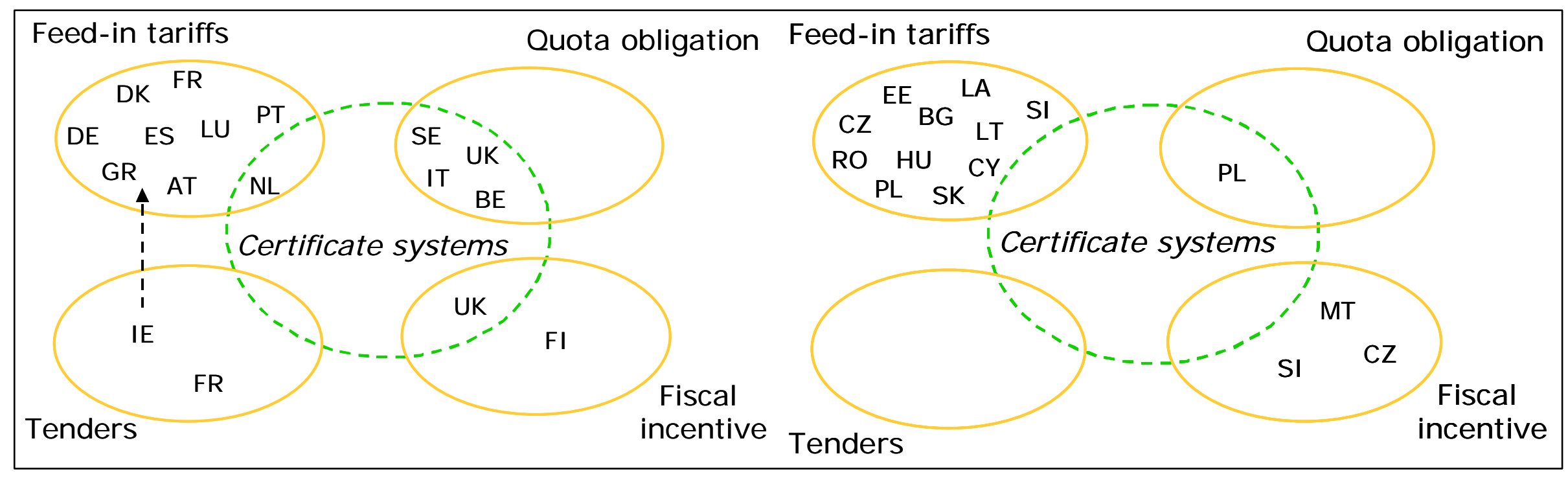




\section{Support Systems in EU}

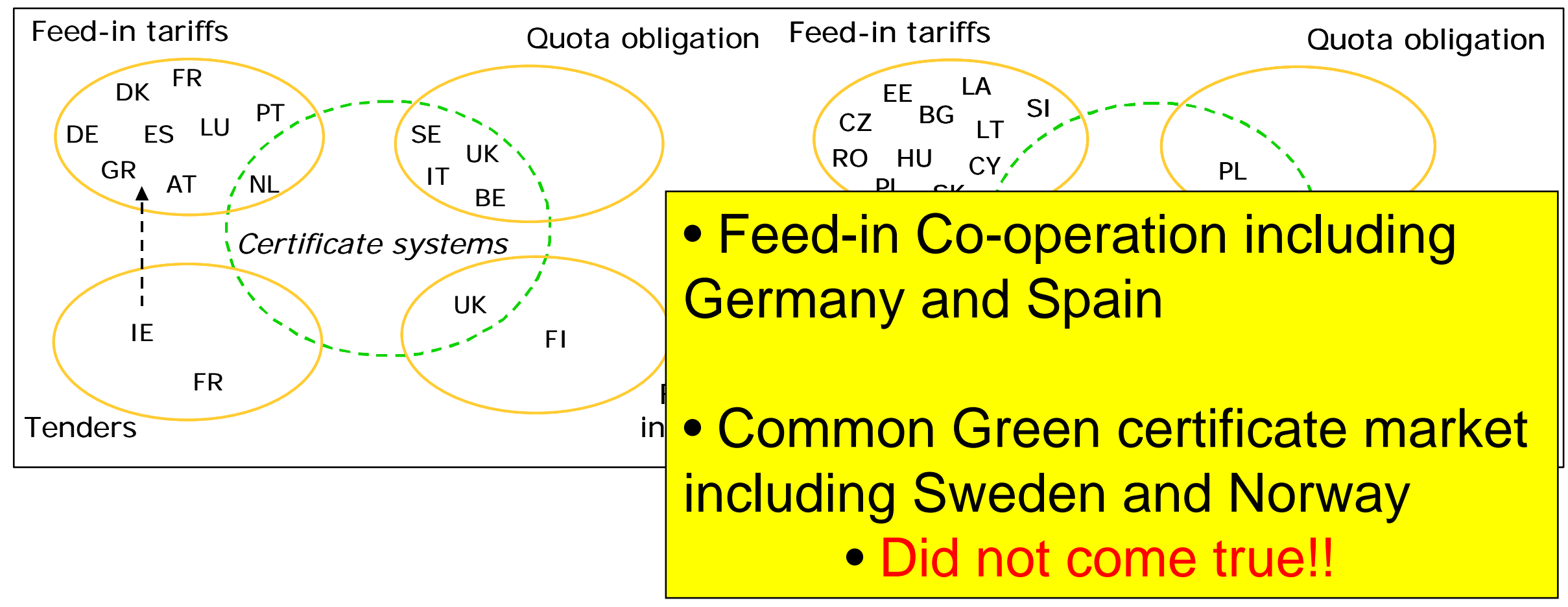




\section{Future Support Systems and the Internal Market in EU}

- With regard to RES-E, what do we want to achieve in the EU?

- An economic and resource efficient siting of renewables

- A replacement of the most inefficient power plants

- A reduction of $\mathrm{CO}_{2}$-emissions achieved in the most effective and cheapest way

- Coordination and regionalization

- The way forward for RES-E support in the EU

- Interactions of Power markets and RES support schemes

- How can we get the most efficient transition to a coordinated RES-E development in EU? 


\section{Ways to Go - The almost Ideal Case}

- Regional power market and regional support system

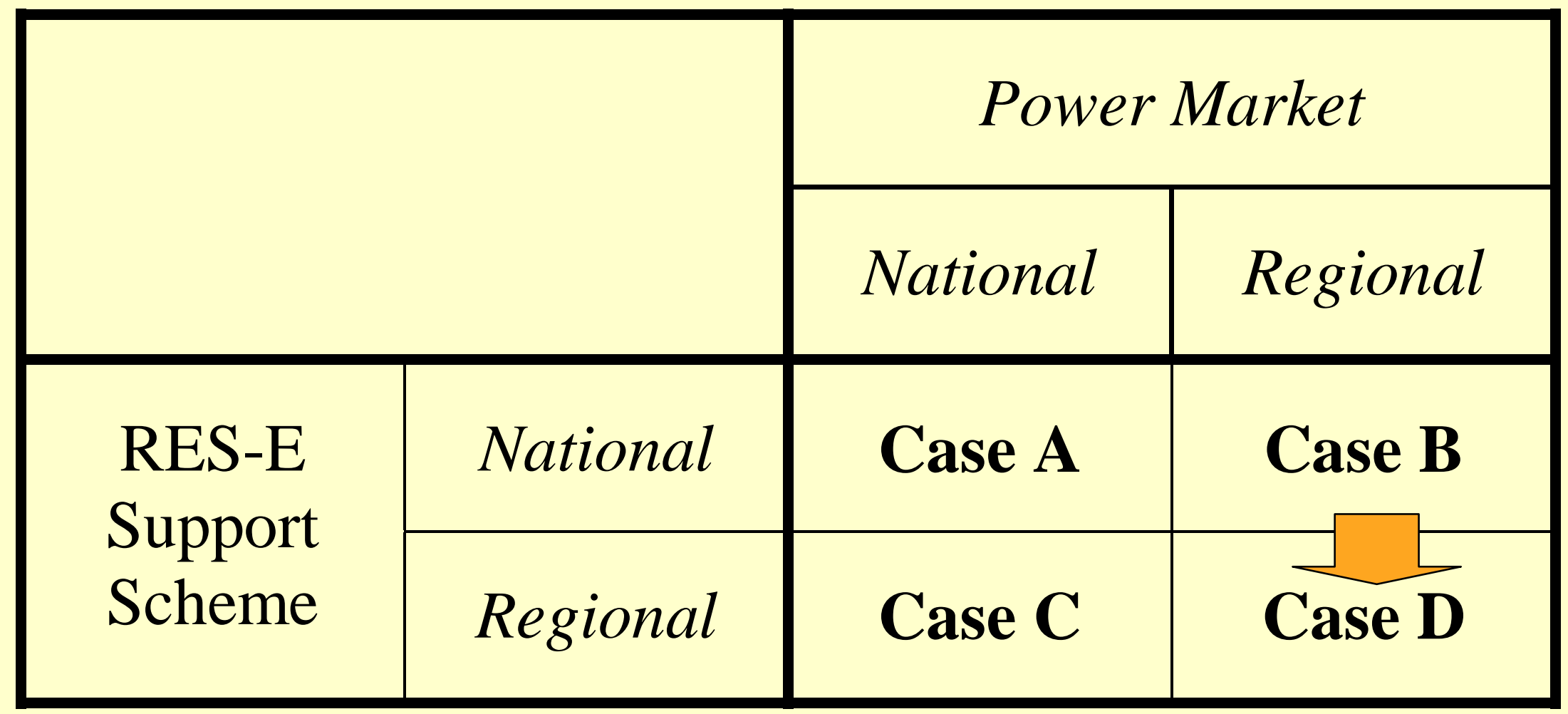




\section{TGC - Almost Ideal Case}

Country A - high wind and efficient

\section{system}

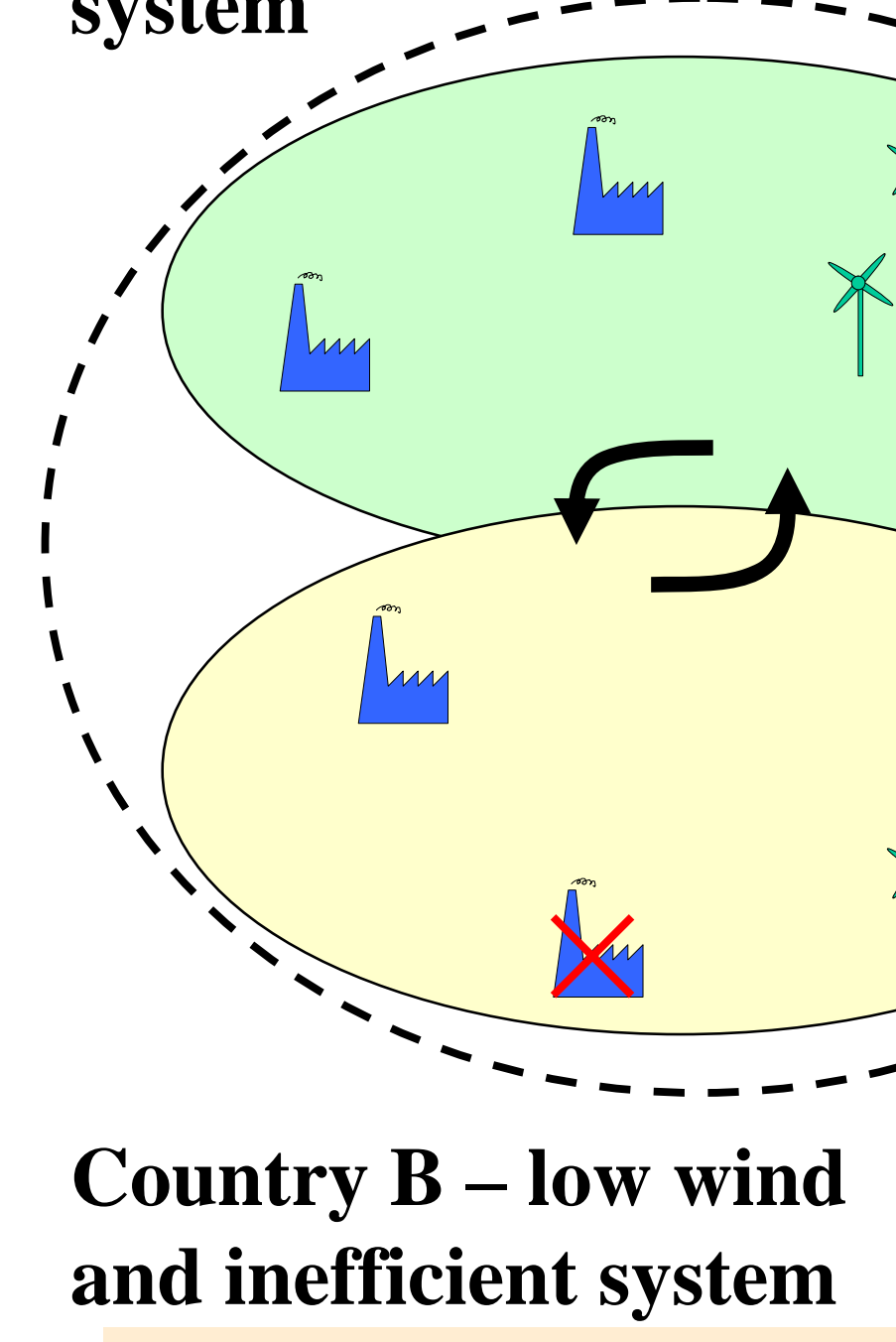

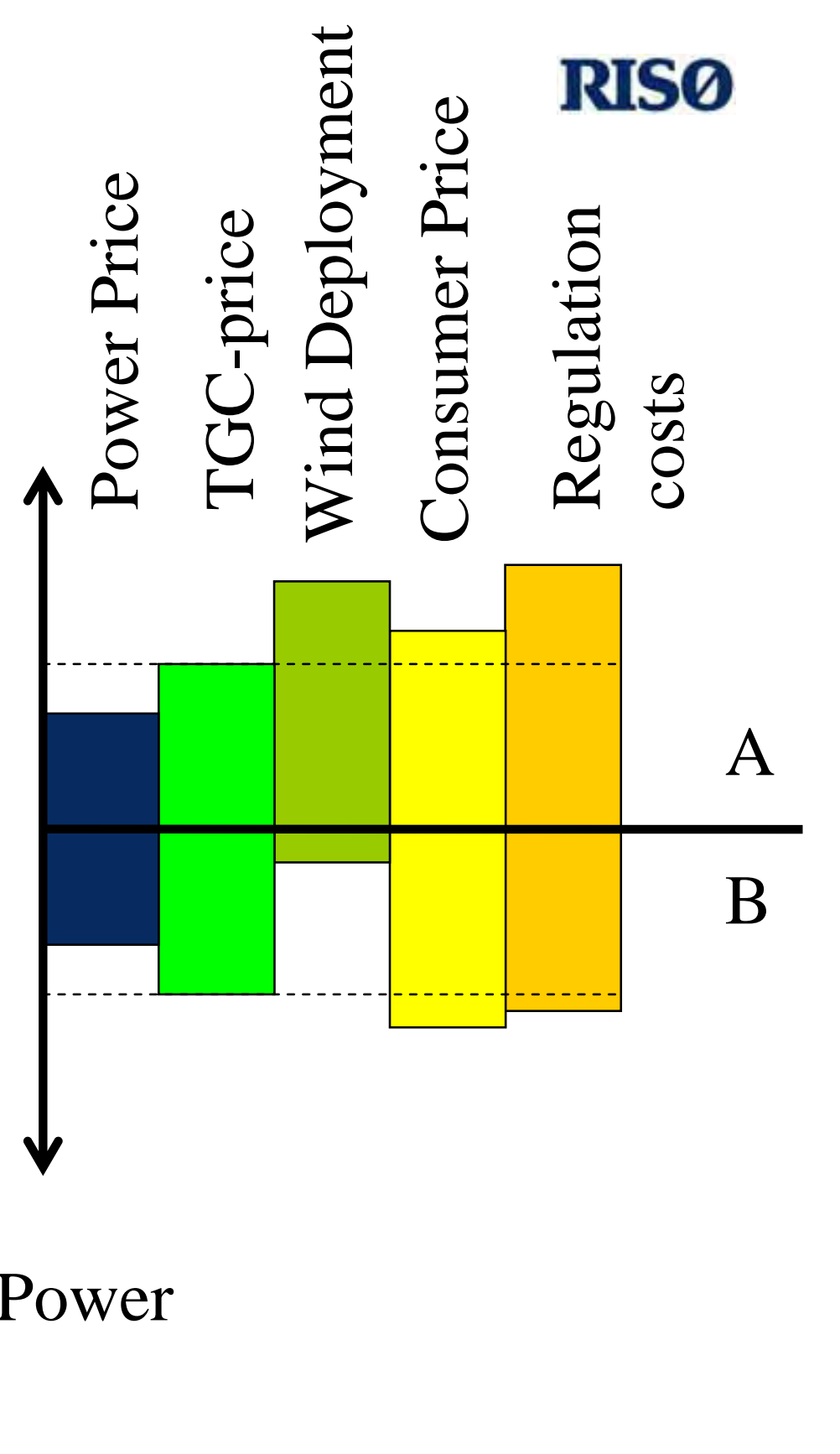




\section{TGC - Almost Ideal Case}

- Renewables are sited in the most efficient way

- Only the wind regime matters

- Consequences for the Power Market

- The most inefficient plants will be replaced by renewables

- The more different the two countries are the more beneficial will a common TGC-system be

- Effective reduction of $\mathrm{CO}_{2}$, but where the reduction takes place (country A or B) will depend on the marginal conditions at the power market

- Burden sharing of regulation costs is a problem

- Comparison to a Feed-in tariff

- The burden sharing is implicitly given by the TGC-quotas in each country - thus there is no need for a common fund as will be the case in a feed-in system 


\section{Ways to Go - The troublesome Case}

- National Power market and regional support system

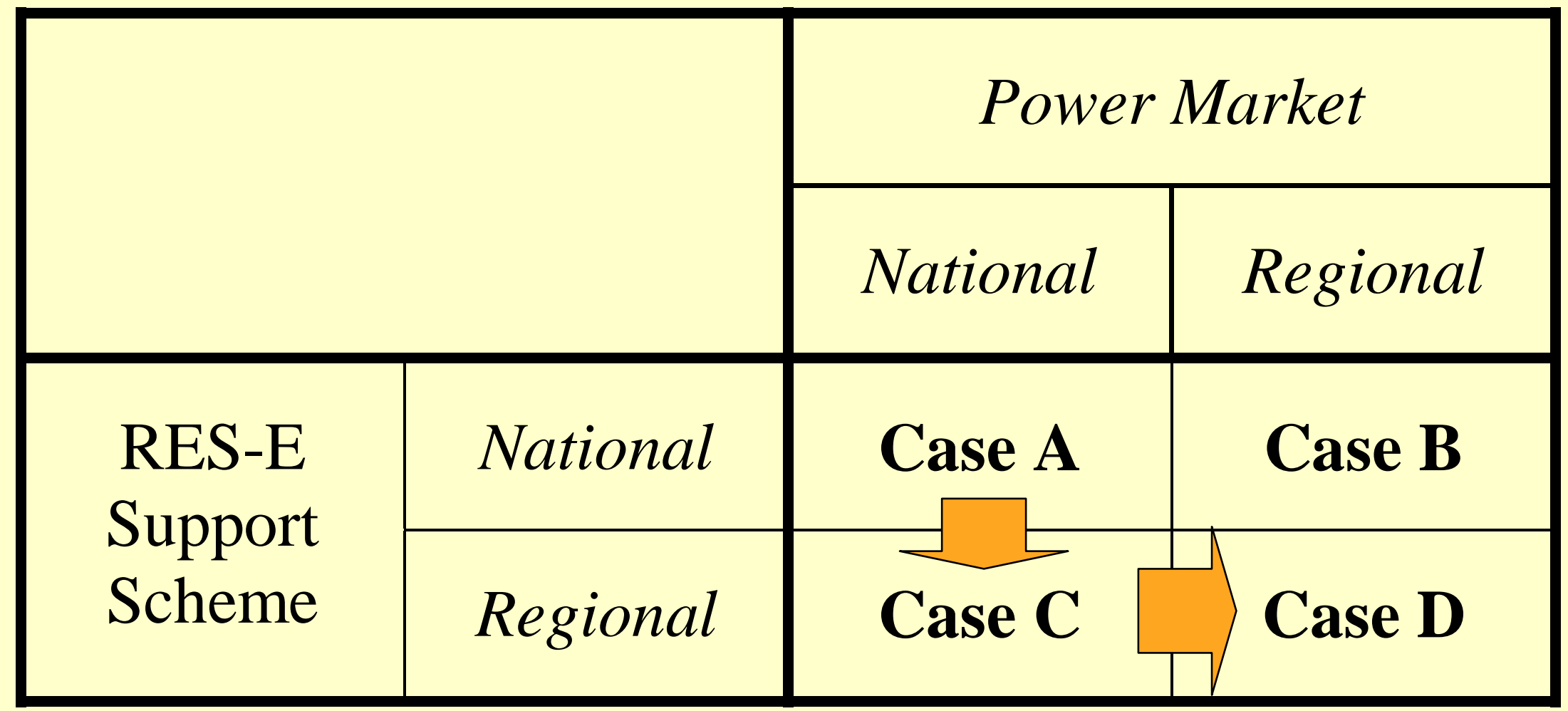


Tradable Green Certificates The Troublesome Case

Country A - high wind and efficient system

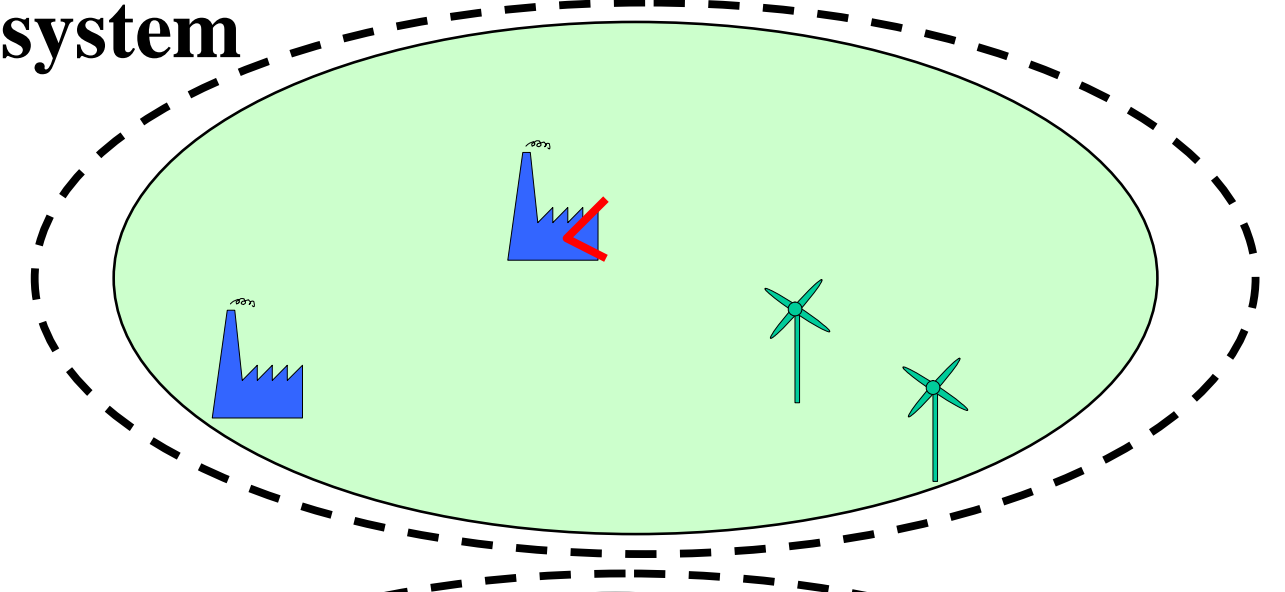

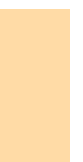
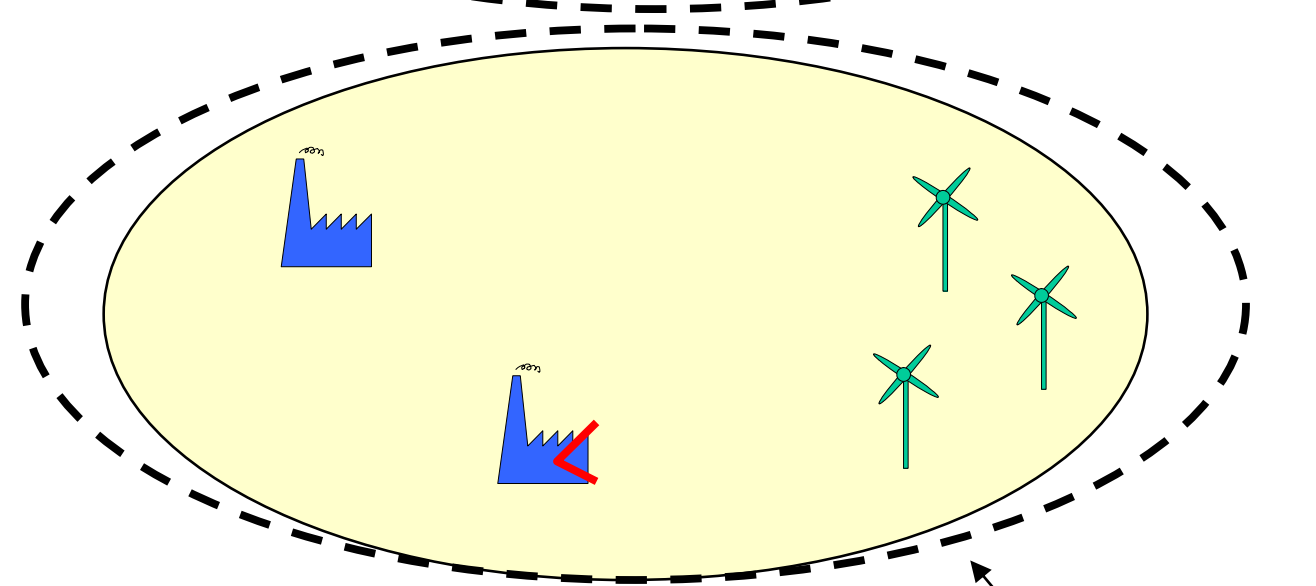

Country B - low wind and inefficent system
范

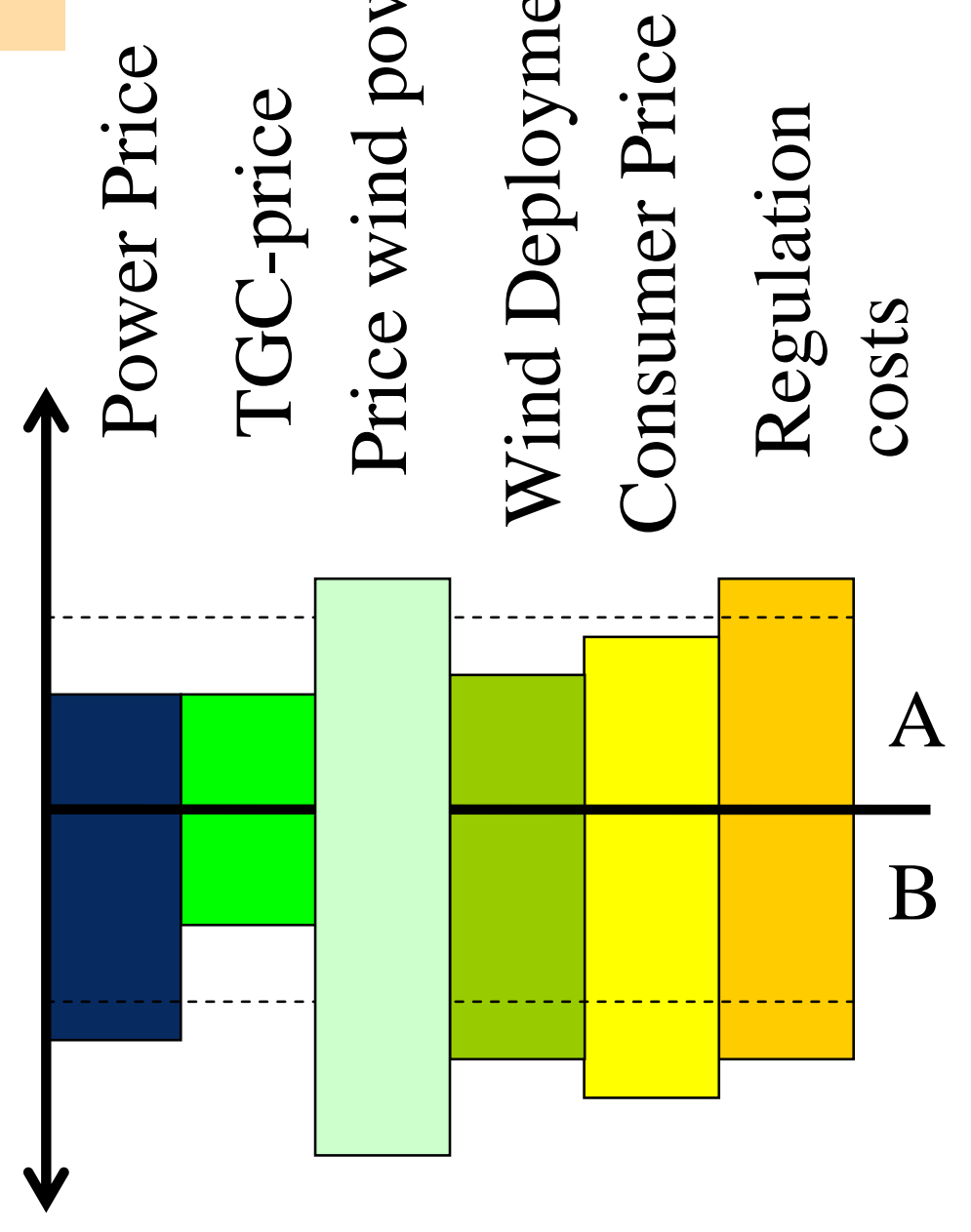

Separate Power

Markets 


\section{Green Certificates - Troublesome Case}

Consequences for renewables and the Power Market

- Renewables will be sited the most economic efficient places, but not the sites with the highest resources

- Renewables will not replace the most inefficient power plants

- $\mathrm{CO}_{2}$-reduction in the region will not be efficient implying higher prices for $\mathrm{CO}_{2}$-allowances

- Burden sharing of regulation costs is also a problem in this case

The Green Certificates system is economically optimal at the given market conditions ..... but

- Short term solution - If we want to move towards a common power market, a common TGC system does bias both the development of renewables and the conventional power system 


\section{Conclusions}

- A common and efficiently working power market is a prerequisite for an efficient common support system

- Separate power markets might bias the development of the conventional power system

- But other barriers exist as well

- Lack of competition (monopolies), weak interconnectors...

- The way forward

- Co-ordination of support schemes

- Regionalization 


\title{
Bioethanol
}

Second generation Bio-fuel - close to commercialisation

\author{
Charles Nielsen \\ DONG Energy
}




\section{IBUS (Integrated Biomass Utilisation System)}

\section{Inbicon A/ S (new name for Elsam Biosystems A/S)}

Integrated Biomass Conversion

Founded 2003 by

Elsam A/ S (now DONG Energy A/S ) and

Holm Christensen Biosystemer ApS

for commercialisation of the IBUS concept

\section{Inbi:}




\section{Content}

- IBUS technology

- Demonstration

- Commercialisation 


\section{The IBUS concept}

1. Integrated utilisation of sugar/ starch and lignocellulosic feedstocks

- Most crops comprises both sugar or starch and lignocellulose

- Lower cost from field to plant

- More biomass can be collected within a given area

- Substantial process synergies 


\section{The IBUS concept}

2. Integrated production of bioethanol and electricity

- Electricity generation looses 55-65 \% of the input energy as heat

- Ethanol fermentation looses only 3-5\% of the input energy as heat, but requires a lot of process heat

- The huge loss of heat energy from the global electricity generation can be used to cover the demand for heat energy of the future fuel ethanol production

\section{Co-production is the solution}




\section{The IBUS}

concept

\section{Surplus steam}

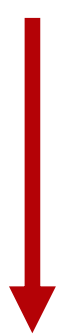

Inbi \%" con

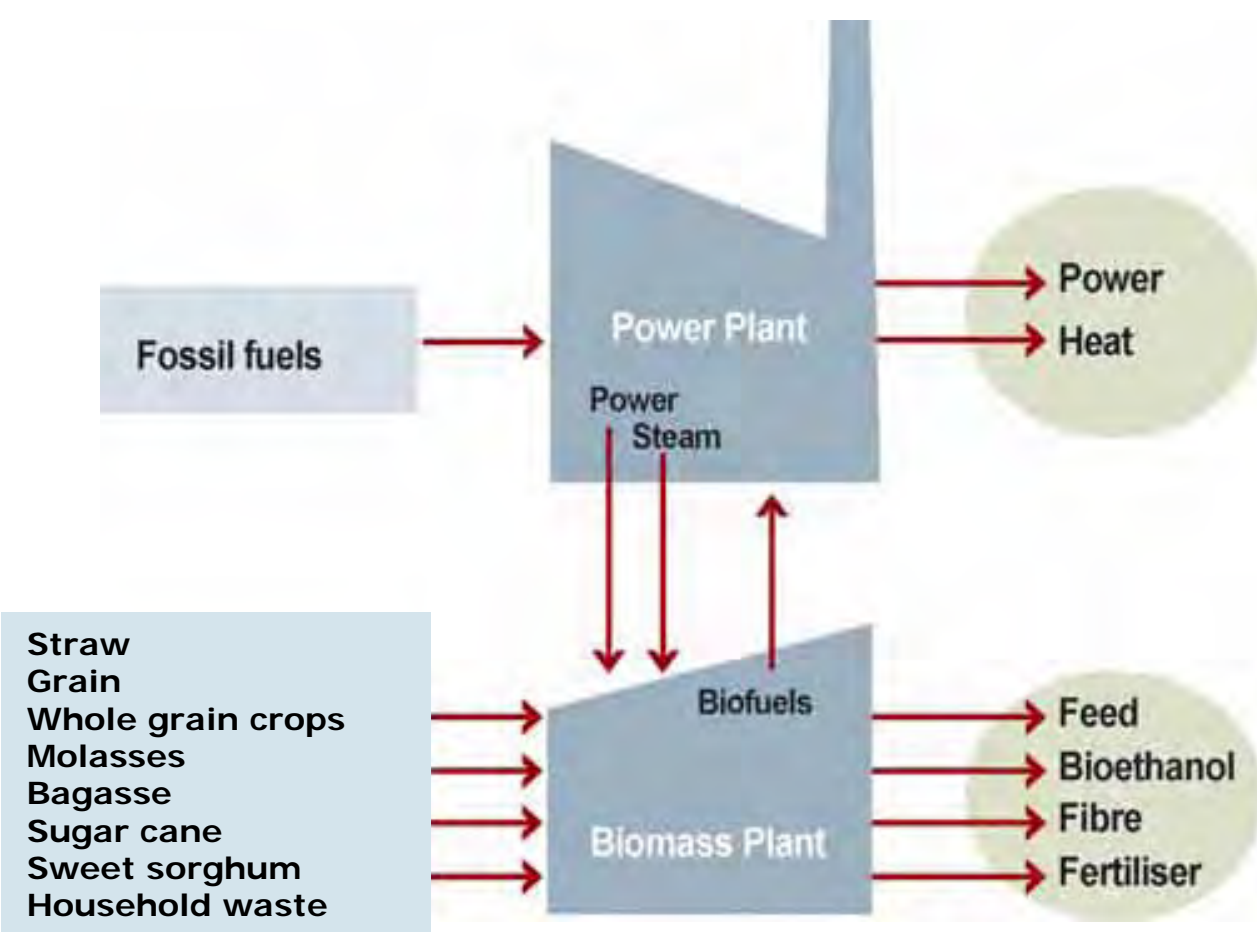

High quality solid biofuel 


\section{The IBUS concept}

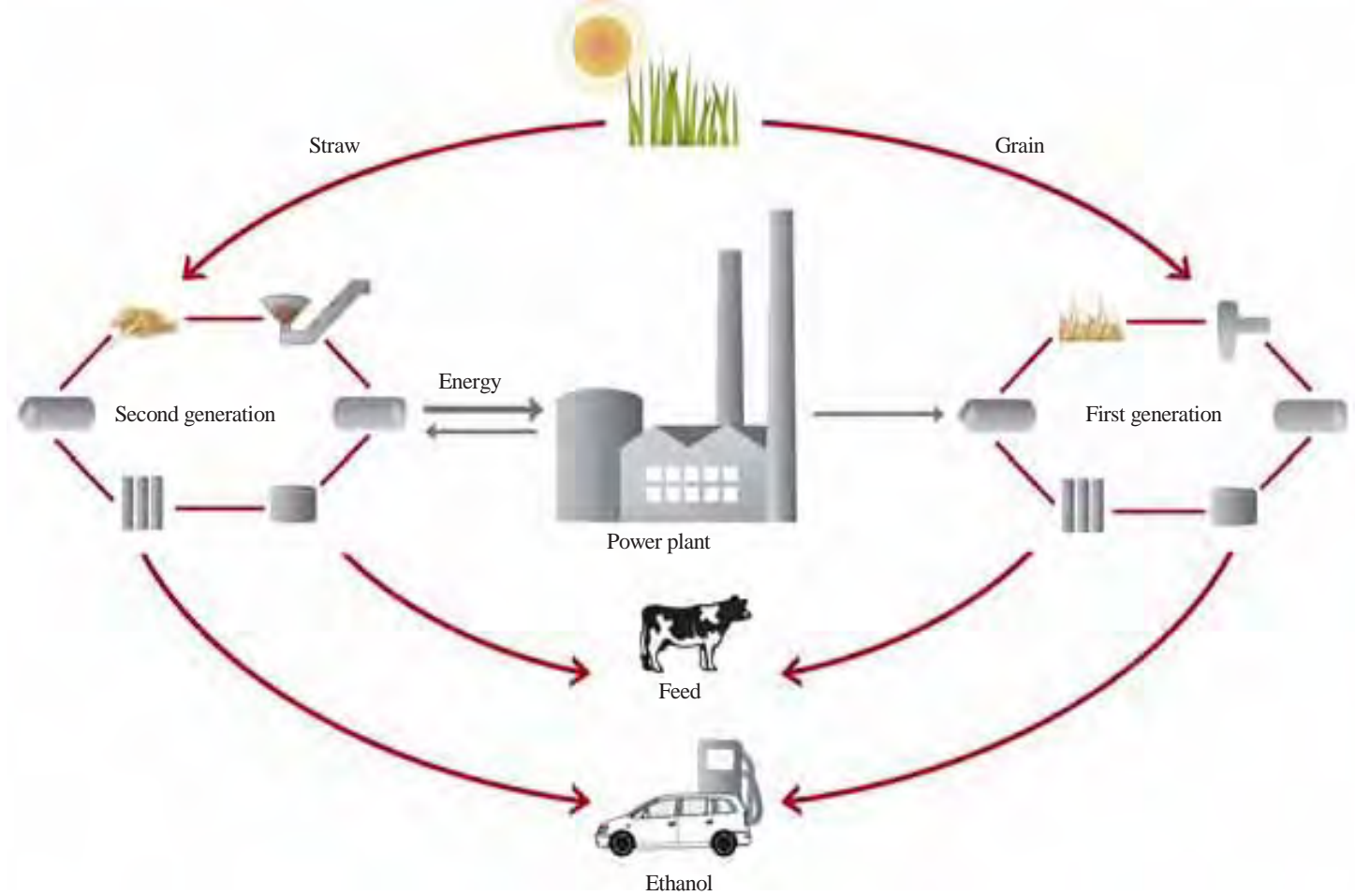

Integration 1. and 2.nd generation technology

Integration with electricity generation and utilization of surplus heat

\section{Inbi\% \\ con}




\section{The IBUS process}

Continued pretreatment

High dry matter content

High energy efficiency

No ligning separation

Recycling of plant nutrients (nitrogen, phosphor, potassium, and micro minerals)

Integrated water utilization - no waste water

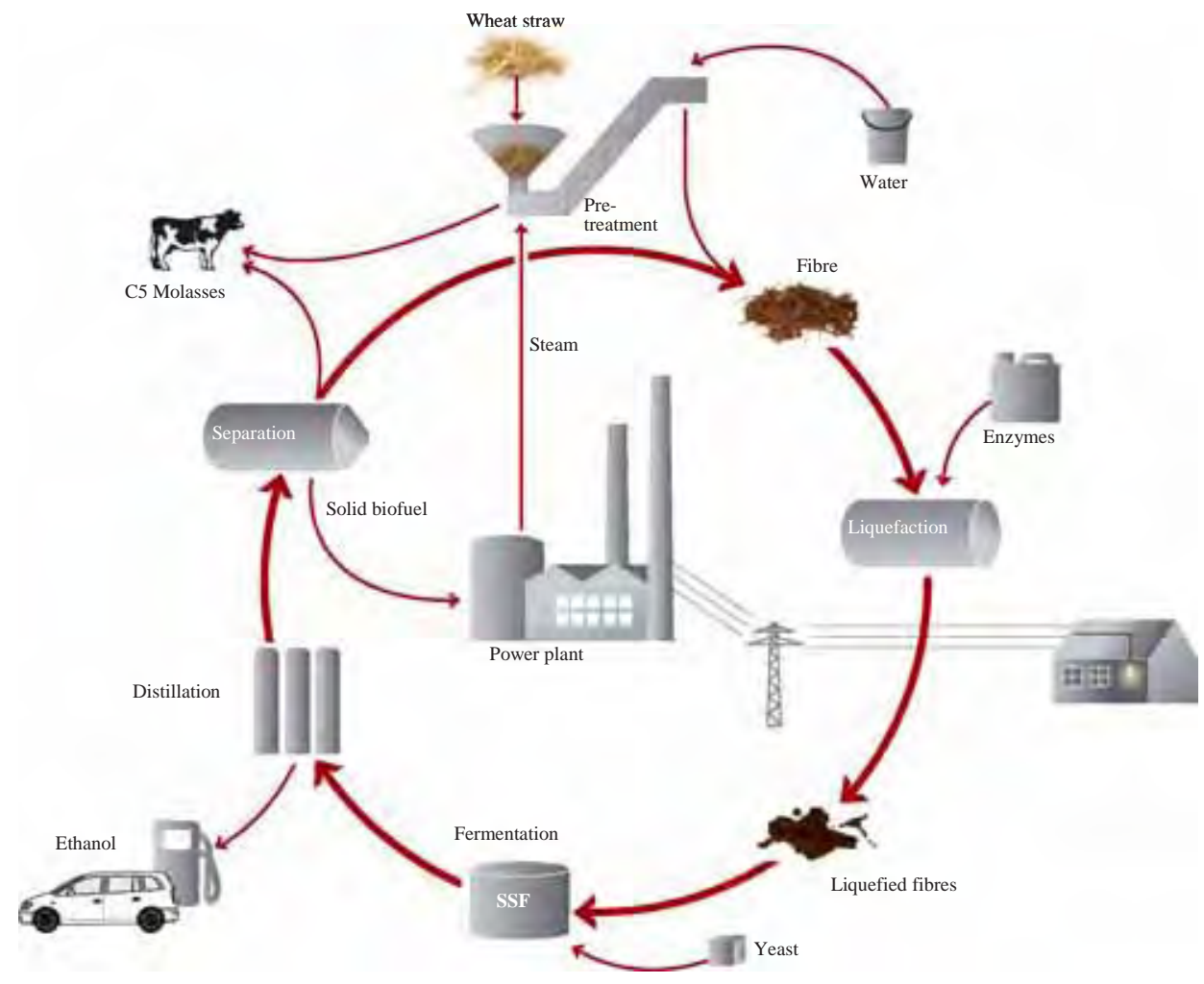

\section{Inbi \%}

con 


\section{IBUS results based on wheat straw}

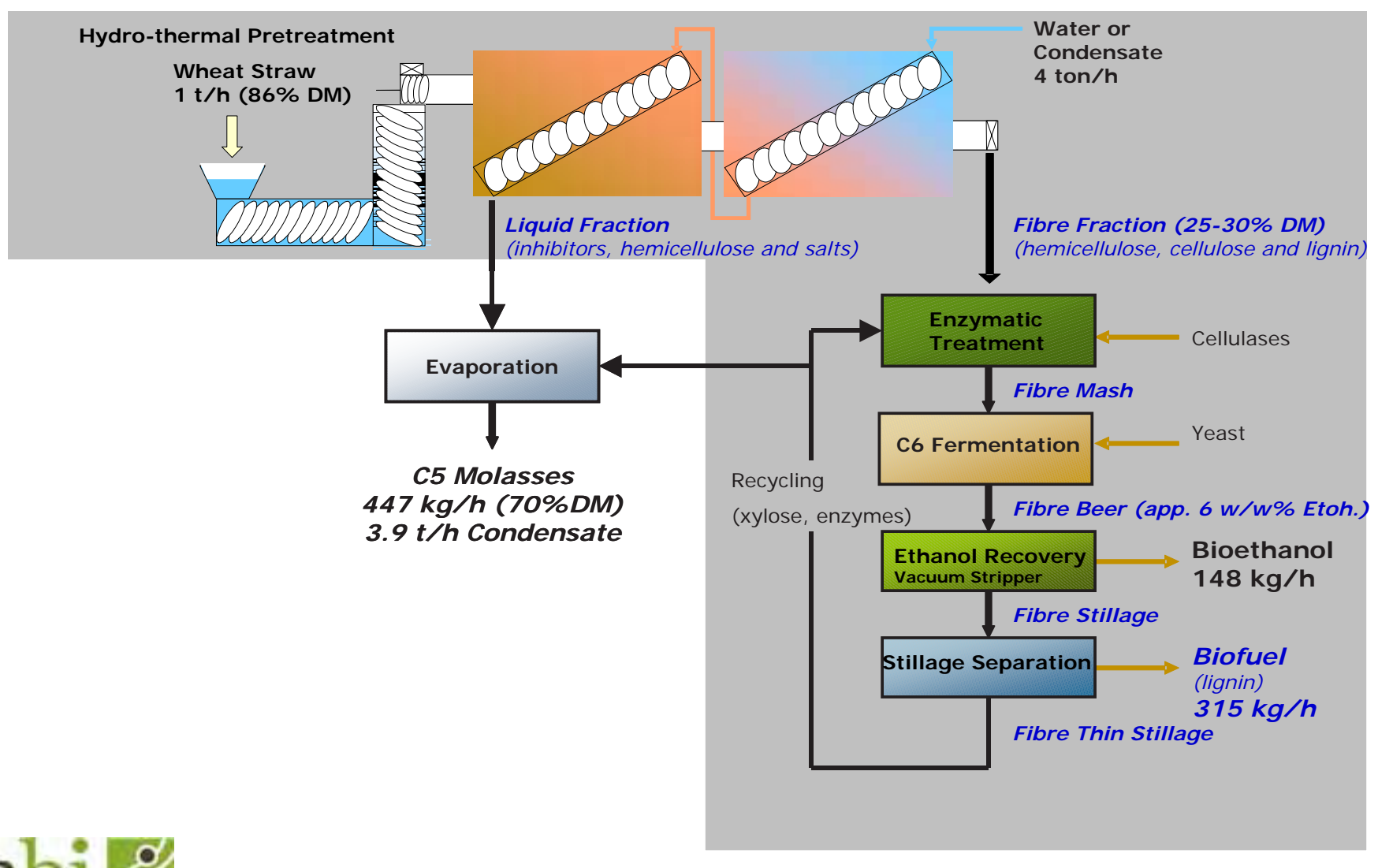

\section{Inbi : con}




\section{Pretreatment}

Chopped wheat straw

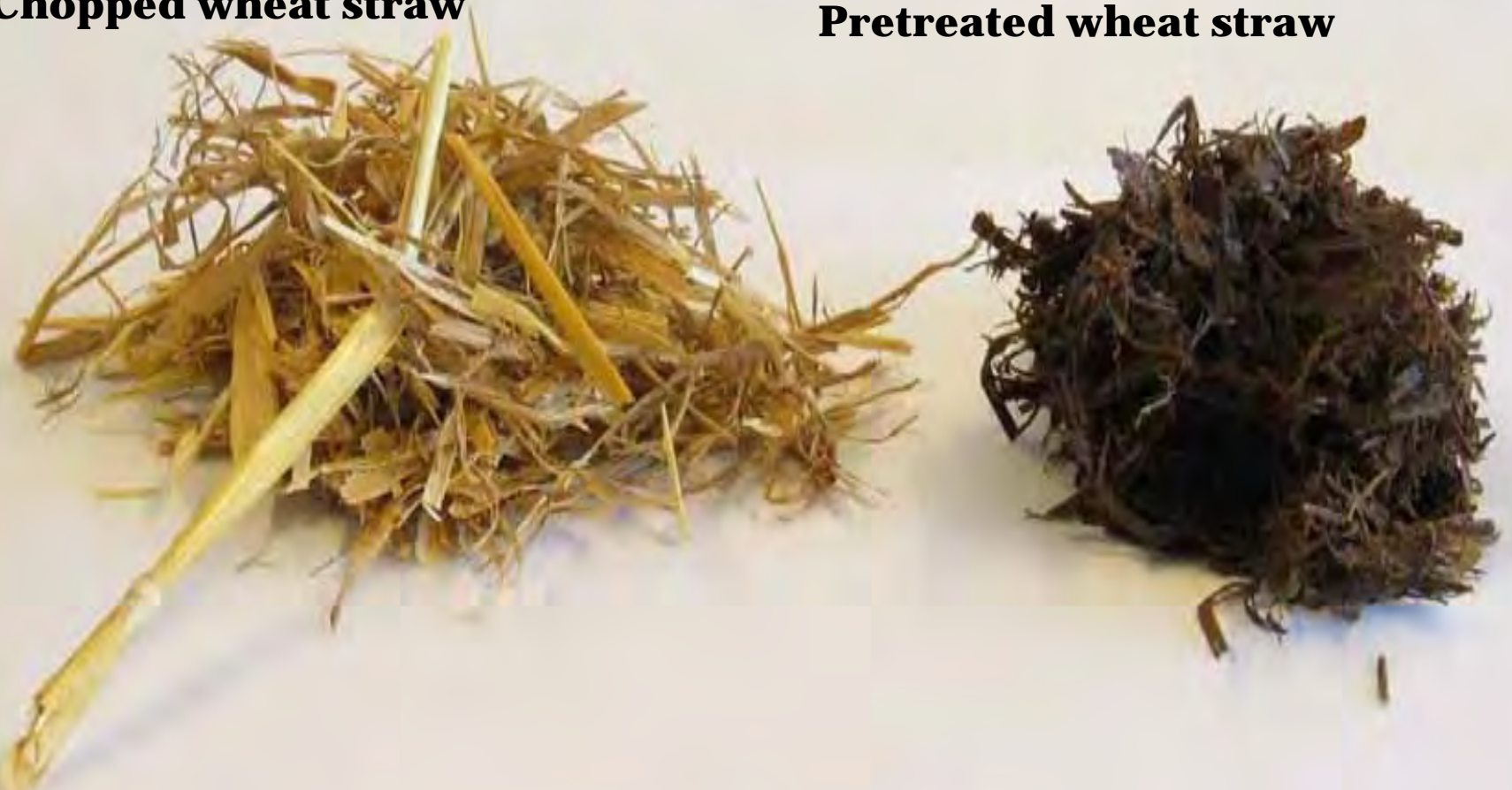

Inbi:

con 


\section{IBUS pretreatment removes lignin as nano-particles}

Height angle Surfaze vormal Clear Ca:zulator

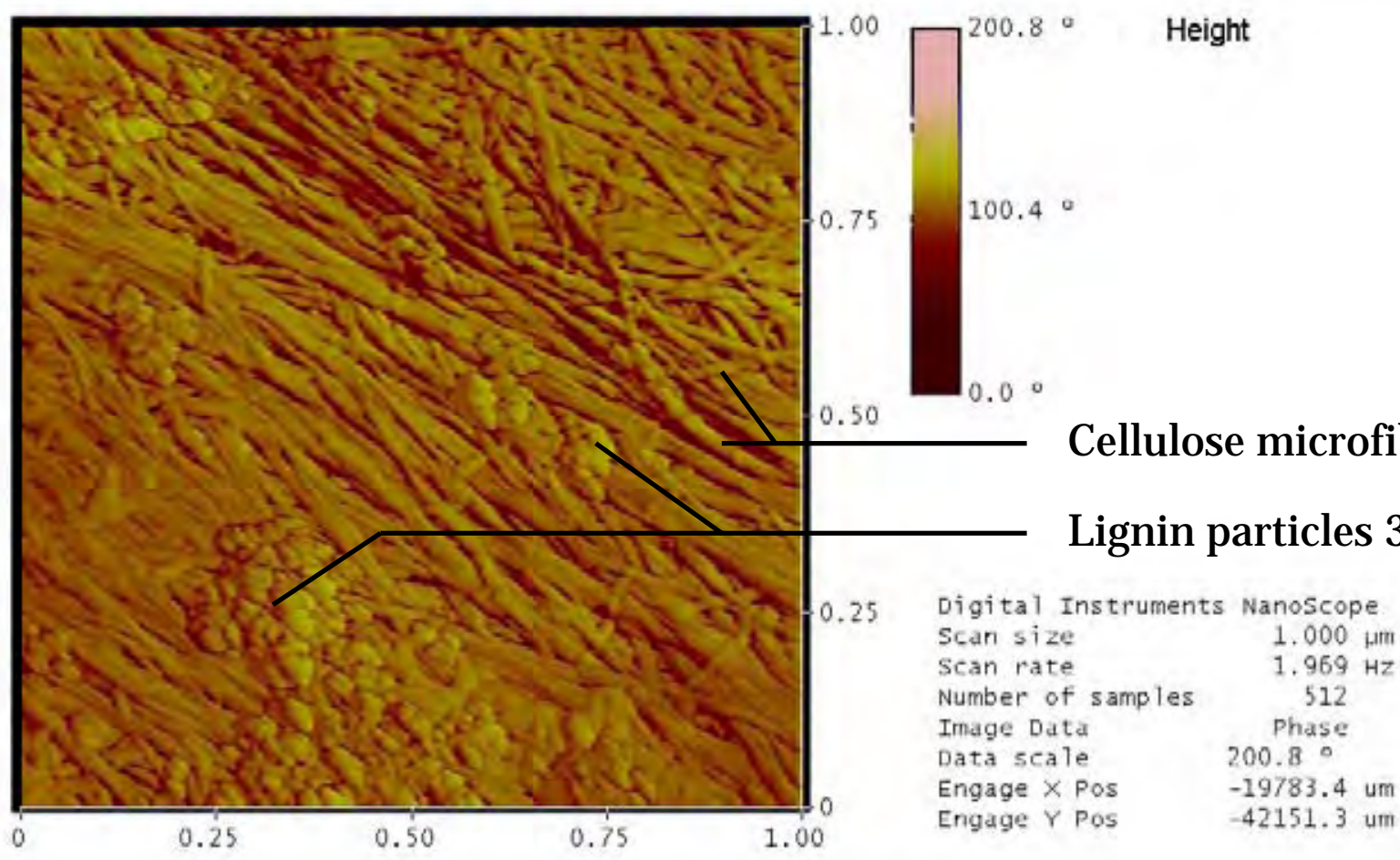

Inbi \%

$\mu \mathrm{m}$

Photo:Royal Veterinary and Agricultural University 
Enzymatic liquifaction with high dry matter content

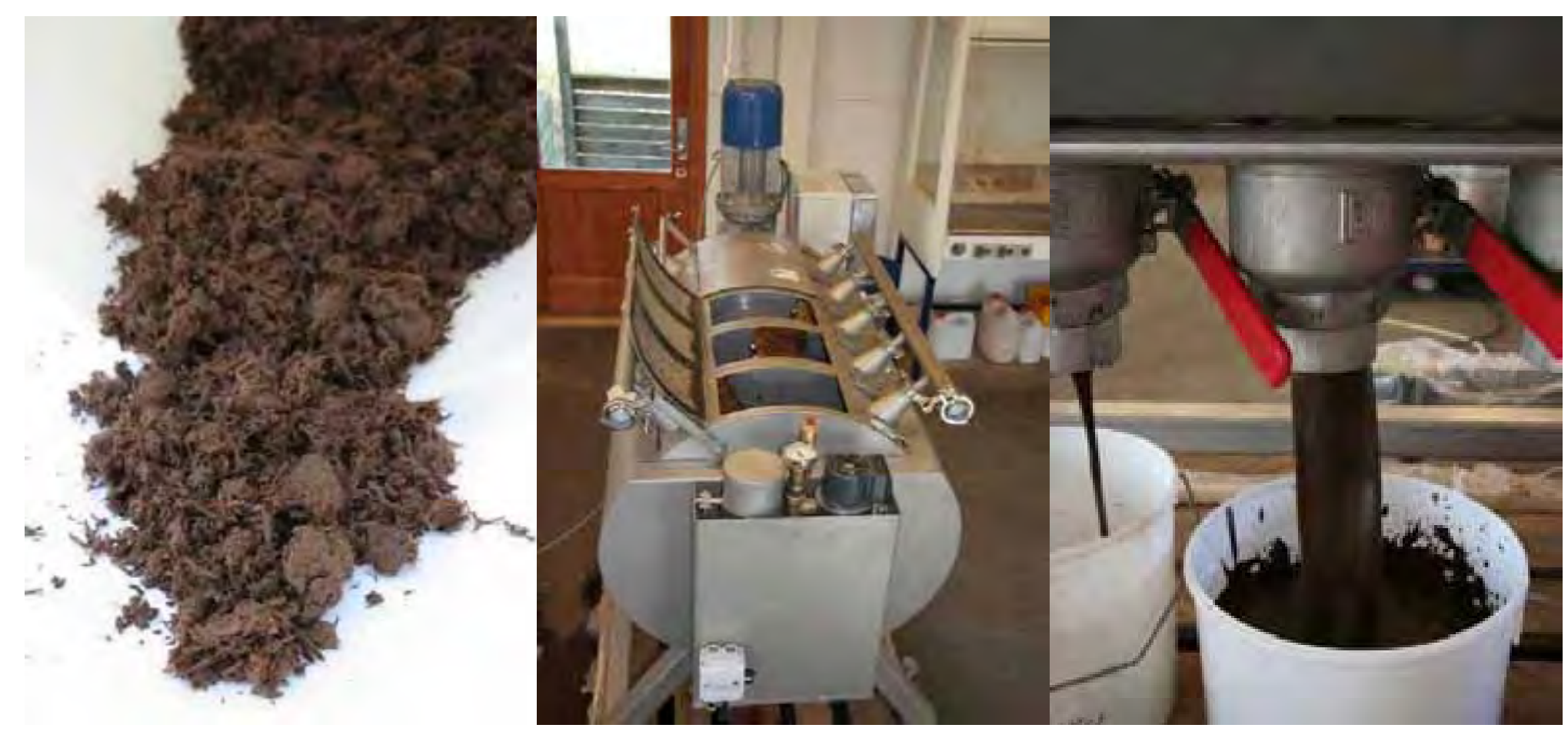

5 Chamber Liqiufaction Reactor

Inbi:

con

Risø • Maj 2007 


\section{Liquifaction with high dry matter content and fermentation (26\% DM)}
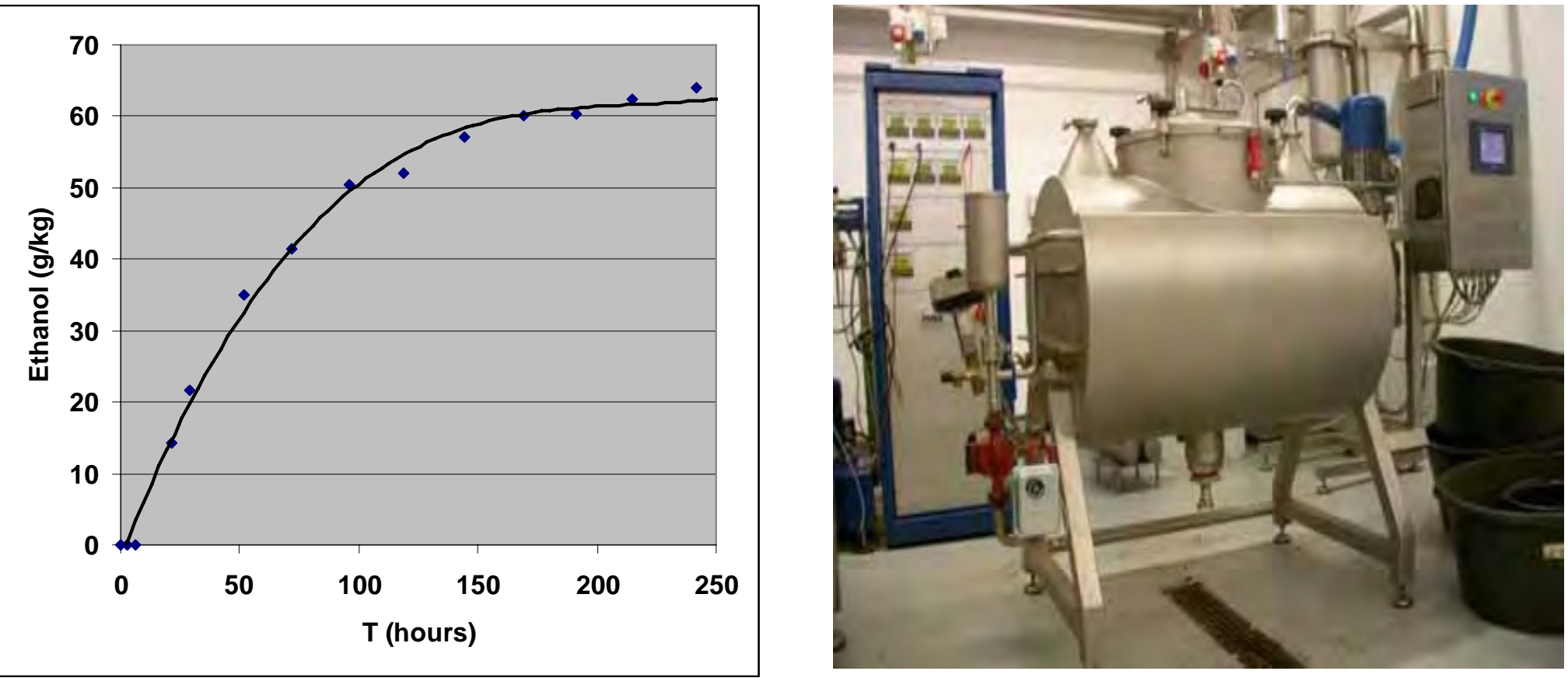

\section{Ethanol concentration:}

- $63 \mathrm{~g} / \mathrm{kg}$ incl. suspended material

- $83 \mathrm{~g} / \mathrm{l}$ in the liquid fraction (excl. suspended material)

Inbi

- $105 \mathrm{ml} / /$ (10,5 vol\%) in liquid fraction (excl. suspended material) 


\section{Next step output from the IBUS process}

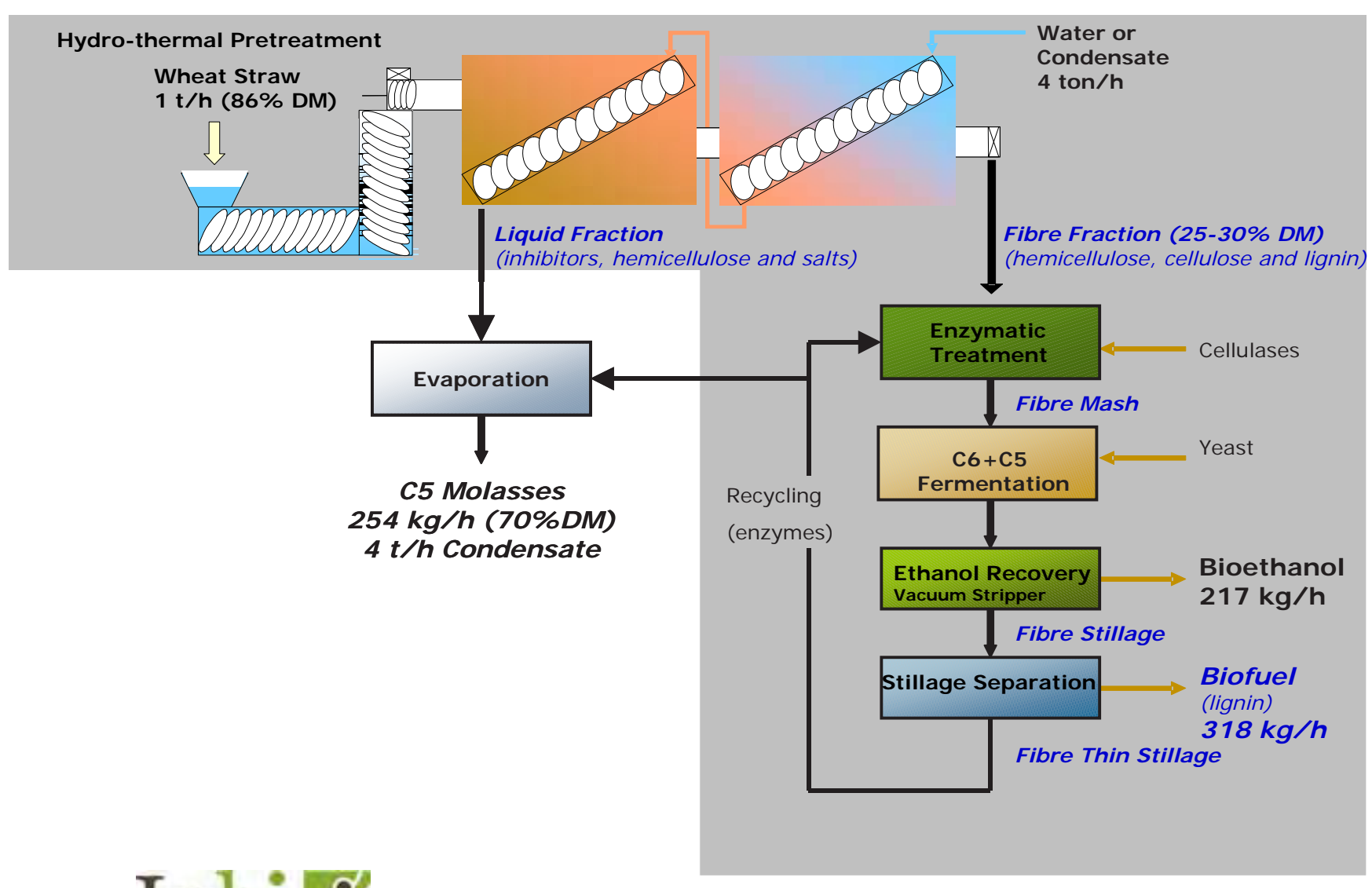




\section{Actual energy balance (state-of-the-art)}

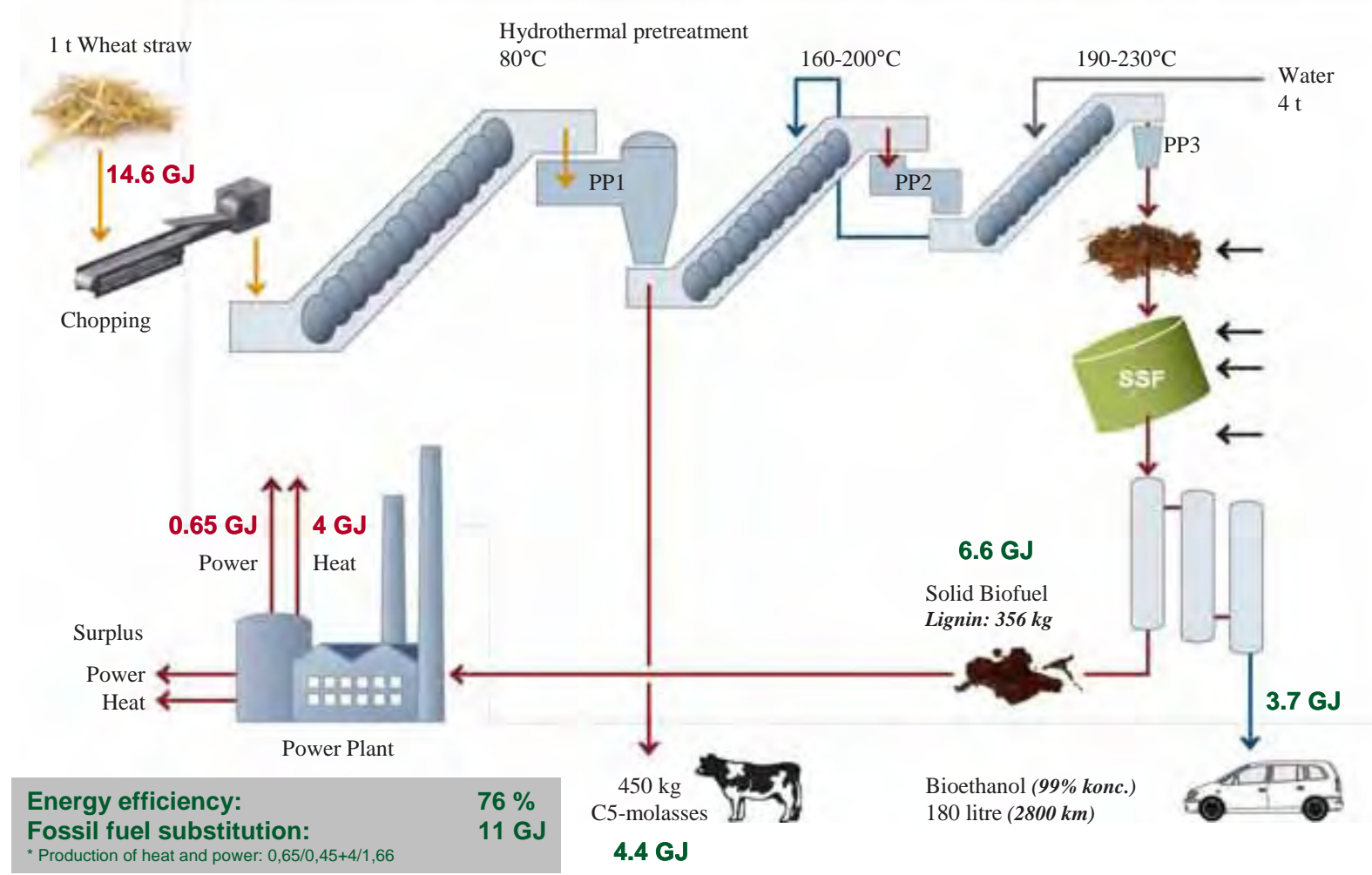

\section{Inbi \% \\ con}




\section{Main results from the EU project: Co- production of Biofuels}

- The IBUS pretreatment can work at high gravity without chemicals

- Fast (5-10 hours), high gravity (30-40 \% d.m.) liquefaction at low enzyme concentration (3-4 FPU/g)

- Effective high gravity fermentation (SSF) of more than $80 \%$ of cellulose to ethanol by yeast

- Yeast fermentation can be carried out in the presence of lignin

- See more at www.bioethanol.info 
- Low price, 4 bar steam from electricity generation

- High gravity processing reduces steam consumption

- Novel particle generation system saves 50-75\% electricity compared to traditional hammer milling

- Novel distillation system energized by heat pumps or 1-2 bar steam, is expected to reduce costs with $50 \%$ compared with traditional systems

- Drying with superheated steam at 3-5 bar generates steam for multistage evaporation recovering about $90 \%$ of drying energy

- The lignin fraction can cover the process energy required for conversion of the straw and a similar quantity of grain 


\section{IBUS - long term sustainability}

- Use of low pressure steam from electricity generation means energy without $\mathrm{CO} 2$ emission

- Recycling of plant nutrients (nitrogen, phosphorus, potassium and microminerals)

- Recycling of process water and condensates means no waste water

- Drying with superheated steam means no VOC emission 


\section{IBUS - best basis for biorefineries}

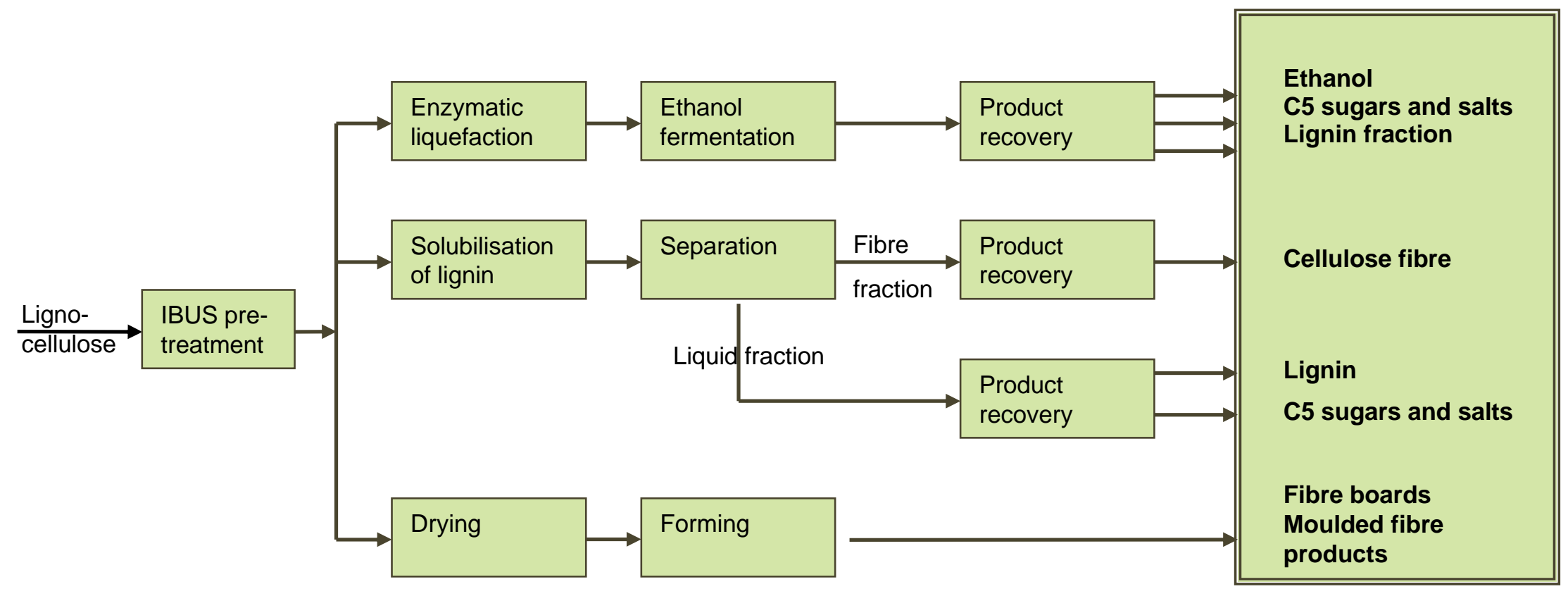

\section{Inbi\%




\section{Stepwise implementation of biorefineries}

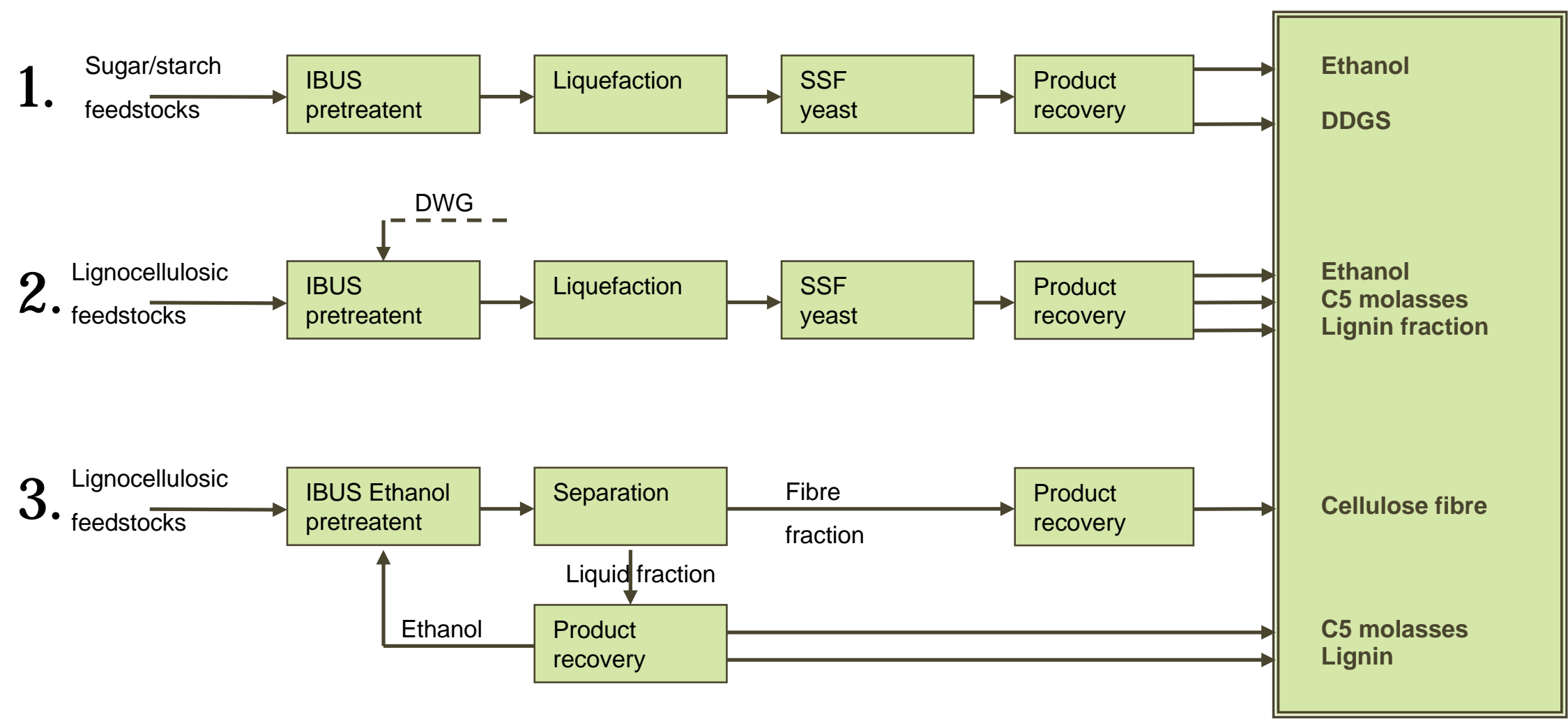

\section{Inbi : \\ con}




\section{IBUS - R \&D}

\begin{tabular}{|l:l|l|}
\hline $\begin{array}{l}\text { Lab scale } \\
10 \mathrm{~kg} / \mathrm{h} \text { of straw }\end{array}$ & Pretreatment & Risoe National Laboratory \\
\cline { 2 - 3 } & Hydrolysis and fermentation & $\begin{array}{l}\text { The Royal Veterinary and } \\
\text { Agricultural University }\end{array}$ \\
\hline $\begin{array}{l}\text { Pilot scale } \\
100 \mathrm{~kg} / \mathrm{h} \text { of straw }\end{array}$ & $\begin{array}{l}\text { Particle generation, pretreatment, } \\
\text { liquefaction, fermentation, product recovery }\end{array}$ & Dong Energy A/ S \\
\hline $\begin{array}{l}\text { Pilot scale } \\
1000 \mathrm{~kg} / \mathrm{h} \text { of straw }\end{array}$ & Particle generation, pretreatment & Dong Energy A/ S \\
\hline $\begin{array}{l}\text { Process } \\
\text { Innovation }\end{array}$ & From field to fuel & Holm Christensen \\
\hline $\begin{array}{l}\text { Demonstration } \\
\text { plant } \\
4 \mathrm{t} / \mathrm{h} \text { of straw d.m. } \\
4 \mathrm{t} / \mathrm{h} \text { of grain d.m. }\end{array}$ & $\begin{array}{l}\text { Fully integrated IBUS plant located at one of } \\
\text { Dong Energy's Power Plants (Kalundborg) }\end{array}$ & \\
\hline
\end{tabular}

\section{Inbi $\%$}




\section{Content}

- IBUS technology

- Demonstration

- Commercialisation 


\section{Feedstock development}

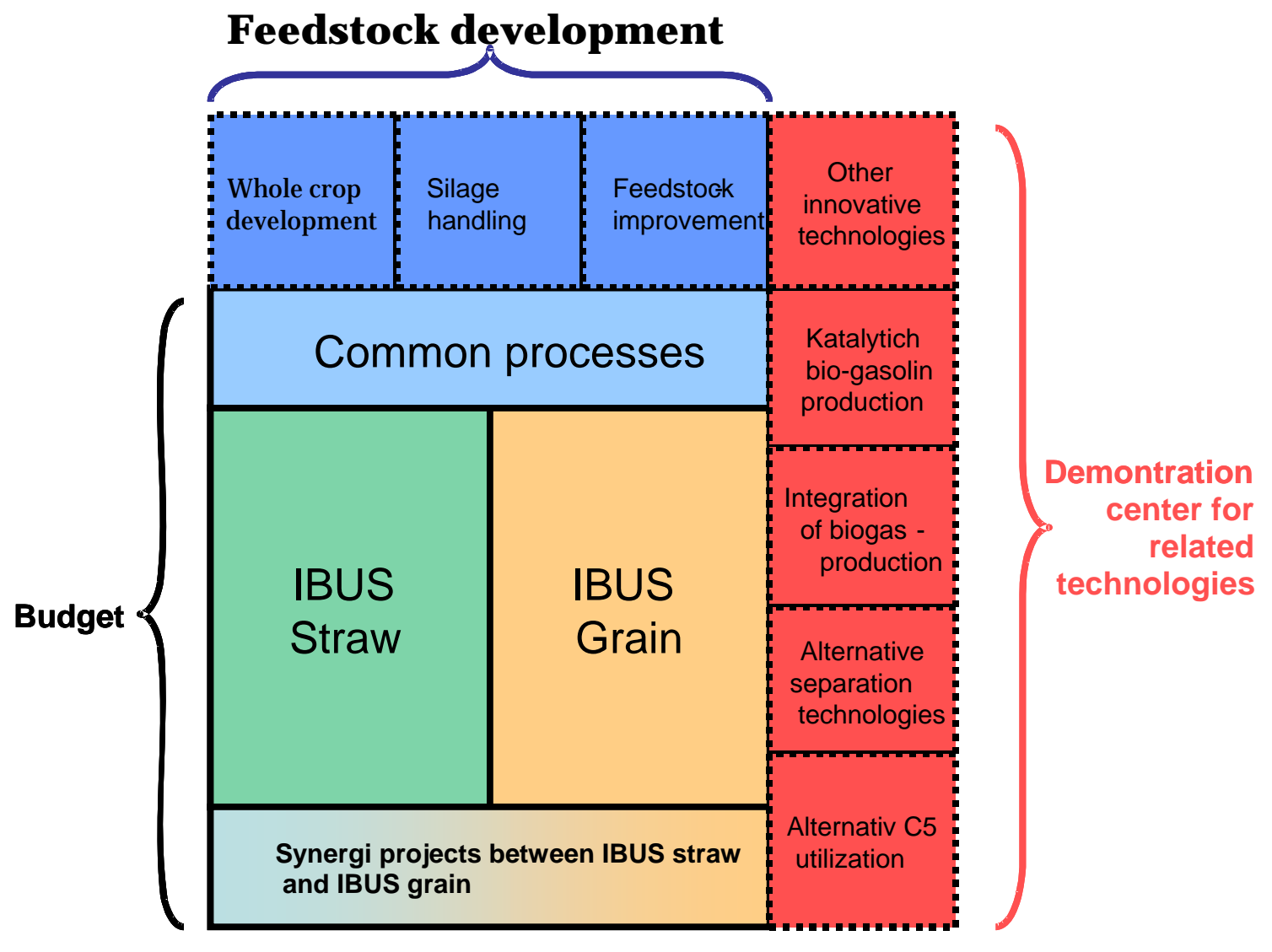




\section{Demonstration concept}

\section{Synergies between straw and grain}

Large international potential for technology integrating 1. and 2nd generation ethanol

Examples af synergies at demo-plant:

- DWG as feedstock in the straw process

- Surplus of energy from the straw process goes to the grain process

- Water and energy exchange between the to processes

- Optimiazation of field to ethanol plant (whole crop handling)

- Compound feed production based on DWG and C5 molasses

- Integration of main processes

- Improvement of feedstocks

- Logistic and marketing 


\section{Kalundborgs industrial symbiose}

The existing symbiose is extended with biofuel and byproducts

\section{Inbi con}

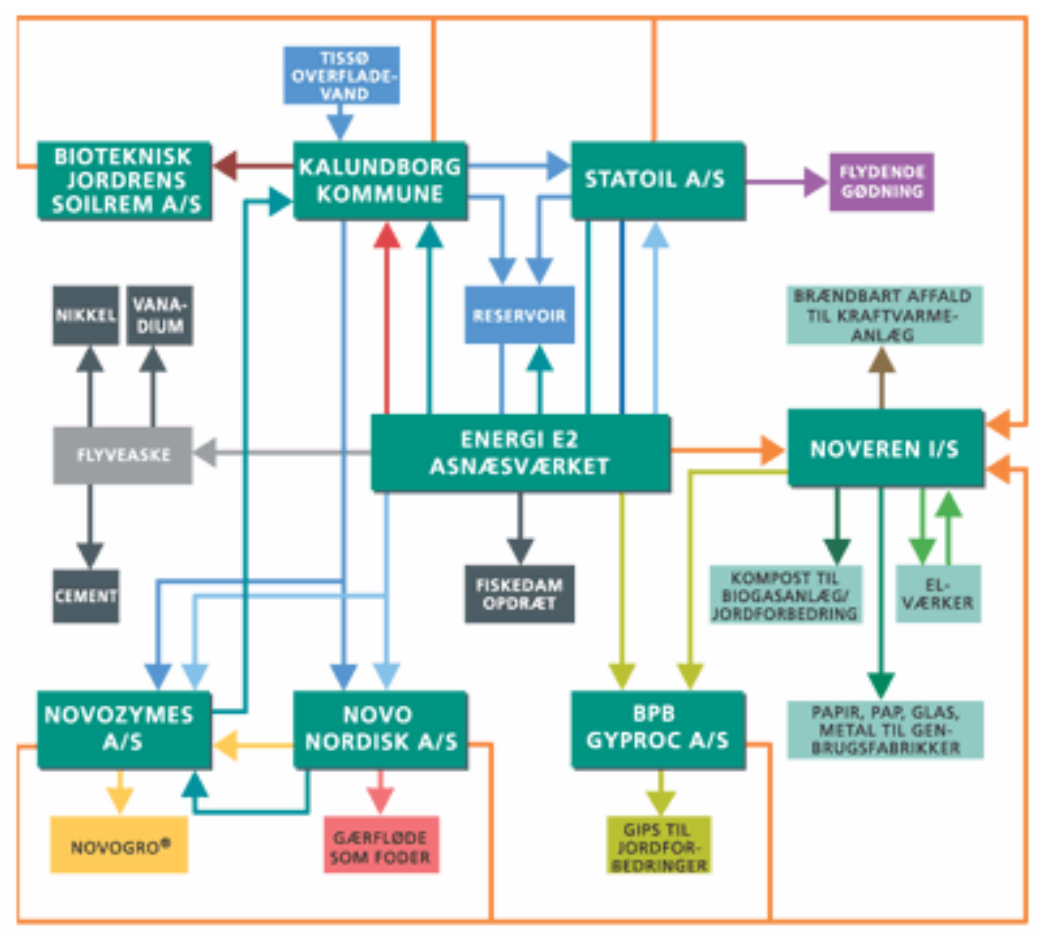

\begin{tabular}{|c|c|c|c|c|c|c|c|c|}
\hline ASKE & VAND & DANP & $\begin{array}{l}\text { KOLE: } \\
\text { VAND }\end{array}$ & $\begin{array}{l}\text { SPILDE- } \\
\text { vaND }\end{array}$ & GIPS & $\begin{array}{l}\text { AYDENDE } \\
\text { GOONING }\end{array}$ & $\begin{array}{l}\text { MLSF. } \\
\text { VWRME }\end{array}$ & $\begin{array}{l}\text { GAR: } \\
\text { fLDEE }\end{array}$ \\
\hline NONOGRO" & SLAM & ANDET & $\begin{array}{l}\text { gVRuG } \\
\text { AFfaLI }\end{array}$ & 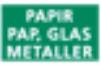 & EL & 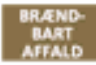 & $\begin{array}{l}\text { KOMPOST } \\
\text { MaIforiaus }\end{array}$ & \\
\hline
\end{tabular}




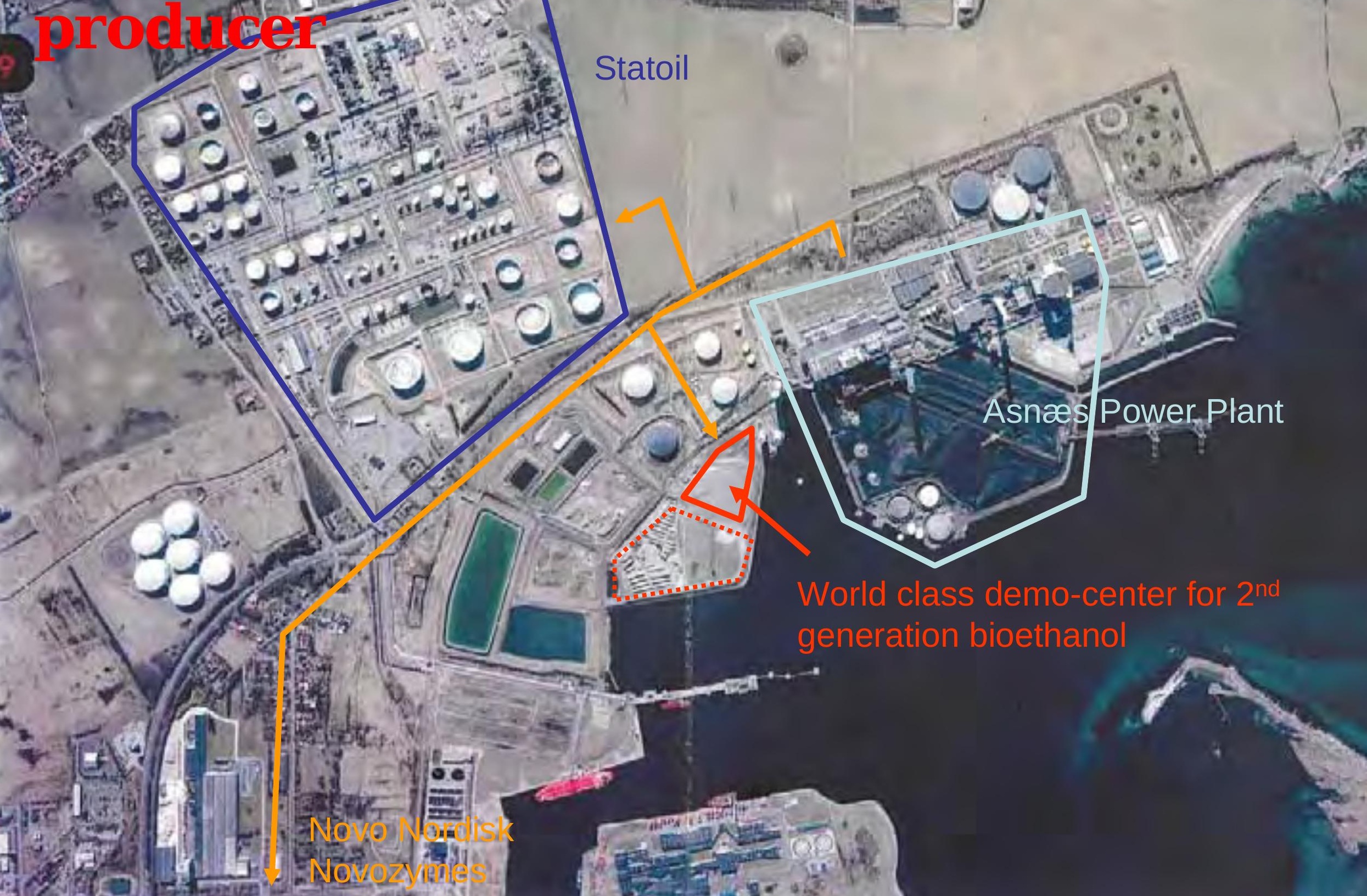

ner hexime

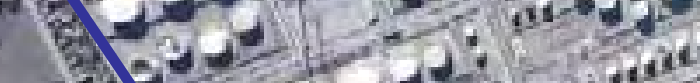

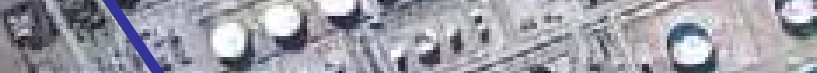

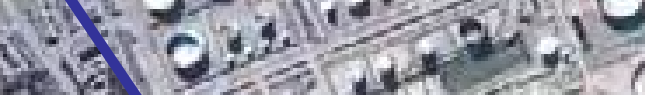
arint? generation bioethano

$\frac{1}{4}$ 



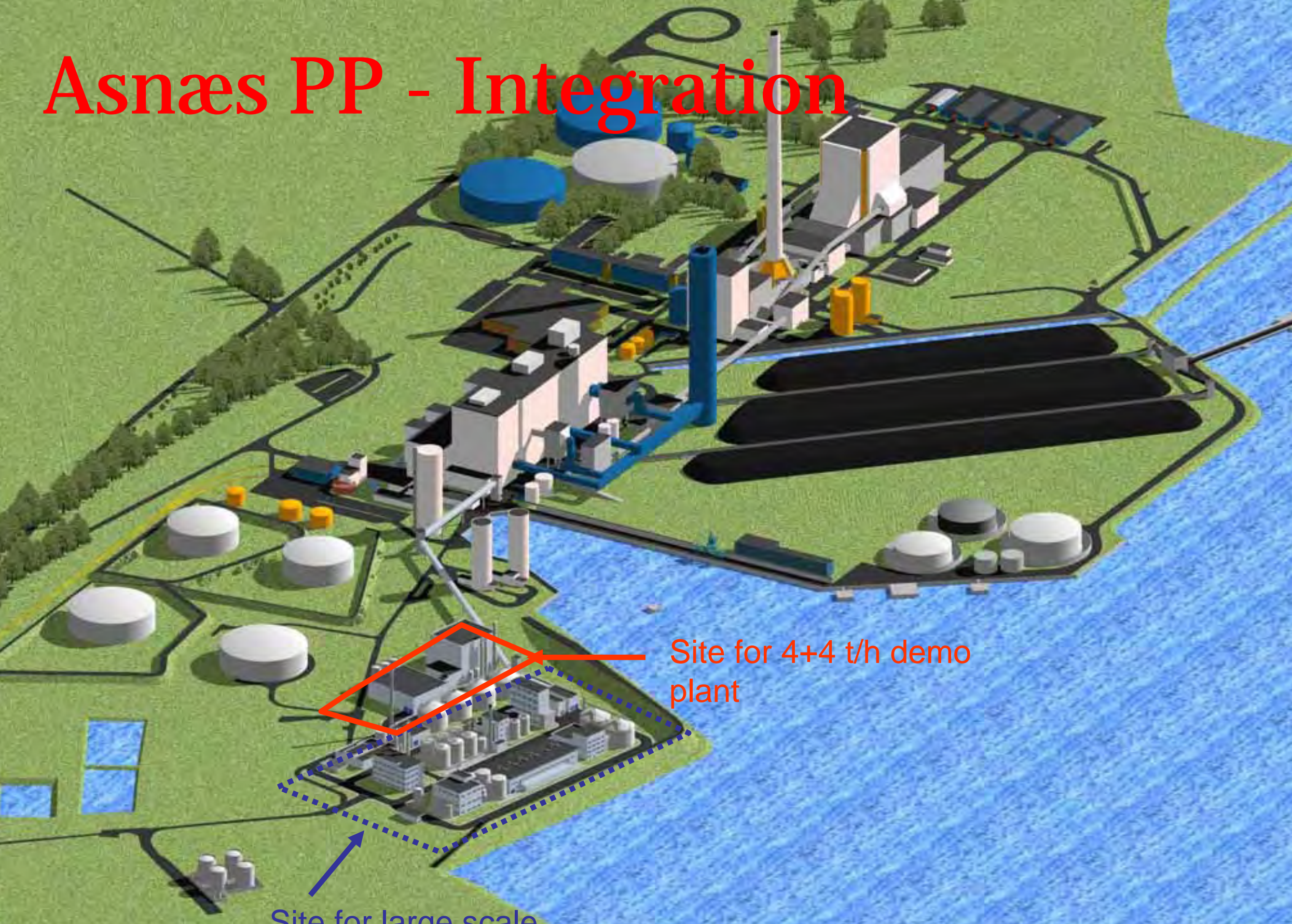

Site for large scale ethanol nlant 


\section{Content}

- IBUS technology

- Demonstration

- Commercialisation

\section{Inbi :}

con 


\section{Demo plant}

- Goal: Production before UN Copenhagen Clima Summit November 2009

- Capacity: 4 ton straw +4 ton grain (budget ca. 40 mill US)

- Partners (Inbicon, Dong Energy, Novozymes, Statoil and Danish Farmers COOP)

- Technology: (IBUS technology - integration of 1. and 2. bio ethanol connectd to Power Plant) 


\section{Commercialization}

- Technology company - new investors

- Verification of technology (scale-up, reliability, demonstration of yields, environmental impact and feasibility)

- Partners: (North America, China and Brazil)

- Owerseas demonstration projects

- Contracts 


\section{Succes criteria}

- Best economy

(energy efficiency, enzymes, capital cost and value of byproducts)

- Market share

(the right partners and fast deployment) 


\section{Thank you for your attention}




\title{
Intelligent Energy Europe

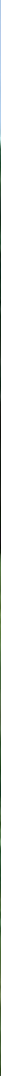

Long-term biofuels scenarios: preliminary results from REFUEL A European Road Map for Biofuels

\author{
Henrik Duer \\ COWI A/S, Denmark
}

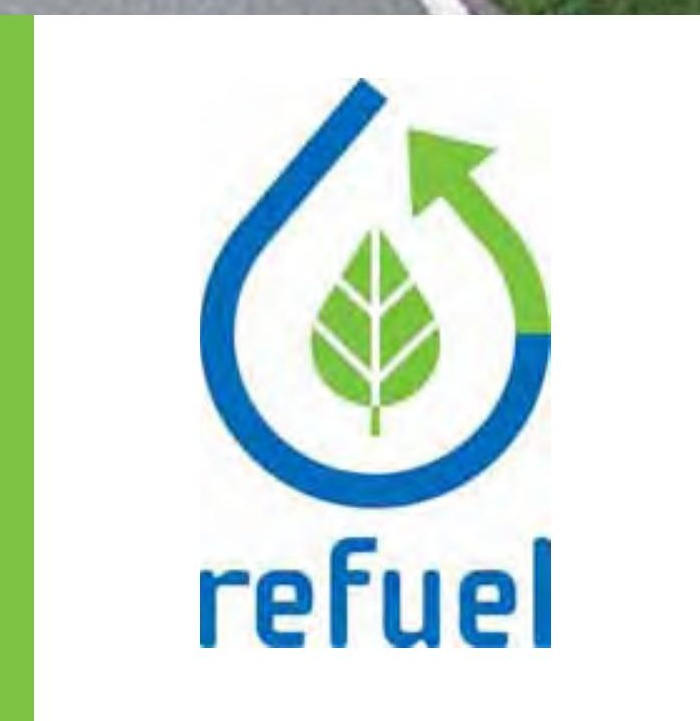




\section{Contents}

COWI

1. Introduction

2. REFUEL objectives

3. Resource base assessment

4. Biofuels mix development

5. Barriers identified

6. Conclusions 


\section{I ntroduction}

\section{Biofuels production in Europe 1991-2005}

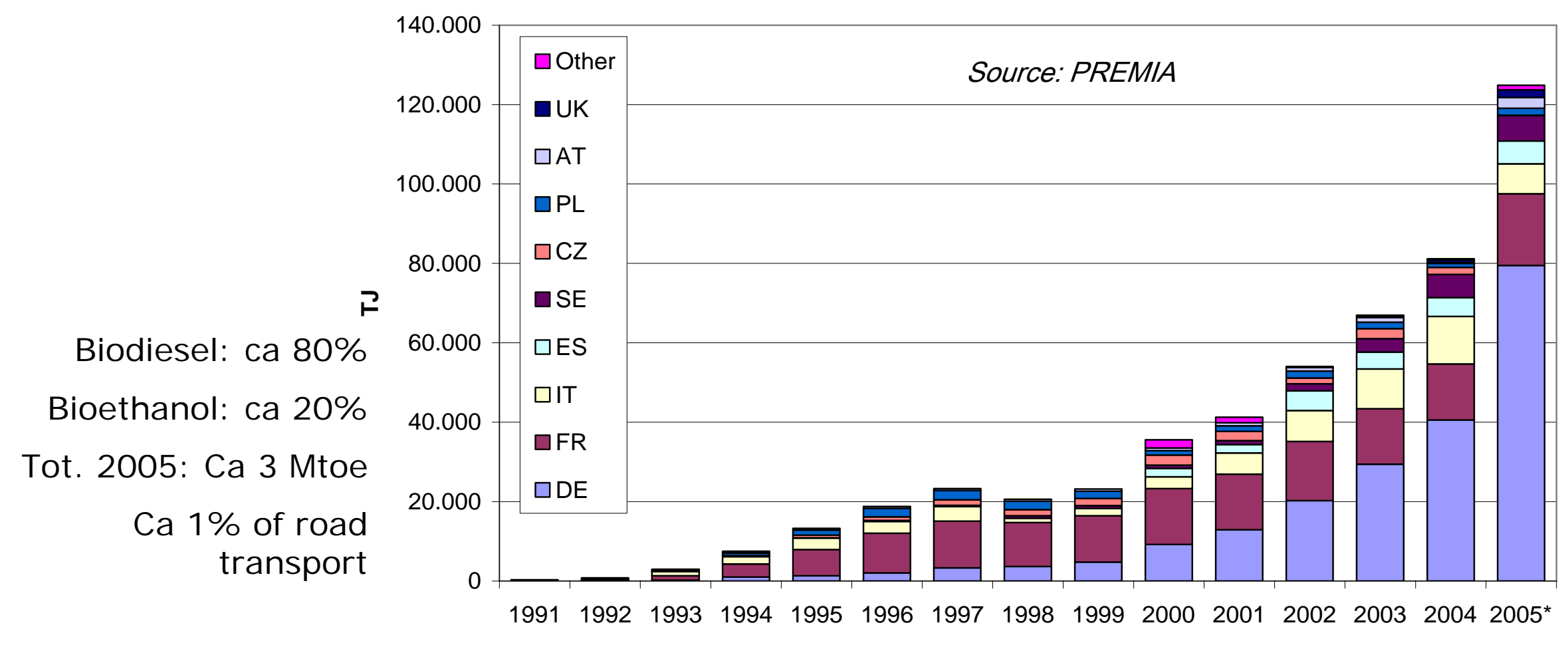




\section{Development}

Now $1^{\text {st }}$ generation in rapid deployment:

- Major investments in biodiesel, bioethanol

- Long-term feedstock availability

- Sustainability, GHG performance?

Future biofuels mix:

- Advanced biofuels (FT-diesel, advanced bioethanol)

- Remaining $1^{\text {st }}$ generation?

\section{Central question: what can we expect from biofuels in the long run?}




\section{Technological learning and land scarcity}

COWI
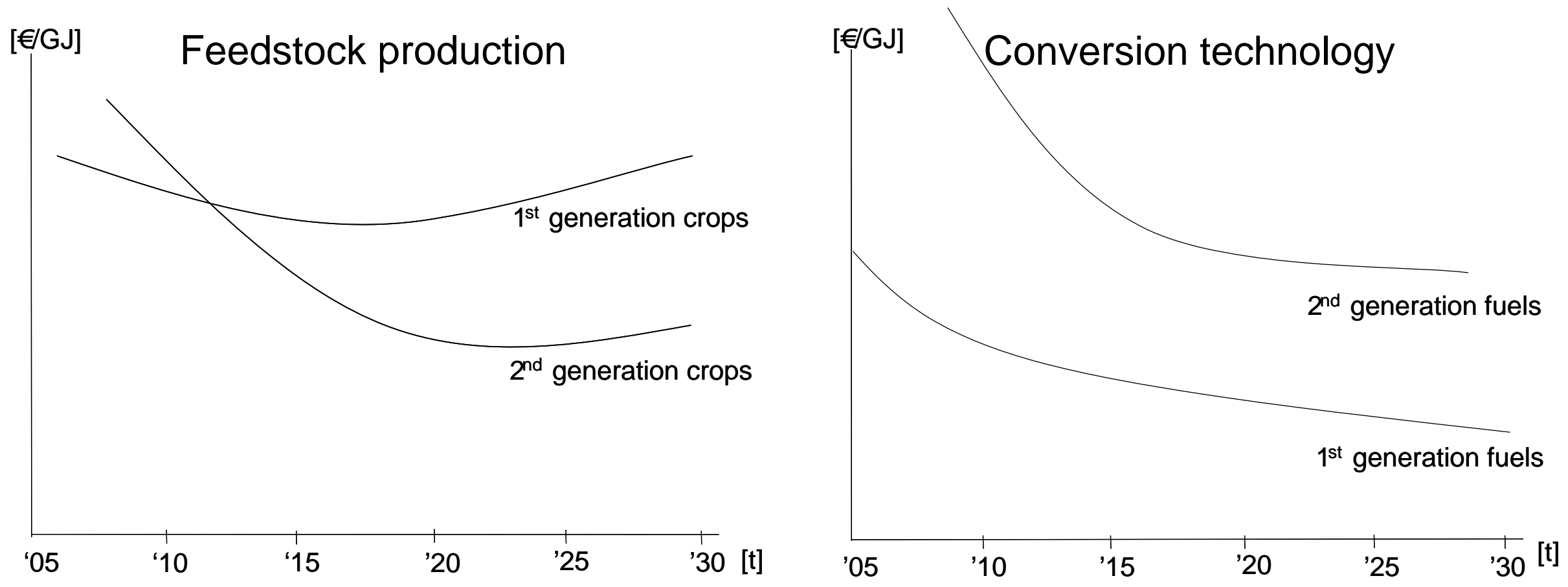


\section{REFUEL, main objectives}

To develop an ambitious, yet realistic road map for an effective deployment of biofuels until 2030 in the EU25+

- The destination: Ambitious, but realistic biofuels targets

- The route: the least-cost biofuel mix and biofuel chains

- The purpose of the journey: impact assessments on GHG, SoS, socio-economics, stationary sector, environment

- At the wheel: key stakeholders, technological innovation needed, learning, options and barriers

- Paving the way: related policies on energy, agri, technology, measures (incentives, obligations)... 


\section{Resource assessment}

COWI
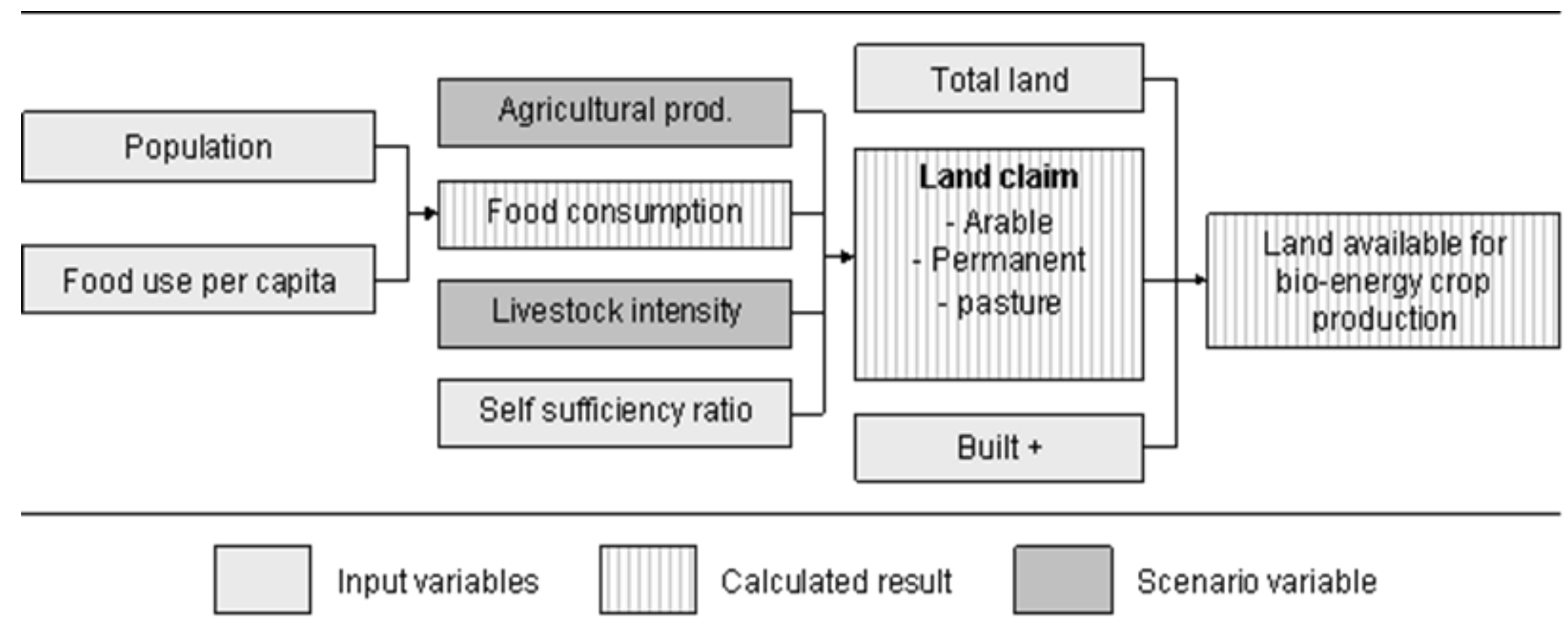

Input variables

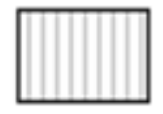

Calculated result

Scenario variable 


\section{Land suitability to crops}

- Priority for food etc.

- Demand scenarios

- Agric. production

- Natura2000

- No drastic land use changes

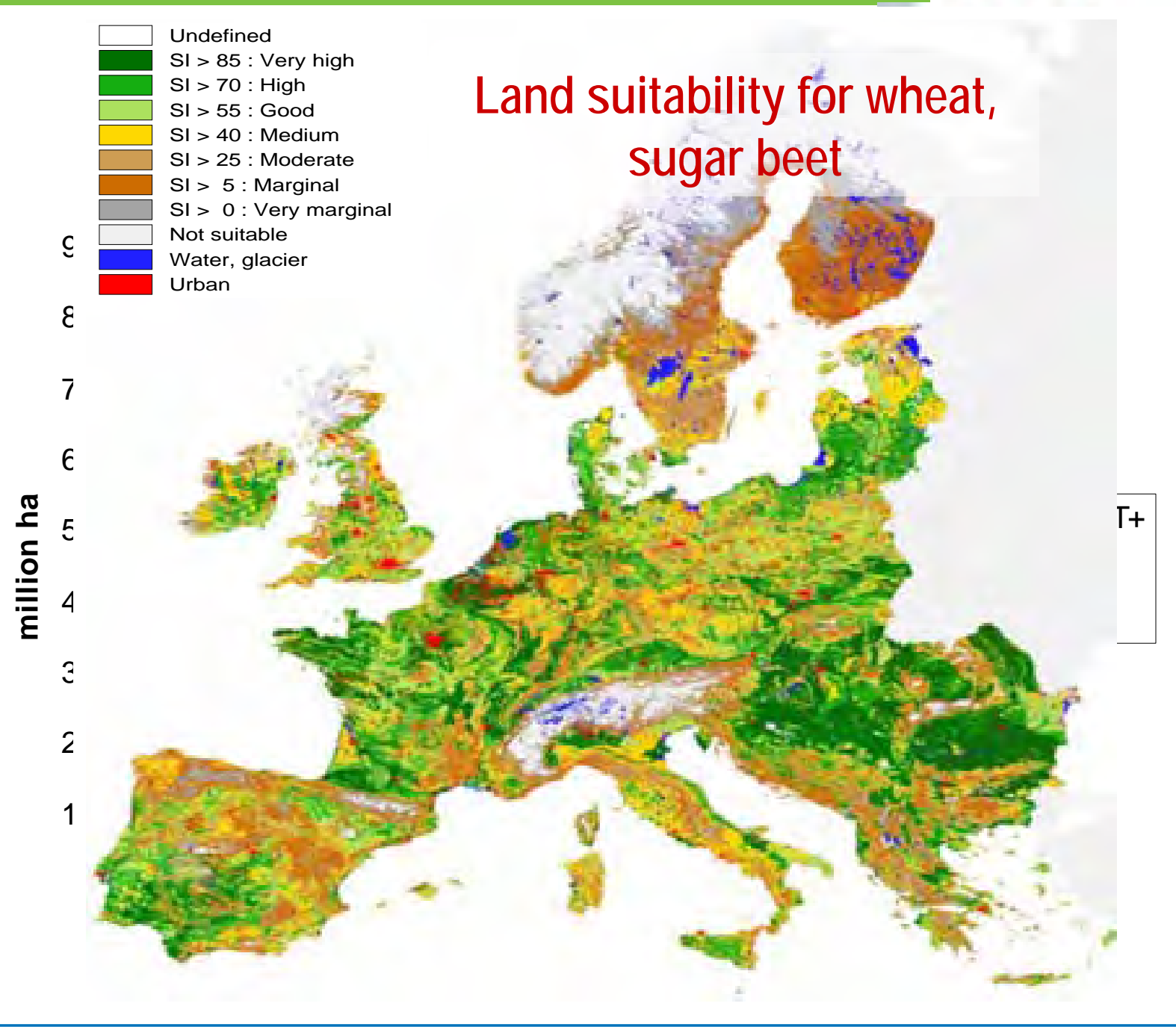

Intelligent Energy [B] Europe 8

planning the road ahead for biofuels 


\section{Some prelliminary results: Feedstock}

\section{Total land potential if used for perennial grasses:}

EU27:

$1 / 10$ of prim. energy demand 1/3 of gasoline/diesel demand
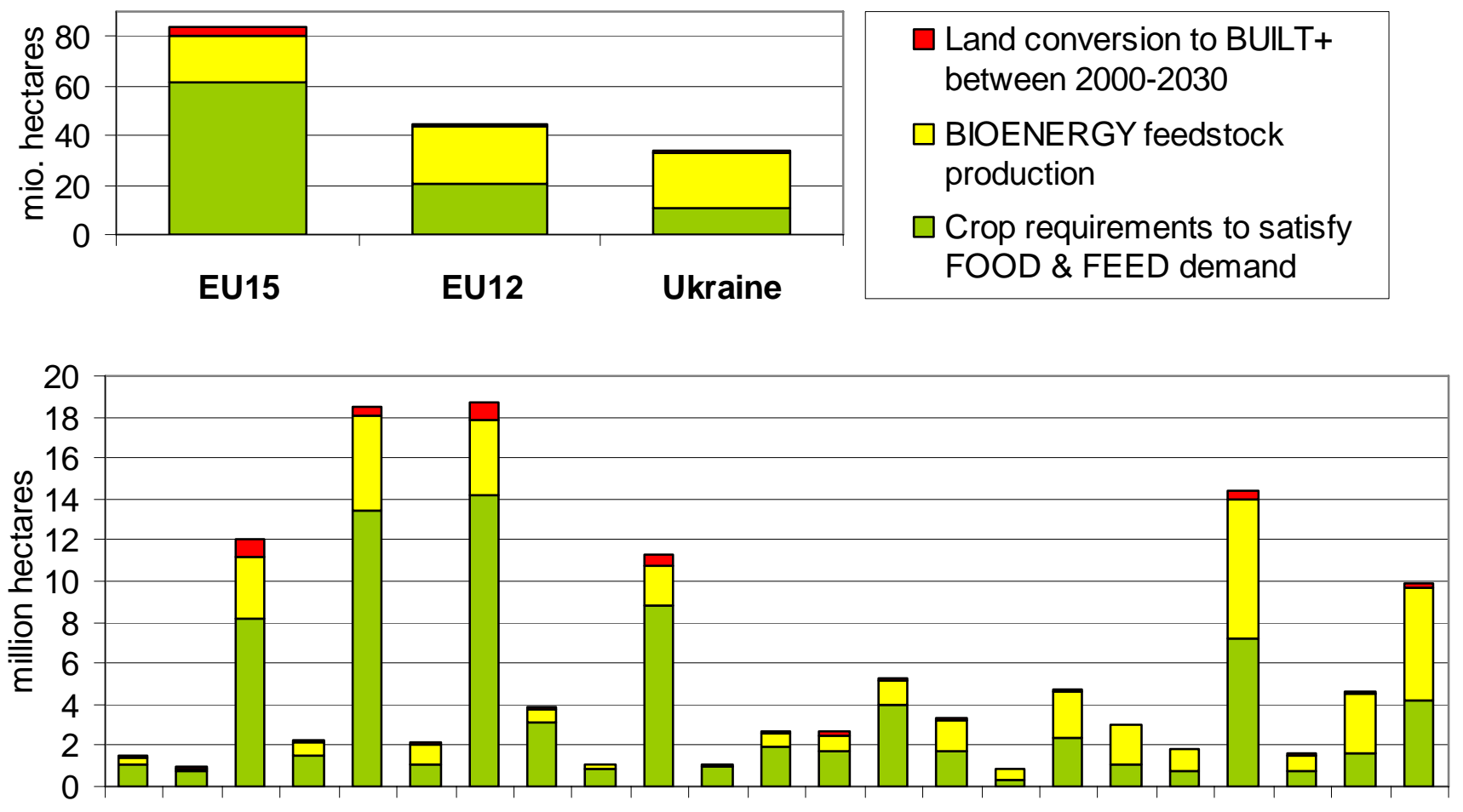

at bel de dk es fi fr $\mathrm{gr}$ ie it $\mathrm{nl}$ pt se uk cz ee hu It Iv pl sk bg ro $\square$ Land conversion to BUILT+ between 2000-2030

$\square$ BIOENERGY feedstock

$\square$ Crop requirements to satisfy FOOD \& FEED demand production
1/6 of EU 2030 prim. energy demand Or half of gasoline/diesel dem. 


\section{Sensitivities}

COWI

More conservative:

- More organic farming

- Less rapid productivity developments in CEEC

Ca $10 \%$ less land potential

More optimistic:

- GMO's

- Faster convergence in CEEC

Ca $15 \%$ more land potential 


\section{Nota bene: CowI}

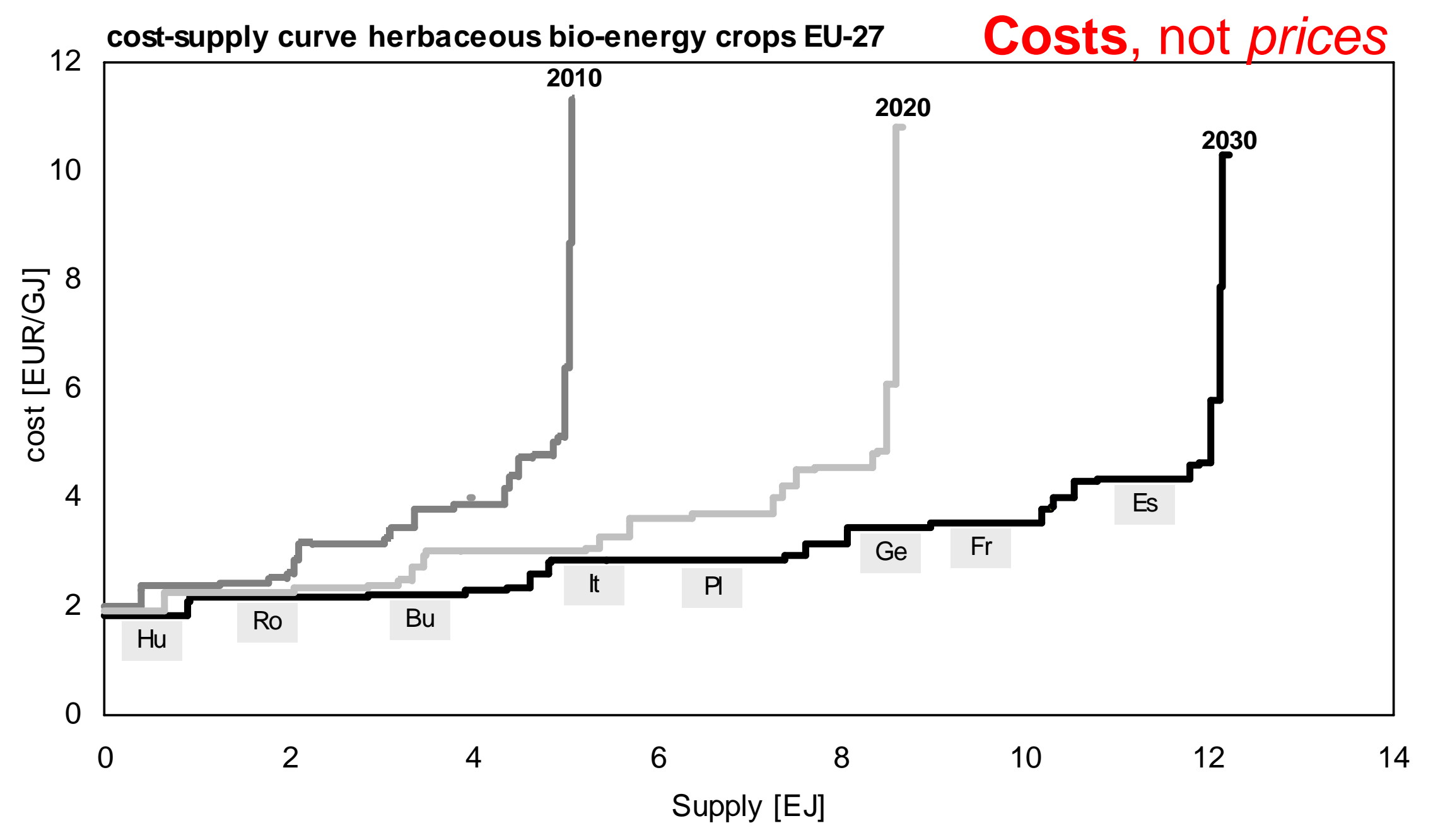




\section{Biofuel mix assessment}

COWI

- Least-cost biofuels mix over full chain:

Production, transport, conversion, distribution, enduse (Biotrans model)

- $1^{\text {st }}$ and $2^{\text {nd }}$ generation biofuels

- Crops, residues etc.

- Within-EU trade, imports

- Key issue: Learning -

- In feedstock production

- In conversion 


\section{5 biofuel costs built-up in Biotrans}

\section{5}

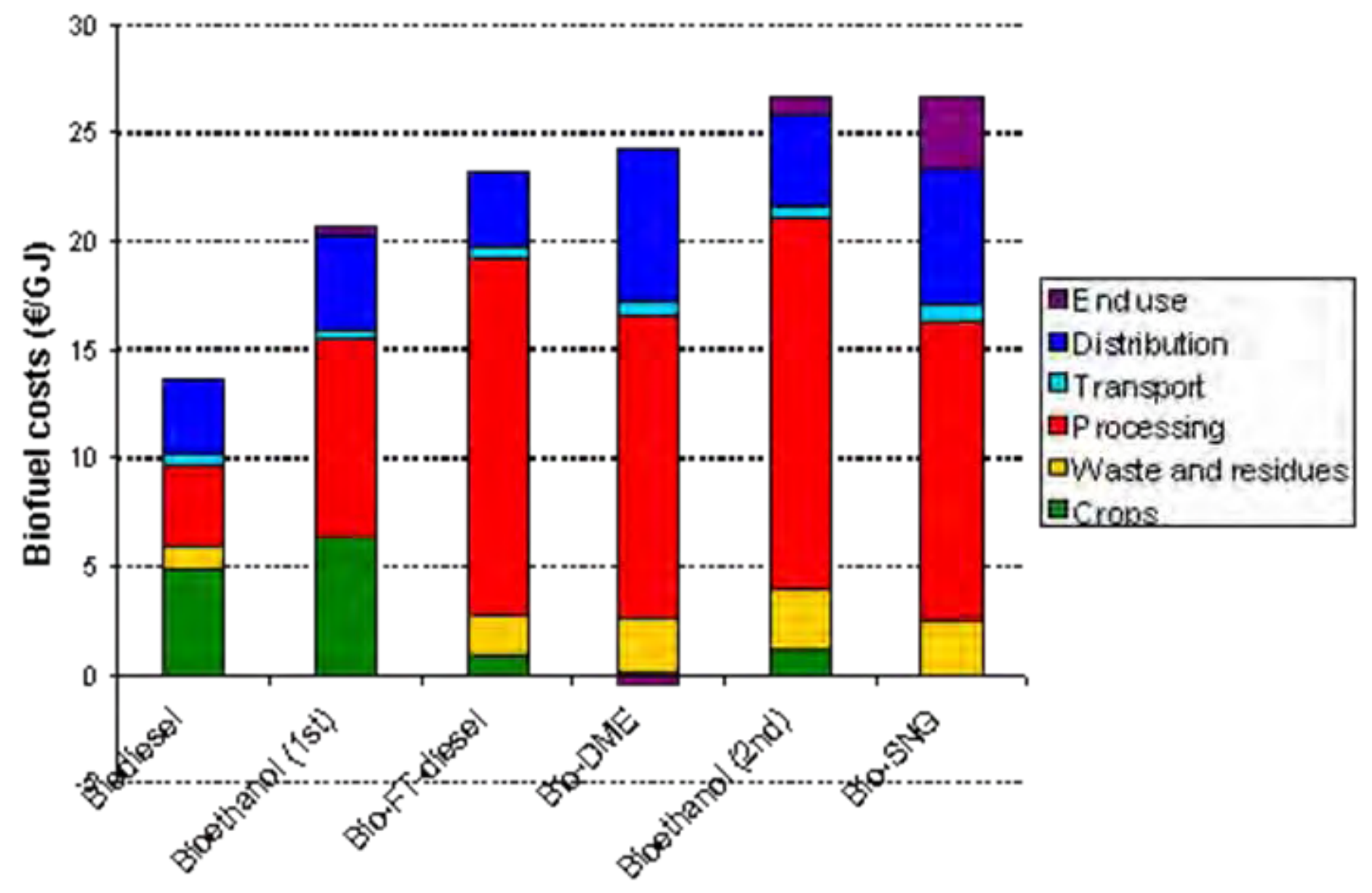




\section{Preliminary results: Biofuel consumption}

\section{COWI}

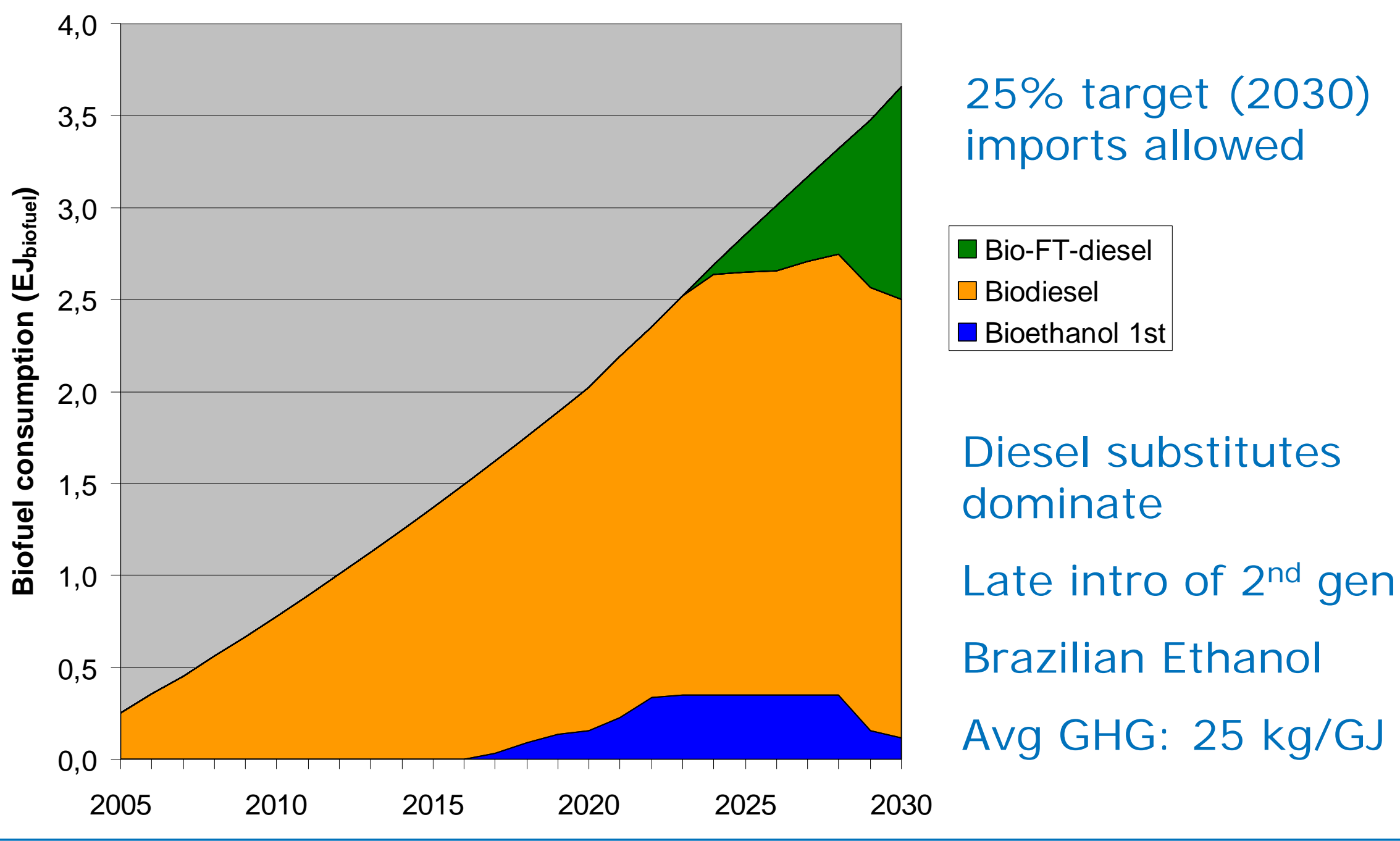




\section{Preliminary results: Feedstock base}

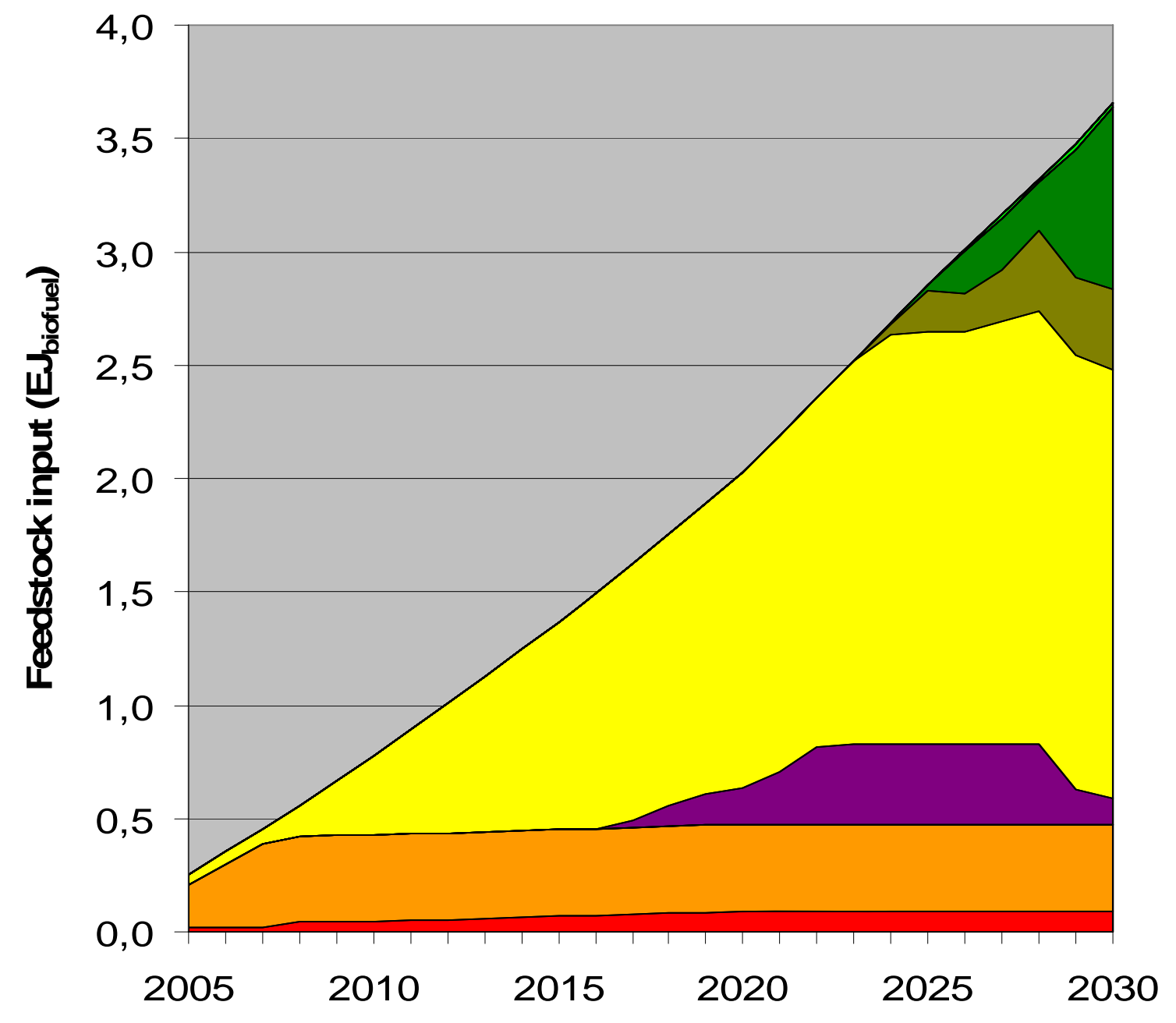

$25 \%$ target (2030) imports allowed

$\square$ Grassy crops

$\square$ Woody crops

$\square$ Wood processing residues

$\square$ Oil crops

$\square$ Brazilian import ethanol

$\square$ Palm oil import

$\square$ Used fats/oils

Diesel substitutes dominate

Late intro of $2^{\text {nd }}$ gen.

Brazilian Ethanol 


\section{Aggregated cost builld-up}

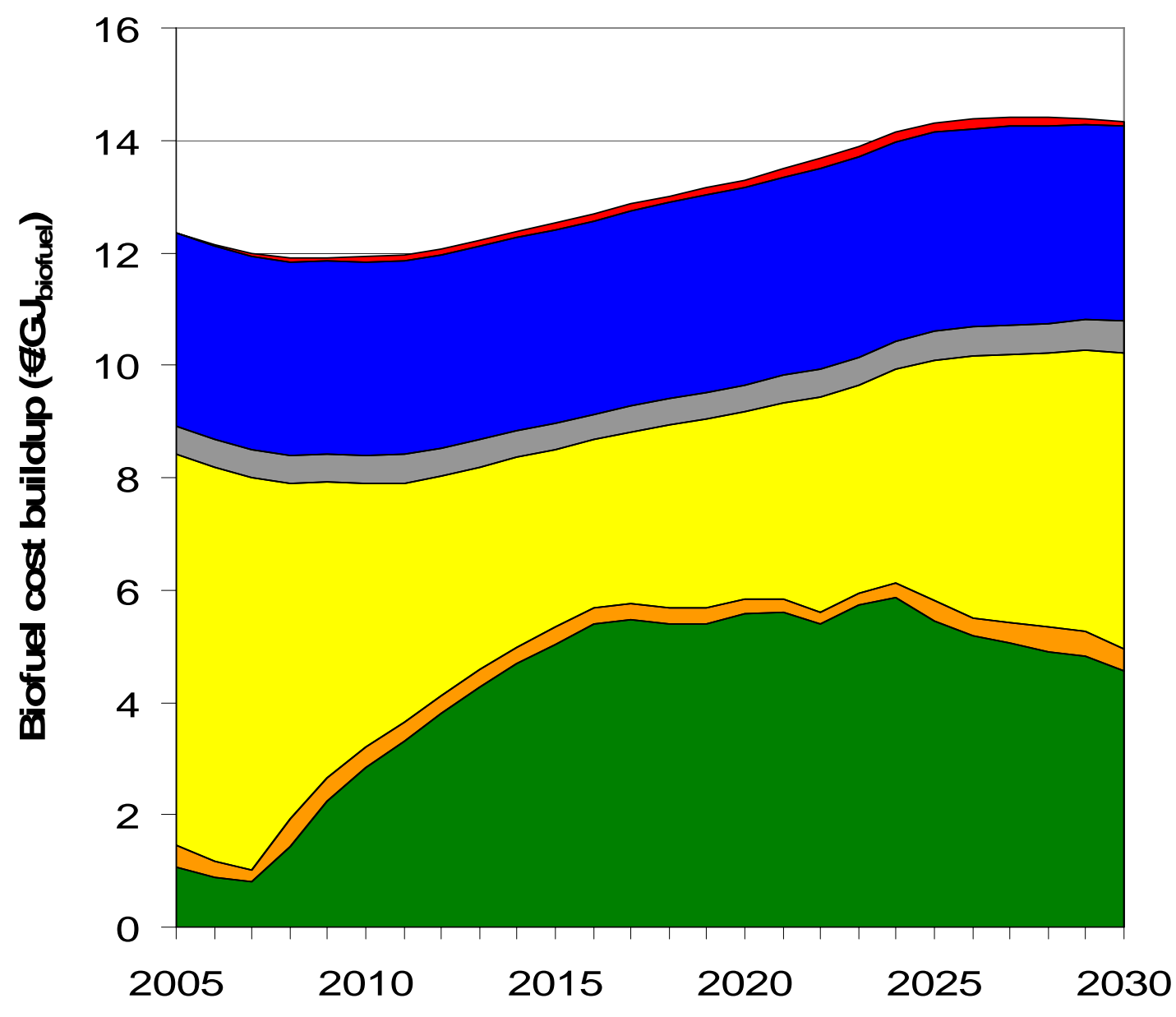

Additional end use

- Distribution (excl. transport)

$\square$ Transport

$\square$ Conversion (incl. import)

$\square$ Waste and residuals

$\square$ Energy crops 


\section{Other scenarios and policy options:}

No imports:

- Earlier introduction of 2nd generation (2013)

- Higher average fuel costs until 2025

- Better GHG profile: < 20 g/MJ biofuel

Lower biofuels ambitions (15\% in 2030):

- No introduction of 2 nd generation

- Lower average fuel costs

- Worse GHG profile: >30 g/MJ

I mpact of $2^{\text {nd }}$ generation biofuel obligation by 2020:

- Higher costs in 2015-2025, lower costs afterwards?

- Better GHG performance 


\section{Further work}

Assessment of biofuel growth limitations

- Adoption rates to new crops

- Competition for ligno feedstock

- RES-Electricity and Heat production

- CHP is attractive

- Assessment of potential and effects in Peep model

Implications of other policies

- Specific targets for diesel and gasoline substitutes?

- Active AGRI policy?

- (internal and external) trade policy? 


\section{Barriers identified}

COWI

Basic fact that:

- the process is politically and not market driven

Four key barriers identified by stakeholders:

1. No clear strategy on how to achieve the biofuel targets

2. There is no common market for biofuels

3. There is no common technical standards

4. Limited resources of land

We address issues related 


\section{Conclusions}

COWI

- Rapid development of biofuels in EU: need for robust long-term strategy

- Significant land potential available (Central and East)

- Least-cost: $1^{\text {st }}$ general may dominate long

- Policy driven

- For development of best GHG-performing biofuels:

- Specific incentives needed

- Adequate incentives and policies will be crucial 


\title{
Thank you
}

\section{COWI}

Further information and updates:

\section{www.refuel.eu}

\author{
info@refuel.eu
}

hdu@cowi.dk

londo@ecn.nl 

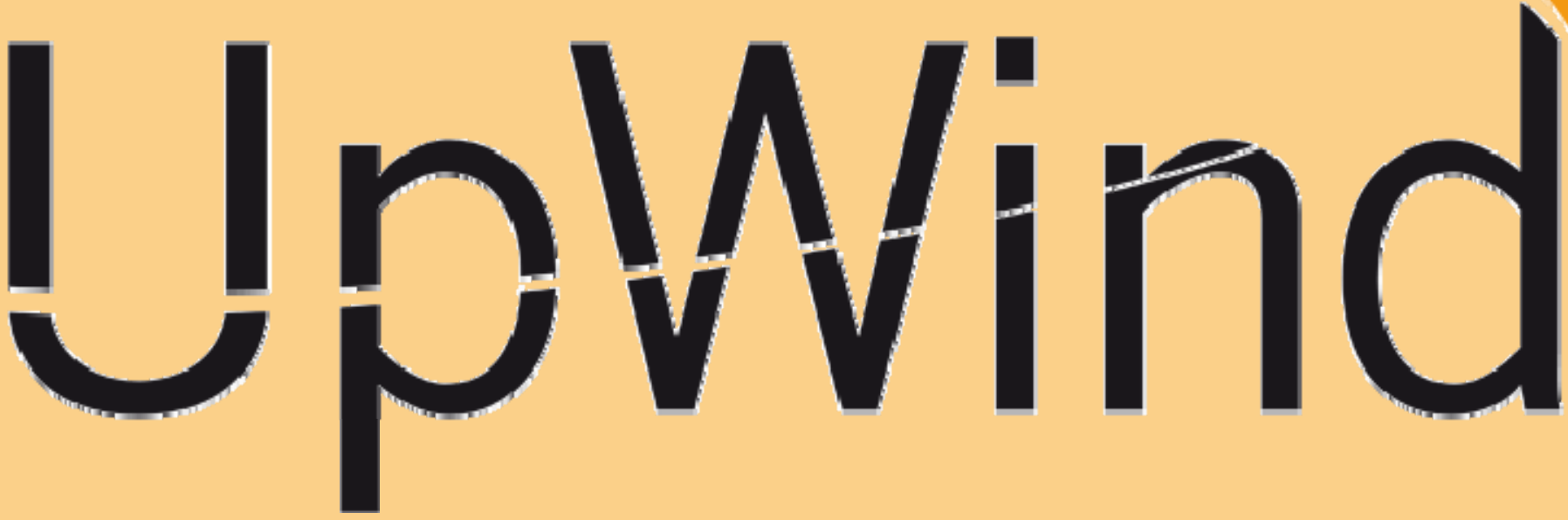

A Wind Research Project under the 6th Framework Programme

\author{
Program Manager \\ Peter Hjuler Jensen \\ RIS $\varnothing$ National Laboratory \\ Technical University of Denmark
}




\section{Outline}

1. Background

2. Global development of Wind Energy

3. Presentation of UpWind

4. UpWind - First year results

5. Questions and discussion 


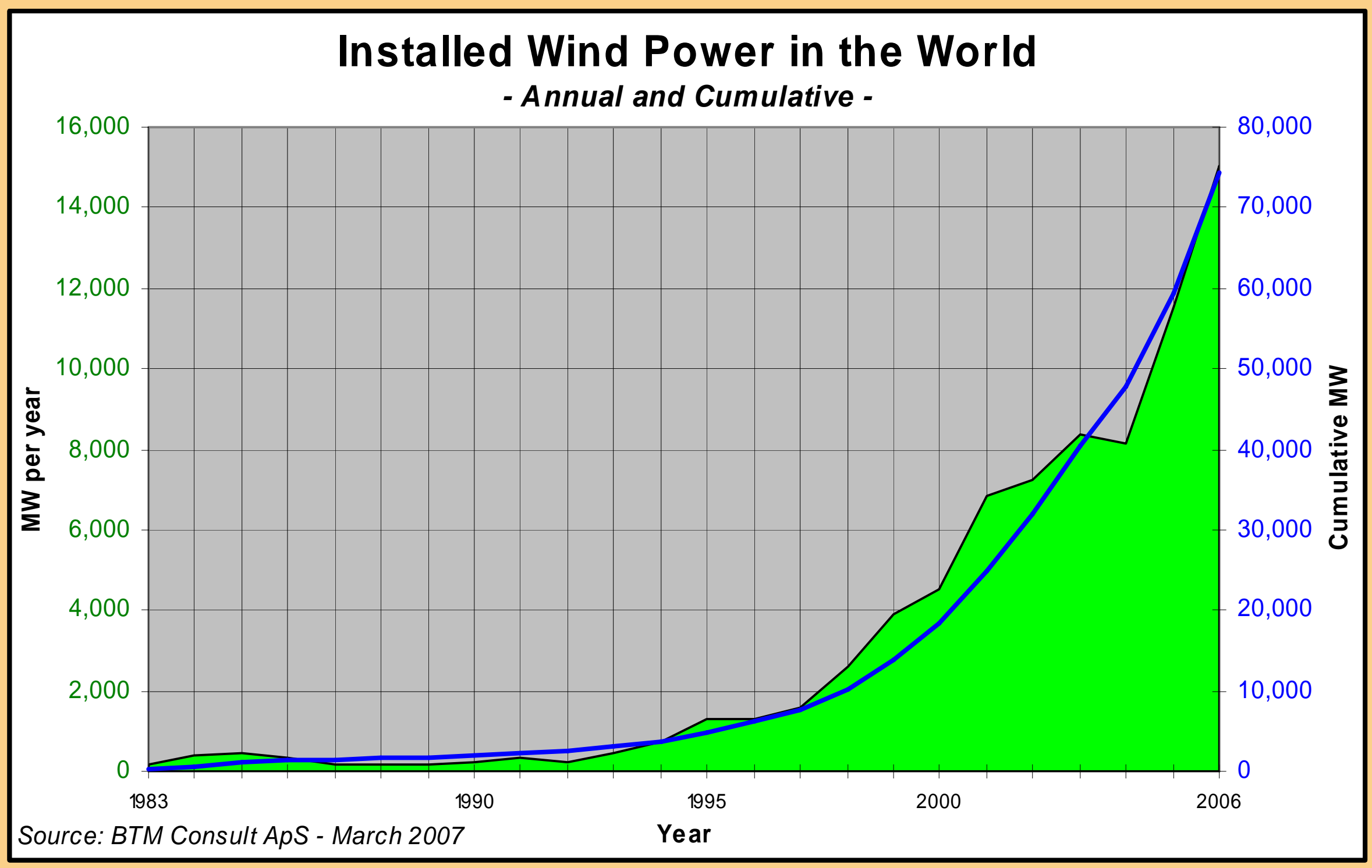




\section{Global Wind Power Status}

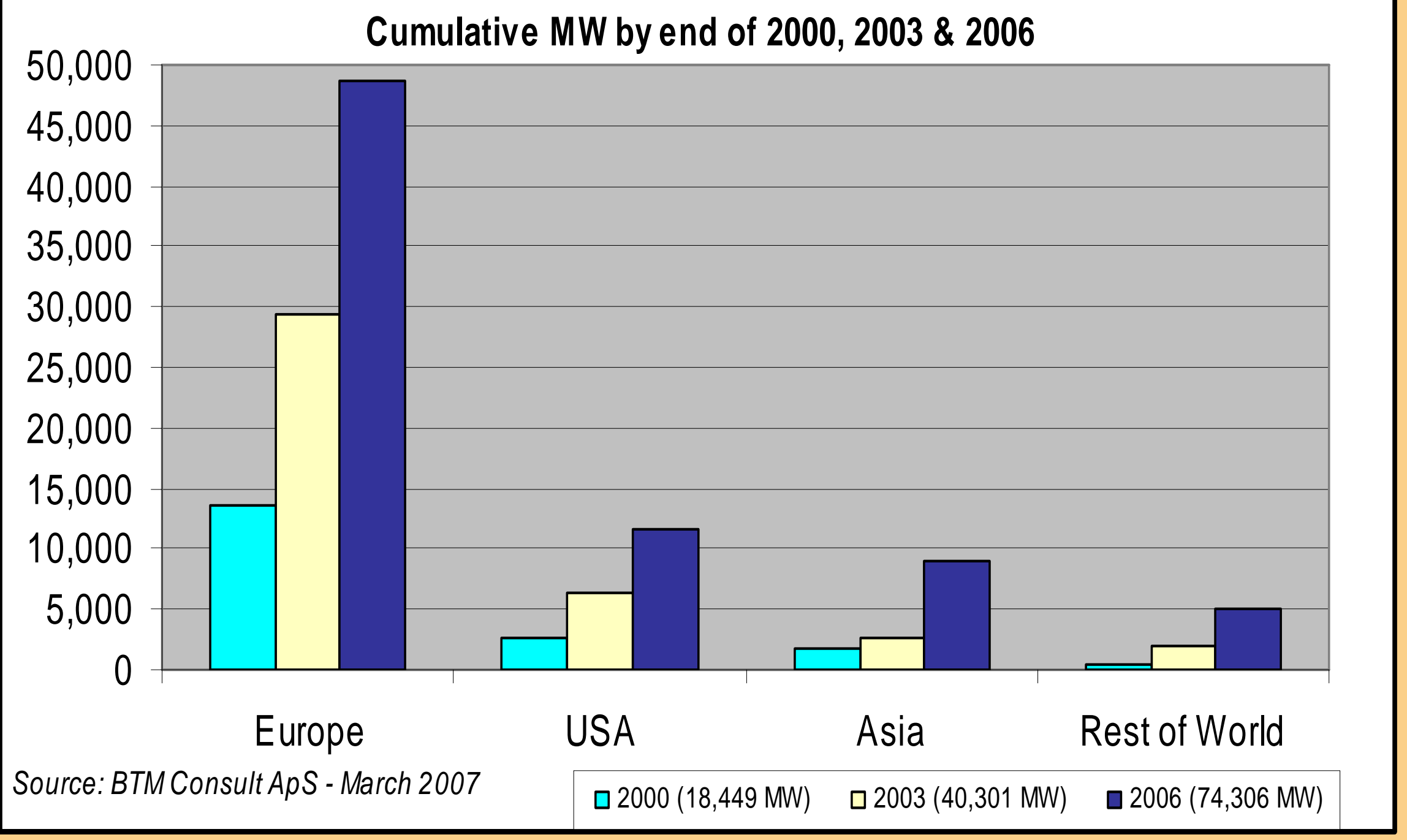




\section{Installed capacity in 2005 and 2006 (Americas)}

\begin{tabular}{|l|c|c|c|c|}
\hline \multirow{2}{*}{ (C) } & $\begin{array}{c}\text { Installed } \\
\text { MW } \\
\mathbf{2 0 0 5}\end{array}$ & $\begin{array}{c}\text { Accu. } \\
\text { MW } \\
\mathbf{2 0 0 5}\end{array}$ & $\begin{array}{c}\text { Installed } \\
\text { MW } \\
\mathbf{2 0 0 6}\end{array}$ & $\begin{array}{c}\text { Accu. } \\
\text { MW } \\
\mathbf{2 0 0 6}\end{array}$ \\
\hline Argentina & 1 & $\mathbf{3 1}$ & 0.0 & $\mathbf{3 1}$ \\
\hline Brazil & 0 & $\mathbf{3 1}$ & 199.6 & $\mathbf{2 3 1}$ \\
\hline Canada & 239 & $\mathbf{6 8 3}$ & 776 & $\mathbf{1 , 4 5 9}$ \\
\hline Costa Rica & 0 & $\mathbf{7 9}$ & 0 & $\mathbf{7 9}$ \\
\hline Mexico & 0 & $\mathbf{3}$ & 83 & $\mathbf{8 6}$ \\
\hline USA & 2,431 & $\mathbf{9 , 1 8 1}$ & 2,454 & $\mathbf{1 1 , 6 3 5}$ \\
\hline Other Americas & 0 & $\mathbf{5 4}$ & 2 & $\mathbf{5 6}$ \\
\hline Total Americas & $\mathbf{2 , 6 7 1}$ & $\mathbf{1 0 , 0 6 2}$ & $\mathbf{3 , 5 1 5}$ & $\mathbf{1 3 , 5 7 7}$ \\
\hline
\end{tabular}

Source: BTM Consult ApS - March 2007 


\section{Installed capacity in 2005 and 2006 (Asia)}

\begin{tabular}{|l|c|c|c|c|}
\hline & $\begin{array}{c}\text { Installed } \\
\text { MW } \\
2005\end{array}$ & $\begin{array}{c}\text { Accu. } \\
\text { MW } \\
\mathbf{2 0 0 5}\end{array}$ & $\begin{array}{c}\text { Installed } \\
\text { MW } \\
2006\end{array}$ & $\begin{array}{c}\text { Accu. } \\
\text { MW } \\
2006\end{array}$ \\
\hline P.R. China & 498 & 1,264 & 1,334 & 2,588 \\
\hline India & 1,388 & $\mathbf{4 , 3 8 8}$ & 1,840 & $\mathbf{6 , 2 2 8}$ \\
\hline Taiwan & 60 & $\mathbf{7 2}$ & 46 & 118 \\
\hline $\begin{array}{l}\text { Rest of Asia: Indonesia, N. } \\
\text { Korea, Malaysia, Philippines, } \\
\text { Thailand, Vietnam, etc. }\end{array}$ & 25 & 28 & 0.0 & $\mathbf{2 8}$ \\
\hline Total South \& East Asia & 1,971 & $\mathbf{5 , 7 5 3}$ & $\mathbf{3 , 2 2 0}$ & $\mathbf{8 , 9 6 3}$ \\
\hline
\end{tabular}

Source: BTM Consult ApS - March 2007 
Installed

capacity in

2005 and 2006

(Europe)

\begin{tabular}{|c|c|c|c|c|}
\hline 76 & $\begin{array}{c}\text { Installed } \\
\text { MW } \\
2005 \\
\end{array}$ & $\begin{array}{c}\text { Accu. } \\
\text { MW } \\
2005 \\
\end{array}$ & $\begin{array}{c}\text { Installed } \\
\text { MW } \\
2006 \\
\end{array}$ & $\begin{array}{c}\text { Accu. } \\
\text { MW } \\
2006 \\
\end{array}$ \\
\hline Austria & 218 & 820 & 146 & 966 \\
\hline Belgium & 71 & 177 & 45 & 222 \\
\hline Denmark & 22 & 3,087 & 14 & 3,101 \\
\hline Finland & 6 & 85 & 4 & 89 \\
\hline France & 389 & 775 & 810 & 1,585 \\
\hline Germany & 1,808 & 18,445 & 2,233 & 20,652 \\
\hline Greece & 118 & 705 & 157 & 862 \\
\hline \begin{tabular}{|l|l} 
Ireland (Rep.) \\
\end{tabular} & 159 & 498 & 250 & 748 \\
\hline Italy & 452 & 1,713 & 417 & 2,118 \\
\hline Luxembourg & 0 & 12 & 0 & 12 \\
\hline Netherlands & 154 & 1,221 & 351 & 1,557 \\
\hline Norway & 117 & 275 & 53 & 328 \\
\hline Poland & 10 & 65 & 105 & 170 \\
\hline Portugal & 502 & 1,087 & 629 & 1,716 \\
\hline Spain & 1,764 & 10,027 & 1,587 & 11,614 \\
\hline Sweden & 76 & 554 & 62 & 571 \\
\hline Switzerland & 3 & 11 & 0 & 11 \\
\hline Turkey & 0 & 20 & 56 & 76 \\
\hline UK & 447 & 1,336 & 631 & 1,967 \\
\hline $\begin{array}{l}\text { Rest of Europe: Other East } \\
\text { European and Baltic countries. }\end{array}$ & 57 & 132.1 & 130.6 & 262.7 \\
\hline Total Europe & 6,372 & 41,044 & 7,682 & 48,627 \\
\hline
\end{tabular}

Source: BTM Consult ApS - March 2007 


\section{Installed capacity in 2005 and 2006 (Rest of World)}

\begin{tabular}{|c|c|c|c|c|}
\hline (C) & $\begin{array}{l}\text { Installed } \\
\text { MW } \\
2005\end{array}$ & $\begin{array}{l}\text { Accu. } \\
\text { MW } \\
2005\end{array}$ & $\begin{array}{c}\text { Installed } \\
\text { MW } \\
2006\end{array}$ & $\begin{array}{l}\text { Accu. } \\
\text { MW } \\
2006\end{array}$ \\
\hline Australia & 296 & 717 & 79 & 796 \\
\hline Japan & 168 & 1,159 & 298 & 1,457 \\
\hline New Zealand & $\overline{0}$ & 167 & 3 & 170 \\
\hline Pacific Islands & 0 & 5 & $\overline{6}$ & 11 \\
\hline South Korea & 20 & 89 & 106 & 194 \\
\hline Total OECD-Pacific & 484 & 2,137 & 491 & 2,628 \\
\hline Egypt & 34 & 180 & 51 & 231 \\
\hline \begin{tabular}{|l} 
Morocco \\
\end{tabular} & 10 & 64 & 58 & 122 \\
\hline Tunisia & 0 & 28 & 0 & 28 \\
\hline $\begin{array}{l}\text { Rest of Africa: } \\
\text { Verde, Ethiopia, Libya, Cape } \\
\text { Africa, etc. }\end{array}$ & 0 & 6 & 0 & 6 \\
\hline Total Africa & 44 & 278 & 109 & 386 \\
\hline $\begin{array}{l}\text { Middle East: Jordan, Iran, Iraq, } \\
\text { Israel, Saudi Arabia, Syria, etc. } \\
\text { (excl. Egypt) }\end{array}$ & 0 & 101 & 0 & 101 \\
\hline $\begin{array}{l}\text { Transition Economies: incl. } \\
\text { Russia, White Russia, Ukraine, } \\
\text { Uzbekistan, Kazakstan, etc. }\end{array}$ & 0 & 23.7 & 0.0 & 23.7 \\
\hline $\begin{array}{l}\text { Total other continents and } \\
\text { areas: }\end{array}$ & 0 & 124.4 & 0.0 & 124.4 \\
\hline
\end{tabular}

Source: BTM Consult ApS - March 2007 


\section{Installed offshore wind power in the World}

\begin{tabular}{|c|c|c|c|c|}
\hline 78 & $\begin{array}{c}\text { Installed } \\
\text { MW }\end{array}$ & $\begin{array}{l}\text { Accu. } \\
\text { MW }\end{array}$ & $\begin{array}{c}\text { Installed } \\
\text { MW }\end{array}$ & $\begin{array}{c}\text { Accu. } \\
\text { MW }\end{array}$ \\
\hline Country & 2005 & 2005 & 2006 & 2006 \\
\hline Denmark & $\overline{0}$ & 397.9 & $\overline{0}$ & 397.9 \\
\hline Ireland & 0 & 25 & 0 & 25 \\
\hline The Netherlands & 0 & 18.8 & 108 & 126.8 \\
\hline Sweden & $\overline{0}$ & 23.3 & $\overline{0}$ & 23.3 \\
\hline UK & 90 & 214 & 90 & 304 \\
\hline Total capacity - World & 90 & 679 & 198 & 877 \\
\hline
\end{tabular}

Source: BTM Consult ApS - March 2007 


\section{The 10 largest markets in 2006 (Annual MW)}

\begin{tabular}{|c|c|c|c|c|c|}
\hline Country & 2004 & 2005 & 2006 & Share \% & Cum. Share \% \\
\hline USA & 389 & 2,431 & 2,454 & $16.3 \%$ & $16 \%$ \\
\hline Germany & 2,054 & 1,808 & 2,233 & $14.9 \%$ & $31 \%$ \\
\hline India & 875 & 1,388 & 1,840 & $12.3 \%$ & $43 \%$ \\
\hline Spain & 2,064 & 1,764 & 1,587 & $10.6 \%$ & $54 \%$ \\
\hline P.R. China & 198 & 498 & 1,334 & $8.9 \%$ & $63 \%$ \\
\hline France & 138 & 389 & 810 & $5.4 \%$ & $68 \%$ \\
\hline Canada & 123 & 239 & 776 & $5.2 \%$ & $73 \%$ \\
\hline UK & 253 & 447 & 631 & $4.2 \%$ & $78 \%$ \\
\hline Portugal & 274 & 502 & 629 & $4.2 \%$ & $82 \%$ \\
\hline Italy & 357 & 452 & 417 & $2.8 \%$ & $85 \%$ \\
\hline Total & 6,725 & 9,918 & 12,711 & & \\
\hline Percent of World & $82.5 \%$ & $85.9 \%$ & $84.7 \%$ & & \\
\hline
\end{tabular}

Source: BTM Consult ApS - March 2007 


\section{Growth rates in the Top-10 markets}

\begin{tabular}{|l|c|c|c|c|c|c|}
\hline \multirow{2}{*}{\begin{tabular}{|c|c|c|c|} 
Accu. \\
end \\
$\mathbf{2 0 0 3}$
\end{tabular}} & $\begin{array}{c}\text { Accu. } \\
\text { end } \\
\mathbf{2 0 0 4}\end{array}$ & $\begin{array}{c}\text { Accu. } \\
\text { end } \\
\mathbf{2 0 0 5}\end{array}$ & $\begin{array}{c}\text { Accu. } \\
\text { end } \\
\mathbf{2 0 0 6}\end{array}$ & $\begin{array}{c}\text { Growth rate } \\
\mathbf{2 0 0 5 - 2 0 0 6} \\
\mathbf{\%}\end{array}$ & $\begin{array}{c}\mathbf{3} \text { years } \\
\text { average } \\
\mathbf{\%}\end{array}$ \\
\hline Germany & 14,612 & 16,649 & 18,445 & 20,652 & $\mathbf{1 2 . 0 \%}$ & $12.2 \%$ \\
\hline USA & 6,361 & 6,750 & 9,181 & 11,635 & $\mathbf{2 6 . 7 \%}$ & $22.3 \%$ \\
\hline Spain & 6,420 & 8,263 & 10,027 & 11,614 & $\mathbf{1 5 . 8 \%}$ & $21.8 \%$ \\
\hline India & 2,125 & 3,000 & 4,388 & 6,228 & $\mathbf{4 1 . 9 \%}$ & $43.1 \%$ \\
\hline Denmark & 3,076 & 3,083 & 3,087 & 3,101 & $\mathbf{0 . 5 \%}$ & $0.3 \%$ \\
\hline P.R. China & 571 & 769 & 1,264 & 2,588 & $\mathbf{1 0 4 . 7 \%}$ & $65.5 \%$ \\
\hline Italy & 922 & 1,261 & 1,713 & 2,118 & $\mathbf{2 3 . 6 \%}$ & $31.9 \%$ \\
\hline UK & 759 & 889 & 1,336 & 1,967 & $\mathbf{4 7 . 2 \%}$ & $37.3 \%$ \\
\hline Portugal & 311 & 585 & 1,087 & 1,716 & $\mathbf{5 7 . 9 \%}$ & $76.8 \%$ \\
\hline France & 274 & 386 & 775 & 1,585 & $\mathbf{1 0 4 . 6 \%}$ & $79.4 \%$ \\
\hline Total "Ten" & $\mathbf{3 5 , 4 3 1}$ & $\mathbf{4 1 , 6 3 4}$ & $\mathbf{5 1 , 3 0 3}$ & $\mathbf{6 3 , 2 0 3}$ & $\mathbf{2 3 . 2 \%}$ & $\mathbf{2 1 . 3 \%}$ \\
\hline
\end{tabular}

Source: BTM Consult ApS - March 2007 
The 10 largest markets by end of 2006 (cumulative MW)

\begin{tabular}{|c|c|c|c|c|c|}
\hline Country & 2004 & 2005 & 2006 & Share \% & Cum. Share $\%$ \\
\hline Germany & 16,649 & 18,445 & 20,652 & $27.8 \%$ & $28 \%$ \\
\hline USA & 6,750 & 9,181 & 11,635 & $15.7 \%$ & $43 \%$ \\
\hline Spain & 8,263 & 10,027 & 11,614 & $15.6 \%$ & $59 \%$ \\
\hline India & 3,000 & 4,388 & 6,228 & $8.4 \%$ & $67 \%$ \\
\hline Denmark & 3,083 & 3,087 & 3,101 & $4.2 \%$ & $72 \%$ \\
\hline P.R. China & 769 & 1,264 & 2,588 & $3.5 \%$ & $75 \%$ \\
\hline Italy & 1,261 & 1,713 & 2,118 & $2.9 \%$ & $78 \%$ \\
\hline UK & 889 & 1,336 & 1,967 & $2.6 \%$ & $81 \%$ \\
\hline Portugal & 585 & 1,087 & 1,716 & $2.3 \%$ & $83 \%$ \\
\hline France & 386 & 775 & 1,585 & $2.1 \%$ & $85 \%$ \\
\hline Total & 41,634 & 51,303 & 63,203 & & \\
\hline Percent of World & $86.9 \%$ & $86.4 \%$ & $85.1 \%$ & & \\
\hline
\end{tabular}

Source: BTM Consult ApS - March 2007 
Size of commercial wind turbines at first market introduction

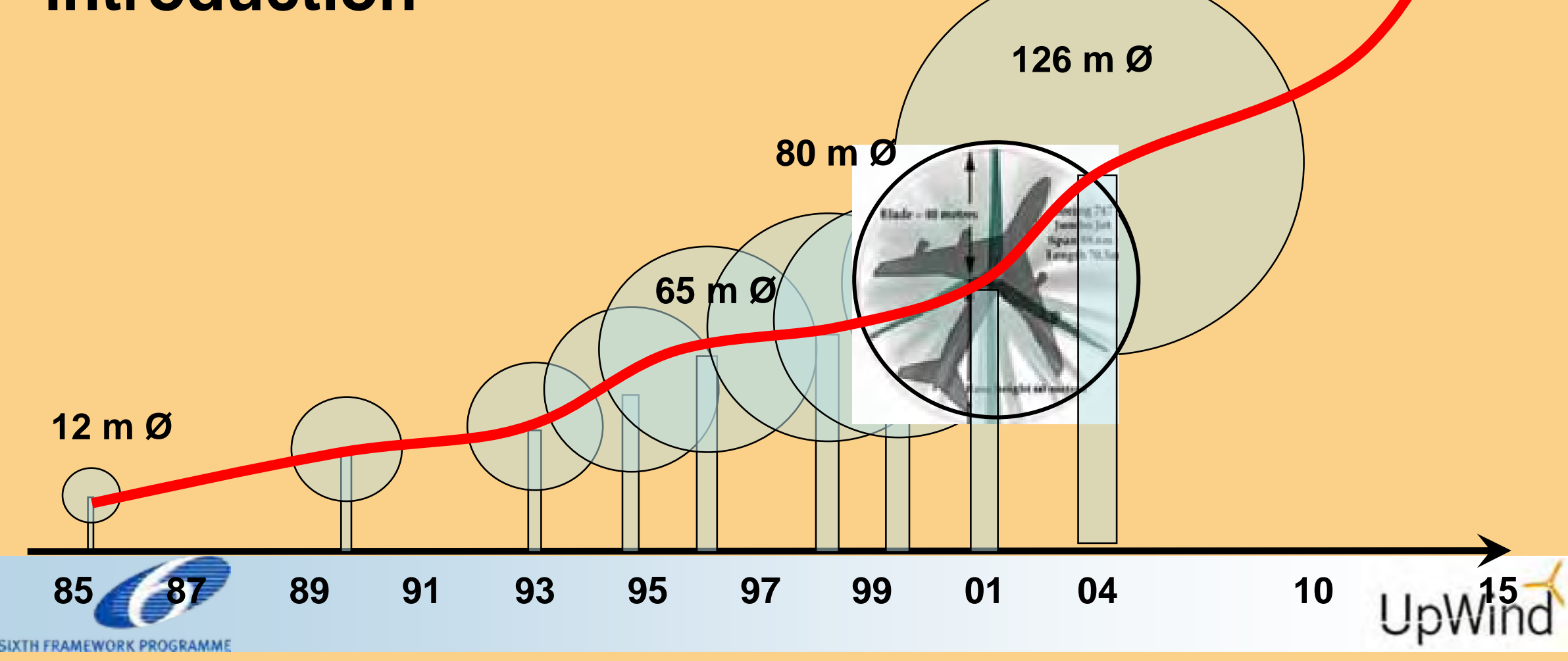


Global Average Annual WTG in kW

Source: BTM Consult ApS - March 2007

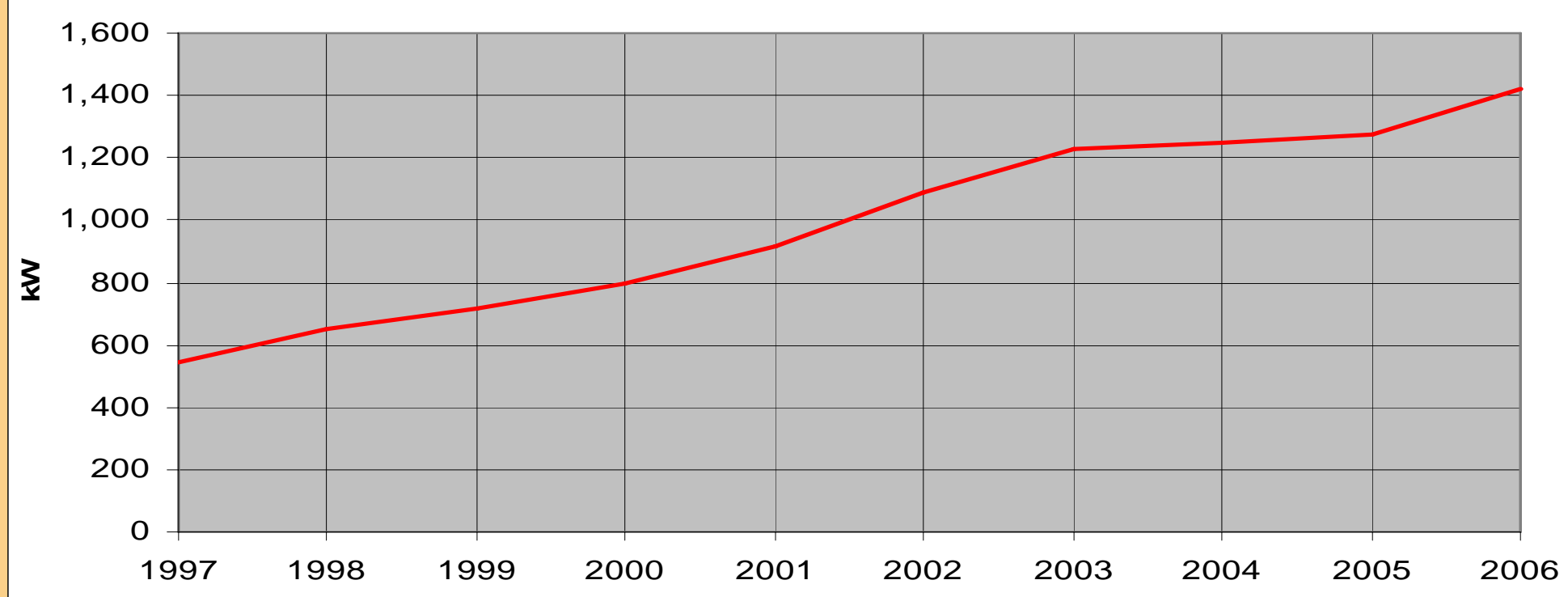

\begin{tabular}{|c|c|c|c|c|c|c|c|c|}
\hline Year & China & Denmark & Germany & India & Spain & Sweden & UK & USA \\
\hline 2002 & 709 & 1,443 & 1,397 & 553 & 845 & 1,112 & 843 & 893 \\
\hline 2003 & 726 & 1,988 & 1,650 & 729 & 872 & 876 & 1,773 & 1,374 \\
\hline 2004 & 771 & 2,225 & 1,715 & 767 & 1,123 & 1,336 & 1,695 & 1,309 \\
\hline 2005 & 897 & 1,381 & 1,634 & 780 & 1,105 & 1,126 & 2,172 & 1,466 \\
\hline 2006 & 931 & 1,875 & 1,848 & 926 & 1,469 & 1,138 & 1,953 & 1,667 \\
\hline
\end{tabular}

Source: BTM Consult ApS - March 2007 


\section{Segmentation of product sizes in 2004-2006}

\begin{tabular}{|l|c|c|c|}
\hline Year & $\mathbf{2 0 0 4}$ & $\mathbf{2 0 0 5}$ & $\mathbf{2 0 0 6}$ \\
\hline Total MW supplied & $\mathbf{8 , 5 0 8}$ & $\mathbf{1 1 , 3 3 8}$ & $\mathbf{1 6 , 0 0 7}$ \\
\hline Product (Size range) & \multicolumn{3}{|c|}{ \% of total MW } \\
\hline "Small WTGs" <750 kW & $5.4 \%$ & $3.6 \%$ & $2.4 \%$ \\
\hline "One-MW " 750-1500 kW & $50.9 \%$ & $48.2 \%$ & $43.3 \%$ \\
\hline "Mainstream" 1501-2500 kW & $42.8 \%$ & $45.8 \%$ & $49.9 \%$ \\
\hline "Multi-MW Class" >2500 kW & $0.9 \%$ & $2.4 \%$ & $4.3 \%$ \\
\hline Total & $100.0 \%$ & $100.0 \%$ & $100.0 \%$ \\
\hline
\end{tabular}

Source: BTM Consult ApS - March 2007 


\section{Top-10 Suppliers in 2006}

\section{$\%$ of the total market $15,016 \mathrm{MW}$}

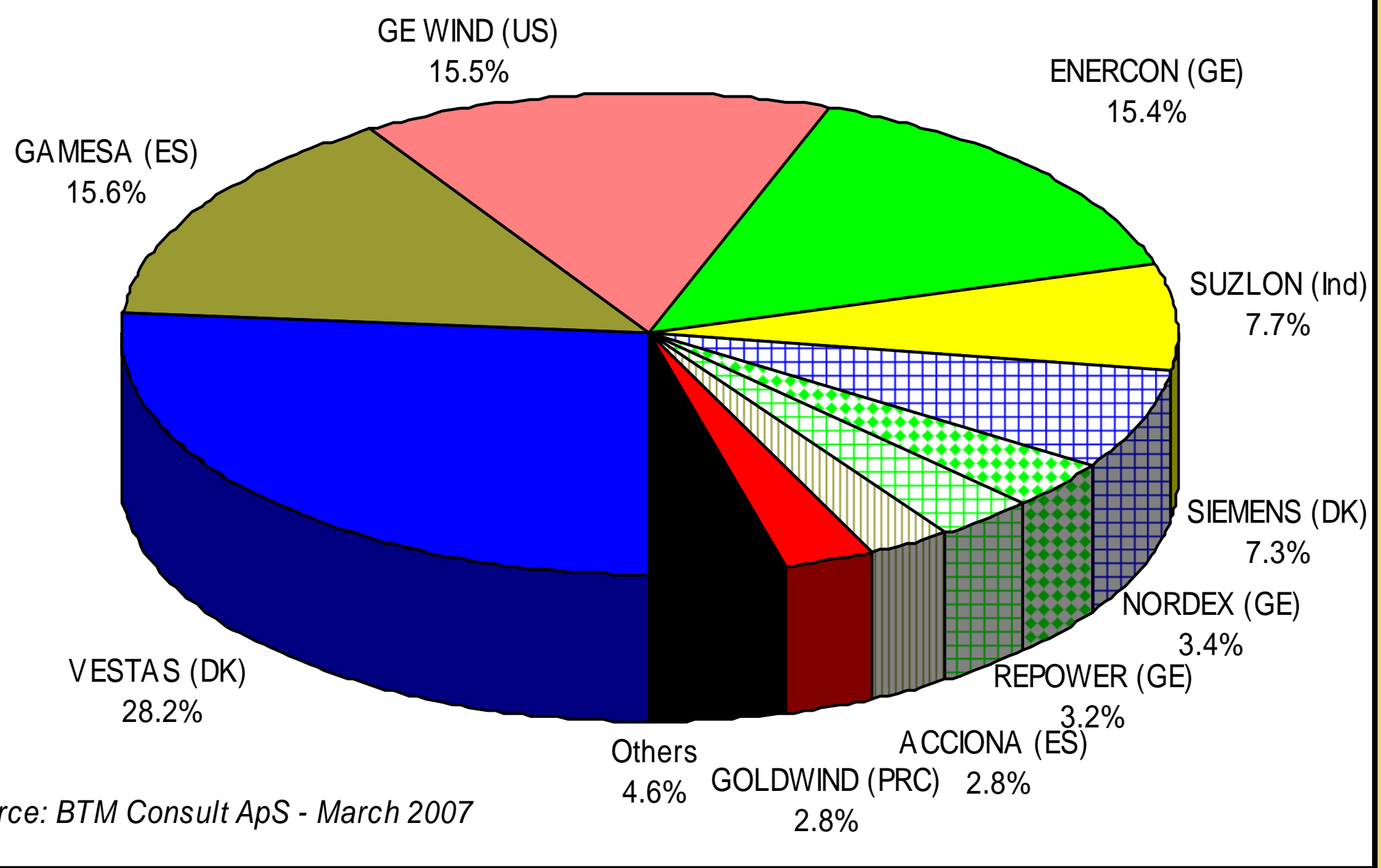




\section{UpWind Background}

UpWind: FP6 Integrated project

UpWind got Wind Energy back in the EU 6 Framework Energy Research program

Result of AOT.'s EWEA Thematic Network(EU-project):

1. EWEA Research Strategy

2. UpWind

3. EWEA Strategic Research Agenda

4. Technology Platform

Behind UpWind application were EAWE, EWEA and the partners (December 08 2004)

Last minute saving of Wind Research Network in EU

UpWind the glue/network and Lighthouse for EU R\&D 


\section{The UpWind Project}

UpWind subtitle: Integrated Wind Turbine Design

Start date: 1 March 2006

Duration: 60 months

Costs: 22,340,000 EUR

EC funding: 14,288,000 EUR

Coordinator Risø National Laboratory,

Denmark's Technical University 


\section{Participants from Start}

39 participants

-11 EU countries

-10 research institutes

-11 universities

- 7 turbine \& component manufacturers -6 consultants \& suppliers

-2 wind farm developers

-2 standardization bureaus

-1 branch organisation

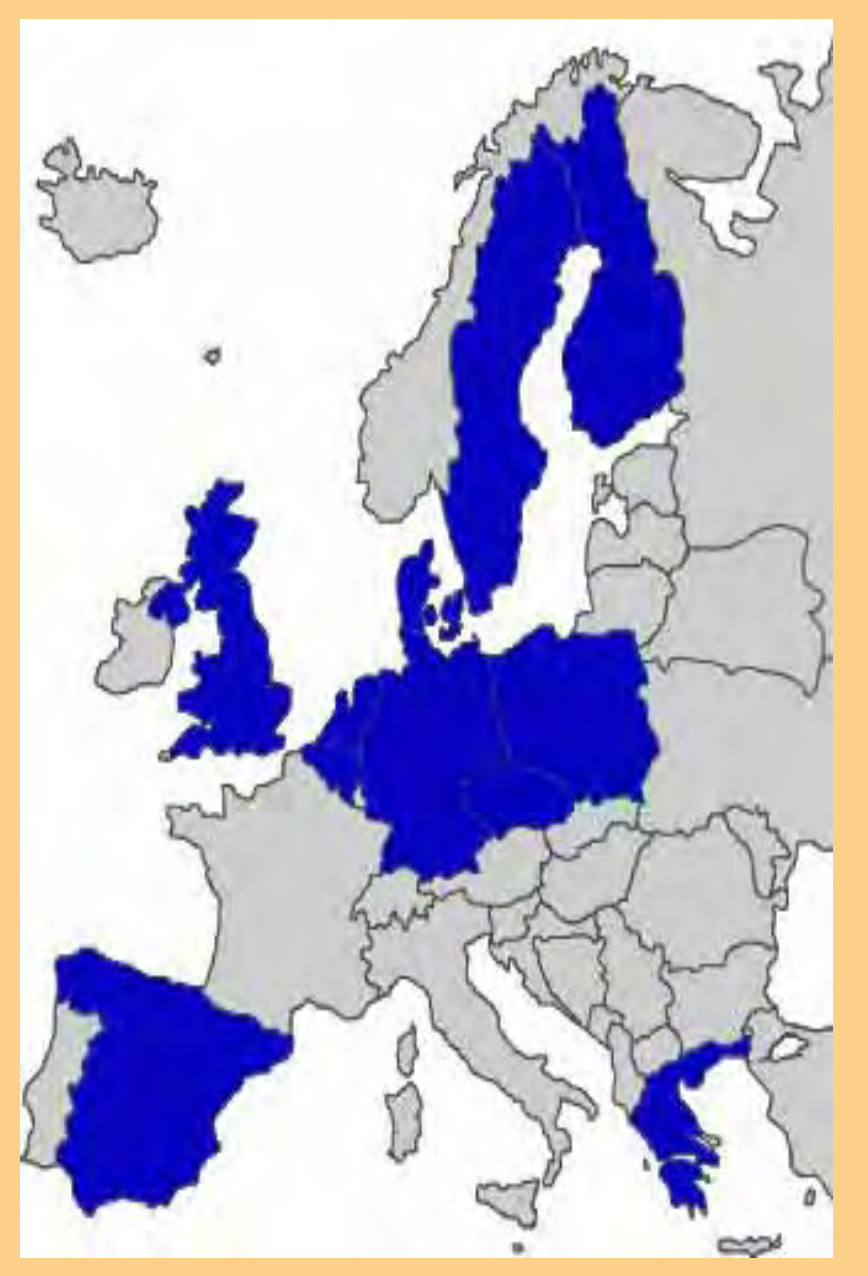




\section{Partner's first year}

\section{9 partners in UpWind Consortium from start}

Cener added (+1)

Risø and DTU merged to DTU and RisøDTU (-1)

Elsam sold to Dong Energy and Wattenfall $(+1)$

INCO call added 3 new partners ( +3$)$ :

- ISM: Institute for Superhard Materials of the Nat. Academy of Science, Ukraine

- IITB: Department of Civil Engineering of the Indian Inst. of Technology Bombay

- $\quad$ CUMTB: China University of Mining and Technology Beijing 43 partners in UpWind Consortium May 2007 Other potential partners: NREL USA 


\section{Objective - 1}

Develop and verify substantially improved design models and verification methods for wind turbine components, industry needs for future design and manufacture of:

$1 \quad$ Very Large Wind Turbines

2 More Cost Efficient Wind Turbines

3 Offshore wind farms of several hundred MW 


\section{Objective - 2}

Consortium integrates the disciplines and sectors needed for the entire development chain of wind turbine technology

8 Scientific Work Packages - work programme

7 Integration Work Packages - work programme Upscaling

Today: WT up to $\mathrm{P}=5 \mathrm{MW}$ and $\mathrm{D}=120 \mathrm{~m}$

Future: WT upscaling: $P=10 \mathrm{MW}$ and $\mathrm{P}=20 \mathrm{MW}$ Develop methods to overcome showstoppers/optimize 


\section{Organisation}

\section{Classic and integrated research approach Advanced Flexibel Modern Organisation}

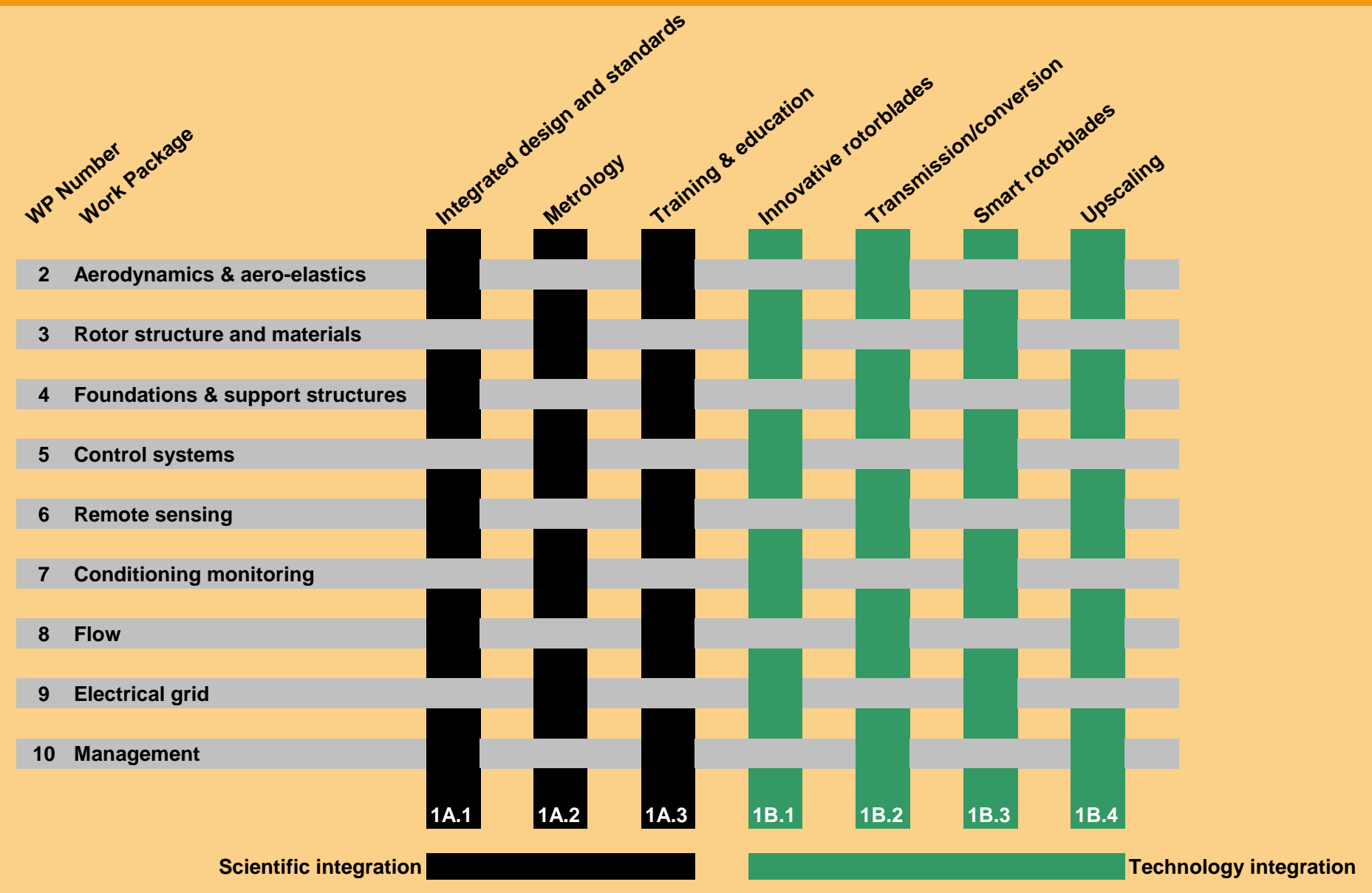




\section{Work Programme and Selected Results \\ From first UpWind Year}


WP 1A1 Integrated design and standards

$\measuredangle$ Develop a reference wt and reference site conditions for communication, integration and benchmarking of outcomes of the horizontal work packages;

$\succ$ Development and definition of an integral design method to be applied in the real design of wind turbines; and

$\prec$ Development (pre)standards for the formal international standardization effort. 


\section{WP 1 A2 Metrology}

First year to create a list of measured parameters through communication with other work packages

First draft of list of parameters

The list has led to lively discussions between WPs

The final list is being reported

Next step reduce list and to

Develop method's to reduce uncertainty 


\section{WP $1 A 3$ and WP 1B1}

$\checkmark$ Work Package 1 A3 Education and Training

1. Survey of existing infrastructures related to education and training

2. Next step make a database for education and training

$\downarrow$ Work Package 1B1 Inovative rotorblades

1. Survey over existing blade assampling methods

2. Next step: select a assembling method and design a blade in two segments 


\section{Results from First Year 1B2 Transmission and conversion}

$\prec$ WP 1B2.a - "Mechanical Transmission"

$\prec$ WP 1B2.b - "Generators"

$\prec$ WP 1B2.c - "Power Electronics" 


\section{Mechanical Transmission Modeling example}

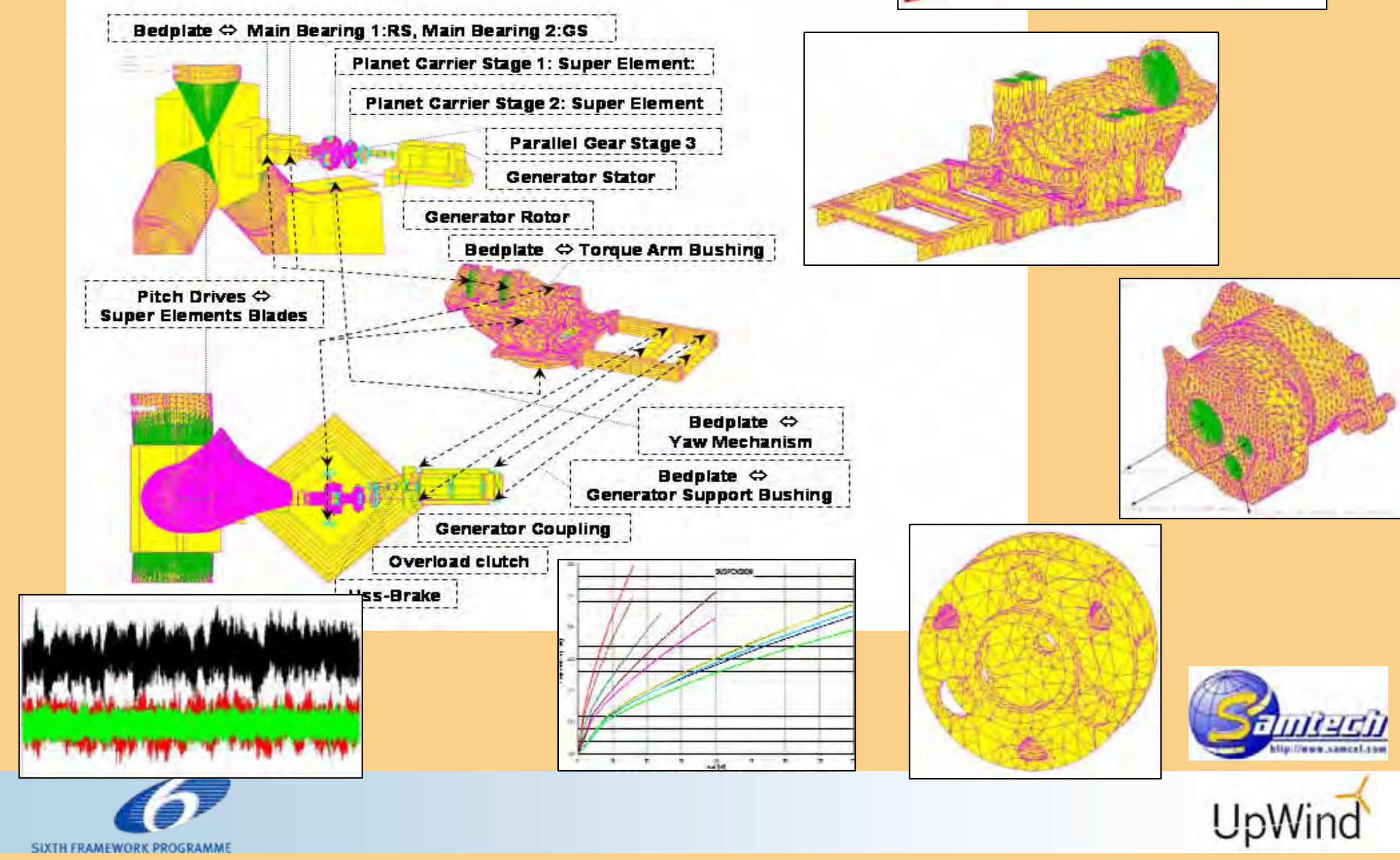




\section{Task 1B.2.c_1: Benchmark and concept reports on devices and converters.}

\section{Analysis of Matrix Converters}

$\downarrow \quad$ "all silicon" AC/AC converter

$\triangleleft \quad$ without DC-link

$\downarrow \quad$ formed by $\mathrm{n} \times \mathrm{m}$ bidirectional switches

$\downarrow \quad$ any of the outputs can be connected to any input phase.

$\prec \quad$ bidirectional topology, it can operate in four quadrants

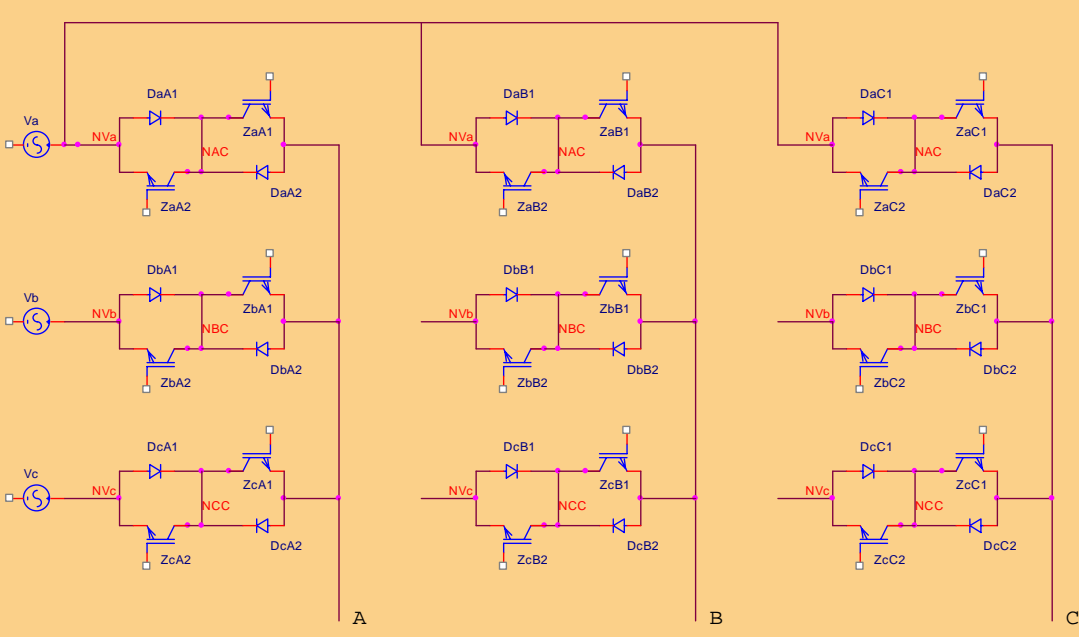

Structure of a three-phase matrix converter

robotiker (t) 


\section{WP1B4 Up-scaling}

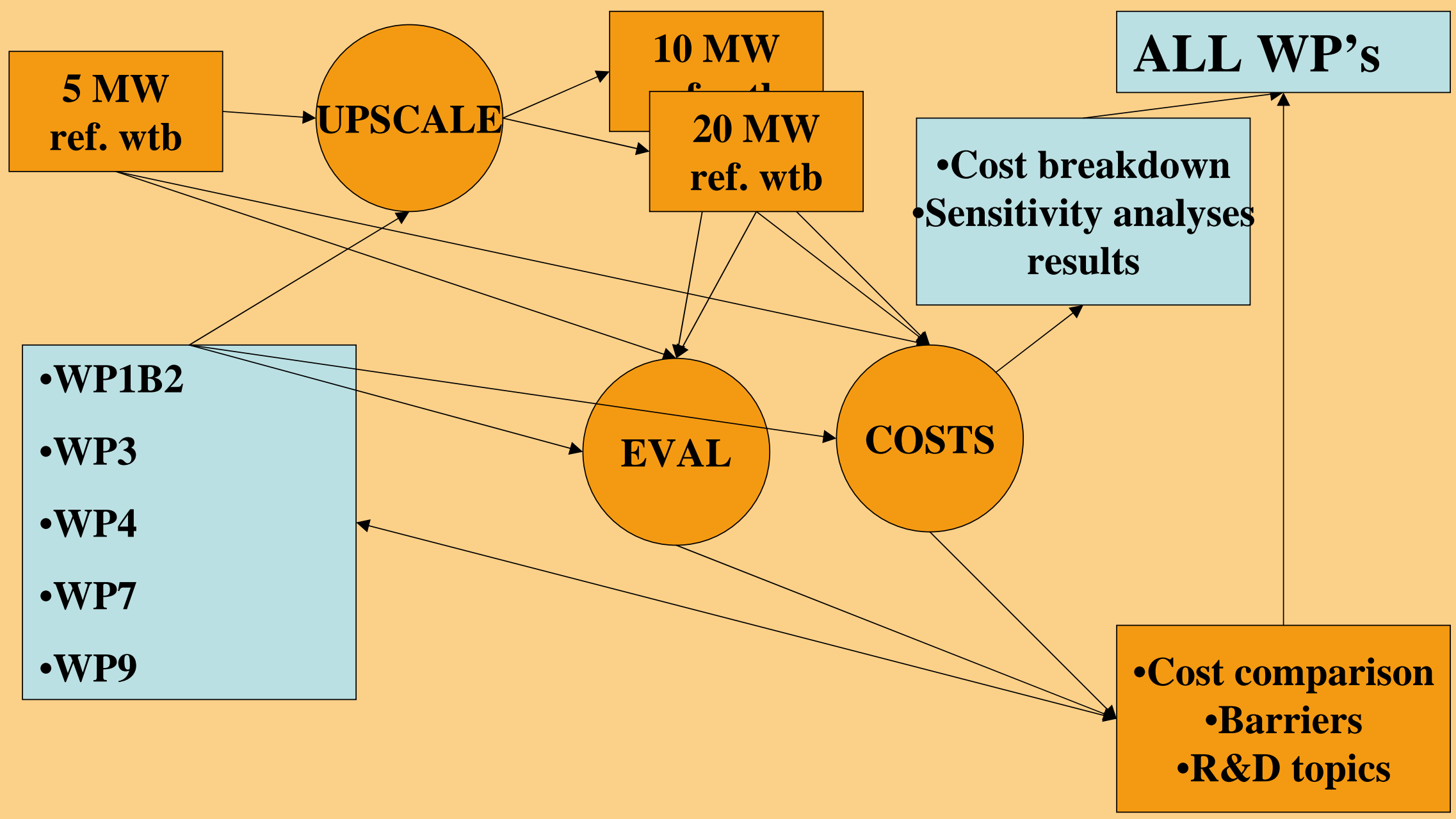




\section{WP2 Aero-dynamics and Aero-elastics OBJECTIVES}

1. Development of nonlinear structural dynamic models (modeling on the micromechanical scale is input from WP3).

2. Advanced aerodynamic models covering full $3 D$ CFD rotor models, free wake models and improved BEM type models. (The wake description is a prerequisite for the wake modeling in WP8).

3. Models for aerodynamic control features and devices. (This represents the theoretical background for the smart rotor blades development in WP 1.B.3)

4. Models for analysis of aeroelastic stability and total damping including hydroelastic interaction

5. Development of models for computation of aerodynamic noise. 


\section{Deliverables to other work packages (60 months)}

Upscaling:

-Aeroelastic modelling of scaled-up WT

Smart rotor blades:

-Modelling of camber line deformation

-Vortex generators

\section{Flow:}

-CFD models of terrain

-Wake models

Innoblade:

-CFD computations

- Flutter calculations

-Aeroacustics

\section{Foundations:}

-Hydroelastic models 
WP 4 Offshore support structures: fixed \& floating
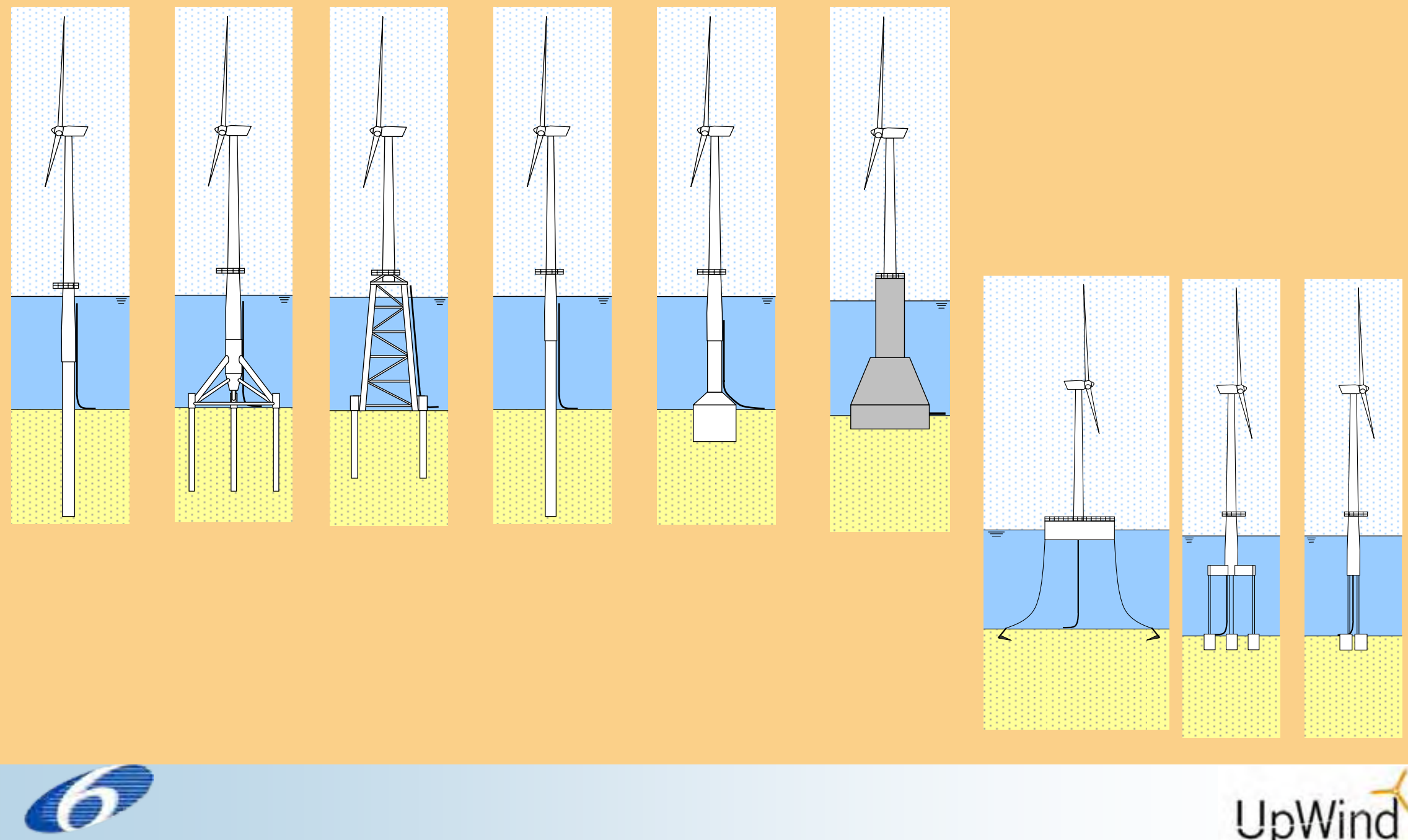


\section{Support structure evaluation:}

\section{Average results}

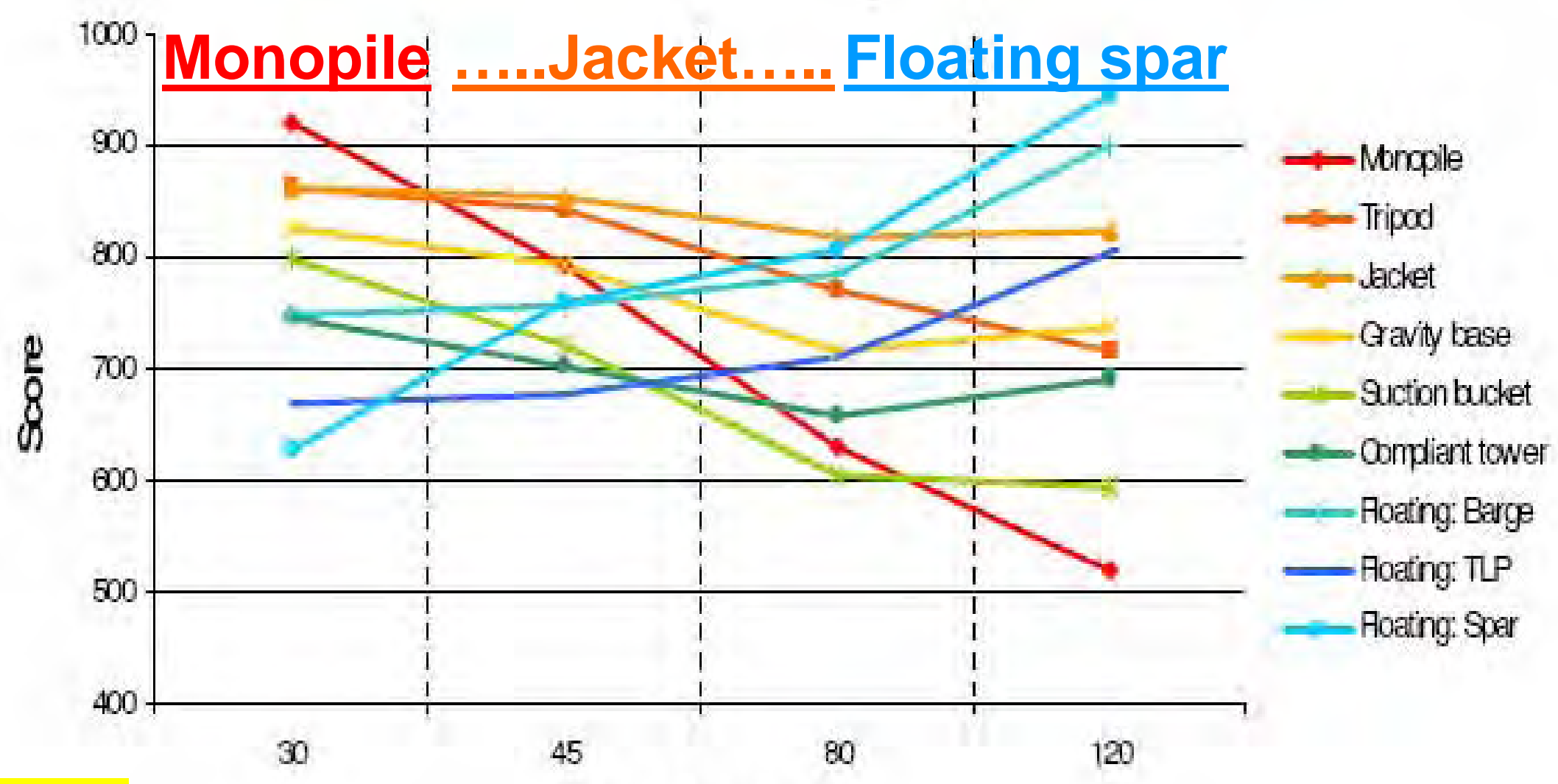

Current designs (<20 m): Monopile, (GBS)
Water depth [m]

\section{Current} design:

$1^{\text {st }}$ Jacket 


\section{Results from First Year WP 5: Control}

Controller design and évaluation

1. Algorithm development and evaluation

2. Hardware testing and optimisation

Field testing and evaluation

Grid and farm integration

1. Wind Farm optimization

2. Electrical interaction in the network

$\downarrow \quad$ Interaction with other work packages 
WP6. Remote sensing EWEC Posters
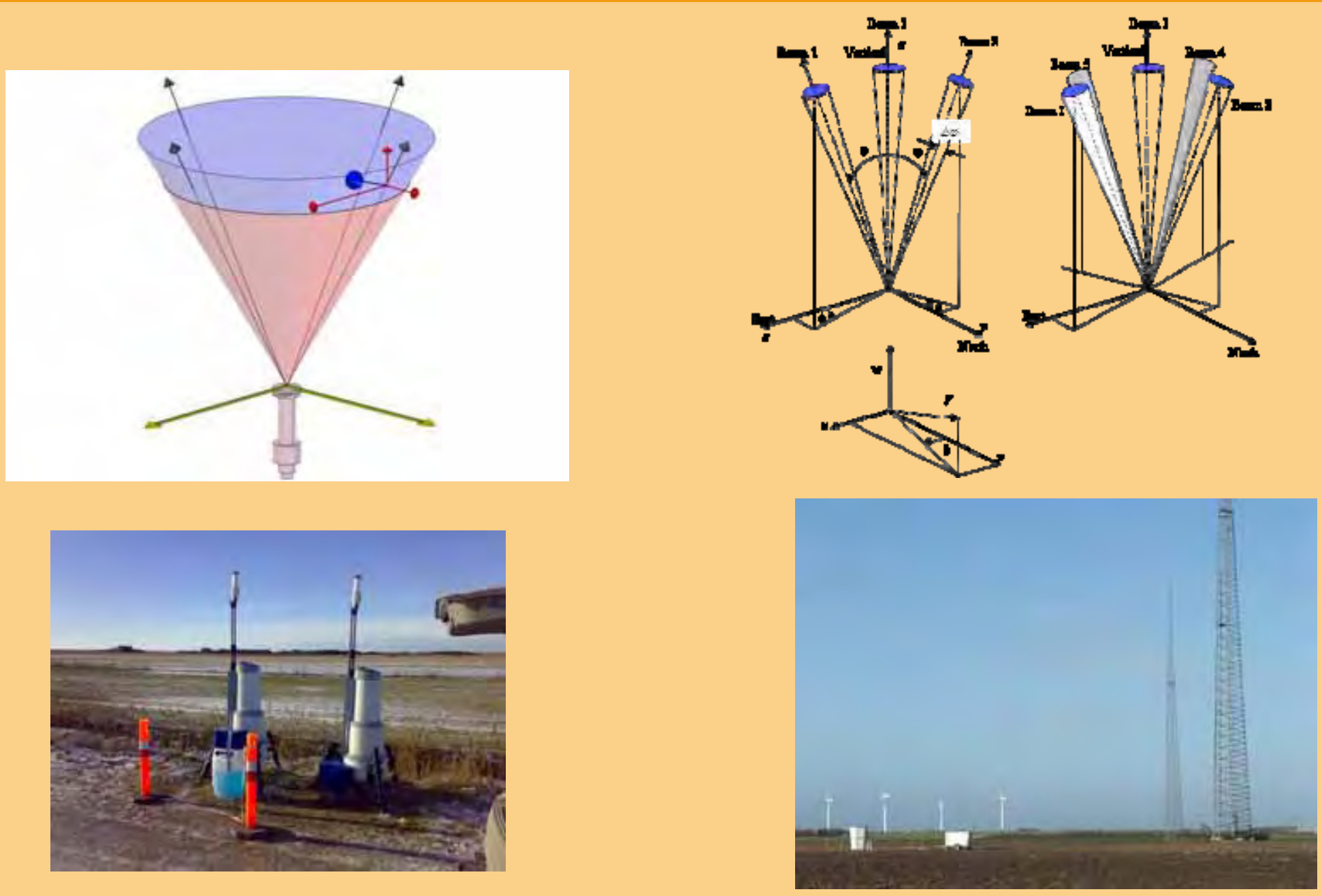


\section{Lidar and cup at $116 \mathrm{~m}$ vs time, all data (unfiltered)}

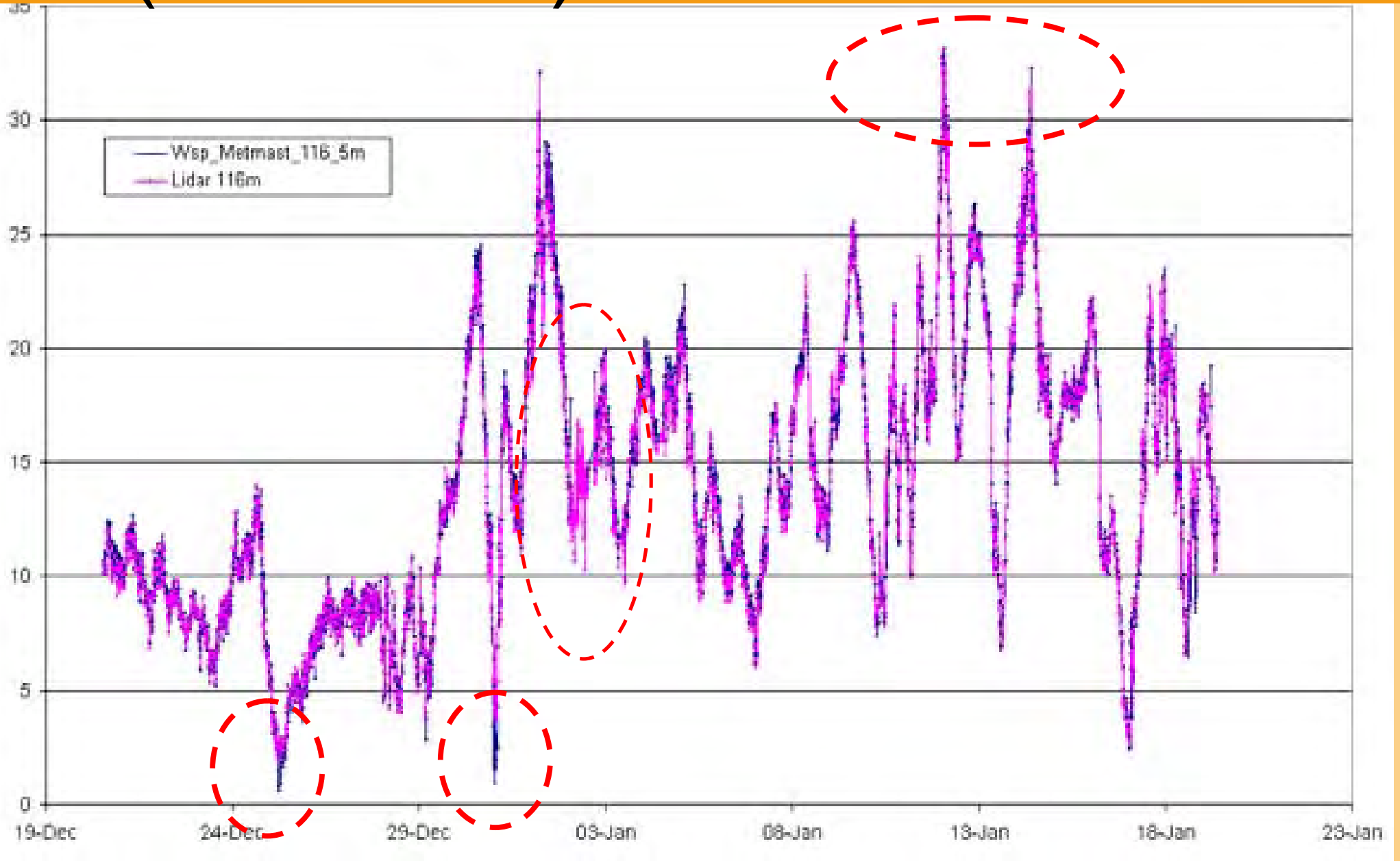




\section{WP 8 Flow}

- Data collection from Wind Farms - Wakes

- Comparison with existing flow models

-Participate in international standardization (IEC) 


\section{WP 9 Grid}

- Emphasis on grid reliability and design conditions for WT coming from grid conditions

-Participate in international standardization (IEC) 


\section{Conclusions}

-UpWind succesfully started up - hudge project

-Results from all Work Packages

-Integration activities are very effective

-Industry - and the Scientific communities do work very efficiently together

-European Wind Energy Research Community now well organized in UpWind

-EU Technology Platform starting up 


\section{Questions?}




\section{Wind Power Costs in Portugal}

Carla Saleiro Madalena Araújo

Paula Ferreira 


\section{Introduction}

- Under the Kyoto Protocol, Portugal, as an EU member state should limit the increase of their GHG emissions to $27 \%$ from 1990 levels by 2008 - 2012;

- In 1990 the energy sector contributed with $67 \%$ of the total GHG emissions and, in this sector, the activities related with the electricity and heat industry with 35\%;

- Under the Directive on Renewable, Portugal must achieve a target of $39 \%$ of its electricity production from RES in terms of gross electricity consumption in 2010; 


\section{Introduction}

- The Portuguese Government reinforced the promotion of hydroelectric resources and the support to the development of renewable energy resources, such as wind, mini-hydro, biomass, photovoltaic and waves;

- Portugal is strongly dependent on external energy sources and the only national resources come from the renewable sources, specially the hydro sector;

- The large hydro is the most important source for electricity production, but it is dependent on the climatic conditions and has been facing serious environmental obstacles;

- With the marginal contributions of the remaining energy sources it is expected that the wind power sector will be very important for the objectives fulfilment. 


\section{Portuguese Electricity System}

\section{Public Electricity System (PES) Independent Electricity System (IES)

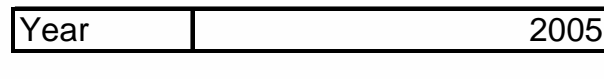 \\ - Special Regime Producers (SRP) - cogeneration and renewable plants \\ - Non-binding Electricity System (NES)}

Costs Analysis

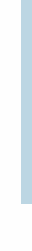

Figure 1. Installed power, in Portugal (Source: REN).

\begin{tabular}{|c|lr|}
\hline \multirow{2}{*}{ Hydro } & PES Central & 4339 \\
Production & NES Central & 243 \\
\cline { 2 - 3 } & Total & $\mathbf{4 5 8 2}$ \\
\hline
\end{tabular}

\begin{tabular}{|c|lr|}
\hline \multirow{4}{*}{ Thermal } & Coal & 1776 \\
Production & Fuel+Diesel & 1673 \\
& Fuel/Gas & 236 \\
& Natural Gas & 2166 \\
\cline { 2 - 3 } & Total & $\mathbf{5 8 5 1}$ \\
\hline
\end{tabular}

\begin{tabular}{|c|lr|}
\hline Special & Thermal & 1159 \\
Regime & Hydro & 333 \\
Production & Wind & 896 \\
\cline { 2 - 3 } & Total & $\mathbf{2 3 8 8}$ \\
\hline
\end{tabular}

Installed Power (PES/NES) 10433

Total Installed Power cogeneration and renewable plants

SPR reached $18,5 \%$ of the total installed power and represent almost $14 \%$ of the total electricity production. 


\section{Renewable Energy Source}

Table 1. National targets for the electricity production from RES.

\begin{tabular}{lcc}
\hline Renewable Source & 2004 (MW) & 2010 (MW) \\
\hline Wind & 616 & 4700 \\
Small hydro ( $\leq 10 \mathrm{MW})$ & 265 & 400 \\
Large hydro $(\geq 10 \mathrm{MW})$ & 4294 & 5000 \\
Biomass & 456 & 330 \\
Photovoltaic & 2 & 150 \\
Tide & & 50 \\
Total & $\mathbf{5 6 3 3}$ & $\mathbf{1 0 6 3 0}$ \\
\hline
\end{tabular}

In 2010, hydro will maintain a dominant position, but its share will be reduced largely due to the increase of the wind sector. 


\section{Portuguese Electric Power System}

\section{Wind Power Sector}

Introduction

Costs Analysis

Discussion of the Results

Conclusions

The average annual rate $(1999$ - 2005) was $67 \%$.

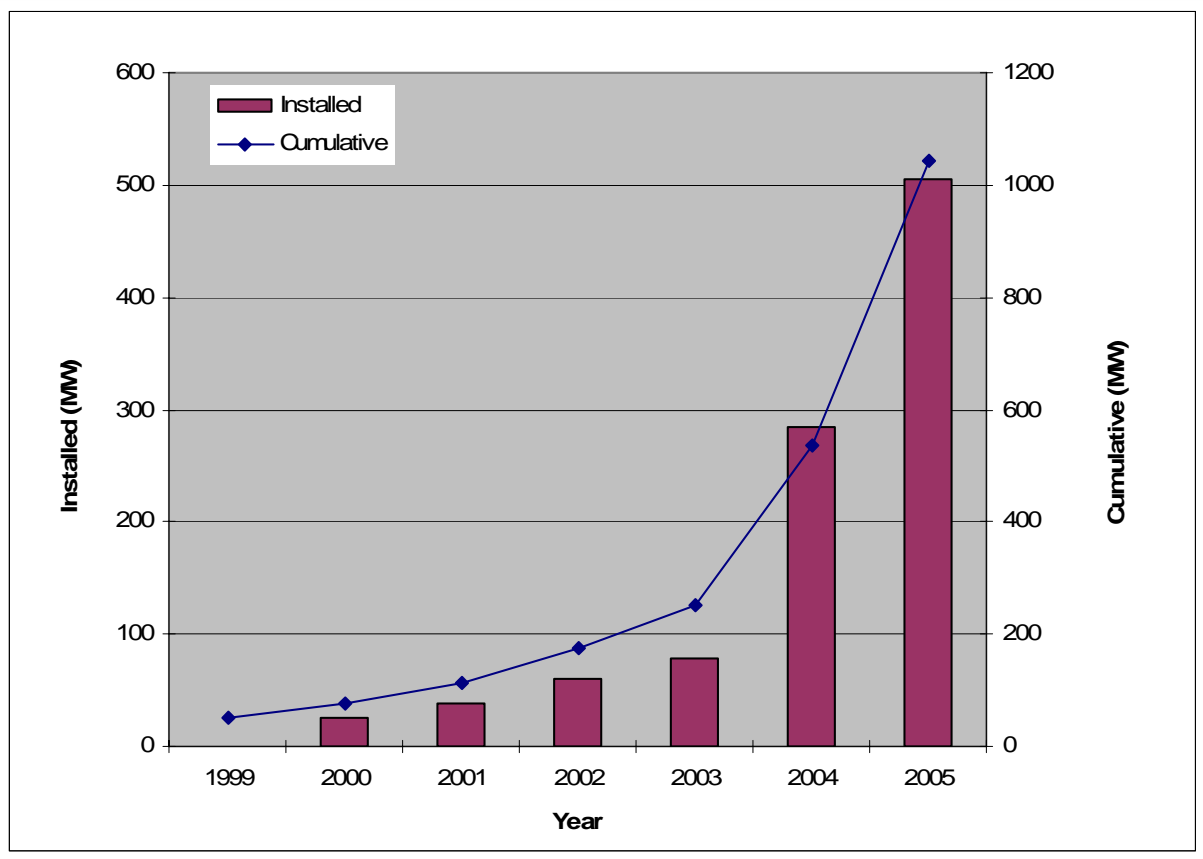

Figure 2. Installed and cumulative wind power, in Portugal (Source: DGGE, 2006).
This source of energy represented: - $20 \%$ of the renewable electricity production

- $3,3 \%$ of the total electricity production
Portugal is still distant of the European leaders, namely from:

> Germany - 18 GW

> Spain - 10 GW

> Denmark - $3 \mathrm{GW}$ 


\section{Wind Power Sector}

To reach the national objectives it is necessary:

> to install an average of $732 \mathrm{MW} / \mathrm{year}$

to grow to an annual average rate $\approx 36 \%$

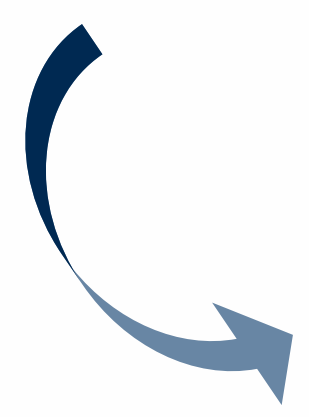

Although the great potential, some barriers exist:

$>$ delays in the licensing processes;

$>$ difficulties on the access to the grid. 


\section{Method}

The equation used to calculate the Levelized Electricity Generation Cost $(E G C)$ is:

$$
E G C=\sum\left[\left(I_{t}+M_{t}+F_{t}+X_{t}\right)(1+r)^{-t}\right] / \sum\left[E_{t}(1+r)^{-t}\right]
$$

were:

EGC - Average lifetime levelized electricity generation cost

$I_{t}$ - Investment expenditure in the year $t$

$M_{t}$ - Operations and maintenance expenditure in the year $t$

$F_{t}$ - Fuel expenditure in the year $t$

$X_{t}$ - External expenditure in the year $t$

$E_{t}-$ Electricity generation in the year $t$

$r$ - Discount rate 


\section{Data Sources}

Table 2. Data and system characteristics of wind farm and CCGT.

\begin{tabular}{lll}
\hline & Wind & CCGT \\
\hline Installed capacity & $20 \mathrm{MW}$ & $1200 \mathrm{MW}$ \\
Load factor & $22 \%$ & $85 \%$ \\
Thermal efficiency & - & $57 \%$ \\
Life time & 20 years & 25 years \\
Investment costs & $1206.20 € / \mathrm{kW}$ & $514.19 € / \mathrm{kW}$ \\
O\&M annual costs & $15.37 € / \mathrm{kW}$ & $23.59 € / \mathrm{kW}$ \\
Fuel costs & - & $22.23 € / \mathrm{MWh}$ \\
\hline
\end{tabular}

Table 3. External costs for different damage estimates (ExternE).

\begin{tabular}{lcc}
\hline External costs & Wind (€/MWh) & CCGT (€/MWh) \\
\hline Low & $0.02-0.07$ & 1.93 \\
Mid 3\% & $0.11-0.31$ & 9.41 \\
Mid 1\% & $0.29-0.81$ & 24.02 \\
High & $0.87-2.44$ & 72.54 \\
\hline
\end{tabular}

constant pricing was used. - based on the 2005 value. discount rate of 5 and $10 \%$.

Not included: backup capacity to compensate wind intermittency and fluctuations;

- reinforce the distribution and transmission systems;

feed-in tariffs. 


\section{Analysis and Discussion of the Results}

Introduction

Portug. Electr Power System

Costs Analysis

Discussion of the Results

Conclusions

$14 \%$

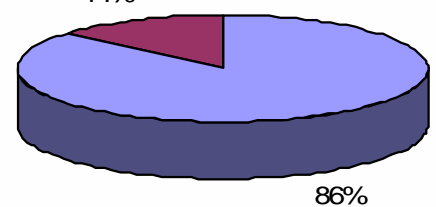

$86 \%$
$10 \%$

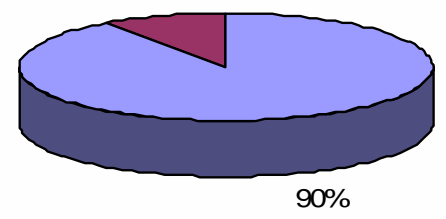

\% $\%$

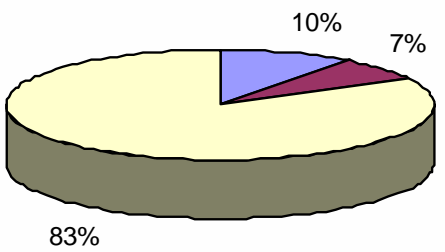

Figure 4. Estimated cost structure for CCGT (5\% and $10 \%$ discount rate). 


\section{Analysis and Discussion of the Results}

Including external costs it can be verified that:

- In wind technology the investment costs still represent a high proportion (\% total cost);

- In gas technology the fuel costs have a significant weight for low estimates, but in high estimates the external costs are the one that most contribute to the total cost;

CCGT continues to be more attractive than the wind technology, except for high estimates

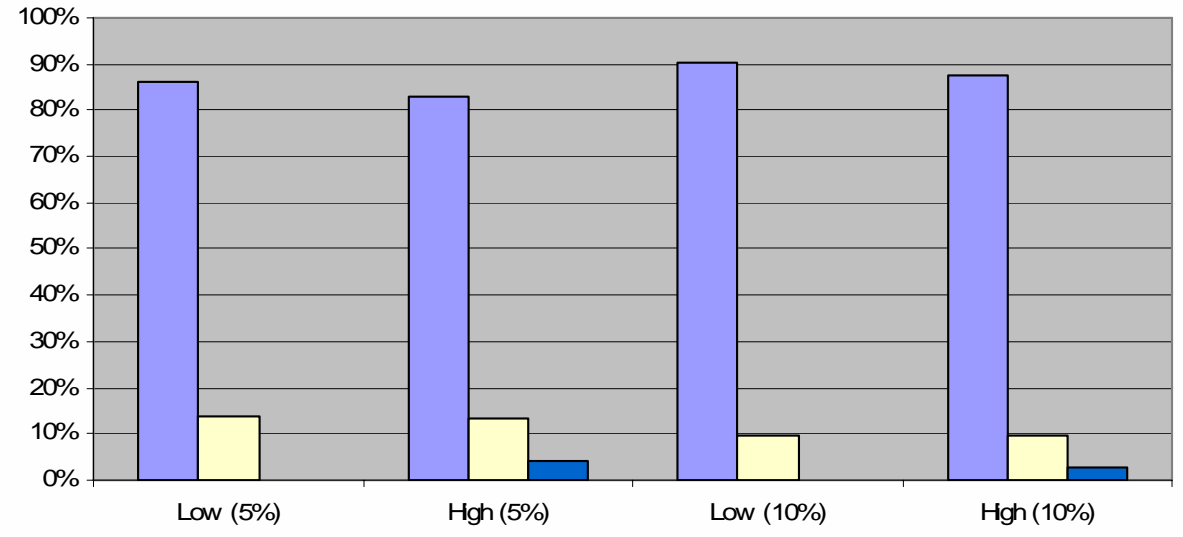

Figure 5. Estimated cost structure for wind plant (5\% and $10 \%$ discount rate).

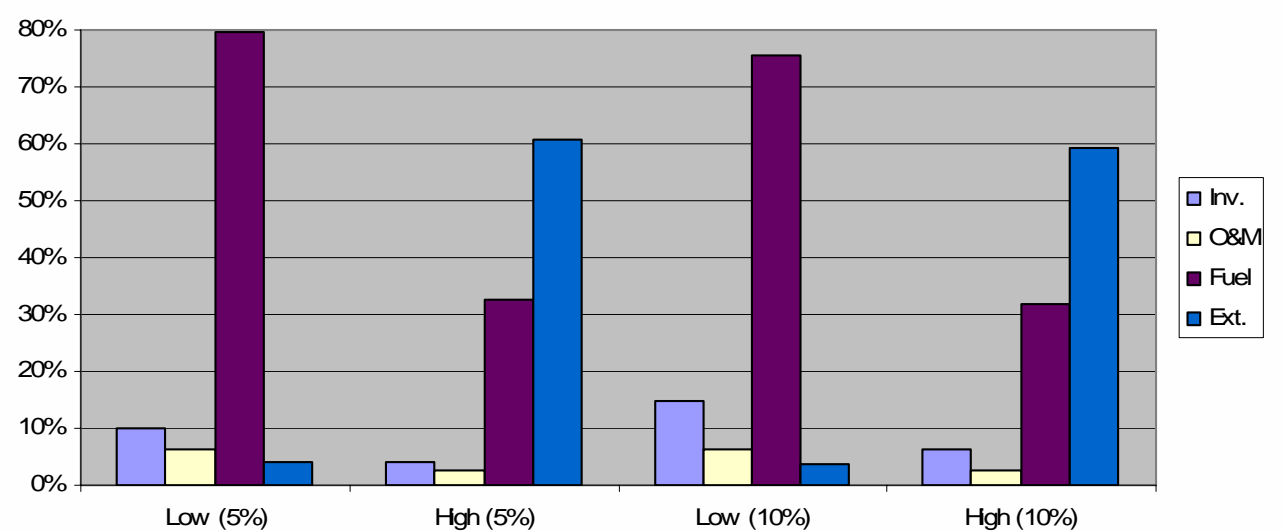

Figura 6. Estimated cost structure for CCGT (5\% and $10 \%$ discount rate). 


\section{Sensitive Analysis}

\section{- Discount rate:}

The CCGT technology is less affected by the variation of the discount rate.

\section{- O\&M escalation rate:}

The increase of the total costs diminishes as the load factor increases (the percentage of the costs of O\&M is smaller).

\section{- Fuel escalation rate:}

The total costs for the CCGT increase significantly, being more accentuated for lower discount rates and for larger load factors.

\section{- Load factor:}

The larger the load factor the lower the production costs.

The reduction of the costs is less accentuated in the CCGT system than in the wind system. 


\section{Conclusions}

\section{Conclusions}

- CCGT is still more attractive than the wind energy when only financial aspects are accounted for.

-When external costs are considered, the electricity generation costs for the two technologies are similar.

- However, for high estimates (of GHG emissions) the wind system reaches more attractive values.

- The sensitivity analysis showed that :

- the increasing of fuel escalation rates is the parameter that originates larger effects in the Levelized Electricity Generation Cost.

- the Levelized Electricity Generation Cost (without environmental costs) of a wind farm is more positively influenced by the load factor than the CCGT system. 


\section{Conclusions}

- The results were obtained assuming 2005 constant values. However, in the near future, it can be expected:

- an increase on conventional systems costs

- a decrease on renewable systems costs

- an increase of the natural gas price (almost 84\% between 2003 and 2005)

- The expansion of the wind technology in Portugal will influence significantly the energy system costs, but it is fundamental for the attainment of the European and National Energy and Environment goals.

- The expectations and incentives around the wind energy are comprehensible:

- it is a renewable energy source

- the reduction of the investment costs expectedly may turn this technology economically attractive to the investors

- if the life cycle is analysed, and the external costs included, it can become more advantageous than the conventional systems.

- the increase of the fossil fuel prices is creating a new competitive advantage for wind power systems. 


\section{THANKS}


Risø I nternational Energy Conference 2007, 22 - 24 May

(Presentation is based on the work carried out under the EU-Asean Facility funded project: Feasibility Assessment and Capacity Building for Wind Energy Development in Cambodia, the Philippines and Vietnam)

$$
\text { Jyoti Prasad Painuly }
$$




\section{Energy Policy in Philippines}

․ $60 \%$ self-sufficiency by $2010(55.5 \% 2004)$

$\square$ Increase $100 \%$ RE based capacity in 10 years (to reach $9147 \mathrm{MW}$ in 2003)

$\square$ Wind Energy;

- $425 \mathrm{MW}$ in 10 years (2005 base year)

- 16 sites in Wind Investment Kit

$\square$ Renewable Energy Bill 2006

- Renewable portfolio standard

- Green energy option for end users

- Net metering 
- Clean energy funds

- Fiscal incentives- IT holidays, duty rebates, VAT rebate etc.

$\square \quad$ Wind Energy Potential

- Initial assessment $76000 \mathrm{MW}$ (NREL)

- Realizable 7400 (WWF)

- Target for 10 years; $425 \mathrm{MW}$

$\square \quad$ First wind energy investment kit; $345 \mathrm{MW}$

$\square$ Installed 25MW (Northwind in Luzon) 


\section{Sites in the Philippines}

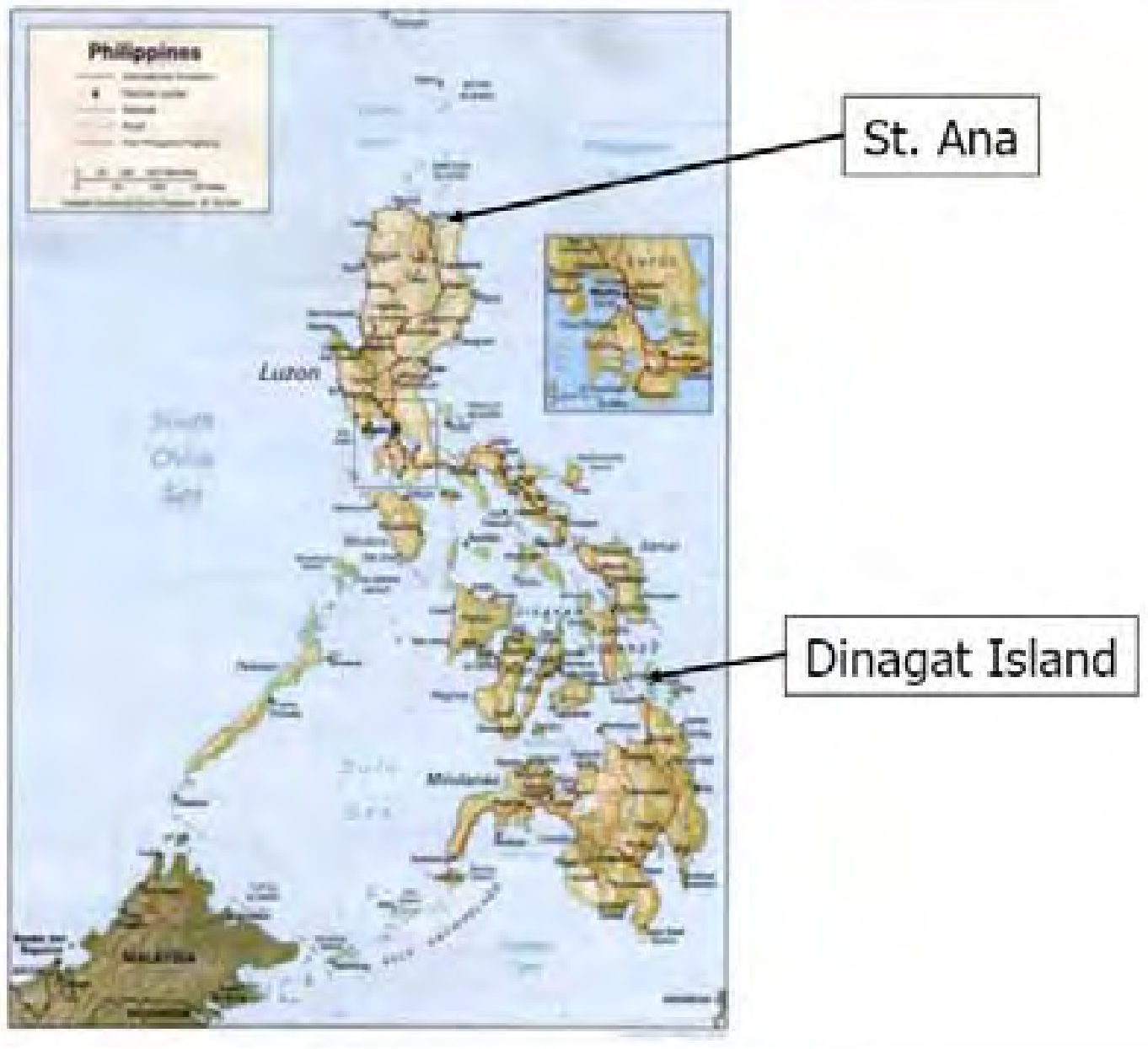




\section{Sta. Ana}
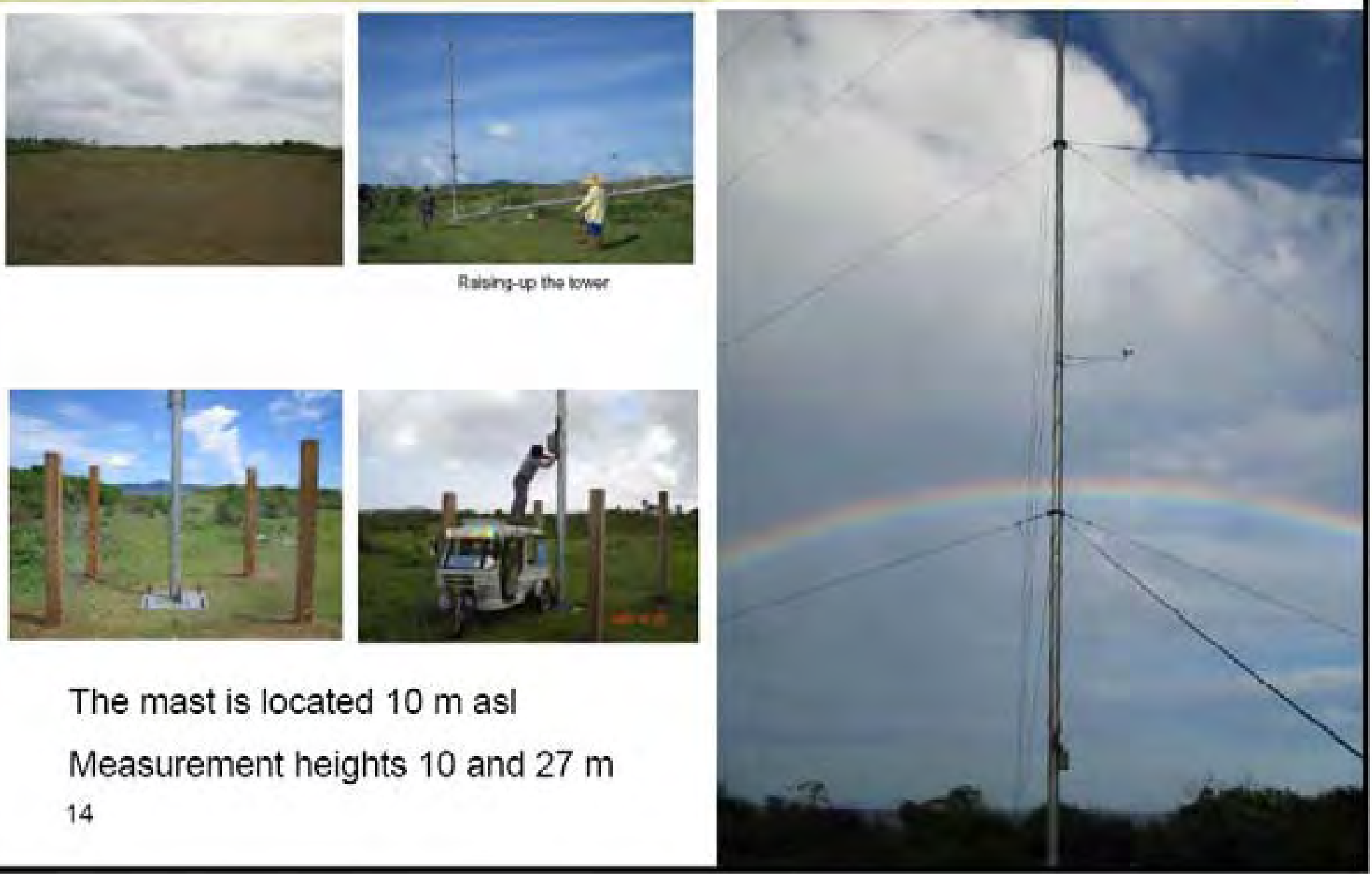

The mast is located $10 \mathrm{~m}$ asl

Measurement heights 10 and $27 \mathrm{~m}$ 14 


\section{Location and wind data}

$\square$ St. Ana (30 MW)

- Cagayan region (Luzon Island)

- Zone 1 (wind upto $70 \mathrm{~m} / \mathrm{sec}$

$\square$ Wind Data

- Mean wind speed $4.9 \mathrm{~m} / \mathrm{sec}$ (8 months; Sept 2005April measurements)

- Max. $18 \mathrm{~m} / \mathrm{sec}$

$\square$ Est. Generation

- 80 GWh /yr (57-79, depending on location) using 2 MW V66/67 $\mathrm{m}$ wind turbine

- 60MWh/ yr (43-61) using 2MW V80/67 


\section{Financial Analysis of St. Ana Wind Power Project}

\begin{tabular}{|l|l|}
\hline Background & \\
\hline Investment & $\begin{array}{l}\$ 51.8 \text { mill. Includes feasibility study, } \\
\text { project and site development work, } \\
\text { engineering, plant and equipments, } \\
\text { installation, transmission lines } \\
(1 \$=52 \text { P) }\end{array}$ \\
\hline $\begin{array}{l}\text { O \& M Costs } \\
\text { (increase 3\% per year) }\end{array}$ & $\begin{array}{l}\$ 1.1 \text { mill. per year. includes land } \\
\text { lease, property tax, labour, other }\end{array}$ \\
\hline Annual Energy & $\mathbf{8 0}$ GWh (net) \\
Production & $-7 \%$ losses (Transmission) \\
\hline Plant life & - From year 1, above AEP \\
\hline
\end{tabular}




\begin{tabular}{|c|c|}
\hline Income tax & $\begin{array}{l}\text {-No tax for } 6 \text { years } \\
-30 \% \text { after that }\end{array}$ \\
\hline $\begin{array}{l}\text { Projected power sale } \\
\text { rate }\end{array}$ & $\begin{array}{l}\text { P } 4.91 \text { / kWh } \\
\text { (and escalation 3\% per year) }\end{array}$ \\
\hline $\begin{array}{l}\text { CDM } \\
\text {-CER prices } \\
\text { - Emission red. coeff. (eq. CO2) }\end{array}$ & $\begin{array}{l}\$ 6 / \text { ton and } \$ 10 / \text { ton } \\
0.625 \mathrm{t} / \mathrm{MWh}\end{array}$ \\
\hline $\begin{array}{l}\text { Note: CDM revenues assumed for entire } \\
\text { plant life }\end{array}$ & \\
\hline
\end{tabular}




\section{Financial Structuring}

$\square$ Ownership Structures

- Private

- Utility

- Public (Central or Provincial)

Each has its own costs and financial arrangement possibilities.

Base Case:

Equity $20 \%$

Loan $80 \% ; 8 \%, 15$ Yrs+ 6 Yr (Grace Period) 


\section{NPV and IRR Calculations}

\section{$\square$ Discount rate}

- Hurdle rate was calculated based on cost of financing

- $8.68 \%$ (base case) 


\section{Hurdle rate}

$\square \quad$ Required $I R R>=$ hurdle rate

$\square$ The hurdle rate is weighted average cost of the capital (wacc)+ spread

$\square \quad$ WACC is calculated using the following formula;

$\square \quad W C=(E / T C) * R E+(D / T C) * R D *(1-T)$

Where;

WC is weighted average cost of capital

$E$ is the equity contribution

$\mathrm{D}$ is the debt

$T C$ is the total cost $(D+E)$

$R E$ is the required return on equity ( $11 \%$ )

$\mathrm{RD}$ is required rate of return on debt (rate of interest $+\mathrm{FE}$ risk $(1.5 \%)$ and guarantee $(2 \%)$ for foreign loans), and

$T$ is the tax rate $(30 \%)$

Discount rate $=$ Hurdle rate + spread $(2 \%)$ 


\begin{tabular}{|l|l|}
\hline $\begin{array}{l}\text { 80GWh site location } \\
\text { NPV }\end{array}$ & \\
$\begin{array}{l}\text { Base Case: Discount rate 8.68\% } \\
\text { (Domestic loan at 8\% with } 15 \\
\text { year term+ 6 yr GP) }\end{array}$ & P 243 Mill. \\
\hline \multicolumn{1}{|c|}{ Discount rate 13.2\% } & (P 553 mill) \\
(Risk adjusted) & \\
\hline IRich one to choose? & $9.83 \%$ \\
\hline MIRR & 1 USD = 57P) \\
\hline
\end{tabular}




\section{Check}

\section{$\square$ I mpact of CDM}

\begin{tabular}{|l|l|l|}
\hline CER Prices & $\$ 6 /$ ton & $\$ 10 /$ ton \\
\hline IRR & 10.46 & 10.87 \\
MIRR & 7.78 & 7.93 \\
\hline
\end{tabular}

Is it acceptable now? 
- What is my acceptable IRR? $17-18 \%$ private investors?

- This is economic IRR, and if tariff and investment and other data is without distortion, it gives a basis for decision making at policy level (although it is not strictly an economic analysis).

- For an investor, decision criteria will typically be Financial IRR, which depends on financing arrangements.

- Analysis- nominal v/s real 
Table1; Base Case and variations

(NPV in million P)

\begin{tabular}{|c|c|c|c|c|c|}
\hline Indicator & $\begin{array}{l}\text { Base } \\
\text { case }\end{array}$ & $\begin{array}{l}\text { Elect } \\
\text { Tariff } \\
+\mathbf{1 0 \%}\end{array}$ & $\begin{array}{l}\text { Invest } \\
\text { ment } \\
+20 \%\end{array}$ & $\begin{array}{l}\text { El. } \\
\text { Gen. } \\
-20 \%\end{array}$ & $\begin{array}{l}\text { O\&M } \\
\text { costs } \\
+20 \%\end{array}$ \\
\hline $\begin{array}{l}\text { NPV } 8.68 \% \\
\text { (hurdle rate) } \\
\text { With CDM; } \$ 6 / t \\
\text { With CDM } \$ 10 / t\end{array}$ & $\begin{array}{l}243 \\
379 \\
469\end{array}$ & $\begin{array}{l}614 \\
750 \\
840\end{array}$ & $\begin{array}{l}-230 \\
-95 \\
-5\end{array}$ & $\begin{array}{l}-385 \\
-276 \\
-204\end{array}$ & $\begin{array}{l}138 \\
273 \\
364\end{array}$ \\
\hline $\begin{array}{l}\text { NPV } 13.2 \% \\
\text { With CDM; } \$ 6 / \mathrm{t} \\
\text { With CDM; } \$ 10 / \mathrm{t}\end{array}$ & $\begin{array}{l}-553 \\
-453 \\
-386\end{array}$ & $\begin{array}{l}-278 \\
-178 \\
-110\end{array}$ & $\begin{array}{l}-1052 \\
-951 \\
-884\end{array}$ & $\begin{array}{l}-1020 \\
-939 \\
-885\end{array}$ & $\begin{array}{l}-632 \\
-531 \\
-464\end{array}$ \\
\hline $\begin{array}{l}\text { IRR } \\
\text { With CDM; } \$ 6 / \mathrm{t} \\
\text { With CDM; } \$ 10 / \mathrm{t}\end{array}$ & $\begin{array}{l}9.83 \% \\
10.46 \% \\
10.87 \%\end{array}$ & $\begin{array}{l}11.53 \% \\
12.14 \% \\
12.54 \%\end{array}$ & $\begin{array}{l}7.75 \% \\
8.30 \% \\
8.66 \%\end{array}$ & $\begin{array}{l}6.79 \% \\
7.33 \% \\
7.69 \%\end{array}$ & $\begin{array}{l}9.33 \% \\
9.97 \% \\
10.39 \%\end{array}$ \\
\hline $\begin{array}{l}\text { MIRR } \\
\text { With CDM; } \$ 6 / \mathrm{t} \\
\text { With CDM; } \$ 10 / \mathrm{t}\end{array}$ & $\begin{array}{l}7.56 \% \\
7.78 \% \\
7,93 \%\end{array}$ & $\begin{array}{l}8.16 \% \\
8.36 \% \\
8.50 \%\end{array}$ & $\begin{array}{l}6.75 \% \\
6.97 \% \\
7,11 \%\end{array}$ & $\begin{array}{l}6.35 \% \\
6,58 \% \\
6,72 \%\end{array}$ & $\begin{array}{l}7.37 \% \\
7.61 \% \\
7.76 \%\end{array}$ \\
\hline $\begin{array}{l}\text { IRR-Investor } \\
\text { With CDM; } \$ 6 / \mathrm{t} \\
\text { With CDM; } \$ 10 / \mathrm{t}\end{array}$ & $\begin{array}{l}14.03 \% \\
16.47 \% \\
18.19 \%\end{array}$ & $\begin{array}{l}21.08 \% \\
23.93 \% \\
25.89 \%\end{array}$ & $\begin{array}{l}7.28 \% \\
8.89 \% \\
10.02 \%\end{array}$ & $\begin{array}{l}4.71 \% \\
6.13 \% \\
7.11 \%\end{array}$ & $\begin{array}{l}12.26 \% \\
14.57 \% \\
16.20 \%\end{array}$ \\
\hline
\end{tabular}




\section{Financing Scenarios}

S.No.

Financing scheme

Discount

rate

B Base case; Domestic loan at an interest rate of $8 \%$, 15year term with a grace period 8.68 of 6 years

F1 Loan, financed through ODA at $0.3 \%$ for 20 years, with a grace period of 10 years.

6.33

F2 JBIC ODA at $0.90 \%$ for 20 years and a grace period of 6 years (untied, as applicable

6.66 to Philippines; http://www.jbic.go.jp/english/oec/standard/

F3 OECD commercial loan at 5\% for 10 years, with a grace period of 1 year (construction period).

F4 Danida financing; $35 \%$ grant and balance $65 \%$ as loan at $7 \%, 10$ year term 
Table 3; Financing Scenarios

\begin{tabular}{|c|c|c|c|c|c|}
\hline \multirow{4}{*}{ Indicator } & & & & & \\
\hline & Base case & FI & $\mathrm{F} 2$ & F3 & $\mathrm{F} 4$ \\
\hline & DBP & ODA & JBIC & OECD $5 \% ; 10$ & Danida $7 \% ; 10$ \\
\hline & $\begin{array}{l}8 \% ; 15 \mathrm{yr}, \mathrm{GP} 6 \\
\mathrm{yr}\end{array}$ & $\begin{array}{l}0.3 \% ; 20 y r, G P \\
10 y r s\end{array}$ & $\begin{array}{l}0.90 \% ; 20 \mathrm{yr} \text {, } \\
\text { GP } 6 \text { yrs }\end{array}$ & $\mathrm{yr}, \mathrm{GP} 1 \mathrm{yr}$ & $\begin{array}{l}\text { yr (grant 35\%), } \\
\text { No GP }\end{array}$ \\
\hline NPV $13.2 \%$ & -553 & -616 & -610 & -609 & 66 \\
\hline With CDM; $\$ 6 / t$ & -453 & -516 & -510 & -508 & 167 \\
\hline With CDM $; \$ 10 / t$ & -386 & -448 & -443 & -441 & 234 \\
\hline Hurdle rate & $8.68 \%$ & $6.33 \%$ & $6.66 \%$ & $8.96 \%$ & $9.80 \%$ \\
\hline NPV & 243 & 753 & 667 & 103 & 567 \\
\hline With CDM; $\$ 6 / t$ & 379 & 915 & 824 & 236 & 692 \\
\hline With CDM $; \$ 10 / t$ & 469 & 1023 & 930 & 324 & 776 \\
\hline IRR & $9.83 \%$ & $9.41 \%$ & $9.45 \%$ & $9.46 \%$ & $13.76 \%$ \\
\hline With CDM; $\$ 6 / t$ & $10.46 \%$ & $10.05 \%$ & $10.09 \%$ & $10.10 \%$ & $14.60 \%$ \\
\hline With CDM; $\$ 10 / t$ & $10.87 \%$ & $10.47 \%$ & $10.51 \%$ & $10.52 \%$ & $15.15 \%$ \\
\hline MIRR & $7.56 \%$ & $7.40 \%$ & $7.41 \%$ & $7.41 \%$ & $8.81 \%$ \\
\hline With CDM; $\$ 6 / t$ & $7.78 \%$ & $7.63 \%$ & $7.65 \%$ & $7.65 \%$ & $9.06 \%$ \\
\hline With CDM $; \$ 10 / t$ & $7,93 \%$ & $7.78 \%$ & $7.80 \%$ & $7.80 \%$ & $9.22 \%$ \\
\hline IRR-Investor & $14.03 \%$ & $50.73 \%$ & $45.17 \%$ & $13.32 \%$ & $21.33 \%$ \\
\hline With CDM ; $\$ 6 / t$ & $16.47 \%$ & $53.50 \%$ & $48.20 \%$ & $14.71 \%$ & $23.24 \%$ \\
\hline With CDM $; \$ 10 / t$ & $18.19 \%$ & $55.34 \%$ & $50.19 \%$ & $15.67 \%$ & $24.54 \%$ \\
\hline
\end{tabular}




\section{Lessons Learnt}

$\square$ Lessons learnt in the case study:

- St. Ana is not viable as a normal project; load factor at $30 \%$ is reasonable.

- Uncertainties (investment cost, O\&M cost, and generation) make it a risky venture even with favourable financing packages.

- A combination of soft financing and high CDM revenues can make it viable. 


\section{$\square$ Conclusions}

$\square$ Economic viability of wind energy is an issue in Philippines

$\square$ Nationally, development of wind can be justified from energy security perspective

$\square$ Development of wind energy for global environmental reasons may require carbon financing, supplemented through grants / soft financing, wherever necessary. 
More info; www. aseanwind.eu

\title{
THANK YOU
}

\author{
Contact; \\ J.P. Painuly \\ UNEP Risoe Centre \\ j.p.painuly@risoe.dk
}




\section{Wave Energy \\ - challenges and possibilities}

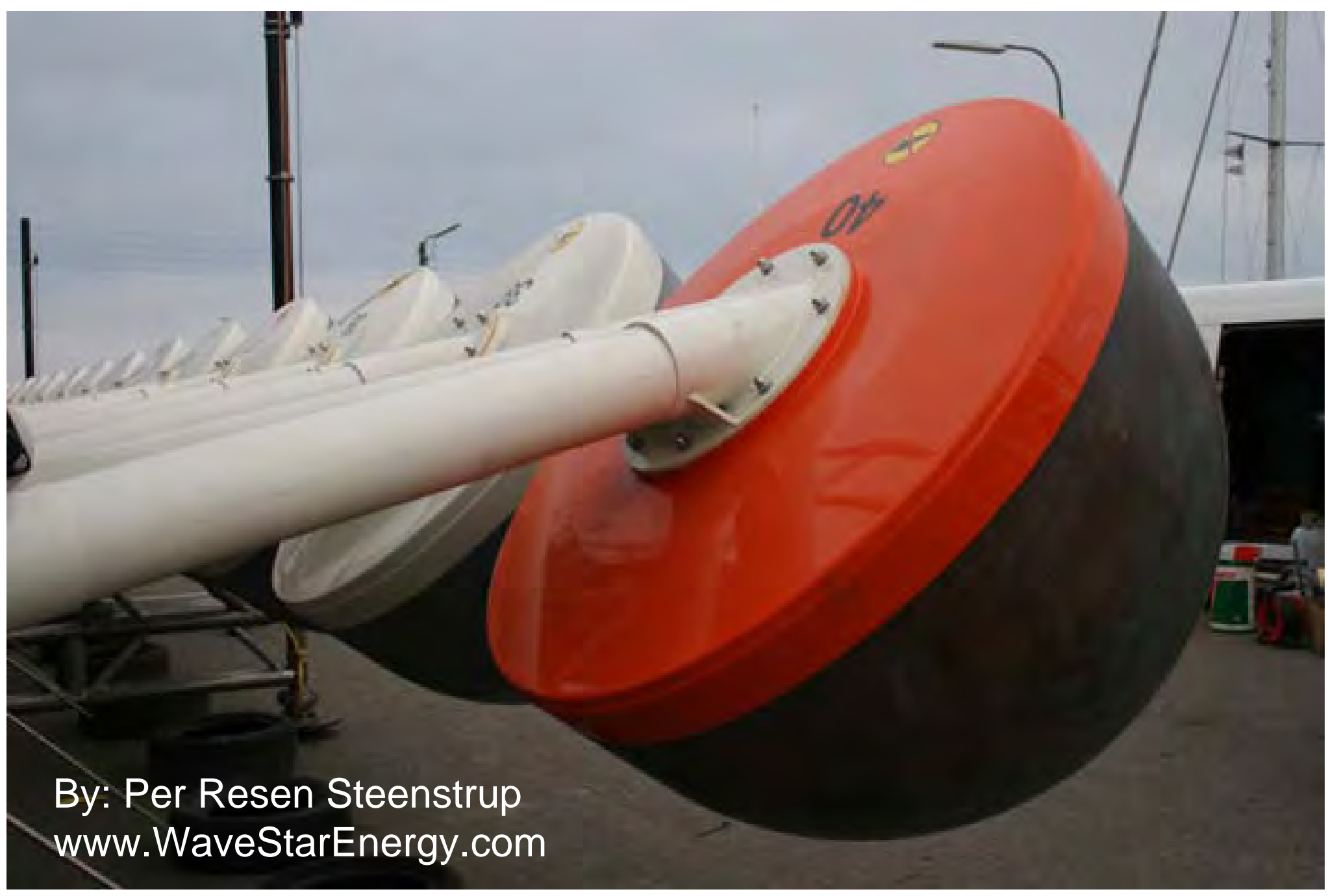




\section{Wave energy is an old story....}

The first wave energy patent is 200 years old.

Over the last 100 years more than 200 new wave energy devices have been developped and more than 1.000 patents have been issued.

Over the last 30 years more than 400 million EUR have been spent on demonstrators in the sea, with little or no success.

Only in the last 5 years the practical solutions have started to show, with real chances of commercialisation.

\section{Main features for success:}

-Simple storm protection concept.

-Proven technology in the sea.

-Simple and reliable concept, with simple power take off system.

-Scalable to big MW systems in the future.

- Low weight per MW - potential for future cost reductions. 
Wave energy concepts World wide, which have been tested in the sea

Oscillating water coloum - floating or fixed coastal installation. Air based Wells turbines as power take off.

Over topping waves into a reservoir, with low head turbines as power take off.

Articulating tubes with hydraulic power take off.

Point absorber, with either water pumps, linear generators or hydraulic power take off systems.

Multi point absorbers, with hydraulic power take off. 

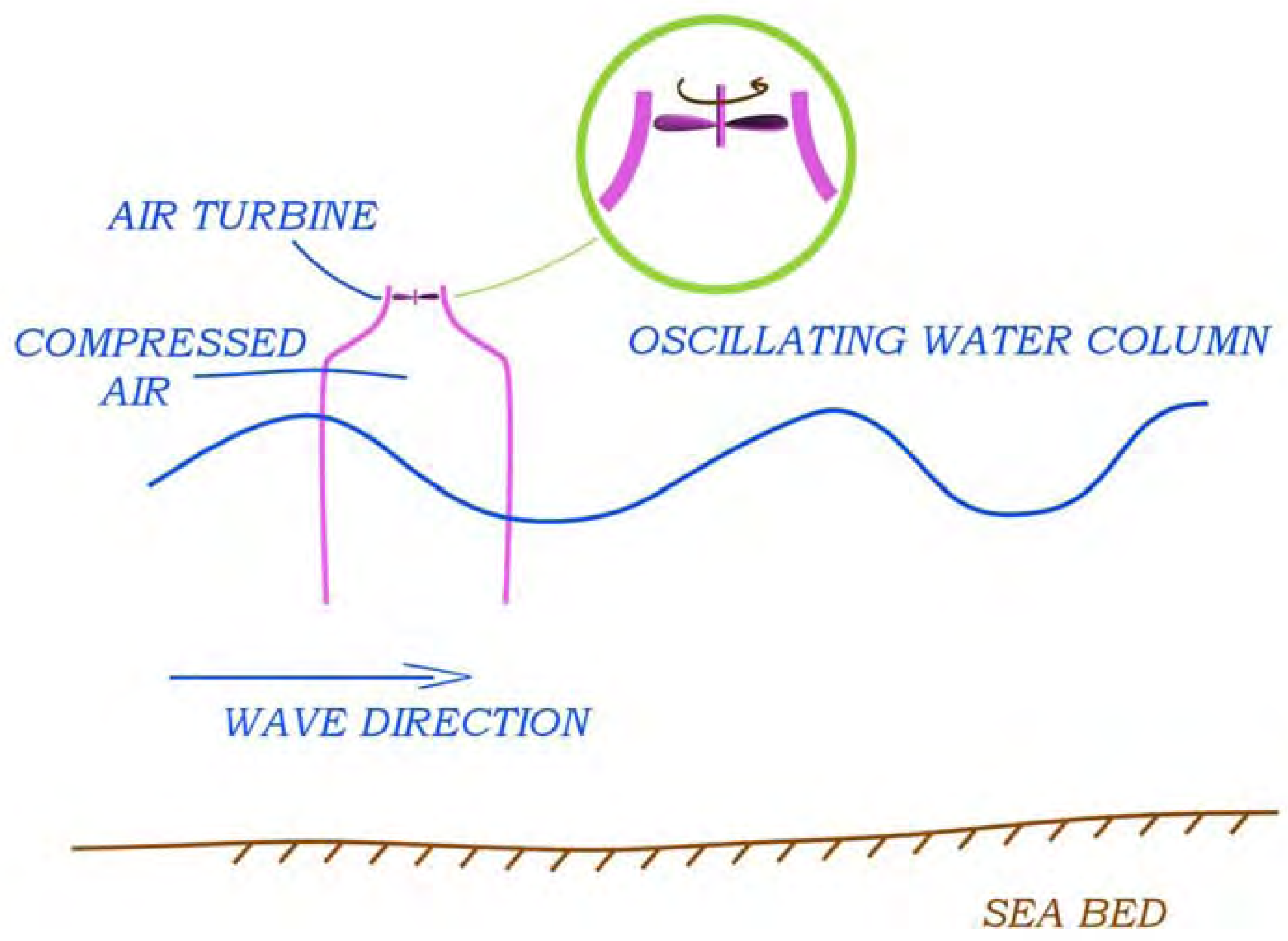


\section{OVER TOPPING RESERVOIR}

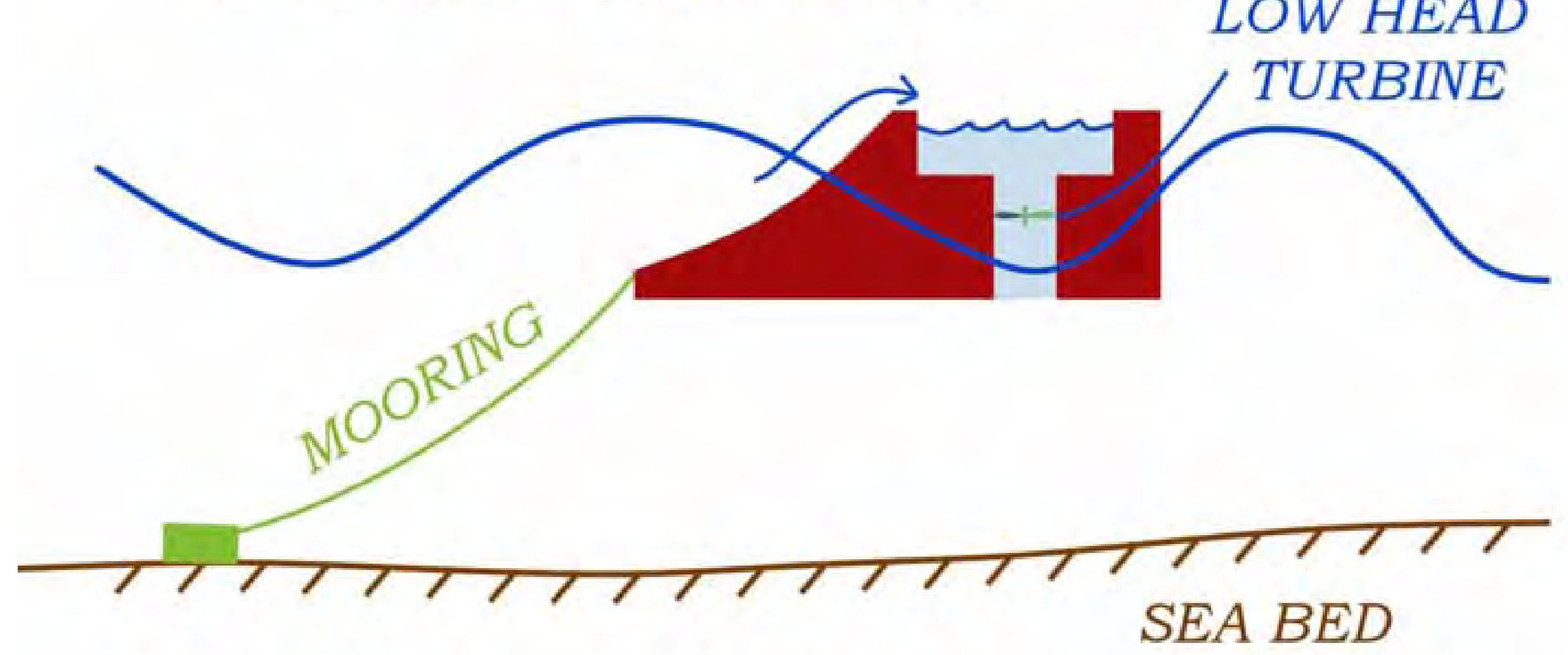


ARTICULATING TUBES WITH HYDRAULIC JOINTS

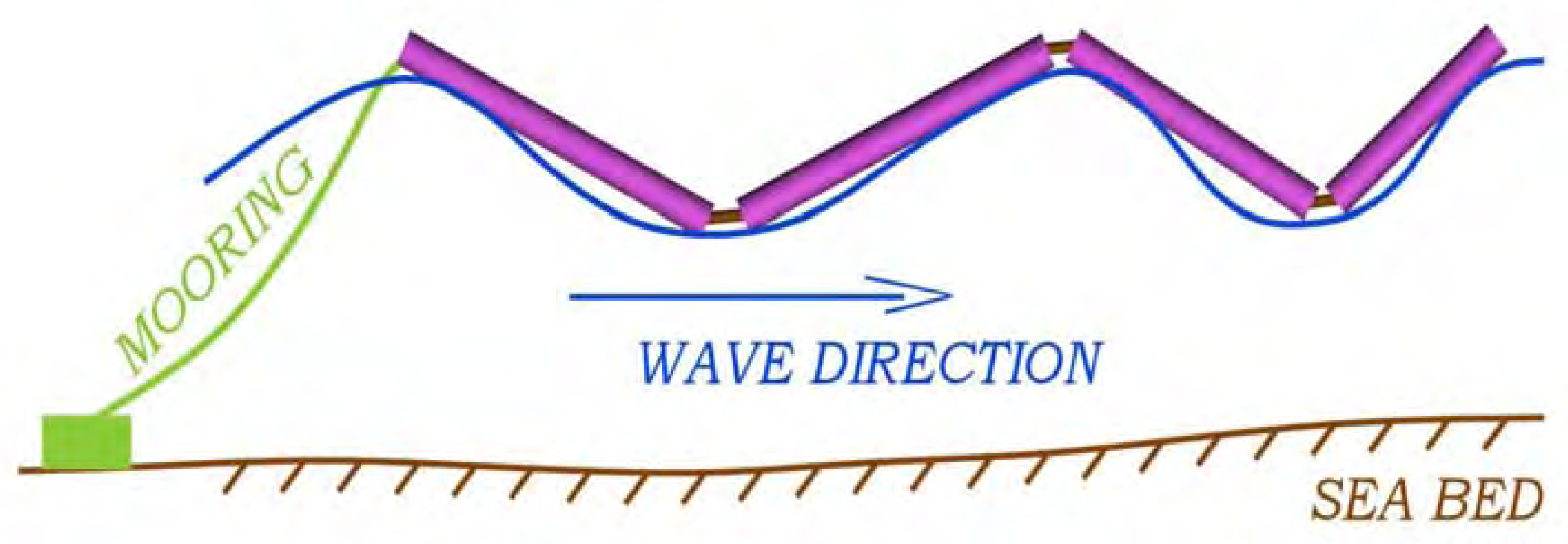




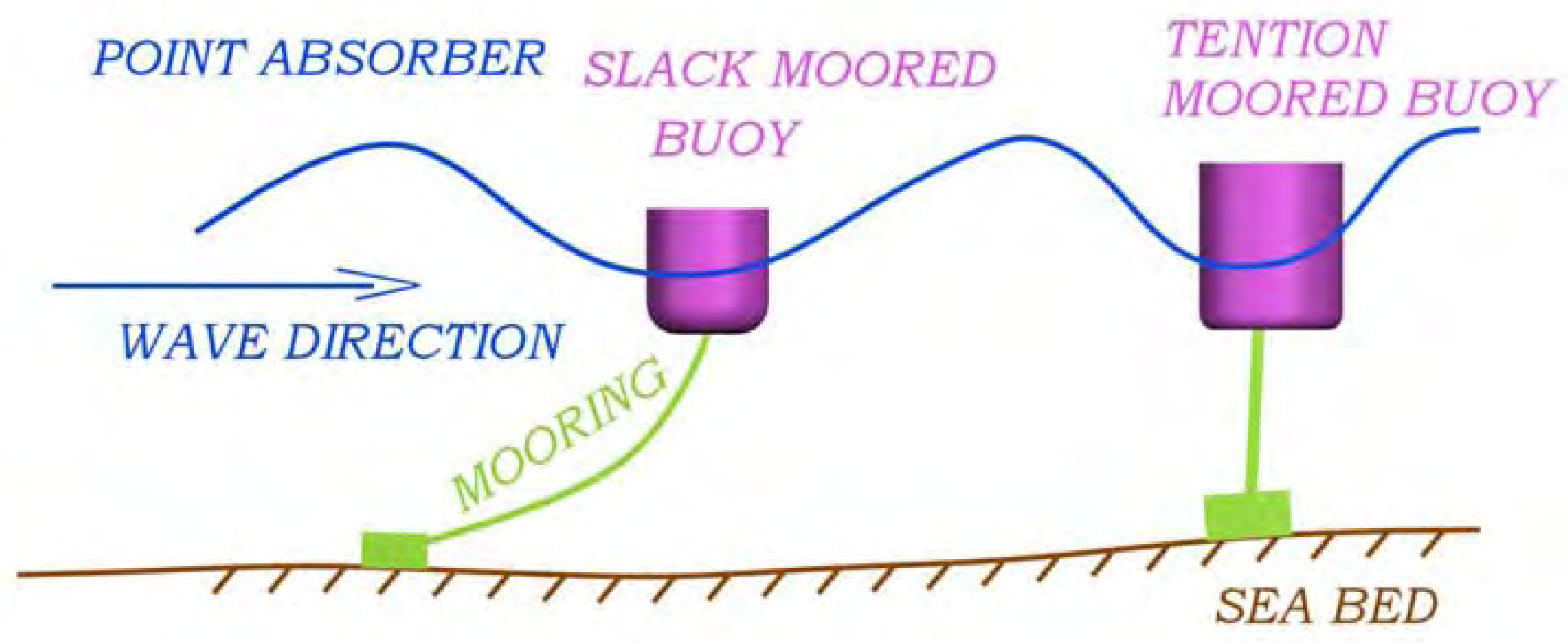




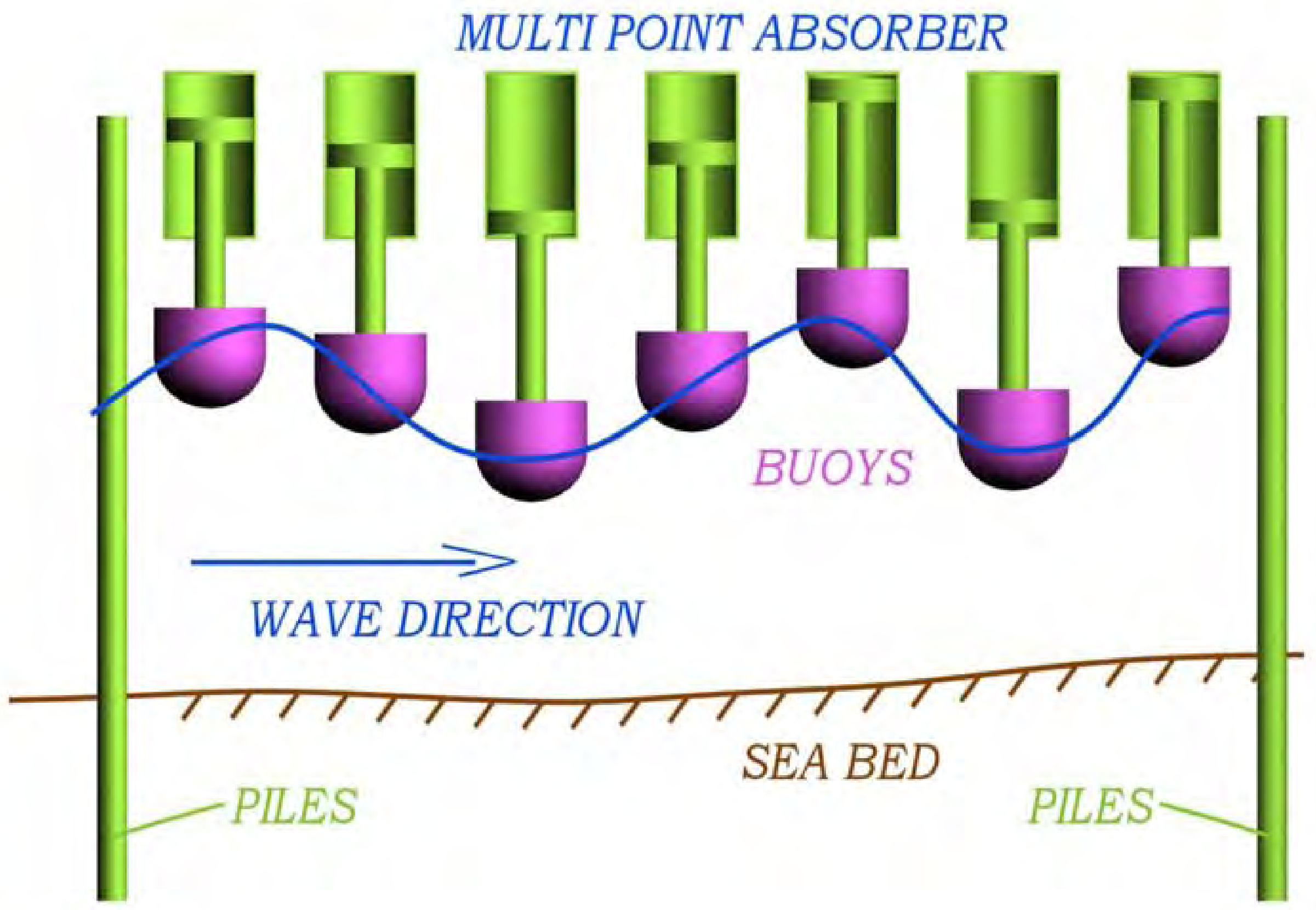




\section{Wave Star's back ground in head lines.}

Wave Star Energy was established October 1st 2003, with the sole purpuse of commercialising wave energy.

Over a period of 10 months in 2004 a scale 1:40 converter was extensively tested in regular as well as irregular waves, to document the configuration, optimize the power output and document dynamic behavior compared to a hydro dynamic model.

Based on the extensive tank testing a scale 1:10 converter was designed and built during 2005 and deployed in the sea on April 6th 2006 at Nissum Bredning (DK). The converter was built and instrumented to the same high standard as a full scale converter.

After initial testing of all sub systems the converter was grid connected and put into unattended operation on July 24st 2006.

It has been in operation since then and logged more than 6.000 hours. 


\section{What is special about the Wave Star concept?}

It is a simple reliable design, which can be storm protected. It sits on piles, just like an offshore structure.

All moving parts are above water and are well protected from the sea environment.

It is only based on standard components and standard offshore

- and wind turbine technology.

It is scalable into multi MW converters.

Price and electric production per MW makes it realistic to become commercial over time, and supplement wind turbines on a big scale. 


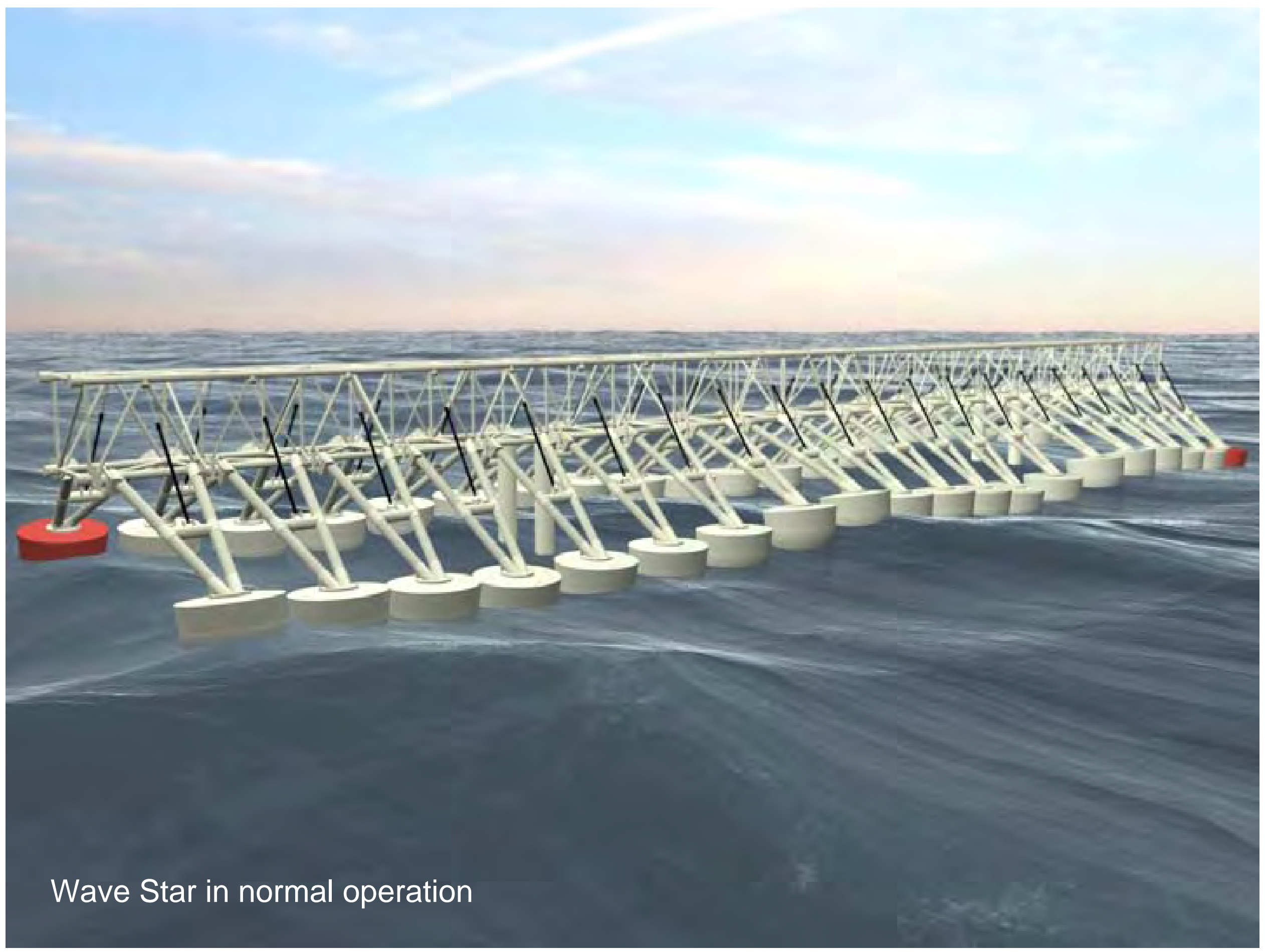




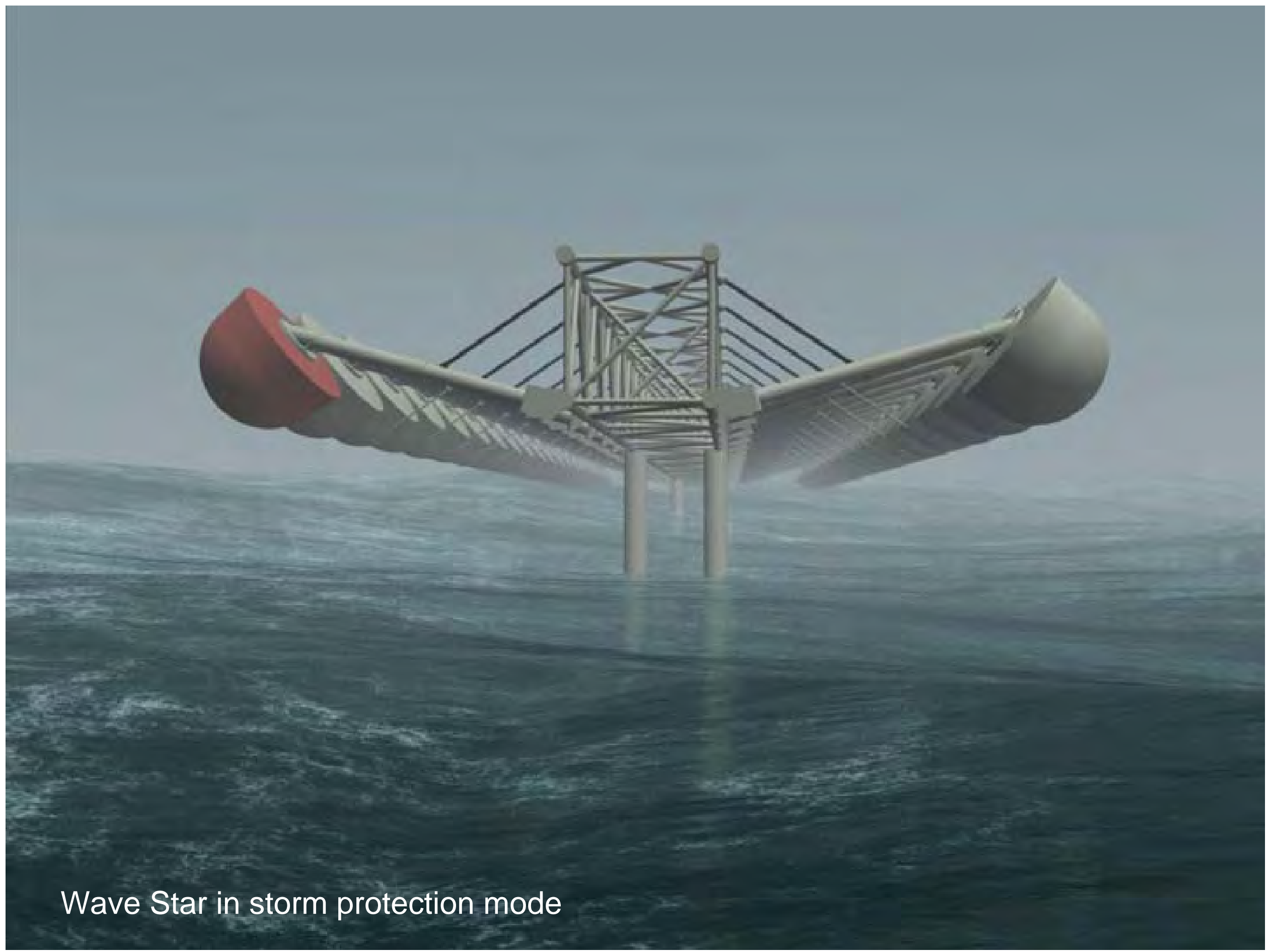




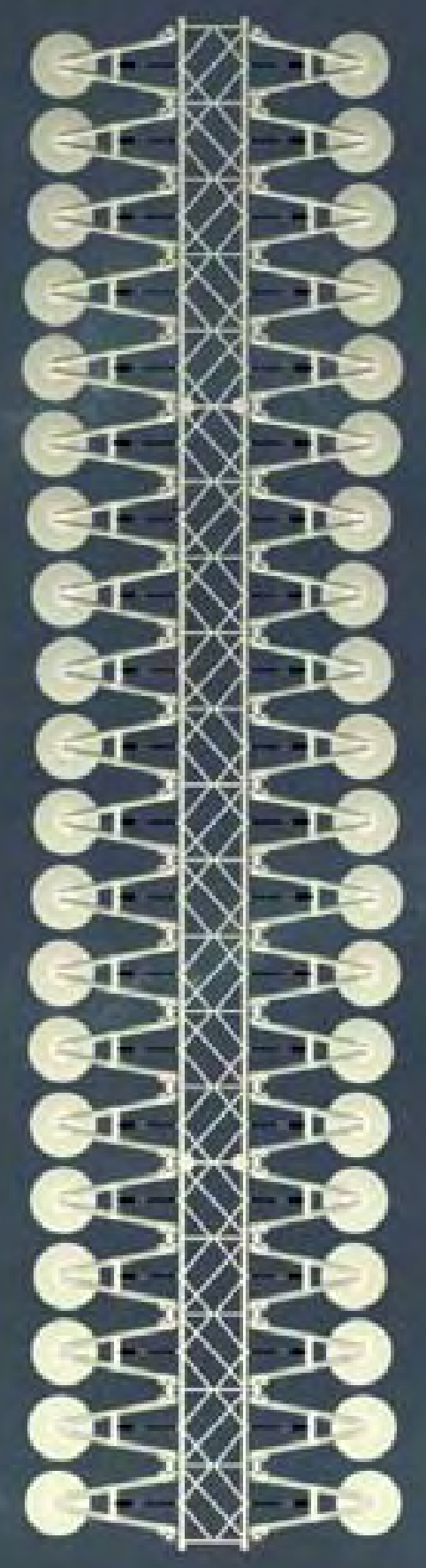

Dominant

Wave Direction

Birds view 


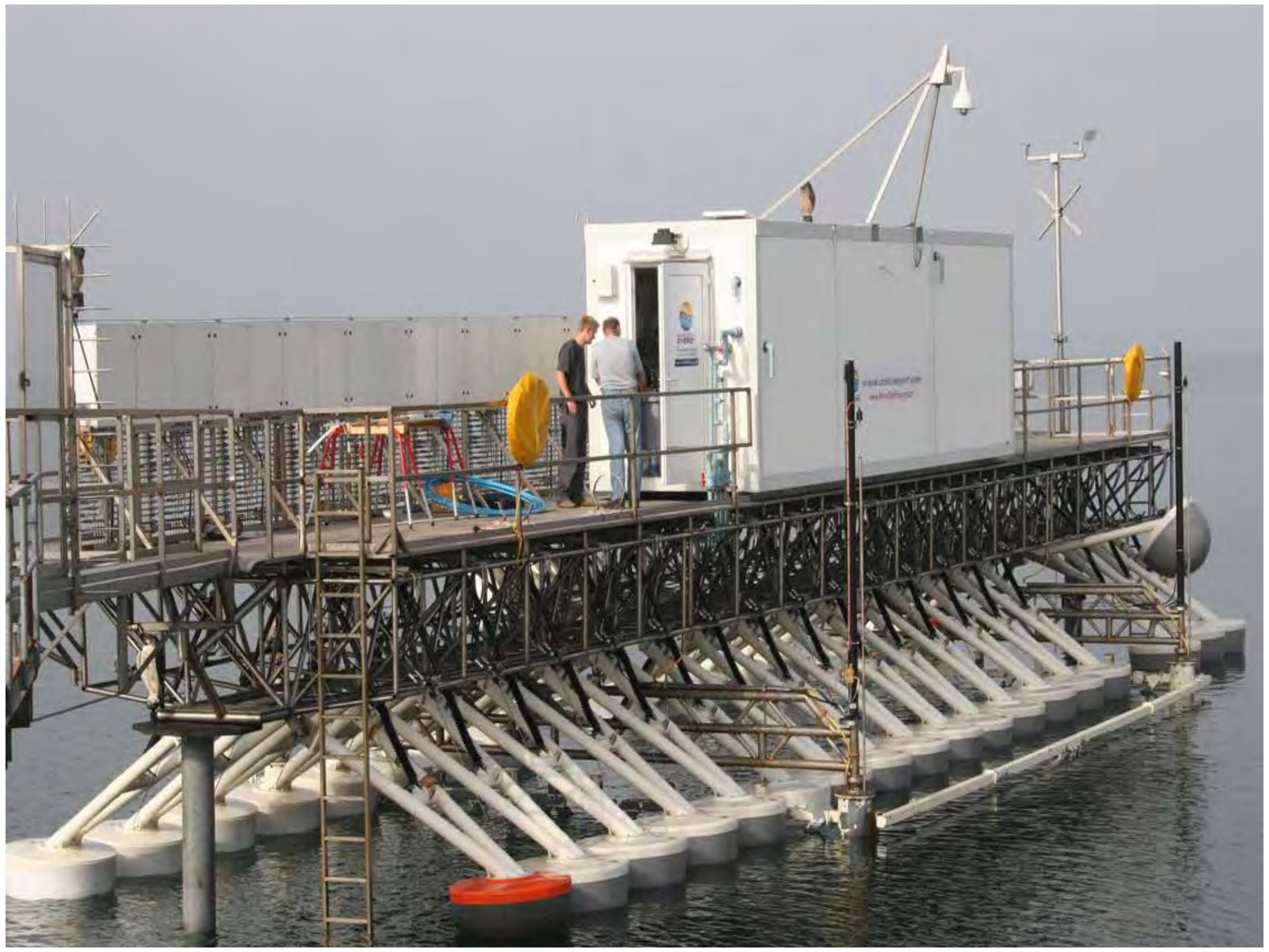




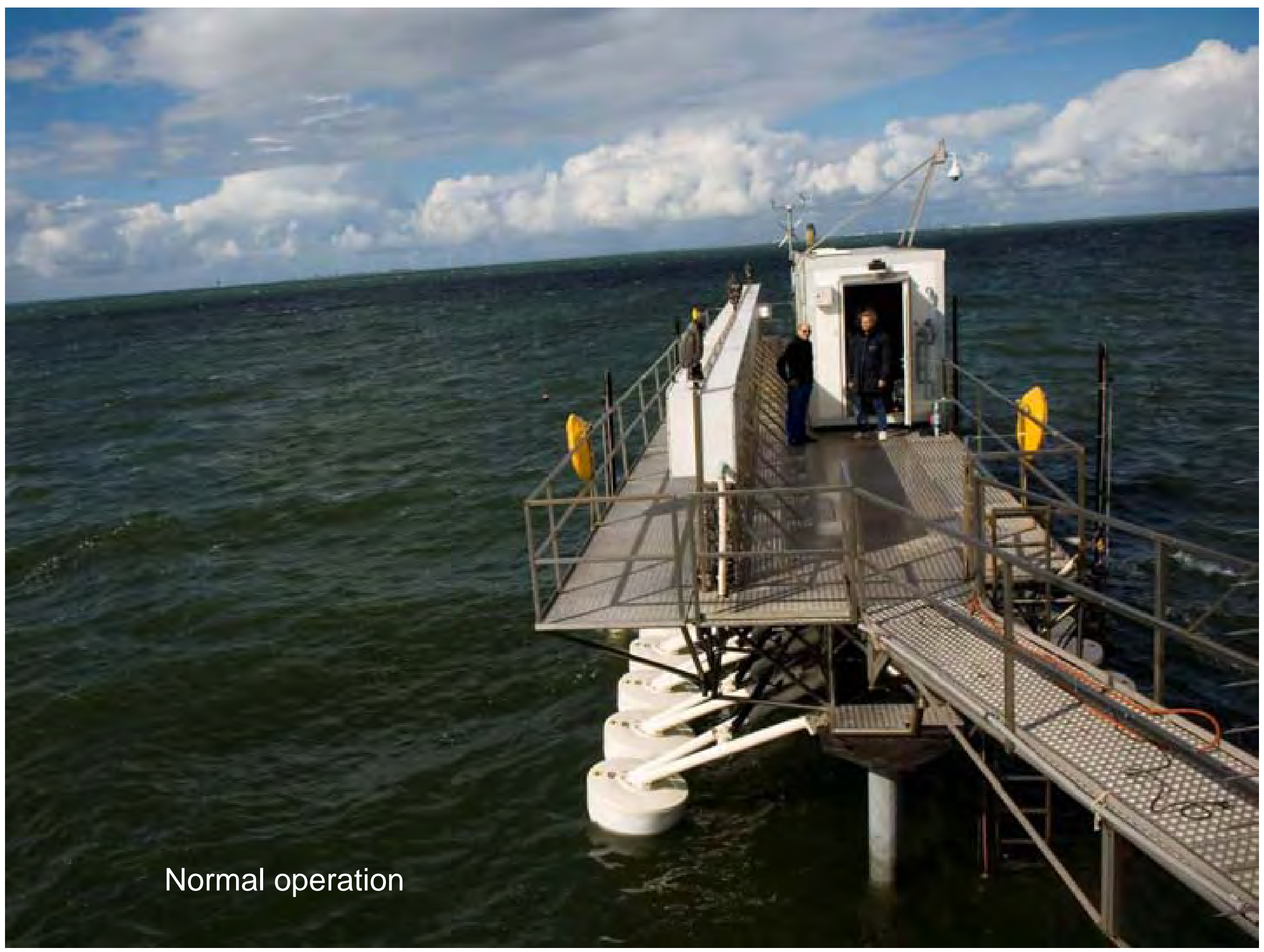




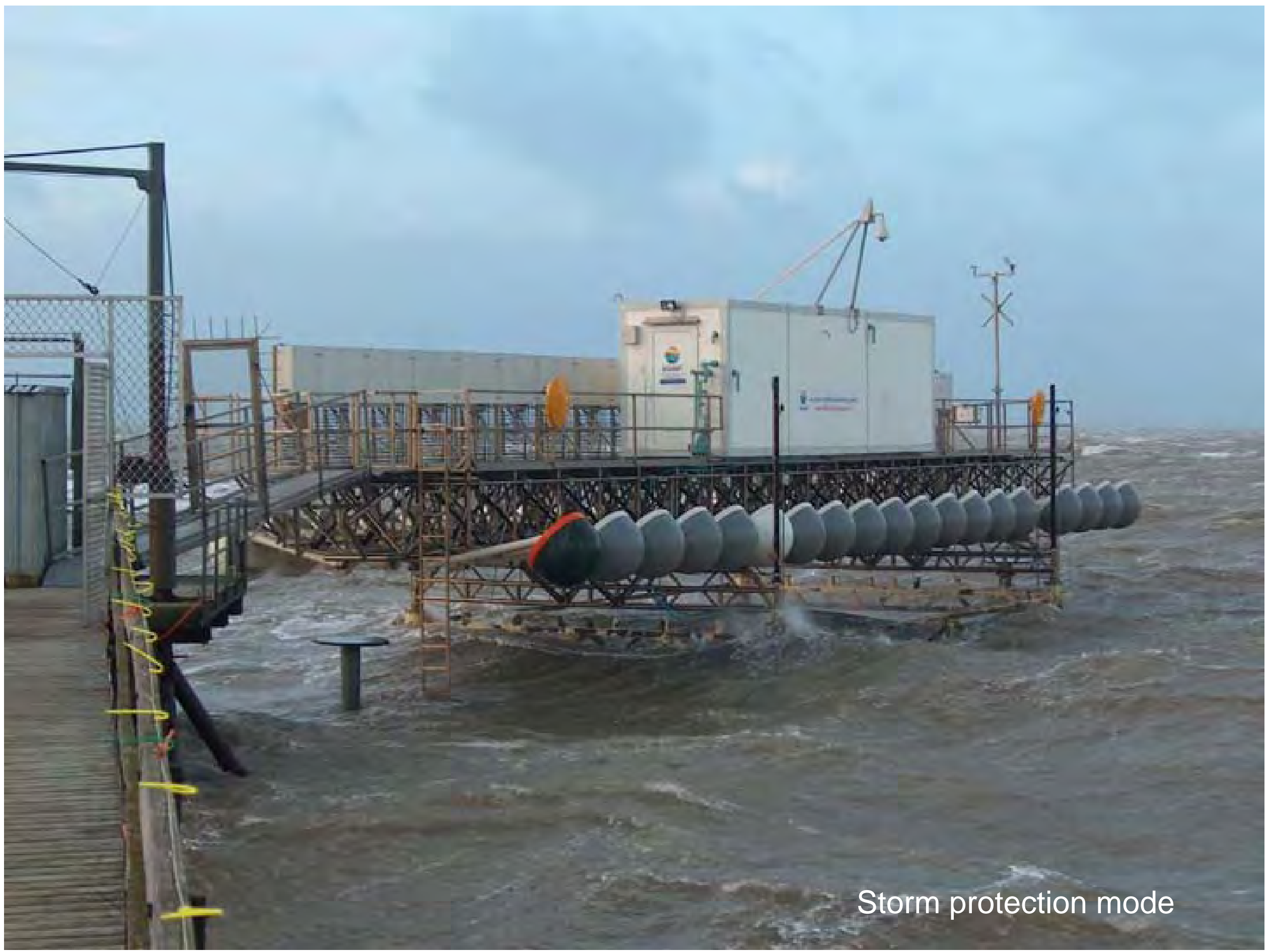




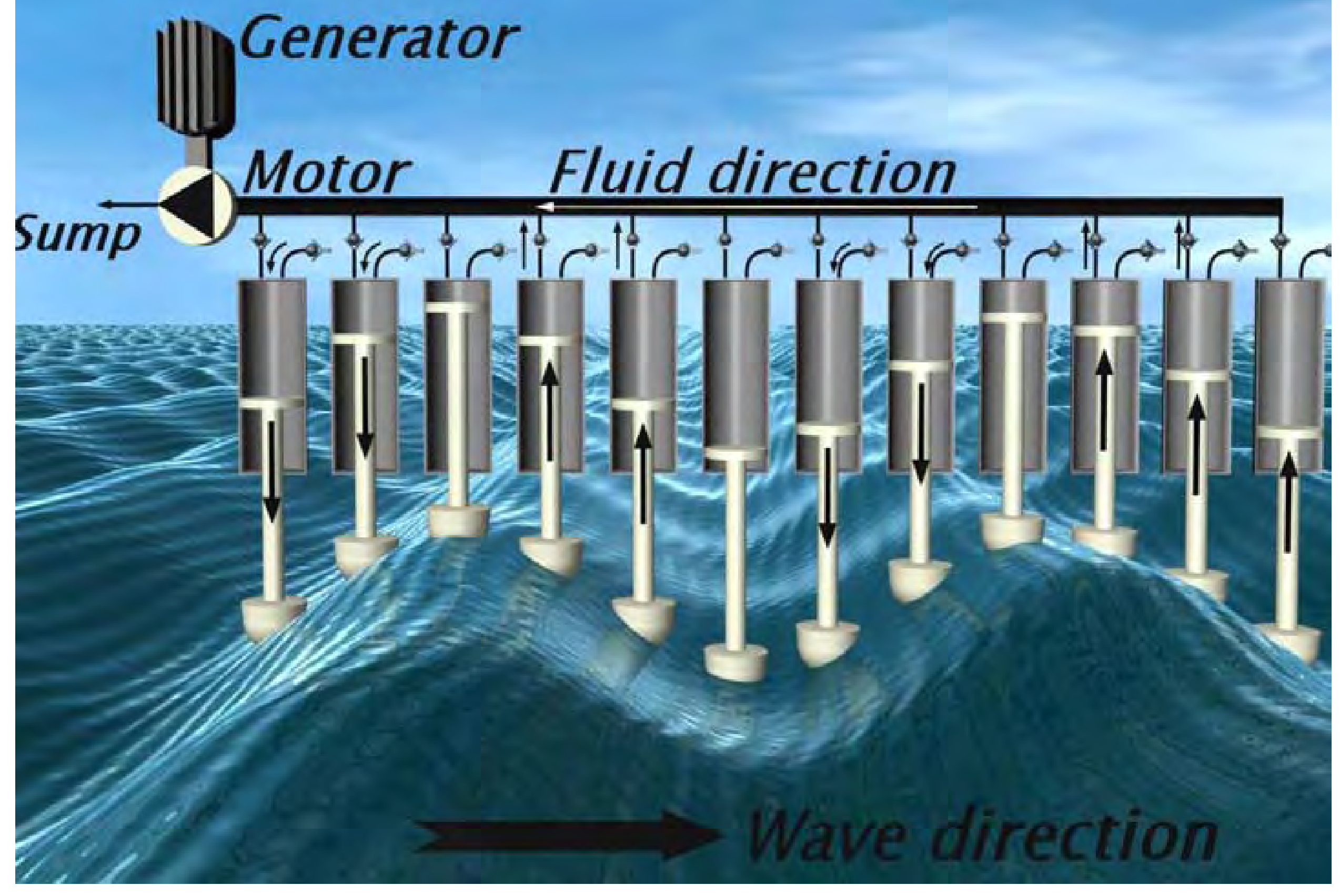




\section{How does the power scale with size?}

The test converter in Nissum Bredning is a scala 1:10 converter. It is $24 \mathrm{~m}$ long with 40 floates of each $\varnothing 1 \mathrm{~m}$, and operates in $2 \mathrm{~m}$ of water. In $\mathbf{0 , 5} \mathbf{~} \mathbf{m}$ Hs the power output is $\mathbf{1 . 8 0 0} \mathbf{W}$ electric power.

The scale 1:2 converter is $120 \mathrm{~m}$ long with 40 floats of $\varnothing 5 \mathrm{~m}$ and operates in $10 \mathrm{~m}$ of water depth. In $\mathbf{2 , 5} \mathbf{~ m ~ H s}$ the power output is $500 \mathrm{~kW}$.

The scale 1:1 converter is $240 \mathrm{~m}$ long with 40 floats of each $\varnothing 10$ $\mathrm{m}$ and operates in $20 \mathrm{~m}$ of water. In $\mathbf{5 , 0} \mathbf{~ m ~ H s}$ the power output is $6 \mathrm{MW}$.

The scale 1,5:1 converter is $360 \mathrm{~m}$ long with 40 floats of each $\varnothing$ $15 \mathrm{~m}$ and operates in $30 \mathrm{~m}$ of water. In 7,5 $\mathrm{m}$ Hs the power output is $24 \mathbf{~ M W}$. 


\section{What are the plans for the future?}

The scale 1:10 converter in Nissum Bredning will continue to operate until August 2008. The goal is to optimize the energy production and obtain long term working experience.

Design and build a scale 1:2, $500 \mathrm{~kW}$ converter for Horns Rev in the North Sea during 2007 / 2008 .

Arms and floats for the $500 \mathrm{~kW}$ converter will be installed and tested at a pier in the North Sea in 2008.

The scale 1:2, $500 \mathrm{~kW}$ will be pre installed at the North of Lolland at Onsevig i 2008 / 2009.

Later transferred and installed at Horns Rev (North Sea) in 2009. 


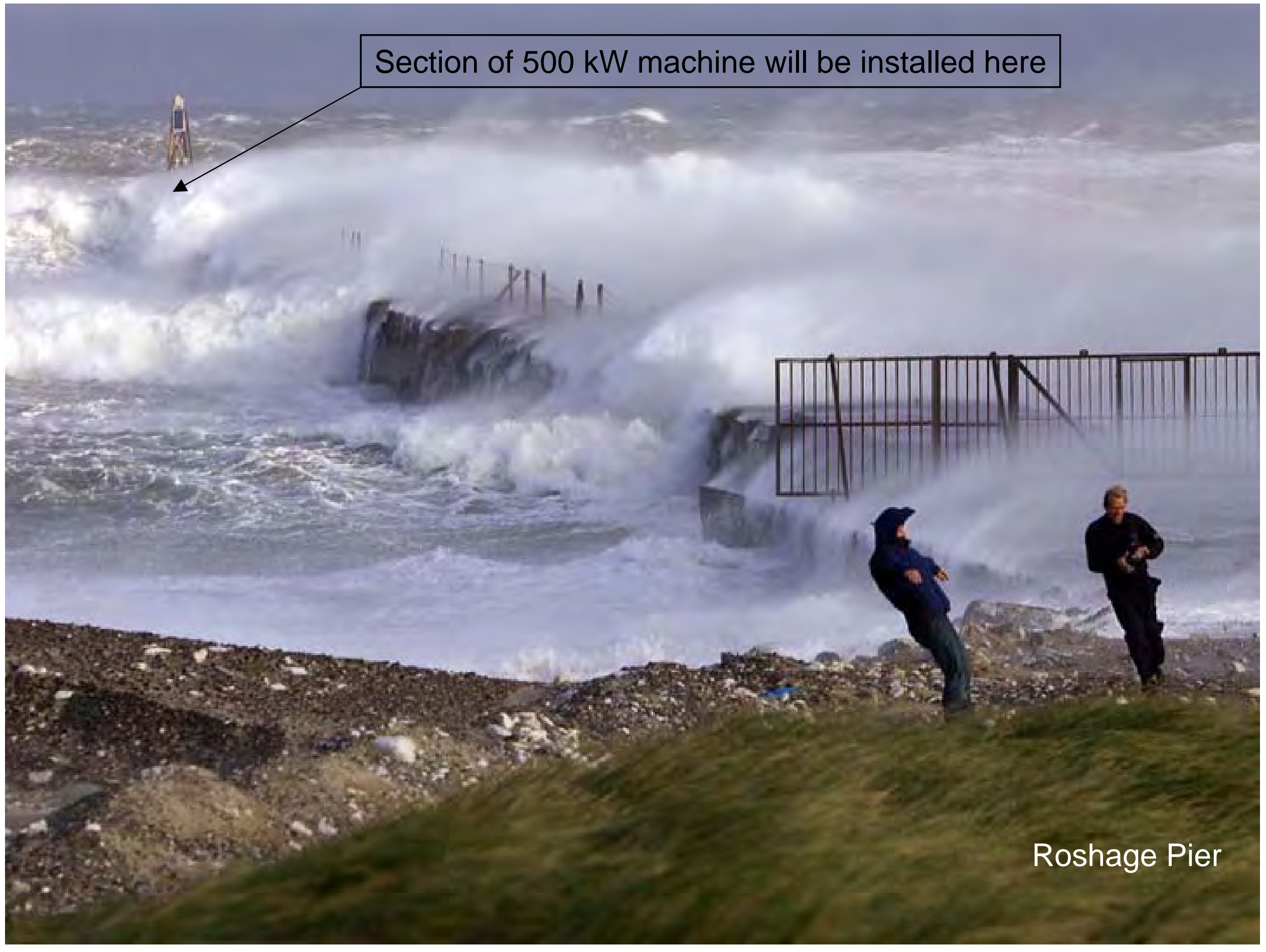




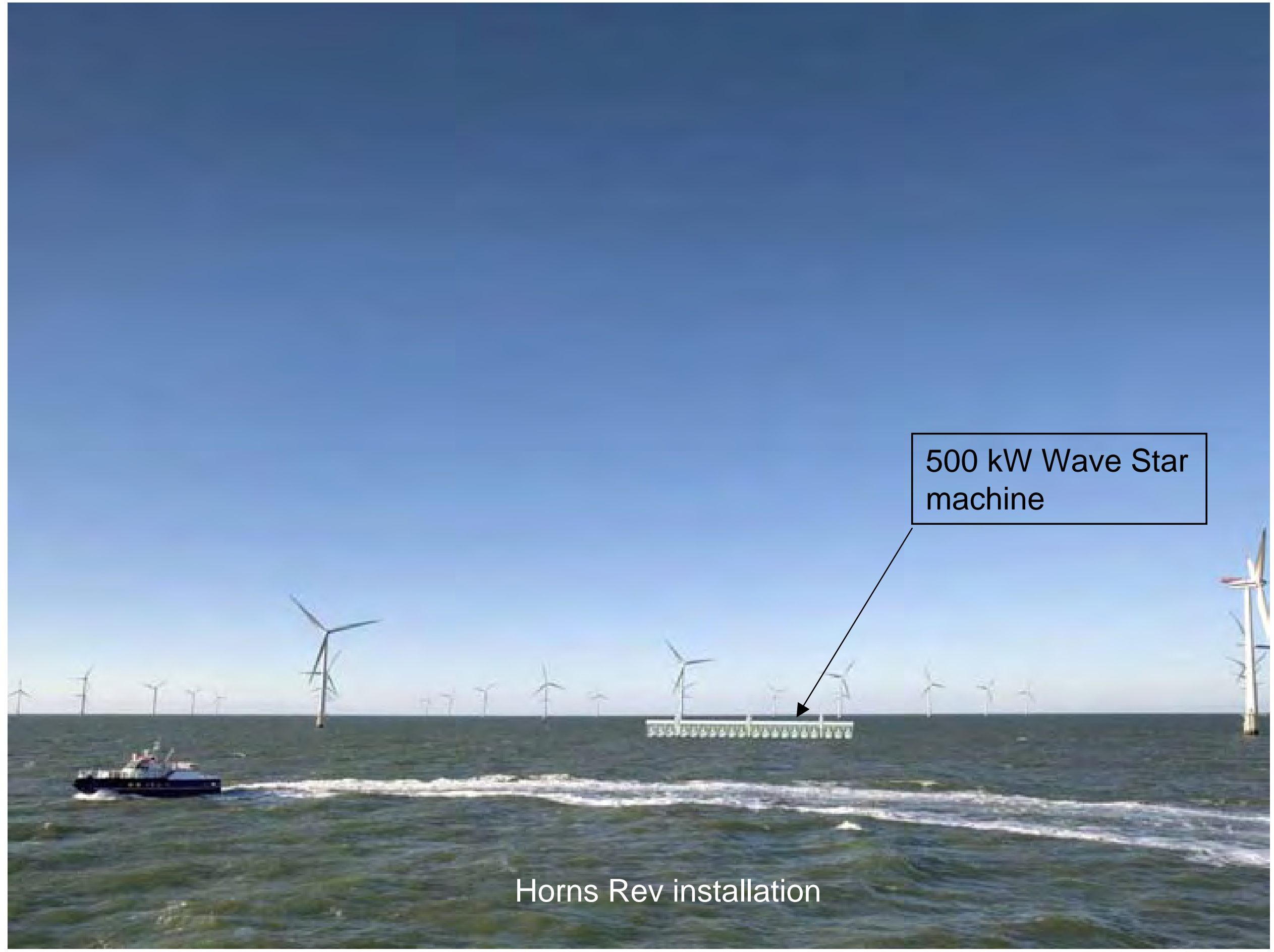




\section{What are the major challenges for Wave Star in reaching a commercial break through?}

Install and operate the first commercial $500 \mathrm{~kW}$ Wave Star Energy machine at Horns Rev i 2009 /2010, without any major technical problems or short commings.

Through cost engineering, in the early development phase of the $500 \mathrm{~kW}$ machine, bring the kWh cost down to less than 20 EUR cent, even when the machine is operated in $10 \mathrm{~m}$ of water depth and in a low wave climate of only $4 \mathrm{~kW} / \mathrm{m}$, in average.

Improve realiability of the first $500 \mathrm{~kW}$ machine, to make it the most reliable machine in the market.

Scale the machines in small steps to minimize risk.

$500 \mathrm{~kW}, 1,5 \mathrm{MW}, 3,0 \mathrm{MW}, 6 \mathrm{MW}, 10 \mathrm{MW}, 15 \mathrm{MW}$, 20MW etc. 


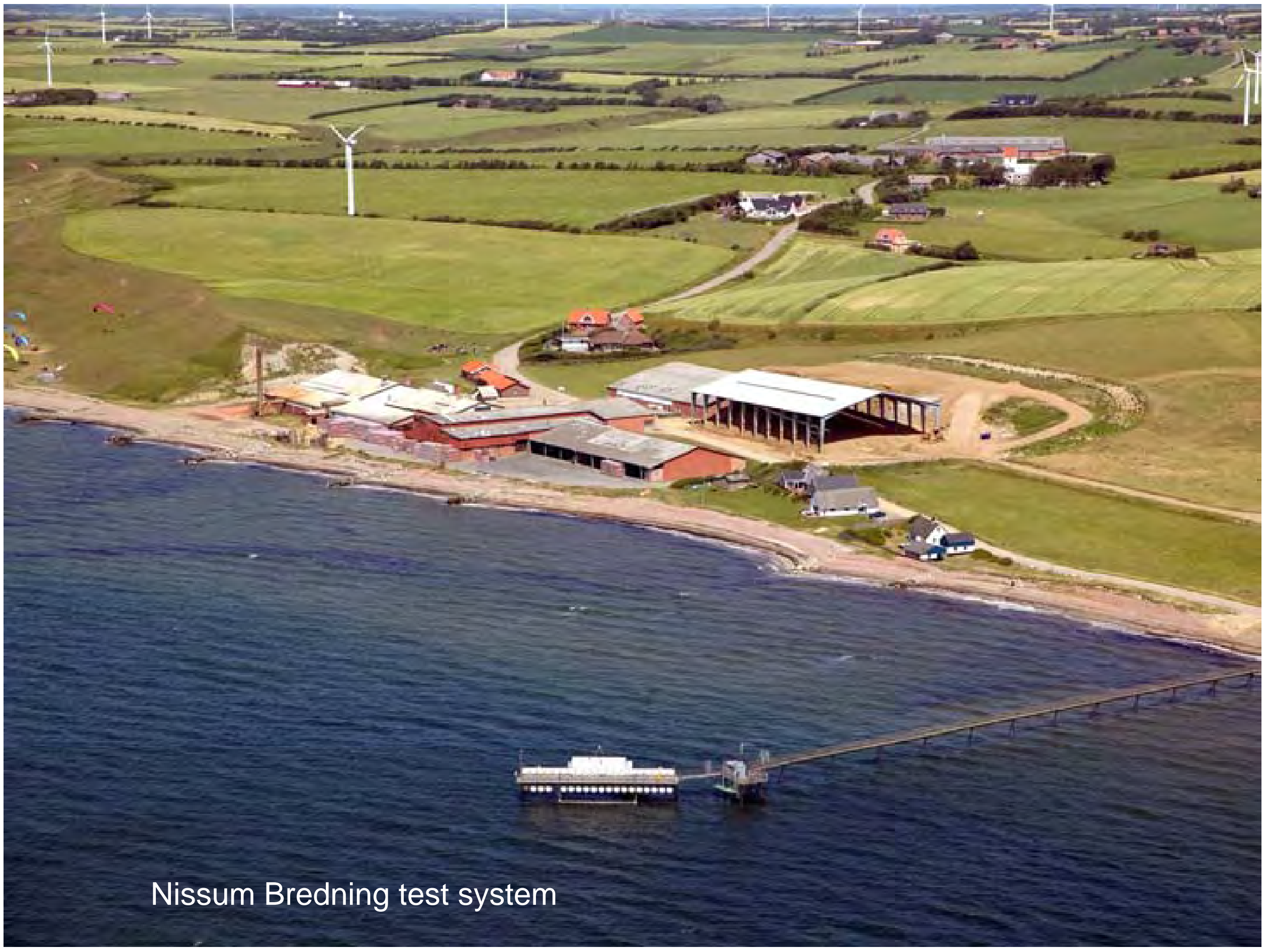




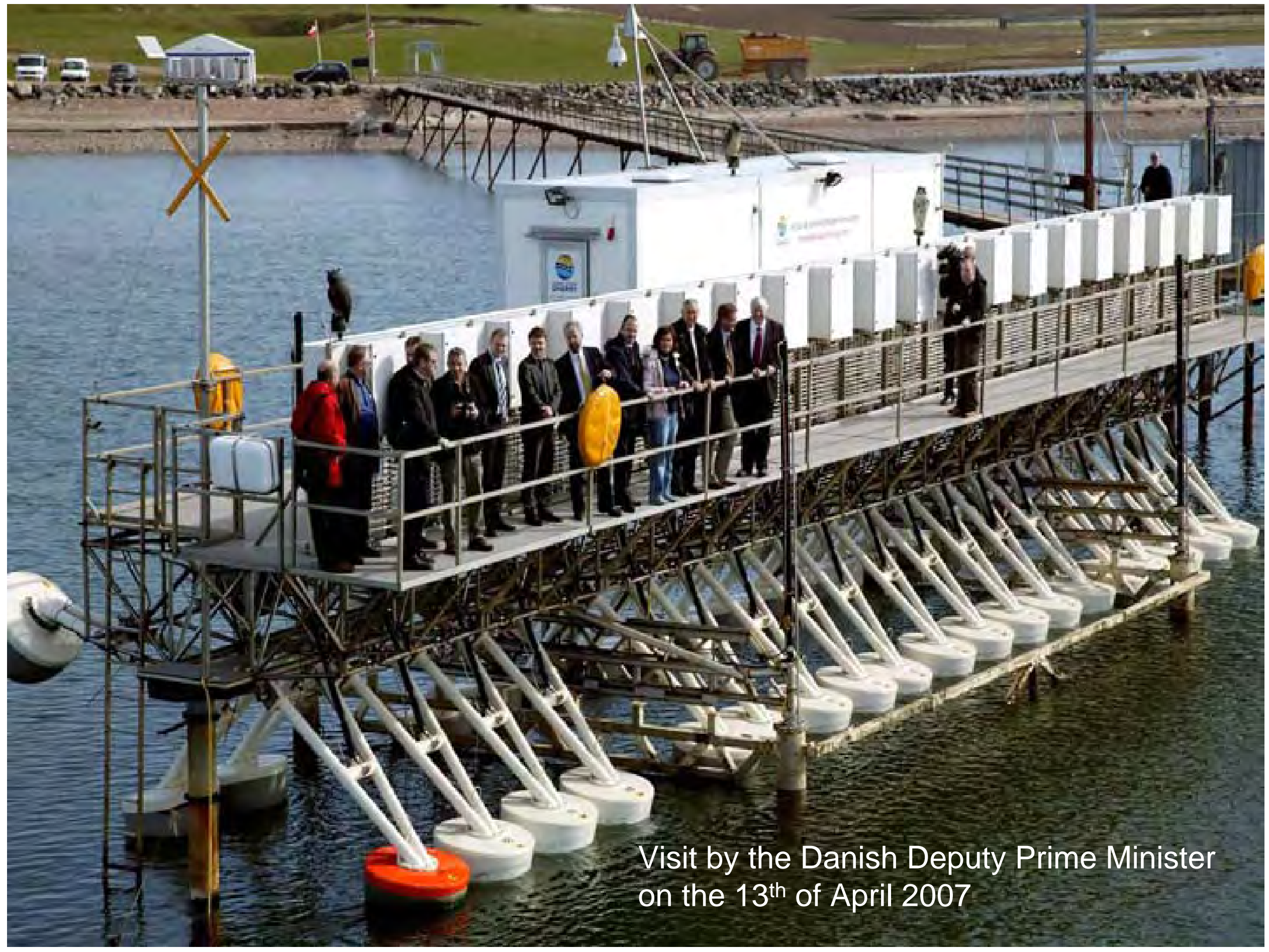


Operational costs induced by fluctuating wind power production in Germany and Scandinavia

Peter Meibom, Risø, Technical University of Denmark Christoph Weber, University Duisburg-Essen Rüdiger Barth \& Heike Brand, IER, University of Stuttgart 


\section{Overview presentation}

- Purpose of the study

- Methodology

- Results

- Discussion of integration costs

- Outlook 


\section{Purpose of study}

- Analyse the impact on operational costs from increased wind power in Germany and the Nordic countries

- Part of the so-called integration costs of wind power:

- Grid reinforcements

- Investment in balancing power plants

- Increase in operational costs due to more variable operation of conventional plants 


\section{Definition of integration costs of wind power}

- Difference between

- Expected reduction in system costs (need clarification)

- Realised reduction in system costs

- Expected reduction? (often reduction achieved with dispatchable technology):

- Gas turbine with same energy production as wind production

- Constant production with same energy production as wind production 


\section{Methodology}

- Calculations with the Wilmar Planning tool (www.wilmar.risoe.dk)

- Compare operational costs in three model runs:

1. With stochastic wind power production

2. With deterministic wind power production

3. With constant wind power production

- 1 minus 2: Costs of partial predictability

- 2 minus 3: Costs of variability

- 1 minus 3: Integration costs of wind power

- Each model run covers 5 selected weeks 


\section{Overview Planning tool}

\section{Wilmar Planning Tool}
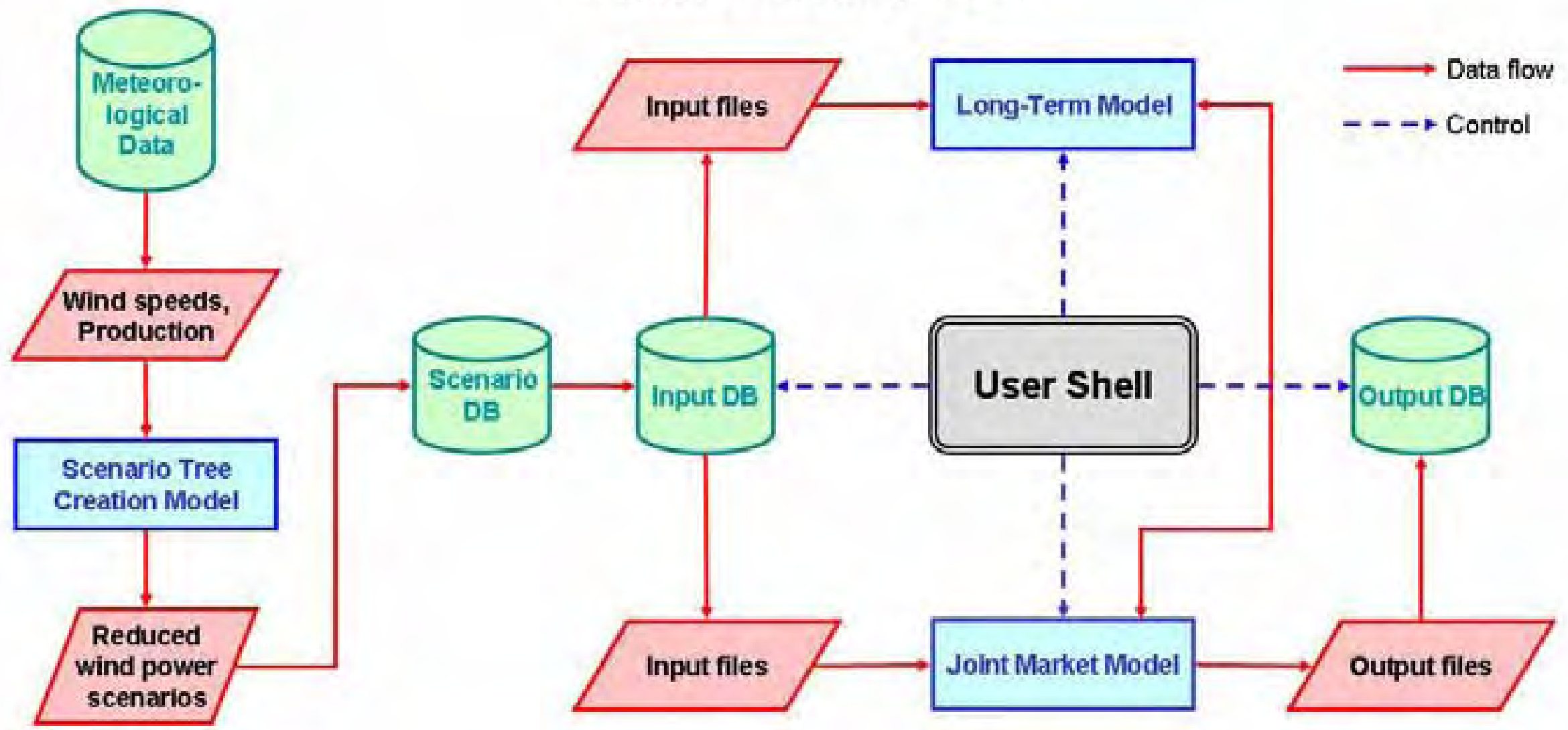
Overview of the Planning Tool
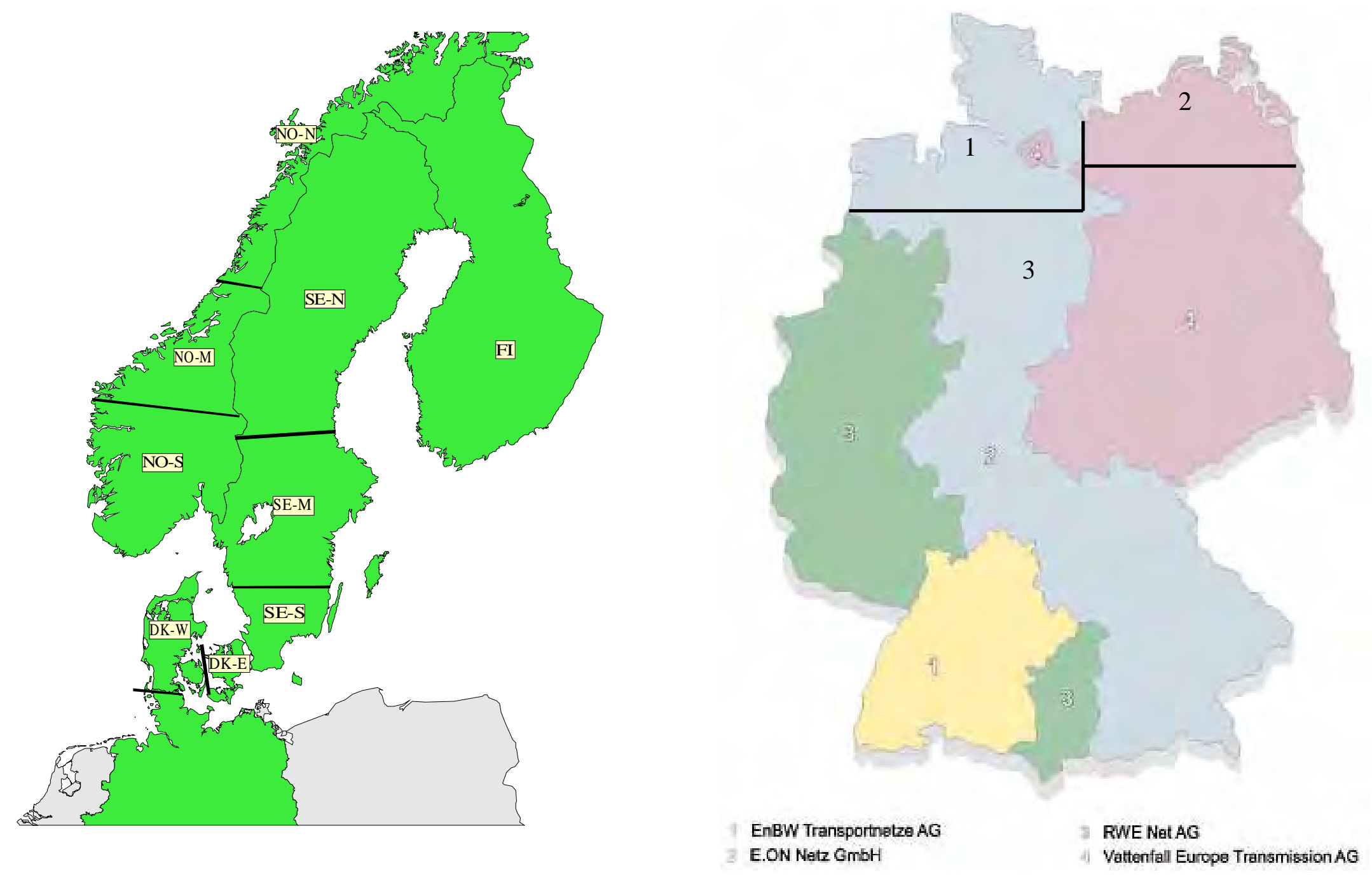


\section{Design of Joint Market model}

Rolling Planning Period 1:

Day- ahead market cleared

Rolling Planning Period 2

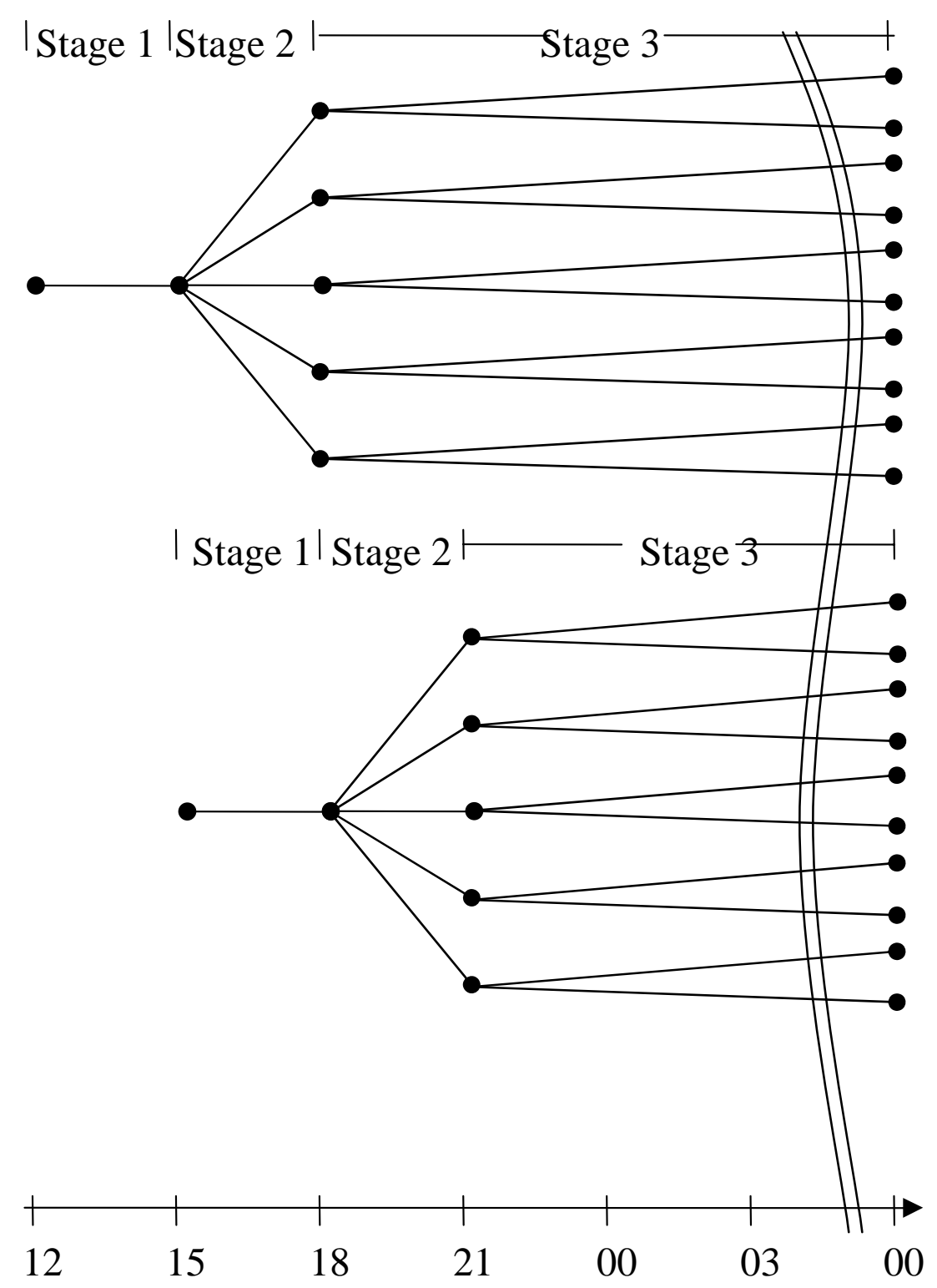




\section{Methodology}

- 2010 power system configuration case:

- Yearly load

- Transmission lines

- Power plants

- Fuel prices

- CO2 price

- Three cases for installed wind power 


\section{Installed wind power capacity in each wind scenario}

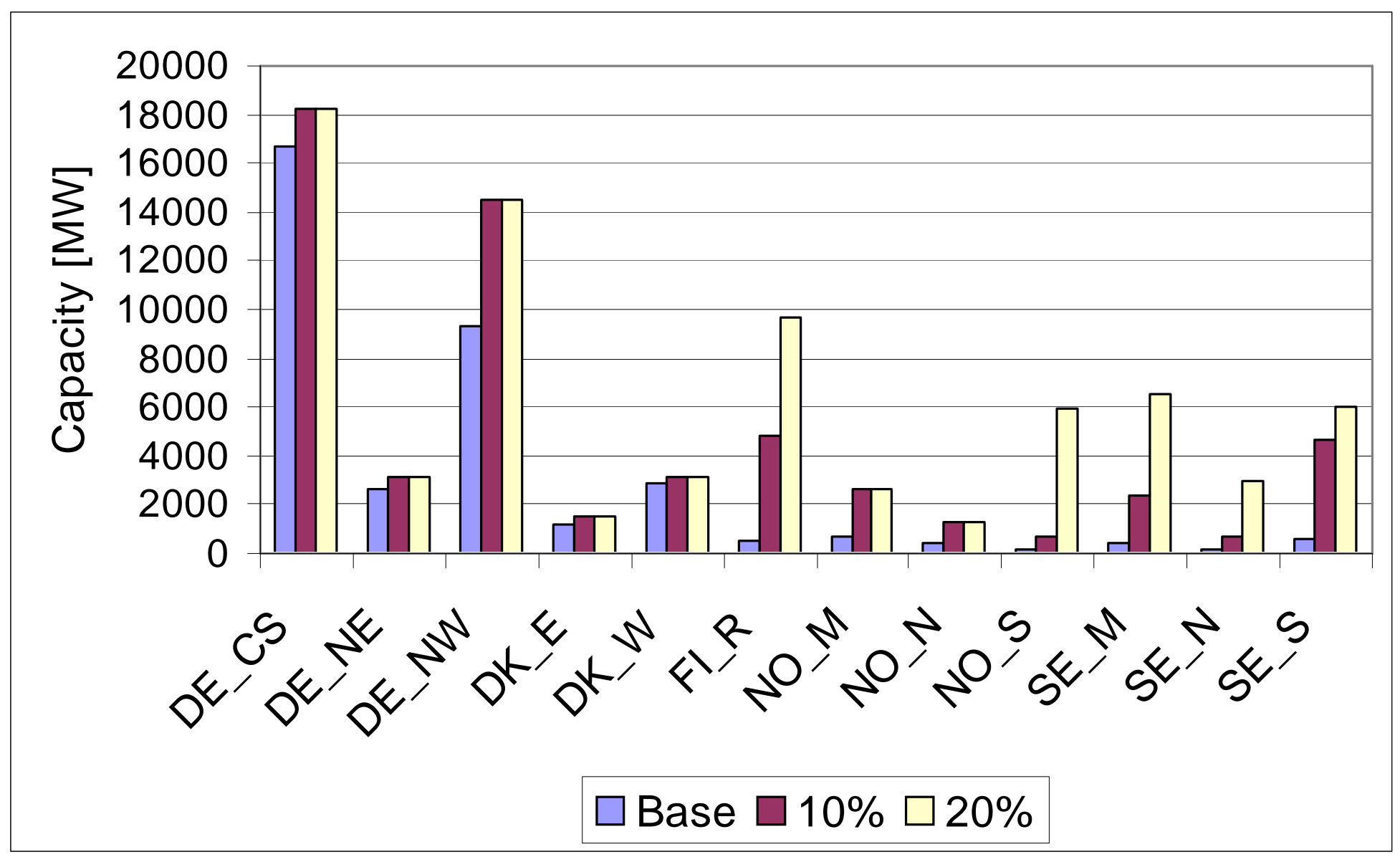




\section{Difference in system operation costs}

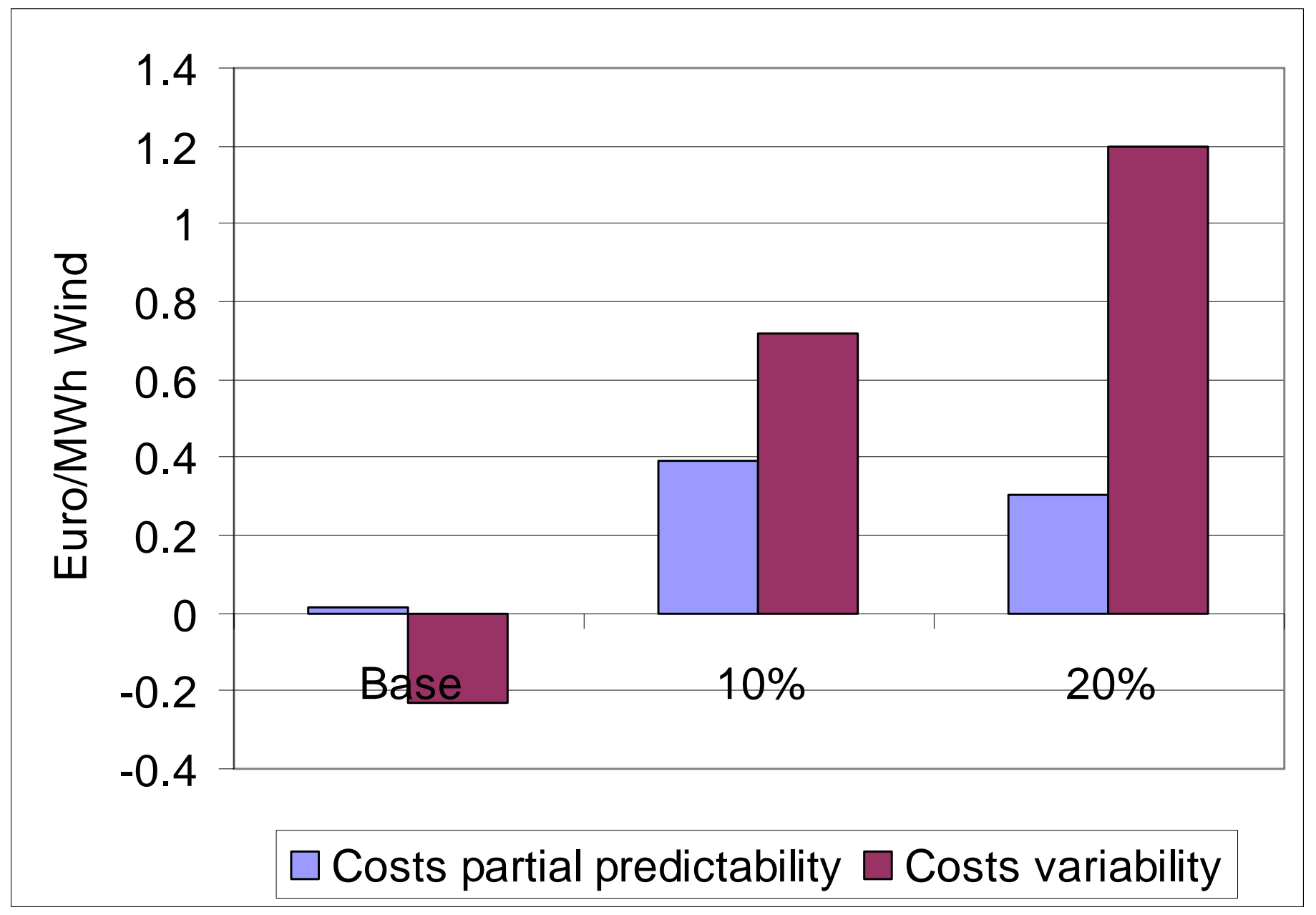




\section{Results}

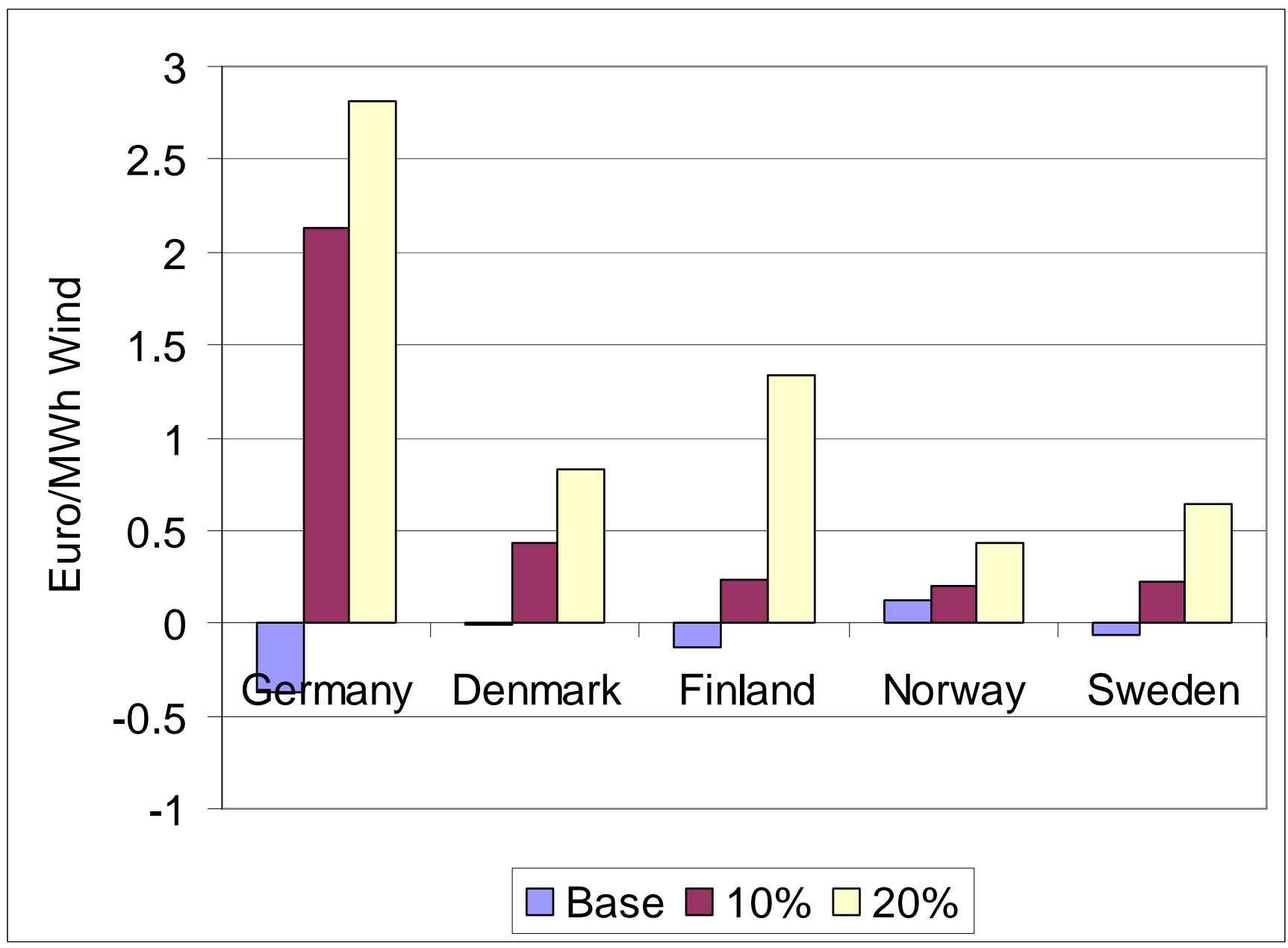

Difference in system operation costs per MWh wind power production for the three wind cases and divided on countries. 


\section{Discussion}

- Integration costs a ill-defined concept:

- Involves comparison with a hypothetical power system configuration (e.g. constant wind power production)

- What can the information be used for?

- We should use comparison of system costs and benefits in stead:

- Power system configurations with different amounts of wind

- Comparison should include:

- Investment costs (grid and plants)

- Operational costs

- Emissions $(\mathrm{CO} 2, \ldots)$

- Different scenarios for fuel prices and CO2

- Security of supply 


\section{Outlook}

- The development and usage of the Wilmar Planning tool is continued in

- SUPWIND: EU sixth framework programme project, www.supwind.risoe.dk

- All-Island Grid study: Irish wind integration study

- Anemos-plus: EU sixth framework programme project

- Model developments:

- Load uncertainty

- Forced outages

- Unit commitment with mixed integers

- Interaction with investment model

- Case studies:

- Irish case

- New Nordic and German cases

- Probably other European cases 
A COO LING SYS TEM FOR BUI LDINGS US ING WIND ENERGY

\author{
Hamid Daiyan
}

Azad University-Semnan Branch, Iran

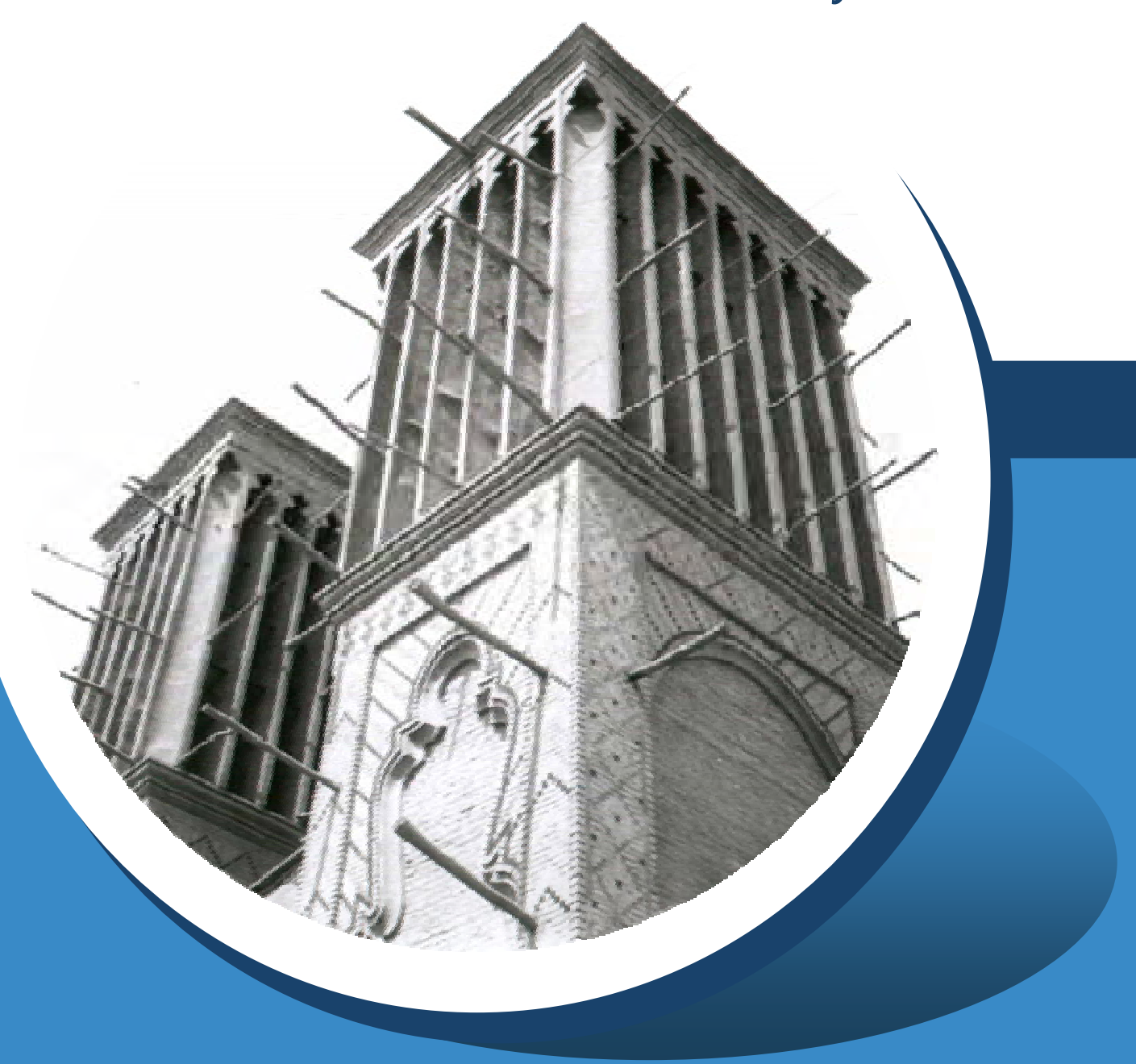

Risø International Energy

Conference 2007

Risø National Laboratory

22- 24 May 2007

Denmark 


\section{Contents}

Introduction

Kind Of Wind Tower

\section{Function of Wind Tower}

Case Study

Conclusion 


\section{Introduction}

In Iranian historical architecture wind tower is used for cooling and ventilation. Wind tower is a tall structure that stands on building. Wind tower is used in dray land, and only uses wind energy for conditioning.

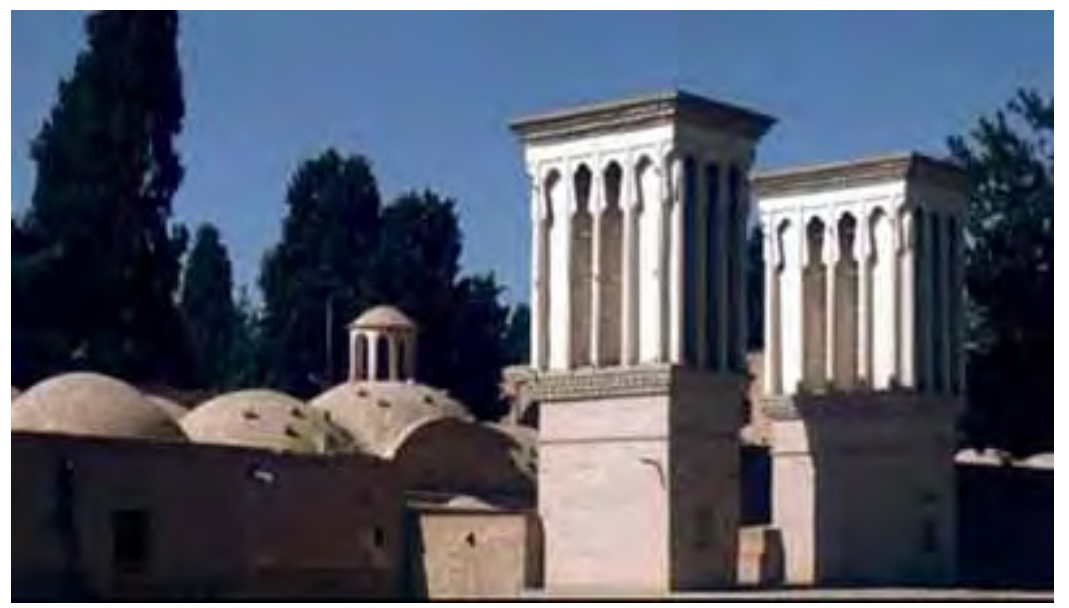




\section{Introduction}

It technologies date back over 1000 years. It technologies date back over 1000 years. Wind towers were designed according to several parameters, some of the most important of which were building type, cooling space volume, wind direction and velocity and ambient temperature.

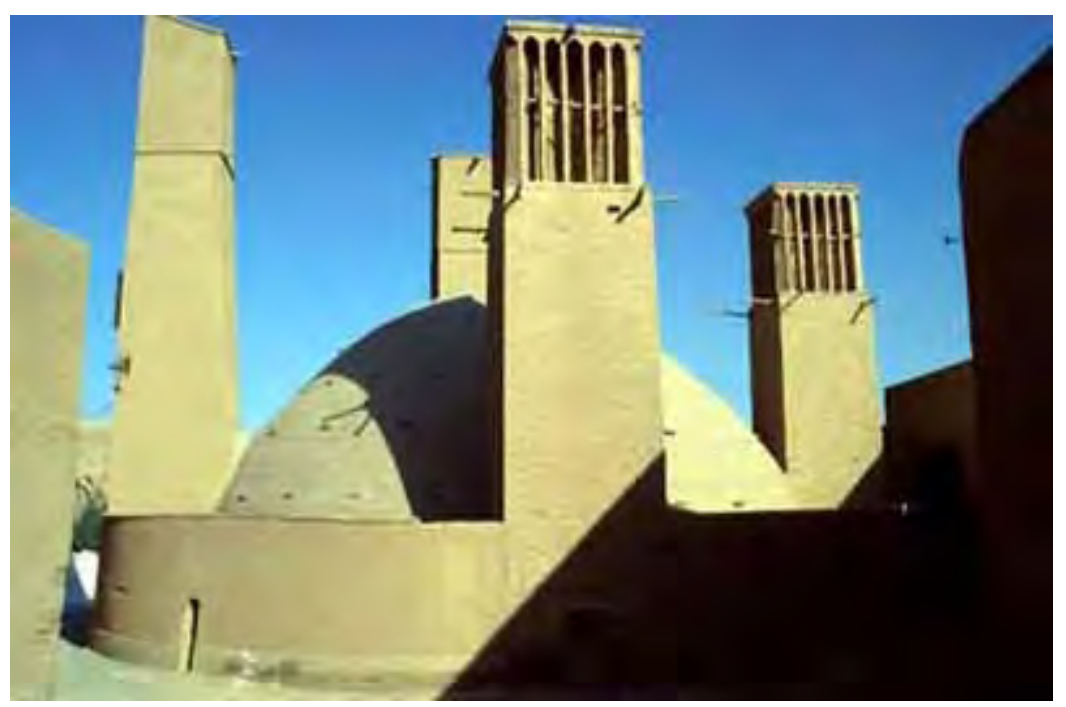




\section{Introduction}

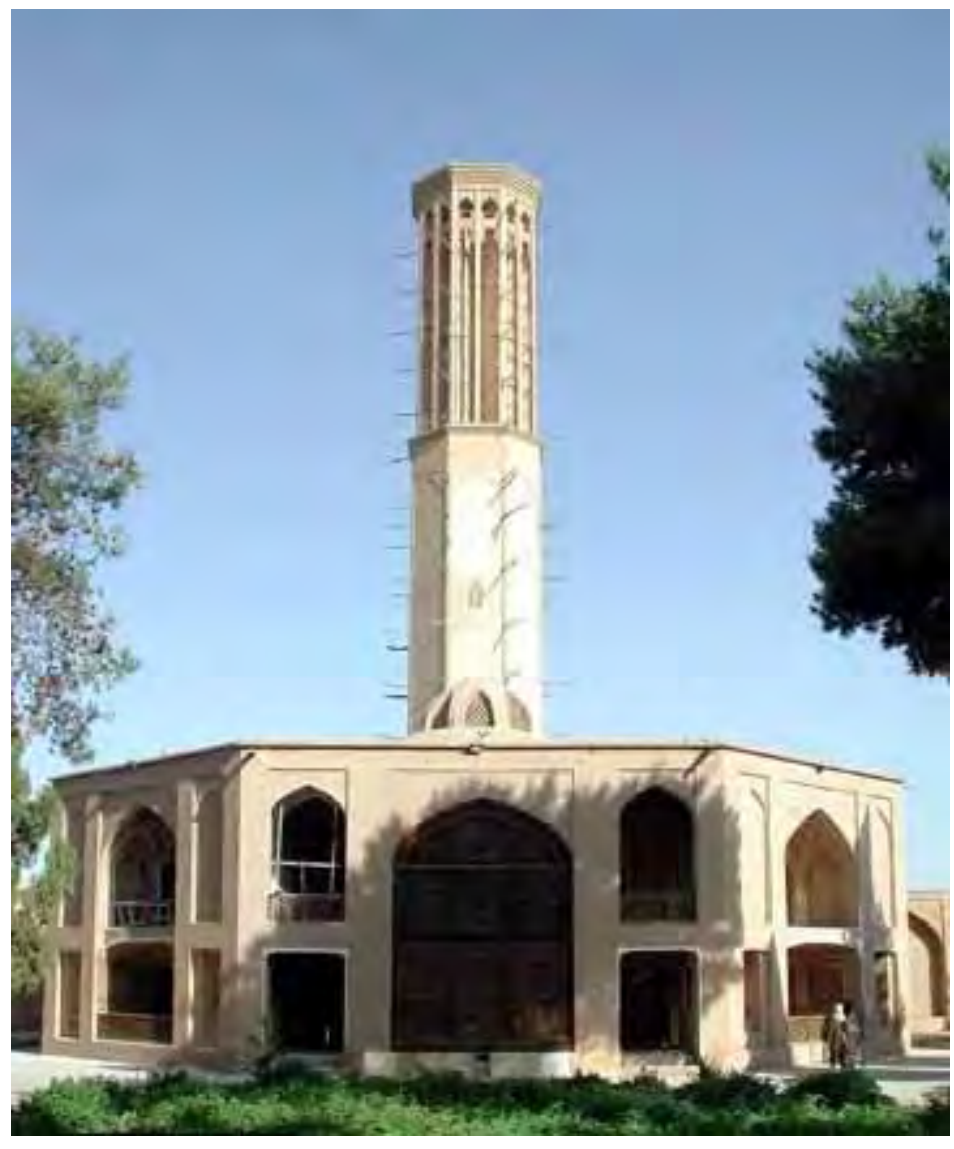

Wind tower of Doulat-Abad garden of Yazd with it's altitude is 33 meters and 80 centimeter. It is highest wind tower in Iran. It has built in 1750 . This wind tower has octagon plan. It can receive wind from eight directions and conduct it inside of room. 
1) Square and octagon wind tower is suitable for regions that direction of pleasant wind is various, specially in the warm seasons that some times pleasant wind blows from north to south and some times from east to west.

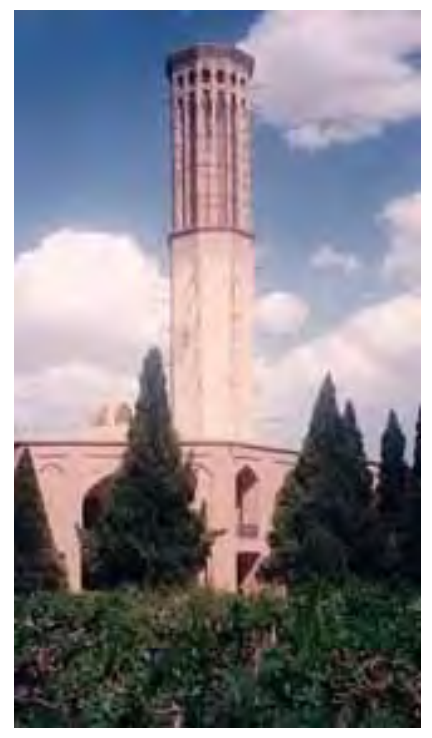

An octagon wind tower in Yazd 
2) Rectangular wind tower has built in the area that direction of wind is from north-east to south-west. For this reason architectures make it in front of big surface of outward appearance.

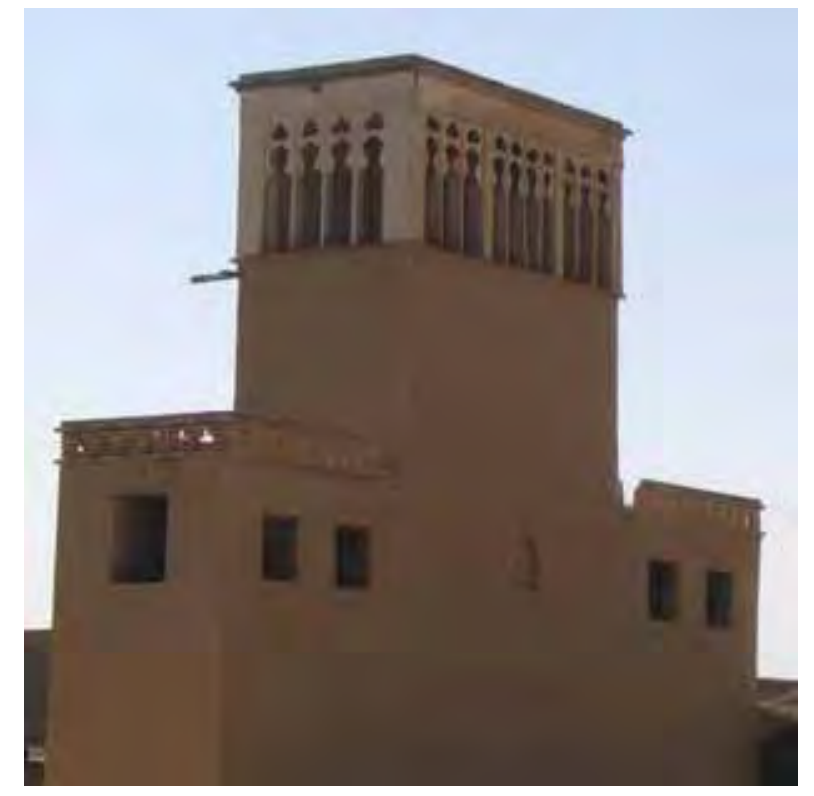

A rectangular wind tower in Semnan 
3) In the villages of edge of desert and villages of inside of desert to avoid harm of whirlwind and storm architectures make it only direction, it has made north-east and other sides have been closed. Its direction is to the mountain breeze. 


\section{Function of Wind Tower}

Function of wind tower basically constructed method of utilization from blowing of wind to take pleasant air in to building and use from its reflection energy to suck for drive away hot and polluted weather.

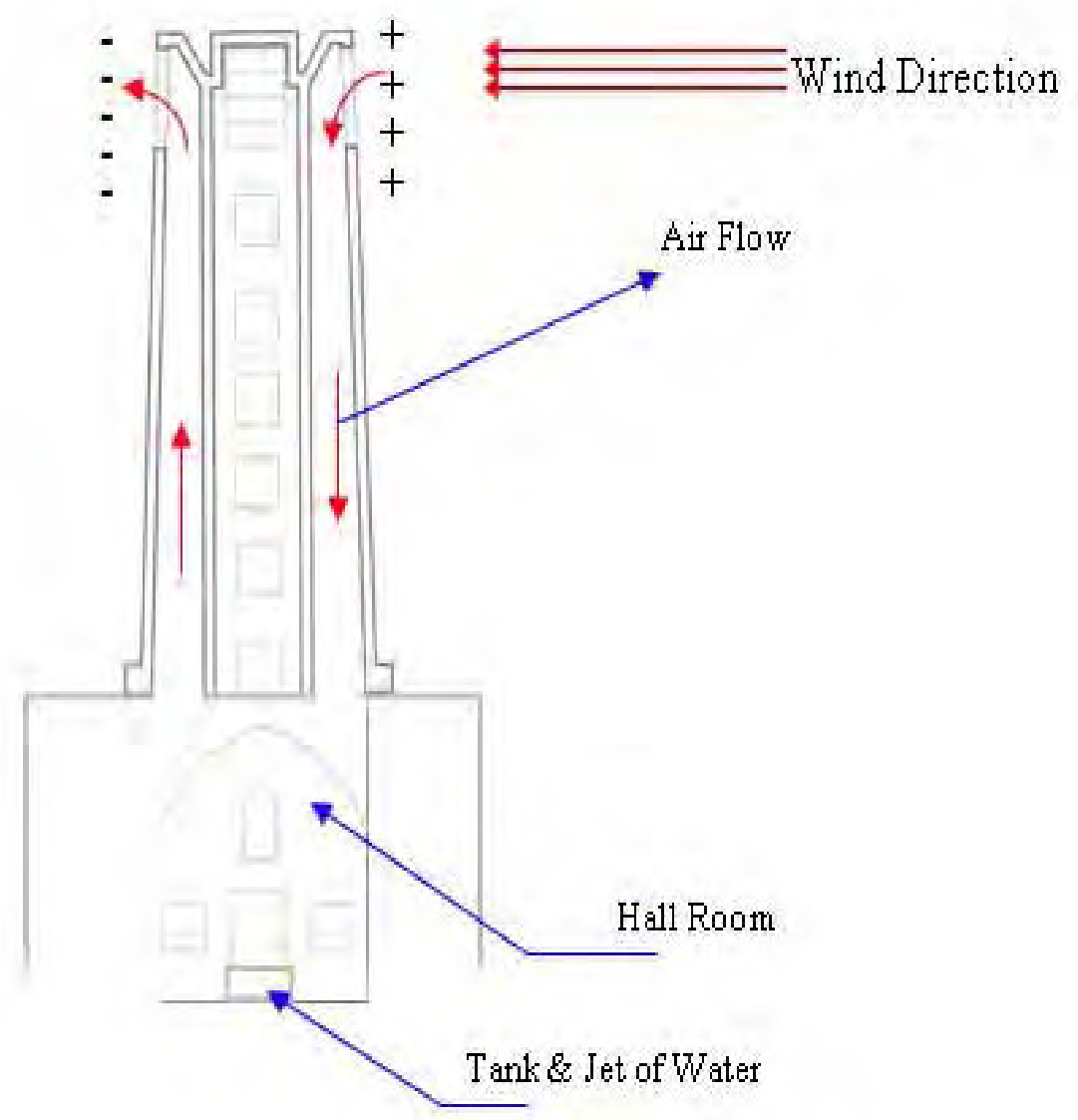




\section{Function of Wind Tower}

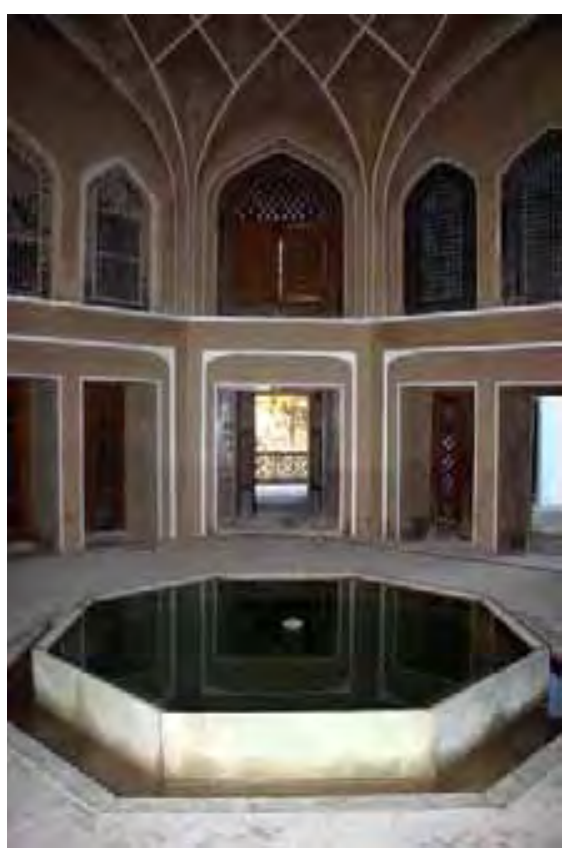

Dry weather that wind tower receives path above of little pool and fountain it becomes cool by method of evaporation and goes into the room. 


\section{Case Study}

This section indicates conclusion of inside and outside temperature of building that has equipped wind tower in one of summer hot day. This specimen ventilation has been made about 135 years ago in south of Semnan it's high is 20 meters. It is highest wind tower of Semnan.

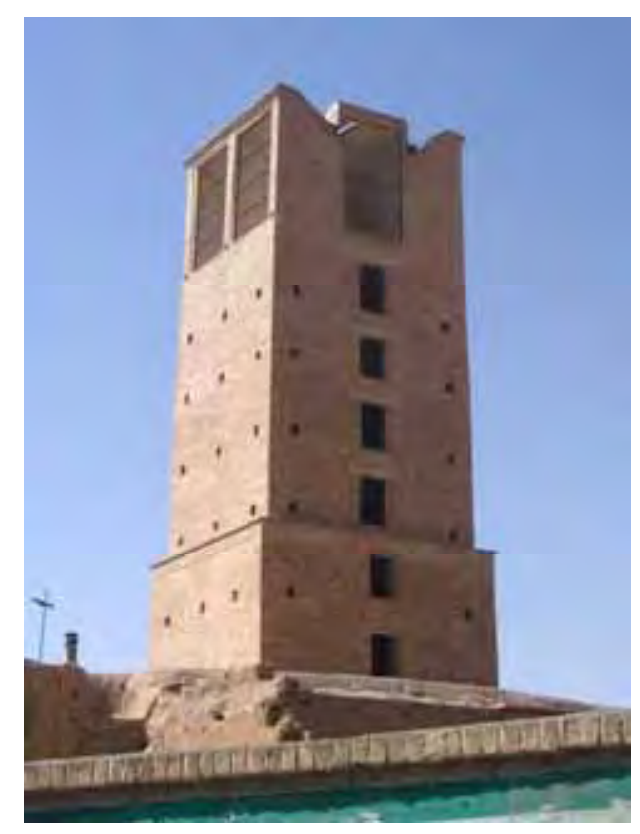




\section{Case Study}

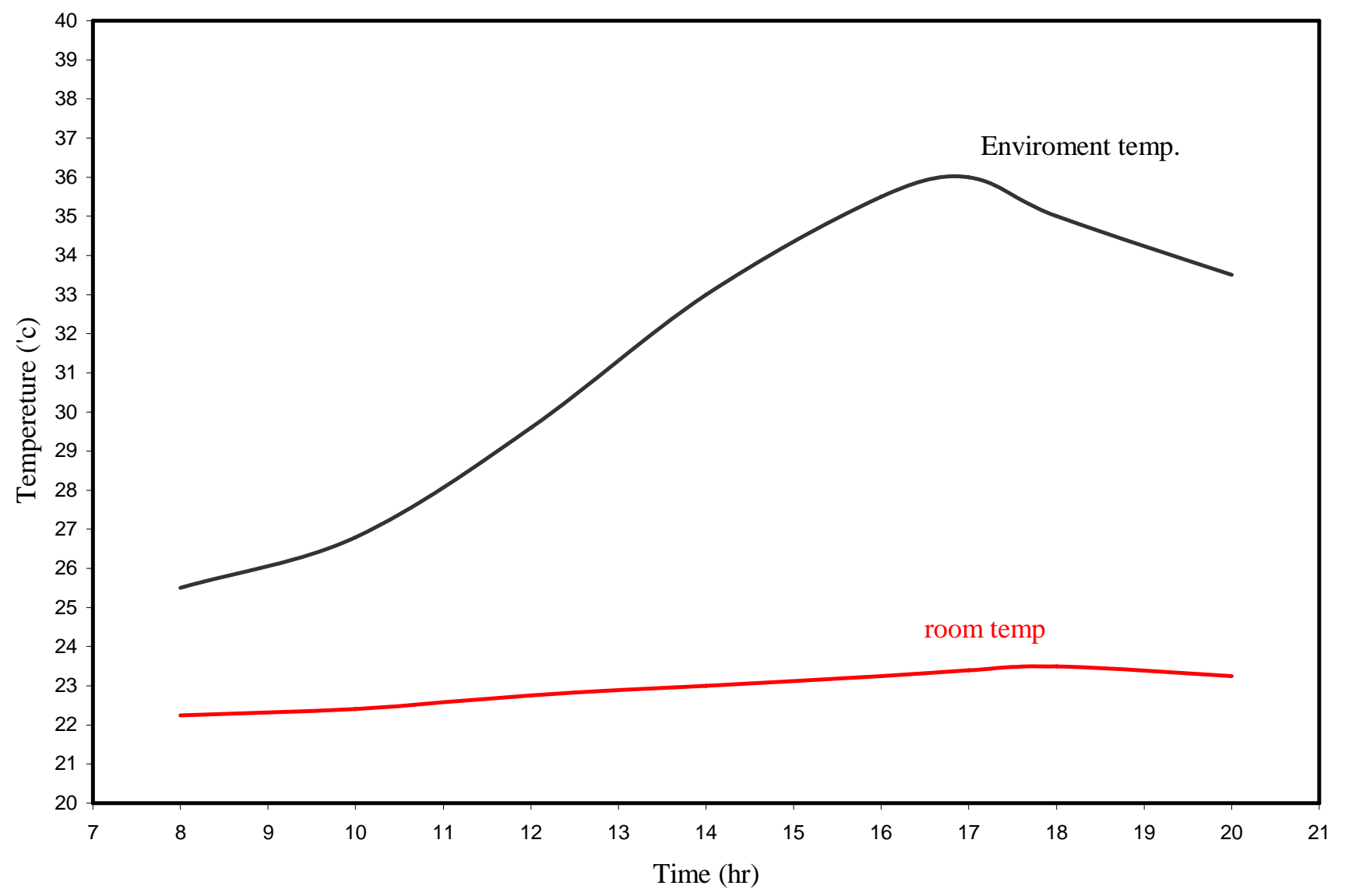

Room temperature comparison 


\section{Conclusion}

As shown in above graph wind tower can moderate weather of room. Other important point is fixing temperature of room and keeps it in suitable situation. Above graph shown average degree of environment in the outside is $32^{\circ} \mathrm{C}$ and average temperature of room is $23^{\circ} \mathrm{C}$. It is desirable weather in the warm area. 
Thank you very much for your attention

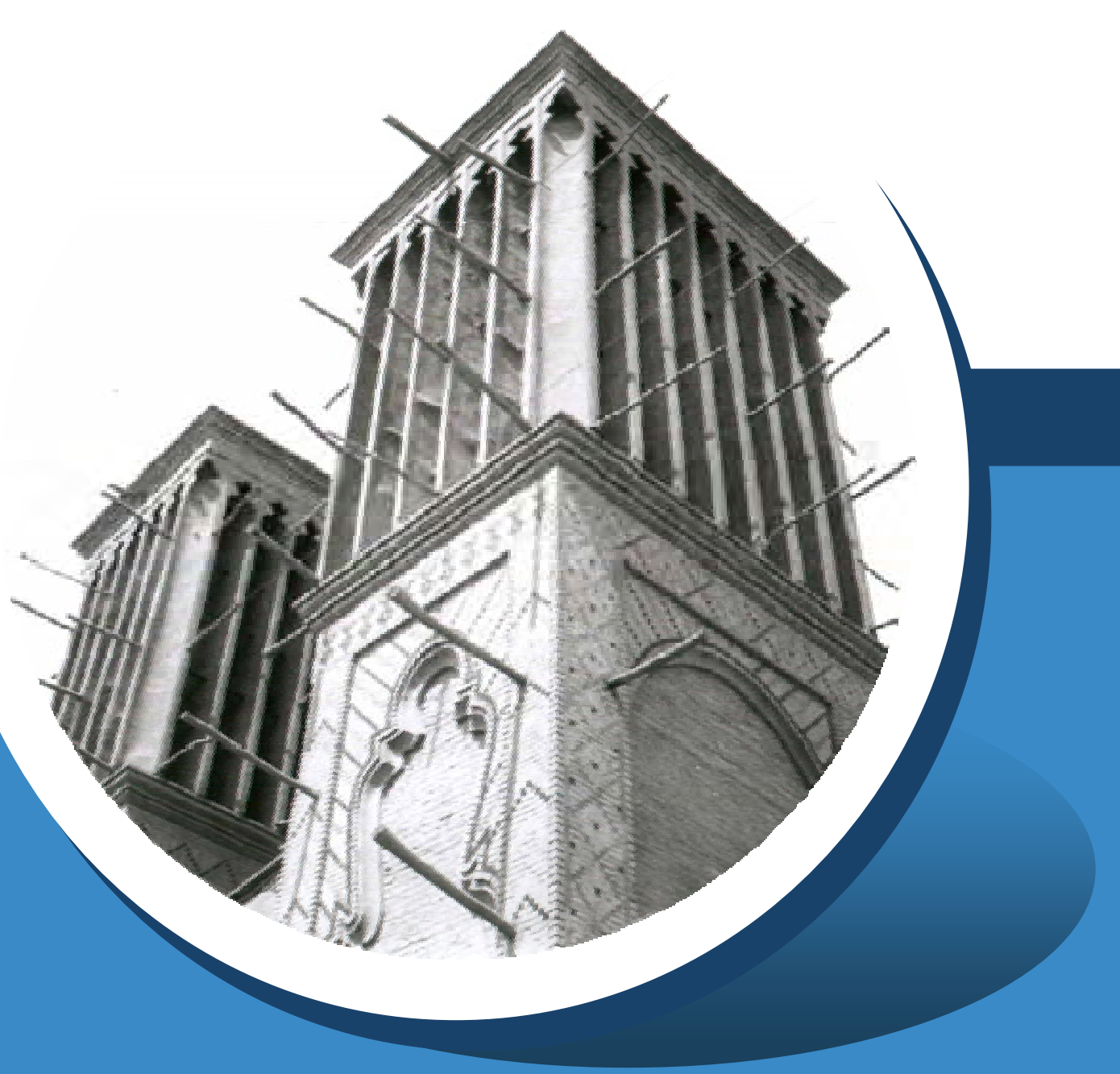

Risø International Energy Conference 2007

Risø National Laboratory

22- 24 May 2007 Denmark 


\title{
Energy Demand Patterns
}

\section{The Effects Substitution and Productivity}

\author{
Nico Bauer \\ Potsdam Institute for Climate Impact Research (PIK)
}

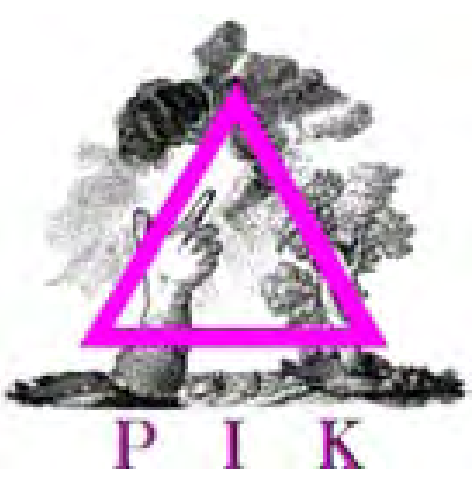




\section{Contents}

- Production theory

- Substitution

- Biased technological change

- Separability

- Econometric framework

- Results

- Discussion and further research 


\section{Contents}

- Production theory

- Substitution

- Biased technological change

- Separability

- Econometric framework

- Results

- Discussion and further research

Nico Bauer

Potsdam Institute for Climate Impact Research
Risø International Energy Conference

May 22 - 24, 2007 


\section{Contents}

- Production theory

- Substitution

- Biased technological change

- Separability

- Econometric framework

- Results

- Discussion and further research

Nico Bauer

Potsdam Institute for Climate Impact Research
Risø International Energy Conference

May 22 - 24, 2007 


\section{Contents}

- Production theory

- Substitution

- Biased technological change

- Separability

- Econometric framework

- Results

- Discussion and further research

Nico Bauer

Potsdam Institute for Climate Impact Research
Risø International Energy Conference

May 22 - 24, 2007 


\section{Contents}

- Production theory

- Substitution

- Biased technological change

- Separability

- Econometric framework

- Results

- Discussion and further research

Nico Bauer

Potsdam Institute for Climate Impact Research
Risø International Energy Conference

May 22 - 24, 2007 


\section{Contents}

- Production theory

- Substitution

- Biased technological change

- Separability

- Econometric framework

- Results

- Discussion and further research

Nico Bauer

Potsdam Institute for Climate Impact Research
Risø International Energy Conference

May 22 - 24, 2007 


\section{Contents}

- Production theory

- Substitution

- Biased technological change

- Separability

- Econometric framework

- Results

- Discussion and further research

Nico Bauer

Potsdam Institute for Climate Impact Research
Risø International Energy Conference

May 22 - 24, 2007 


\section{Production Theory}

- Aggregate production function $f()$

- Output y

- Inputs $X$

- Prices $p$

$y=\left[\left(a_{1} x_{1}\right)^{\rho}+\left(a_{2} x_{2}\right)^{\rho}\right]^{1 / \rho}$;

$$
\sigma=(1+\rho)^{-1}=-\frac{\partial x / x}{\partial p / p} .
$$

- Optimal Factor Allocation

- Marginal productivities equal prices

$$
p_{i}=\frac{\partial y}{\partial x_{i}} \quad \Leftrightarrow \quad x=\tilde{f}(p) .
$$




\section{Production Theory}

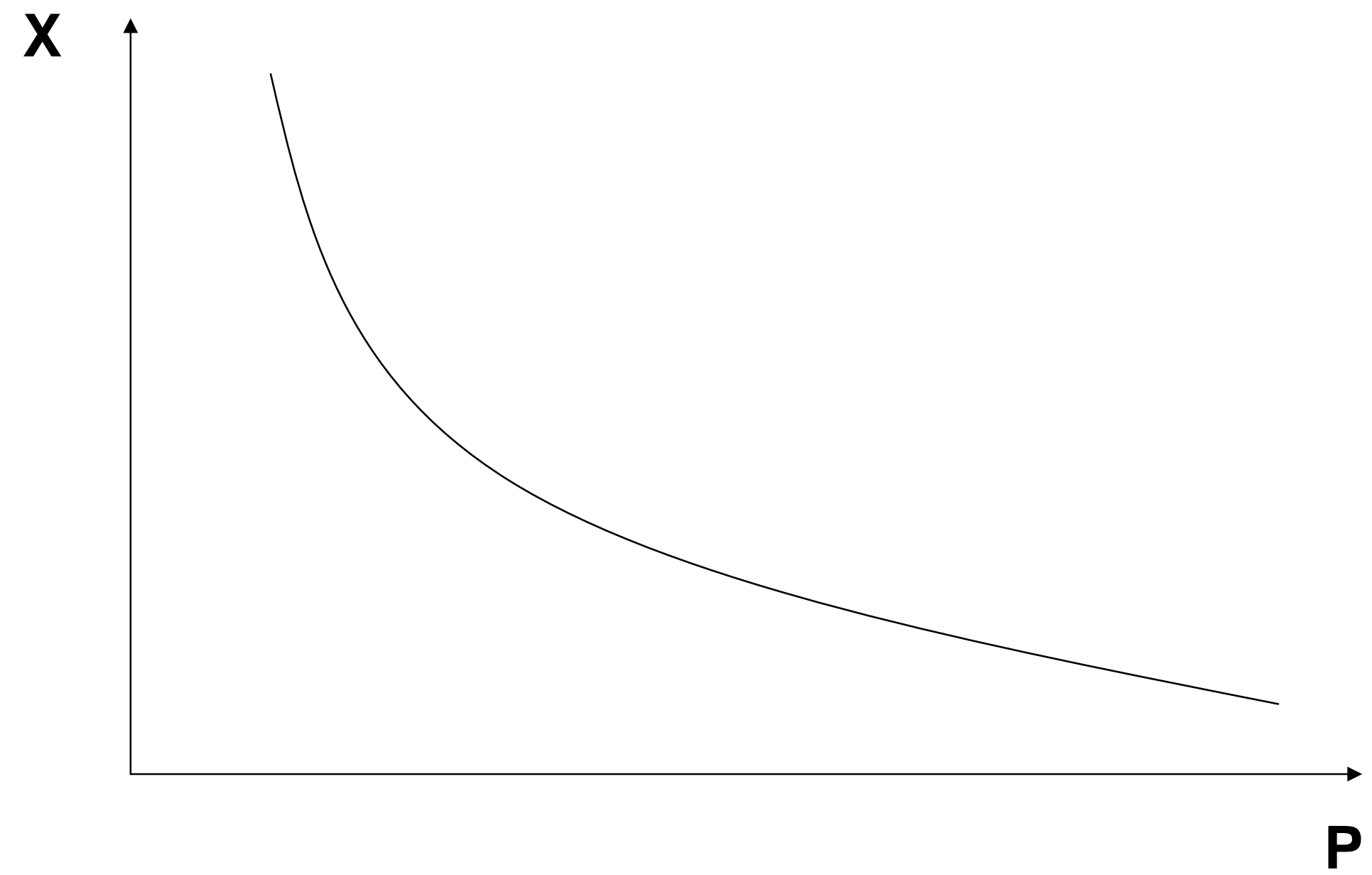




\section{Production Theory}

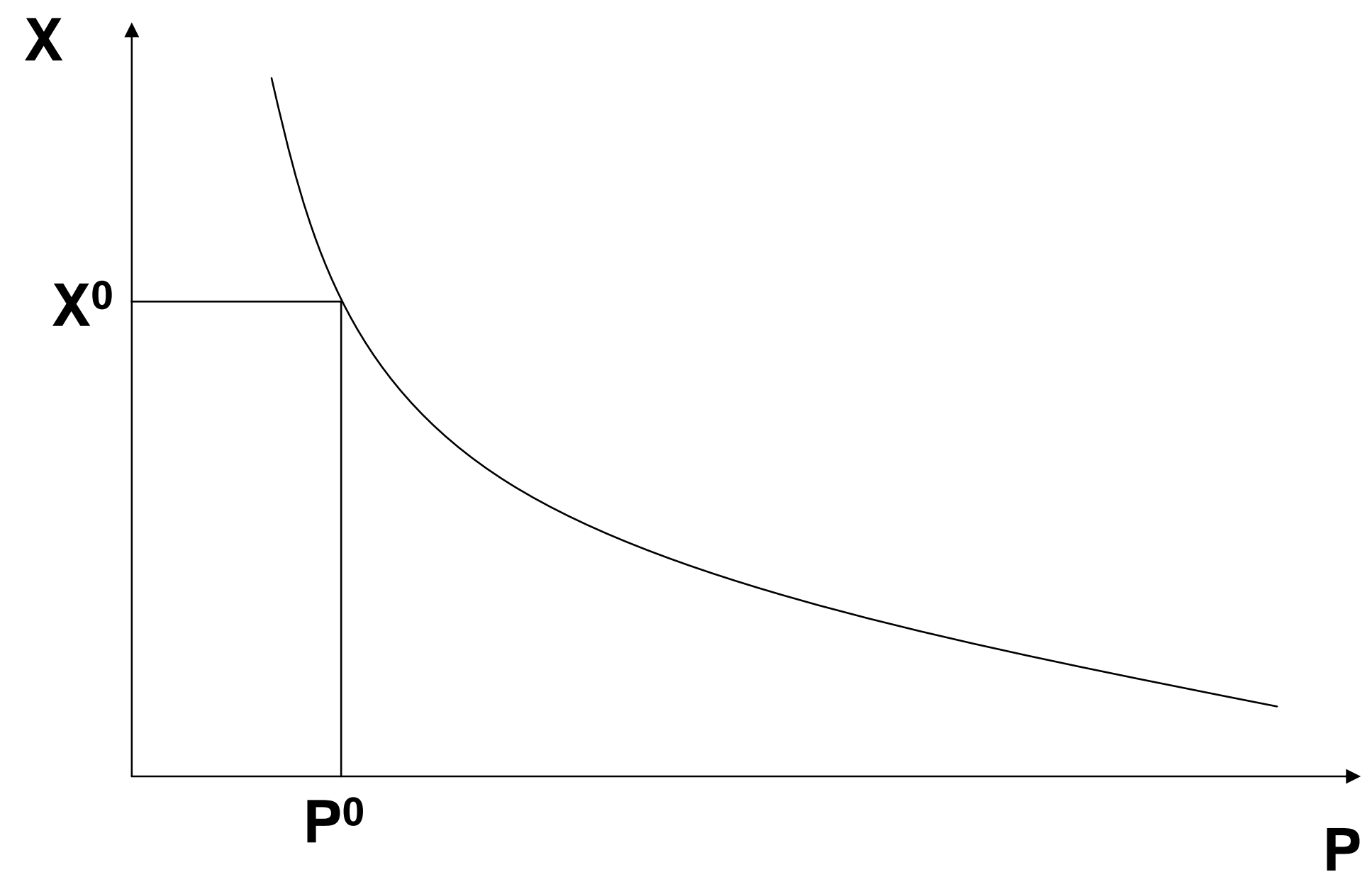




\section{Production Theory}

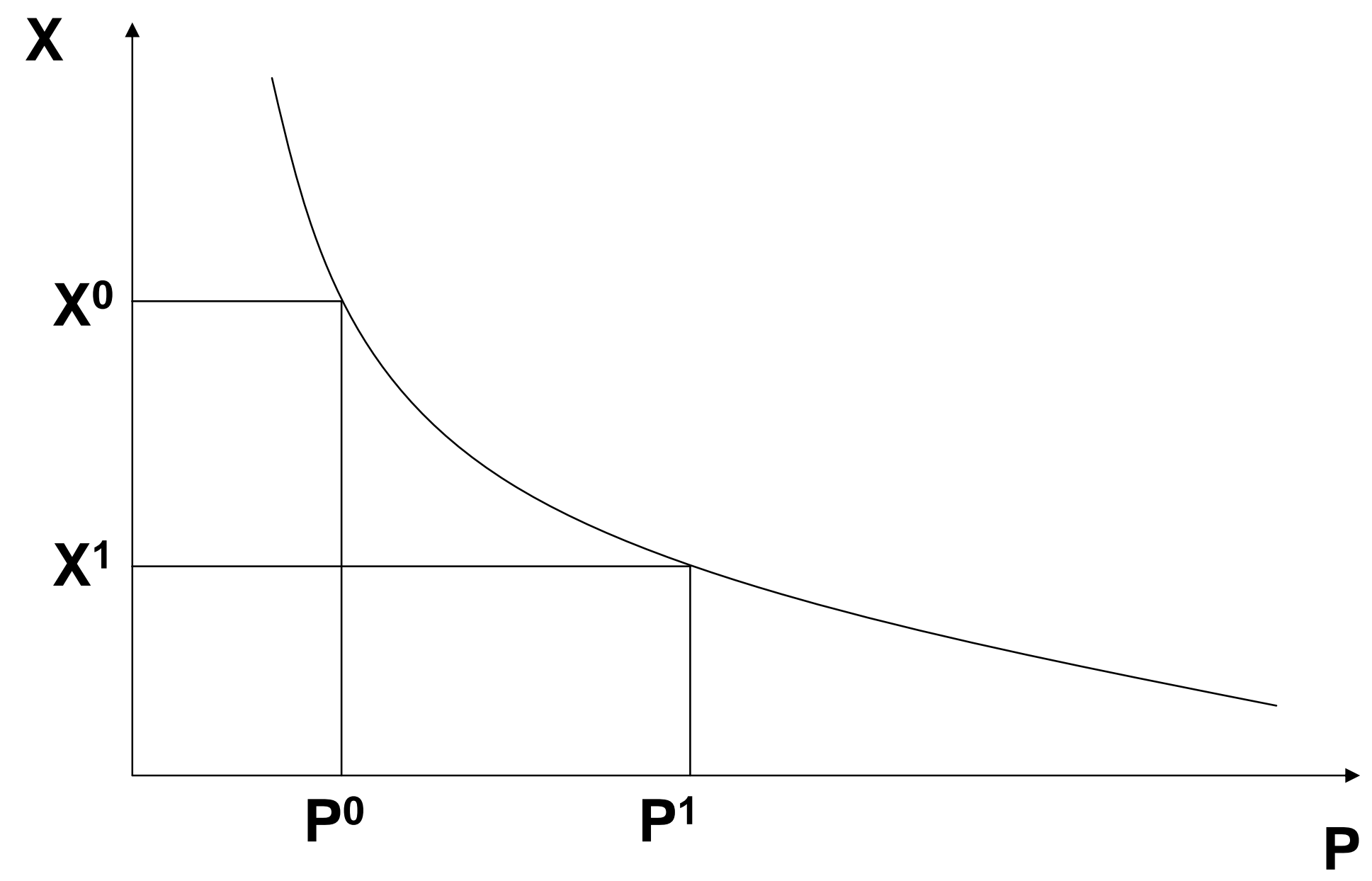




\section{Production Theory}

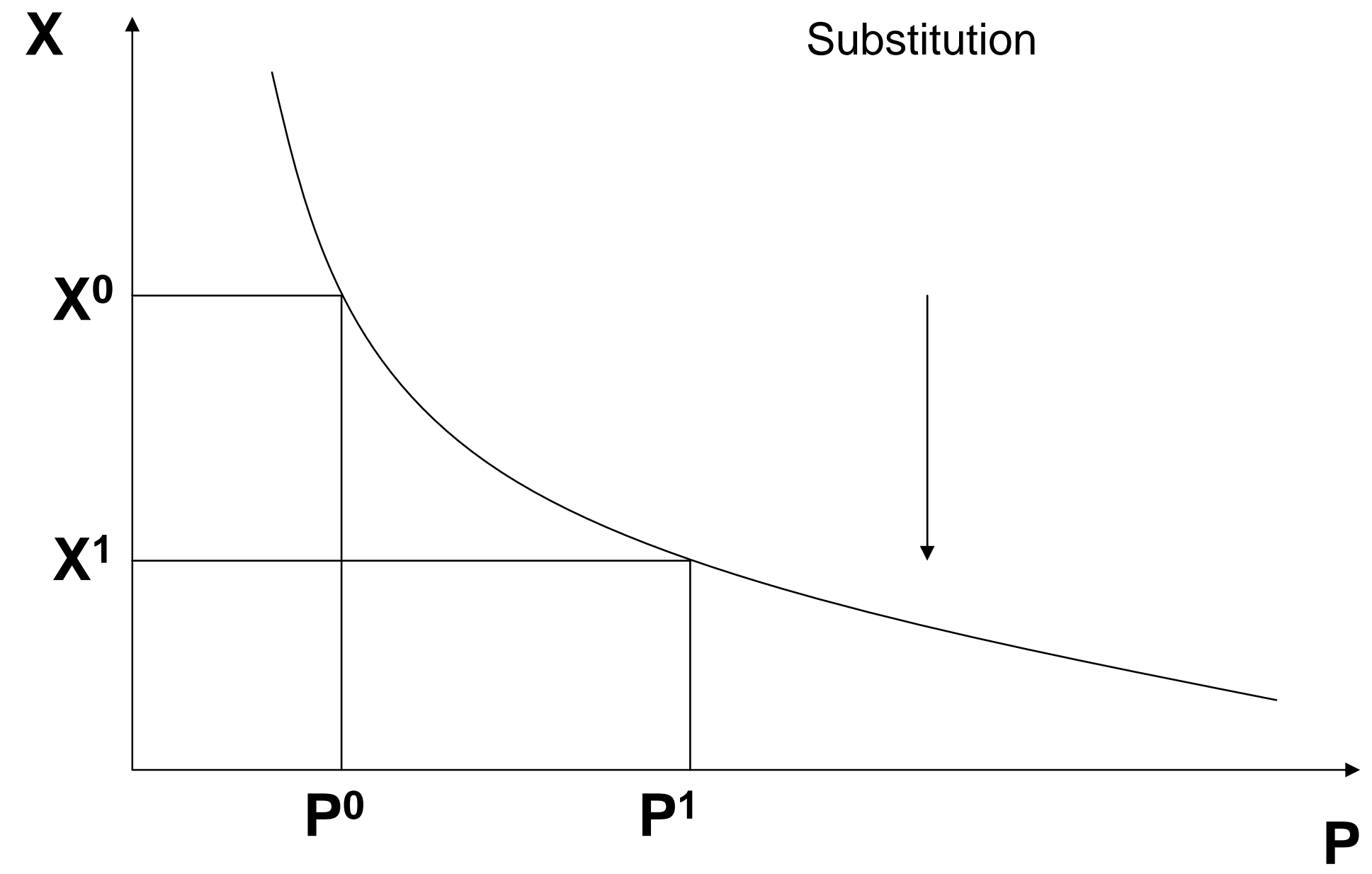




\section{Production Theory}

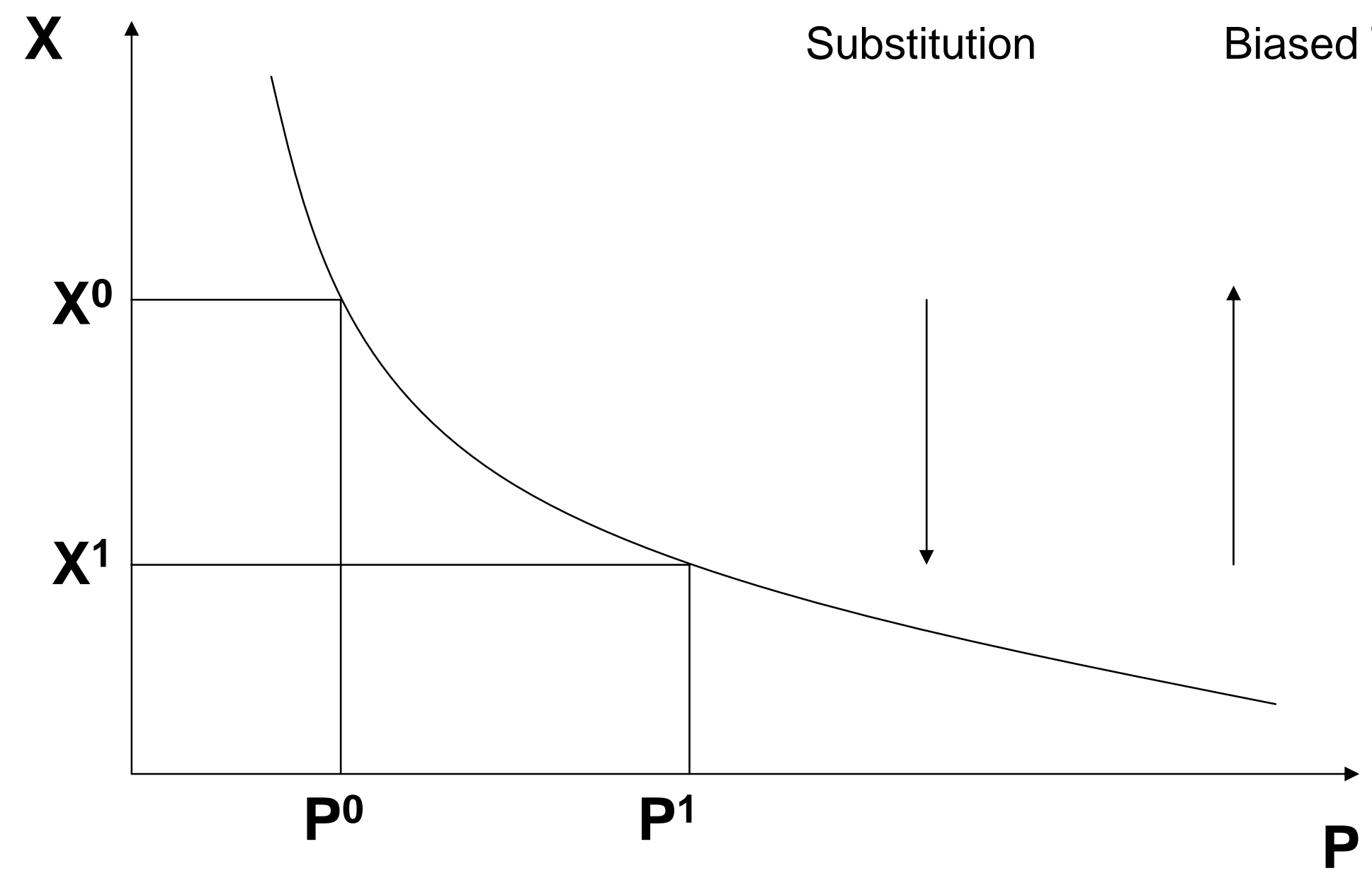




\section{Production Theory}

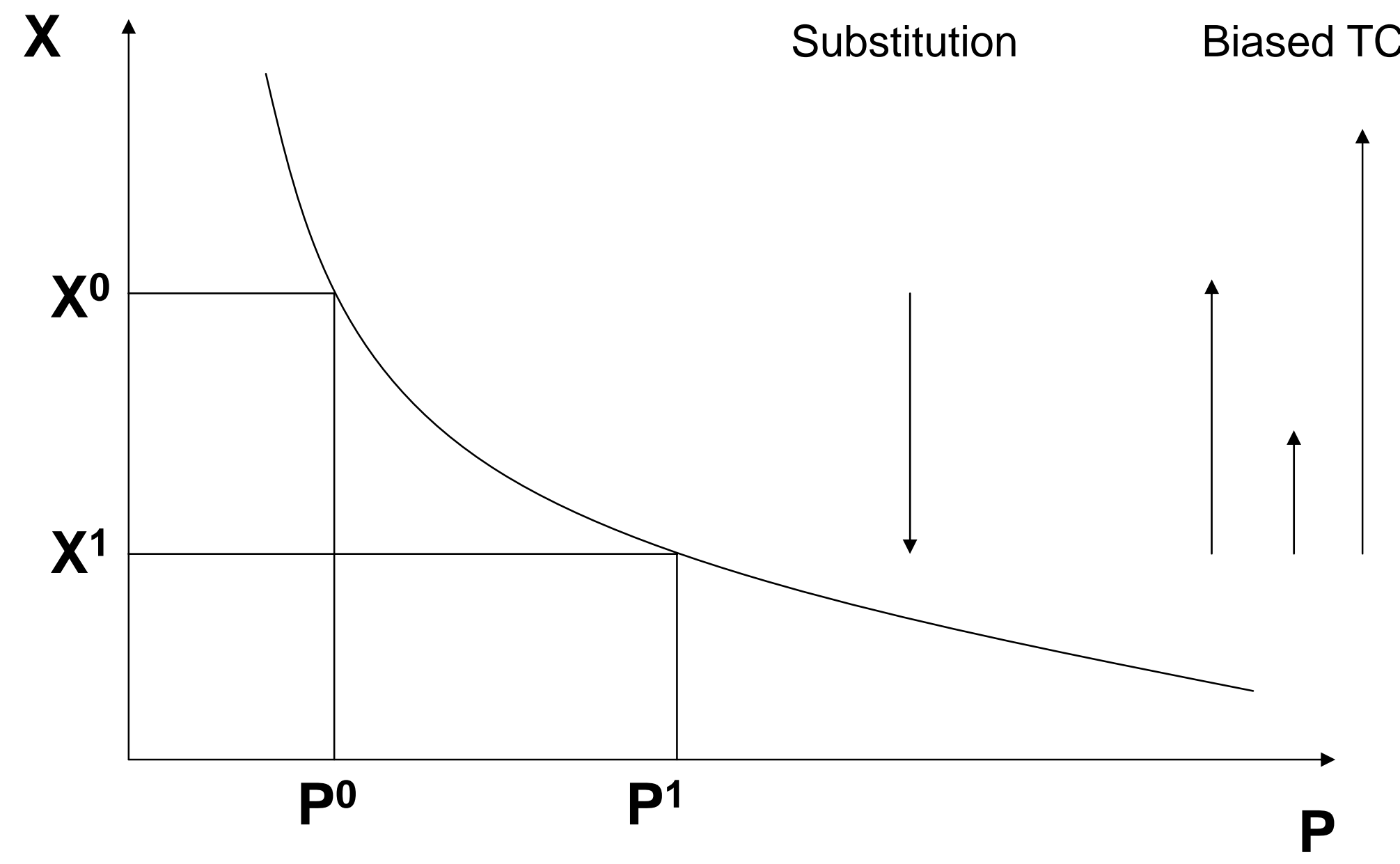




\section{Production Theory}

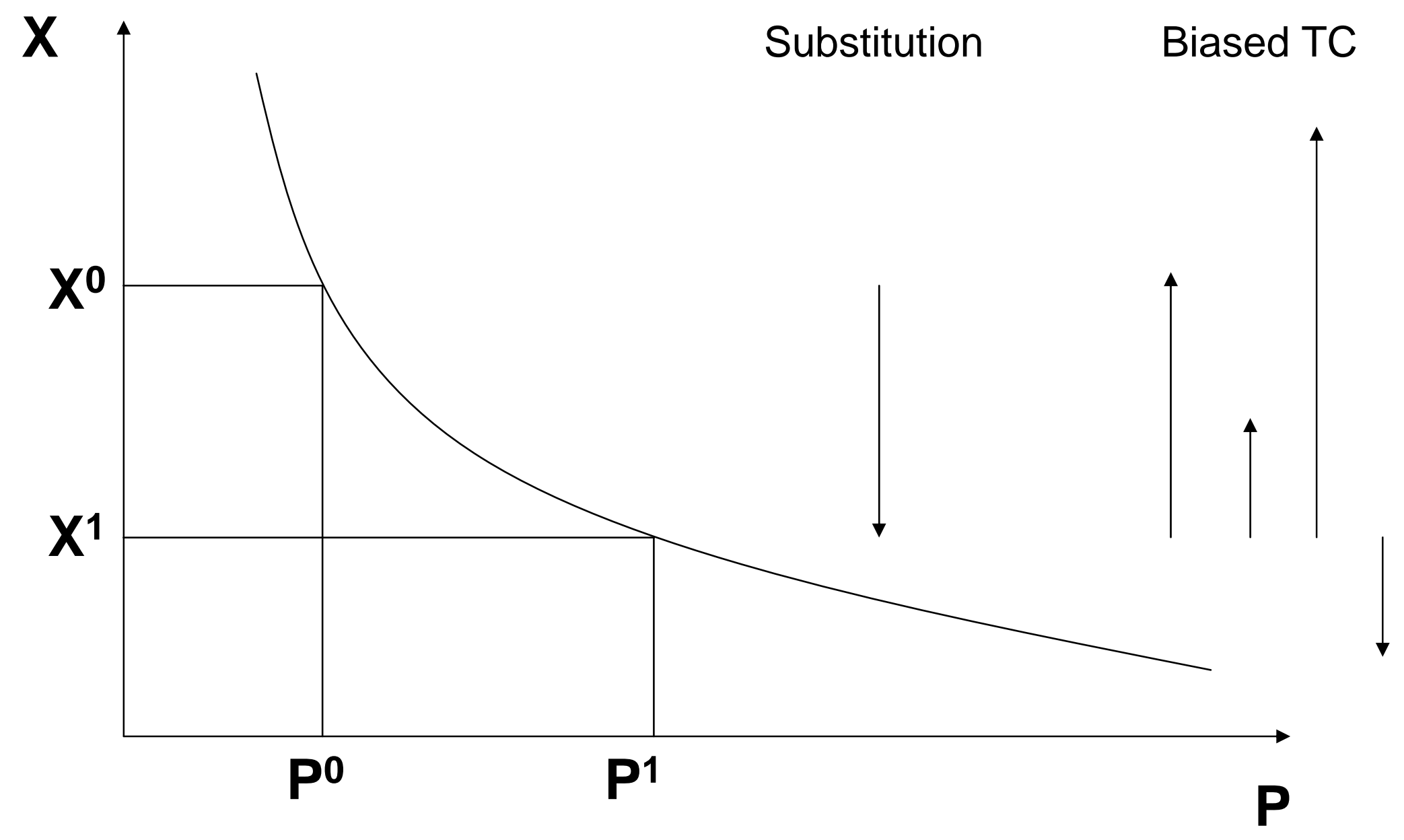




\section{Production Theory}

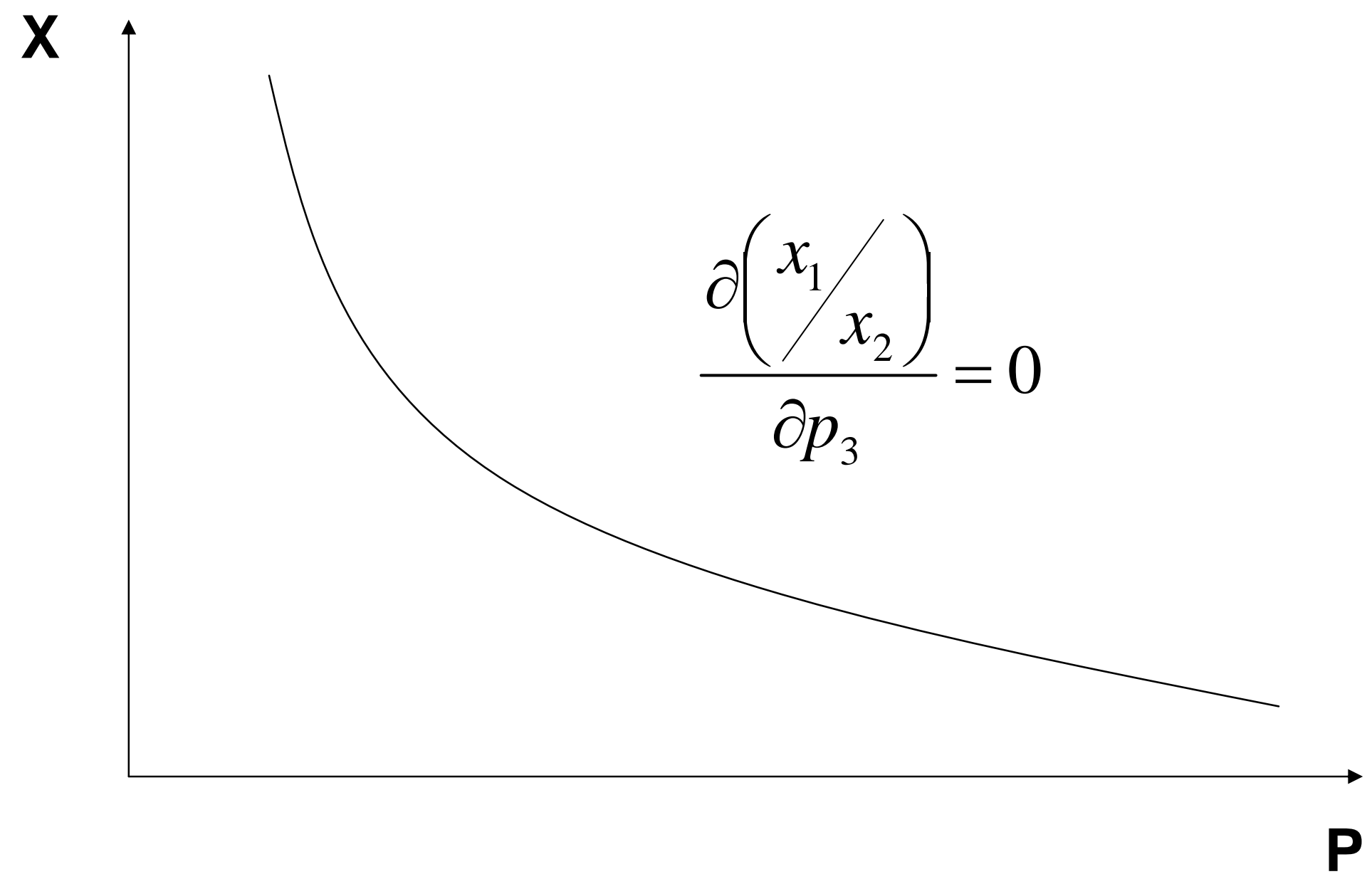




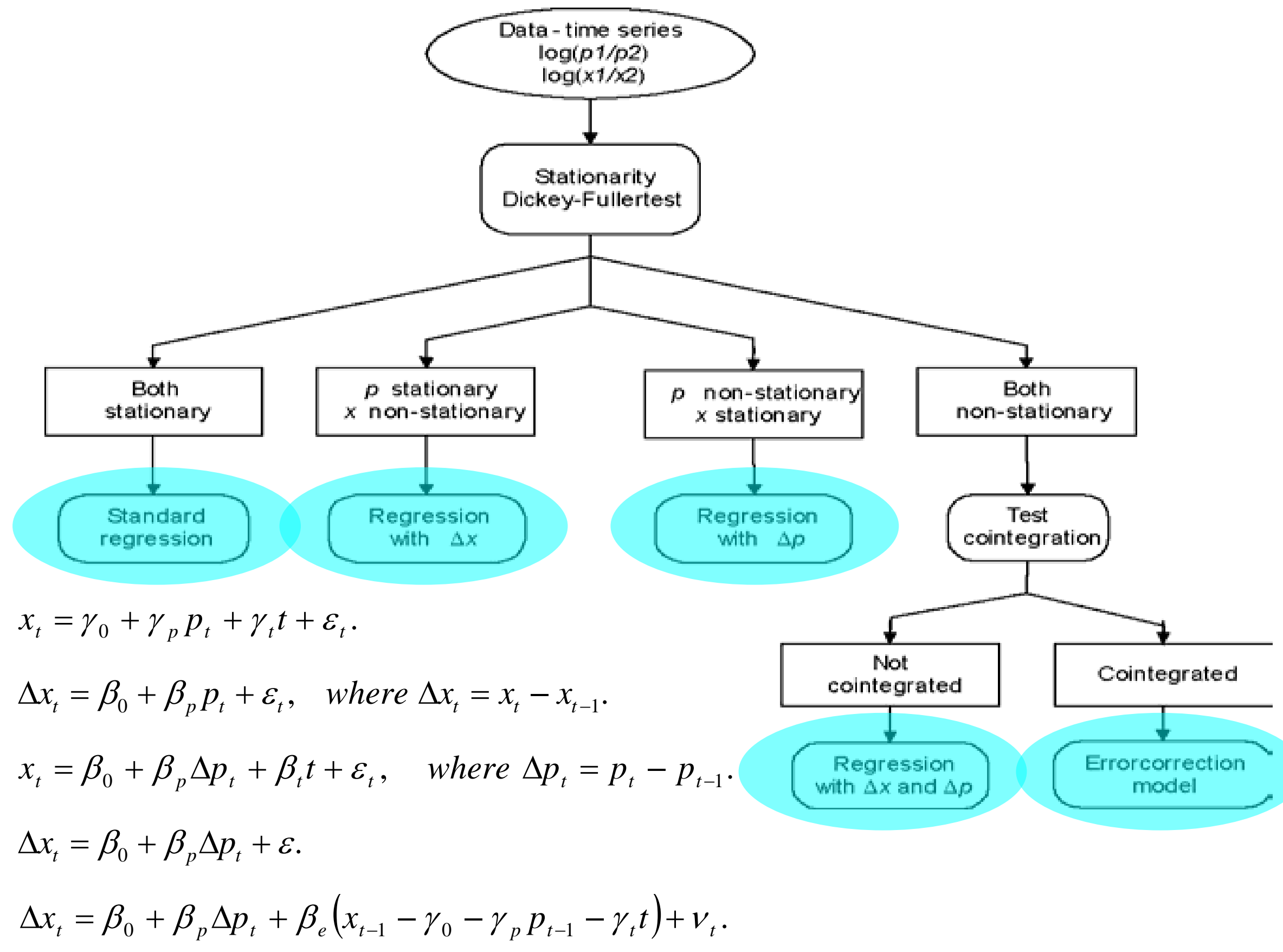




\section{Results - Overview}

- Nearly all energy ratios are trended; not so much price ratios

- High share of ratios is non-stationary

$\rightarrow$ models with differences

- Substitution: rarely significant

- BTC: significant with many structural breaks

Nico Bauer

Potsdam Institute for Climate Impact Research
Risø International Energy Conference

May 22 - 24, 2007 


\section{Results - Gas-Oil}

- Trend to gas $\rightarrow$ Ö, Bel, CH, J, NL, SP

- Slowed down $\rightarrow$ Cz93, F85, D85, 192, UK89

- Switch to oil $\rightarrow$ SI92, USA88

- Trend to oil $\rightarrow$ Mex

- 3 of 24 substitution parameters significant, ...

- One having the wrong sign. 


\section{Results - Gas-Coal}

- Trend to coal $\rightarrow$ Bel

- Trend to gas $\rightarrow \mathrm{F}, \mathrm{J}, \mathrm{SI}, \mathrm{US}$

- Accelerated $\rightarrow \mathrm{CH} 91, \mathrm{D} 89, \mathrm{UK} 92$

- Slowed down $\rightarrow$ Cz92

- Switch to gas $\rightarrow$ Ö85, 185

- Switch to coal $\rightarrow$ T93

- 2 of 21 substitution parameters significant 


\section{Results - Oil-Coal}

- Trend to coal $\rightarrow$ Ö, Bel, NL, Nor

- Trend to oil $\rightarrow \mathrm{Cz}, \mathrm{J}, \mathrm{UK}, \mathrm{SI}$

- Switch to oil $\rightarrow$ CH87, F90, D89, I85, US91

- 6 of 22 substitution parameters significant, ...

- One having the wrong sign. 


\section{Discussion}

- Low evidence for substitution

- High evidence for BTC; structural breaks

- Countries show different patterns

- What may explain BTC? 


\section{Discussion}

- Investments and depreciation re-structure capital stock

- Changes relative energy demands

- Investments determined not only by energy prices

- Contradiction with separability assumption!

- BTC can capture changed energy demand due to capital stock restructuring

- Problem: how to endogenise BTC? 


\section{Further Research}

- Improvement of data

- Sectoral resolution

- Investment data

- Theoretical analysis

- Bottom-up vs. top-down $\rightarrow$ capital theory

- Separability and BTC

- Integrated modeling

- Pragmatic approach: exogenous BTC

- Scenarios, sensitivity analysis 


\section{STREAM: \\ A Model for a Common Energy Future}

Risø Energy Conference, 24 May 2007

Peter Markussen

DONG Energy Generation 


\section{Background}

- The future Danish Energy System (2004-2007)

- Initiated by The Danish Board of Technology

- Public body established by the Danish parliament

- Project content

- Open scenario process

- Quantification of scenarios

- www.tekno.dk 


\section{Goal of the project}

- Lay dawn objective and possible futures for the Danish Energy System

- Steering group to agree on the process and overall goals for scenarios

- 10 interested parties from the energy sector and NGO's

- Working group to supply a modeling tool and facts:

- Mette Behrmann, Jens Pedersen (Energinet.dk)

- Kenneth Karlsson (Risø)

- Anders Kofoed-Wiuff, Jesper Werling (EA Energianalyse)

- Peter Markussen (DONG Energy)

\section{TEKNOLOGI-RÅDET}




\section{Agenda}

1. The scenario process

2. The results

3. The modelling tool

- Energy savings model

- The time series model

- The energy flow model

4. Perspectives 


\section{Agenda}

1. The scenario process

2. The results

3. The modelling tool

- Energy savings model

- The time series model

- The energy flow model

4. Perspectives 


\section{The scenario process}

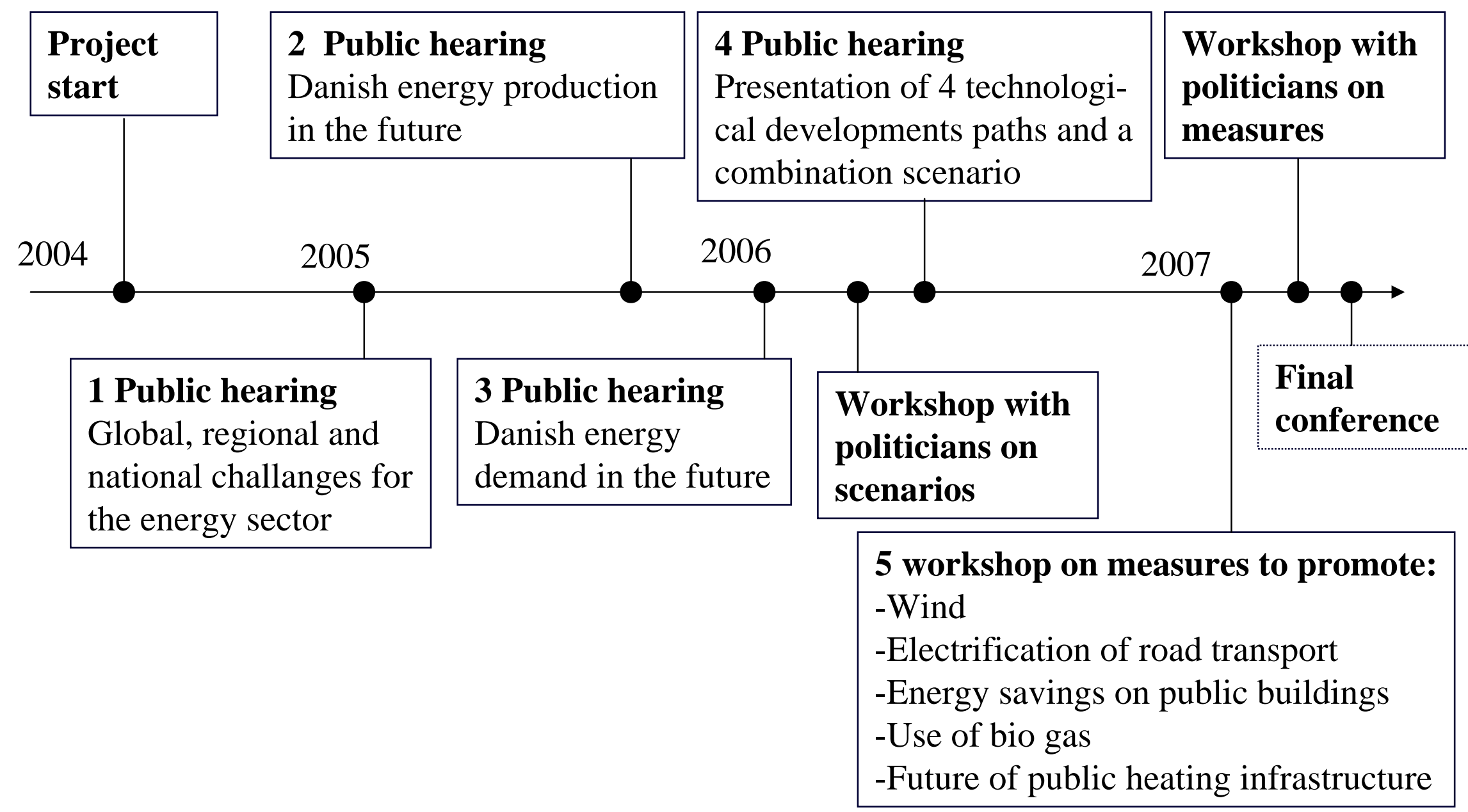

\section{TEKNOLOGI-RẢDET}




\section{Quantitative targets}

- Reduce CO2 emissions by 50\% in 2025 compared to 1990

- Reduce oil consumptions by $50 \%$ in 2025 compared to 2003

- Take into account global responsibility and national economics 


\section{Agenda}

1. The scenario process

2. The results

3. The modelling tool

- Energy savings model

- The time series model

- The energy flow model

4. Perspectives 


\section{4 technological scenarios to 2025}

\begin{tabular}{|l|l|}
\hline$A^{+}$Cost savings & Gas \\
- Energy savings \\
-Zero energy buildings
\end{tabular}

\section{TEKNOLOGI-RÅDET}




\section{The Combination scenario}

- Combination of the 4 technology scenarios

- Inspiration from the workshop with politicians

- Savings and increased electricity production from wind and biomass for transport. Gas as back up for wind. 


\section{The Combination Scenario Fuel use}

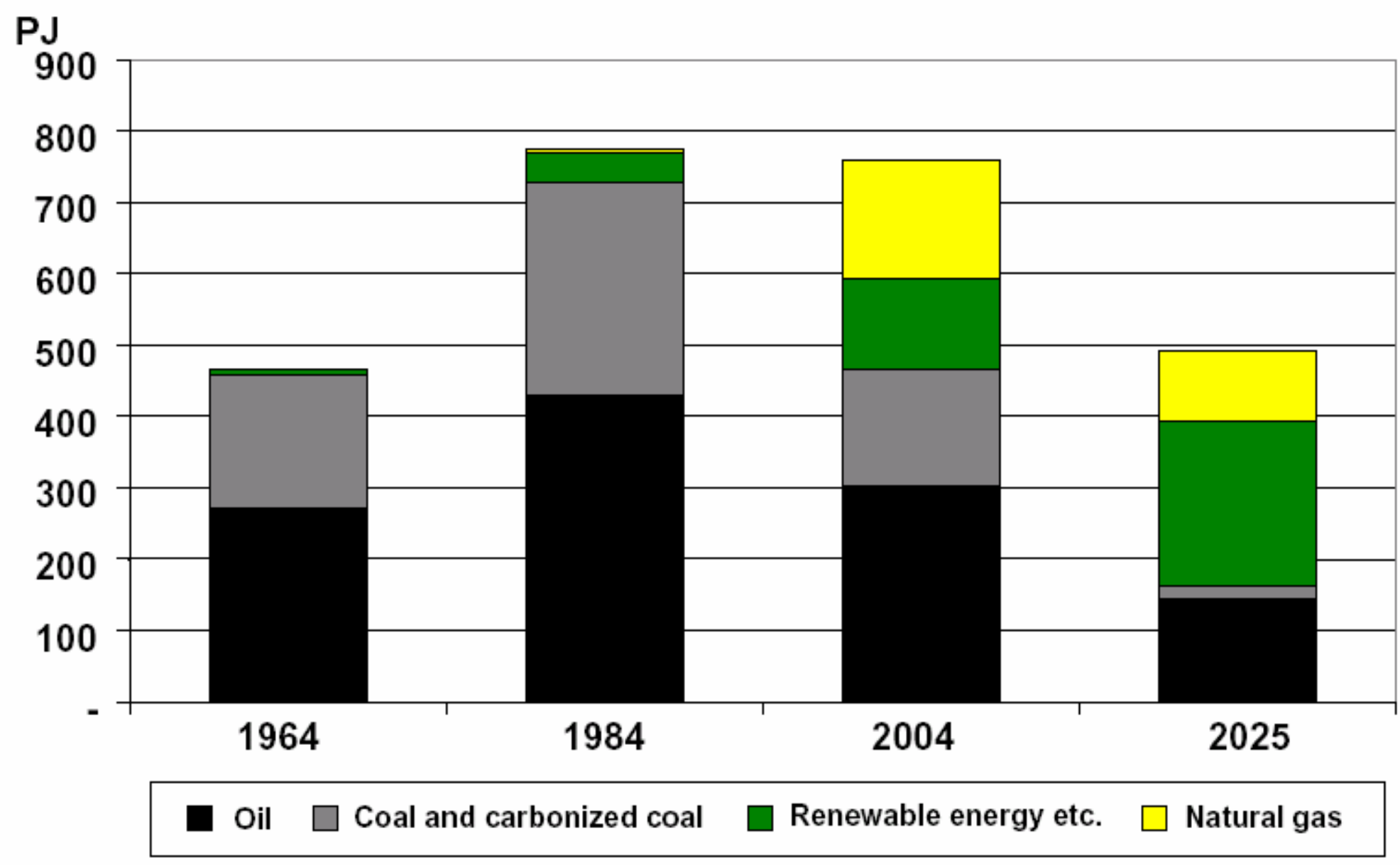

\section{TEKNOLOGI-RÅDET}




\section{The Combination Scenario $\mathrm{CO} 2$ emissions}

Million tons $\mathrm{CO} 2$

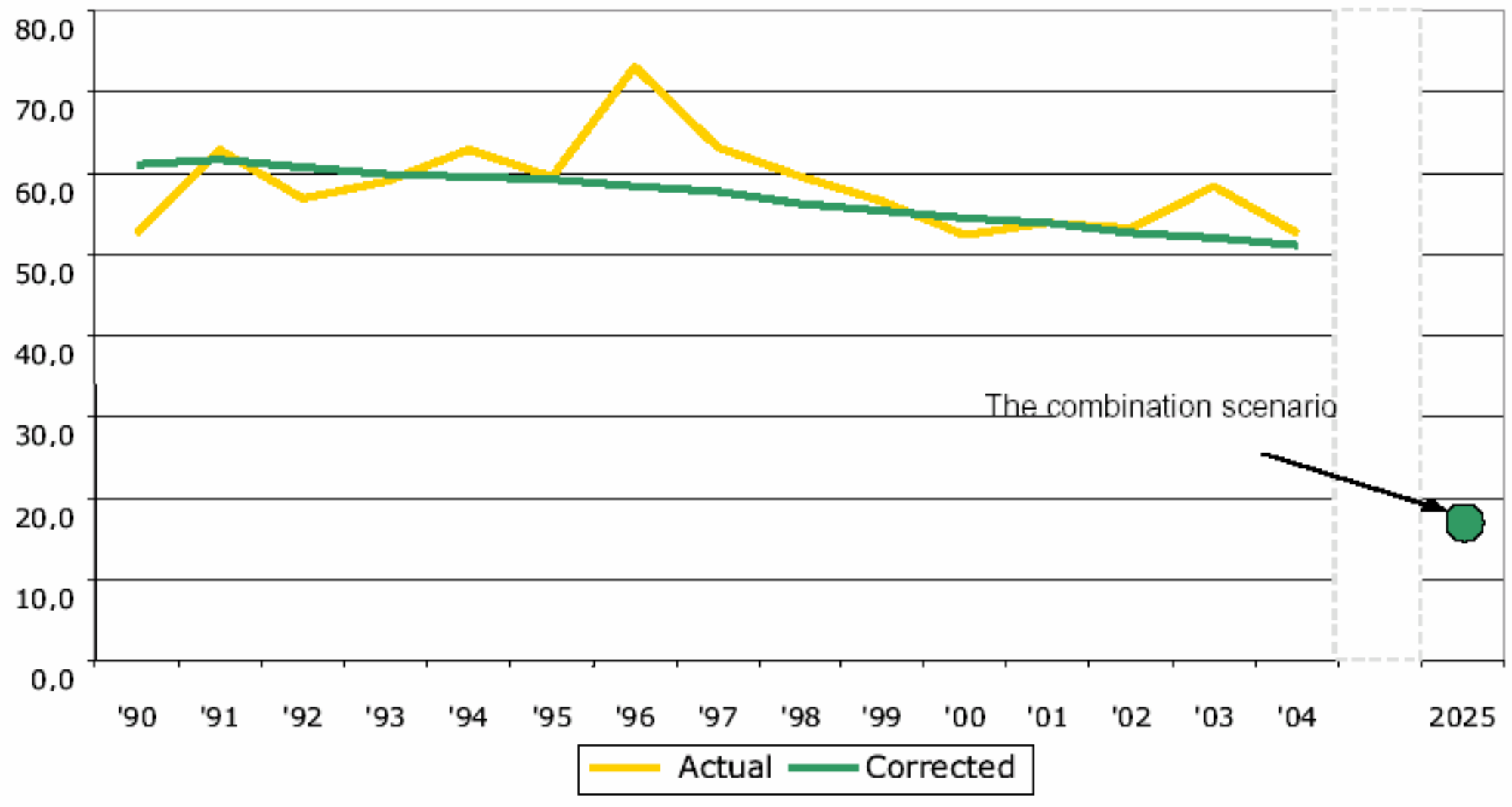

\section{TEKNOLOGI-RÅDET}




\section{The Combination Scenario Import/export balance}

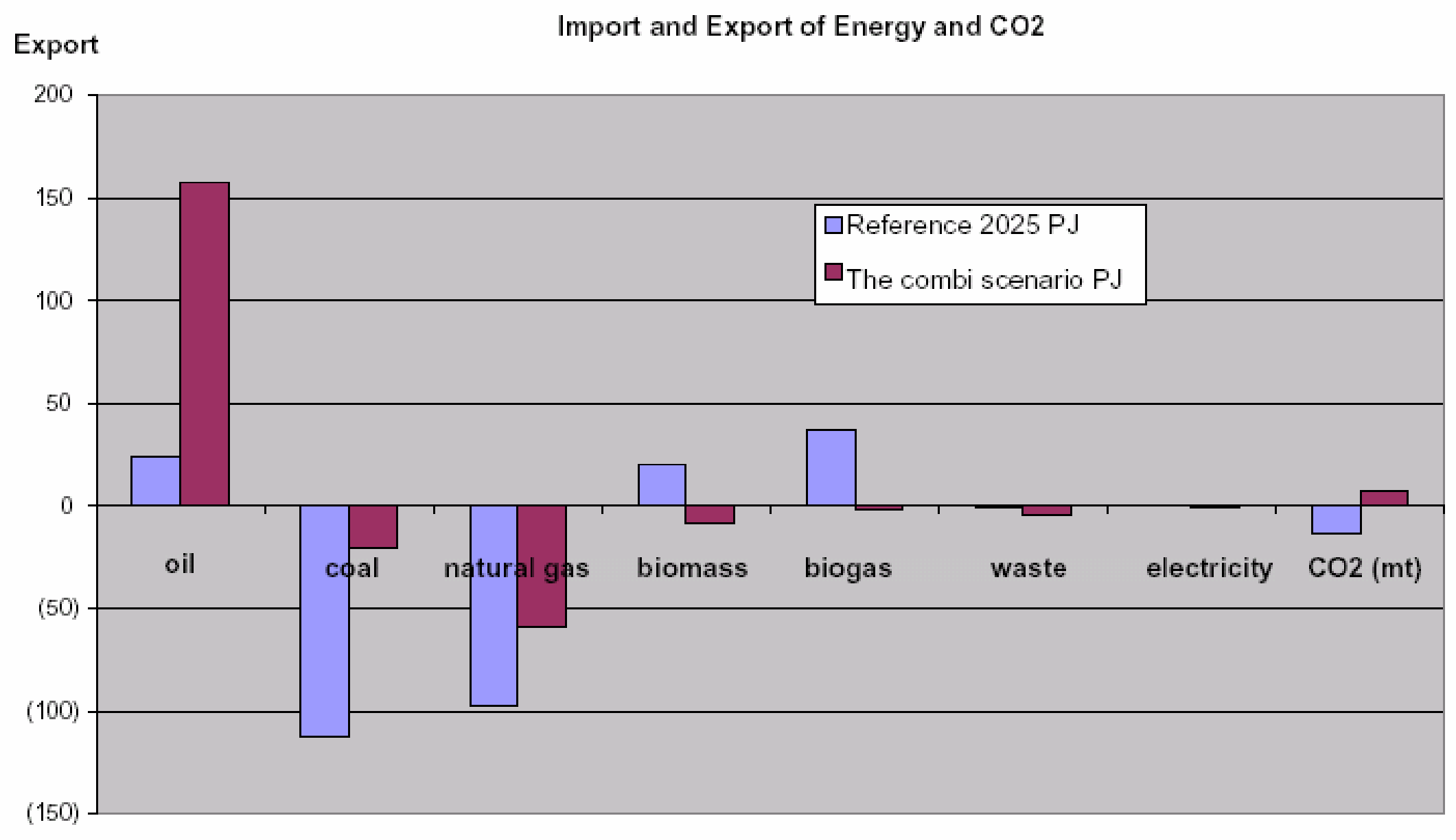

Import

\section{TEKNOLOGI-RÅDET}




\section{The Combination Scenario National economics}

Forskel $\mathrm{i}$ årlige annuise rede omkostninger mellem scenario og reference

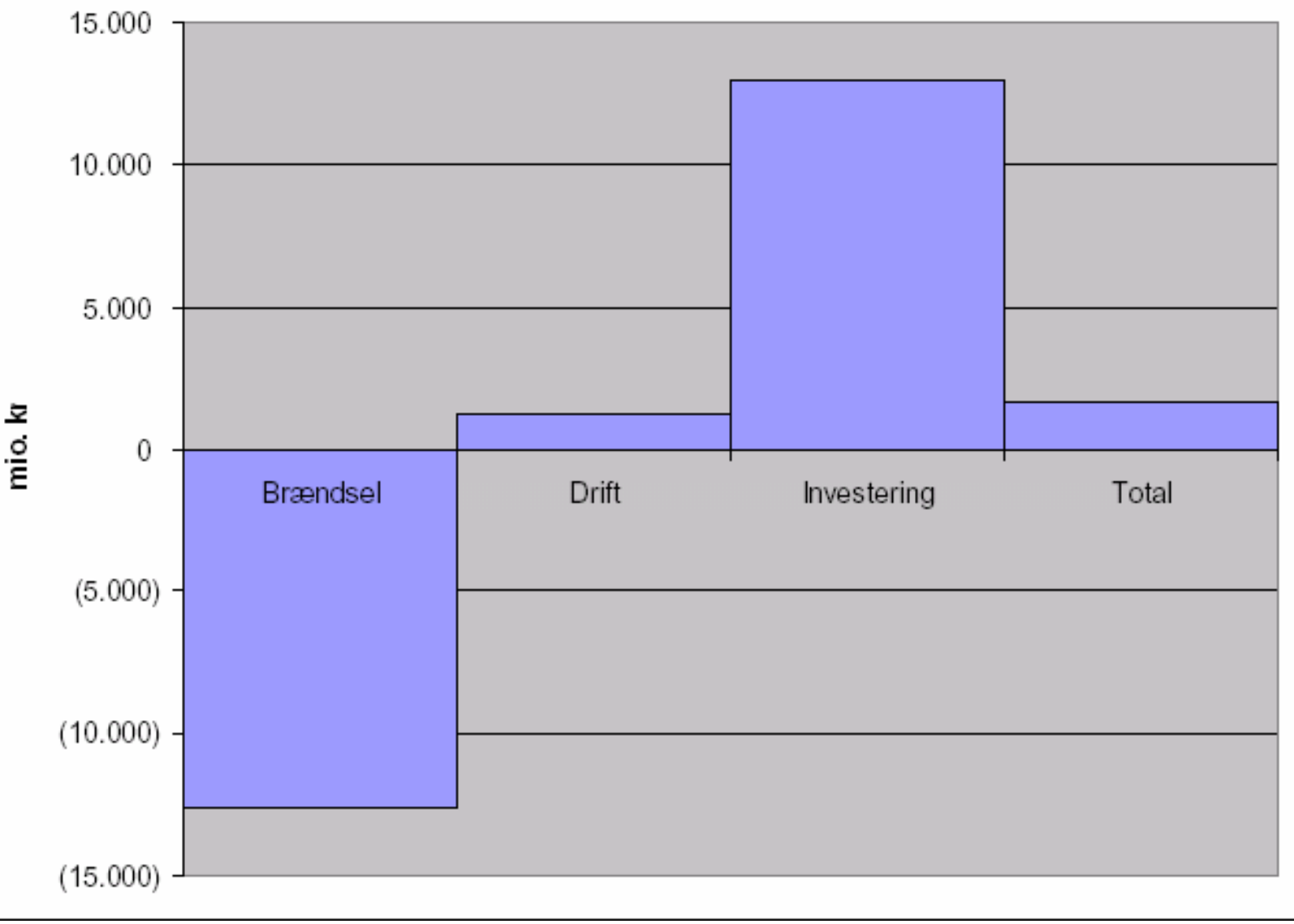

\section{TEKNOLOGI-RÅDET}




\section{Agenda}

1. The scenario process

2. The results

3. The modelling tool

- Energy savings model

- The time series model

- The energy flow model

4. Perspectives 
The modeling tool: STREAM

- STREAM: Sustainable Technology, Research and Energy Analysis Model

- Simple and transparent model

- Enhance complete energy flow

- Developed in cooperation with broad range of parties

- Conduct new analysis quickly

- Qualify scenarios through quantification

- Give project attendants better insight on the spot in scenario discussions

\section{TEKNOLOGI-RÅDET}




\section{STREAM}

Overall goals (CO2 emissions, fuel use, etc.

\section{Input}

-Production capacity -Energy service demand

-Conversion factors

-Technological development -Fuel prices

-Time series (heat, wind and electricity consumption)

\section{STREAM}

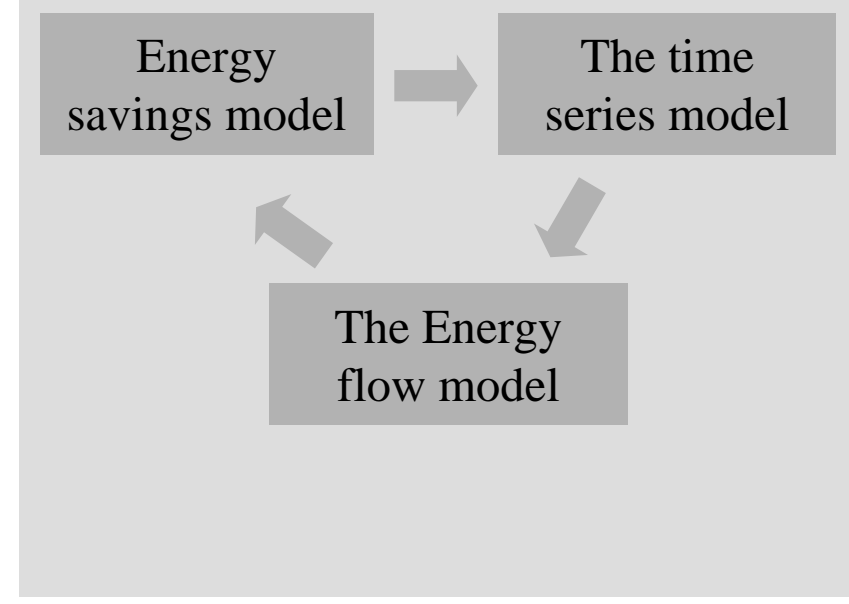

\section{Output}

-Energy balance

-Import/export

- Cost calculations

(capital, fuel, O\&M)

- System efficiency

\section{TEKNOLOGI-RÅDET}




\section{The energy savings model}

- Projection of demand for energy services

- Calculated for households, service sector, industry and transport

- In each area different end uses is identified as well as savings potentials and costs

- Starting point for transport is amount of person kilometres 


\section{The energy savings model}

$\underline{\text { Regnearksmodel til fremskrivning af efterspørgslen efter endeligt energiforbrug baseret på baggrundstal fra Energistrategien og Energispareplanen. }}$

\begin{tabular}{|c|c|c|c|c|c|c|c|c|}
\hline \multicolumn{2}{|l|}{ Energisparescenario: } & \multicolumn{2}{|c|}{ "Besparelse Scen1" } & \multirow[t]{2}{*}{ Scenarier: } & \multirow{2}{*}{$\begin{array}{l}\text { Reference } \\
\text { Kombiscenariet }\end{array}$} & & \multirow[b]{3}{*}{$\begin{array}{l}\text { Reference } \\
\text { scenario } \\
2025 \\
\text { TJ }\end{array}$} & \multirow[b]{3}{*}{$\begin{array}{c}\text { Kombiscenariet } \\
\text { scenario } \\
2025 \\
\text { TJ }\end{array}$} \\
\hline Anvendt rente ved inv & & $6 \%$ & & & & \multirow[b]{2}{*}{$\begin{array}{l}\text { Basis forbrug } \\
2025\end{array}$} & & \\
\hline $\begin{array}{c}\text { Endeligt } \\
\text { energiforbrug } \\
\text { i sektorer }\end{array}$ & $\begin{array}{c}\text { Forbrug } \\
2003 \\
\text { TJ }\end{array}$ & $\begin{array}{c}\text { Økonomisk } \\
\text { vækst } \\
\text { \% p.a. }\end{array}$ & $\begin{array}{l}\text { Intensitet } \\
\text { faktor }\end{array}$ & $\begin{array}{l}\text { Reference } \\
\text { scenario } \\
2025 \\
\text { Ekstra omk. } \\
\text { ifht. basis } \\
\text { mill. krlår }\end{array}$ & $\begin{array}{c}\text { Kombiscenariet } \\
\text { scenario } \\
2025 \\
\text { Ekstra omk. } \\
\text { ifht. reference } \\
\text { mill. kr/år }\end{array}$ & & & \\
\hline Handel \& Service & 83.706 & 1,6 & 0,75 & 879 & 1.184 & 111.940 & 79.691 & 50.861 \\
\hline Produktion & 162.494 & 1,5 & 1,00 & 1.748 & 2.280 & 233.304 & 171.234 & 130.550 \\
\hline Husholdninger, el & 186.324 & 1,9 & 0,90 & 3.496 & 2.734 & 225.950 & 162.210 & 123.000 \\
\hline - rumvarme & & & 0,26 & & & & & \\
\hline \multirow[t]{2}{*}{$I$ alt } & 432.524 & & & 6.123 & 6.524 & 571.193 & 413.135 & 304.411 \\
\hline & & \multicolumn{2}{|c|}{ Vækst transportarbejde } & \multicolumn{3}{|c|}{ Årlig besparelse ifht. Basis : } & & \\
\hline Transport, person & 107.456 & $1,0 \%$ & 1,00 & & 2952 & 133.753 & 122.160 & 97.462 \\
\hline Transport, gods & 60.720 & $1,0 \%$ & 1,00 & & 591 & 75.579 & 64.308 & 53.372 \\
\hline$I$ alt inkl. transport & 600.700 & & & & 10.067 & 780.525 & 599.603 & 455.245 \\
\hline
\end{tabular}

\begin{tabular}{|c|c|c|c|c|c|c|c|c|c|c|}
\hline $\begin{array}{l}\text { Endeligt } \\
\text { forbrug fordelt } \\
\text { på brændsler } \\
\text { (uden transport) }\end{array}$ & $\begin{array}{c}\text { Forbrug } \\
2003 \\
\text { TJ }\end{array}$ & $\begin{array}{c}\text { Basis forbrug } \\
2025 \\
\text { TJ }\end{array}$ & & & $\begin{array}{l}\text { Reference } \\
\text { scenario } \\
2025 \\
\text { TJ }\end{array}$ & & & $\begin{array}{c}\text { Kombiscenariet } \\
\text { scenario } \\
2025 \\
\text { TJ }\end{array}$ & & \\
\hline El & 115.647 & 157.367 & $28 \%$ & & 114.631 & $28 \%$ & & 76.017 & $25 \%$ & \\
\hline Fjernvarme & 108.270 & 128.958 & $23 \%$ & & 96.351 & $23 \%$ & & 82.183 & $27 \%$ & \\
\hline Kul & 9.199 & 12.682 & $2 \%$ & $5 \%$ & 9.603 & $2 \%$ & $5 \%$ & 4.524 & $1 \%$ & $3 \%$ \\
\hline Olie & 91.755 & 118.758 & $21 \%$ & $45 \%$ & 85.172 & $21 \%$ & $42 \%$ & 25.991 & $9 \%$ & $18 \%$ \\
\hline Naturgas & 74.572 & 94.372 & $17 \%$ & $35 \%$ & 74.964 & $18 \%$ & $37 \%$ & 67.524 & $22 \%$ & $46 \%$ \\
\hline Biomasse (Energiafgrøder) & 0 & 0 & $0 \%$ & $0 \%$ & 0 & $0 \%$ & $0 \%$ & 0 & $0 \%$ & $0 \%$ \\
\hline Biomasse (halm,træaffald) & 33.081 & 40.485 & $7 \%$ & $15 \%$ & 32.413 & $8 \%$ & $16 \%$ & 48.172 & $16 \%$ & $33 \%$ \\
\hline$I$ alt & 432.524 & 552.624 & $100 \%$ & $100 \%$ & 413.135 & $100 \%$ & $100 \%$ & 304.411 & $100 \%$ & $100 \%$ \\
\hline
\end{tabular}

* Alle investeringer er omregnet til annualiserede afdrag i 2003-kr. Svarende til lån, der afdrages med samme årlige betaling over investeringens levetid.

\section{TEKNOLOGI-RÅDET}




\section{The time series model}

- Analyse correlations in the Danish electricity and CHP system on an hourly level.

- Indicates coherence between wind and combined heat and power production 


\section{The time series model}

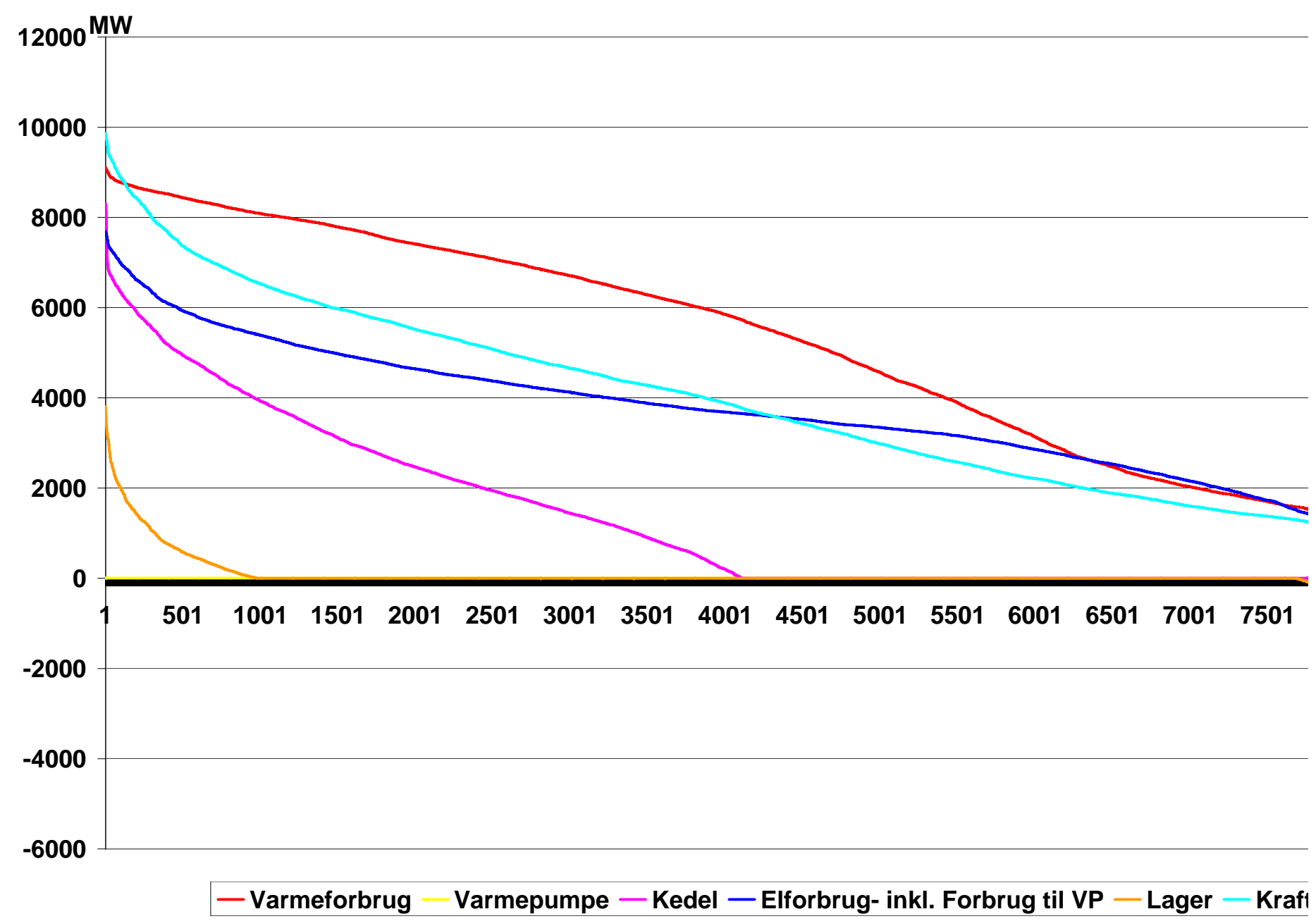

\section{TEKNOLOGI-RÅDET}




\section{The time series model}

Elforbrugsvarighedskurve - fordelt på segmenter af 500 MW (Husk: varighedskurven skal opdateres vha. makro)

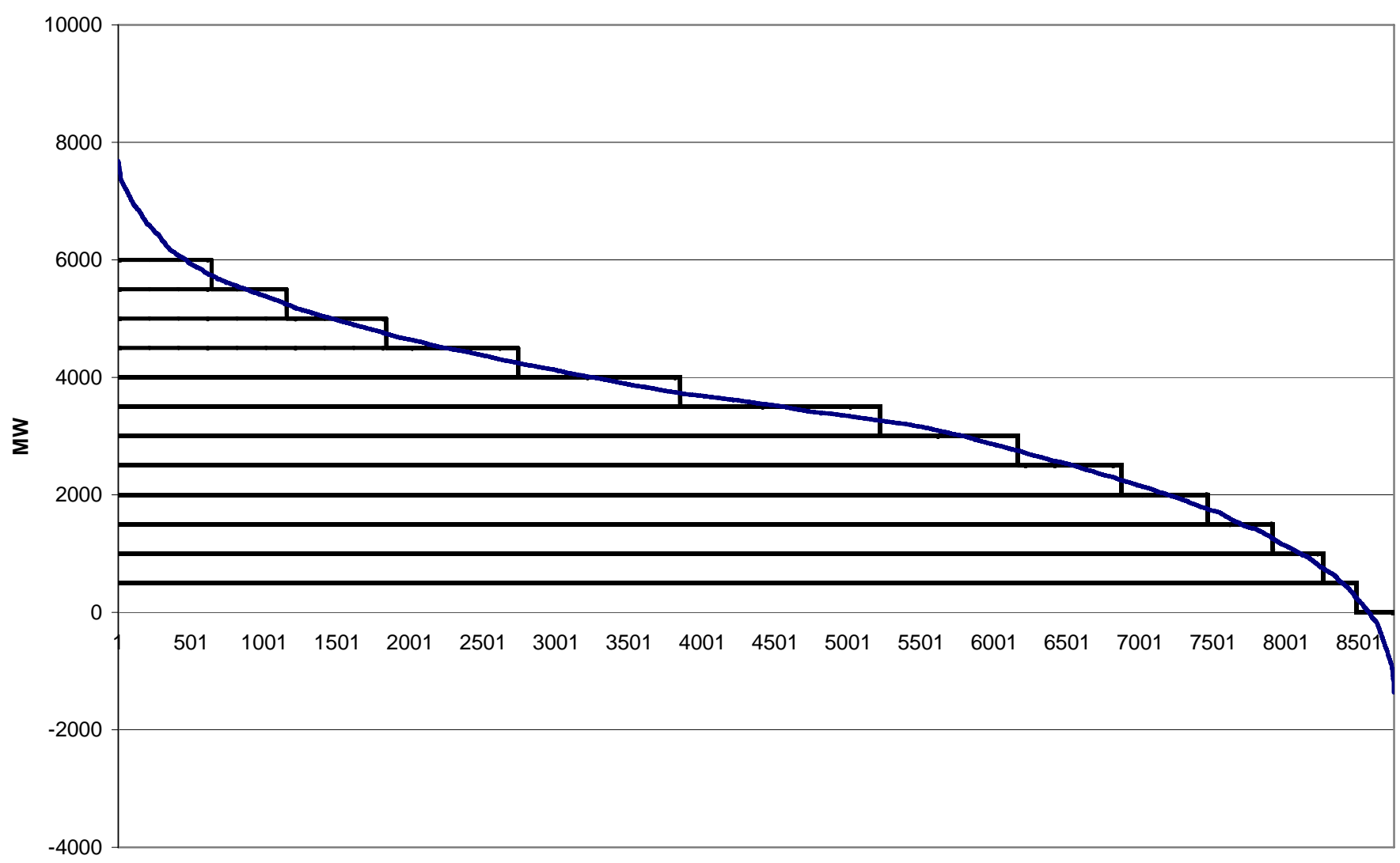

\section{TEKNOLOGI-RÅDET}




\section{The energy flow model}

- Combine models with economics and technology data for a given year

- Produce tables and figures

- Economic costs is determined as the annual costs of running the system in a given year 


\section{The energy flow model}

\begin{tabular}{|c|c|c|c|c|c|c|c|c|c|}
\hline $\begin{array}{l}\text { Ambitiose scenario } \\
\text { Energiprodukter } \\
\text { (PJ) }\end{array}$ & el & fjernvarme & $\begin{array}{c}\text { varmel } \\
\text { brændsel }\end{array}$ & Total & $\begin{array}{c}\text { Brændsler } \\
\text { el }\end{array}$ & fjernvarme & olie & kul & naturgas \\
\hline $\begin{array}{l}\text { el produktion } \\
\text { el, brændselsforbrug } \\
\text { virkningsgrad }\end{array}$ & $\begin{array}{c}96,27 \\
144,60 \\
67 \% \\
\end{array}$ & & & $\begin{array}{c}96,27 \\
144,60 \\
67 \% \\
\end{array}$ & & & $\begin{array}{l}0,96 \\
1,77 \\
54 \% \\
\end{array}$ & $\begin{array}{c}7,22 \\
12,67 \\
57 \% \\
\end{array}$ & $\begin{array}{c}9,63 \\
15,05 \\
64 \% \\
\end{array}$ \\
\hline $\begin{array}{l}\text { brint, produktion } \\
\text { ethanol, produktion } \\
\text { methanol, produktion } \\
\text { biodiesel, produktion } \\
\end{array}$ & & $51 \%$ & $\begin{array}{c}\text { Produkt } \\
0,11 \\
10,12 \\
0,00 \\
10,15 \\
\end{array}$ & $\begin{array}{c}0,20 \\
19,70 \\
0,00 \\
12,10 \\
\end{array}$ & $\begin{array}{l}0,2 \\
1,3 \\
0,0 \\
1,3 \\
\end{array}$ & $\begin{array}{l}5,2 \\
0,2 \\
\end{array}$ & & & \\
\hline $\begin{array}{l}\text { varmeforbrug } \\
\text { varmeforbrug, brændsel } \\
\text { virkningsgrad } \\
\text { nettab } \\
\text { egetforbrug } \\
\text { Tvungen el-eksport } \\
\text { ikke energiformål } \\
\end{array}$ & $\begin{array}{l}6,01 \\
0,00 \\
(0,55)\end{array}$ & 20,38 & $\begin{array}{c}65,42 \\
73,75 \\
89 \% \\
\\
\\
\\
0,00 \\
\end{array}$ & 158,54 & $\begin{array}{r}7,18 \\
7,18 \\
100 \% \\
\end{array}$ & $\begin{array}{c}74,51 \\
77,61 \\
96 \% \\
\end{array}$ & $\begin{array}{c}11,80 \\
13,11 \\
90 \% \\
\end{array}$ & $\begin{array}{l}1,83 \\
2,28 \\
80 \% \\
\end{array}$ & $\begin{array}{r}32,36 \\
34,06 \\
95 \% \\
\end{array}$ \\
\hline & El & Fjernvarme & $\begin{array}{l}\text { Summen af } \\
\text { brændsler }\end{array}$ & Total & \multicolumn{5}{|c|}{ Brændselsforbrug inkl. konverteringstab } \\
\hline $\begin{array}{l}\text { Handel og service } \\
\text { Produktionserhvery }\end{array}$ & $\begin{array}{l}20,13 \\
36,02\end{array}$ & $\begin{array}{l}23,90 \\
10,87\end{array}$ & $\begin{array}{c}6,83 \\
83.67\end{array}$ & $\begin{array}{c}50,86 \\
130,55\end{array}$ & $\begin{array}{l}20,13 \\
36,02\end{array}$ & $\begin{array}{l}23,90 \\
10,87\end{array}$ & $\begin{array}{c}0,68 \\
1956\end{array}$ & $\begin{array}{l}0,00 \\
4,35\end{array}$ & $\begin{array}{c}3,41 \\
38,03\end{array}$ \\
\hline Husholdning & 19,86 & 47,42 & 55,72 & 123,00 & 19,86 & 47,42 & 5,75 & 0,18 & 26,08 \\
\hline Transport & 7,67 & & 146,53 & 162,45 & 10,51 & 5,41 & 121,35 & & 1,45 \\
\hline Forbrug excl. transport & 76,02 & 82,18 & 146,21 & 304,41 & & & 25,99 & 4,52 & 67,52 \\
\hline Forbrug & 83,68 & 82,18 & 292,74 & 466,86 & & & 147,34 & 4,52 & 68,97 \\
\hline Total bruttoenergiforbrug & 144,60 & 66,14 & 292,74 & 503,48 & & & 149,58 & 20,38 & 102,76 \\
\hline
\end{tabular}

\section{TEKNOLOGI-RÃDET}




\section{Modelling challenges}

- Economic costs from investments and measures handled in a very simple manner

- No economic or advanced optimization of the energy flow and exchange with neighbouring countries. 


\section{Origin of data}

- Data availability often decisive for modelling

- Especially in the Energy savings model

- Access to many parties through the scenario process and the active involvement from the politicians 


\section{Agenda}

1. The scenario process

2. The results

3. The modelling tool

- Energy savings model

- The time series model

- The energy flow model

4. Perspectives 


\section{Perspectives}

- Consolidation of model

- Public access to modelling tool

- Modelling tool creates common references and understanding of challanges in scenario discussions

- Also outside Denmark 


\section{Vanadium redox-flow batteries}

- Installation at Risø for characterisation measurements

\section{Henrik Bindner}

Wind Energy Systems

Wind Energy Department

Risø, DTU

Risø International Energy Conference May 2007

Acknowledgement:

The work presented is supported by Energinet.dk through the PSO-project "karakterisering af vanadium batteri" 


\section{Presentation outline}

- Power system with a high penetration of wind

- Applications of energy storage and energy storage technologies

- Vanadium batteries

- Vanadium battery as part of SYSLAB

- Current Status and test results 


\section{Power Systems with high penetration of wind}

- Production and consumption has to match at any instant

- Issues with wind

-Fluctuations

- Variations

-Predictability

- The rest of the system has to compensate for the fluctuations on the short time scale (sec-min) and variations and prediction errors on a longer time scale (hours-days)

- Flexibility of the rest of the system is crucial for achieving high penetration

- More and more functions are provided via a market

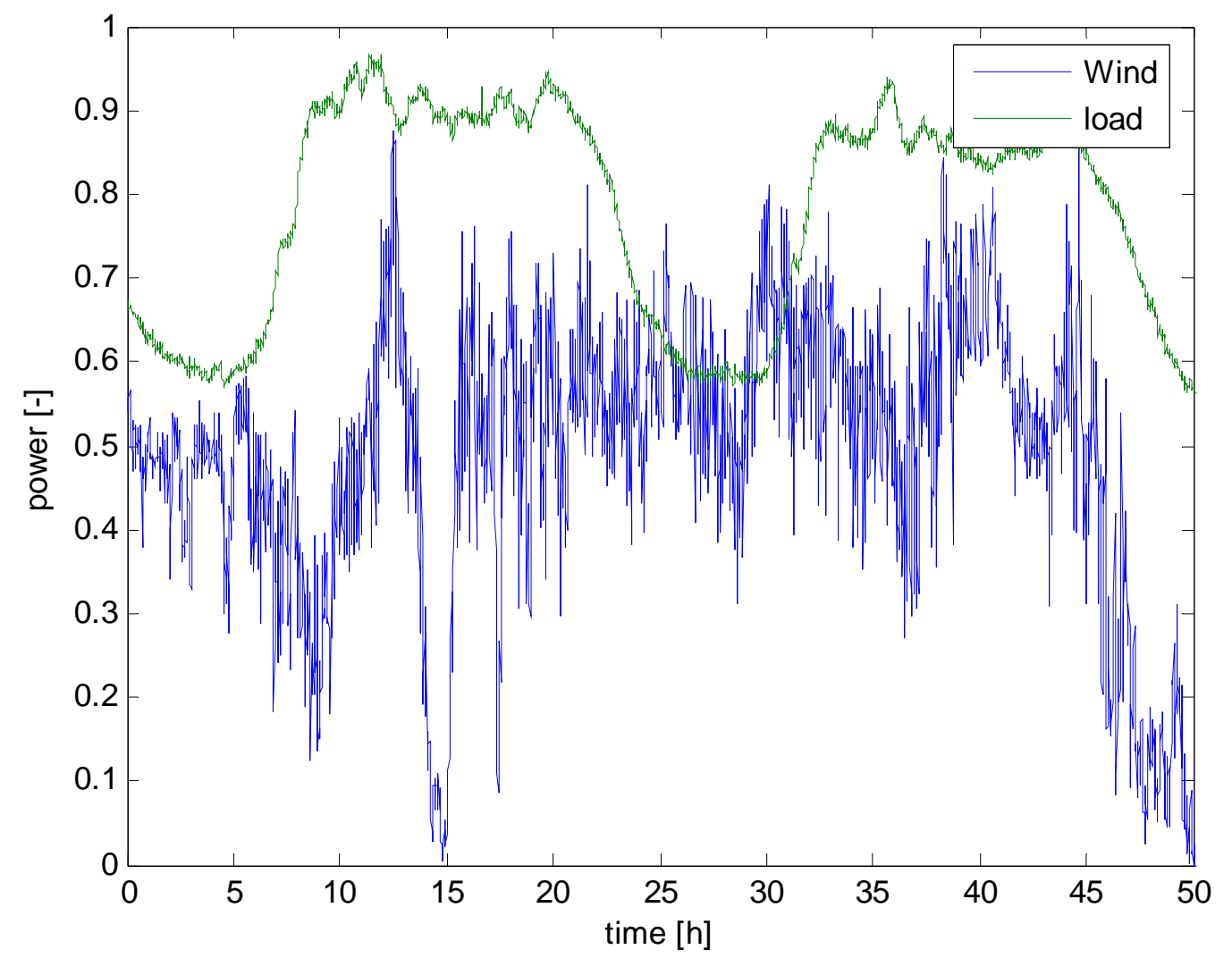

- Flexibility can be provided by several means

-Production

-Flexible/intelligent consumption

-Energy storage 


\section{Power plant functions from wind farms}

- Wind turbines are installed in larger and larger wind farms

- The spatial smoothing is reduced resulting in larger fluctuations

- but coordinated control of all the wind turbines is improved
- During recent years there has been an effort to develop functions similar to other power plants to provide frequency and voltage control support

- Due to the stochastic nature of wind it is limited what can be obtained without support technologies
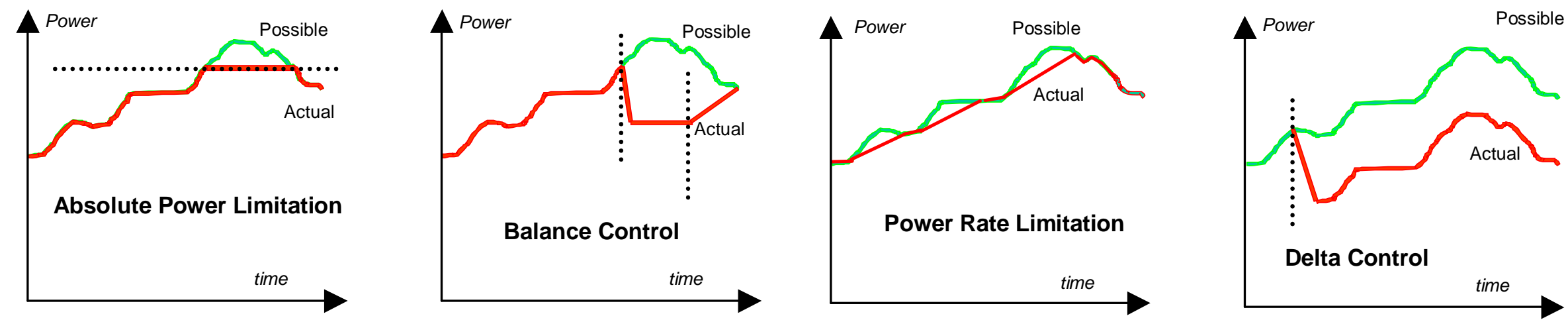


\section{Energy storage functions and issues}

- Batteries can have many functions in the power system

- Several of the storage technologies can provide several functions simultaneously

- Potential functions include:

- Very short term power quality improvement

- Uninterruptible power supplies

- Reduction of short term fluctuations in renewable energy production

- Reduction of spinning reserve

- Reduction of standing reserve

- Daily smoothing

- Seasonal storage

- Energy arbitrage
- Issues with application of batteries:

- Costs

- Uncertainty of cost

- Lifetime

- O\&M cost

- Efficiency

- Self-discharge

- Operational capabilities

- Reliability

- Safety and environmental issues 


\section{Energy storage technology overview}

\begin{tabular}{|c|c|c|c|}
\hline Technology & Power/Energy Range & Applications & State of development \\
\hline $\begin{array}{l}\text { Supercapacitors, superconducting } \\
\text { magnetic energy storage }\end{array}$ & $\begin{array}{l}\text { High power } \\
\text { Low energy }\end{array}$ & UPS, power quality & Pre-mature \\
\hline Flywheels & $\begin{array}{l}\text { High Power } \\
\text { Low Energy }\end{array}$ & Power quality & Mature \\
\hline $\begin{array}{l}\text { Batteries: lead acid, lithium, natrium- } \\
\text { sulphur, nickel }\end{array}$ & $\begin{array}{l}\text { Medium power } \\
\text { Medium Energy }\end{array}$ & UPS, RE fluctuation reductions & Pre-mature - mature \\
\hline $\begin{array}{l}\text { Redox-flow batteries: Vanadium, Br-S, } \\
\text { Zn-Br }\end{array}$ & $\begin{array}{l}\text { Medium power } \\
\text { High Energy }\end{array}$ & $\begin{array}{l}\text { RE fluctuation reduction, } \\
\text { spinning/standing reserve }\end{array}$ & Pre-mature \\
\hline Pumped hydro & $\begin{array}{l}\text { High Power } \\
\text { Very High Energy }\end{array}$ & $\begin{array}{l}\text { Spinning/standing reserve, energy } \\
\text { arbitrage }\end{array}$ & Mature \\
\hline Compressed air & $\begin{array}{l}\text { High Power } \\
\text { Very High energy }\end{array}$ & $\begin{array}{l}\text { Spinning/standing reserve, energy } \\
\text { arbitrage }\end{array}$ & Mature \\
\hline Hydrogen & $\begin{array}{l}\text { Medium Power } \\
\text { High Energy }\end{array}$ & $\begin{array}{l}\text { RE fluctuation reduction, } \\
\text { spinning/standing reserve }\end{array}$ & Prototype \\
\hline Thermal & - & $\begin{array}{l}\text { RE fluctuation reduction, } \\
\text { spinning/standing reserve }\end{array}$ & Mature \\
\hline Demand response & - & $\begin{array}{l}\text { RE fluctuation reduction, } \\
\text { spinning/standing reserve }\end{array}$ & Pre-mature \\
\hline
\end{tabular}




\section{Vanadium redox-flow battery technology}

- Flow/membrane based battery

- Electrolyte is vanadium dissolved in sulphuric acid

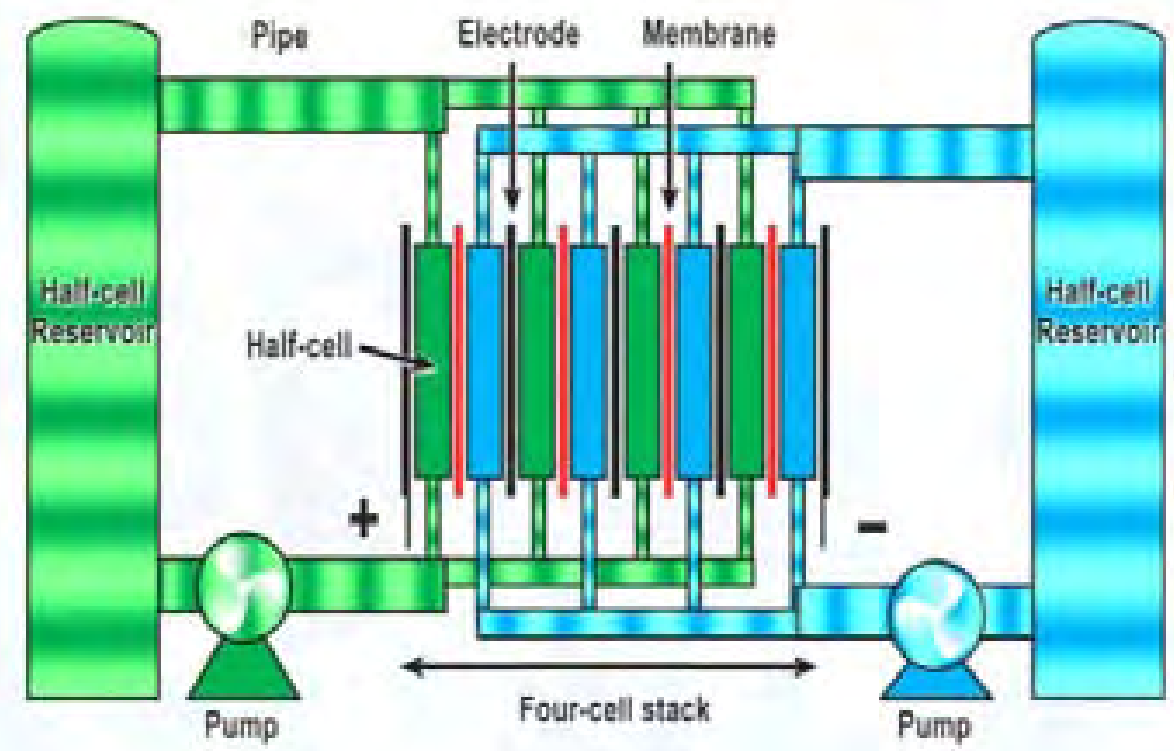

- Only change in valence of vanadium

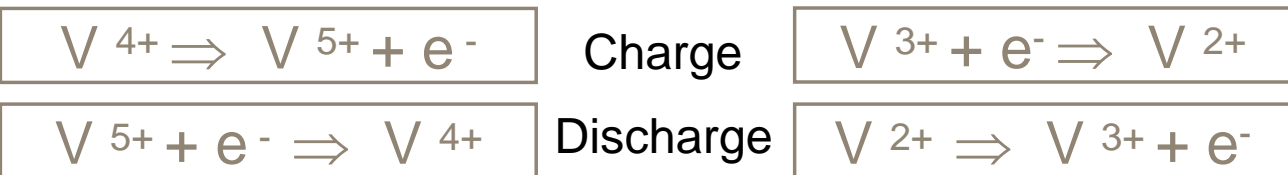

- Electrodes do not participate in the electro-chemical process

- Same electrolyte on both sides

-No cross-contamination

- Very long lifetime

- Independent sizing of power and energy capacity

- Low maintenance

- Very good cycling capability more than 10000 cycles

- Good efficiency $\sim 75 \%$

- Low self-discharge

- Fast response 


\section{Vanadium flow battery}

- Current costs:

- 250kW/2MWh: $\$ 1.000 .000$

- Potential for lower cost if mass-produced

- Energy density:

$\sim 25 \mathrm{Wh} / \mathrm{kg}$

- Risø unit:

- $15 \mathrm{~kW} / 120 \mathrm{kWh}$

- 4 quadrant power electronics

- Island and grid connected mode of operation
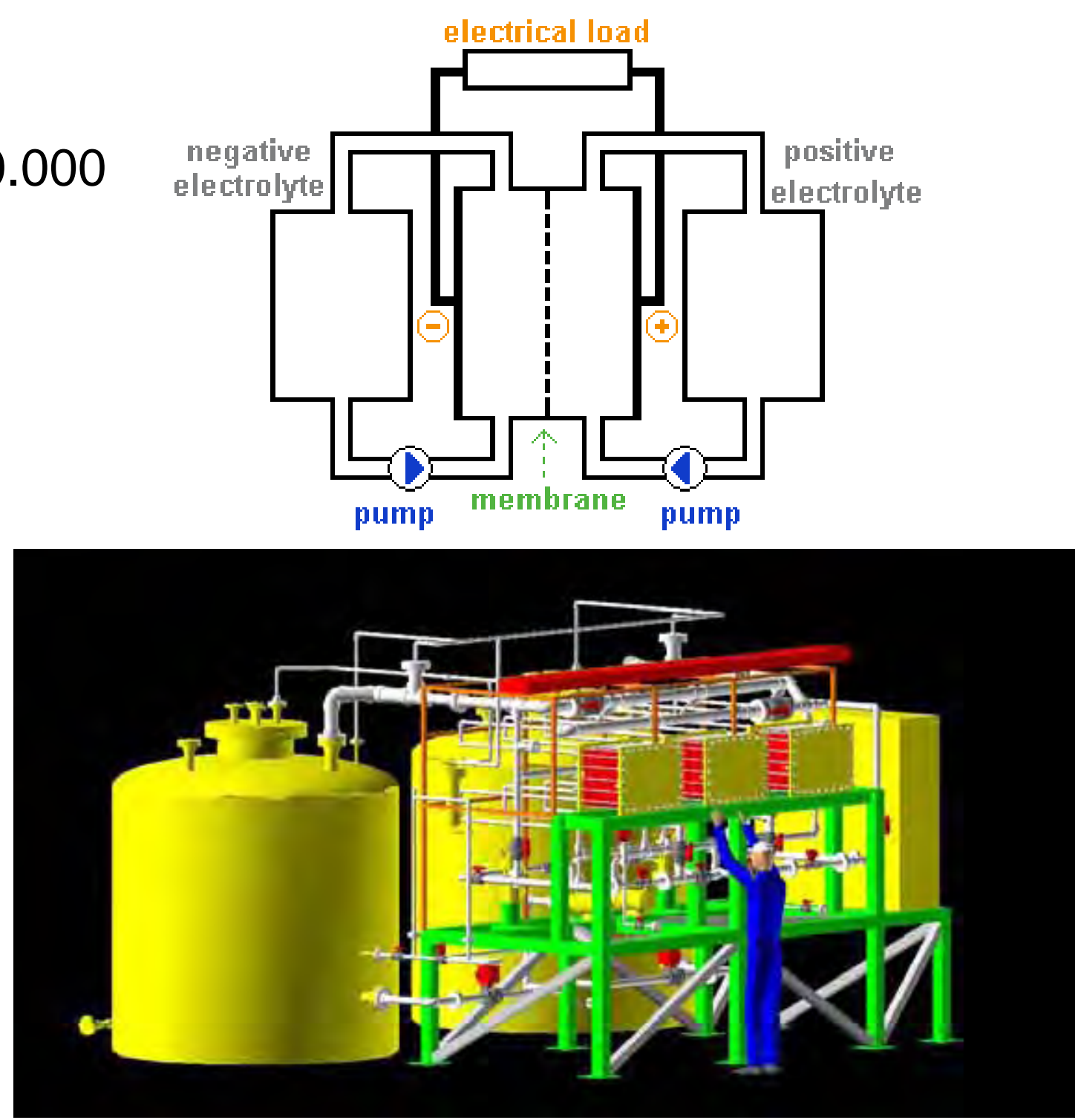
Component testing - Characterisation of vanadium batteries

- $\quad$ PSO-project supported by Energinet.dk

- Hands-on experience

- Efficiency @ different operating conditions

- Response time etc.

- Limits for operating range

- Cycling ability

- Grid interface

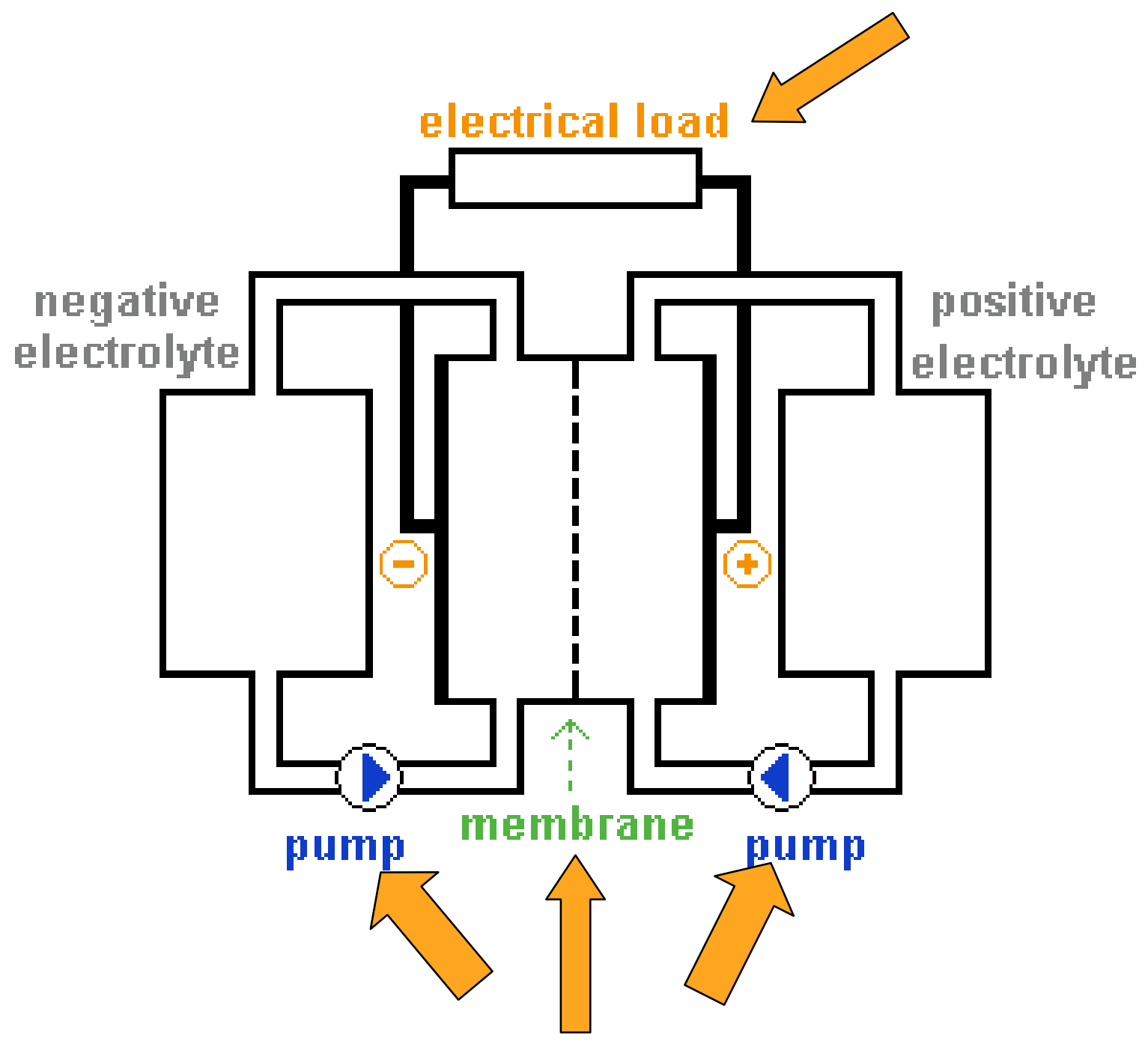




\section{SYSLAB - Distributed Energy System Laboratory}

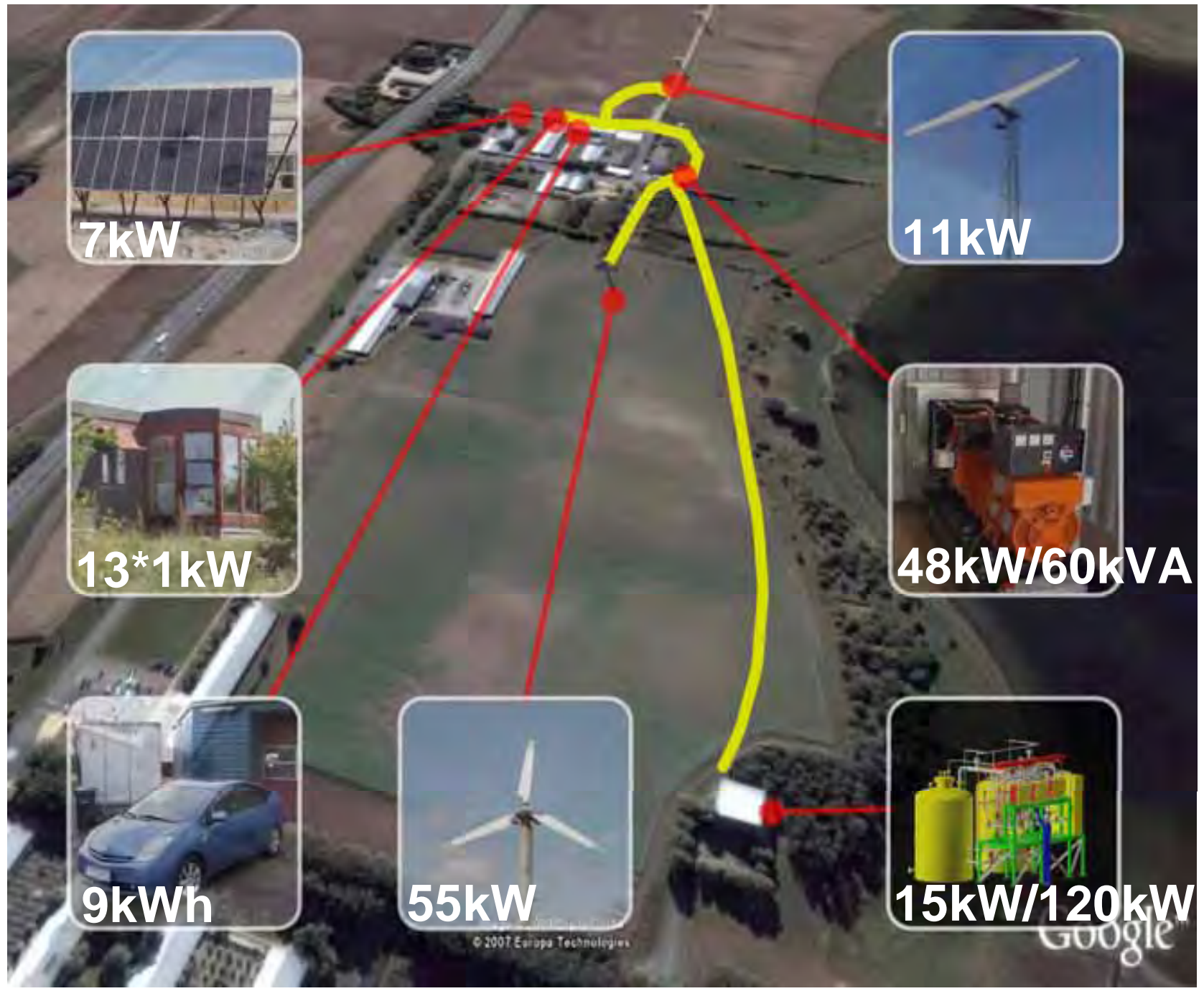

High penetration wind power systems

- Intelligence/

Communication

- Embedded, distributed control

- Self-organising distributed control

- Flexibility

- FlexHouse, Demand response

- Vanadium battery

- Hybrid/Electric car 


\section{SYSLAB - Development perspectives}

- Investigate technical possibilities

-Embedded intelligence

-Distributed control

-Integration of energy carriers

-Multiple RE sources

- Possible extensions

-Hydrogen/Fuel cells

-Biomass

-Risø district heating/ houses

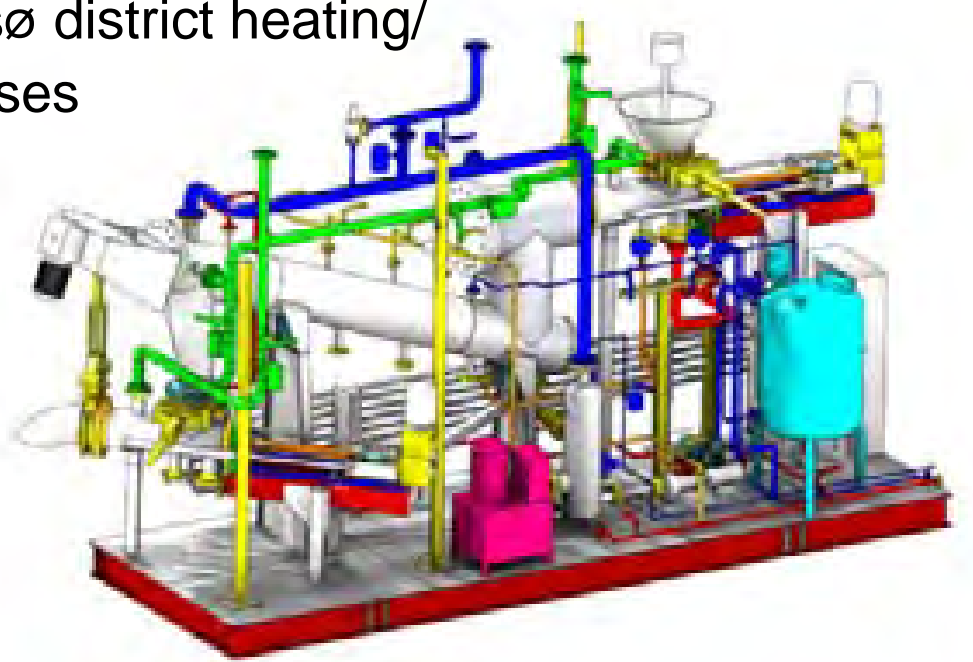

- Integrates several areas of research

- Upscaling to nationwide system

-Simulations (IPSYS)

- Facility used in PhD and MSc projects
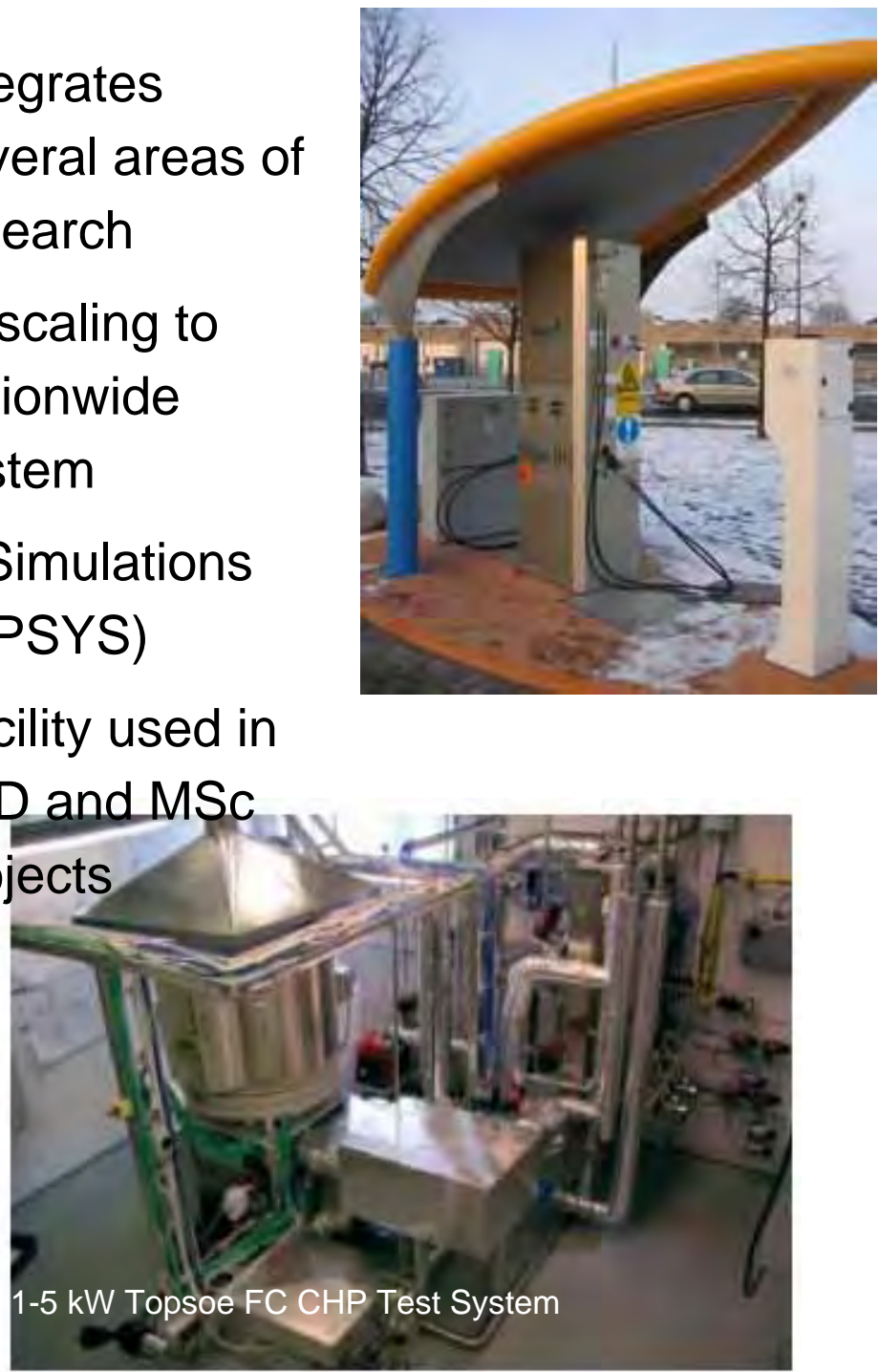


\section{Electrical layout of SYSLAB}

- Flexible grid configuration

- Autonomous grid

- Units can be tested in under various grid conditions

- Suitable for component and system tests

- Very flexible control

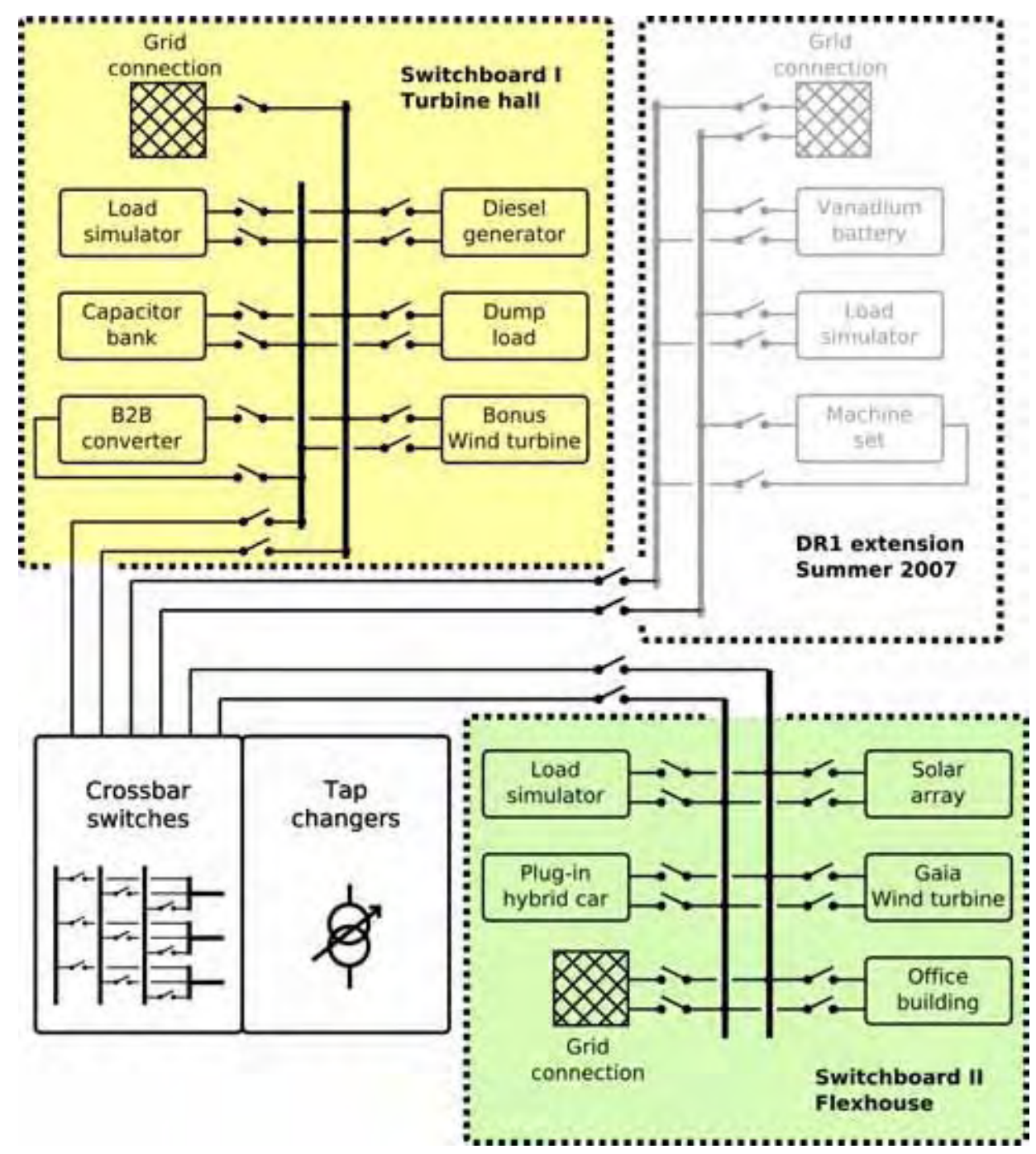




\section{PowerFlexhouse}

- Intelligent control

- Demand response

- Many individually controllable loads

- Heater

- Airconditioners

- Water heater, coffee machine

- Many sensors

- System-house and houseusser interaction and communication

- Plug-in/vehicle2grid hybrid car: Toyota Prius with extended battery and bidirectional converter
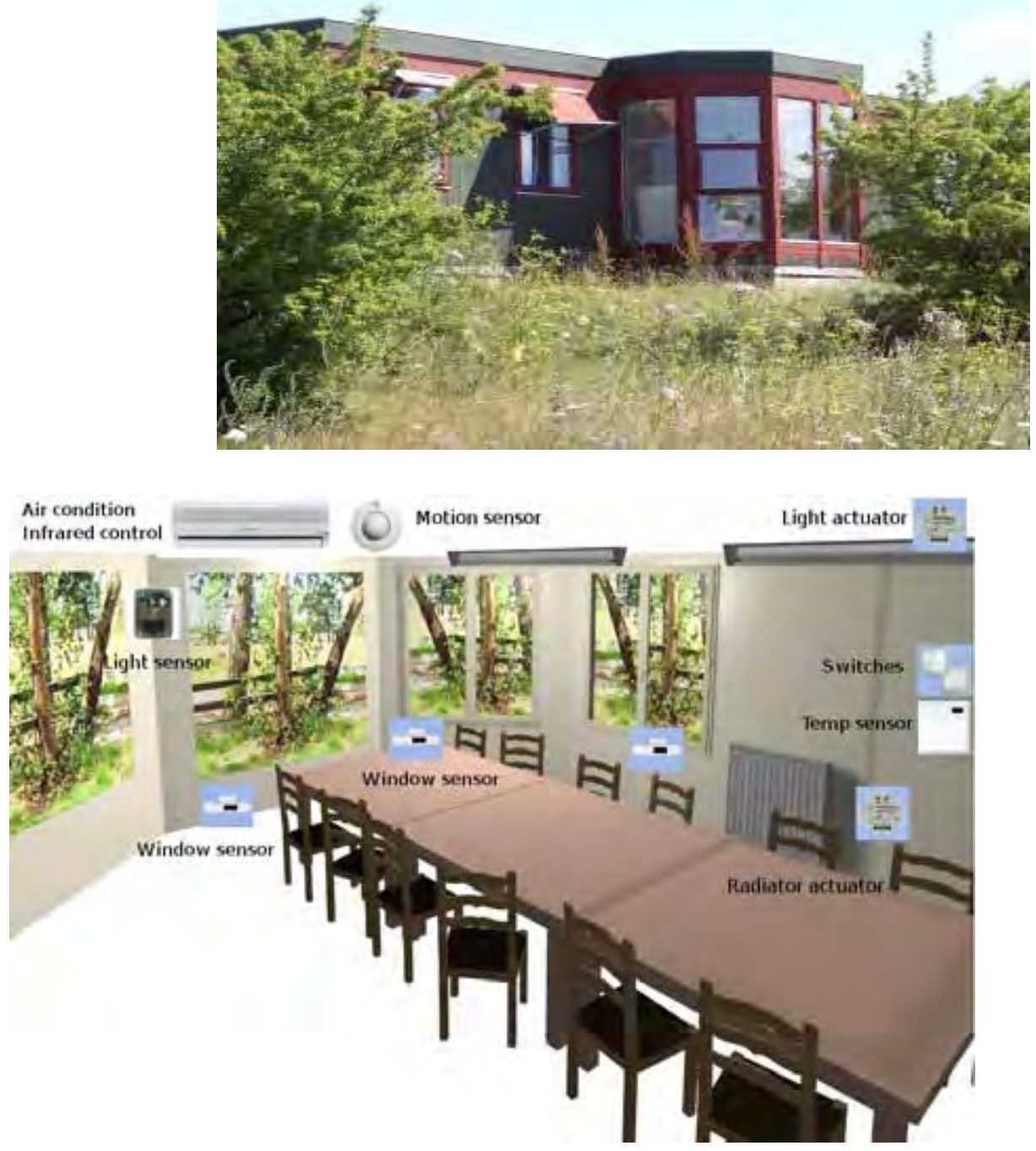


\section{Vanadium redox-flow batteries - initial results}

- Unit will be installed in August 2007

- Unit is being factory testet
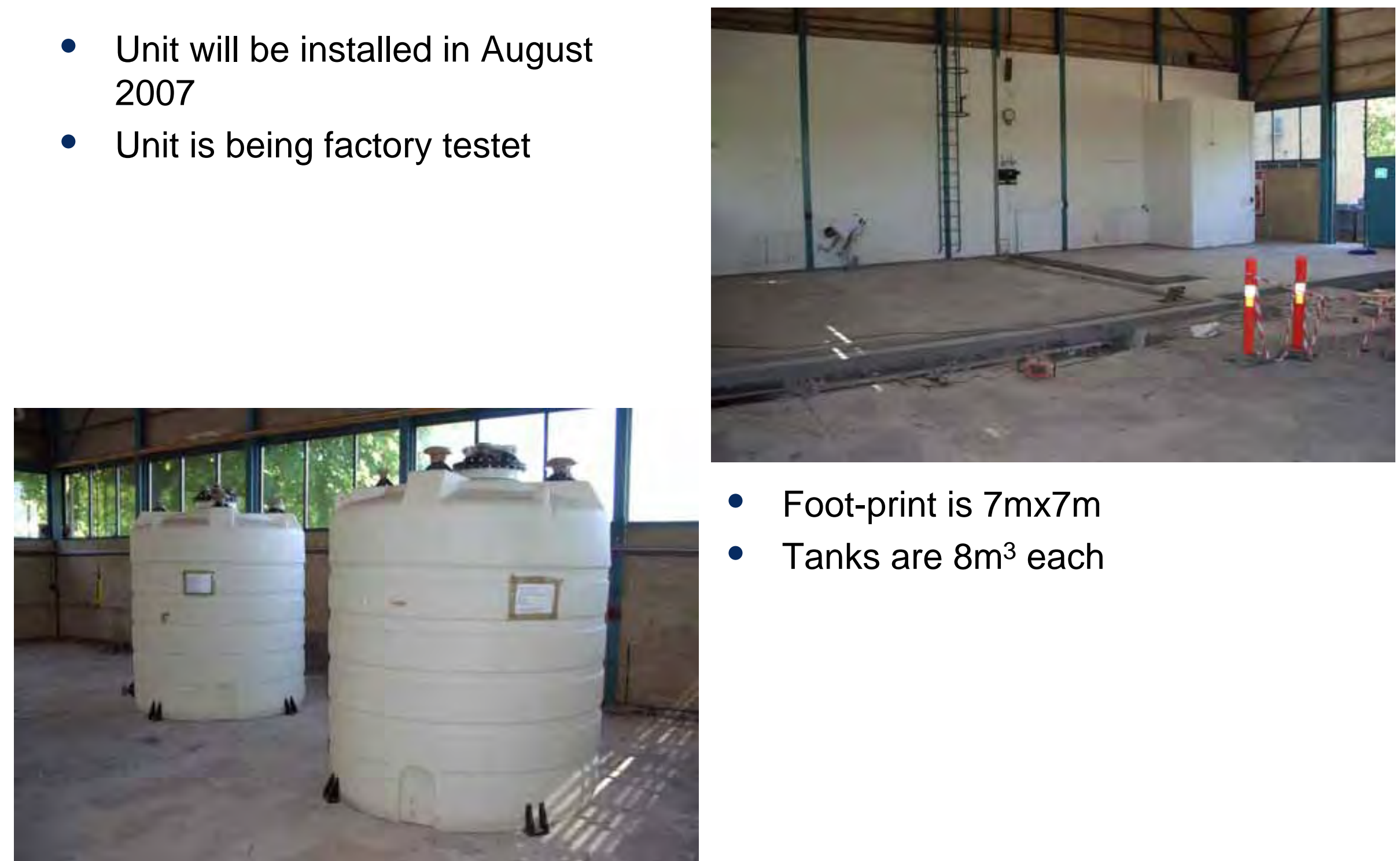

- Foot-print is $7 \mathrm{~m} \times 7 \mathrm{~m}$

- Tanks are $8 \mathrm{~m}^{3}$ each 


\section{Factory test of system}

- $3^{*} \mathrm{~kW}$ cells stacks

- 15kW/20kVA power electronics

1
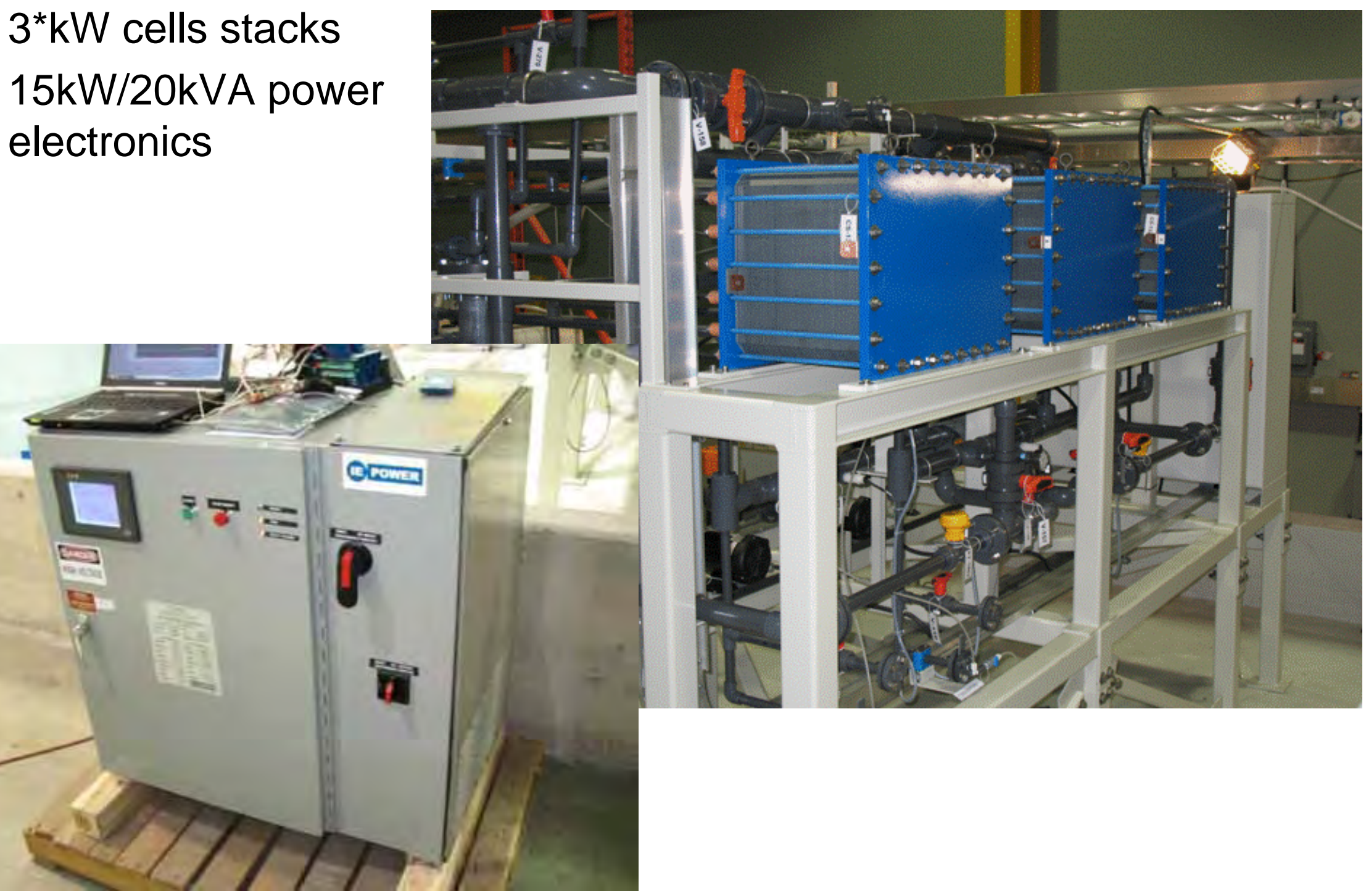


\section{Factory tests II}

\section{ENERGY}

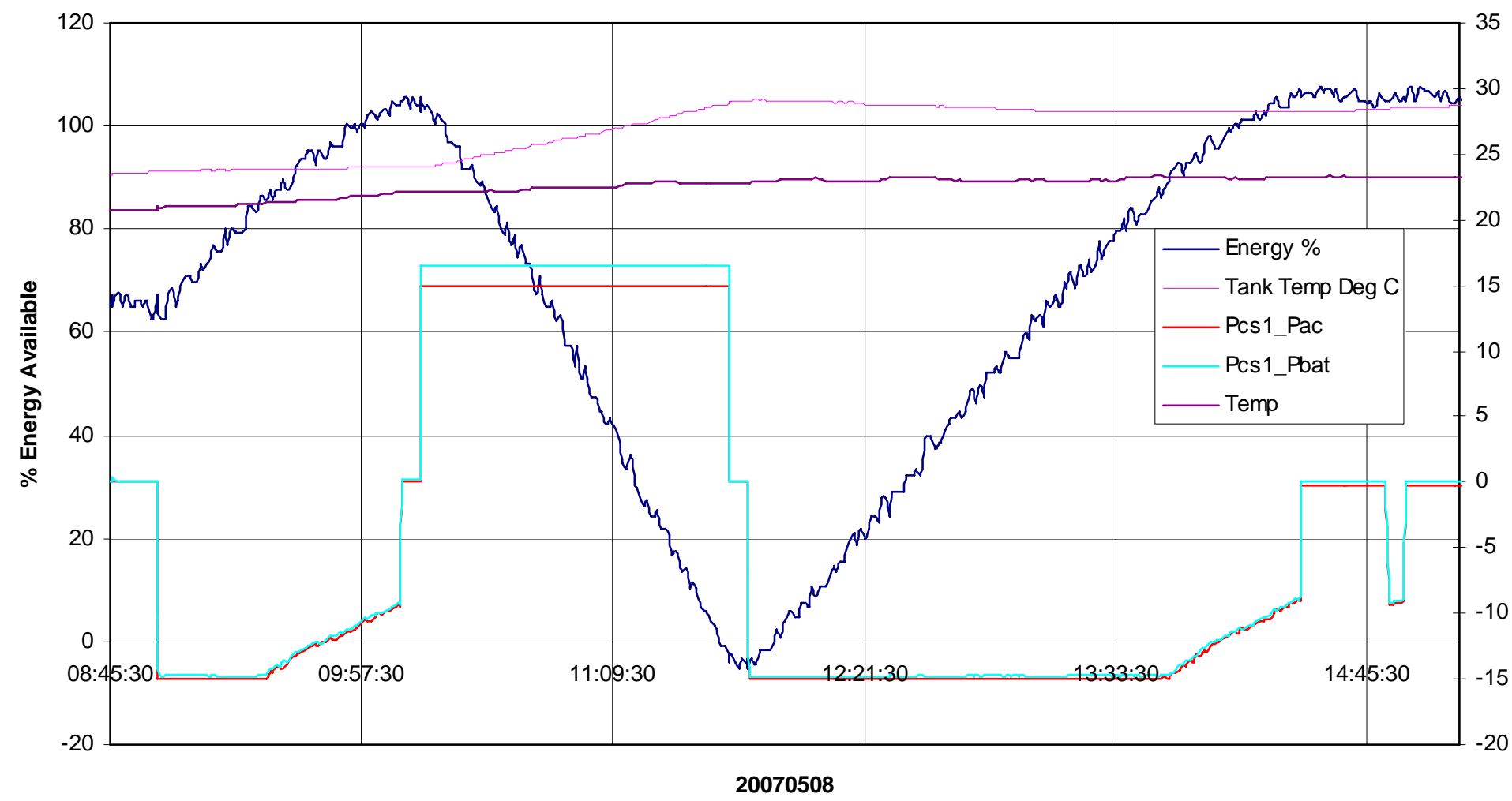




\section{Factory test III}

- Cycling test

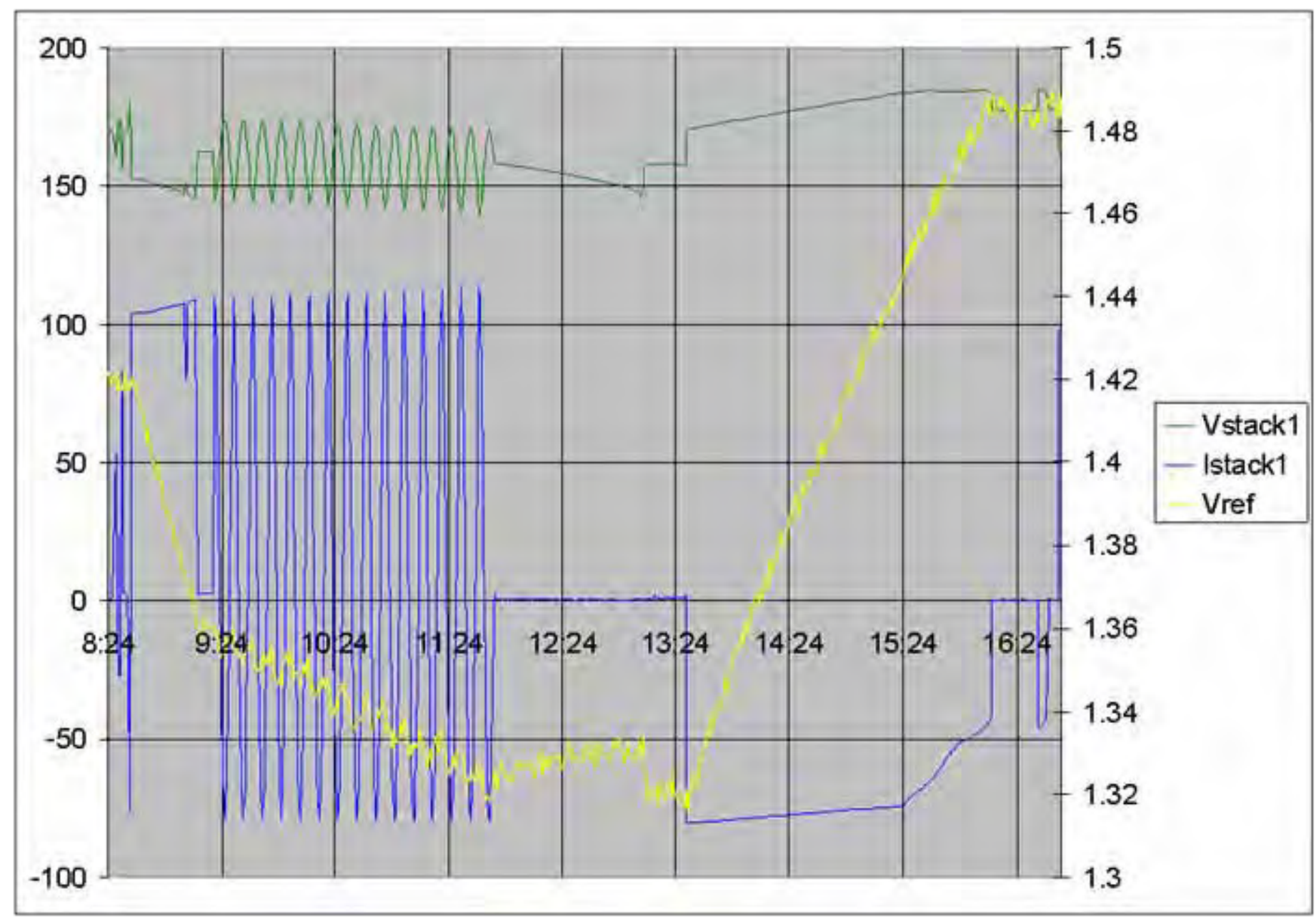




\section{Factory test IV}

- Single charge-discharge cycle

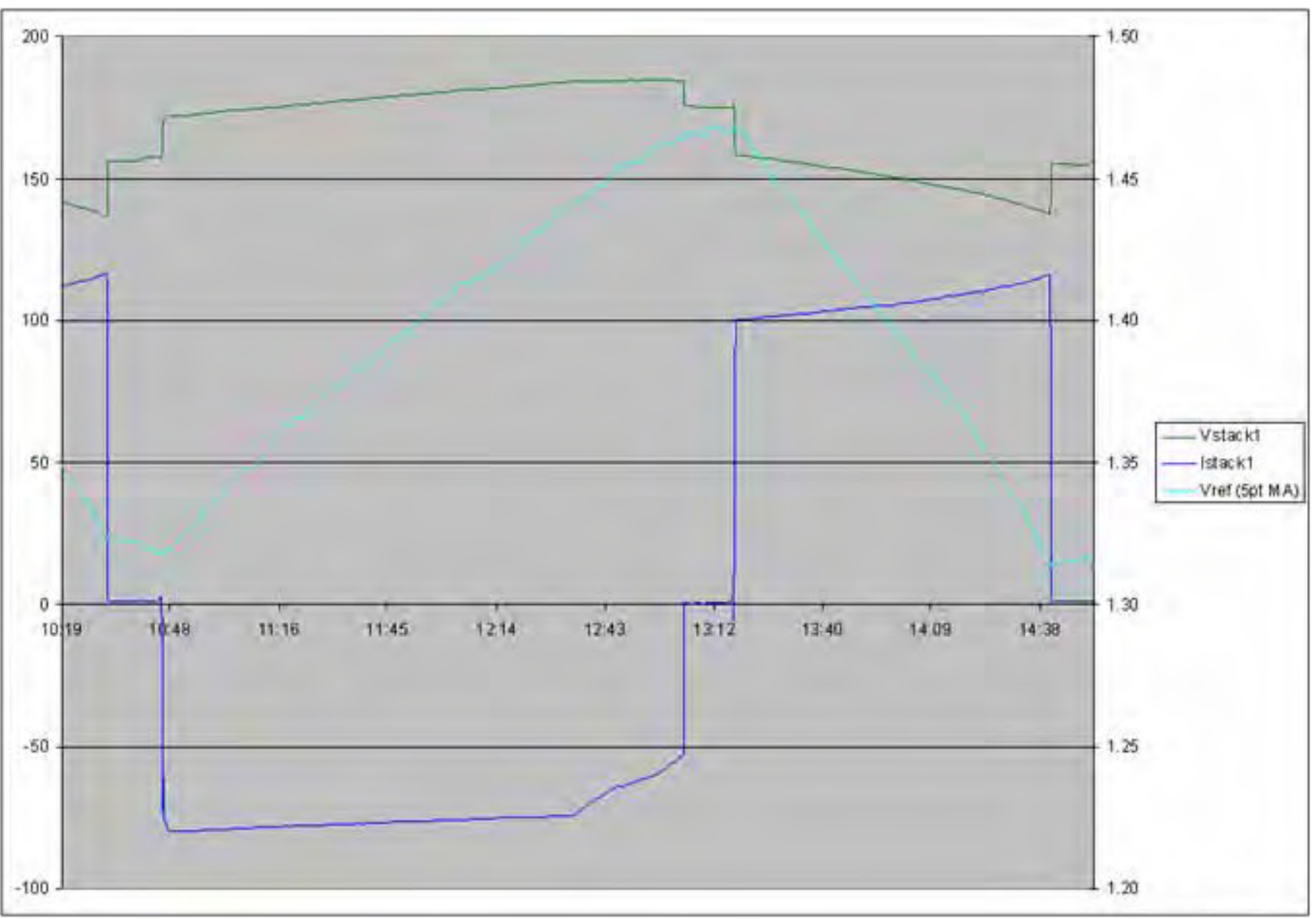




\section{Demonstration of the SYSLAB facility}

- Everyone is welcome at SYSLAB after the conference

- The SYSLAB will be demonstrated and there will be time for discussions

- See you at the center of the RED circle (Møllehallen)

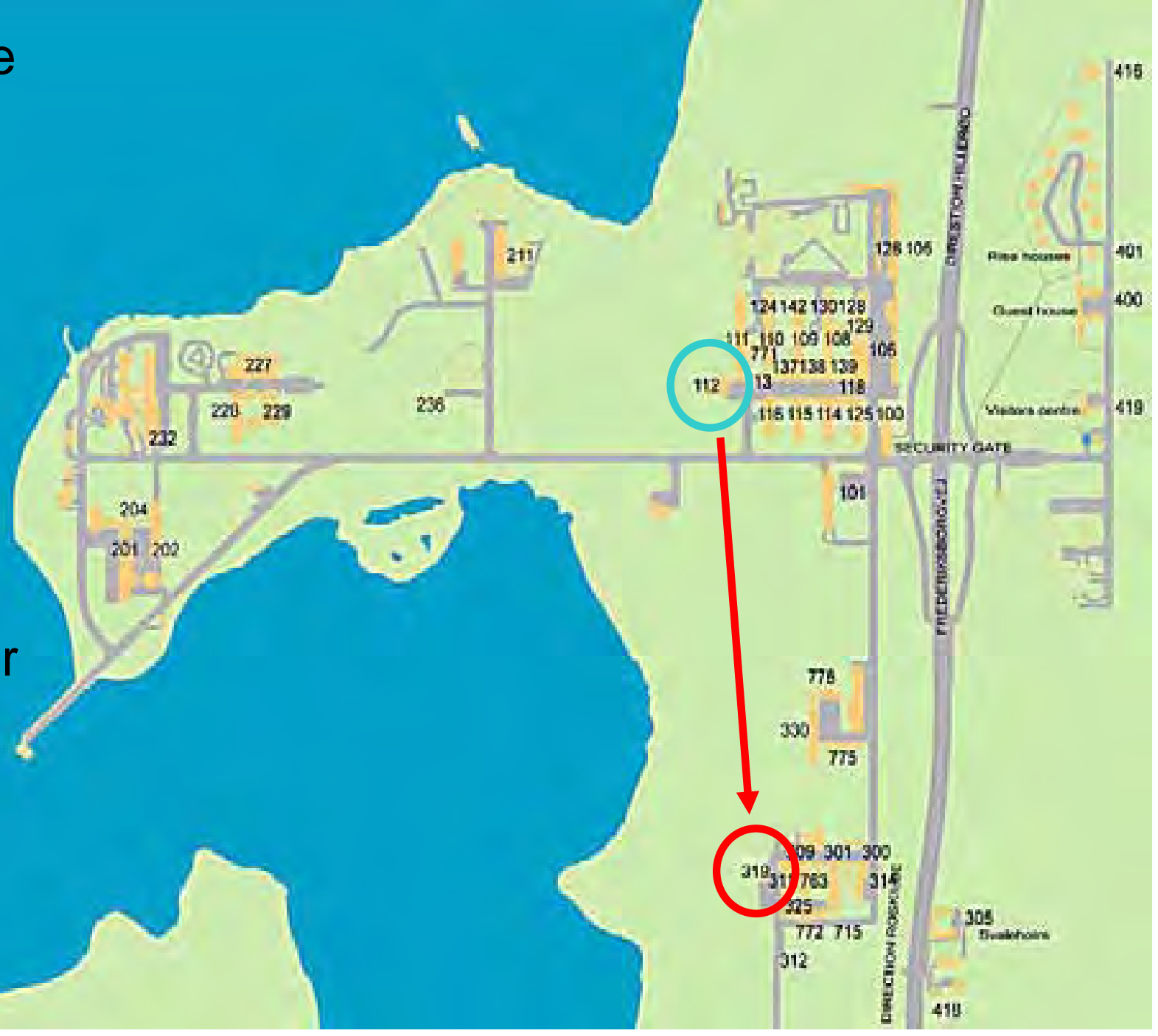




\section{Centralised and decentralised control - a power system point of view}

Oliver Gehrke (Risø/DTU)

Stephanie Ropenus (Risø/DTU)

Philippe Venne (UQAR) 


\section{Outline}

(1) Requirements and challenges for current power systems

(2) Design parameters for power system evolution

(3) Decentralised control

(4) Activities at Risø 


\section{Demands for future power systems}

- Integration of distributed generation

- Integration of intermittent energy sources

- Markets for power and ancillary services

- Open, equal and barrier-free access for third-party service providers

- Security of supply

- Power quality

- Energy efficiency 


\section{Limitations and challenges in current systems}

- Growing complexity, bad scalability

- Limited access to power markets

- Lack of data and automation in large parts of the grid

- Lack of flexibility: Power system structure is considered static in the short and medium term

- DG needs to provide ancillary services, because their peak contribution grows faster than their average contribution

- Large untapped potential for demand response (households, refrigerated warehouses, greenhouses etc.)

- Lack of transmission capacity 


\section{Design parameters}

Not a simple evolution in one area of technology.

Many aspects and design parameters and no general agreement on the target.

-Role of small DER and households

-Types of markets for power and ancillary services

-Market access rules and regulation

-Communication

-Topology of distribution grids

-Role of storage technologies

-Role and providers of ancillary services

-Role of the system operator and its control center

Big differences in current implementations, under technological, economical and political aspects. 


\section{Use of communication technology}

Dedicated (private) communication links between control center and larger units

One-way broadcasts to smaller units

Two-way communication with DER at the household level, using public infrastructure

Communication protocols beyond SCADA (policies, negotiation etc.) 


\section{Small DER interaction}

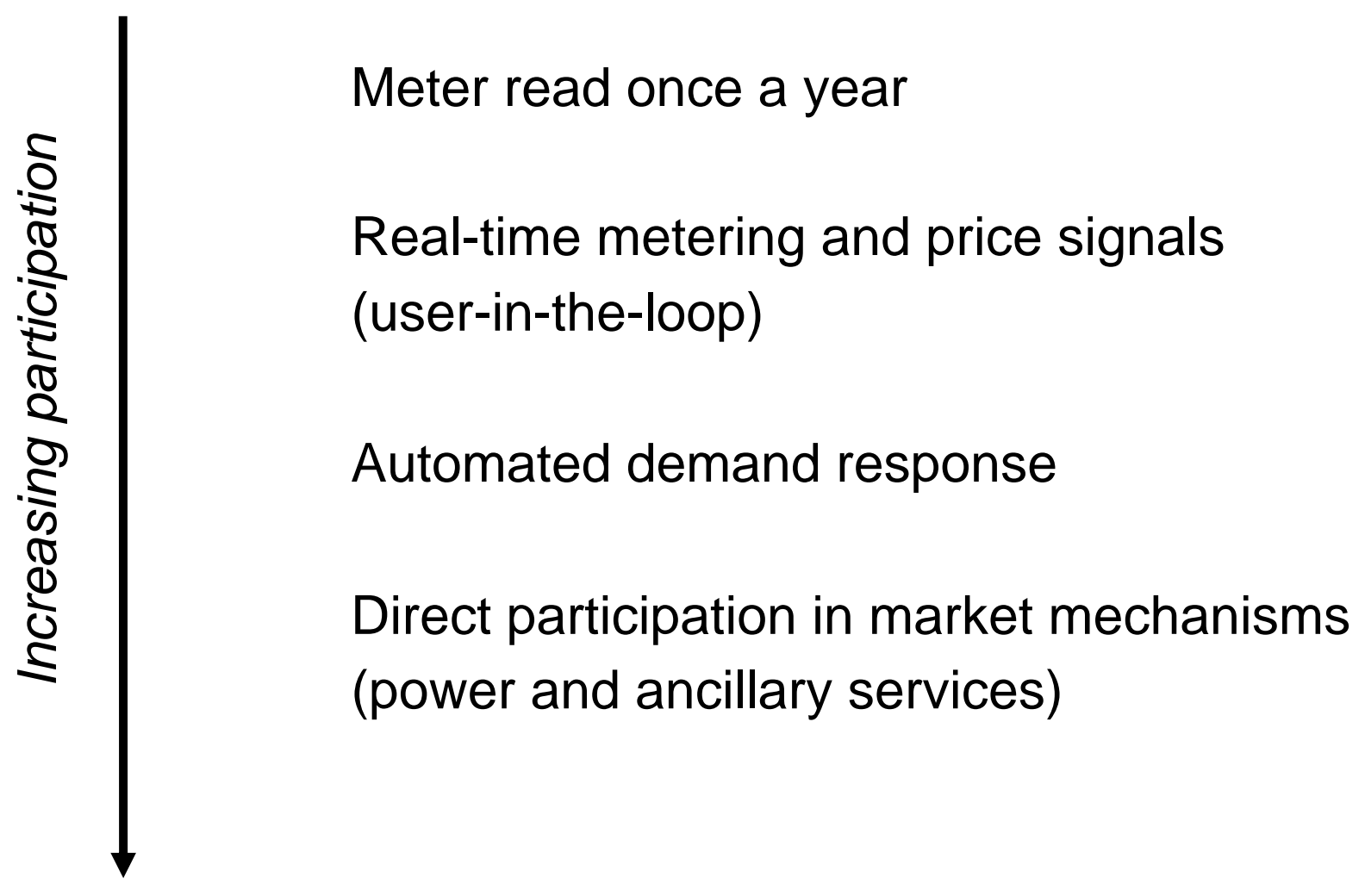




\section{Market access}

High thresholds (capacity requirements, trading fees)

Market aggregators allowed

Open access to markets or sub-markets 


\title{
System control and operation
}

\author{
Control Center
}

Aggregation (Virtual Power Plants)

Delegation (Services provided by grid)

Self-organisation 


\section{Interrelations}

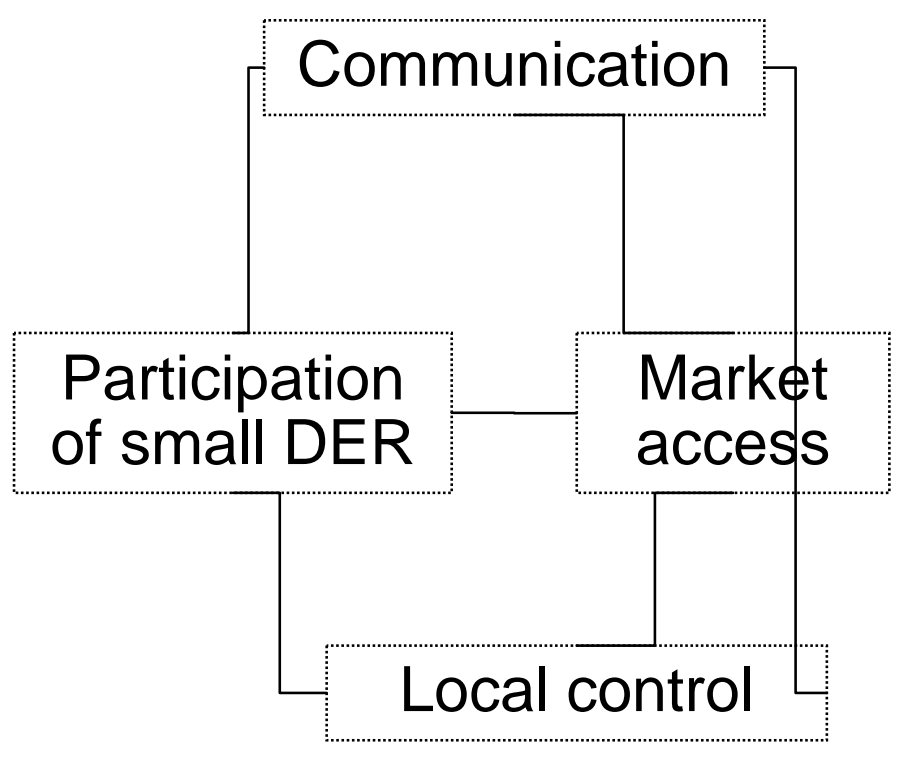

Design parameters are mutually dependent, but not always strongly linked.

Example: Market access for small DER requires some form of communication, but not all types of communication link make sense economically.

Many possible scenarios, picking a particular one is speculative.

The way of operating and controlling the power system is a central issue. It is not clear what is technically possible. 
RISO

\section{Decentralised operation and control}

- Reducing complexity by solving local issues locally, with local data

- Better scalability, making future DER technologies less disruptive

- More flexibility when responding to

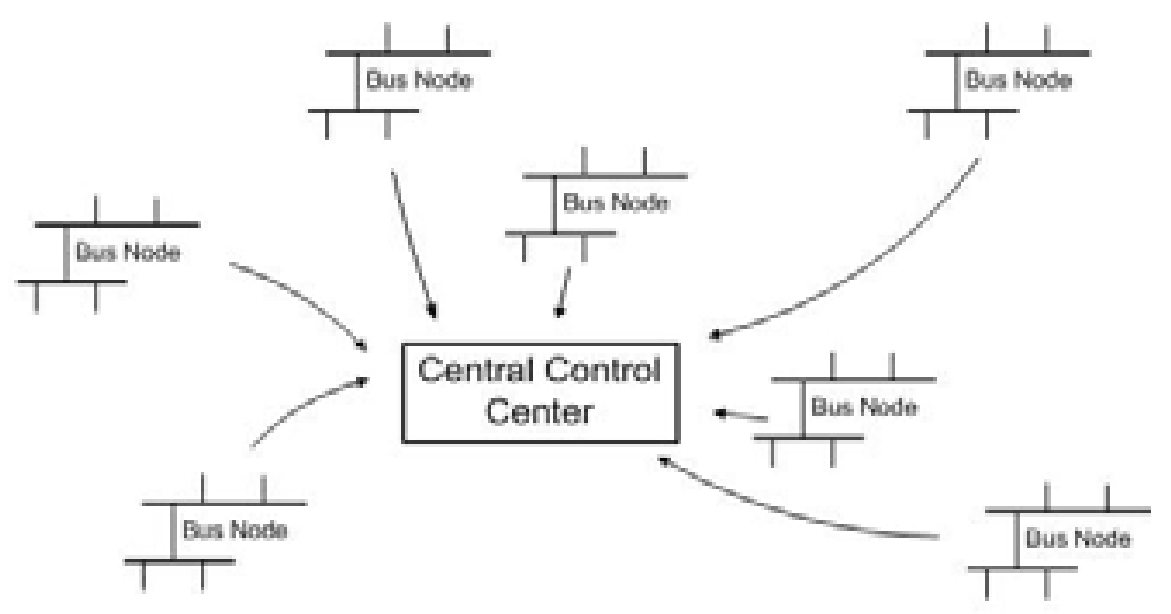
changes in system structure

- Eliminating single points of failure

- Need for widely available protocols and interfaces promotes accessibility

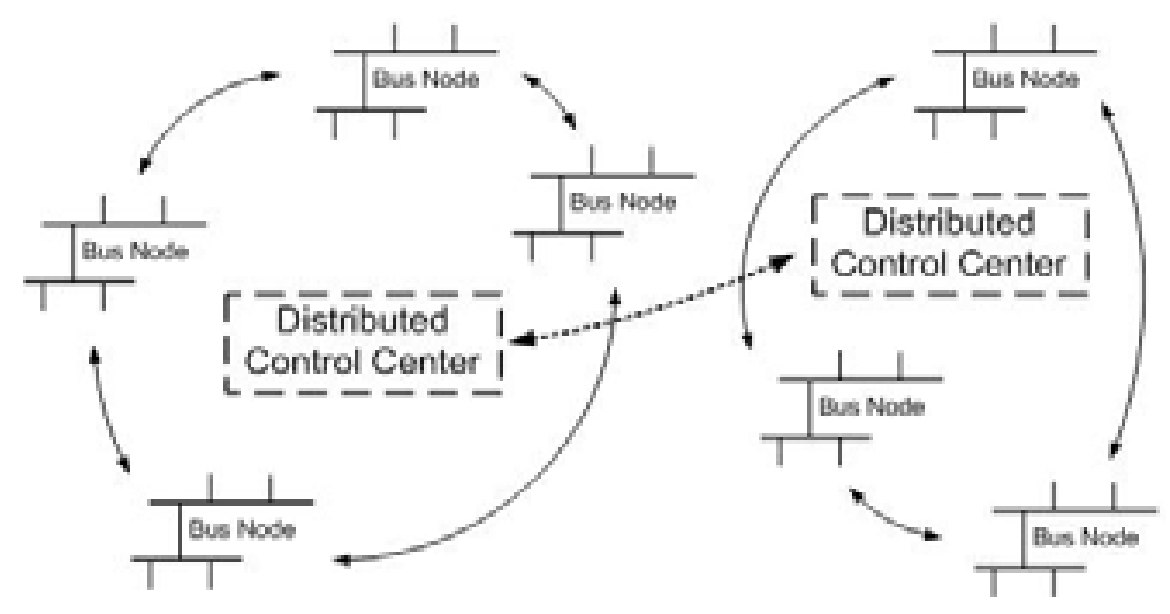




\section{Vision for a future power system (2025+)}

- Grid is self-aware (knows its topology, capabilities, limits and state)

- Role shift: System operator-> System facilitator

- "Human-out-of-the-loop": Supervisors set policies, rather than execute them.

- Flexible, negotiated control hierarchies

- Boundaries between transmission and distribution system become blurred

- Wide-scale use of automated demand response at the household level

- Use of public communication networks (Internet) for small-size DER

- Open - and largely automated - access to markets for power and ancillary services

- New services: Self-islanding, dynamic protection management 


\section{Generic control architecture}

Generic architecture for a decentralised power system

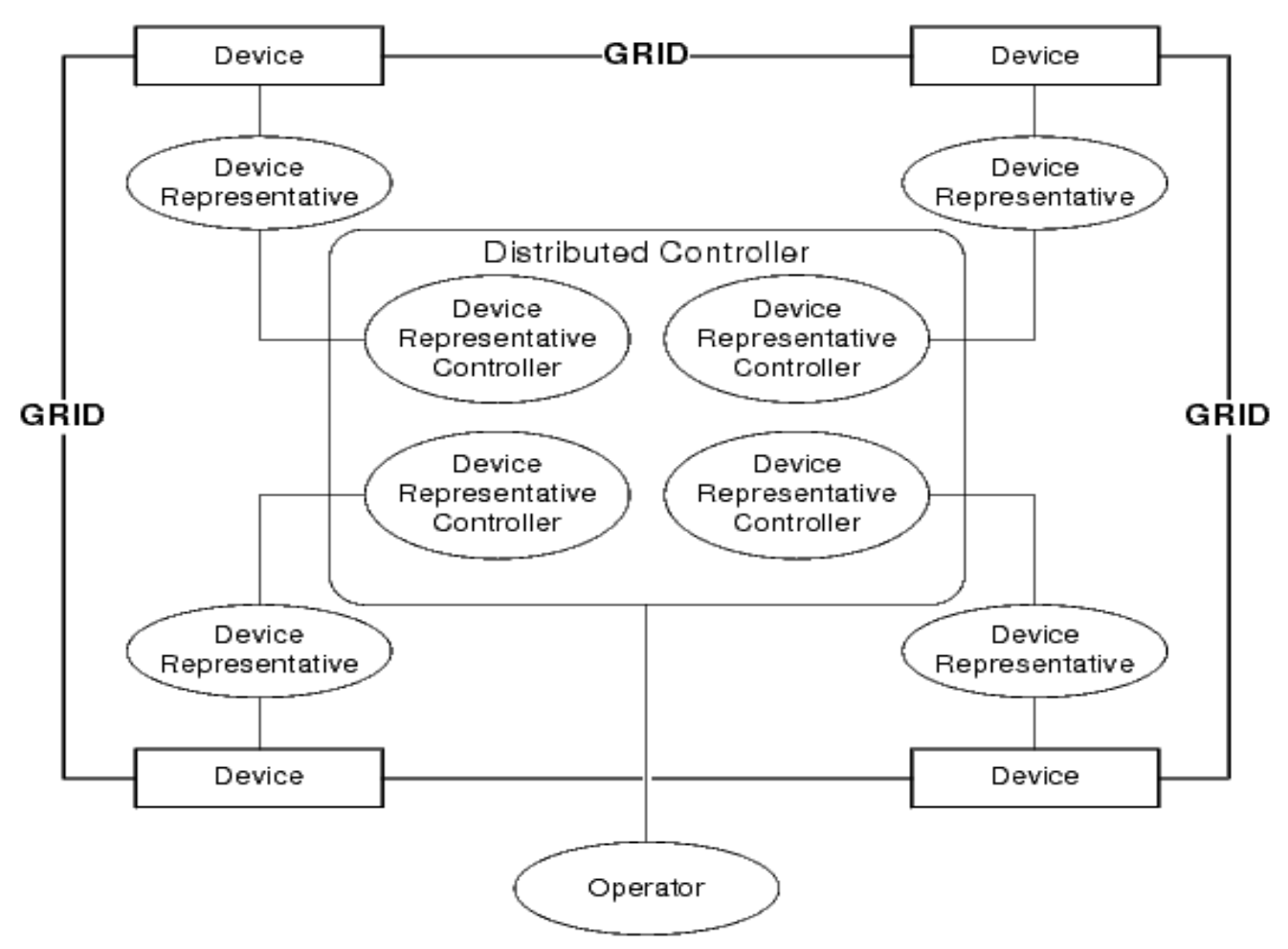

- Device: Grid-connected energy resource

- Device representative: Logical unit providing access to a device

- Device representative controller: Supervises one or more devices

- Distributed controller: Composed of individual controllers 


\section{"Playground" implementation: SYSLAB}

Not feasible to test in a real power system (not at this stage) and no tools available for the combined simulation of

-power system dynamics

-stochastic communication systems

-real-time decentralised decision making

Possible approaches:

-Use a small experimental power system

(accepting that scaling issues are postponed)

- Use a real-time grid simulator with real-world controllers

(accepting that interfacing issues are postponed)

Advantages of an experimental system:

-Most realistic control system studies

-Results have more convincing power

-Advanced environment for component testing 


\section{SYSLAB: Concept}

- One intelligent node per power system component

- Local data acquisition and storage

- Development of selforganising middleware for "plug-and-play" operation

- Supervisory control shared between nodes

Purpose: Testing of communication protocols, control algorithms, energy technologies and components, human-machine

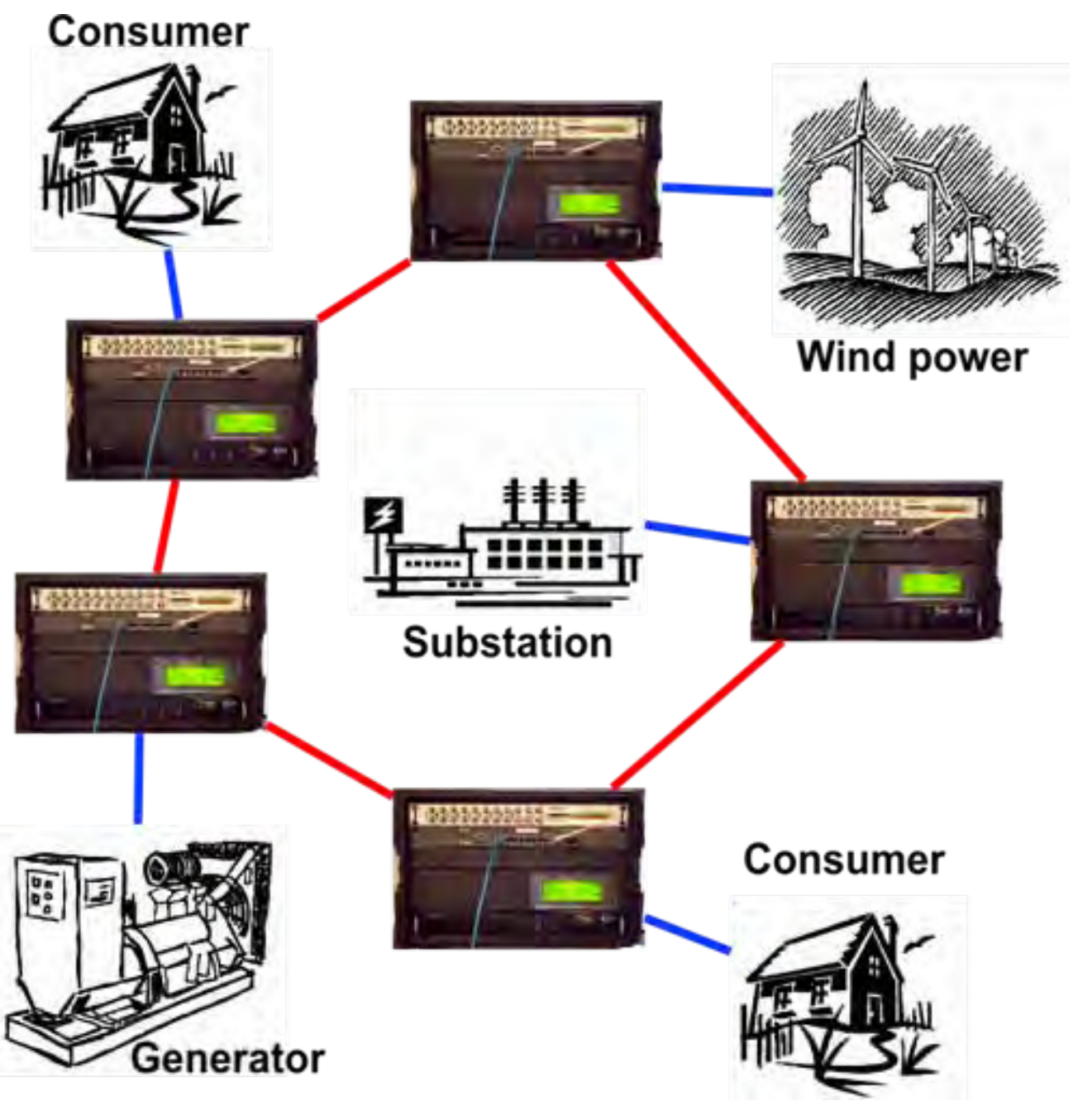
interaction 


\title{
Assessing the Role of Energy in Development and Climate Policies in Large Developing Countries
}

\author{
Amit Garg and Kirsten Halsnæs
}

Risø International Energy Conference 2007

24 May 2007 


\section{Research Enquiry}

$>$ How to align sustainable development, energy and climate change policies at national level (for Brazil, China, India and South Africa)?

$>$ What are sustainable development indicators and their future projections that capture the above alignments?

$>$ What are the $\mathrm{CO}_{2}$ and local pollutant emissions implications of development under a reference scenario for these countries?

$>$ Can alternative development pathways align energy and climate change policy perspectives, and how? 


\section{Development, Energy and Climate Project}
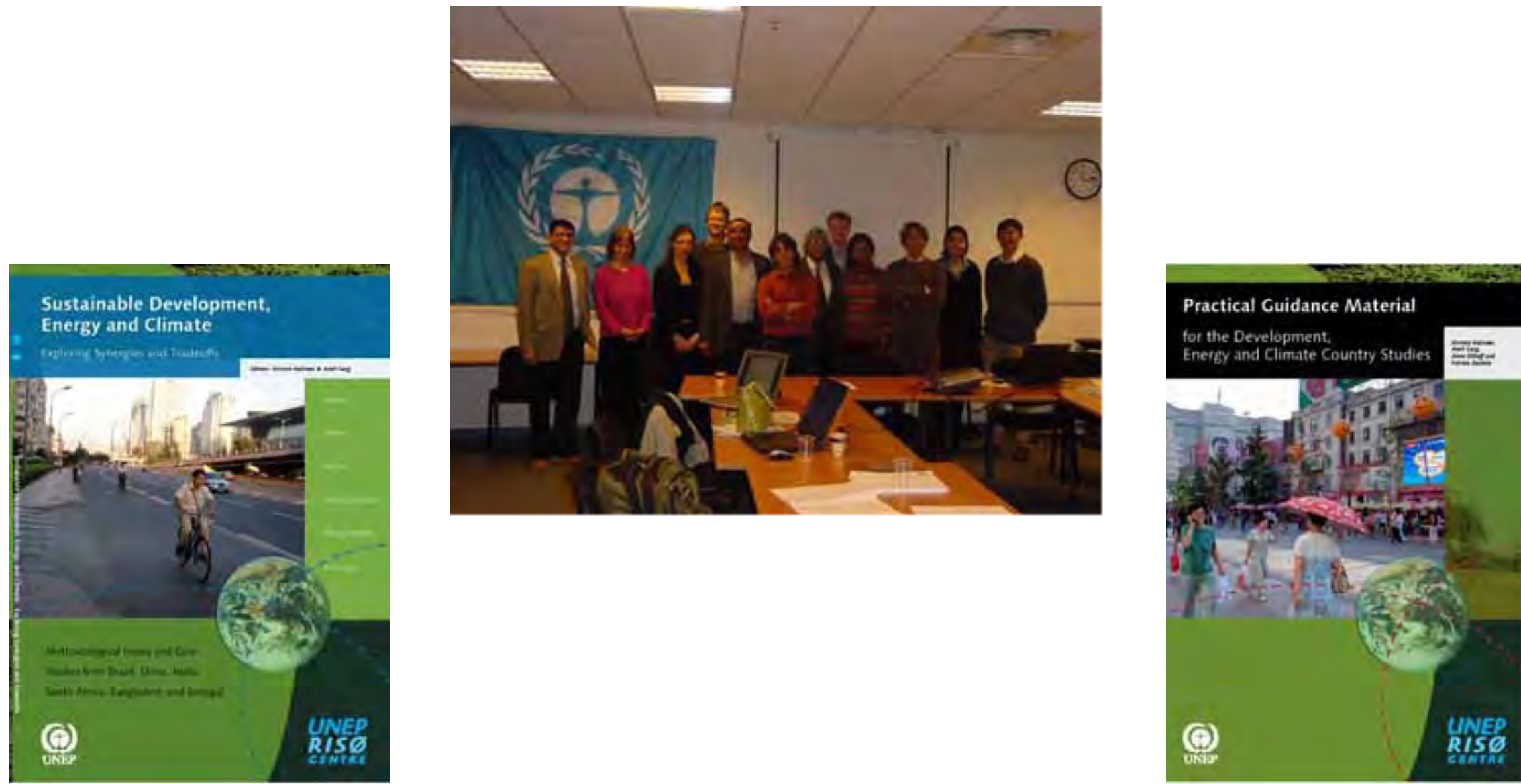


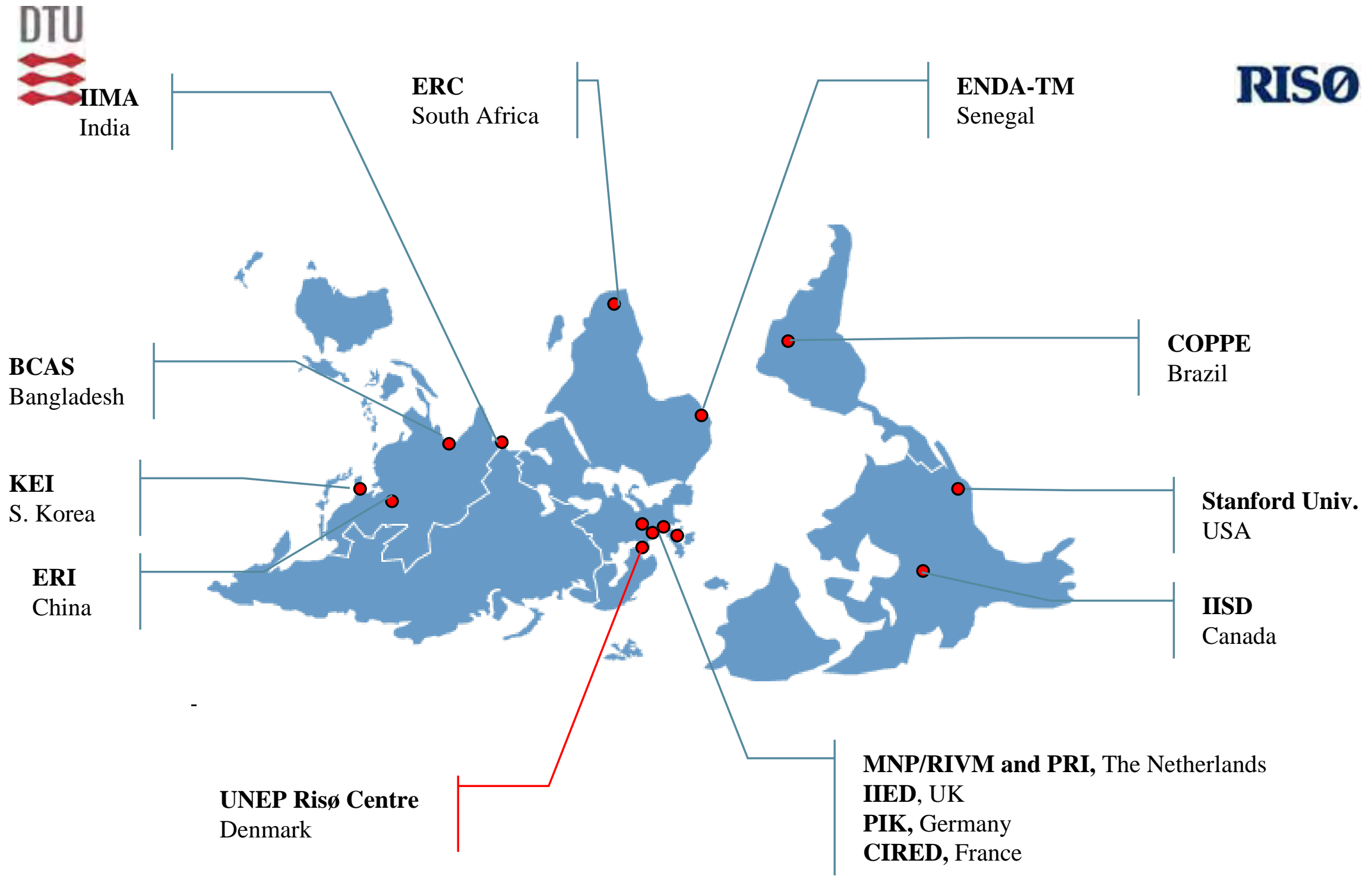




\section{Methodology}

- Used integrated energy modelling framework

- Each country uses comparable energy-environment models

- Consistent reference scenario assumptions in line with global climate change scenario efforts

- Consistent assumptions on oil and gas prices, UN population projections

- National case studies conducted and up scaled to integrate with country models 
Why Use an Integrated Energy Framework for SD Assessment?

$>$ Human activities and most sustainability issues are closely linked to energy use

- Critical component in factor productivity (capital, labor, land), can constrain well being, missing energy imposes time and labor burden on households

- Most important sustainability issues (poverty alleviation, health, education, economic development) as well as climate change issues directly relate to production and use of energy

- Even some of the other important sustainability issues (freshwater, landuse, atmospheric integrity, agriculture) are directly/indirectly related to production and use of energy

$>$ World (humans, systems and environment) can be easily visualized as a flow of and linked through energy 


\section{Why Use an Integrated Energy Framework? (contd.)}

$>$ Offers consistent, comparable and transparent framework for future projections

- Relationships between sustainability dimensions are considered consistently

- Can project and compare across alternative development pathways

- Can compare across different countries (if due care is taken)

- Cab compare SD and CC impacts of competing technologies

$>$ Possible to estimate future energy flows and most of the proposed indicators with commonly used energy models

- Economic models miss out on environmental issues such as climate change

- Environmental models miss out on macro-economic depth and are very sector/region specific 


\section{Modeling SD, Energy and CC Linkages}

\begin{tabular}{|c|c|c|c|}
\hline $\begin{array}{l}\text { Millennium } \\
\text { development goals } \\
\text { and global targets }\end{array}$ & $\begin{array}{l}\text { India's national } \\
\text { development targets }\end{array}$ & $\begin{array}{l}\text { Energy sector } \\
\text { implications }\end{array}$ & $\begin{array}{l}\text { Implications for } \\
\text { energy modeling }\end{array}$ \\
\hline $\begin{array}{l}\text { Goal 1: Eradicate } \\
\text { extreme poverty and } \\
\text { hunger } \\
\text { Target 1: Halve, } \\
\text { between } 1990 \text { and } \\
\text { 2015, the proportion } \\
\text { of people whose } \\
\text { income is less than } \\
\$ 1 \text { a day } \\
\text { Target 2: Halve, } \\
\text { between } 1990 \text { and } \\
\text { 2015, the proportion } \\
\text { of people who suffer } \\
\text { from hunger }\end{array}$ & $\begin{array}{l}\text { - Double the per } \\
\text { capita income during } \\
2002-2012 \\
\text { - Reduction of } \\
\text { poverty ratio by } 5 \\
\text { percentage points } \\
\text { during } 2002-2007 \\
\text { and by } 15 \text { percentage } \\
\text { points during 2002- } \\
2012 \\
\text { - Reduce decadal } \\
\text { population growth } \\
\text { rate to } 16.2 \% \\
\text { between 2001-2011 } \\
\text { (from 21.3\% during } \\
\text { 1991-2001) }\end{array}$ & $\begin{array}{l}\text { - Energy for } \\
\text { increased production } \\
\text { and consumption } \\
\text { • Energy for local } \\
\text { enterprises and } \\
\text { machinery } \\
\text { - Energy and } \\
\text { electricity to } \\
\text { facilitate income } \\
\text { generation } \\
\text { - Energy for } \\
\text { providing family } \\
\text { planning and health } \\
\text { services }\end{array}$ & $\begin{array}{l}\text { - GDP and } \\
\text { population } \\
\text { projections } \\
\text { - Sectoral demand } \\
\text { projections } \\
\text { consistent with the } \\
\text { above } \\
\text { - Reflect/capture } \\
\text { inputs needed for } \\
\text { increased health } \\
\text { services etc in } \\
\text { sectoral demand } \\
\text { projections } \\
\text { - Energy needed for } \\
\text { the above using } \\
\text { sectoral/ national } \\
\text { models }\end{array}$ \\
\hline
\end{tabular}




\section{Proposed Sustainable Development Indicators (SDI)}

Using energy framework for SDI requires an approach where the energy analysis starts with development and human needs rather that structured around energy system logics

$>$ Economic indicators

- Efficiency of production indicators

- Efficiency of energy use indicators

- Energy investment indicators

$>$ Environmental indicators

- GHG and local pollutant emissions (per unit of output and per capita)

- Share of solid fuels in residential sector (households)

Social indicators

- Energy affordability indicators

- Per capita consumption

- Share of clean energy in residential sector (households) 


\section{Integrated Energy Modeling and SDI}

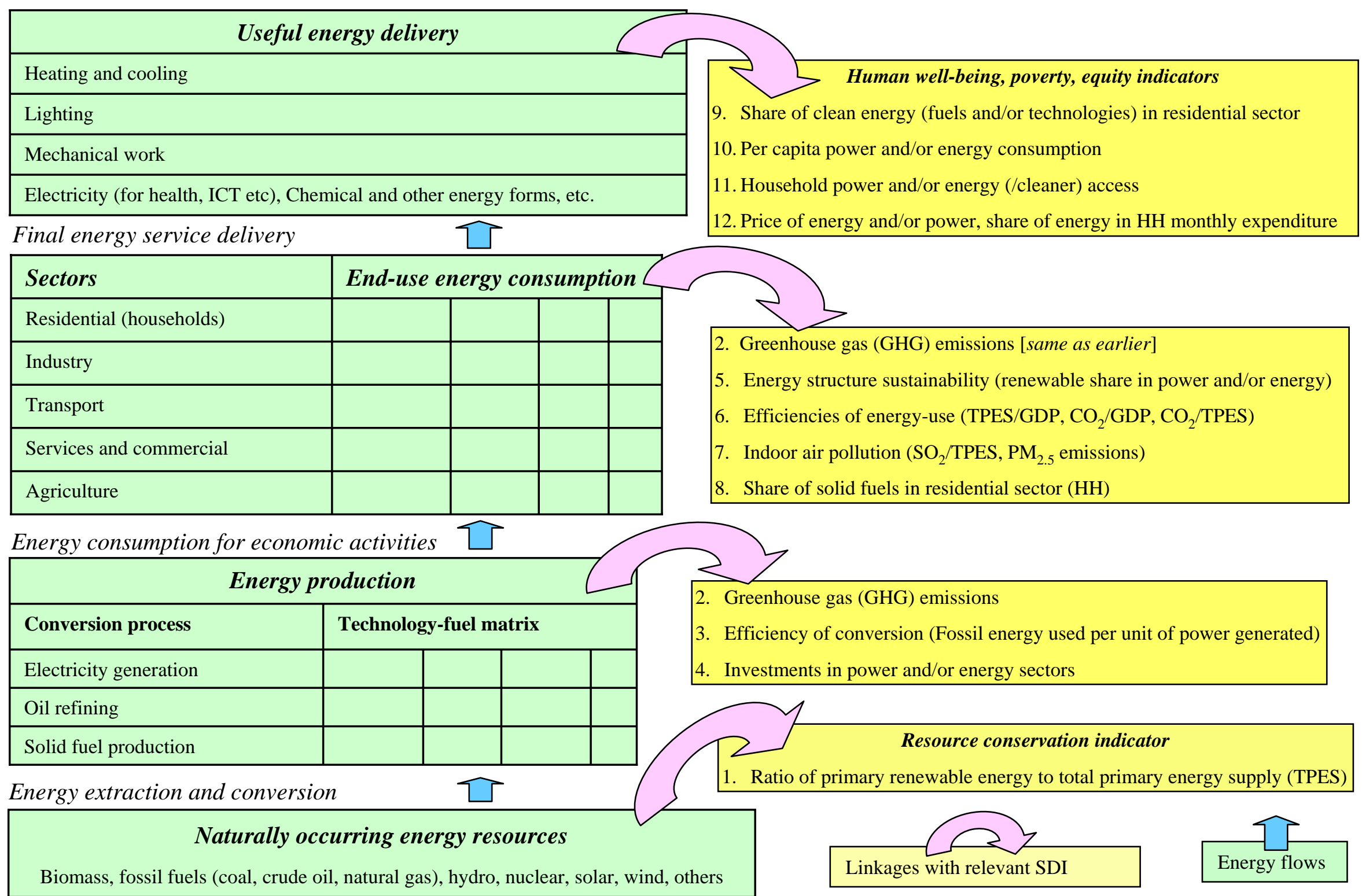




\section{RISO}

\section{Some Cross-country Results}




\section{Energy Policies Linked with SD and CC}

\begin{tabular}{|c|c|}
\hline \multicolumn{2}{|l|}{ China } \\
\hline 2004 & $\begin{array}{l}\text { Energy Medium-Long term Development programme (2004-2020), such as energy } \\
\text { security, energy efficiency, and clean-coal. }\end{array}$ \\
\hline 2004 & $\begin{array}{l}60 \text { GW renewable power capacity by } 2010 \text { ( } 10 \% \text { of total power generating capacity) } \\
\text { and } 121 \text { GW by } 2020 \text { ( } 12 \% \text { of total capacity) }\end{array}$ \\
\hline 2005 & $\begin{array}{l}\text { Medium-Long term Energy Conversation programme, annual energy conservation } \\
\text { rate of } 2.2 \% \text { till } 2020 \text { covering various sectors. }\end{array}$ \\
\hline Current & Strong economic growth, and declining population growth \\
\hline Current & More efficient coal-based power generation from existing and new plants \\
\hline Current & $\begin{array}{l}\text { Strong thrust on energy efficiency improvement in all sectors (e.g. } 20 \% \text { energy } \\
\text { intensity reduction during 2005-2010, efficiency of coal-fired power plants to } \\
\text { increase to } 40 \% \text { by 2030, new building to reach } 75 \% \text { increase standards in } 2030 \text { etc.) }\end{array}$ \\
\hline $\mathrm{UC}$ & Nuclear power capacity of 40 GW by 2020 \\
\hline
\end{tabular}




\section{Energy Policies Linked with SD and CC}

\begin{tabular}{|l|l|}
\hline \multicolumn{2}{|l|}{ India } \\
\hline Current & More efficient coal-based power generation from existing and new plants \\
\hline 2001 & reduce power transmission and distribution losses \\
\hline 2002 & $10 \%$ of new power generation capacity by renewables by 2012 \\
\hline $\begin{array}{l}2002- \\
\text { Current }\end{array}$ & $\begin{array}{l}\text { Doubling per capita income during 2002-2012, and to reduce decadal population growth rate } \\
\text { to 16.2\% between 2001-2011 (from 21.3\% during 1991-2001) }\end{array}$ \\
\hline 2002 & $\begin{array}{l}\text { Auto fuel policy: Emission norms for new vehicles - Euro-3 equivalent norms from 2010 for } \\
\text { the entire country, but for 11 large cities Euro-3 equivalent from 2005 and Euro-4 equivalent } \\
\text { from 2010 }\end{array}$ \\
\hline 2005 & Ethanol blend in gasoline (up to 5-10\% in phases), ongoing discussions for expansion \\
\hline 2005 & $\begin{array}{l}100 \% \text { household electrification in rural areas by 2010 covering 75 million rural households, } \\
\text { and modernizing rural electricity infrastructure }\end{array}$ \\
\hline 2006 & $\begin{array}{l}\text { Minimum employment guarantee scheme for rural areas (100 days' employment per } \\
\text { household per year) in 200 districts (extended to 350 districts now) }\end{array}$ \\
\hline UC & Nuclear power capacity of 20 GW by 2020 \\
\hline
\end{tabular}




\section{Efficiencies of Energy Use}
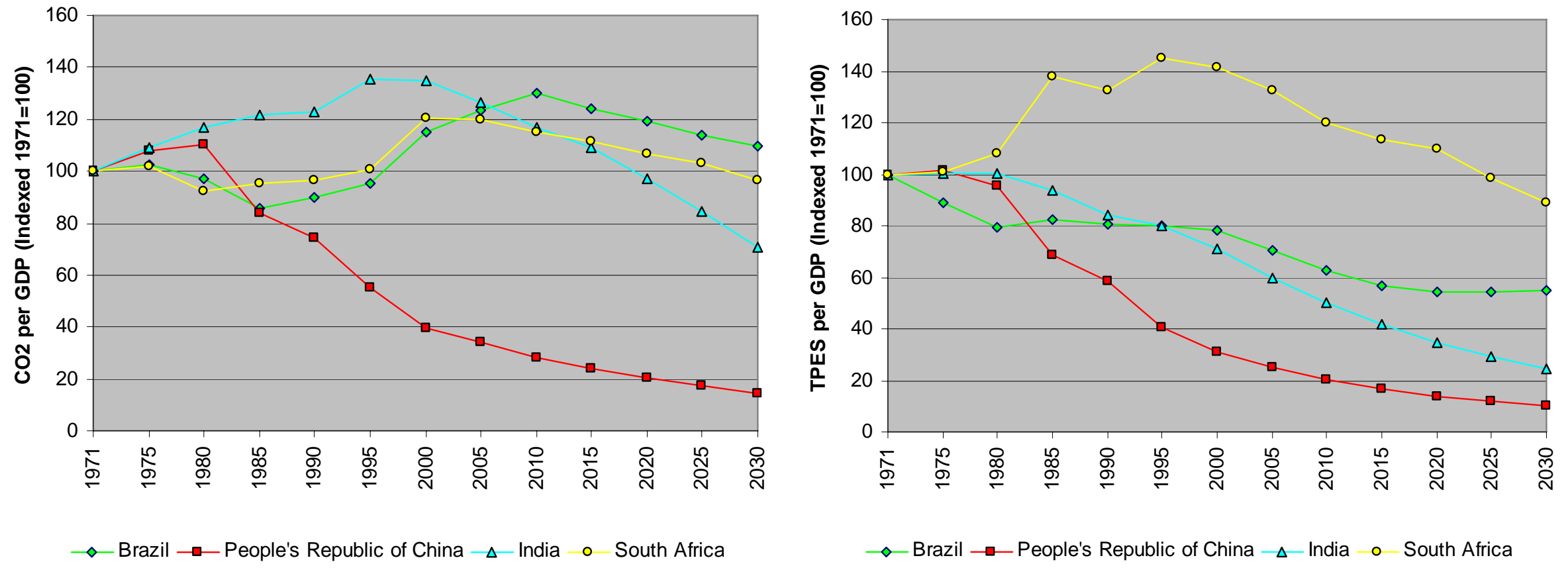

- GDP becomes less energy and less $\mathrm{CO}_{2}$ intensive under all scenarios

- Decoupling rates, timings and extent are however different for different countries

- Sectoral variations exist in each country 


\section{Decoupling of Energy and $\mathrm{CO}_{2}$ Emissions}

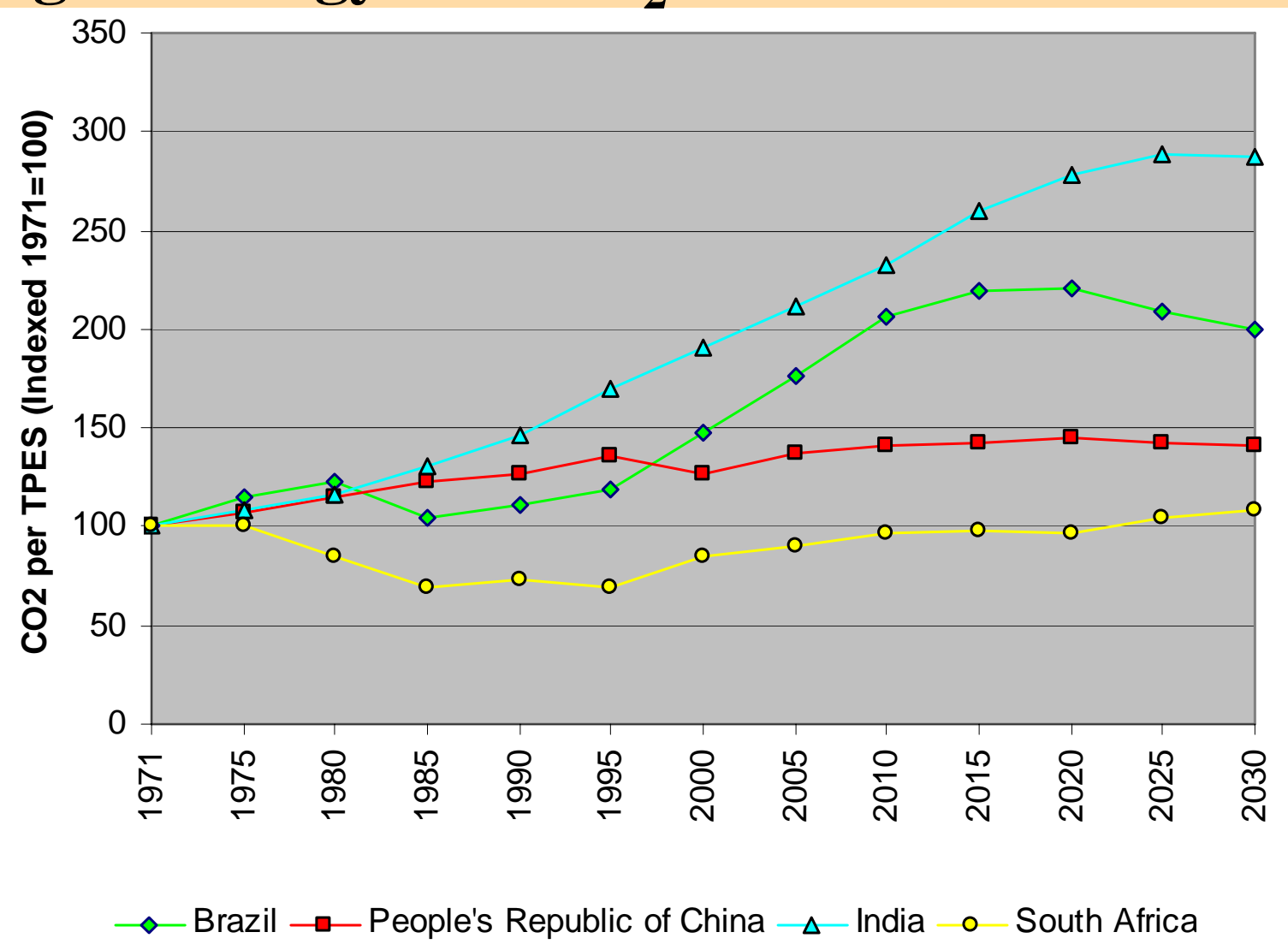

- Energy and $\mathrm{CO}_{2}$ emissions do not decouple much under reference scenario

- Reasons are different for each country 


\section{$\mathrm{CO}_{2}$ and Local Pollutant Emission Projections}

- Large developing countries are projected to add considerable fossil fuel based capacities during 2007-2030

- $\mathrm{CO}_{2}$ emissions are projected to grow as a result
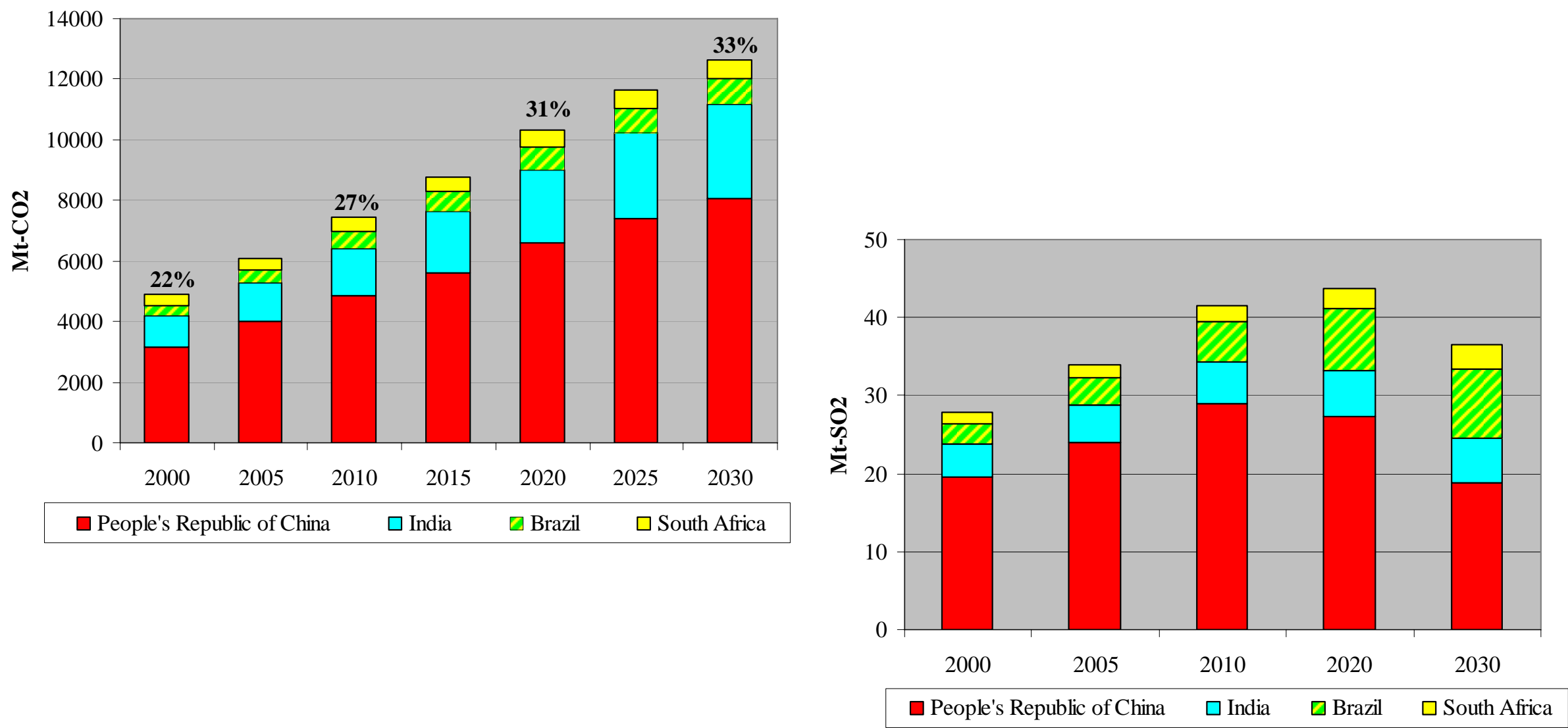


\section{Emission Relationships}

- $\mathrm{CO}_{2}$ and local pollutant emissions (e.g. $\mathrm{SO}_{2}$, $\mathrm{NO}_{\mathrm{X}}$ and particulates) decouple

- Elasticity of mitigating $\mathrm{CO}_{2}$ as a side-benefit of $\mathrm{SO}_{2}$ mitigation policy is lower (0.1-0.01 in 2020 for India) than elasticity of mitigating $\mathrm{SO}_{2}$ as a side-benefit (1.2 to 1.4 in 2020 for India) from a direct $\mathrm{CO}_{2}$ mitigation policy. Same for $\mathrm{CO}_{2}$ and particulates. Similar trends for China.

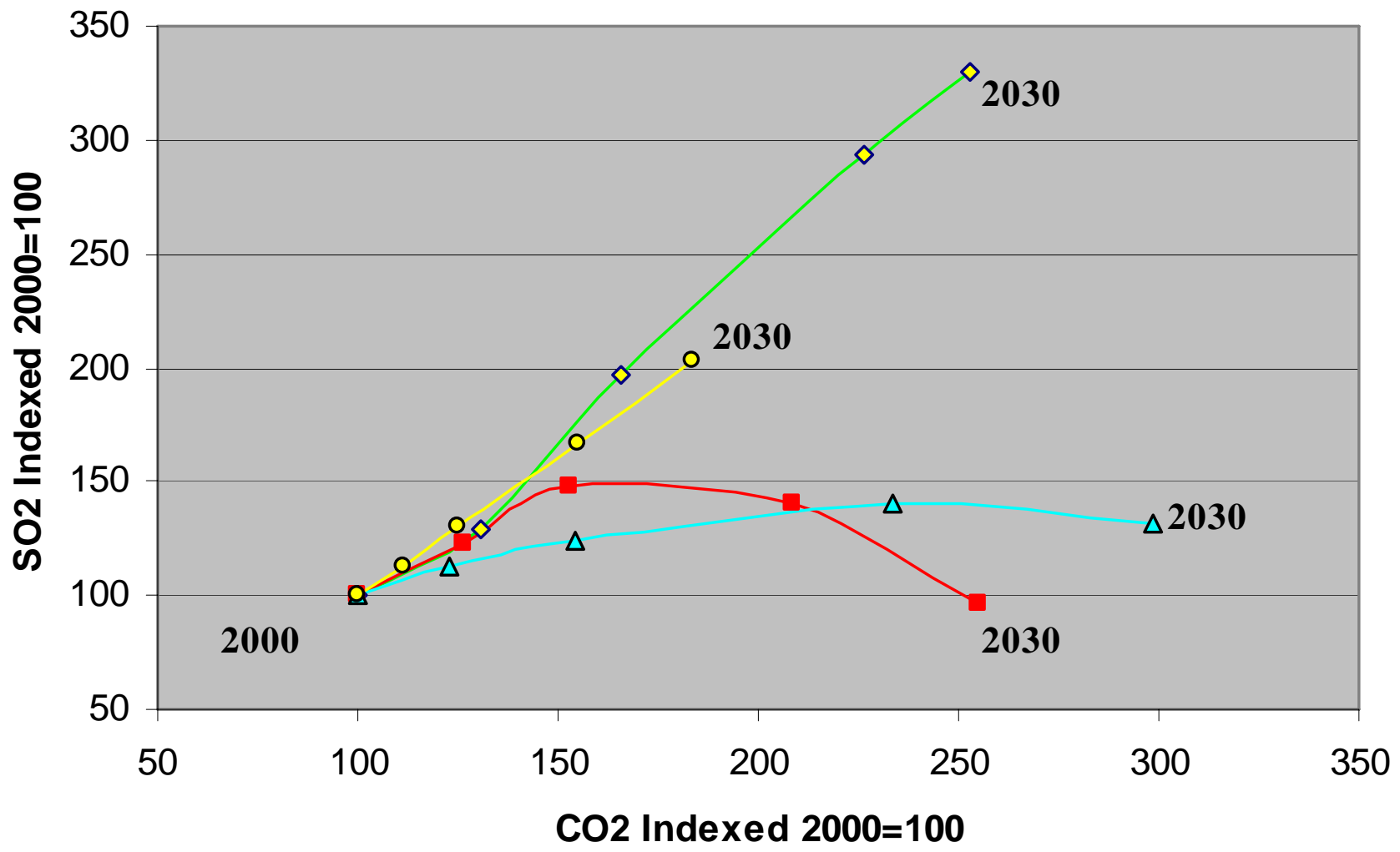

- Policy relevance and investment implications 


\section{SD Indicators Linked with the Power Sector}




\section{Efficiency of Conversion (Energy used basis)}

- Current efficiency of production is relatively lower, however projected to improve in future.

- China, India and South Africa consume over $40 \%$ of global coal, about $2 / 3^{\text {rd }}$ is for power generation.

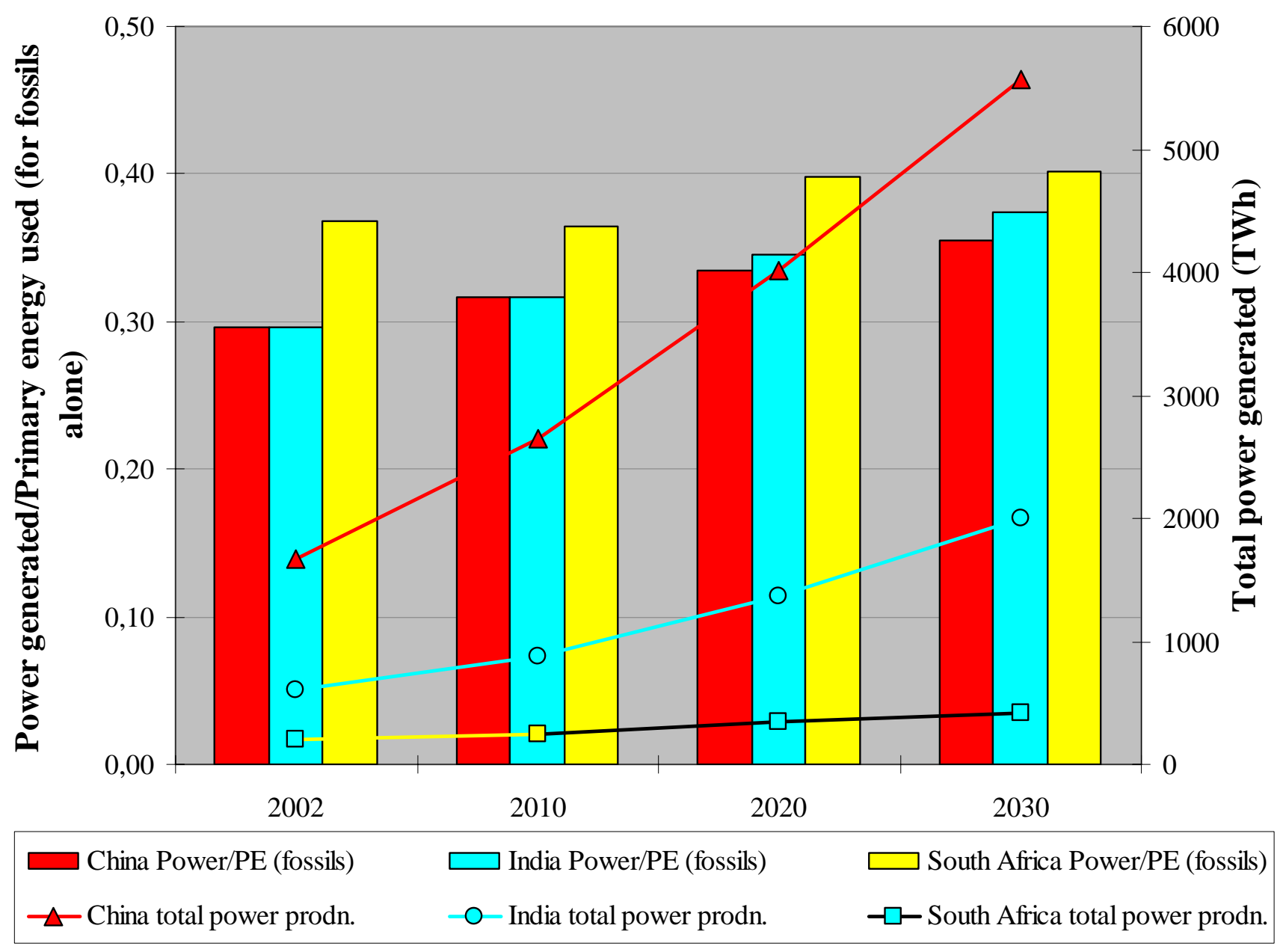




\section{Efficiency of Conversion ( $\mathrm{CO}_{2}$ emissions basis)}

Average $\mathrm{CO}_{2}$ emissions per unit of electricity generated are much higher than the best global practices

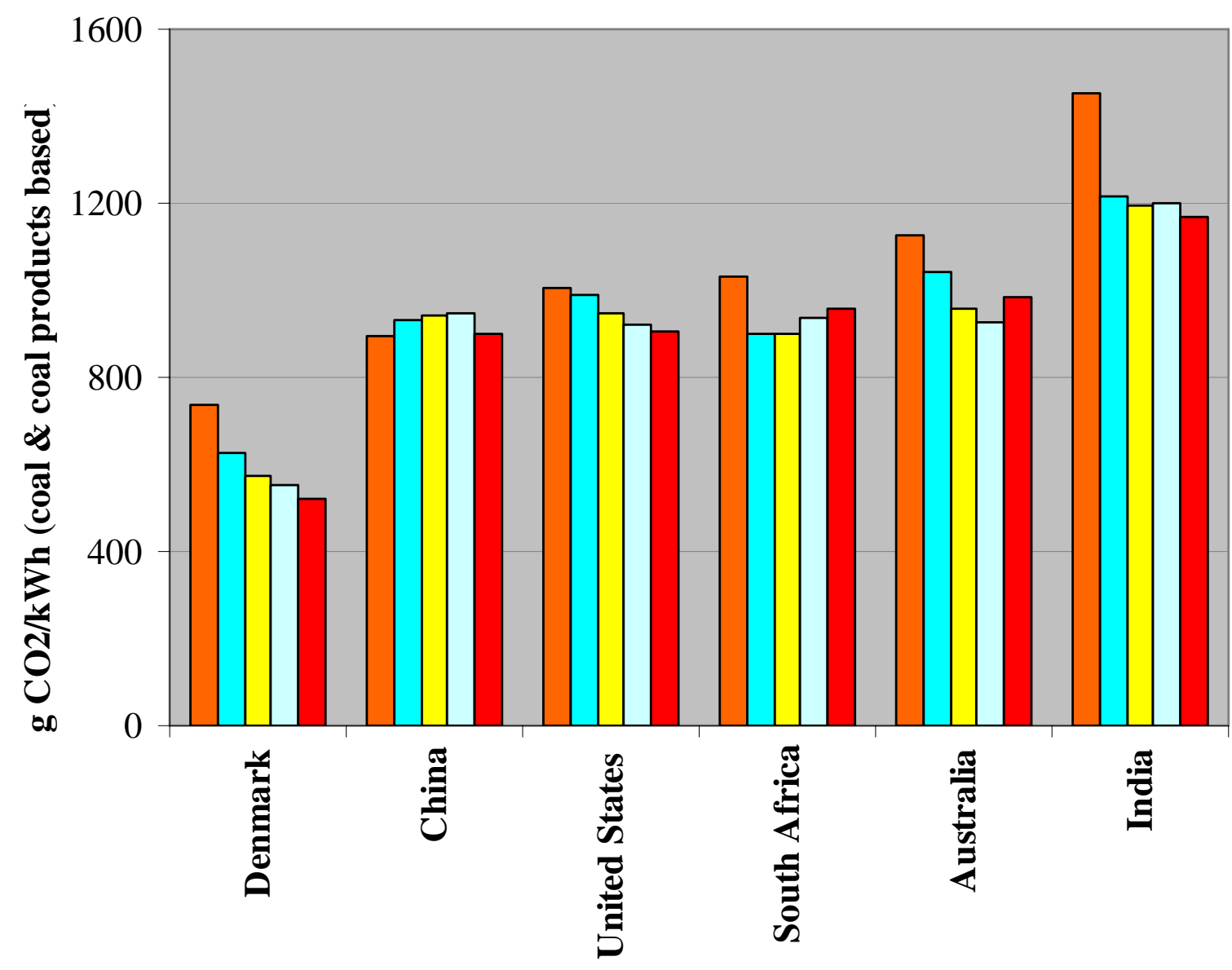

$\square 1980$

$\square 1985$

$\square 1990$

$\square 1995$

$\square 2000$ 


\section{General Conclusions about the Relationship between Development and Energy}

- Reallocation of household time (especially by woman) from energy provision to improved education and income generation and greater specialisation of economic functions.

- Economics of scale in more industrial-type energy provision.

- Greater flexibility in time allocation through the day and evening.

- Enhanced productivity of education efforts.

- Greater ability to use a more efficient capital stock and take advantage of new technologies.

- Lower transportation and communication costs.

- Health related benefits: reduced smoke exposure, clean water and refrigeration. 


\section{Households}

\begin{tabular}{|c|c|c|c|c|c|c|}
\hline \multirow[b]{2}{*}{$\begin{array}{l}\text { HH income } \\
\text { category }\end{array}$} & \multicolumn{2}{|c|}{ India rural, 2000} & \multicolumn{2}{|c|}{ India urban, 2000} & \multicolumn{2}{|c|}{ China urban, 2004} \\
\hline & $\begin{array}{l}\text { Absolute } \\
\text { expenditu } \\
\text { re (USD, } \\
2000 \\
\text { prices) }\end{array}$ & $\begin{array}{l}\% \text { share of } \\
\text { total } \mathrm{HH} \\
\text { expenditure }\end{array}$ & $\begin{array}{l}\text { Absolute } \\
\text { expenditure } \\
\text { (USD, } \\
2000 \\
\text { prices) }\end{array}$ & $\begin{array}{l}\text { \% share of } \\
\text { total } \mathrm{HH} \\
\text { expenditure }\end{array}$ & $\begin{array}{l}\text { Absolute } \\
\text { expenditure } \\
\text { (USD, } \\
2000 \\
\text { prices) }\end{array}$ & $\begin{array}{l}\text { \% share of } \\
\text { total } \mathrm{HH} \\
\text { expenditure }\end{array}$ \\
\hline Poorest $0-5 \%$ & 0.46 & $10.2 \%$ & 0.65 & $10.9 \%$ & 3.00 & $10.3 \%$ \\
\hline $0-10 \%$ & 0.51 & $10.1 \%$ & 0.80 & $10.7 \%$ & 3.33 & $9.8 \%$ \\
\hline $10-20 \%$ & 0.62 & $9.0 \%$ & 1.04 & $10.5 \%$ & 4.10 & $8.7 \%$ \\
\hline $20-40 \%$ & 0.73 & $8.7 \%$ & 1.46 & $10.1 \%$ & 4.79 & $7.9 \%$ \\
\hline $40-60 \%$ & 0.97 & $8.9 \%$ & 1.73 & $9.6 \%$ & 5.57 & $7.2 \%$ \\
\hline $60-80 \%$ & 1.15 & $8.6 \%$ & 2.13 & $8.9 \%$ & 6.55 & $6.6 \%$ \\
\hline $80-90 \%$ & 1.44 & $8.1 \%$ & 2.67 & $7.8 \%$ & 7.67 & $6.0 \%$ \\
\hline Тор 90-100\% & 1.79 & $7.2 \%$ & 4.01 & $5.7 \%$ & 10.10 & $5.0 \%$ \\
\hline
\end{tabular}




\section{Households}

\section{Table 2 Summary of How a Typical Household in Rural Philippines Benefits} from Electricity, 1998

\begin{tabular}{|l|l|l|}
\hline Benefit Category & $\begin{array}{l}\text { Benefit Value } \\
\text { US \$ }\end{array}$ & $\begin{array}{l}\text { Unit } \\
\text { Per month }\end{array}$ \\
\hline $\begin{array}{l}\text { Less expensive and expanded } \\
\text { use of lighting }\end{array}$ & 36.75 & Household \\
\hline $\begin{array}{l}\text { Less expensive and expanded } \\
\text { use of radio and television }\end{array}$ & 19.60 & Household \\
\hline $\begin{array}{l}\text { Improved returns on } \\
\text { education and wage income }\end{array}$ & 37.07 & Wage earner \\
\hline $\begin{array}{l}\text { Time savings for household } \\
\text { chores }\end{array}$ & 24.50 & Household \\
\hline $\begin{array}{l}\text { Improved productivity of } \\
\text { home business }\end{array}$ & $\begin{array}{l}34.00 \text { (current business) } \\
75.00 \text { (new business) }\end{array}$ & Business \\
\hline
\end{tabular}

Source: ESMAP, 2002 Table E-1 


\section{Electricity Access and Affordability Indicators}

- Reducing energy poverty, and enhanced electricity access for developmental goals is projected to increase electricity requirements during 2007-2030

- Coal based power is projected to remain the primary source - mainly due to energy security considerations

- Coal use becomes cleaner, but not clean enough.

\section{AcGess}

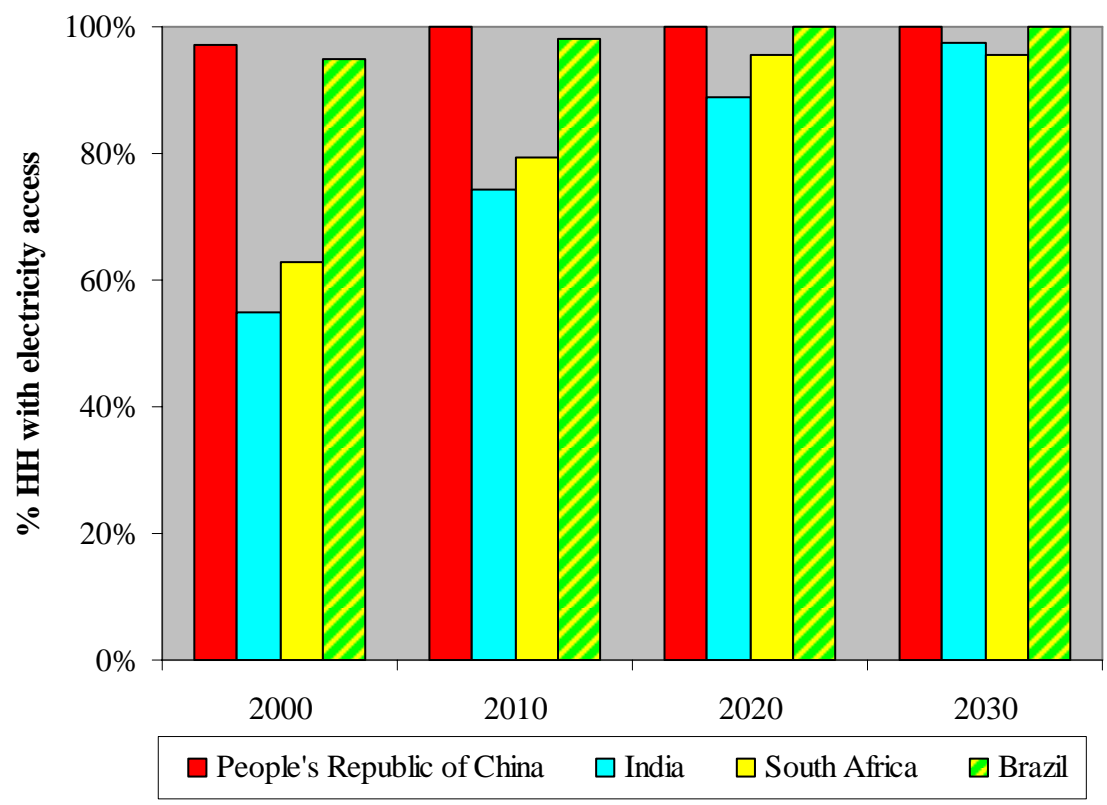

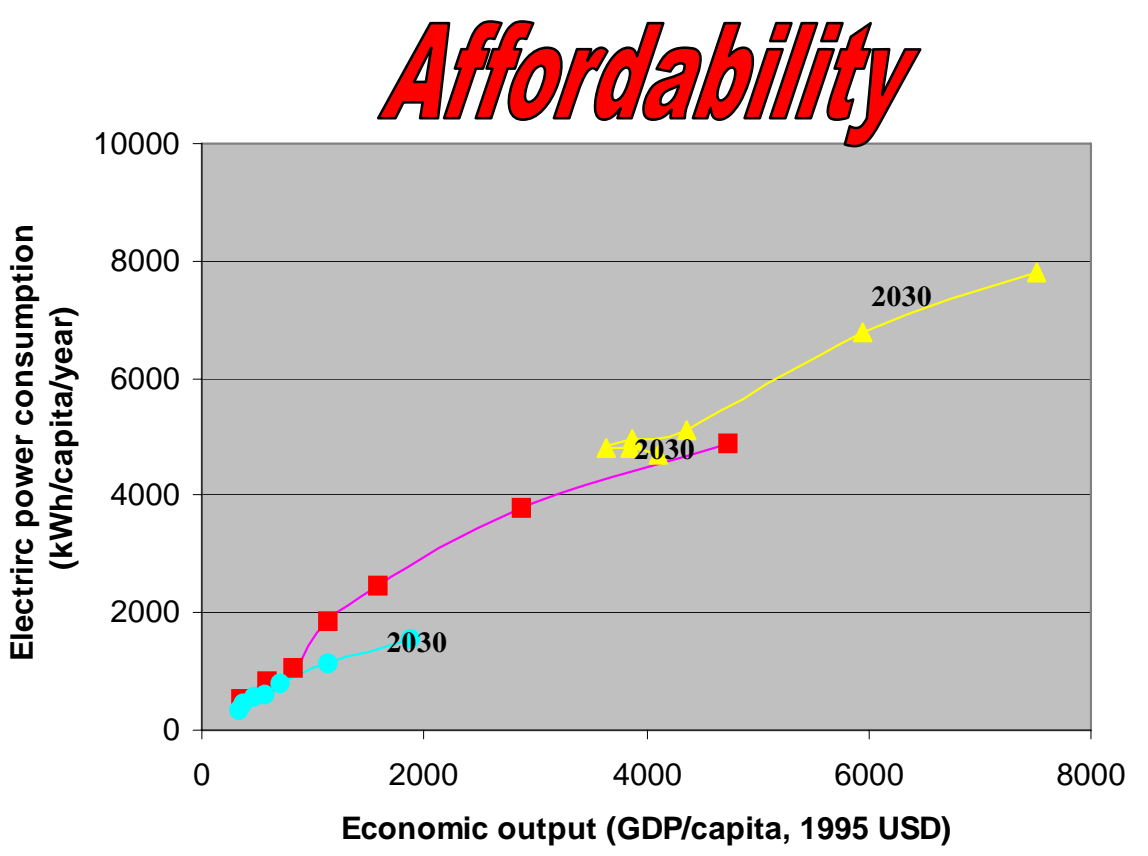

- People's Republic of China

—— India South Africa 


\section{Sustainable Development Indicators for China}

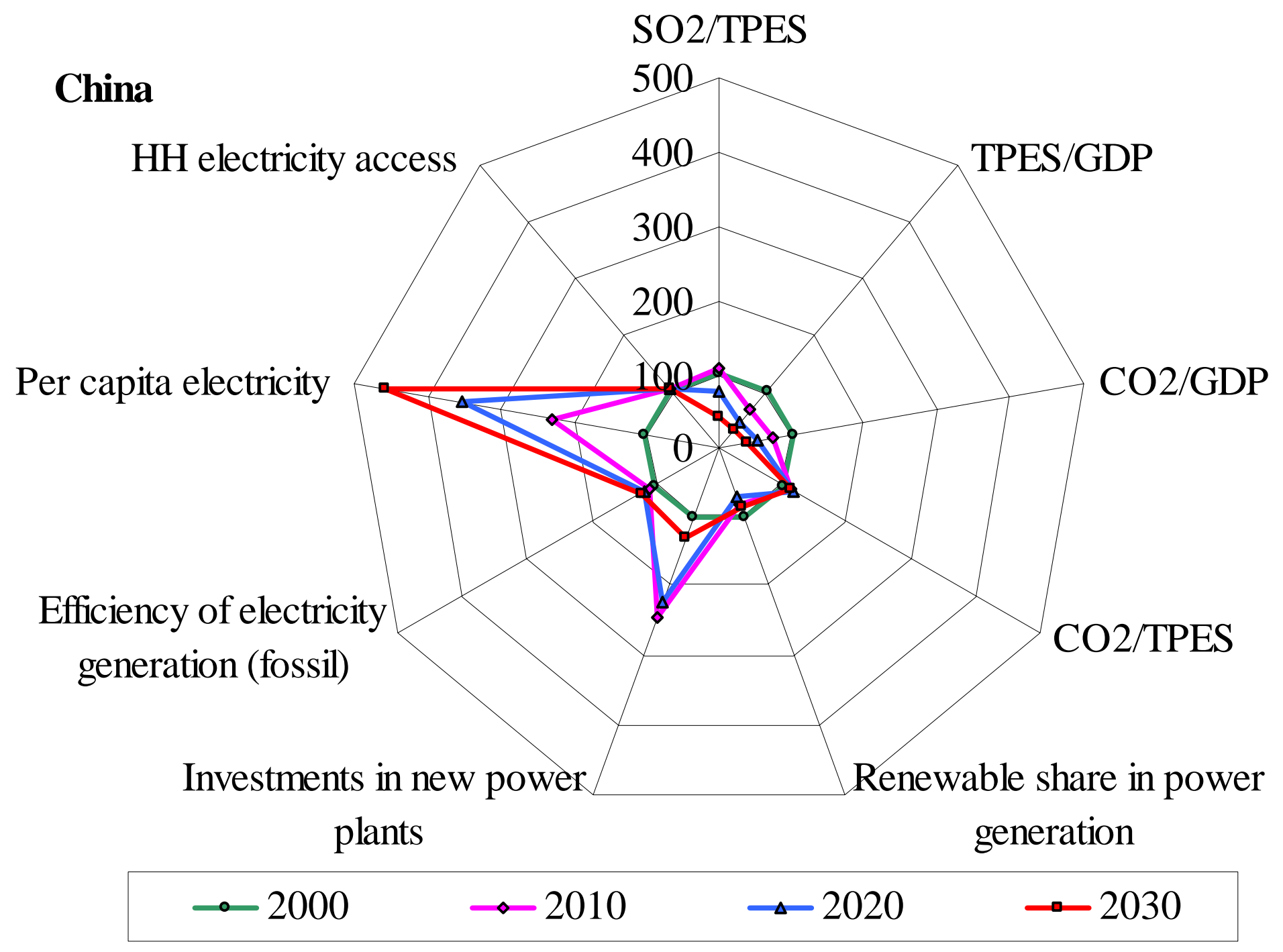




\section{Sustainable Development Indicators for India}

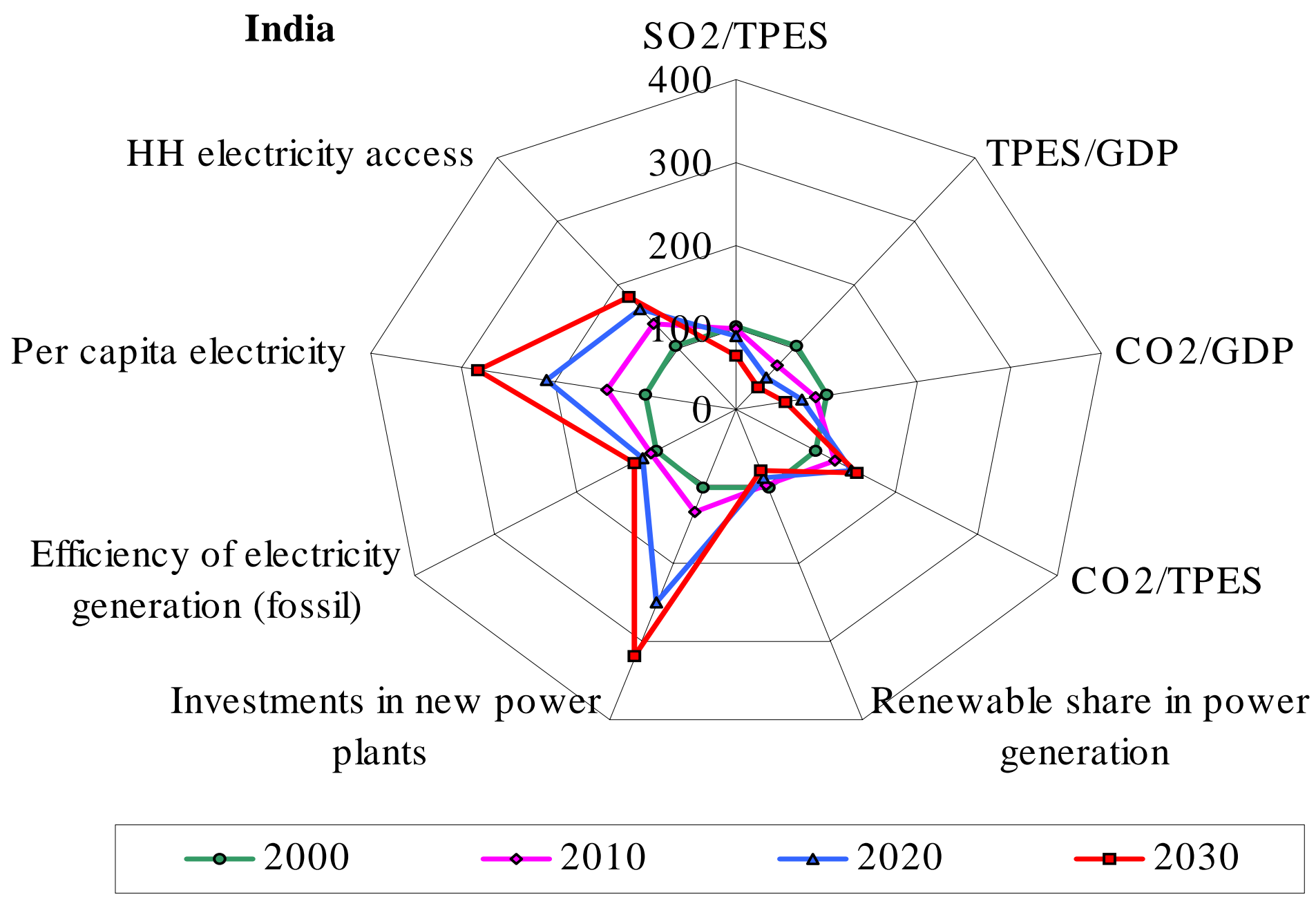




\section{Cross-country SDIs}
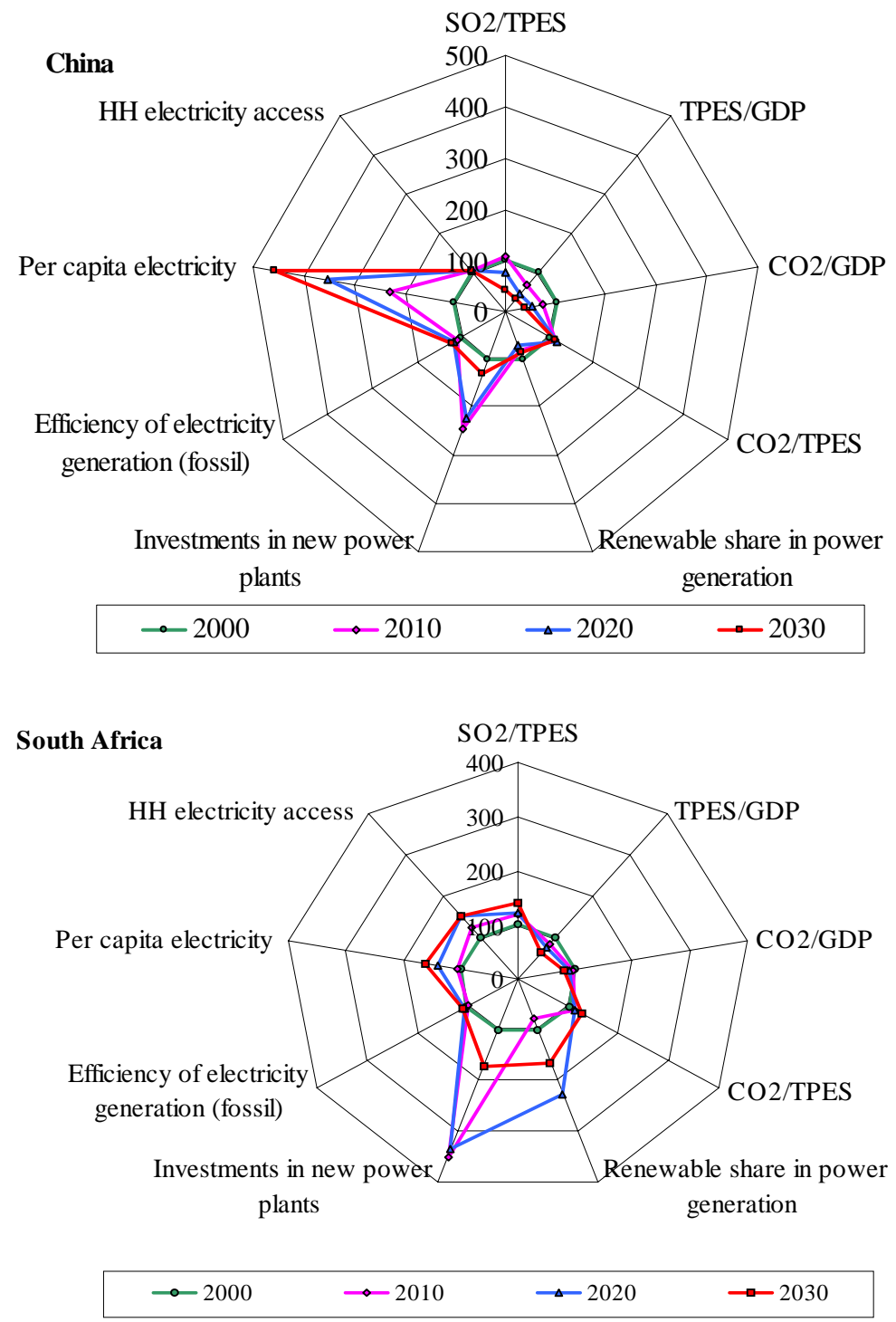

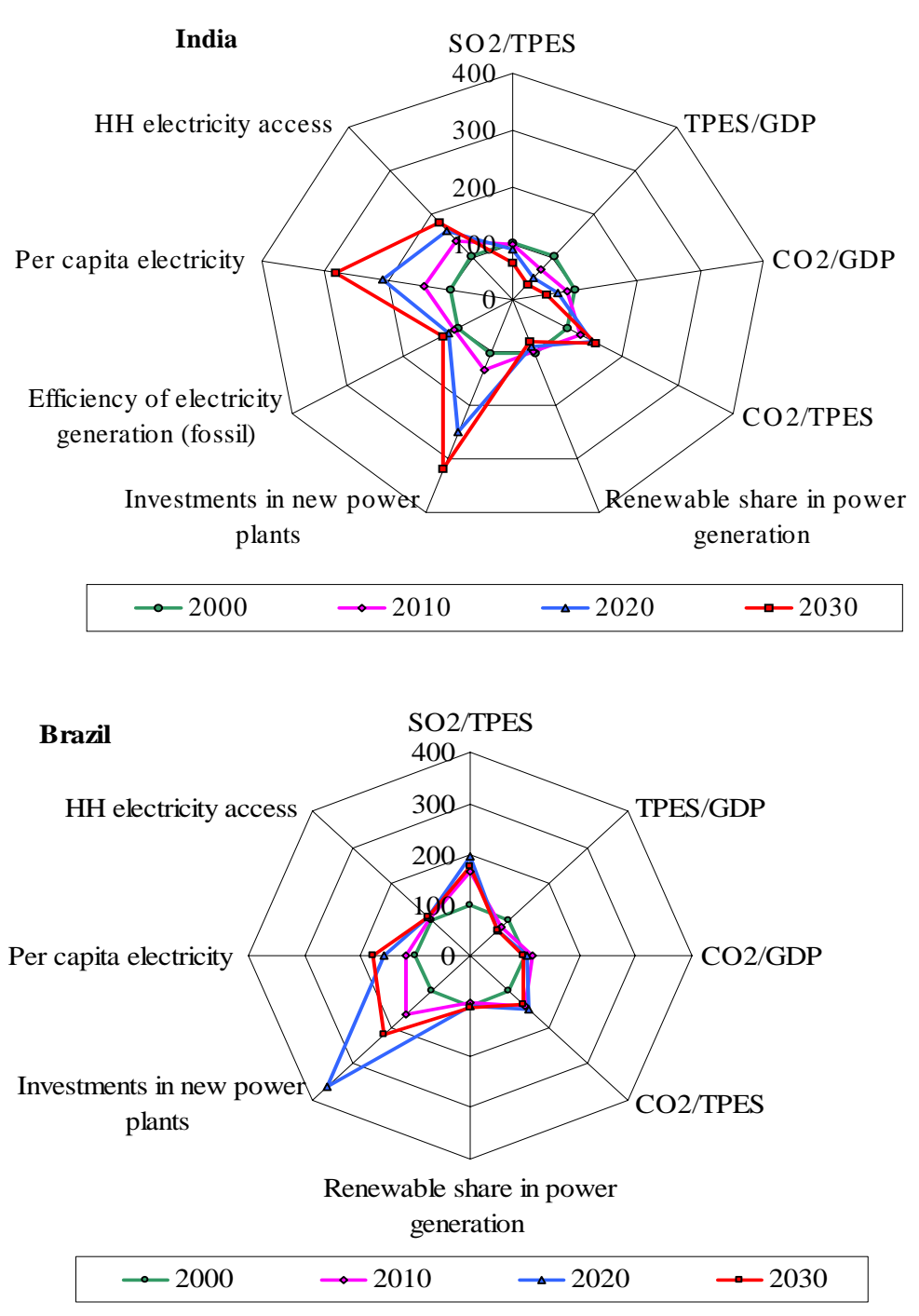




\section{National Energy Case Studies of Climate Friendly Development}




\section{National Success Stories for China and India}

\begin{tabular}{|l|l|l|}
\hline Case example & Development impacts & $\begin{array}{l}\text { Climate change } \\
\text { mitigation/adaptation }\end{array}$ \\
\hline $\begin{array}{l}\text { China: } \\
\text { Energy efficiency in industry } \\
\text { and power production }\end{array}$ & $\begin{array}{l}\text { Local air pollution } \\
\text { control, Energy cost } \\
\text { savings in efficiency } \\
\text { cases }\end{array}$ & $\begin{array}{l}\text { Total SD scenario offers } \mathrm{CO}_{2} \\
\text { reductions of } 1.5 \text { billion } \mathrm{tC} \text { in } \\
2030\end{array}$ \\
\hline $\begin{array}{l}\text { India: } \\
\text { South Asia energy-electricity } \\
\text { market integration }\end{array}$ & $\begin{array}{l}\text { Energy supply savings, } \\
\text { cost savings, } \mathrm{CO}_{2} \text { and } \\
\mathrm{SO}_{2} \text { emission reductions }\end{array}$ & $\begin{array}{l}1.4 \text { billion tC and } 50 \text { million ton } \\
\mathrm{SO}_{2} \text { saved over } 30 \text { years, } \\
\text { Flood control, Reduced } \\
\text { energy/electricity costs }\end{array}$ \\
\hline
\end{tabular}




\section{National Success Stories for Brazil}

\begin{tabular}{|l|l|l|}
\hline Case examples & Development impacts & $\begin{array}{l}\text { Climate change } \\
\text { mitigation/adaptation }\end{array}$ \\
\hline Ethanol programme & $\begin{array}{l}\text { Employment, foreign } \\
\text { exchange savings, local } \\
\text { air pollution }\end{array}$ & $\begin{array}{l}9.45 \mathrm{MtC} \text { saved per year }(17 \% \\
\text { of energy sector emissions in } \\
1994)\end{array}$ \\
\hline $\begin{array}{l}\text { Zero tillage to ensure higher } \\
\text { sontent of organic matters in } \\
\text { soil }\end{array}$ & $\begin{array}{l}\text { Increased use of } \\
\text { herbicides, energy cost } \\
\text { savings }\end{array}$ & $\begin{array}{l}\text { 199-80 Mt } \mathrm{CO}_{2} \text { not released in } \\
\text { consumption }\end{array}$ \\
\hline
\end{tabular}




\section{National Success Stories for South Africa}

\begin{tabular}{|l|l|l|}
\hline Case examples & Development impacts & $\begin{array}{l}\text { Climate change } \\
\text { mitigation/adaptation }\end{array}$ \\
\hline $\begin{array}{l}\text { Clean energy generation mix: } \\
\text { Gas, hydro, renewables, } \\
\text { nuclear }\end{array}$ & $\begin{array}{l}\text { Energy security } \\
\text { benefits, local } \\
\text { environmental } \\
\text { improvements }\end{array}$ & $\begin{array}{l}\text { Annual } \mathrm{CO}_{2} \text { savings in 2025: } \\
70 \mathrm{Mt} \mathrm{CO}_{2}\end{array}$ \\
\hline $\begin{array}{l}\text { Industrial energy efficiency in } \\
3 \text { major companies }\end{array}$ & $\begin{array}{l}\text { Energy cost savings, } \\
\text { local environmental } \\
\text { benefits }\end{array}$ & $\begin{array}{l}\text { Annual } \mathrm{CO}_{2} \text { savings of around } \\
0.07 \mathrm{mtCO}_{2}\end{array}$ \\
\hline
\end{tabular}


Analysing Alternative Pathways for Aligning SD, Energy and CC 


\section{Points of Intervention}

- Business-As-Usual energy policies will not change the development path to a desirable climate friendly pathway

- We need to intervene at critical times (starting now) and through appropriate policies to change the development (and therefore emission) pathways

- These Points of Intervention could be, e.g.

$>$ Bringing in cleaner coal technologies for power generation

$>$ Biofuels

$>$ Rural electrification

$>$ Efficient transport (e.g. strengthening railway networks including metros)

$>$ Dematerialization of product designs at all levels

$>$ Cleaner fuels/technologies for cooking

$>$ Environmental education and consciousness at all levels 


\section{Alternative Developmental Pathways for India:}

\section{Comparative Performances}

Parameters

Global equivalent Scenarios

GDP annual growth (2000-2030)

Cumulative $\mathrm{Bt}-\mathrm{CO}_{2}$ (2000-2030)

Per capita $\mathrm{CO}_{2}$ in 2030 (ton- $\mathrm{CO}_{2}$ )

\begin{tabular}{|c|c|c|c|}
\hline IA1 & IA2 & IB1 & IB2 \\
\hline $\begin{array}{c}\text { Fossil } \\
\text { intensive }\end{array}$ & $\begin{array}{c}\text { Markets } \\
\text { first }\end{array}$ & $\begin{array}{c}\text { Global } \\
\text { sustainability }\end{array}$ & $\begin{array}{c}\text { regional } \\
\text { solutions }\end{array}$ \\
\hline $7.1 \%$ & $5.5 \%$ & $6.5 \%$ & $4.2 \%$ \\
\hline 61 & 53 & 45 & 23 \\
\hline 2.3 & 1.8 & 1.7 & 1.4 \\
\hline
\end{tabular}




\section{Clean Coal Technologies in China Under Alternative pathways}

\begin{tabular}{|l|l|l|l|}
\hline \multirow{2}{*}{ Sector } & Technology & Share in $\mathbf{2 0 3 0}$ \\
\cline { 3 - 4 } & & $\begin{array}{l}\text { Reference } \\
\text { scenario }\end{array}$ & $\begin{array}{l}\text { Alternative } \\
\text { scenario }\end{array}$ \\
\hline Power generation & Super Critical & $25 \%$ & $25 \%$ \\
\hline Power generation & IGCC & $4 \%$ & $30 \%$ \\
\hline Industry/Boiler & Advanced boiler & $45 \%$ & $75 \%$ \\
\hline Industry/Kiln & Advanced kiln & $38 \%$ & $70 \%$ \\
\hline Coal processing & Coal liquefaction & $2 \%$ of total coal & $10 \%$ of total coal \\
\hline Desulphurization in power plants & $58 \%$ of all plants & $80 \%$ of all plants \\
\hline
\end{tabular}




\section{Promoting Clean Coal Technologies in China}

Policy impacts on development, energy and climate change:

- Energy security

- Large employment to low income families that are employed with the production of the technologies (7.6 million people in 2004 and 7.8 million people in 2030)

- Establishment of a strong position for China on international markets for cleaner coal technologies

- Reduction in local and global emissions 


\section{Key Lessons Learnt}

- BAU energy policies of large developing countries will not align their national developmental goals with global climate change mitigation concerns

- Integration of climate and broader SD concerns early in energy policy process (path change) is cost-effective both from development and climate change perspectives

- Each country has to choose its own development pathway. Diversity of alternative opportunities, projects and approaches exist

- National case studies demonstrate that many dedicated development policies and activities make ("unintended") positive climate contributions

- Quantifying development and climate change impacts of energy policies enhances policy relevance of the research considerably

- The 'non-climate' route for international climate change policy making is feasible and cost-effective

- Main challenge is implementation 
Thanks 


\title{
Sustainable Transport Practices in Latin America
}

Risø International Energy Conference 22-24 May 2007

Energy Solutions for Sustainable Development

\author{
Jorge Rogat and Miriam Hinostroza \\ UNEP Risø Centre \\ Roskilde, Denmark
}




\section{The Transport Situation in Latin America}

- Lack of efficient, reliable and safe public transport systems

- Excessive number of old, unsafe and highly polluting buses

- Deregulated sector

- Lack of resources and political will

- Steadily increasing private motorisation in the region (250\% increase in the car fleet between 1970 and 1990)

- Increased congestion, number of accidents and air pollution 


\section{The turning point}

- Need to reformulate transport policies with the aim of providing safe, cost-effective, and environmental-friendly public transport systems

- Curitiba in Brazil became the first city in Latin America to rethink transport policies and found in integrated urban planning and mass rapid transit, with BRT (Bus Rapid Transit) as the main component, the answer to the problem 
- The example was first followed by Bogota, Colombia with the implementation of Transmilenio

- Today BRT systems have been implemented, or are in the implementation phase in Guayaquil, Ecuador; Guatemala City, Santiago, Chile and other LA cities 
- BRT systems have been implemented or are planned in Jakarta, Indonesia; Beijing, China; Bangkok, Thailand; Nantes, France, Eindhoven, Netherlands; Boston and Orlando in the USA; Adelaide, Australia

- Unique example of South-South, South-North technology transfer

\section{Definition of BRT}

is a system that emphasises priority for rapid movement of buses by securing segregated busways (IEA, 2002) 


\section{How do BRT systems work?}

- In a similar way to light-rail trains or rail-based metros, but operate along corridors on dedicated busways at street level

- Use articulated buses with a carrying capacity of around 160 passengers or bi-articulated buses (270 passengers)

- Supplemented by feeder buses

- Modal integration complementing other transport systems

- Can carry up to 35,000 passengers per hour an direction

- Rapid boarding

- Public-private partnership 


\section{Successful practices}

Curitiba's Integrated Transport Network (ITN)

- Integrates land use and public transport under joint public-private operation with emphasis on equity and affordability

- Government officials started in the 60 s to work on a master plan

- Restructured the city's radial configuration into a linear model of urban expansion 
- Three-part road system with each axis made up of a central street with special lanes for efficient public transportation

- In 1971 Jaime Lerner developed plans for the ITN of Curitiba

- Favouring public transport, using appropriate rather than capitalintensive technologies 
In 1974 the first BRT system in Latin America was operational

$\checkmark$ Thirteen express routes with direct routes using boarding tubes

$\checkmark$ Twenty eight routes including special buses for students and the disabled

$\checkmark$ Approximately 1900 buses of which 500 articulated buses (160) and 300 bi-articulated buses (270) that carry around 2 million passengers/day or about $75 \%$ of the total number of passengers 
$\checkmark$ Around $58 \mathrm{~km}$ of dedicated busways along 5 corridors complemented by $270 \mathrm{~km}$ of feeder routes and $185 \mathrm{~km}$ of inter-district routes

$\checkmark$ Feeder and inter-district routes supplemented by city centre routes

$\checkmark$ Prepaid boarding (one ticket) through 25 transfer terminals and 221 tube stations 


\section{Curitiba}
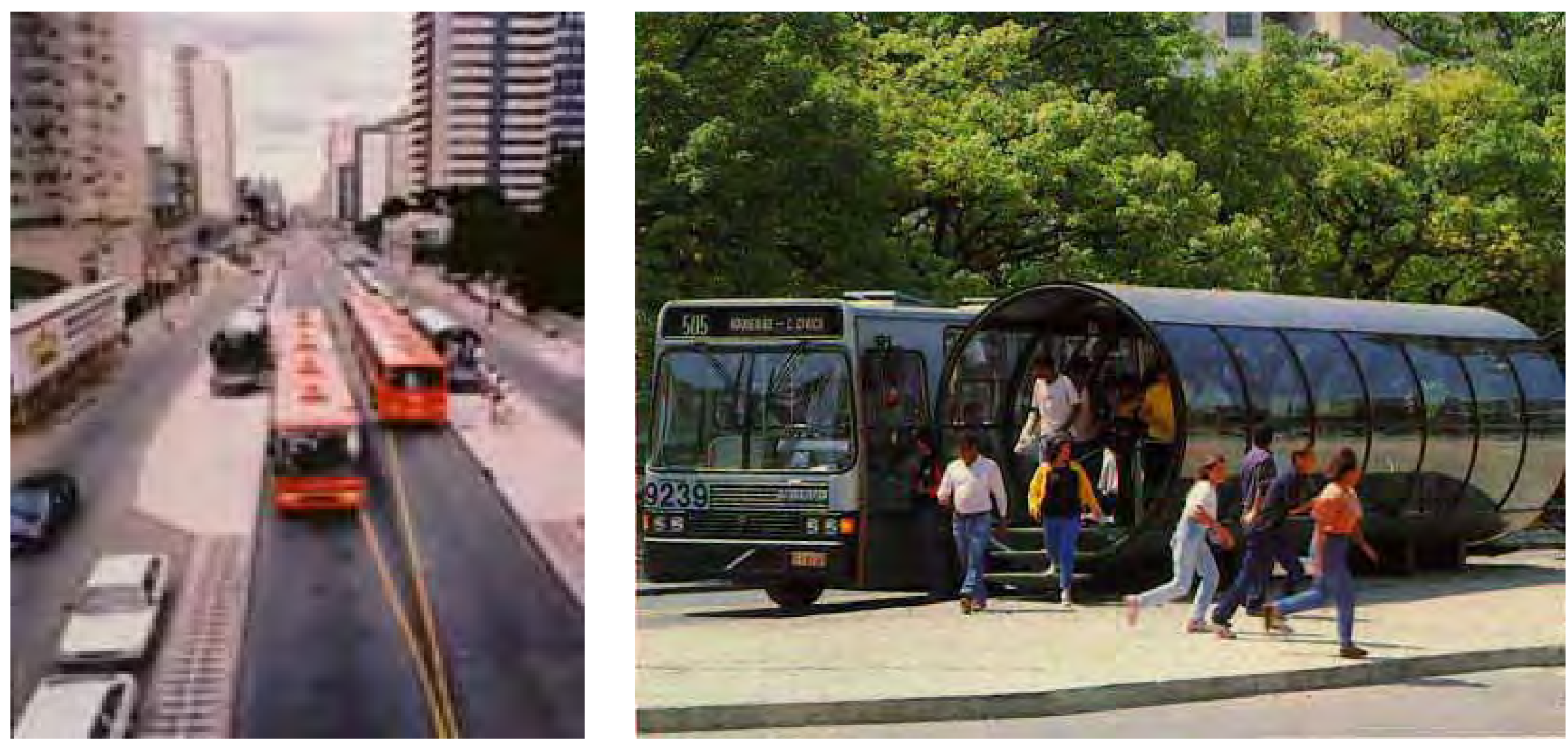

\section{$\infty$}

DTU IRISP 


\section{Bogota's Transmilenio}

- With Curitiba as the source of inspiration, but taking into consideration prevailing local conditions

- More because of the chaotic transport problem affecting the mega city than the aim of urban development as in the case of Curitiba

- A component of the city's Mobility Strategy 
- To provide an efficient, safe and comfortable mass rapid transit system for the people

- With emphasis on affordability meaning: (1) possible for the government to afford the infrastructure; (2) for the private sector to recover costs of bus acquisition and operations and; (3) for the users to pay the fare 
Transmilenio was launched in December 2000

$\checkmark$ The BRT system is currently composed of about 800 articulated buses and 470 feeder buses

$\checkmark$ Covers about $400 \mathrm{~km}$ along 22 dedicated busways with 2 lanes in each direction

$\checkmark$ Carries up to 45 thousand passengers per hour and direction

$\checkmark$ Managed by public-private partnership

$\checkmark$ It aims at transporting 80\% of the people of Bogotá by 2015 


\section{Transmilenio}
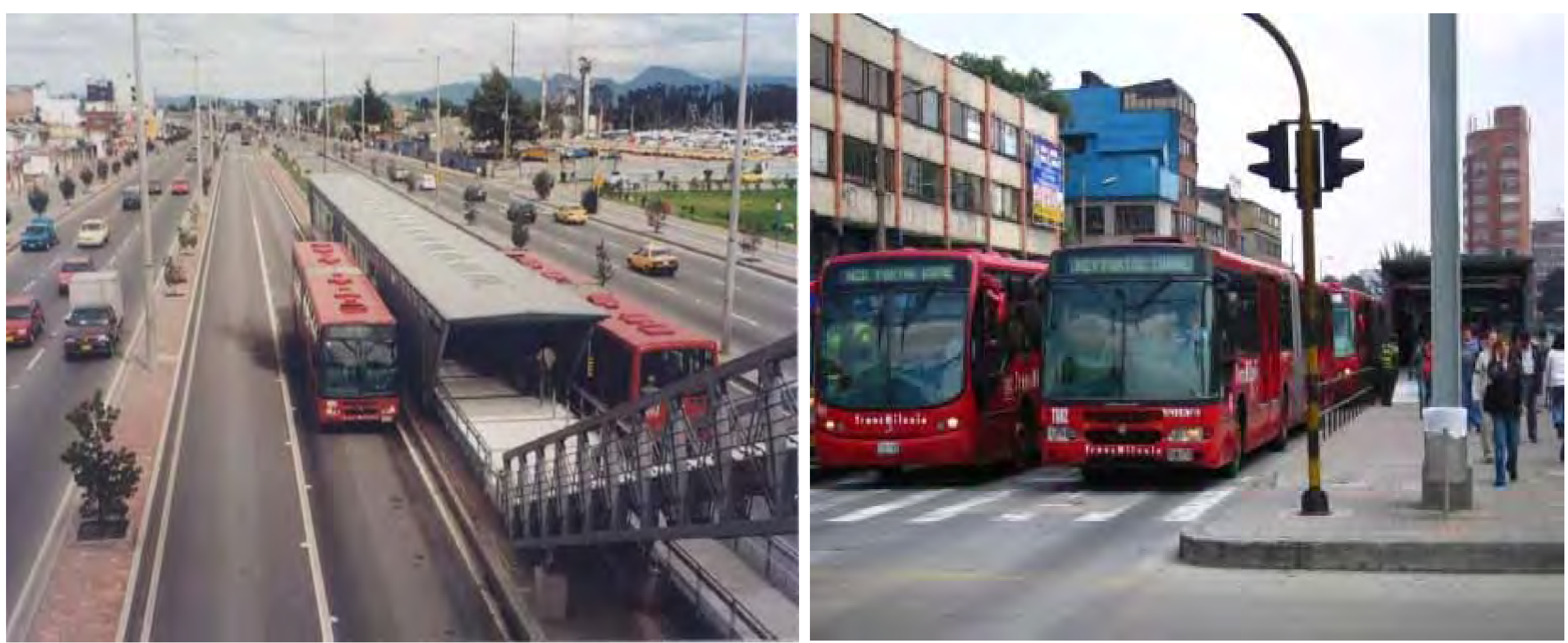


\section{Some of the new initiatives}

Guayaquil's Metrovía

- Metrovía is the main component of the Massive Urban Transport (MUTP) Programme of Guayaquil

- Like in Bogotá it is thought to be the answer to the problems affecting the transport sector

- The main objective of the MUTP is to provide an efficient, safe, reliable, fast and affordable public transport system to the $84 \%$ of the population using public transportation 
The first corridor introduced in August 2006

$\checkmark$ Uses 72 articulated buses and 69 conventional buses as feeder buses

$\checkmark$ It's expected to carry 140 thousand passengers per day

$\checkmark$ Prepaid boarding

$\checkmark$ Managed by a public-private partnership

$\checkmark$ When the complete BRT is in place (2020), 7 corridors will be operational

\section{8


Metrovía
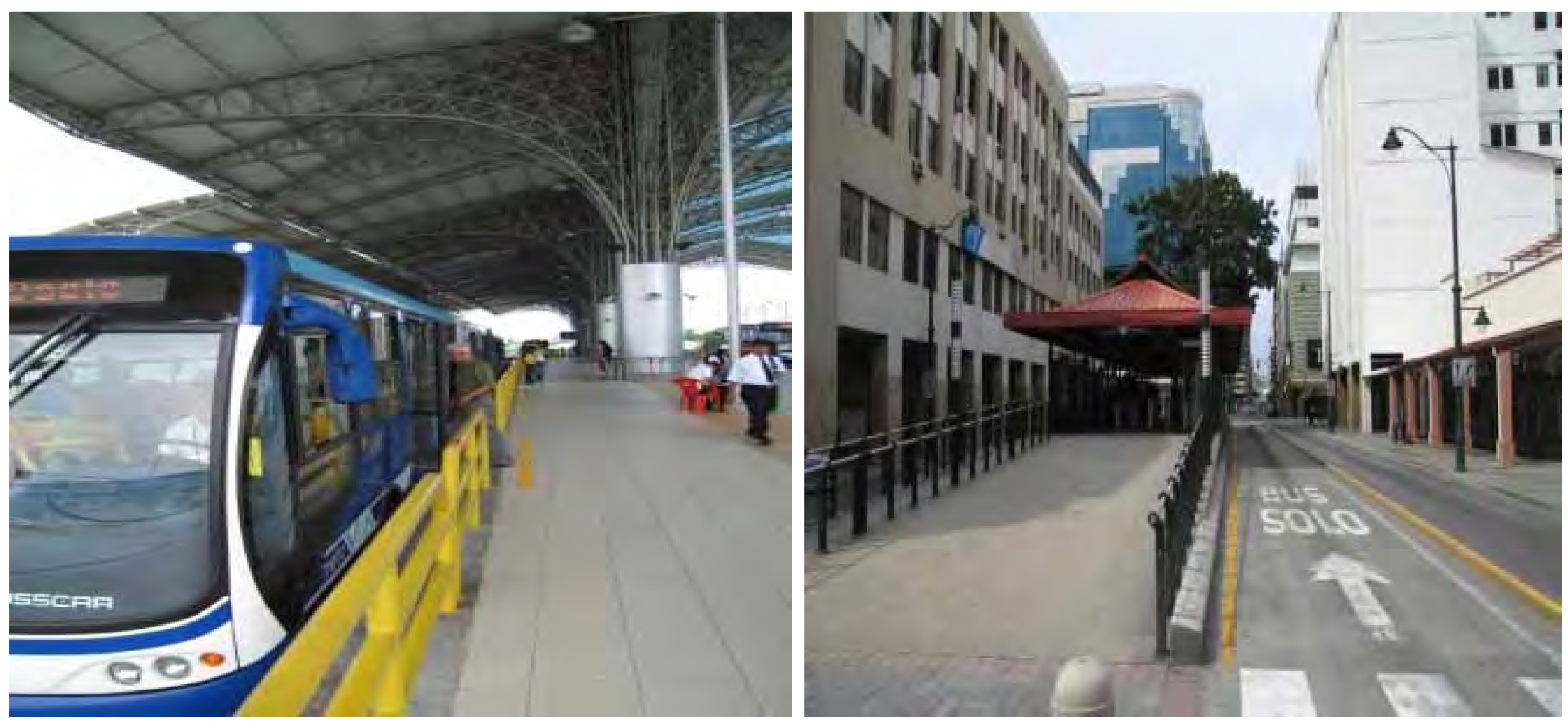

$\infty$

DTU IRISC 


\section{Guatemala City's Transmetro}

- First replication of Curitiba and Transmilenio in Central America

- Main component of the Urban Mobility Plan for 2020

- Main objective to provide reliable, safe and affordable transport services for the people

- To decrease congestion, vehicle operational costs, travel time, traffic accidents, energy consumption and local air pollution

- Transmetro is considered key in achieving these objectives 
First corridor operational in February 2007

$\checkmark$ Managed by a public-private partnership

$\checkmark$ New and cleaner articulated buses with a carrying capacity of 160 passengers (48 articulated buses of which 17 are new)

$\checkmark$ Replace 4-5 old buses by a new bus

$\checkmark$ The system is expected to transport 180 thousand passengers per day

$\checkmark$ When completed in 2020 it will be composed of 12 corridors 


\section{Transmetro}

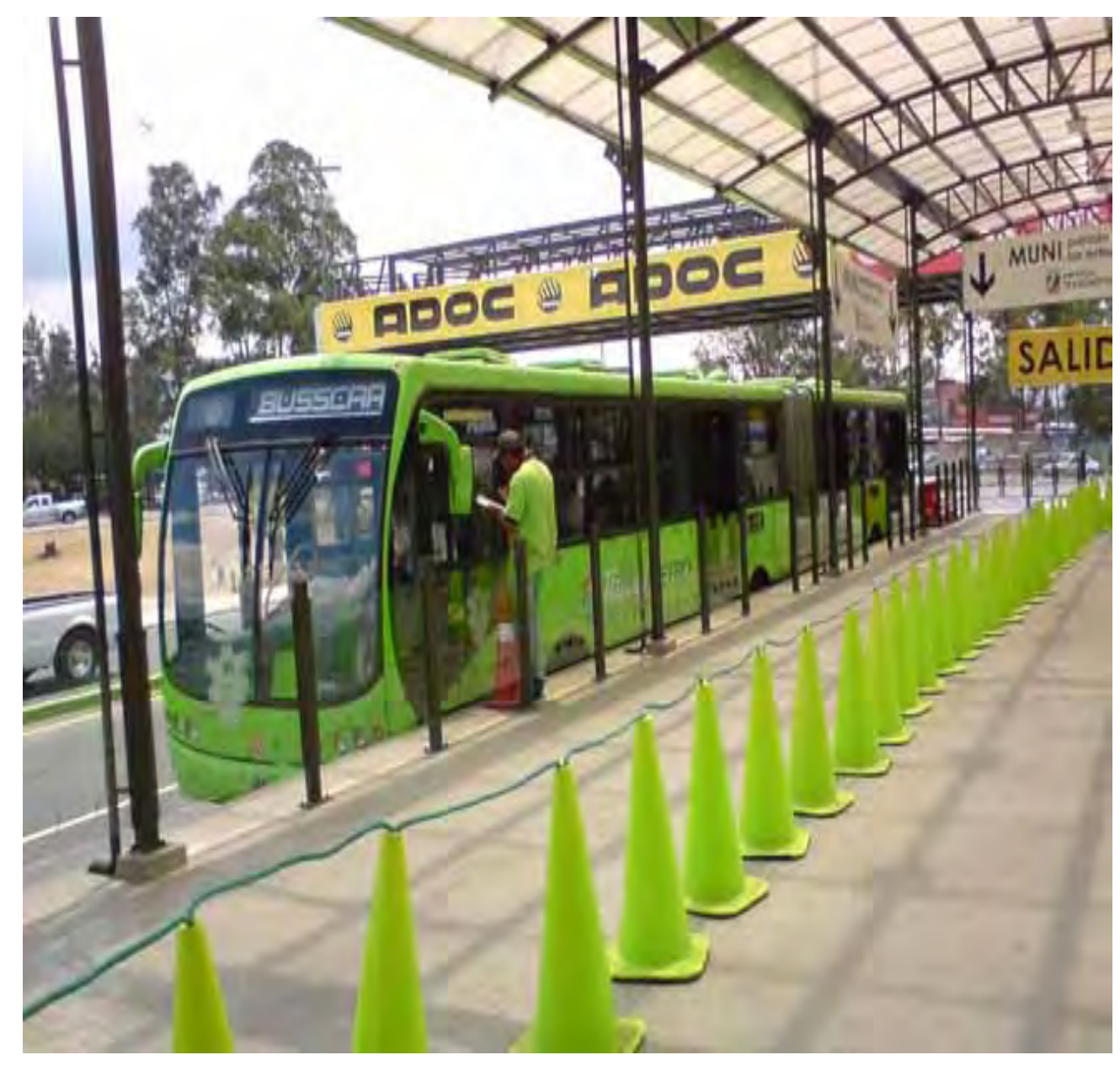

$\theta$

UNEP

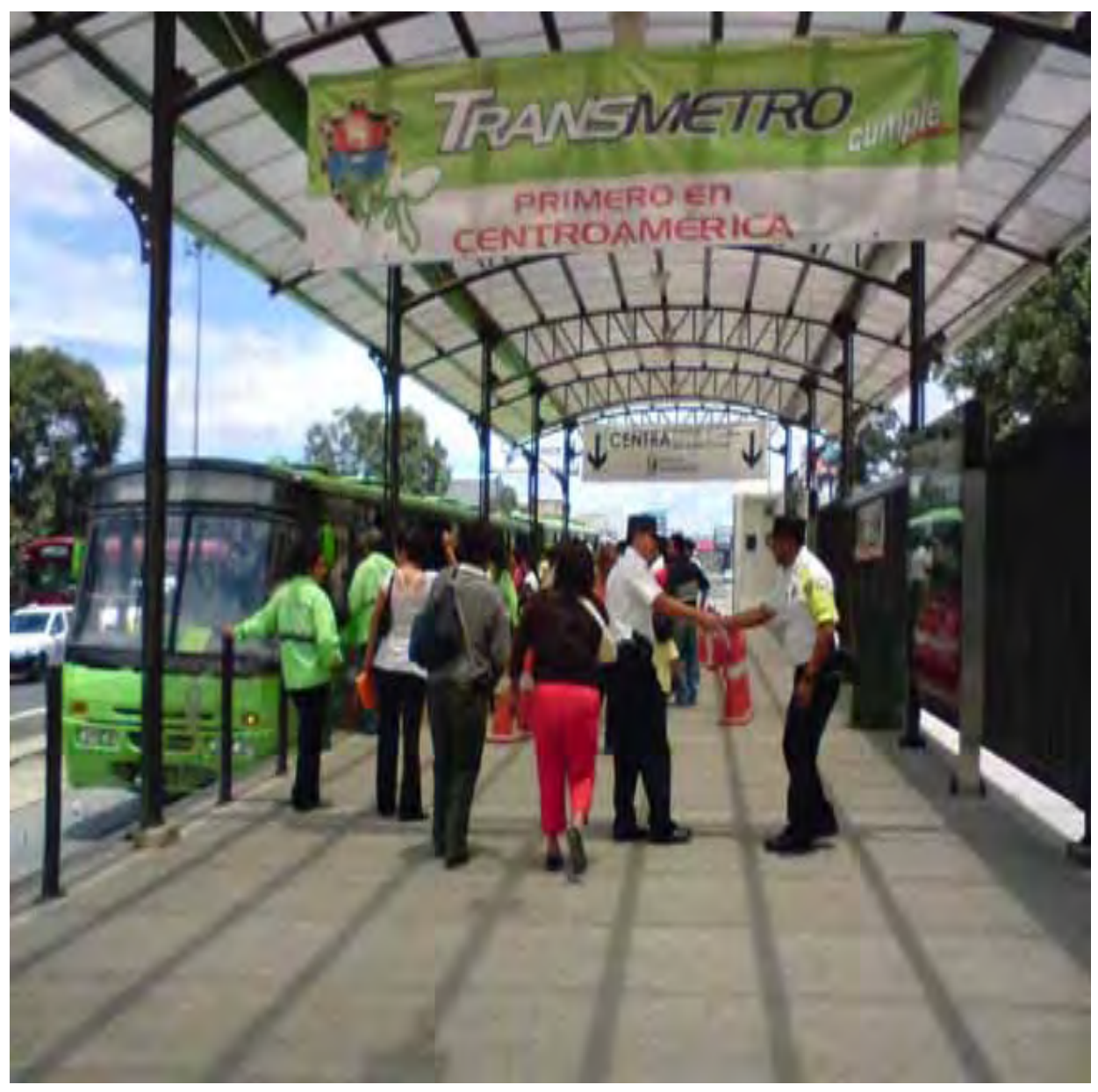

$\stackrel{\mathrm{DTU}}{\Xi} \mathbb{R} T \mathrm{~S}(\theta)$ 


\section{Santiago's Transantiago}

- One of the components of a comprehensive restructuring of the whole public transport sector designed by the government of Chile in 1995

- Main objectives are: (1) to solve the current transport problems; (2) to maintain the current $50 \%$ ridership; (3) to provide a reliable and safe public transport system and; (4) to develop a modern, environmentally clean and economically efficient public transport system

- Is being implemented by various ministries

- When completed will consist of 5 corridors 
Transantiago was launched in February 2007

$\checkmark$ It has been integrated with the Metro and with urban and interurban trains

$\checkmark$ It uses around 4,700 buses (1,200 new buses) including articulated and conventional feeder buses instead of 7,500 used before

$\checkmark$ Feeder buses complement both the BRT and the Metro

$\checkmark$ Fare collection through smart electronic prepaid cards

$\checkmark$ Fare depending on the numbers of transfers made but with a maximum fare of US $\$ 0.80$ 


\section{Transantiago}

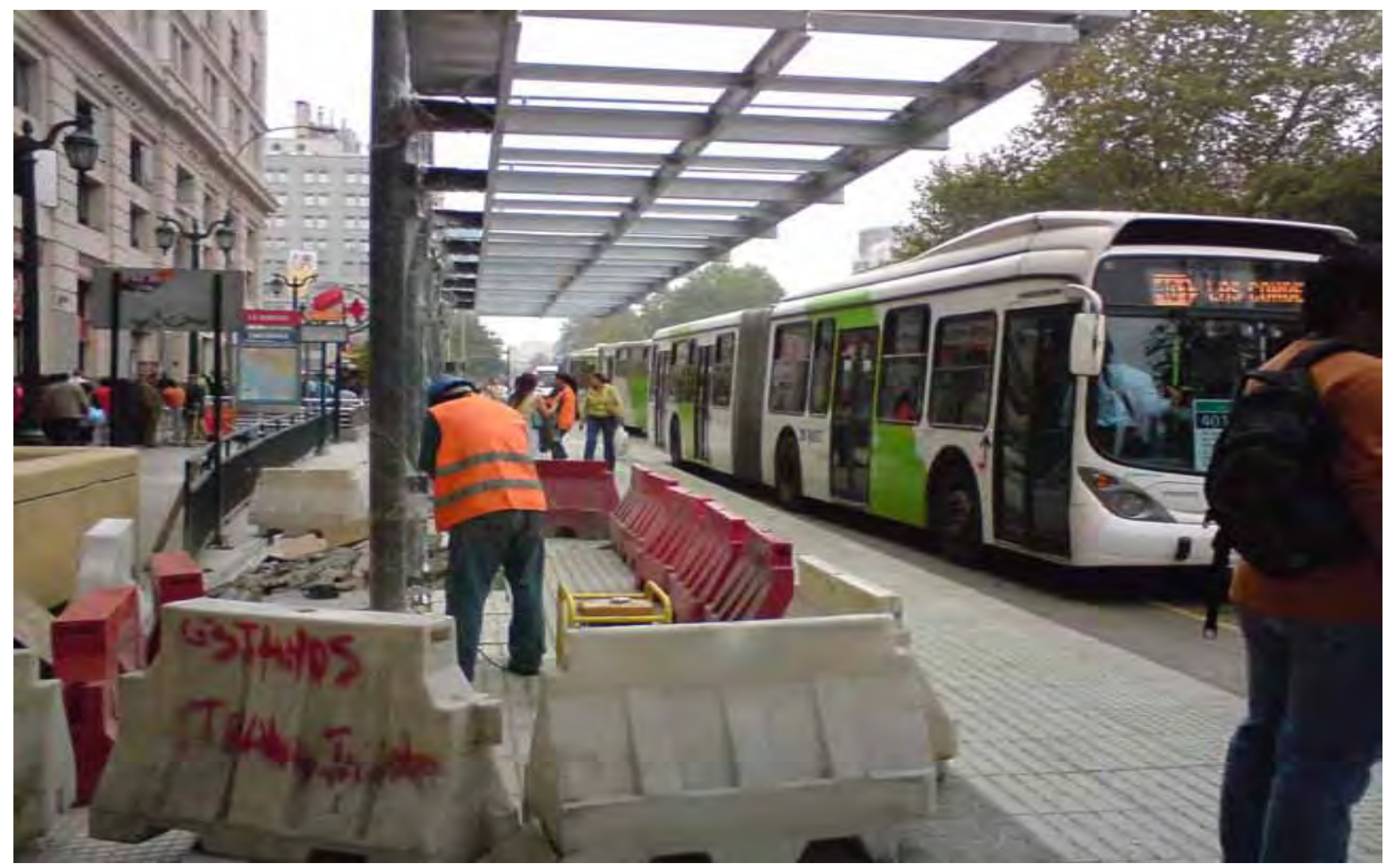

4

DTU IRISSO 


\section{Results}

Curitiba's ITN

$>30 \%$ previously travelled by car

$>27$ million fewer trips made by car

$>$ per capita fuel consumption has decreased by $30 \%$

$>$ air pollution is the lowest in the country 
Transmilenio

$>90 \%$ fewer traffic accidents

$>$ about $40 \%$ less air pollution

$>40 \%$ reduction in travel time

> $90 \%$ passenger satisfaction 
Metrovía

- High passenger satisfaction

- $\quad 97 \%$ on-time performance on both trunks and feeders

- Increased travel speed from 16 to $22 \mathrm{~km}$ 


\section{Transmetro}

- High passenger satisfaction

- Increased safety

- $80 \%$ reduction in travel time 


\section{Transantiago}

- Extremely low passenger satisfaction

- Increased travel time ( 20 to 30 minutes)

- The Metro has collapsed 


\section{Conclusions}

- Well planned and implemented BRT systems have proven to be the right transport solution in many cities

- BRT systems can provide high quality services similar to other MRT systems like light-rail trains or metro

- High political will reflected in continued local transport policy aimed at favouring the use of public transport

- Urban planning compatible with innovative public transport solutions 
- Appropriate rather than capital-intensive technology:

BRT cost $/ \mathrm{km} 2$ - 5US\$ million while rail based metro 60 - 200US\$ per $\mathrm{km}$

- Participatory approach

- Gradual changes in passengers' habits 


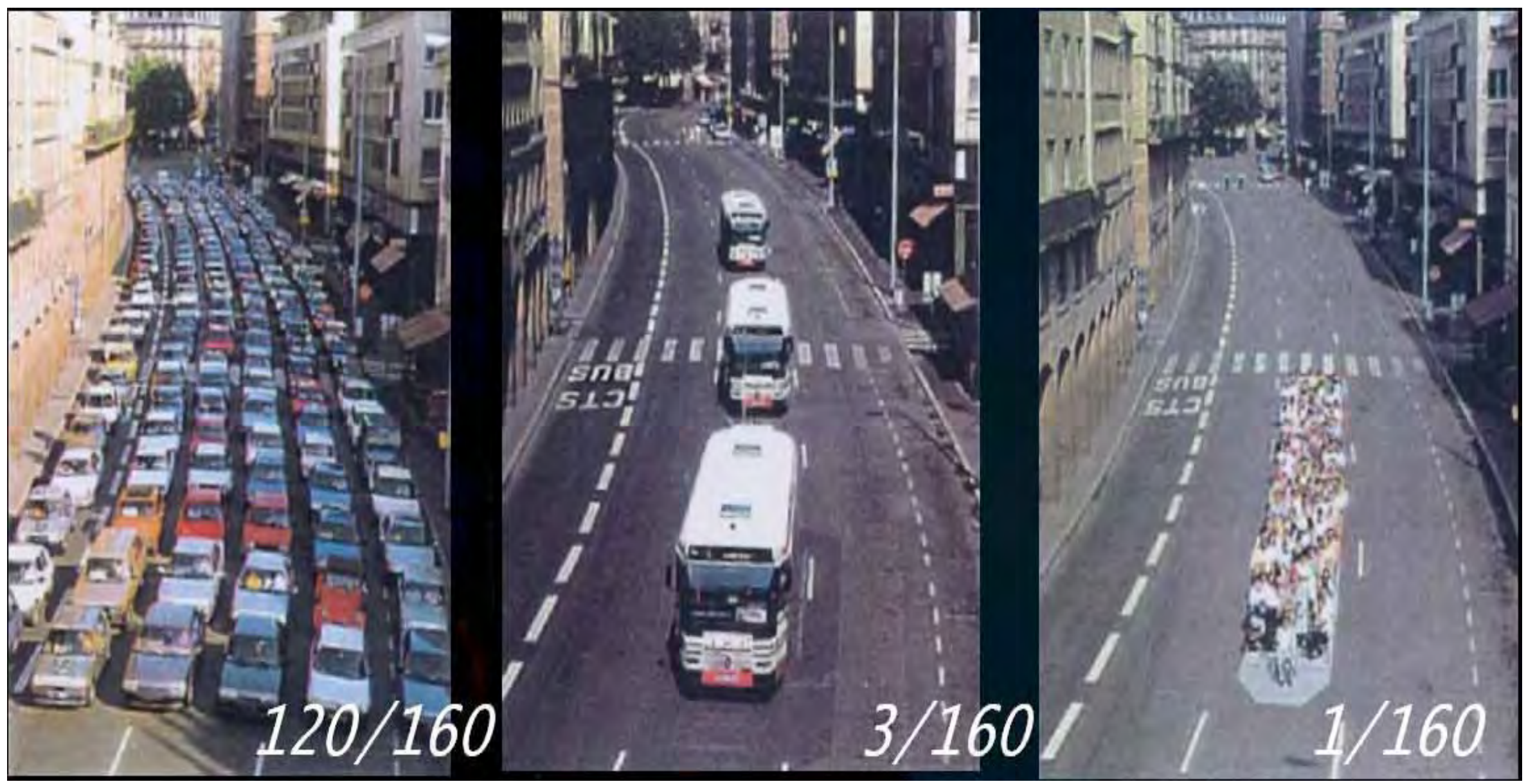

0

DIU IRISSO 


\section{Risø International Energy Conference 2007 $2^{\text {th }}$ May 2007}

\section{Environmental Analysis of Coal-based Power Production with Amine-based Carbon Capture}

W. Kuckshinrichs ${ }^{1}$

J. Nazarko ${ }^{2}$, A. Schreiber ${ }^{1}$, P. Zapp ${ }^{1}$

Institute of Energy Research

1 Systems Analysis and Technology Evaluation (IEF-STE)

2 Fuel Cells (IEF3)

Forschungszentrum Jülich $\mathrm{GmbH}$ 


\section{Outline}

\section{Introduction}

2. $\mathrm{CO}_{2}$ capture concepts

3. Methodology and basic parameters

4. Inventory analysis

5. Impact assessment

6. Summary and outlook 


\section{Introduction}

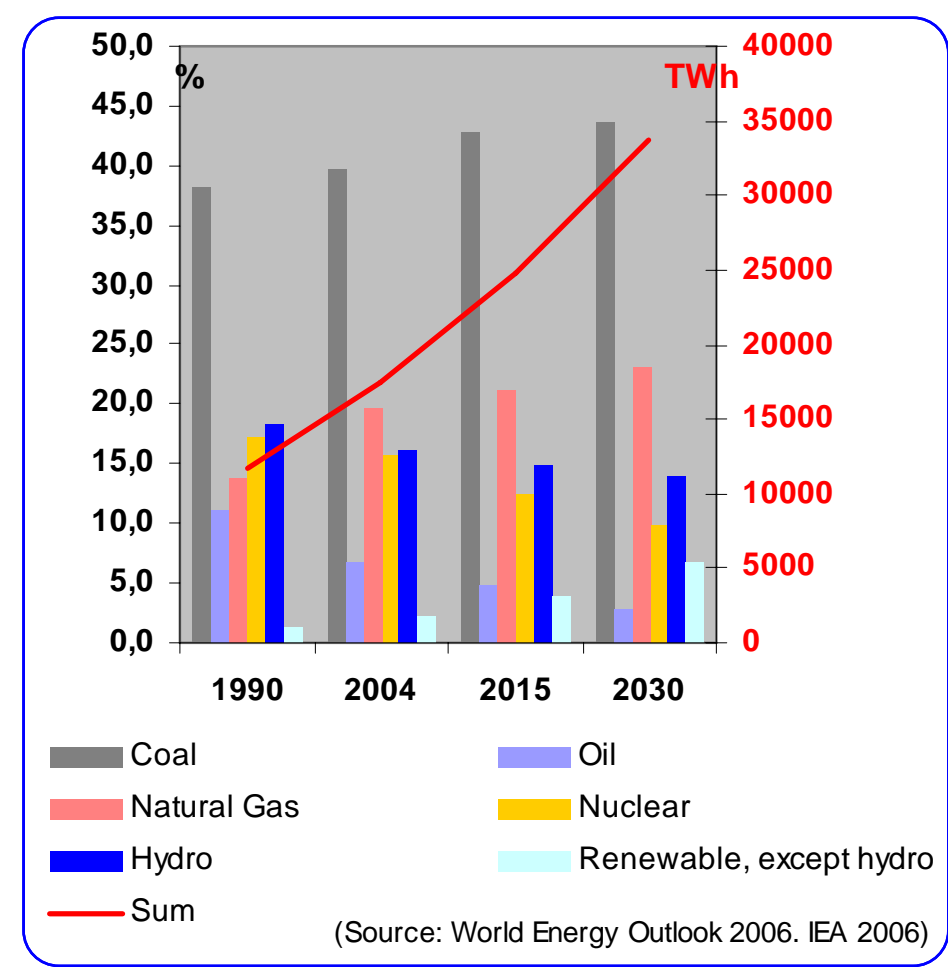

- Increase of future global electricity demand

- Strong dependency on fossil-based power generation (coal, gas)

- Increasing share of renewable energies

- Decreasing share of nuclear power and hydropower

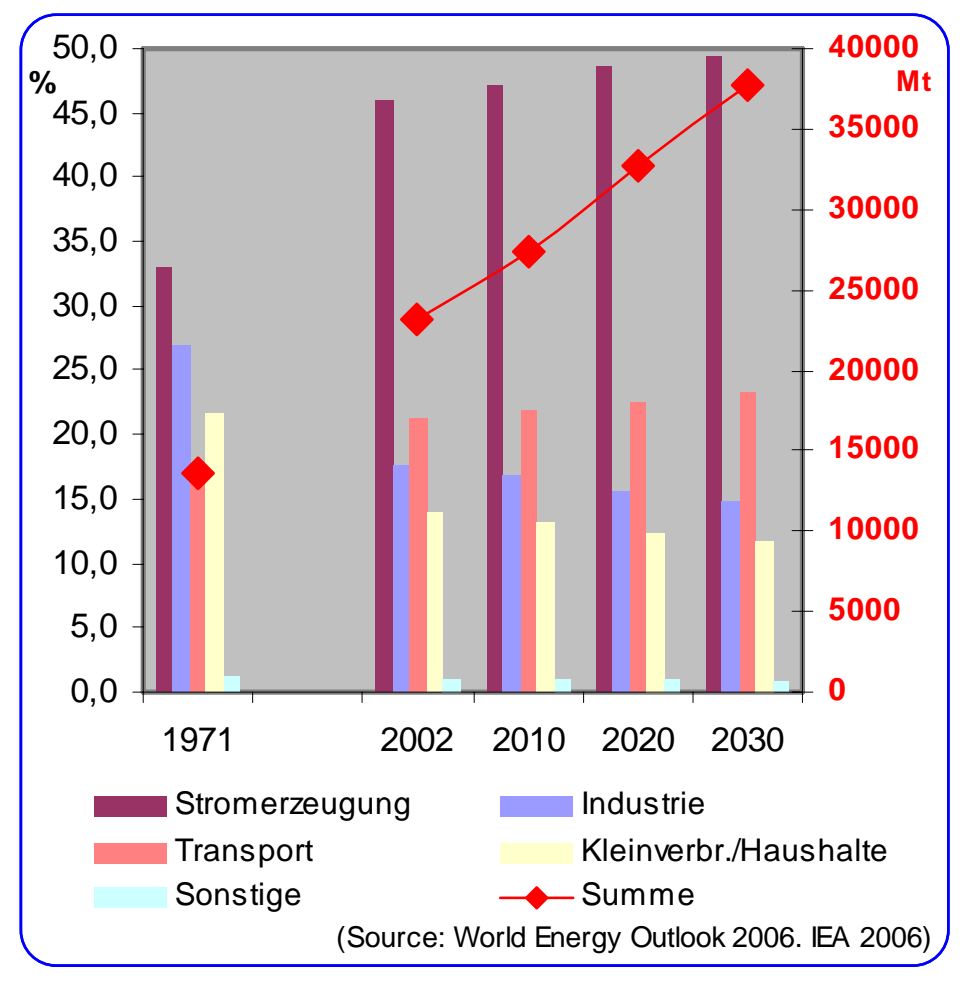

- Increasing global $\mathrm{CO}_{2}$ emissions

- Share of $\mathrm{CO}_{2}$ from transport increasing

- Share of $\mathrm{CO}_{2}$ from industry and households decreasing

- Share of $\mathrm{CO}_{2}$ from power generation increasing, unless measures like CCS are taken 


\section{Introduction}

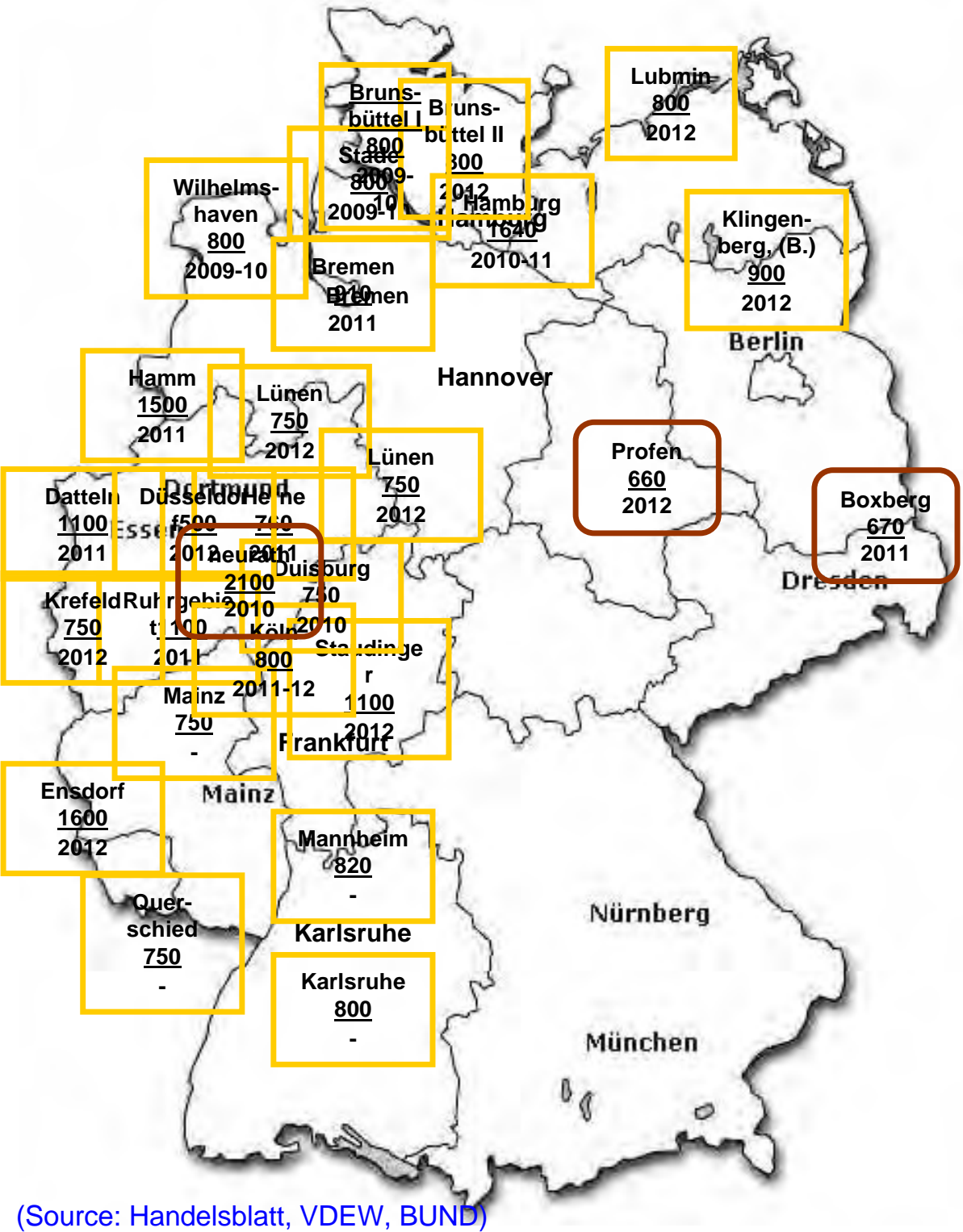

- Worldwide investment in fossilbased power generation capacity expected

- European Union: Announced construction of new plants

- Coal and gas power generation in Germany: 27 announcements of new power plants (coal, lignite), 25,000 MW

location

capacity coal

year

location
capacity

year

// Energy Economics Group //

Institute of Energy Research - Systems Analysis and Technology Evaluation (IEF-STE) 


\section{$\mathrm{CO}_{2}$ capture concepts}

\section{Concepts}

Energy supply perspective: Assets (+) and drawbacks (-)

+ technology available

+ retrofitting possible

- high energy penalty

- high cost increase

Oxyfuel:

$\mathrm{CO}_{2}$ concentration in flue gas

+ compact boiler design

+ high retention rates

- high e-penalty for air sep.

- high invest cost

Pre combustion:

$\mathrm{CO}_{2}$ capture from syngas after CO-shift
+ lower e-penalty

+ hydrogen production

- technical availability of IGCC

- complex $\mathrm{CO}_{2}$ capture

\section{Environmental impacts:}

Assets (+) and drawbacks (-)

+ reduced net $\mathrm{CO}_{2}$ emissions

? process inputs

? process outputs

+ reduced net $\mathrm{CO}_{2}$ emissions

? process inputs

? process outputs

+ reduced net $\mathrm{CO}_{2}$ emissions

? process inputs

? process outputs 
Method for assessment of environmental impacts throughout the life cycle of a product / technique from raw material acquisition through production, use, end-of-life treatment and disposal

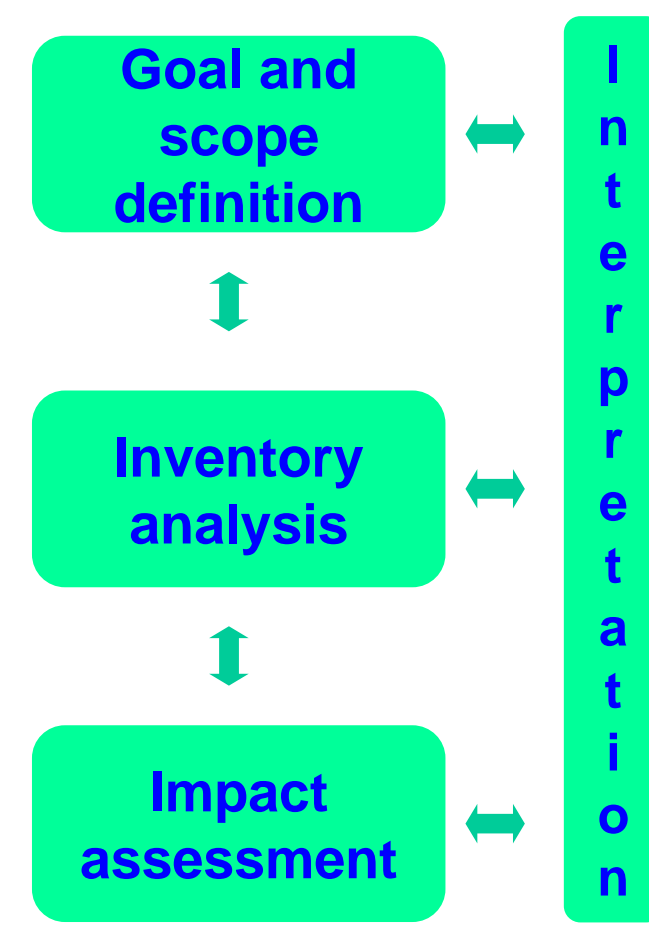

Phases of LCA

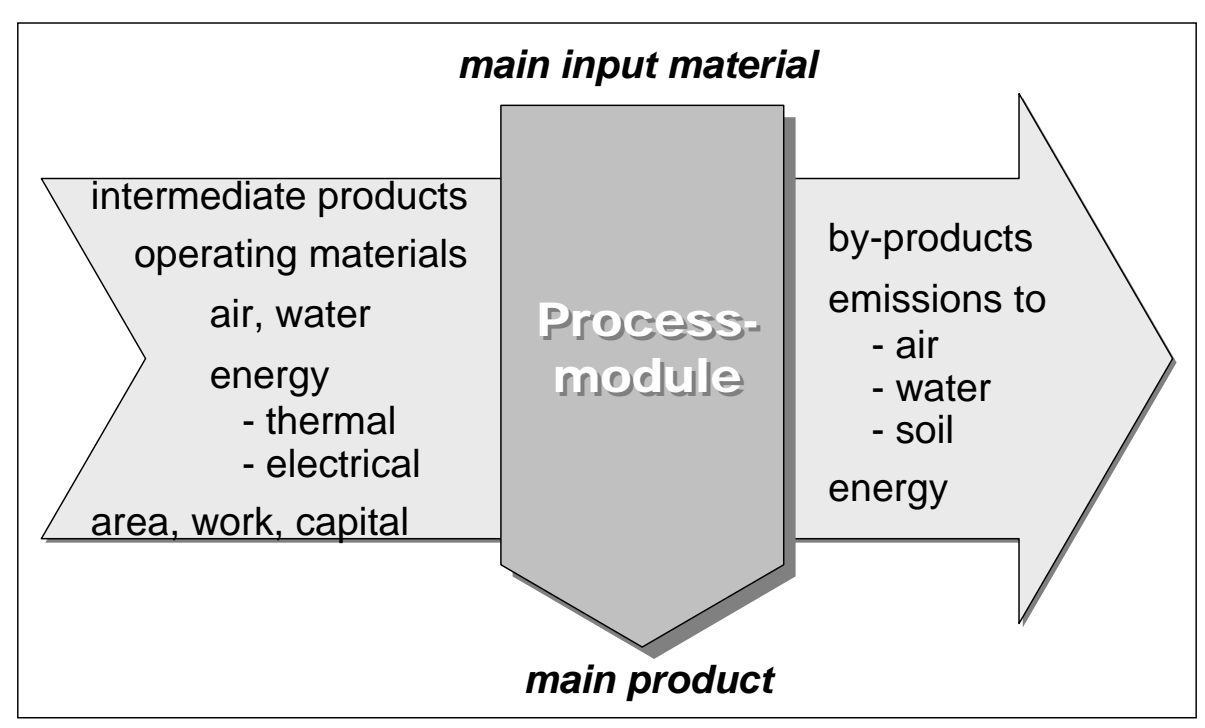

Unit process

Reference: ISO 14040, 14044, 2006 


\section{Goal and scope definition}

- Environmental impact analysis of coal-based power generation without and with MEA-based $\mathrm{CO}_{2}$ capture

- No upstream and downstream activities

- Geography: Germany, Europe

- Point in time: 2005 - $2010-2020$

- Functional unit: $1 \mathrm{kWh}_{\mathrm{el}}$

"Conventional" pulverized coal power plants

1. Coal plant ${ }_{2005}$ : operating in 2005

2. Coal plant ${ }_{2010}$ : installed in 2010

3. Coal plant ${ }_{2020}$ : installed in 2020
Pulverized coal power plants with Aminebased carbon capture

4. MEA $A_{\text {retrofit } 1}$ :

Coal plant $2005+\mathrm{MEA}_{2020}$ retrofitted in 2020

5. MEA $A_{\text {retrofit2: }}$

Coal plant $2010+\mathrm{MEA}_{2020}$ retrofitted in 2020

6. MEA greenfield:

Coal plant $2020+$ MEA $_{2020}$ installed in 2020 


\section{Power plant and $\mathrm{CO}_{2}$ capture: Processes and system boundaries}

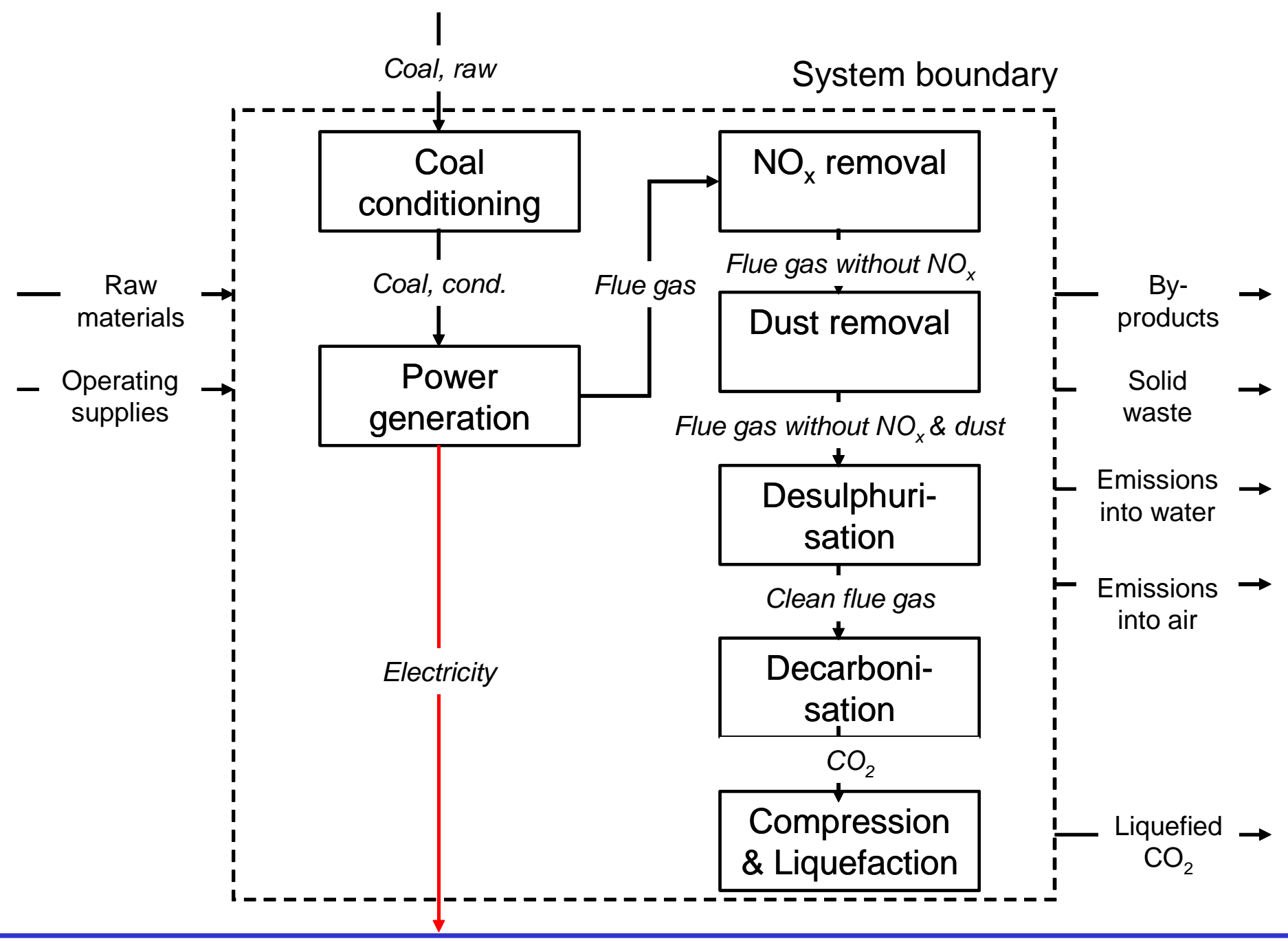




\section{Methodology and basic parameters}

\section{Technical parameters of the power plants}

\begin{tabular}{|c|c|c|c|c|c|c|c|}
\hline Plant parameter & unit & 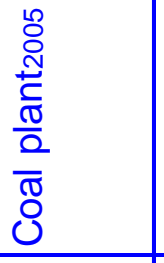 & 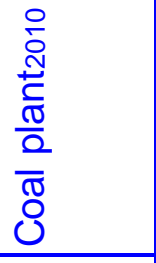 & 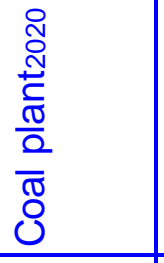 & 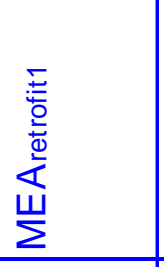 & 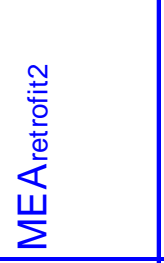 & 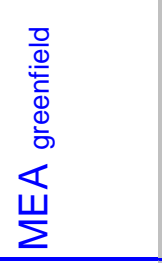 \\
\hline combustion capacity & $\mathrm{MW}_{\text {th }}$ & 1164 & 1200 & 1424 & 1164 & 1200 & 1424 \\
\hline gross capacity & $\mathrm{MW}_{\mathrm{el}}$ & 550 & 600 & 750 & 479 & 527 & 707 \\
\hline net capacity & $\mathrm{MW}_{\mathrm{el}}$ & 500.5 & 552.0 & 697.0 & 378.6 & 426.5 & 592.0 \\
\hline gross efficiency & $\%$ & 47.3 & 50.0 & 52.7 & 41.1 & 43.9 & 49.6 \\
\hline net efficiency & $\%$ & 43.0 & 46.0 & 49.0 & 32.5 & 35.5 & 41.6 \\
\hline $\begin{array}{l}\text { electrical equivalence } \\
\text { factor }\end{array}$ & --- & --- & --- & --- & 0.2 & 0.2 & 0.1 \\
\hline
\end{tabular}

- Coal plant 2005 - coal plant 2020

- Increase of net capacity

- Increase of net efficiency: $43 \%$ to $49 \%$
- $M E A_{\text {retrofitl }}-M E A_{\text {greenfield }}$

- Increase of net capacity

- Decrease of energy penalty: 10.5 to $7.4 \%$ points

- Decrease of electrical efficiency factor 


\section{Inventory analysis}

\section{Inputs}

\begin{tabular}{|c|c|c|c|c|c|c|}
\hline Inputs $\mathrm{g} / \mathrm{kWh} \mathrm{h}_{\mathrm{el}}$ & 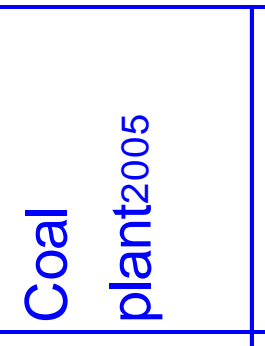 & 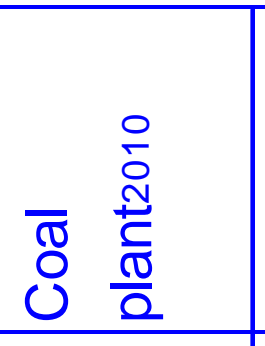 & 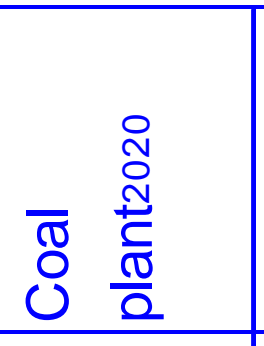 & 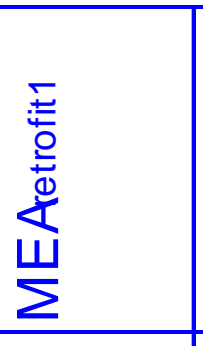 & 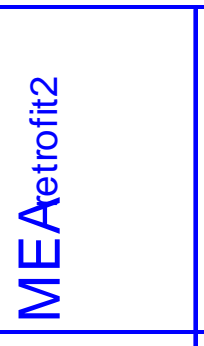 & 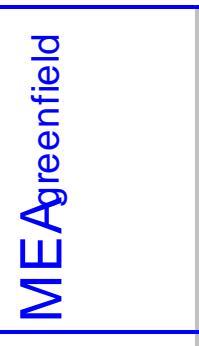 \\
\hline hard coal & 282 & 264 & 247 & 373 & 341 & 291 \\
\hline cooling water & 1398 & 1222 & 1077 & 2126 & 1834 & 1389 \\
\hline ammonia & 0.63 & 0.58 & 0.54 & 0.84 & 0.75 & 0.64 \\
\hline lime stone & 23 & 22 & 20 & 30 & 28 & 24 \\
\hline MEA & 0 & 0 & 0 & 2.3 & 2.1 & 1.1 \\
\hline sodium hydroxide & 0 & 0 & 0 & 0.12 & 0.11 & 0.09 \\
\hline
\end{tabular}

- Coal plant ${ }_{2005}$ - coal plant 2020

- Reduction of hard coal and cooling water

- Reduction of ammonia and lime stone

- No MEA solution and sodium hydroxide
- $M E A_{\text {retrofitl }}-M E A_{\text {greenfield }}$

- Higher, but decreasing level of hard coal and cooling water

- Higher, but decreasing level of ammonia and lime stone

- Decreasing use of MEA solution and sodium hydroxide

- MEA $_{\text {greenfield }}$ most attractive 


\section{Inventory analysis}

\section{Output: $\mathrm{CO}_{2}$}

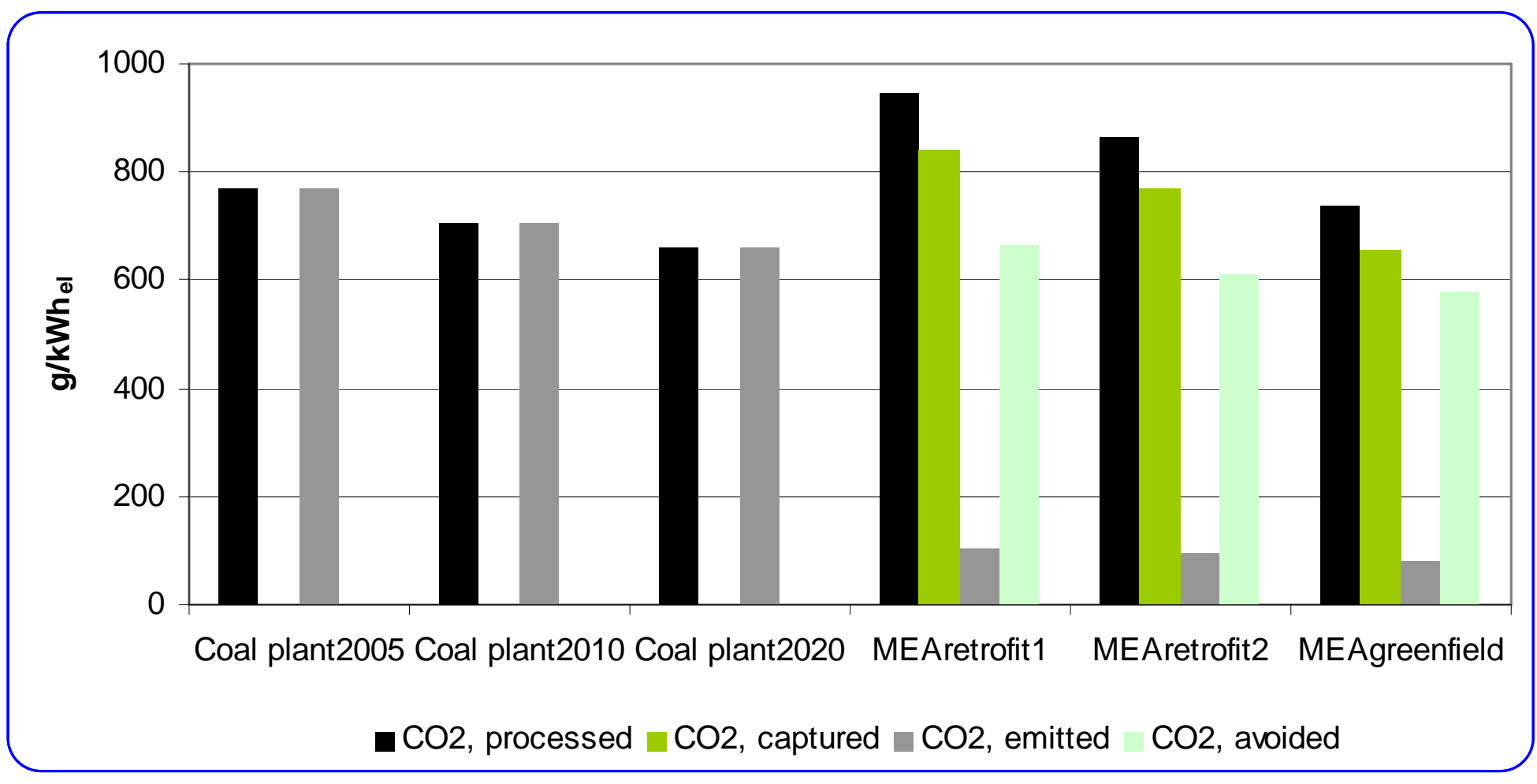

- Coal plant 2005 - coal plant 2020

- $\mathrm{CO}_{2}$ processed $=\mathrm{CO}_{2}$ emitted

- Less carbon dioxide processed
- $M E A_{\text {retrofitl }}-M E A_{\text {greenfield }}$

- Higher, but decreasing level of $\mathrm{CO}_{2}$ processed

- Fixed share of carbon dioxide captured

- Lower and decreasing level of $\mathrm{CO}_{2}$ emitted

- Decrease of carbon dioxide avoided

- MEA areenfield most attractive 


\section{Further outputs}

\begin{tabular}{|c|c|c|c|c|c|c|}
\hline Outputs $g / k W h_{e l}$ & $\begin{array}{ll} & \stackrel{2}{0} \\
\bar{N} & \stackrel{\mathbb{N}}{\frac{\pi}{2}} \\
0 & \frac{\pi}{2} \\
\end{array}$ & 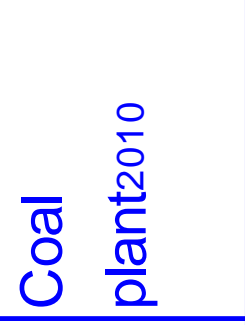 & 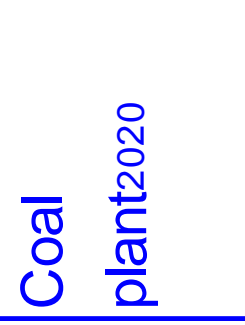 & 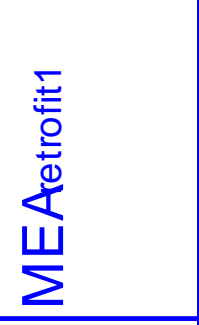 & 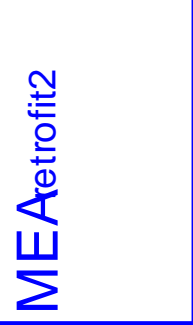 & 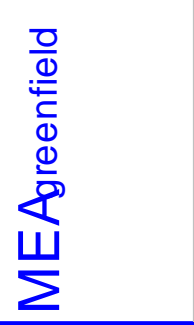 \\
\hline waste heat & 590 & 552 & 518 & 1179 & 1076 & 920 \\
\hline waste water & 120 & 113 & 106 & 159 & 146 & 126 \\
\hline gypsum (FGD) & 40 & 37 & 35 & 52 & 48 & 42 \\
\hline waste, sludge, slag & 0.90 & 0.85 & 0.79 & 1.26 & 1.15 & 1.01 \\
\hline hazardous waste & --- & --- & --- & 3.46 & 3.07 & 1.22 \\
\hline
\end{tabular}

- Coal plant 2005 - coal plant 2020

- Decrease of waste heat and waste water

- Decrease of gypsum

- Decrease of waste, sludge and slag
- $M E A_{\text {retrofitl }}-M E A_{\text {greenfield }}$

- Higher, but decreasing level of waste heat and waste water

- Higher, but decreasing level of gypsum, waste, sludge and slag

- New: hazardous waste (decreasing level)

- MEA greenfield $_{\text {most attractive }}$ 


\section{Selected results of the impact assessment}

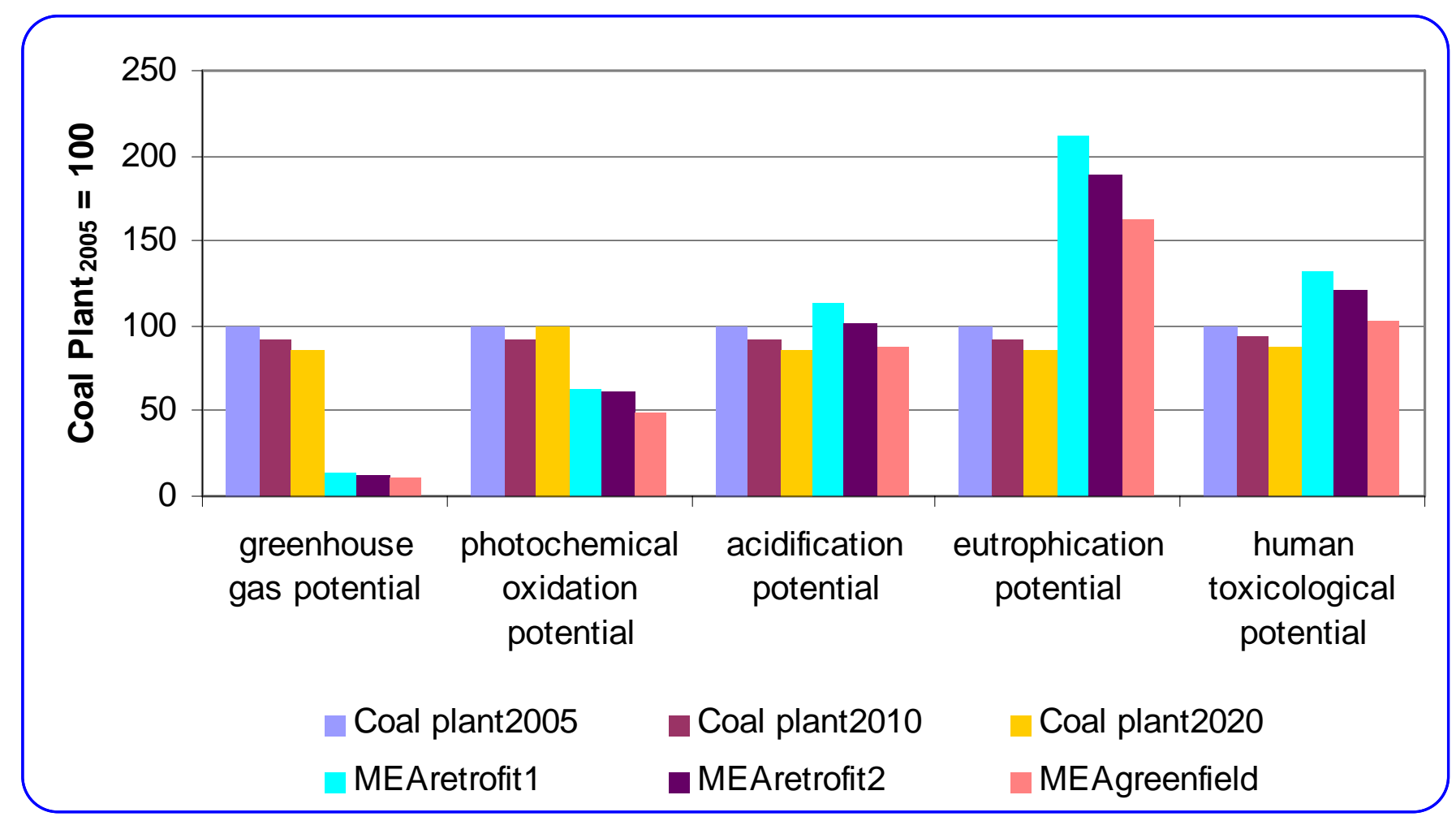

- For greenhouse gas potential and photochemical oxidation potential clear advantage for MEA-based capture

- For acidification potential no clear advantage for MEA-based capture
- For human toxicological potential MEA-based capture unfavourable

- For eutrophication potential clear disadvantage for MEA-based capture 


\section{Summary and outlook}

- High, but decreasing level of energy penalty

- Higher level of material and energy flows and additional flows

- Less $\mathrm{CO}_{2}$ emissions and global warming potential

- Higher level of other emissions and additional emissions

- Subsequently higher level for some environmental impacts

- MEA-based technology superior with respect to $\mathrm{CO}_{2}$

- $M E A_{\text {greenfield }}$ most favorite capture technology

- No clear advantage for MEA-based capture taking into account other environmental impacts 


\section{Summary and outlook}

Future activities for plant-related analysis:

- Inclusion of $\mathrm{CO}_{2}$ transport and storage and up- and downstream processes

- Analysis of other capture routes and technologies (pre combustion and oxyfuel)

Future activities for full capacity-related analysis:

- Adaptation of plant-related results for dynamic analysis taking into account capacity development 


\section{Thank you for your attention}




\section{Solid Oxide Electrolysis for Fuel Production}

Sune D. Ebbesen, Anne Hauch, Søren H. Jensen, and Mogens Mogensen

Fuel Cell and Solid State Chemistry Department

Risø National Laboratory, Technical University of Denmark

DK-4000 Roskilde, Denmark

www.risoe.dk

Sune.Ebbesen@risoe.dk

Risø International Energy Conference, 23 ${ }^{\text {rd }}$ May 2007 


\section{Outline}

\section{Solid Oxide Electrolysis for Fuel Production}

1. Principle for Solid Oxide Electrolysis Cells (SOECs)

- Production of hydrogen and synthetic fuel

- Advantages of SOEC compared to PEM/Alkaline electrolysis

2. Perspectives for SOECs

- Economy estimation for hydrogen production

- Synthetic fuel

3. Conclusions and what about the future? 


\section{DTU \\ Principle for SOECs}

\section{Solid Oxide Fuel Cells}

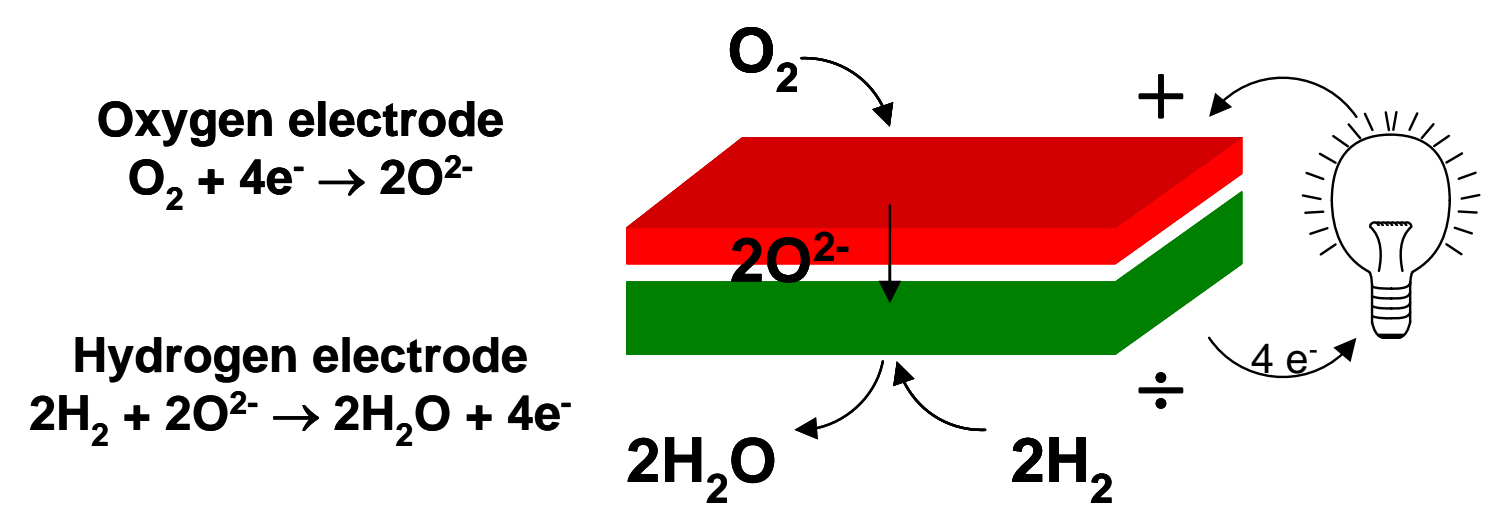




\section{Principle for SOECs}

Solid Oxide Electrolysis Cells

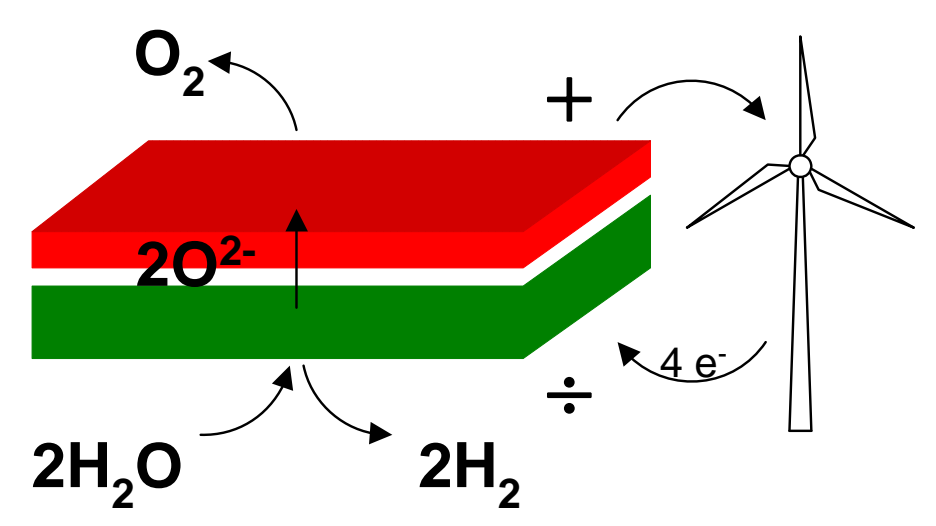

Consuming water and electricity

Producing hydrogen

Electrolysis of $\mathrm{CO}_{2}+\mathrm{H}_{2} \mathrm{O}$ to

synthesis-gas $\left(\mathrm{CO}+\mathrm{H}_{2}\right)$
Solid Oxide Fuel Cells

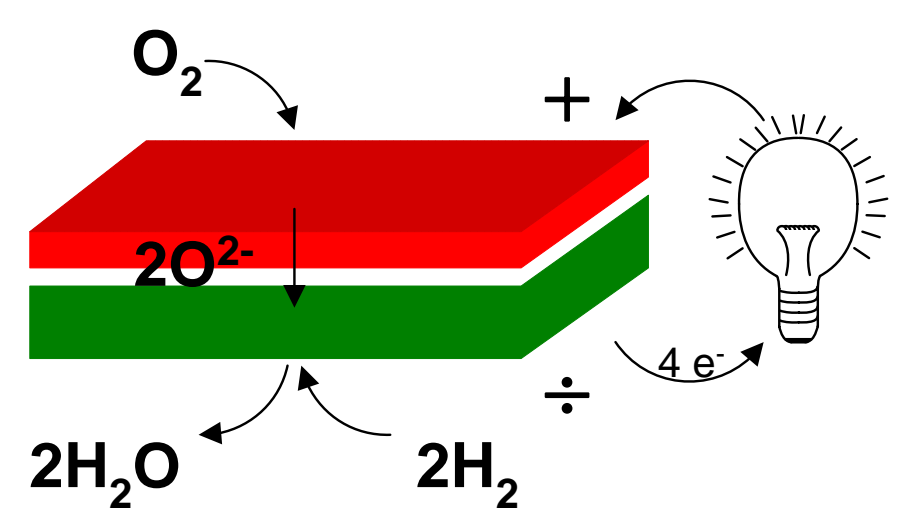

Consuming hydrogen Producing electricity 


\section{Principle for SOECs}

\section{RISO}

\section{Solid Oxide Electrolysis Cells 27, okt. 200610.54 rndland}

\section{Morgenkaffen kogt på strøm fra vindmøller}

Halvdelen af landets husholdninger har i dag kunnet lave morgenkaffe med s

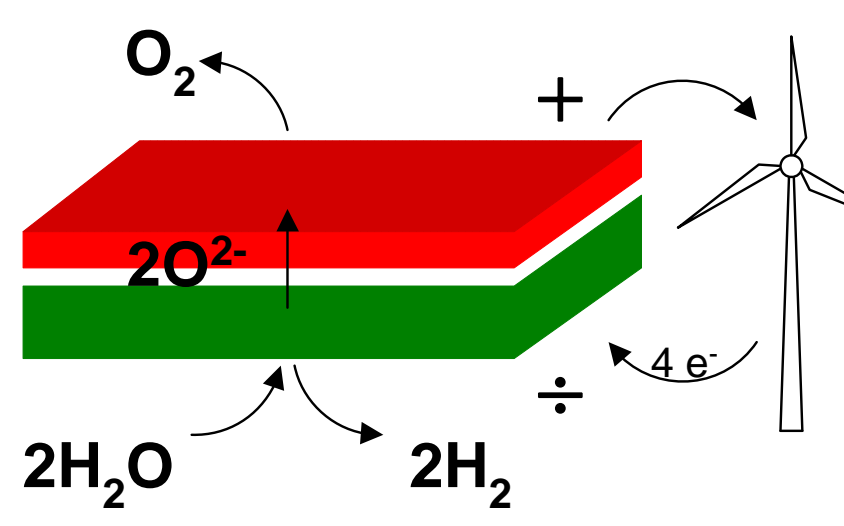

Consuming water and electricity

Producing hydrogen

Electrolysis of $\mathrm{CO}_{2}+\mathrm{H}_{2} \mathrm{O}$ to

synthesis-gas $\left(\mathrm{CO}+\mathrm{H}_{2}\right)$

Efterårets første alvorlige blæsevejr er nemlig guf for den alternative energip

KI. 9 i dag kunne stømmen fra møllerne dække cirka halvdelen af det samled årsplan leverer moller ellers kun stom til 20 procent af forbruget.

Med en vindhastighed op omkring $20 \mathrm{~m} / \mathrm{s}$ i det vestlige Jylland, hvor mange : placeret, er elproduktionen fra vindmoller tæt på det maksimalt mulige.

Kommer vindhastigheden op omkring $25 \mathrm{~m} / \mathrm{s}$, stopper vindmollerne derimod

Gratis el i nat

I nat betød elproduktion fra vindmøllerne, at udbuddet af el på den nordiske var så stort, at elspotprisen i både øst- og Vestdanmark var nul i timerne m€

Vindmollerne producerede strom not til at dække 80 procent af det samlede I Landets kraftværker måtte endda skrue ned for produktionen, fordi der ikke ' eksport på de elektriske forbindelser til udlandet. 


\section{Principle for SOECs}

Solid Oxide Electrolysis Cells

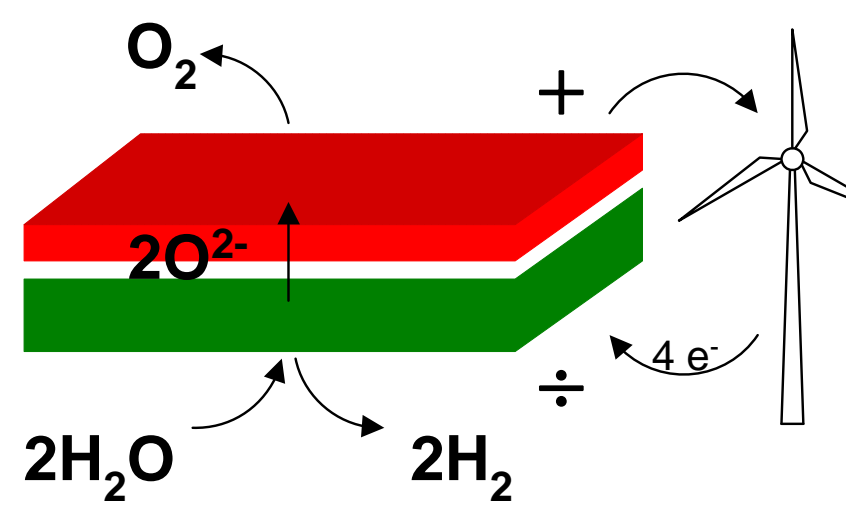

Consuming water and electricity

Producing hydrogen

Electrolysis of $\mathrm{CO}_{2}+\mathrm{H}_{2} \mathrm{O}$ to

synthesis-gas $\left(\mathrm{CO}+\mathrm{H}_{2}\right)$

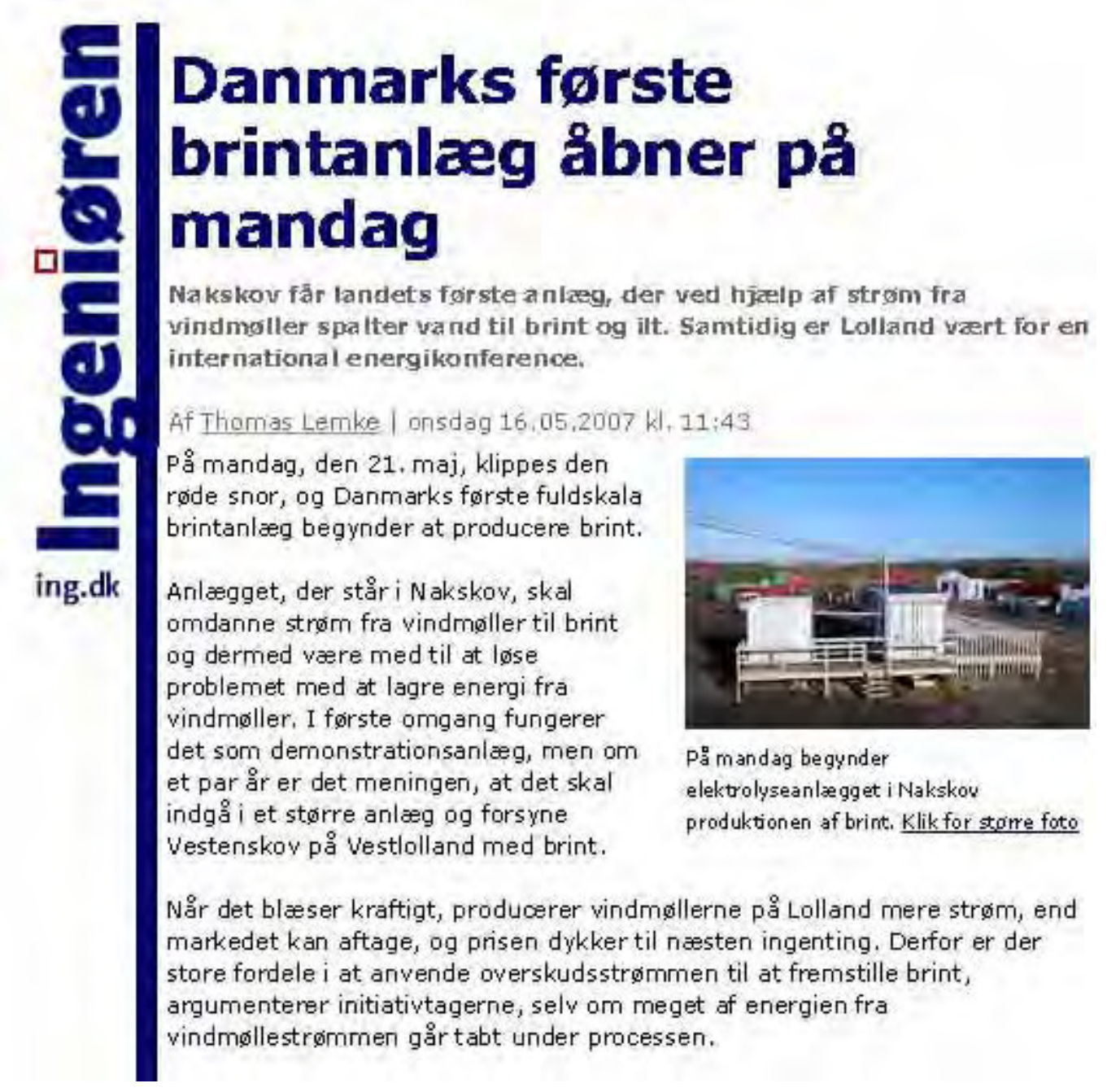




\section{Advantages of SOECs}

\begin{tabular}{|c|c|c|c|}
\hline & SOEC & Alkaline & PEM \\
\hline $\begin{array}{c}\text { Reactants and } \\
\text { products }\end{array}$ & $\begin{array}{c}\mathrm{H}_{2} \mathrm{O} \rightarrow \mathrm{H}_{2} \\
\mathrm{CO}_{2} \rightarrow \mathrm{CO}\end{array}$ & $\mathrm{H}_{2} \mathrm{O} \rightarrow \mathrm{H}_{2}$ & $\mathrm{H}_{2} \mathrm{O} \rightarrow \mathrm{H}_{2}$ \\
\hline Electrolyte & Ceramic & $\mathrm{KOH}$ or $\mathrm{NaOH}$ & Polymer \\
\hline Electrodes & Nickel, ceramics & Nickel & Platinum \\
\hline Temperature & $850^{\circ} \mathrm{C}$ & $80^{\circ} \mathrm{C}$ & $80^{\circ} \mathrm{C}$ \\
\hline
\end{tabular}




\section{Advantages of SOECs}

Thermodynamics for water electrolysis

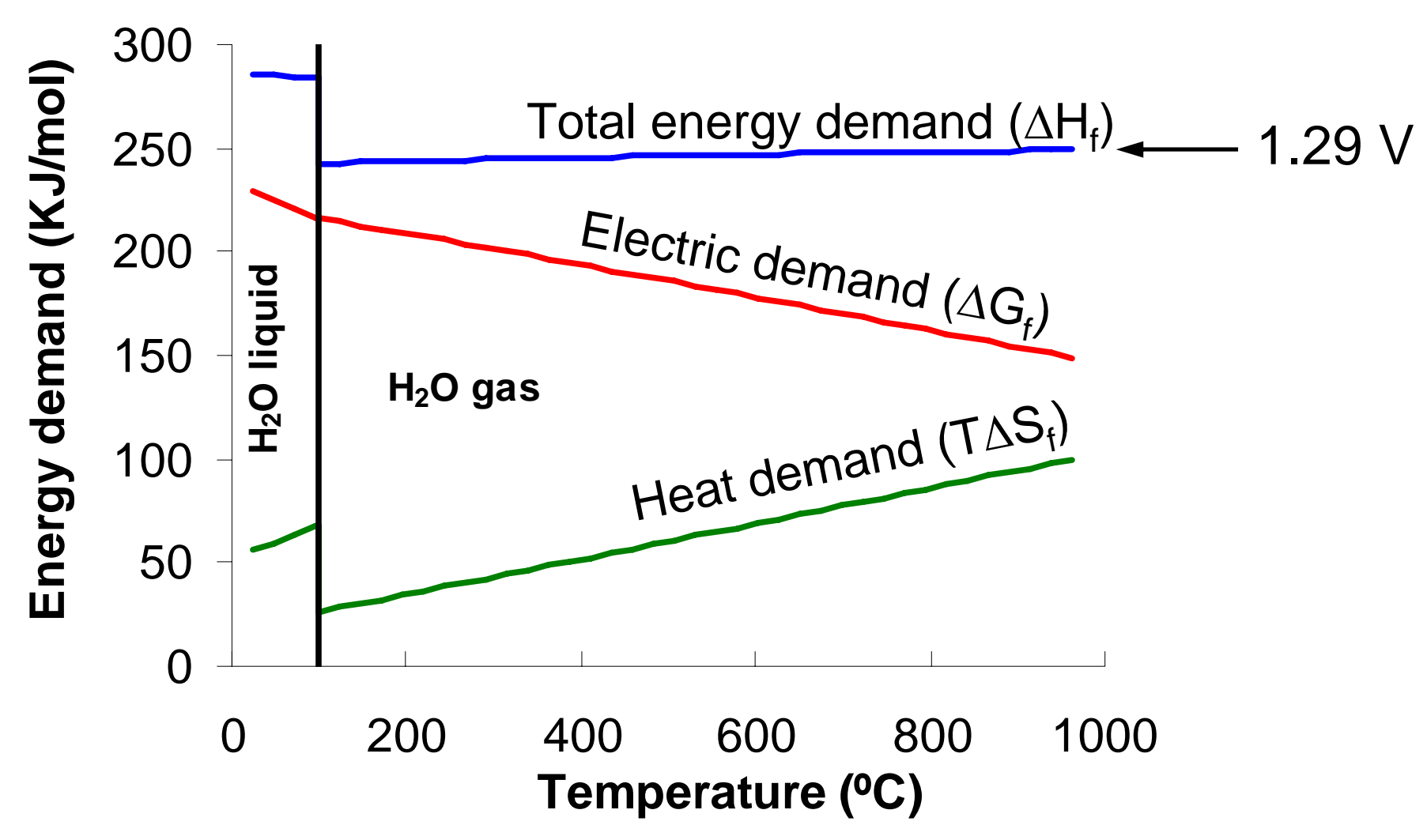




\section{DTU

Thermodynamics is optimal case ... Real life ?

Solid Oxide Electrolysis Cells

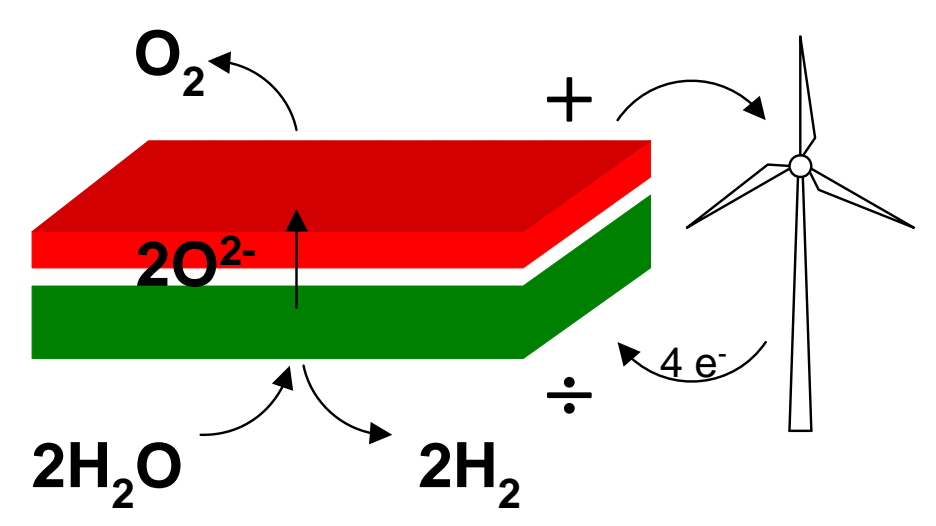

Solid Oxide Fuel Cells

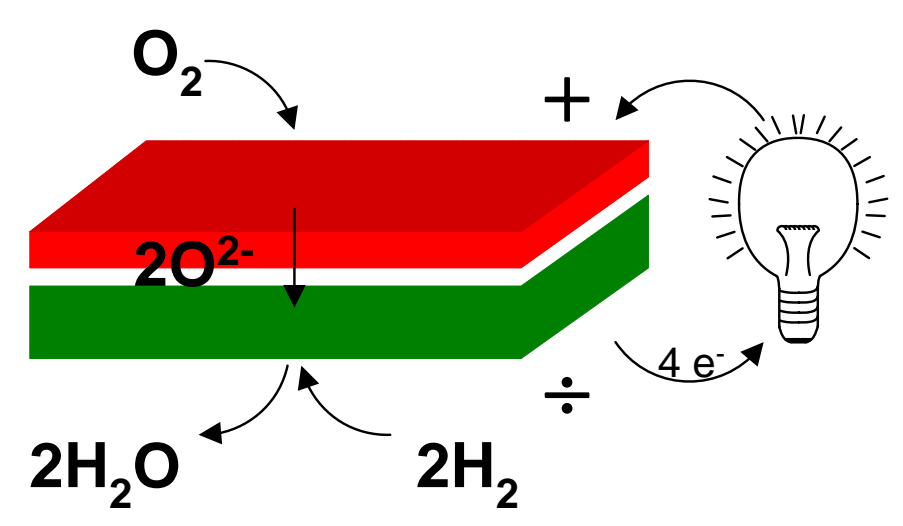




\section{DTU}

\section{Thermodynamics is optimal case ... Real life ?}

RISO

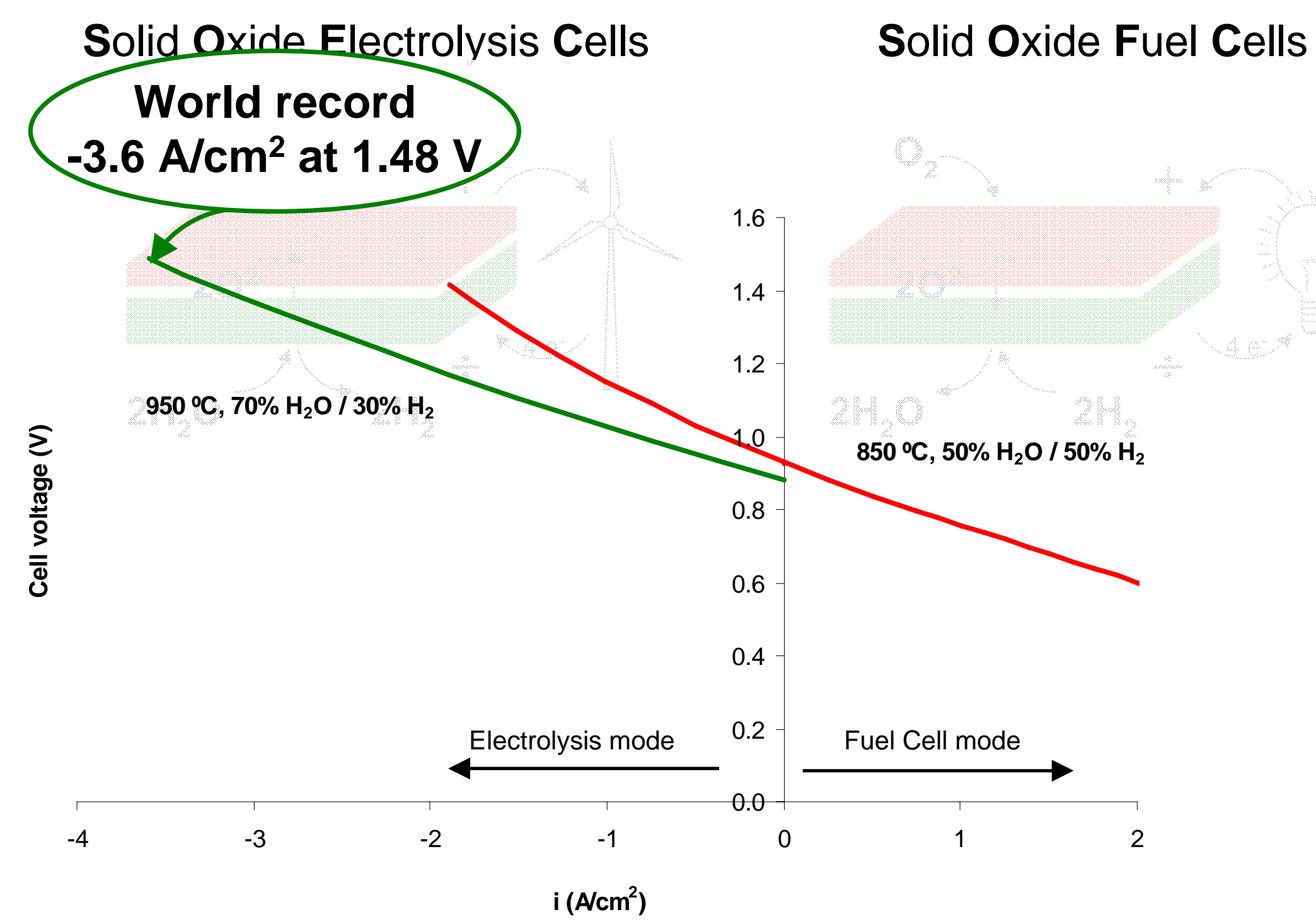




\section{Thermodynamics is optimal case ... Real life?}

Solid Oxide Electrolysis Cells

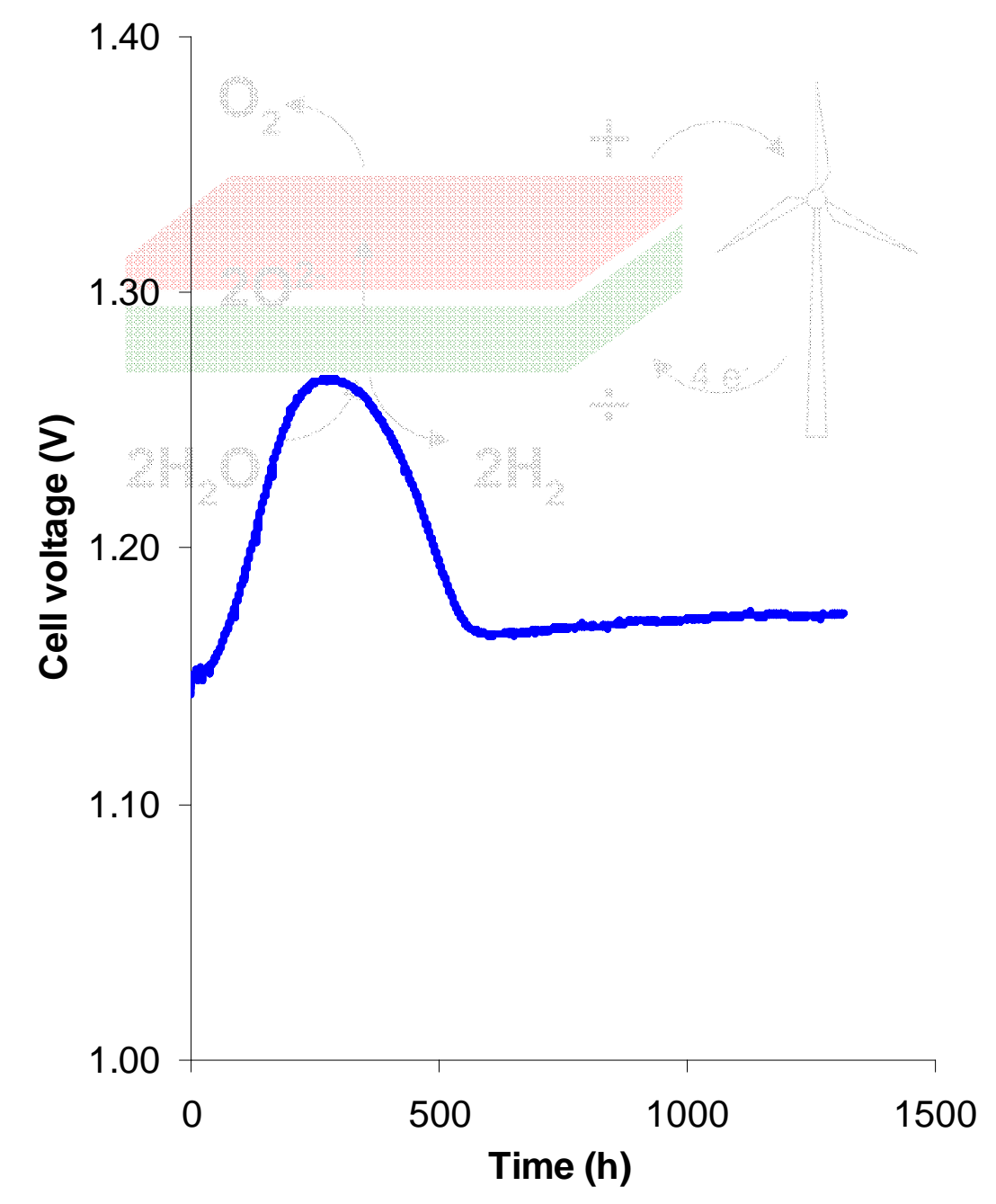

Solid Oxide Fuel Cells

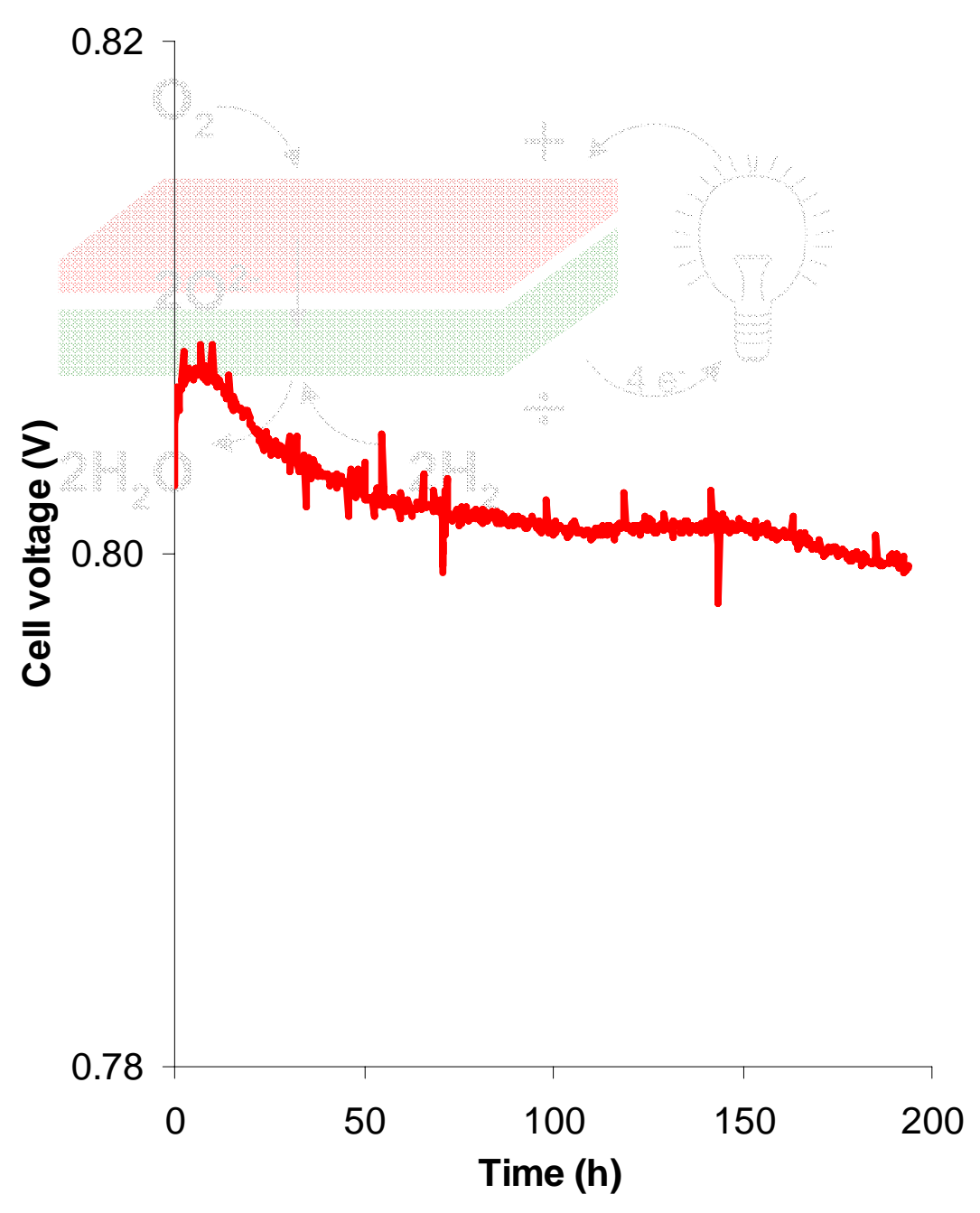




\section{SOEC Durability}

SEM micrograph of hydrogen electrode after electrolysis

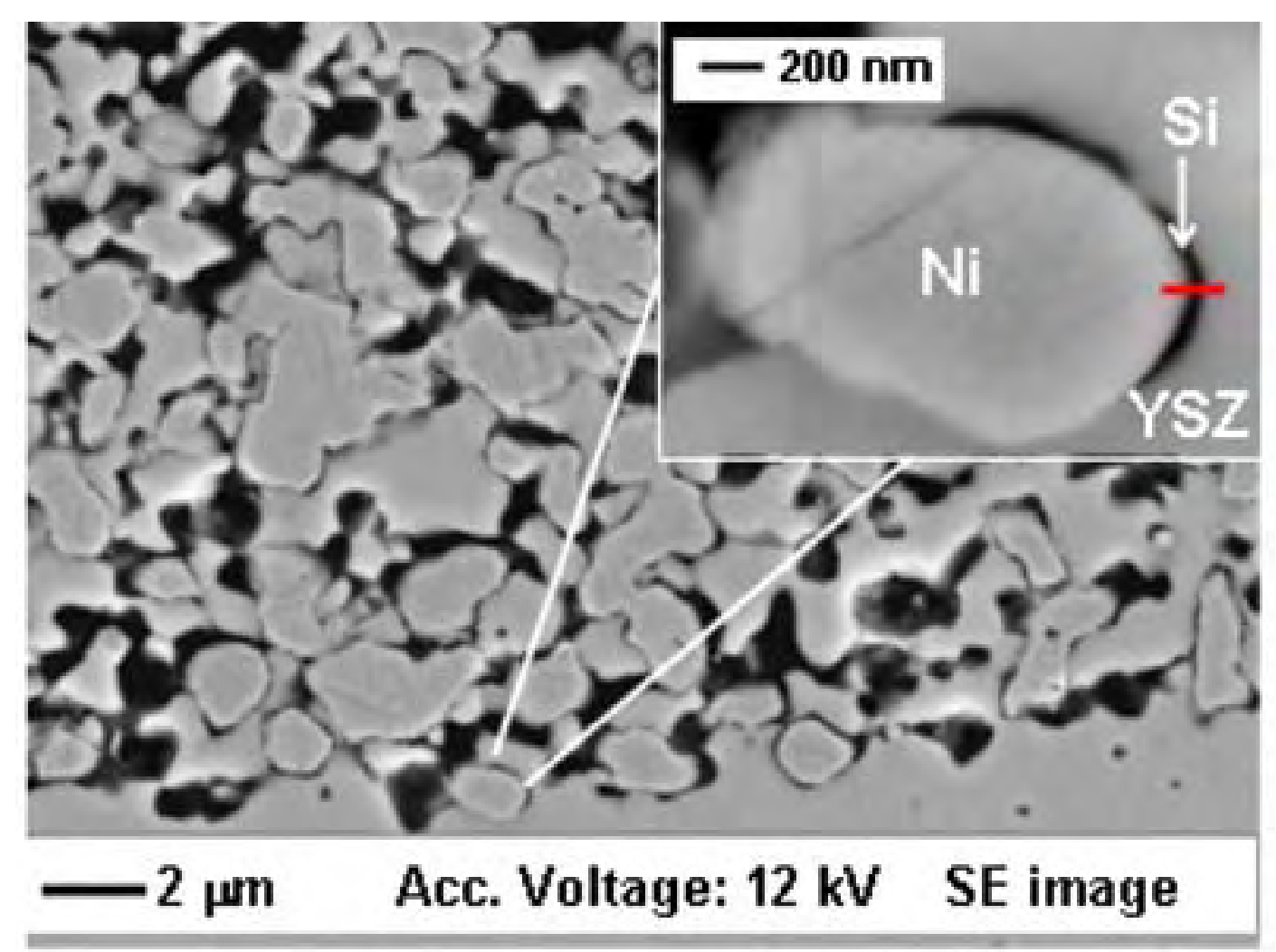

Post examination after electrolysis at $850^{\circ} \mathrm{C}, 70 \% \mathrm{H}_{2} \mathrm{O},-1 \mathrm{~A} / \mathrm{cm}^{2}$ for $353 \mathrm{~h}$ and $-0.5 \mathrm{~A} / \mathrm{cm}^{2}$ for $227 \mathrm{~h}$ 
SOEC Durability

\begin{tabular}{|c|c|}
\hline Electrolysis cell & Fuel cell [1] \\
\hline$-0.5 \mathrm{~A} / \mathrm{cm}^{2}$ at $850^{\circ} \mathrm{C}$ & $1.0 \mathrm{~A} / \mathrm{cm}^{2}$ at $850^{\circ} \mathrm{C}$ \\
\hline$\sim 2 \% / 1000 \mathrm{~h}(1316 \mathrm{~h}$ test $)$ & Below $1 \% / 1000 \mathrm{~h}(1500 \mathrm{~h}$ test $)$ \\
\hline
\end{tabular}

\begin{tabular}{|c|c|}
\hline$-1.0 \mathrm{~A} / \mathrm{cm}^{2}$ at $950^{\circ} \mathrm{C}$ & $1.0 \mathrm{~A} / \mathrm{cm}^{2}$ at $950^{\circ} \mathrm{C}$ \\
\hline$\sim 30 \% / 1000 \mathrm{~h}(620 \mathrm{~h}$ test) & Below $1 \% / 1000 \mathrm{~h}(1500 \mathrm{~h})$ \\
\hline
\end{tabular}




\section{Economy estimation for hydrogen production}

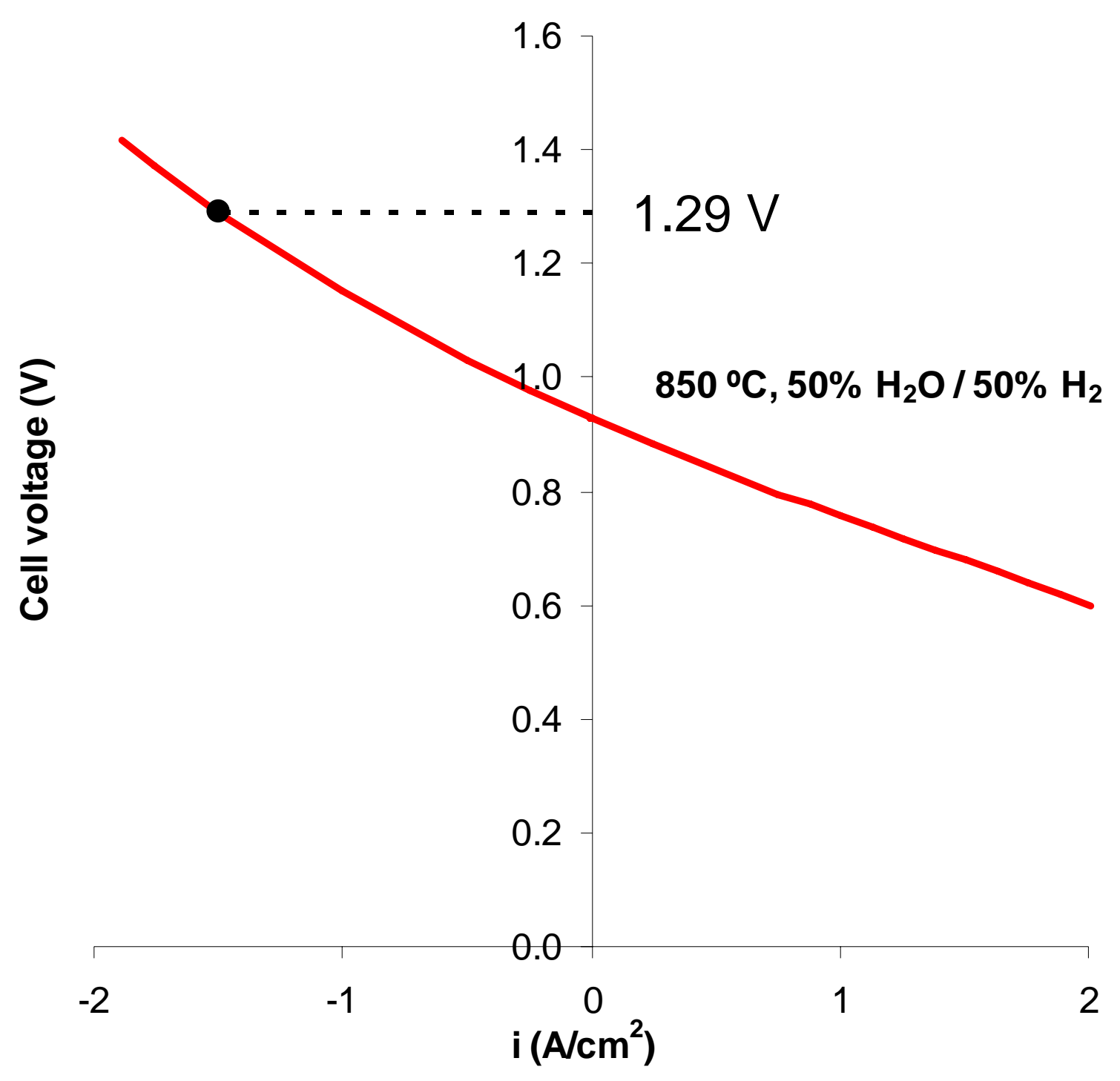




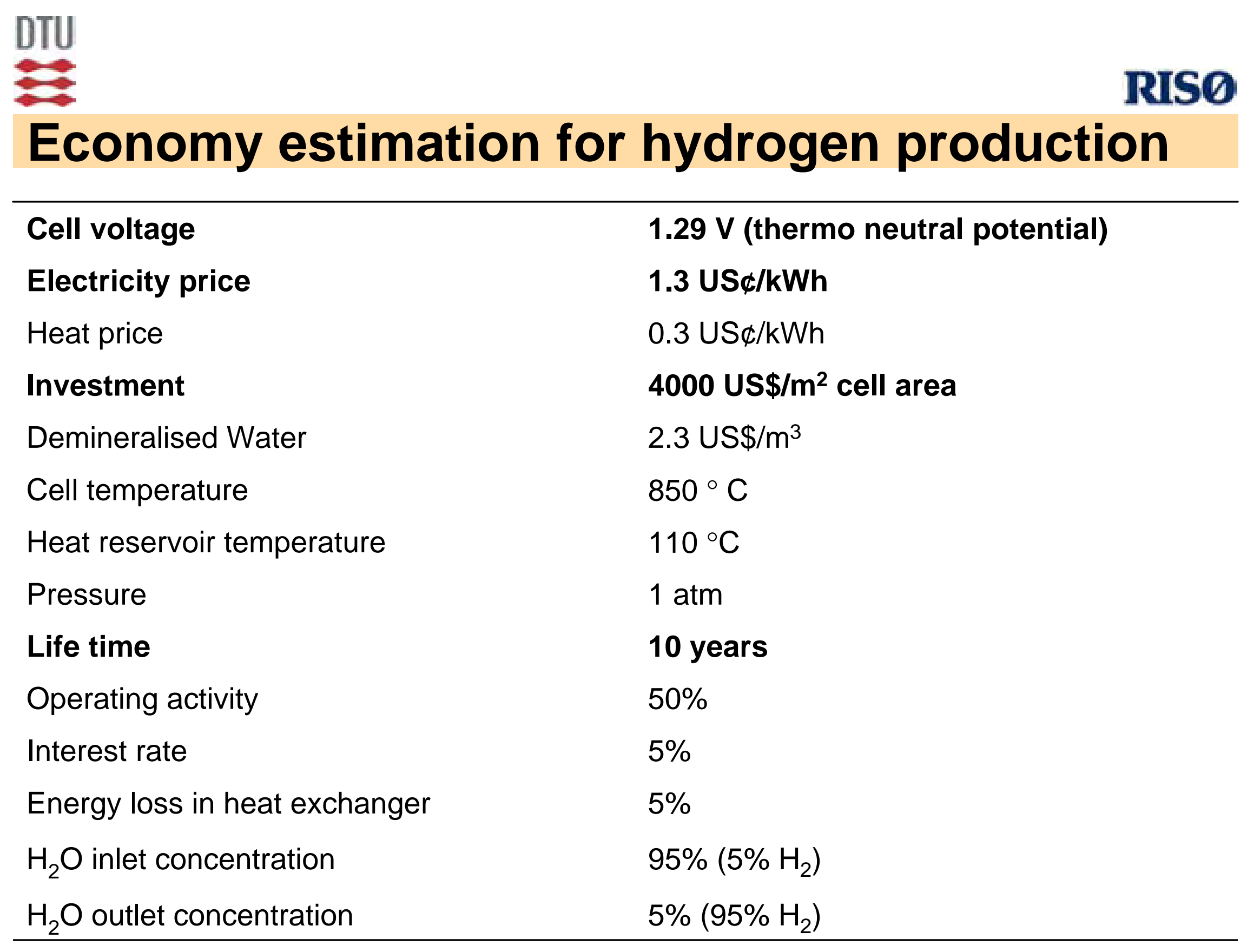




\section{Economy estimation for hydrogen production}

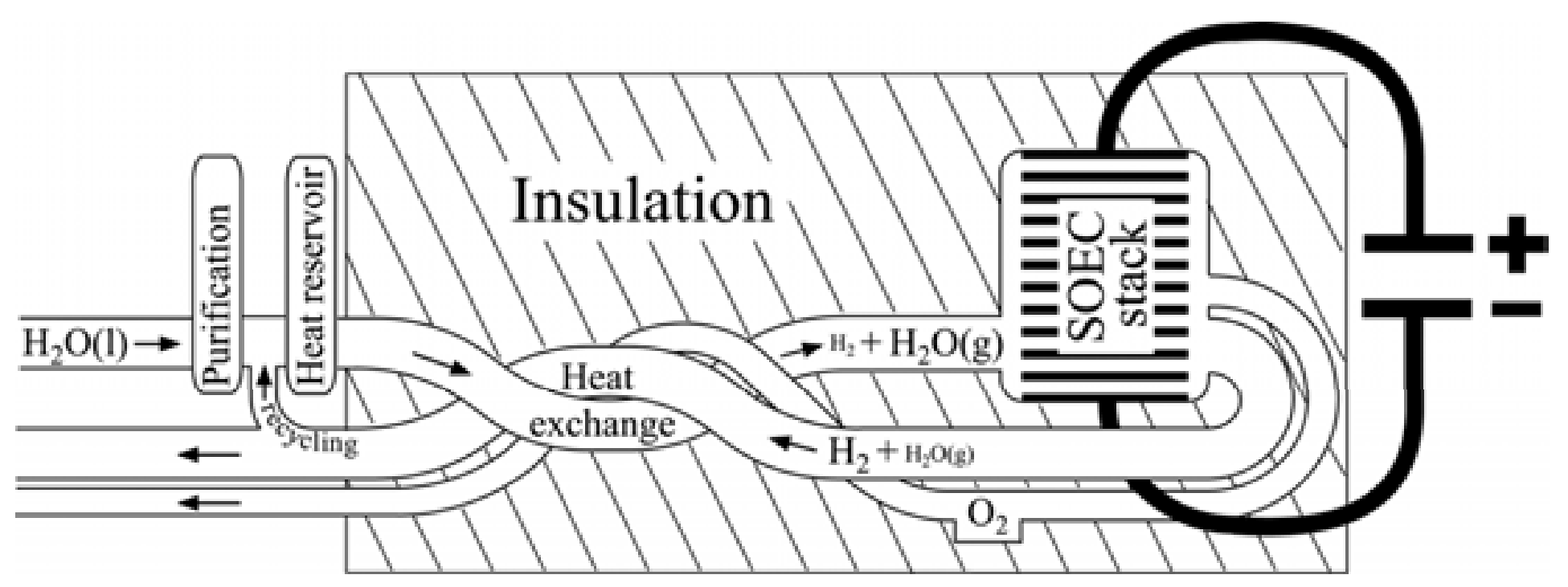




\section{DTU}

\section{Economy estimation for hydrogen production}

\section{RISO}

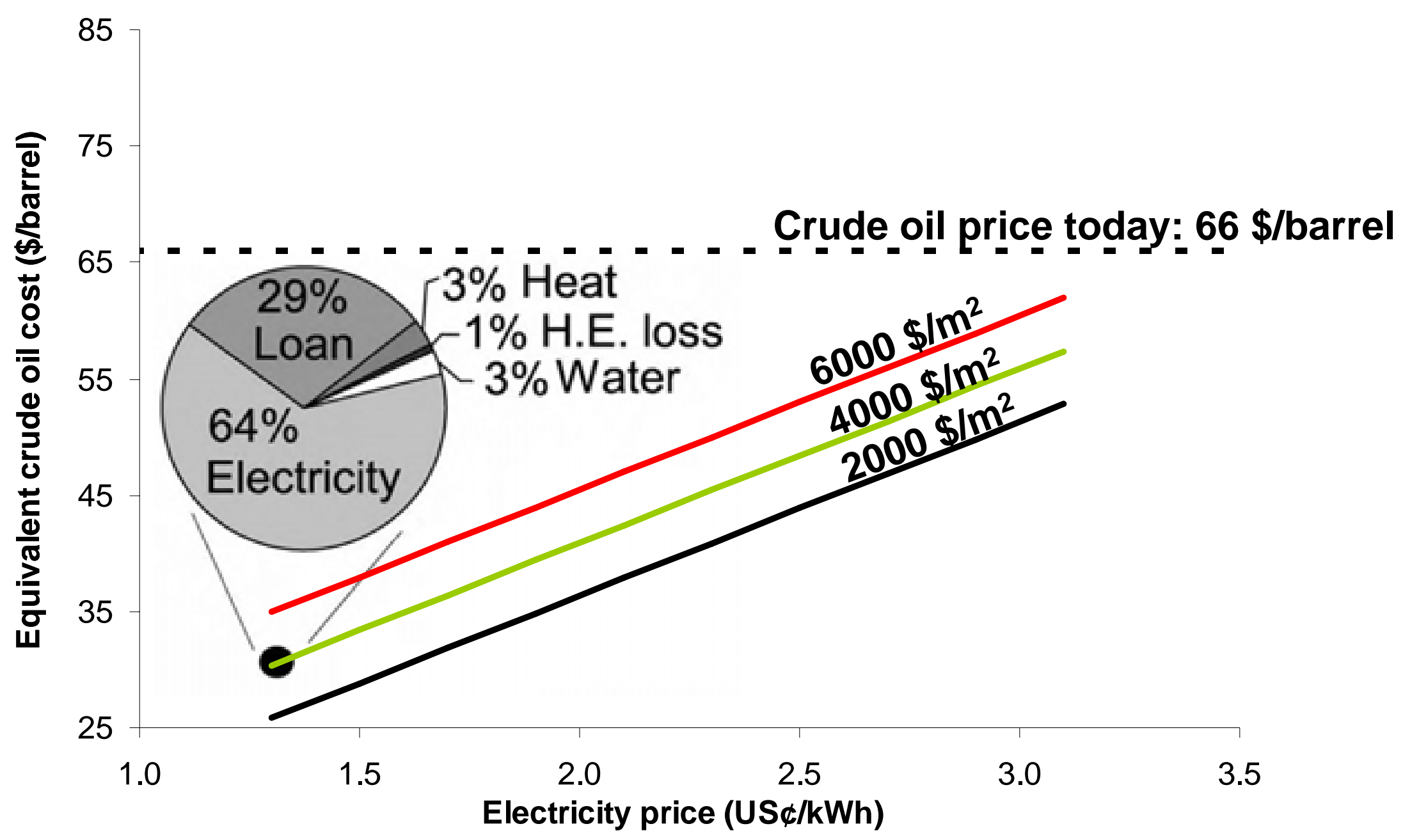




\section{DTU}

\section{Economy estimation for hydrogen production}

\section{RISO}

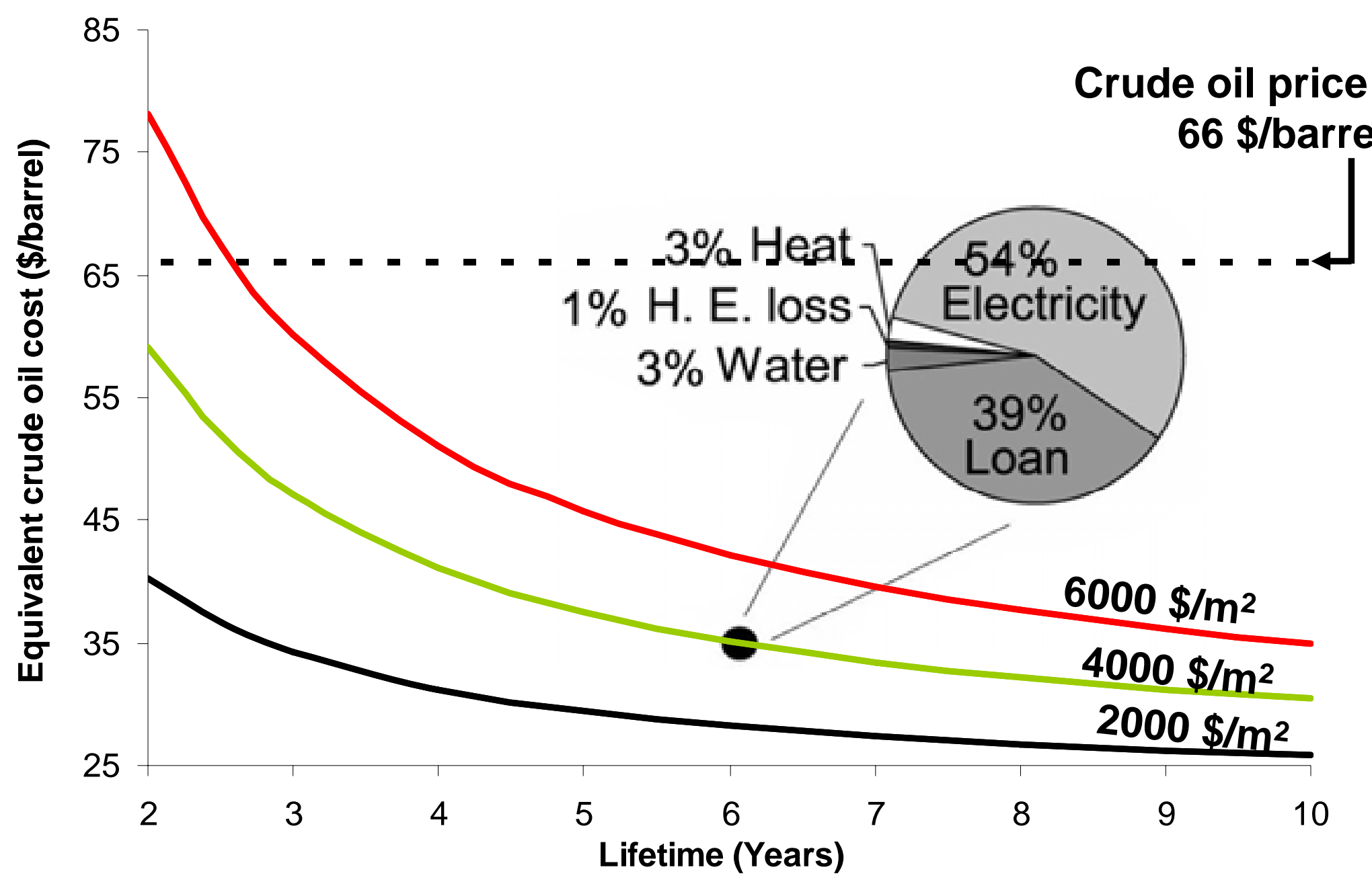




\section{Conclusion (hydrogen production)}

- Excellent initial electrolysis performance

- Main passivation problem on hydrogen electrode

— Significant amount of silica impurities

- Long-term durability needs to be improved

- Low hydrogen production price by electrolysis 


\section{DTU \\ Production of synthetic fuel}

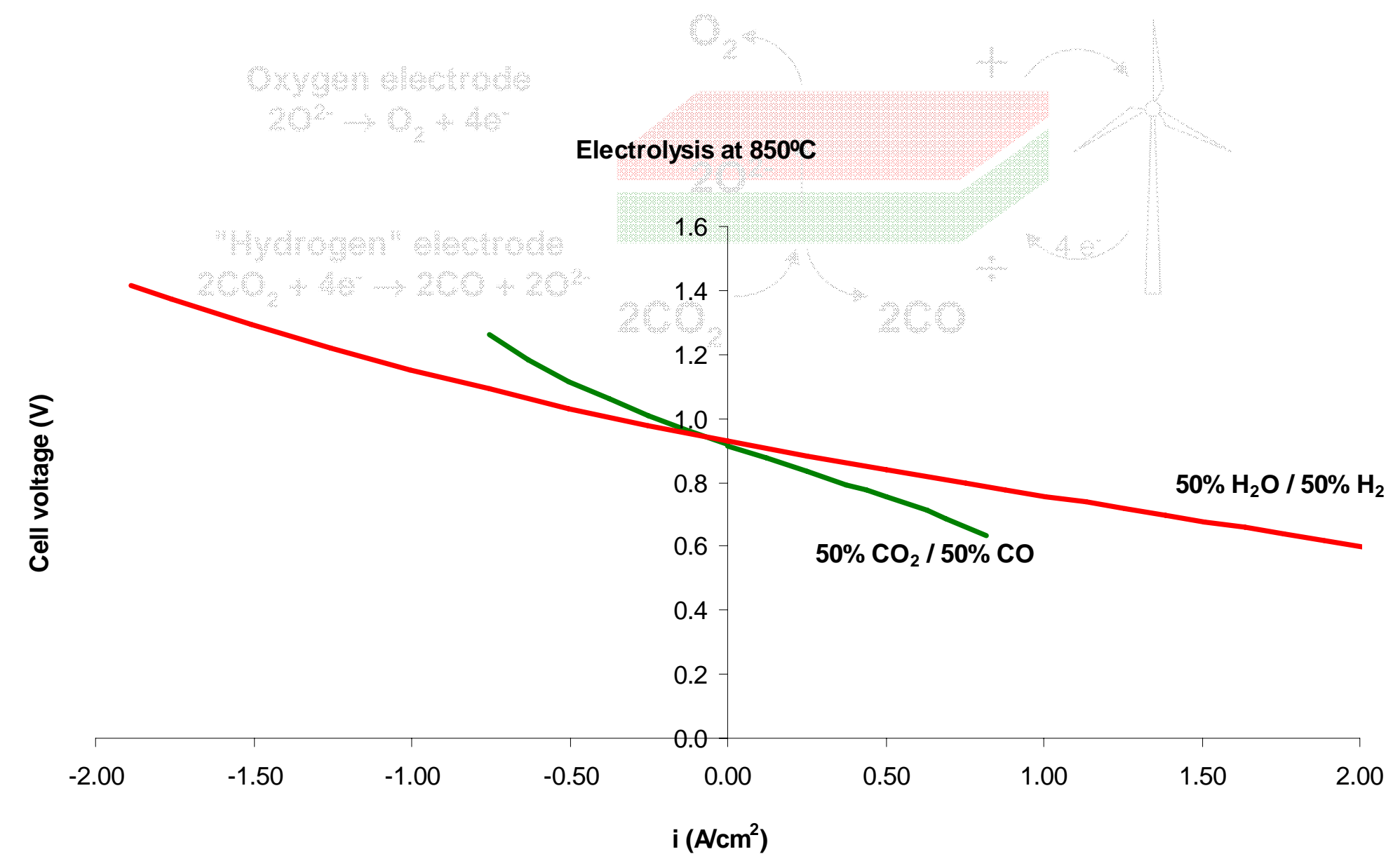




\section{Production of synthetic fuel}

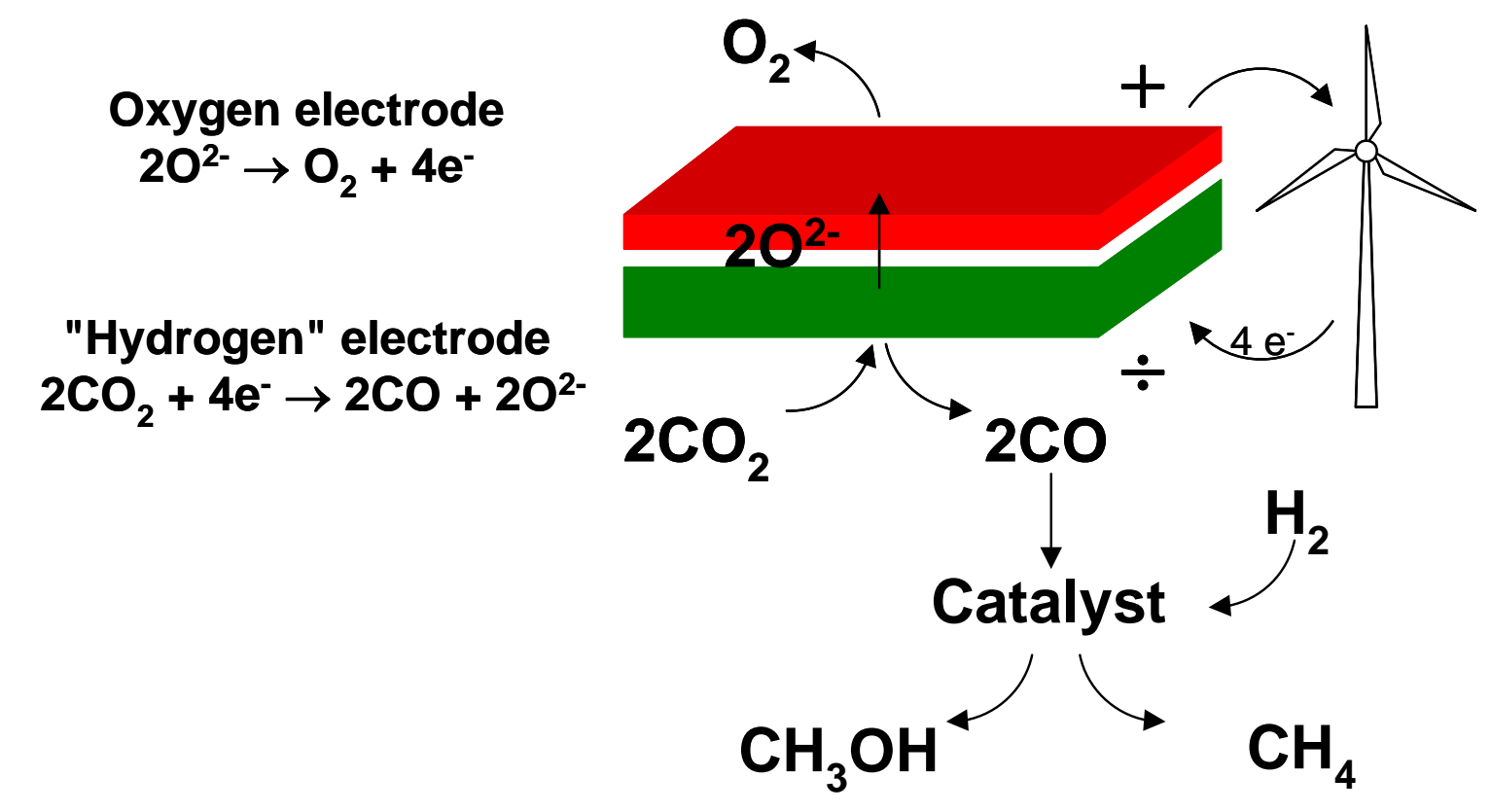




\section{Production of synthetic fuel}

\section{RISO}
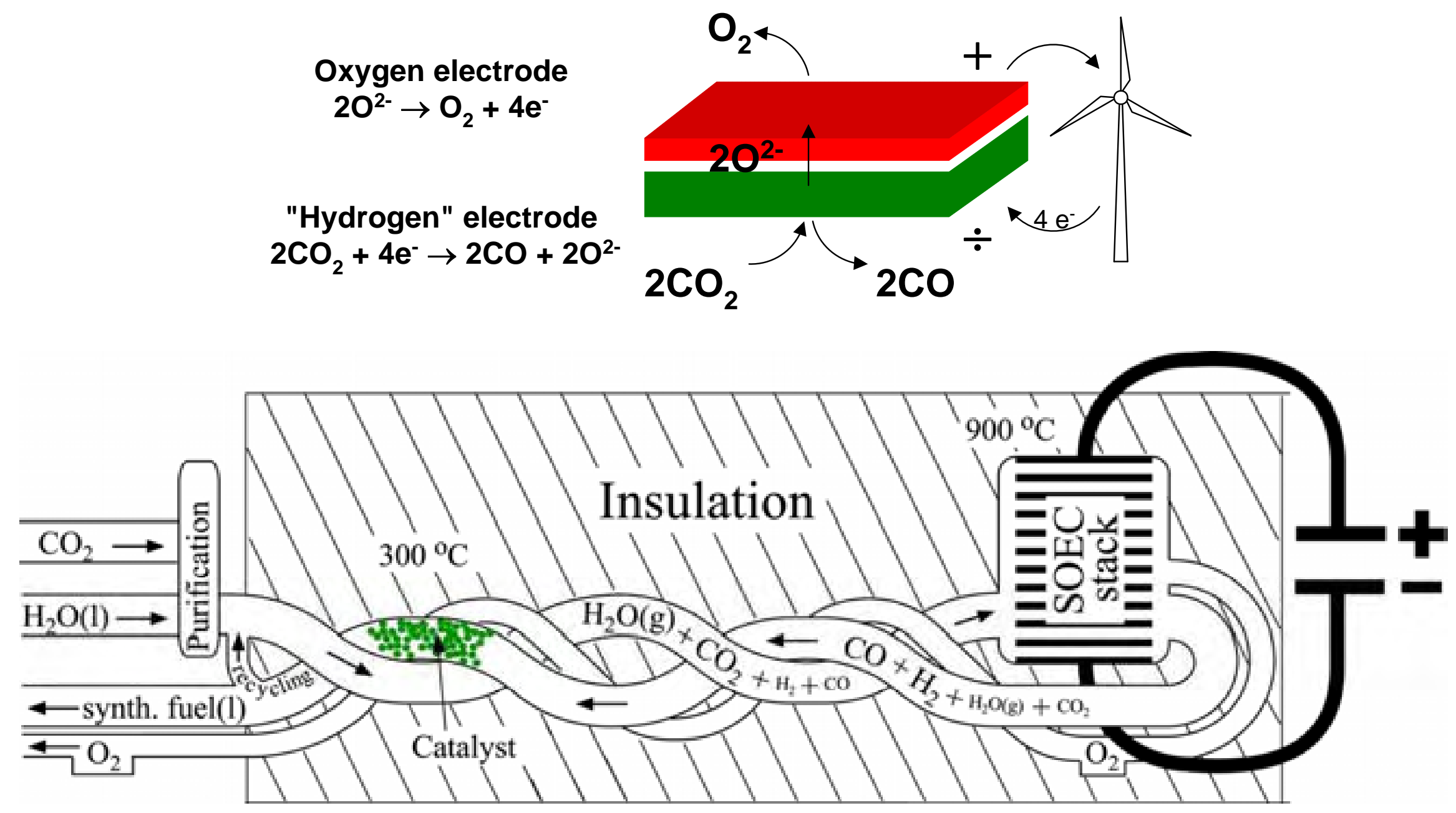


\section{Production of synthetic fuel}

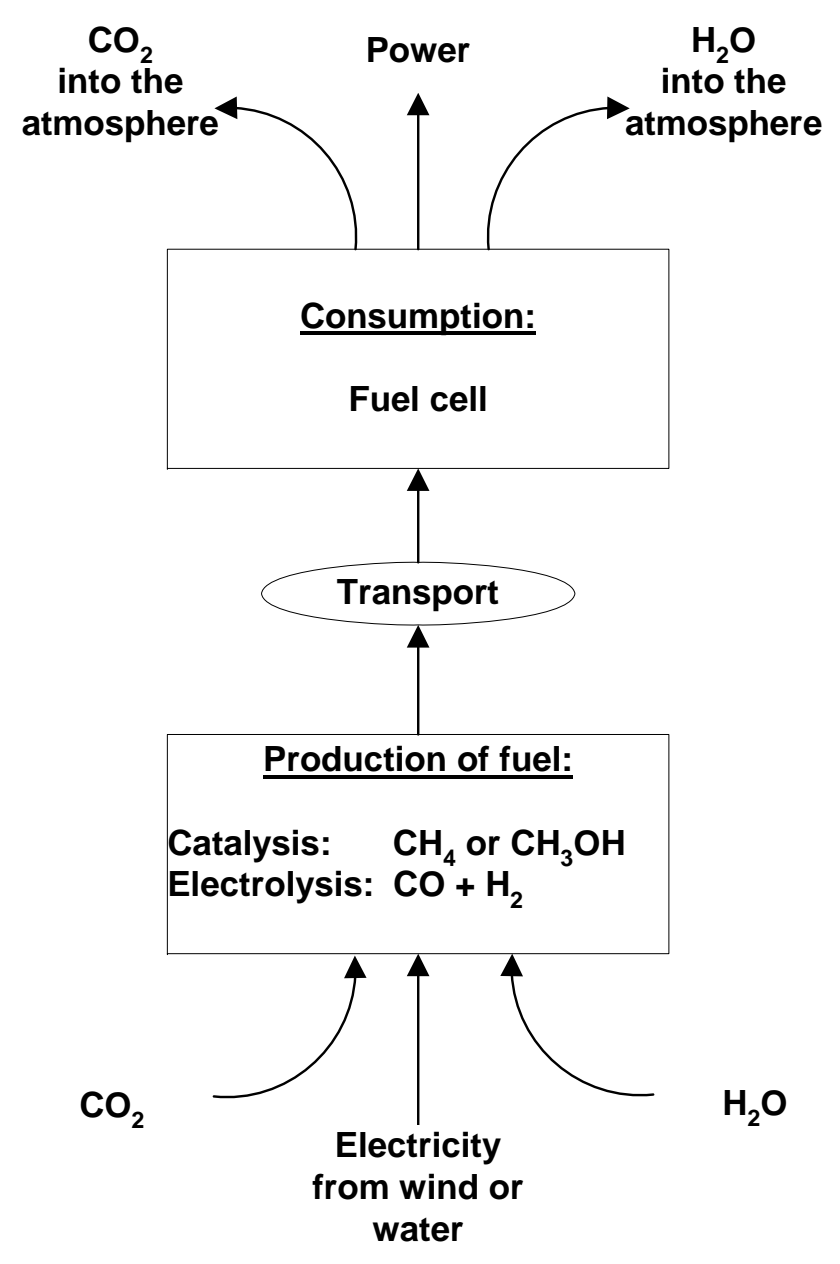




\section{Production of synthetic fuel}

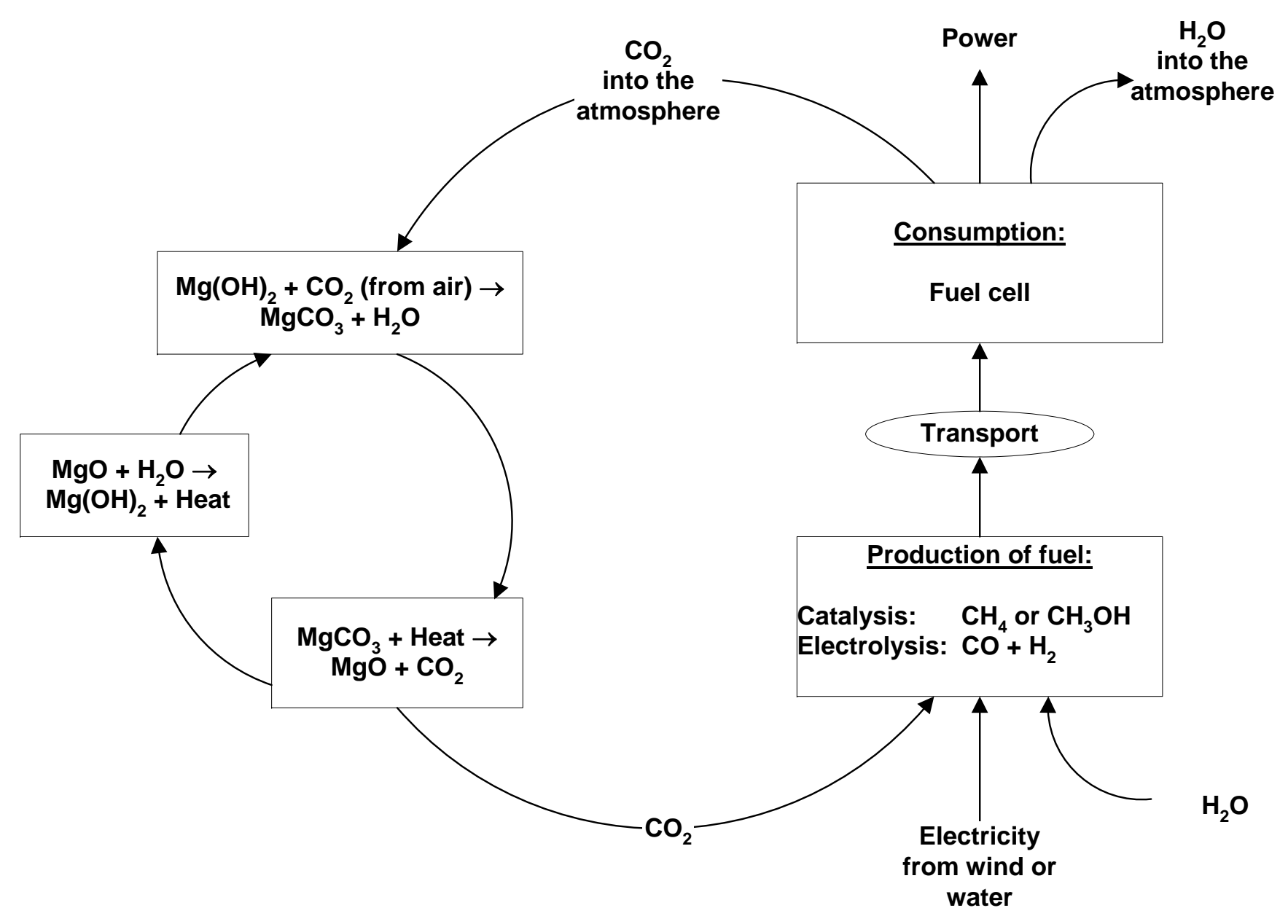




\section{Conclusion \& Outlook}

- Excellent initial electrolysis performance

- Main passivation problem on hydrogen electrode

— Significant amount of silica impurities

- Long-term durability needs to be improved

- Low hydrogen production price by electrolysis

- Synthetic fuel for the future 


\section{Solid Oxide Electrolysis for Fuel Production}

Sune D. Ebbesen. Amme Hauch, Soren H. Jensen, and Mogens Mogensen

Thank you

Risa National Laboraton, Technical Unversiy of Denmak

DKmooo Roskilde, Denmark

WhW Tsoe.dk

Sune Ebbesenorisoedk 
DTU

\section{RISO}

\section{Extra slides}




\section{DTU \\ Crude oil price}

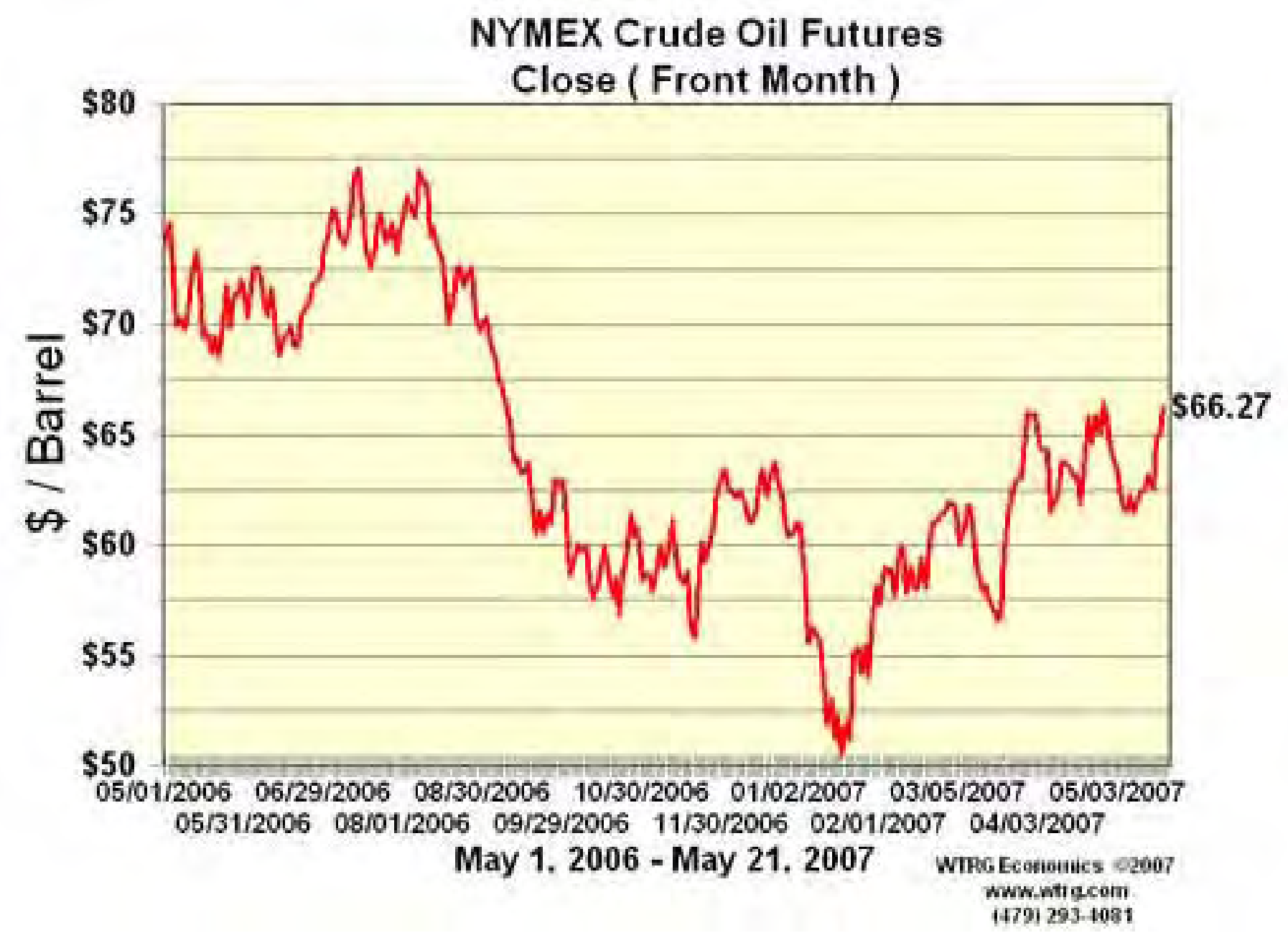




\section{Danmarks første brintanlæg}

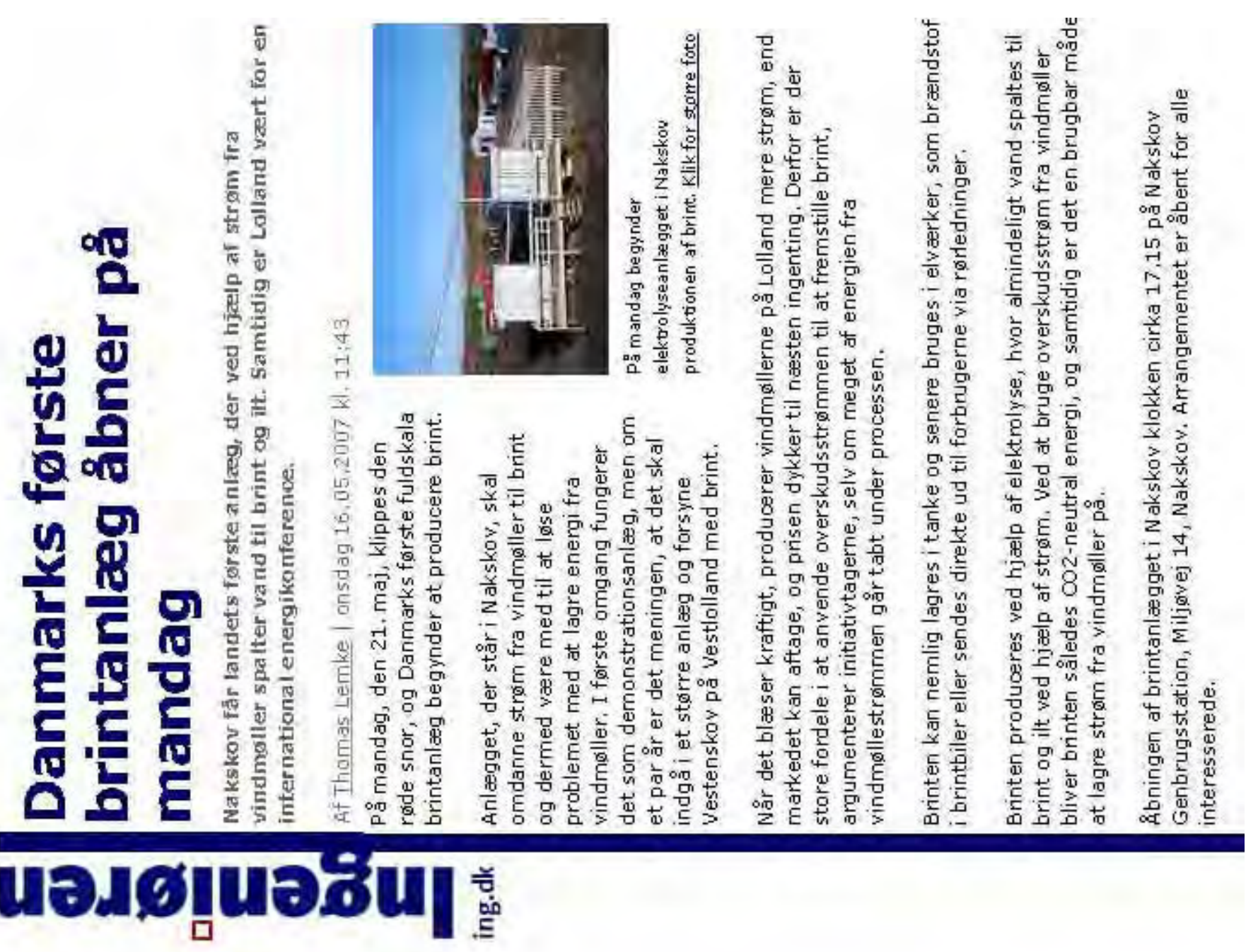




\section{DTU \\ Morgenkaffe kogt på strøm fra vindmøller \\ RISO}

\section{Morgenkaffen kogt på strøm fra vindmøller}

27. okt. 200610.54 Indland

Halvdelen af landets husholdninger har i dag kunnet lave morgenkaffe med strøm fra en dansk vindmølle. Efterårets første alvorlige blæsevejr er nemlig guf for den alternative energiproduktion.

KI. 9 i dag kunne stømmen fra møllerne dække cirka halvdelen af det samlede danske elforbrug. På årsplan leverer møller ellers kun støm til 20 procent af forbruget.

Med en vindhastighed op omkring $20 \mathrm{~m} / \mathrm{s}$ i det vestlige Jylland, hvor mange af Danmarks vindmøller er placeret, er elproduktionen fra vindmøller tæt på det maksimalt mulige.

Kommer vindhastigheden op omkring $25 \mathrm{~m} / \mathrm{s}$, stopper vindmøllerne derimod for at beskytte sig selv.

\section{Gratis el i nat}

I nat betød elproduktion fra vindmøllerne, at udbuddet af el på den nordiske elbørs, Nord Pool Spot, i går var så stort, at elspotprisen i både Øst- og Vestdanmark var nul i timerne mellem kl. 1 og kl. 5 i nat.

Vindmøllerne producerede strøm not til at dække 80 procent af det samlede forbrug klokken 4 i nat. Landets kraftværker måtte endda skrue ned for produktionen, fordi der ikke var plads til yderligere eksport på de elektriske forbindelser til udlandet. 


\section{Use of Alternative Fuels in Solid Oxide Fuel Cells}

Anke Hagen

Fuel Cells and Solid State Chemistry Department

Risø National Laboratory

Technical University of Denmark 


\section{Outline}

- Background

- Conventional - Alternative fuels

- Solid Oxide Fuel cells - SOFCs

- SOFC Fuelled with alternative feed stocks

- Performance/stability

- Effect of impurities

- Summary - Outlook 


\section{Background - Conventional vs. Alternative Fuels}
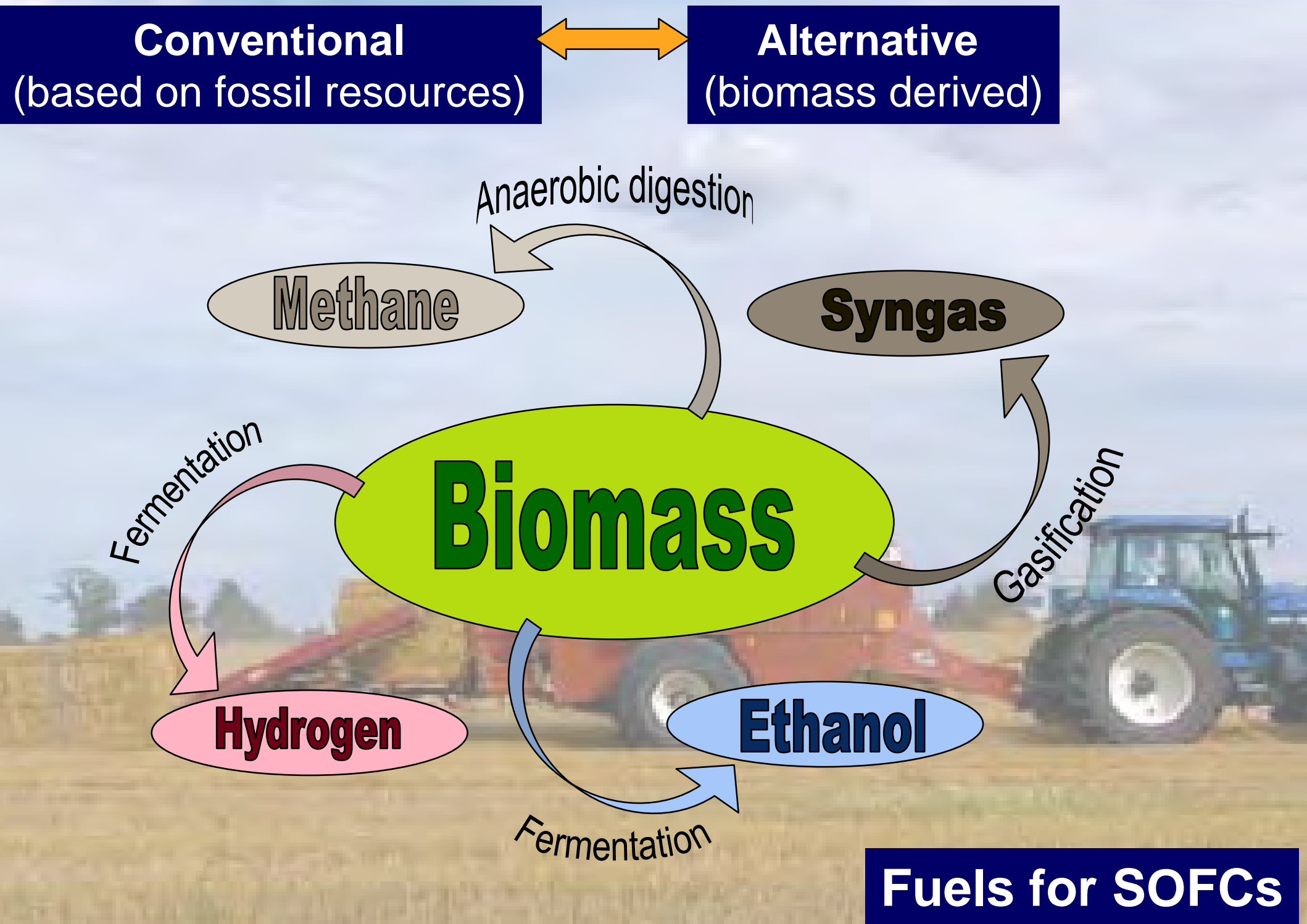
Background - Motivation for the Use of Alternative Fuels

- Reserves of conventional fuel sources (natural oil and gas) limited

- Economic reasons (increase of crude oil price)

- Dependable supply and availability

- Local, de-central solutions

- Environmental restrictions $\left(\mathrm{CO}_{2}\right.$ emissions, stringent pollution limits) 


\section{Solid Oxide Fuel Cells - SOFCs - Vision}
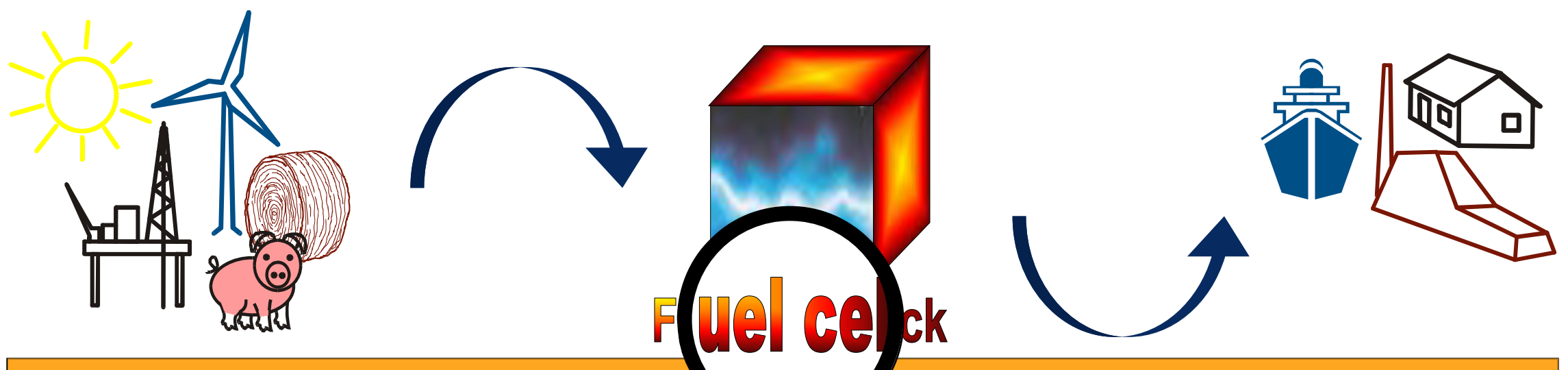

Fuel derived from conventional an sustainable sources

(e.g., methane, natural gas, hy

$>$ Higher efficiency than conventional power generation systems

$>$ Reduction of emissions and pollution ( $\mathrm{NOx}, \mathrm{CO}_{2}$, noise)

$>$ Potential for $\mathrm{CO}_{2}$ sequestration

$>$ Modular concept (from $\mathrm{kW}$ to $\mathrm{MW}$ )

Combination of two (potentially) environmentally benign and efficient technologies - fuels derived from biomass and fuel cells to contribute to a sustainable energy supply system 


\section{Solid Oxide Fuel Cells - SOFCs - Principle}

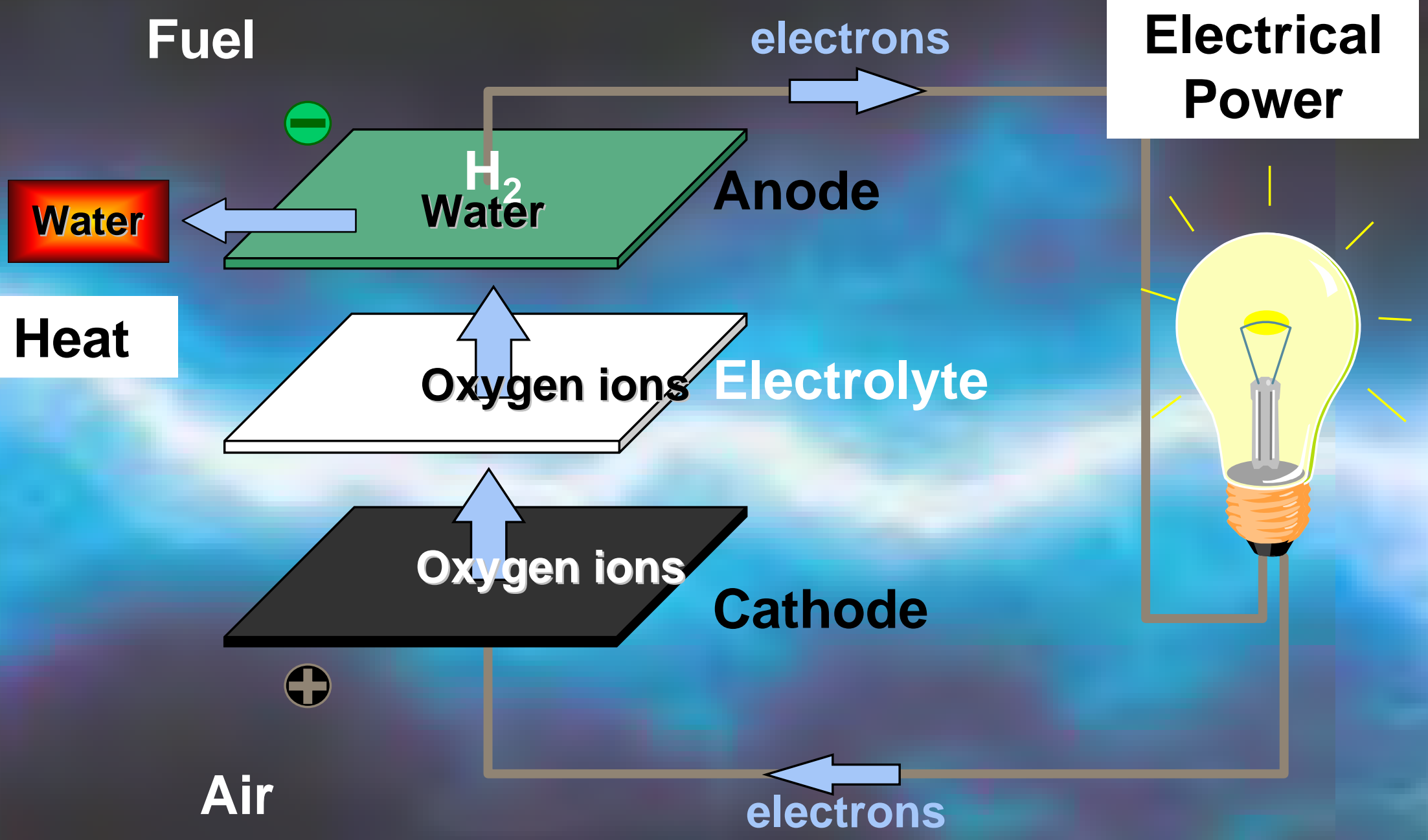




\section{Solid Oxide Fuel Cells - SOFCs - Testing}

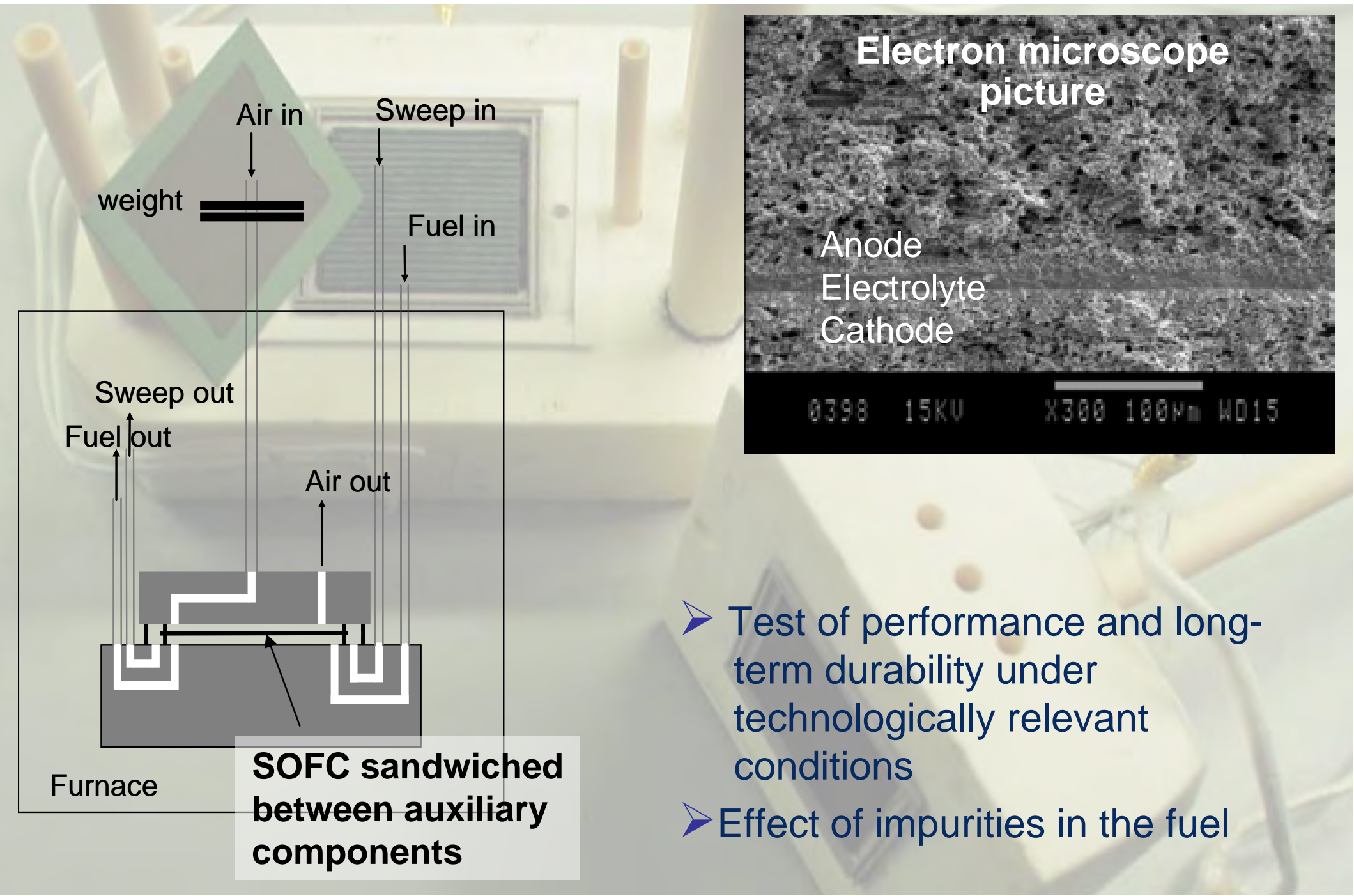




\section{General Considerations about Carbon Containing Fuels}

- $\mathrm{CO}$ and $\mathrm{H}_{2}$ are direct fuels for SOFCs

$$
\mathrm{CO}+\frac{1}{2} \mathrm{O}_{2} \Leftrightarrow \mathrm{CO}_{2} \cdots \cdots \cdots \cdot \mathrm{H}_{2}+\frac{1}{2} \mathrm{O}_{2} \Leftrightarrow \mathrm{H}_{2} \mathrm{O}
$$

- Carbon containing fuels are to be converted to $\mathrm{CO}$ and $\mathrm{H}_{2}$, for example by partial oxidation or reforming (see equations):

$$
\text { Methane: } \mathrm{CH}_{4}-\mathrm{H}_{2} \mathrm{O} 3 \mathrm{H}_{2}+\mathrm{CO}
$$

- The SOFC anode actș catalyst for reforming (see gas analysis):

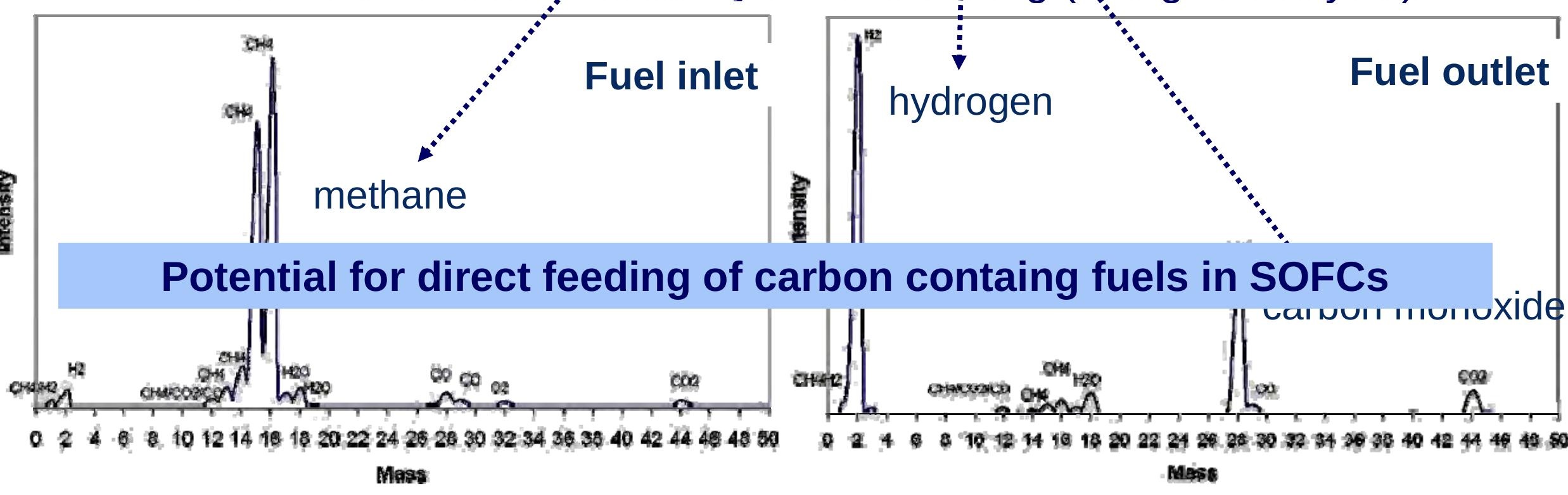




\section{SOFC Anode as Catalytic Converter: Methane}

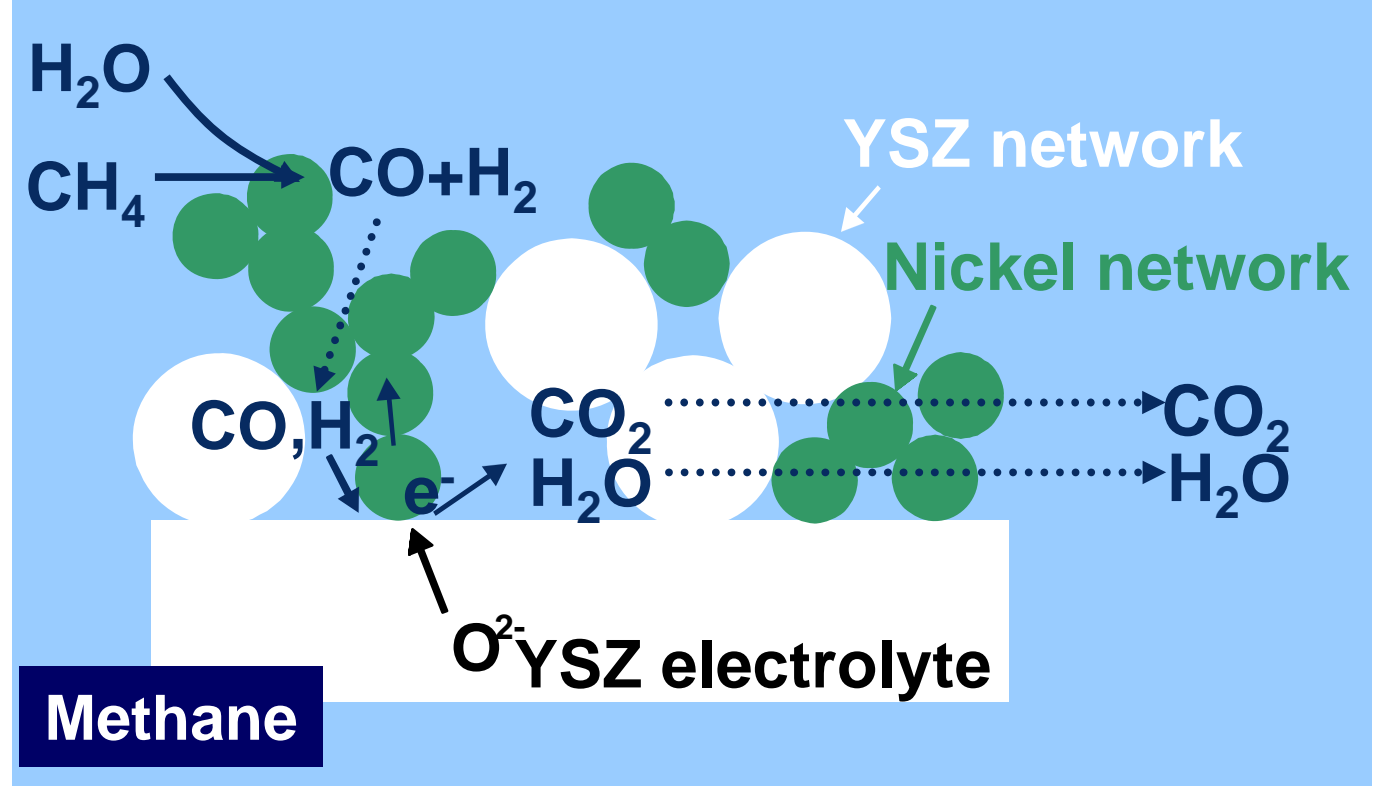




\section{Alternative Fuels - Ammonia}

\section{$\mathrm{NH}_{3}$}

- Becomes liquid at 8 bar: storage and transport

- Comparable power density by weight and volume as carbon fuels such as petrol

- Does not release $\mathrm{CO}_{2}$ under SOFC-process

- Second largest synthetic product in the world (fertilizer, chemicals)

- More than $90 \%$ of the overall consumption manufactured by HaberBosch-Synthesis $\left(\mathrm{H}_{2}+\mathrm{N}_{2}\right.$ on iron-containing catalyst at elevated temperatures $\left(350-550^{\circ} \mathrm{C}\right)$ and pressures above 100 bar) 


\section{SOFC Anode as Catalytic Converter: Ammonia}

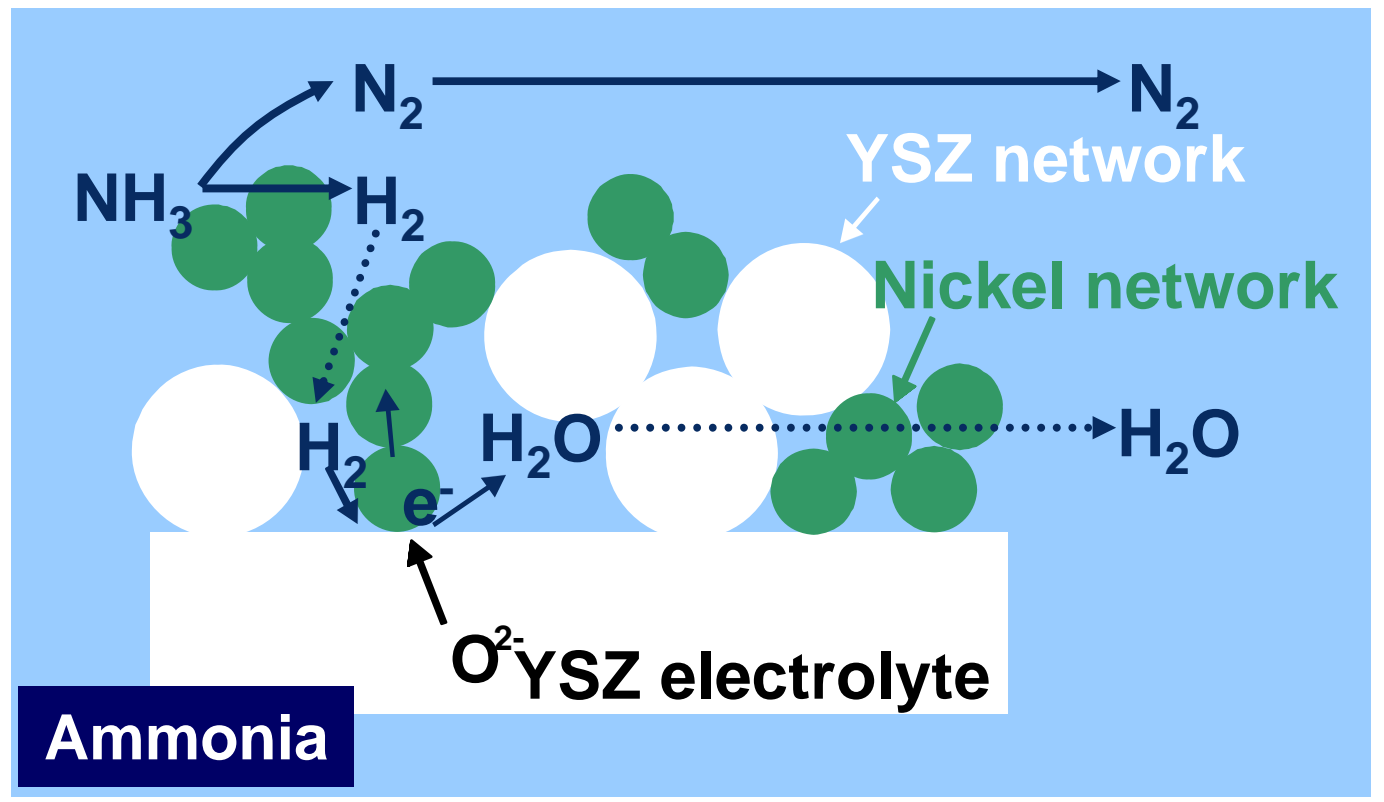




\section{Long-term performance of SOFCs}

$5 \times 5 \mathrm{~cm}^{2}$ SOFC at $850{ }^{\circ} \mathrm{C}, 1 \mathrm{~A} / \mathrm{cm}^{2}$ current density, $\sim 75-80 \%$ fuel utilization

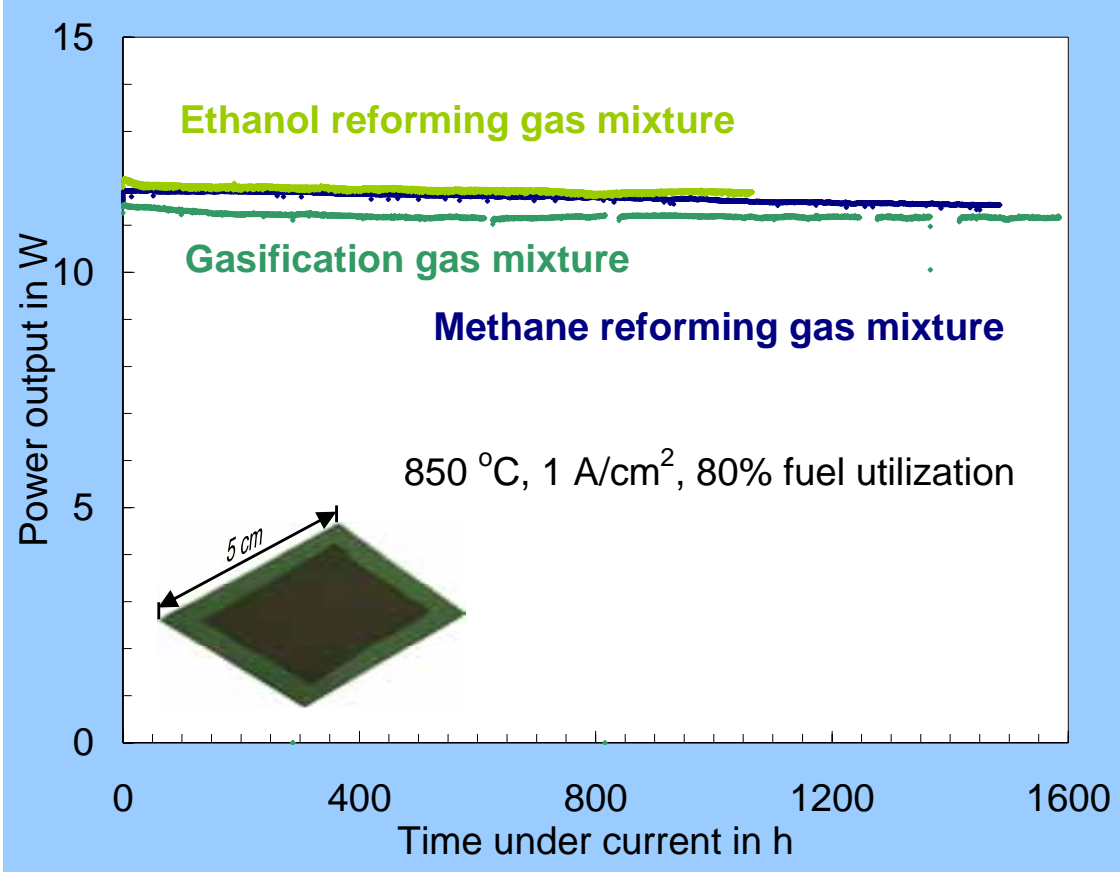

Methane reforming gas mixture: steam to carbon ratio of 2 Gasification gas mixture: wood derived

Ethanol reforming mixture: ethanol/water ratio of $1 / 1.5$

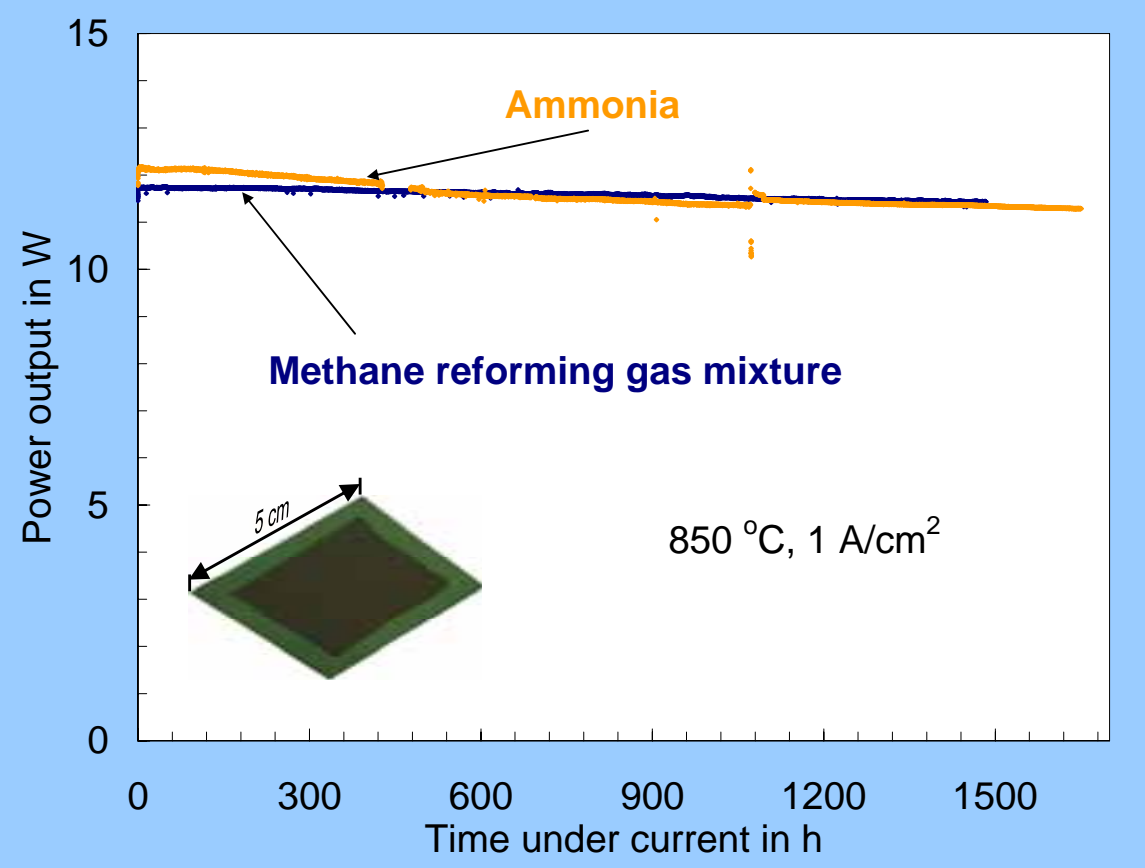

Methane reforming gas mixture: steam to carbon ratio of 2 Ammonia: $100 \%$

- Technologically relevant conditions

- Large power output

- Stable performance over 1500 hours (and beyond) 


\section{Biogas - Composition - Minor constituents - Impurities}

Saturated with water
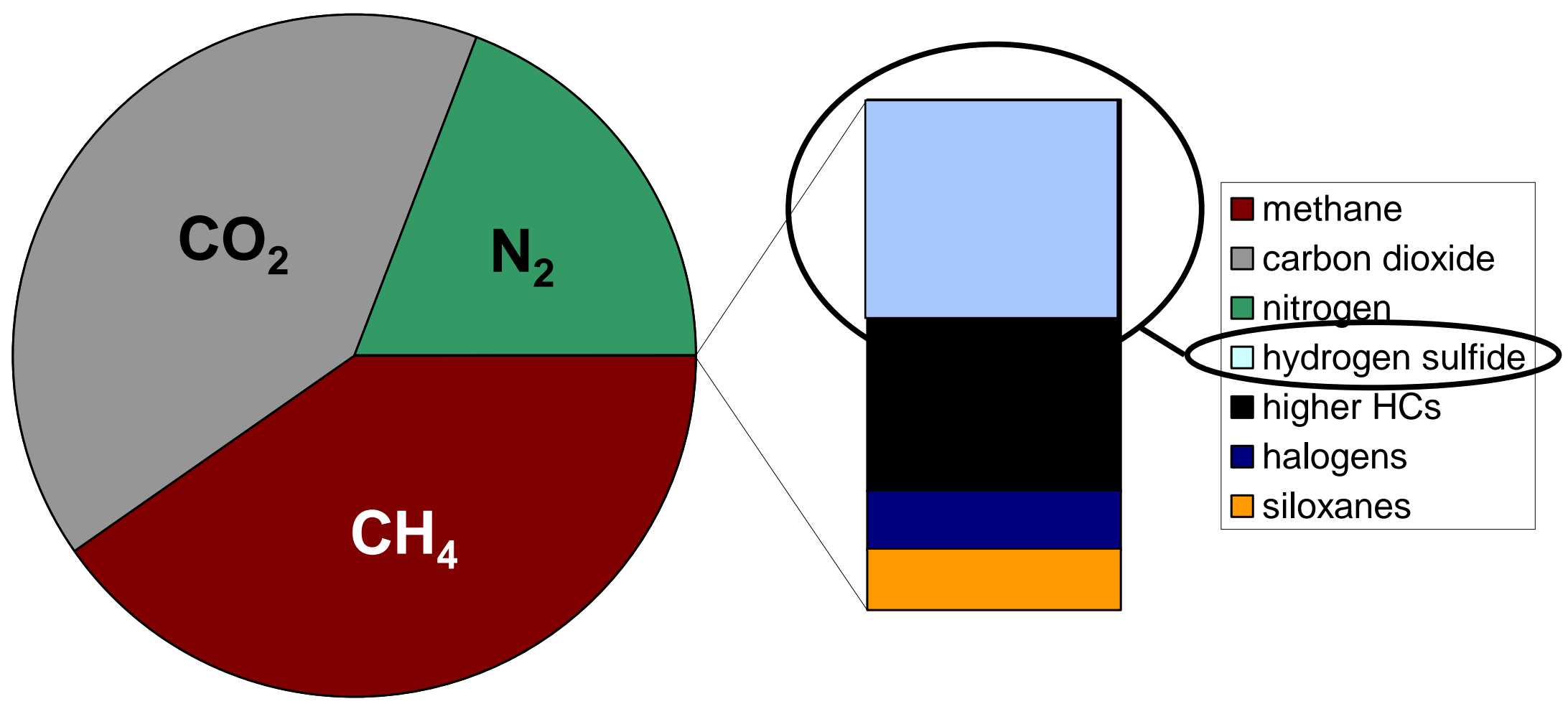

Landfill gas, De Mes et al. 2003 


\section{Effect of $\mathrm{H}_{2} \mathrm{~S}$ impurities on performance of SOFC}

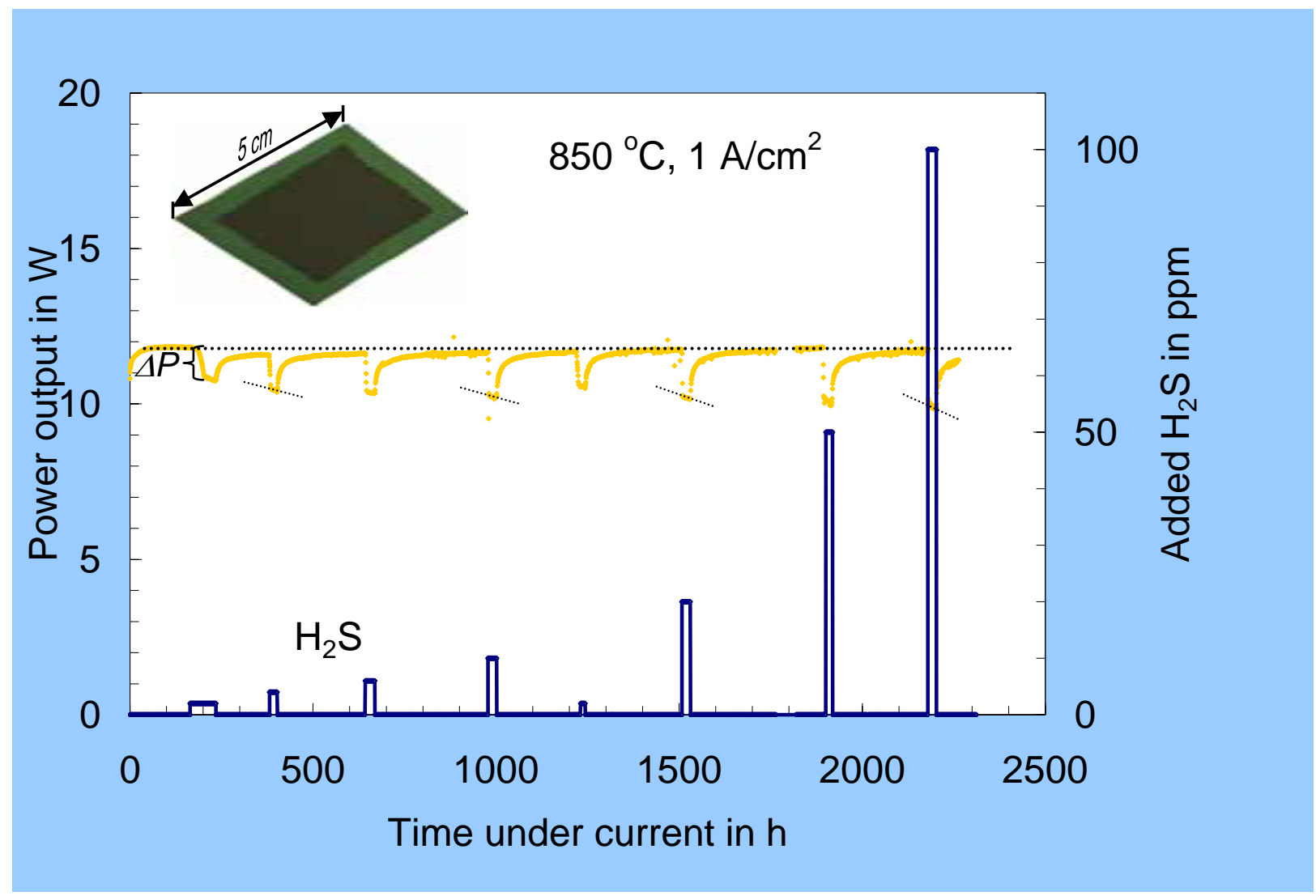

Power output under a long-term test using hydrogen as fuel on a $5 \times 5 \mathrm{~cm}^{2}$ SOFC at $850^{\circ} \mathrm{C}, 1$ $\mathrm{A} / \mathrm{cm}^{2}$ current density, hydrogen

- $\mathrm{H}_{2} \mathrm{~S}$ has two effects:

- drop of power output

- increase of degradation rate

- both effects are reversible until 100 ppm in $\mathrm{H}_{2}$ 


\section{Summary - Outlook}

- SOFCs were operated:

- On a number of fuels based on fossil or bio-derived sources

- With high and stable power-output over 1500 hours and under technologically relevant conditions

- SOFC anodes are versatile catalysts:

- For steam reforming of carbon containing fuels into $\mathrm{CO}$ and $\mathrm{H}_{2}$

- Ammonia is decomposed into $\mathrm{H}_{2}$ and $\mathrm{N}_{2}$

- $\mathrm{CO}$ and hydrogen are electrochemically converted to $\mathrm{CO}_{2}$ and $\mathrm{H}_{2} \mathrm{O}$ under release of electricity (and heat)

- Hydrogen sulfide in hydrogen fuel has an effect on the performance and stability of SOFCs, which is reversible until 100 ppm

- Effect of characteristic impurities has to be further studied (max. possible concentrations, removal technologies) 


\section{Acknowledgement}

We gratefully acknowledge support from our sponsors:

- Topsoe Fuel Cell A/S TOPSOE FUEL CELLL

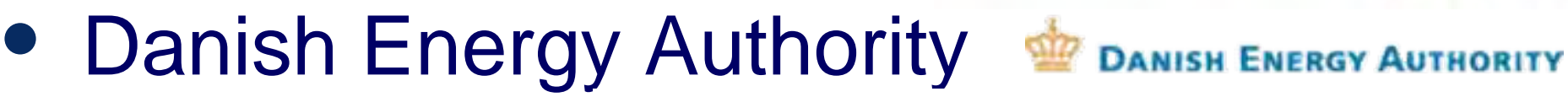

- Energinet.dk enerGinet/ok

- EU

- Danish Programme Committee for Energy and Environment

- Danish Programme Committee for Nano Science and Technology, Biotechnology and IT 


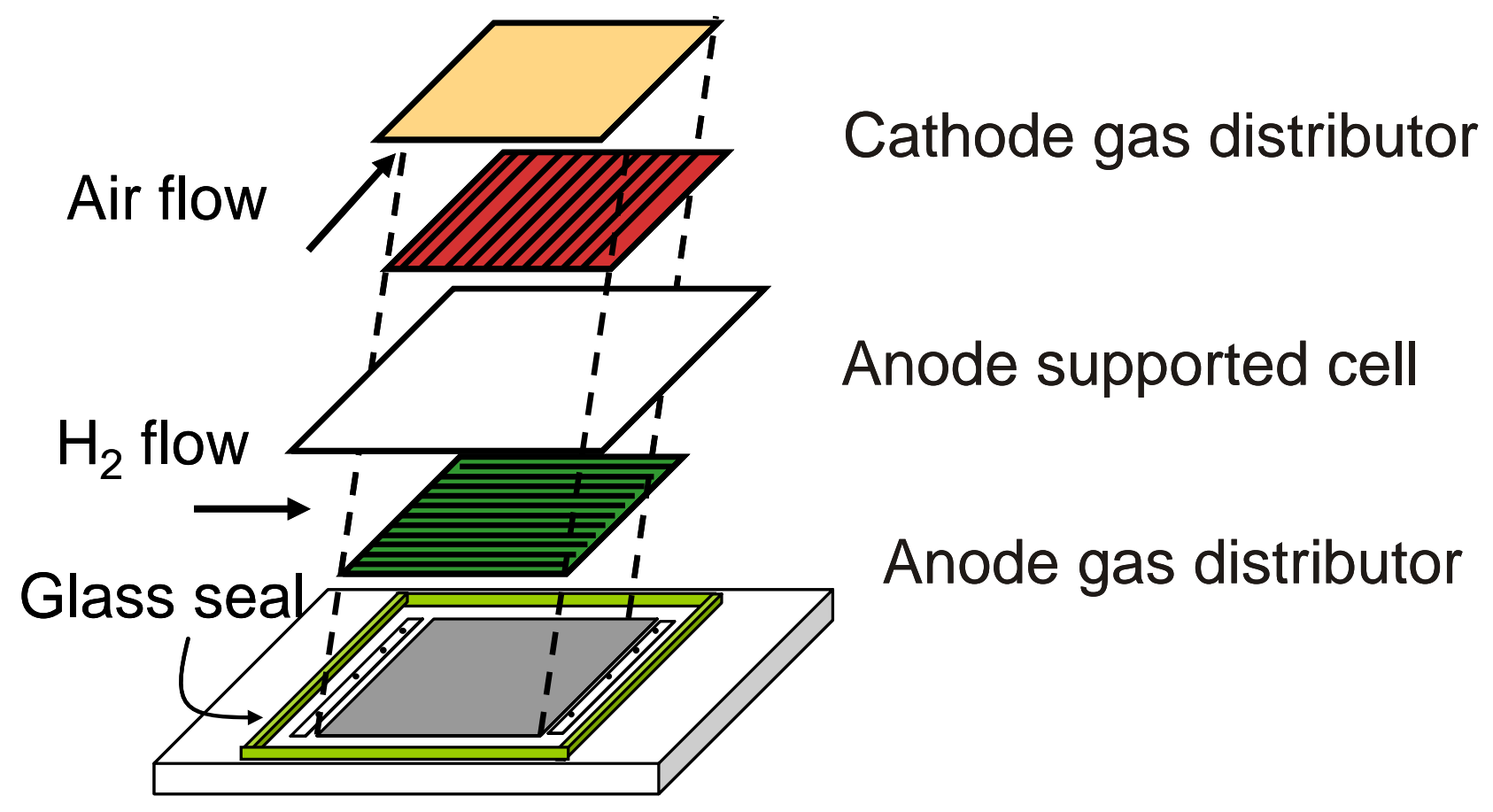

Cell house, alumina 


\section{Carbon formation at SOFC anode}

- (Thermodynamic) risk of carbon formation for all carbon containing fuels

$$
\begin{aligned}
& 2 \mathrm{CO} \Leftrightarrow \mathrm{CO}_{2}+\mathrm{C} \\
& \mathrm{CH}_{4} \Leftrightarrow 2 \mathrm{H}_{2}+\mathrm{C}
\end{aligned}
$$

- Solution: Addition of sufficient water/steam
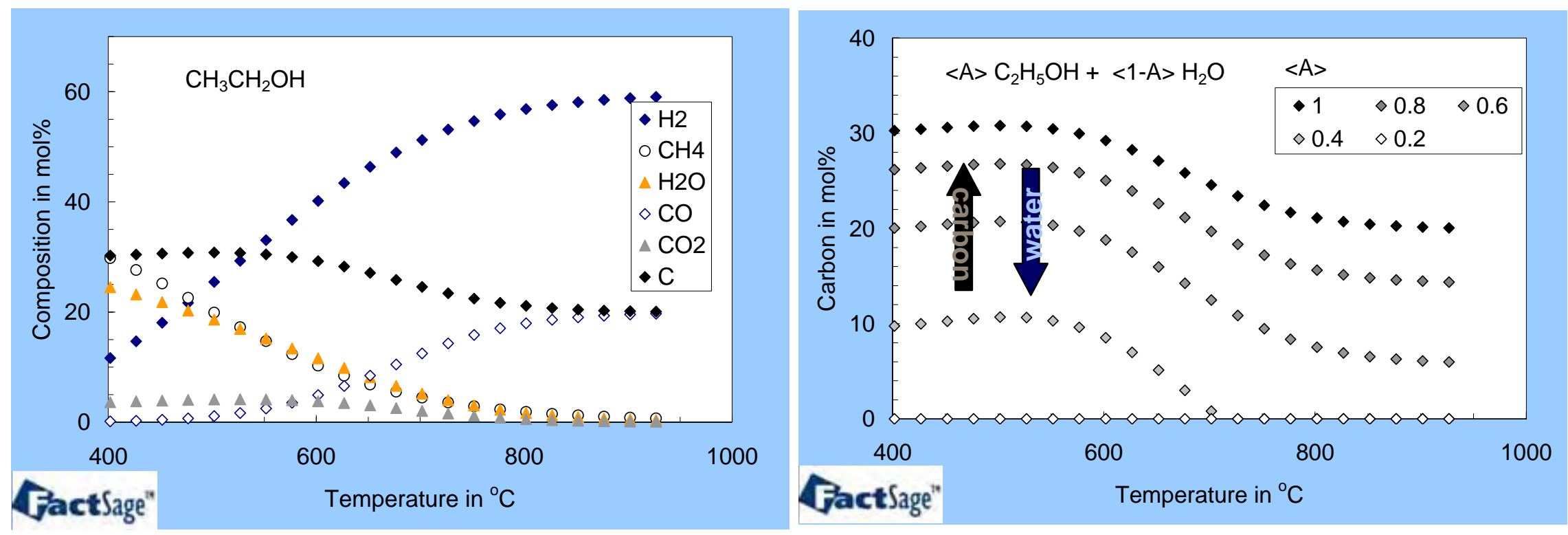


\section{Thermodynamics of ammonia decomposition}

- Nearly complete ammonia decomposition at SOFC operating temperature

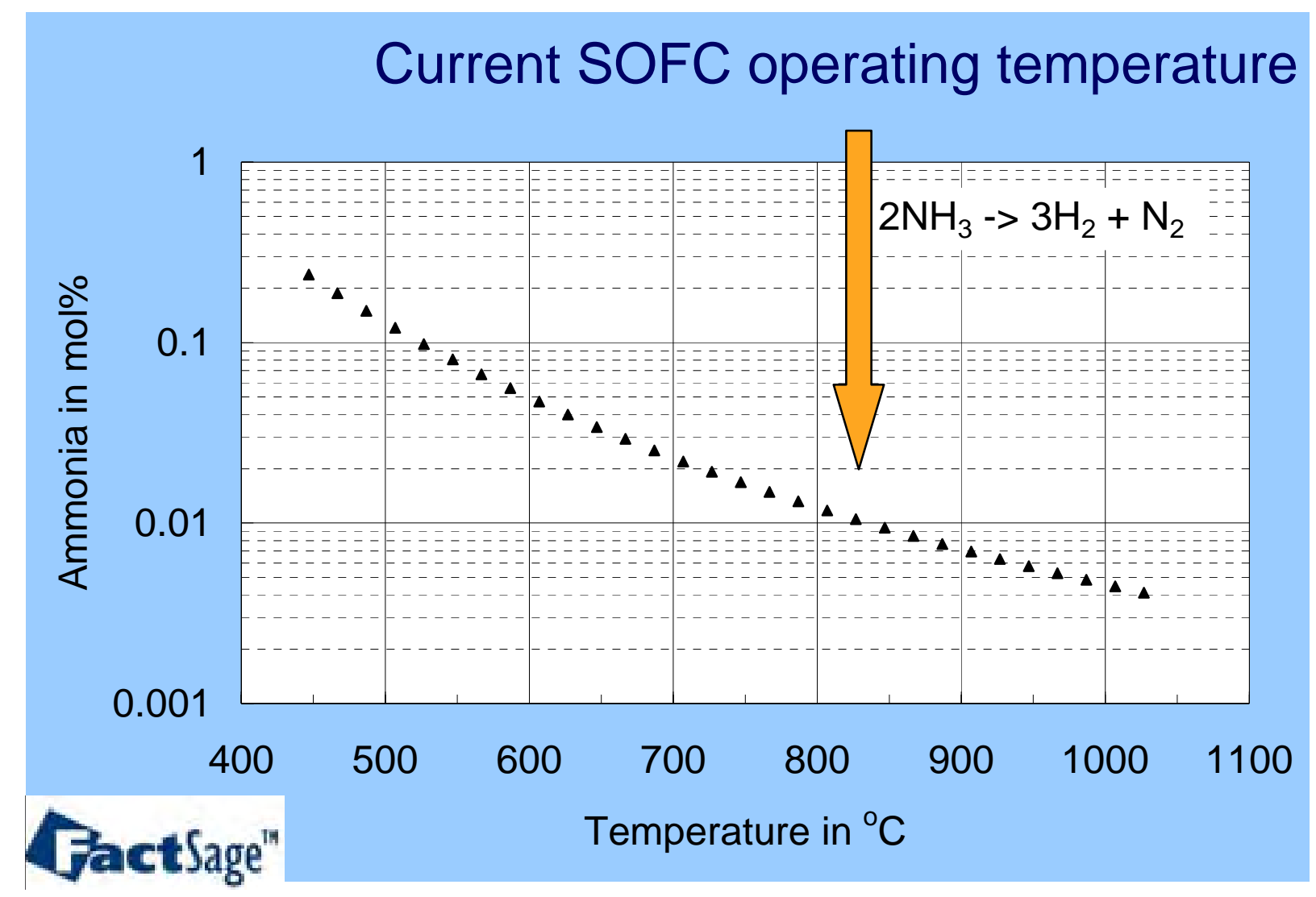




\section{Ammonia decomposition}

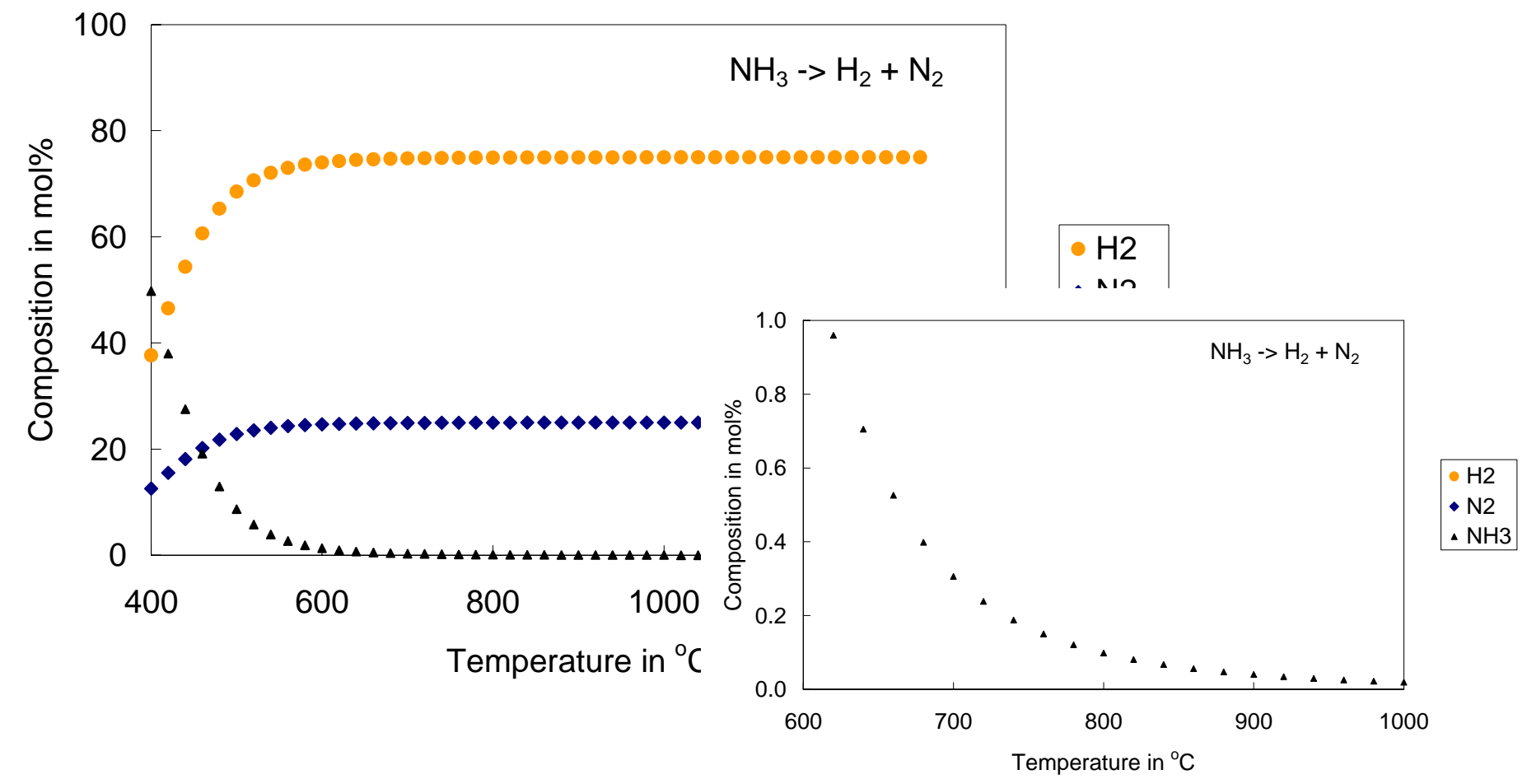




\section{Ammonia - Power output}

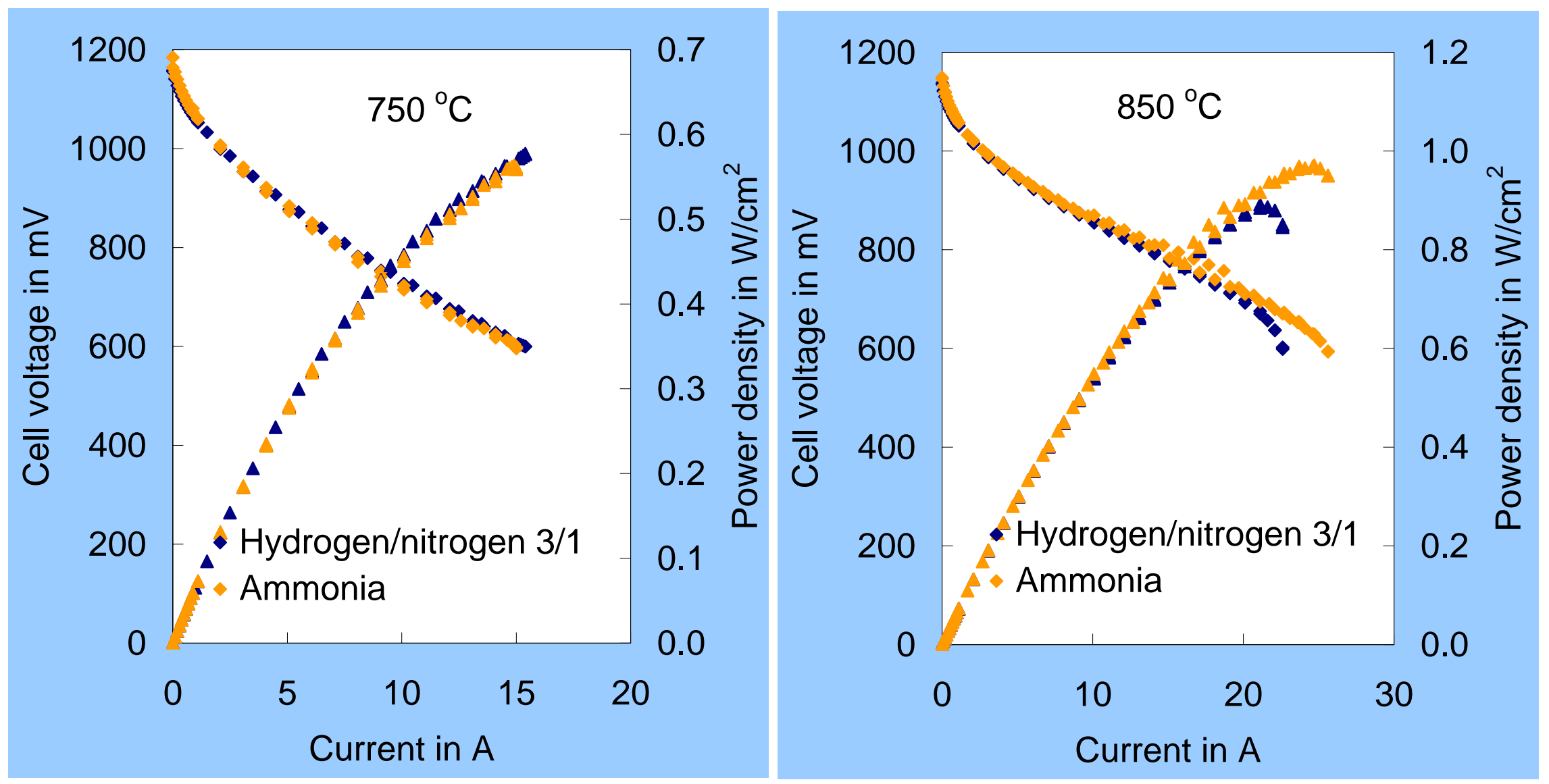




\title{
Fuel Cell - Shaft Power Packs FC-SPP
}

RISø Energy Conference 2007

\author{
Centre Manager \\ Renewable Energy \& Transport
}

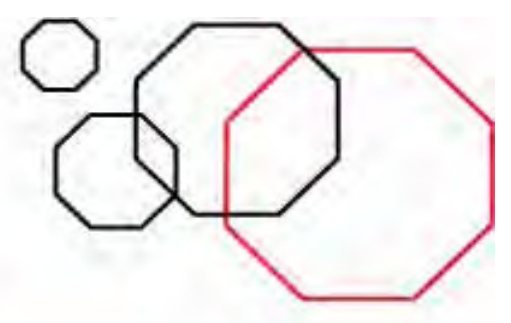




\section{Current Concept}
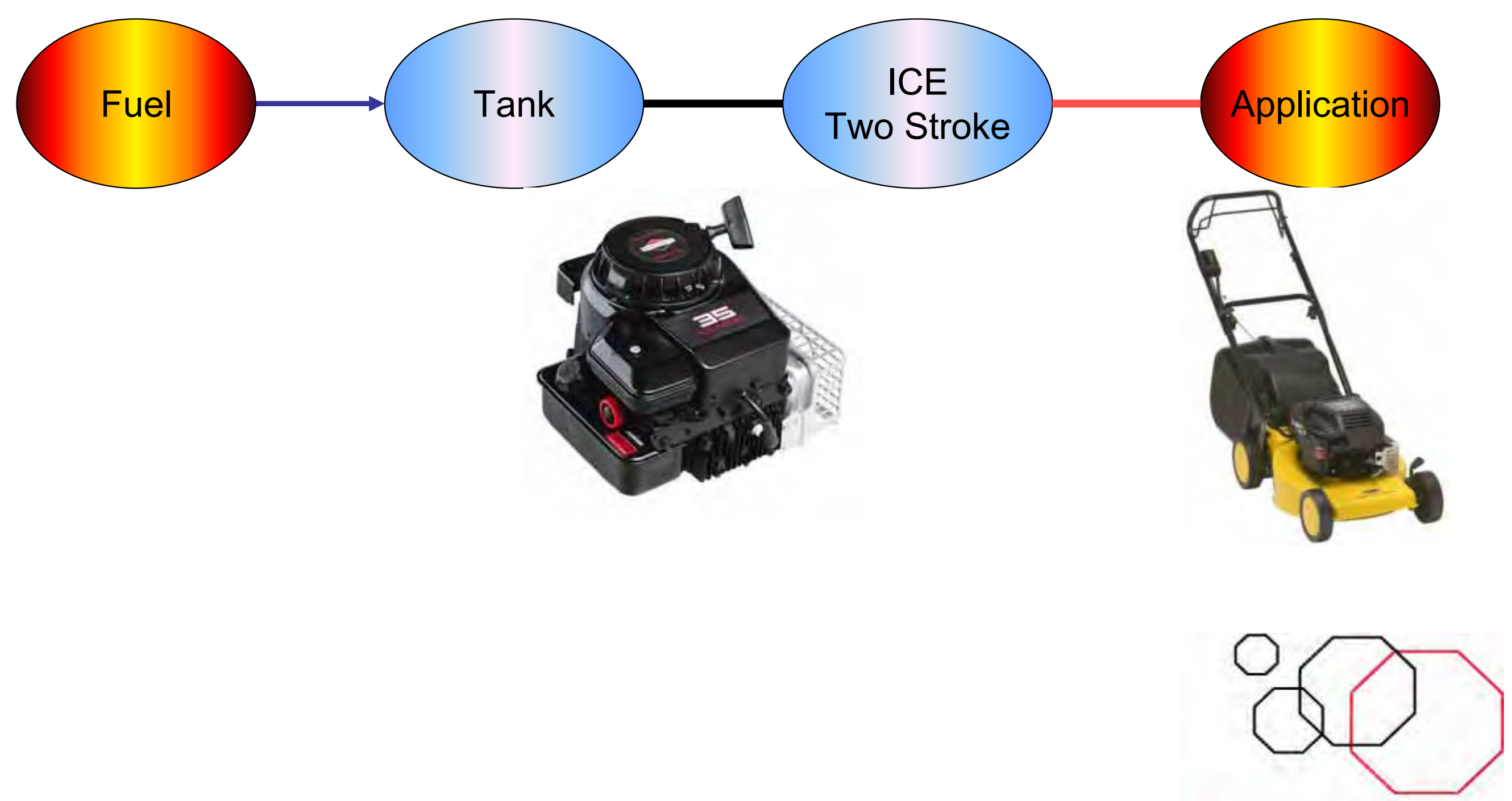


\section{New Concept}

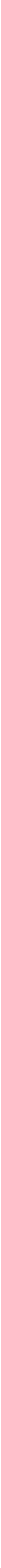




\section{Vision:}

- Through applied research, development and demonstration, the consortium will create the foundation for a production of hydrogen power packs

- The consortium will look at the market for hydrogen based power packs and develop tools that ensures the basis of a commercial production

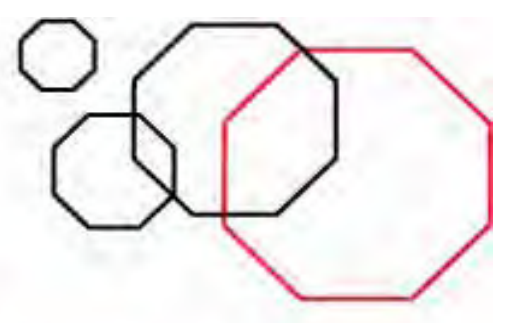




\section{Project Team \& Budget}

\section{Total budget approx. 30 mill. DKK (5.5 mill. USD) Project duration: 3 years}

Demonstration team

-Cykellet/DSR Scandinavia

-GMR Maskiner

-Trans-Lift

-Falsled Højtryk

Research team

aAalborg University

- The Danish Technological Institute

-Copenhagen Business School

uydrogen Innovation Research

Centre
Development team

-Dantherm Airhandling

-Migatronic

-H2Logic

-Parker Hannifin DK

akk-electronic

-Xperion

-EGJ Development 


\section{Project Structure}
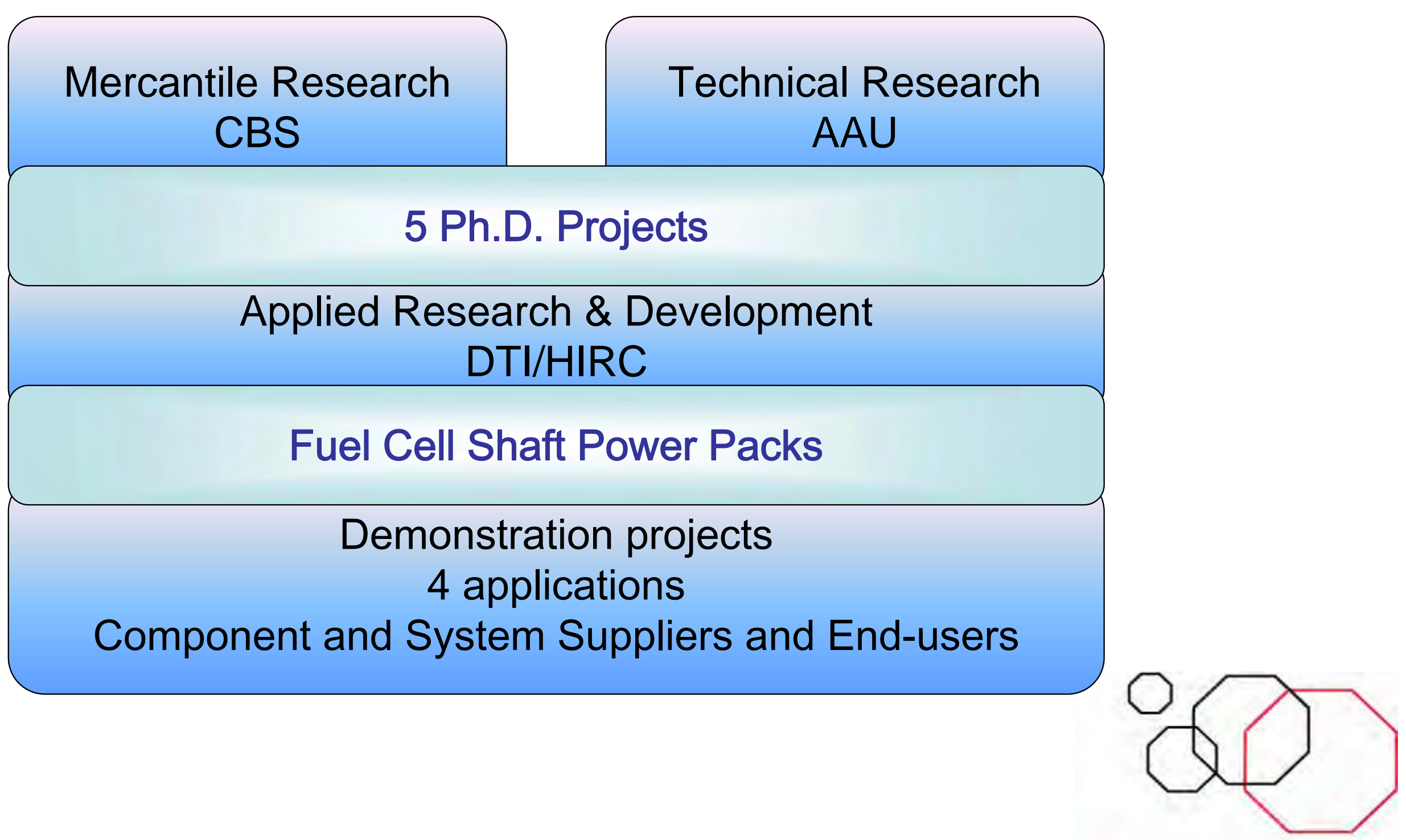


\section{The Research Team}

\section{T1, Fuel Cells}

T2, Power Electronics

T3, Balance of Plant

M1, Market structure

CBS

M2, Business structure 


\section{Technical PhD 1:}

\section{Experimental Characterization of Fuel Cells}

- Investigation of the cathode manifold flow

- Gas-phase micro-PIV (Particle Image Velocimetry) on bipolar plate channels (at University of Victoria BC, Canada)

- Electrochemical Impedance Spectroscopy (EIS)

- In situ temperature measurements (SEMOS)
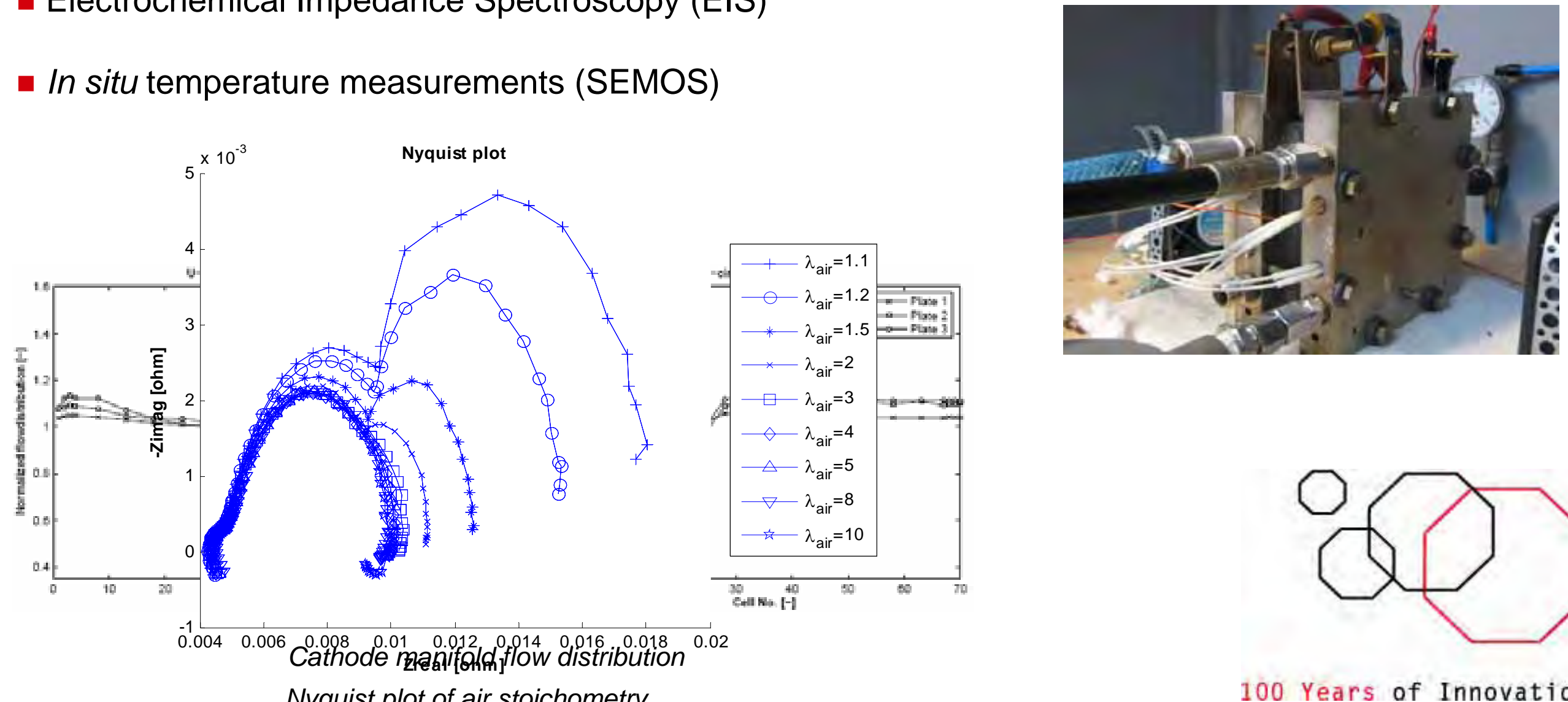

Nyquist plot of air stoichometry 


\section{Technical PhD 2: Power Electronics}

- Field measurement of drive profile (DTI)

- Design of propulsion system

- Energy management strategies

- Transient modeling of fuel cell, battery, ultra capacitor, DC/DC converters, DC/AC converters and motor
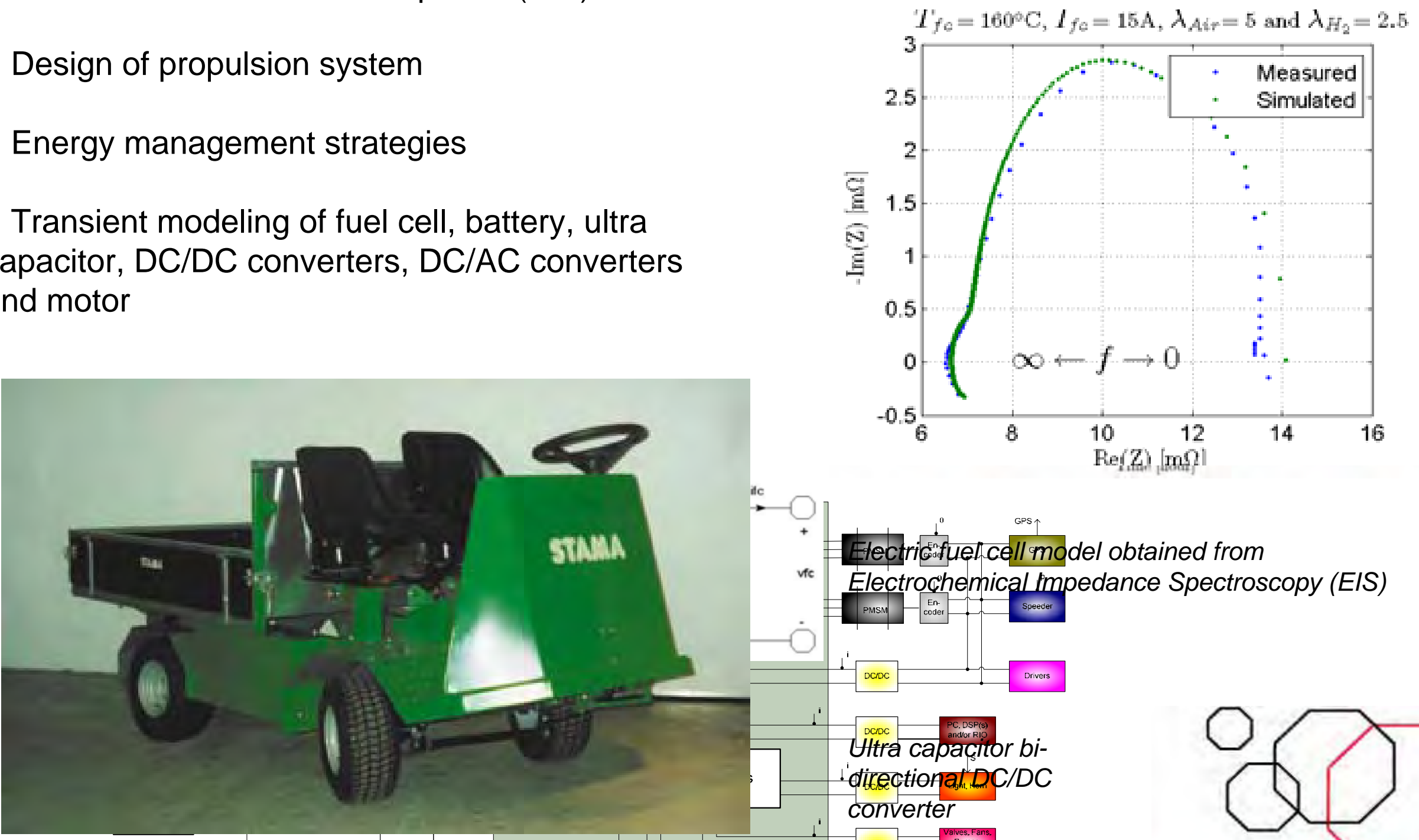

Electrigifuel celllmodel obtained from Electrochemical Impedance Spectroscopy (EIS)

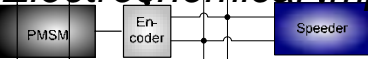

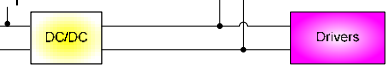

Ultra capacisitor bi-directional DC/DC converter

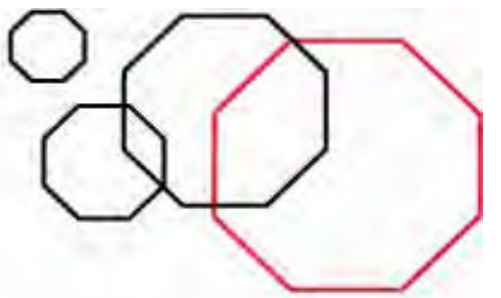




\section{High Temperature PEM Fuel Cell System Design and Control}

- HTPEM fuel cell system design

- System configuration, evaluation of different system concepts

- Modeling of system components and fuel cell stack

- Fuel cell system control

- Identification of critical control states

- Model based control design

- Implementation and testing of developed control strategies

- Application control of electrical hybrid vehicle

- Overall application control strategy control development

- Performance and field testing of vehicle for model verification
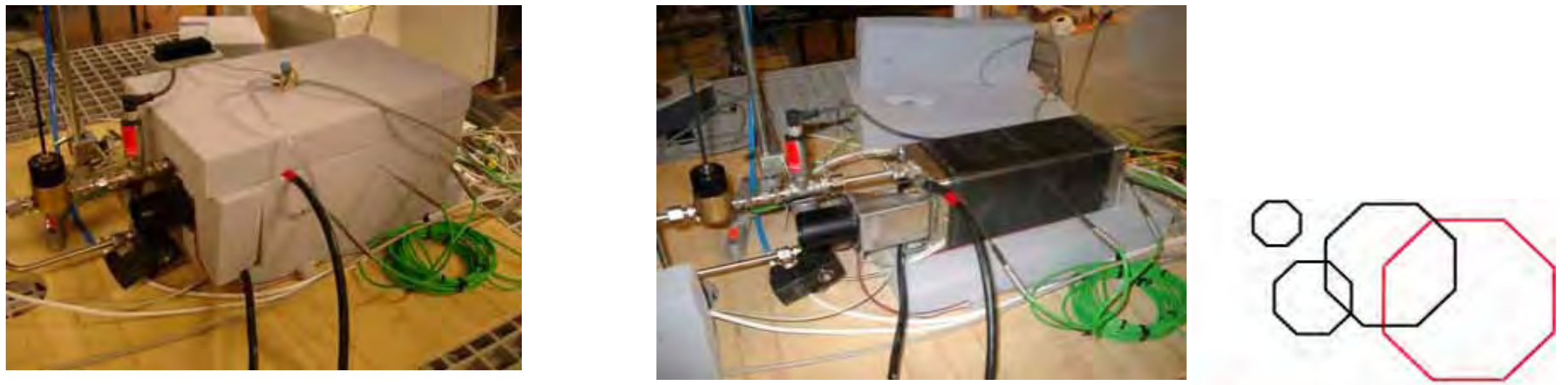


\section{Mercantile PhD 1: \\ FC market drivers and dynamics}

FC is a systemic innovation: value creation of components depends upon incorporation into a system

-Co-evolution of components, systems, and markets

-Dynamic processes unfolding from feedback mechanisms

-Feedbacks transcend disciplinary boundaries

(social/technical/economic factors)

-Analytical tool: system simulation

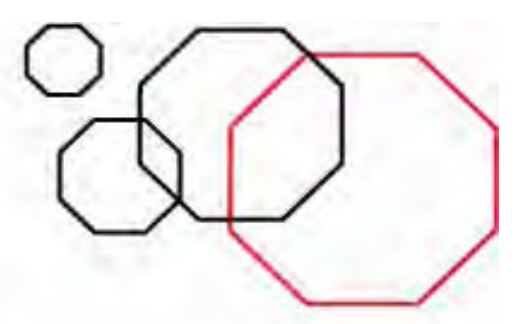




\section{Building Absorptive Capacity in}

\section{Research Collaboration}

-Absorptive capacity - a concept explaining how companies acquire, assimilate and exploit knowledge from external sources

- To what extent is research collaboration a vehicle for development of absorptive capacity?

- How to manage the collaboration to maximise benefits for participants not only in terms of technological research results, but also development of organisational skills?

-Project as an integral part of FC-SPP: using observations and experience of the companies participating in FC-SPP for advancing the research on one hand, and disseminating results to the companies in order to help them better benefit from the cooperation.

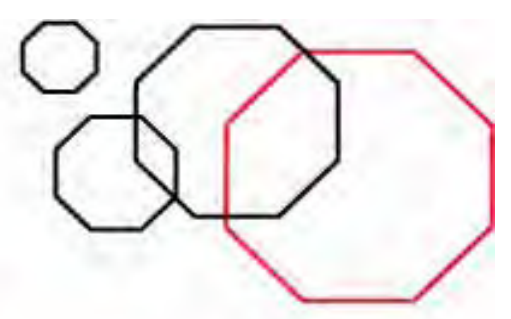




\section{Four demonstration projects}

1. Cykellet/DSR Scandinavia (Electric powered bike)

2. Trans-Lift (Pallet truck)

3. GMR Maskiner (Truck for maintenance of "green areas")

4. H2O Skypump (Professional high pressure cleaner)
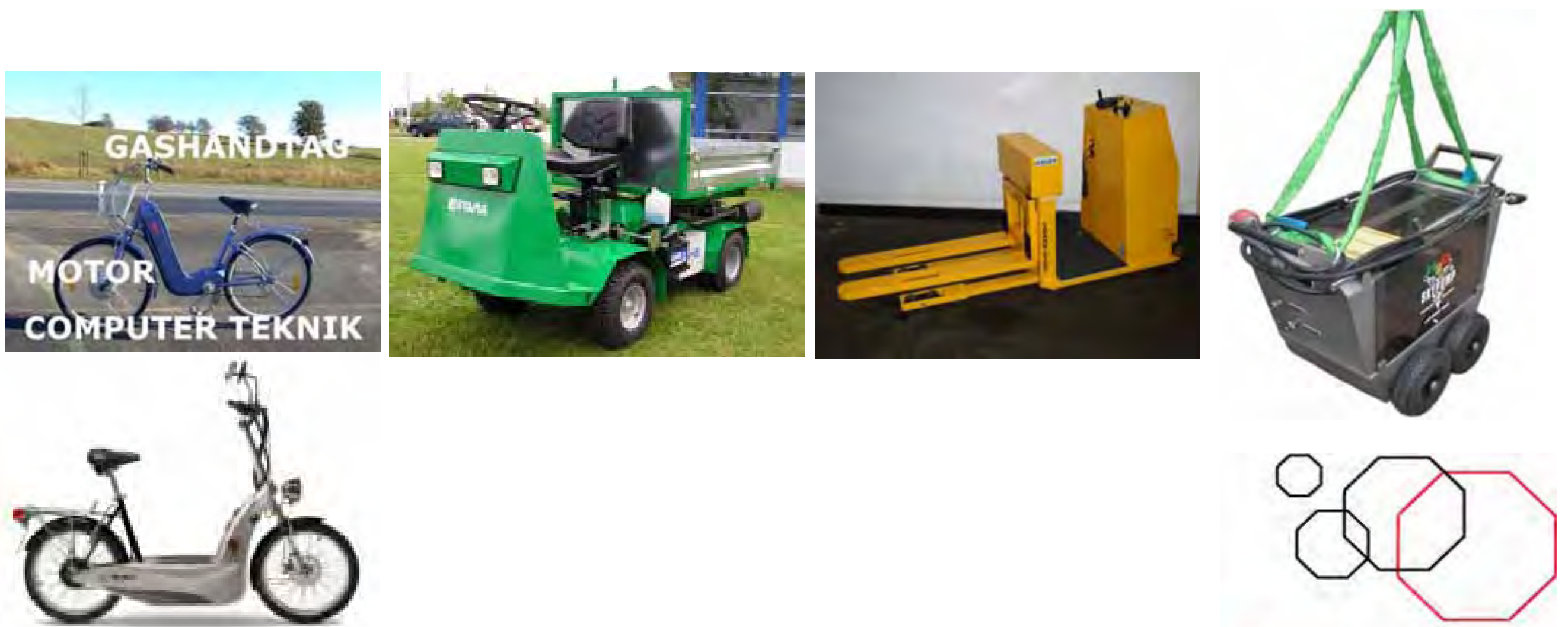


\section{Project types}

\section{Open project}

(FC-SPP)

Project

Starting point

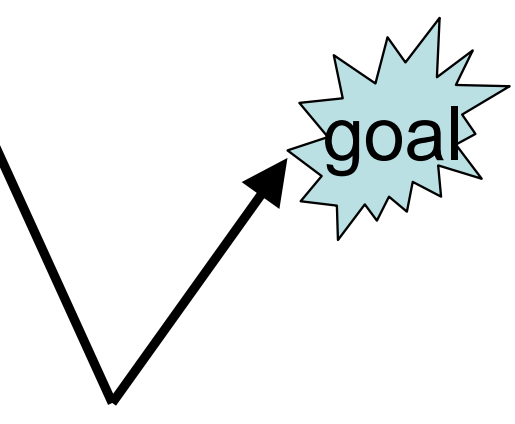

Closed project

Starting point

(Traditional R\&D)

Project duration

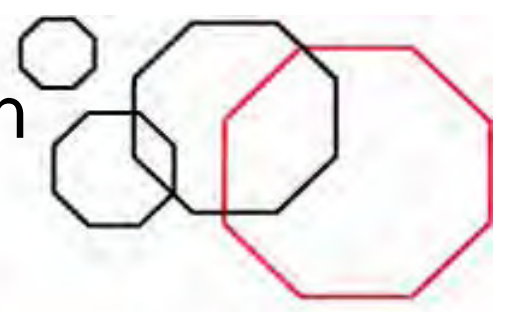




\section{Trans-Lift - case}

Trans-Lift design and produce battery powered vehicles for goods handling.

Problems:

- batteries are expensive

- must be replaced from time to time

- must be recharged

Advantages with FC:

- Lower operating costs

- No wasted time for battery charging
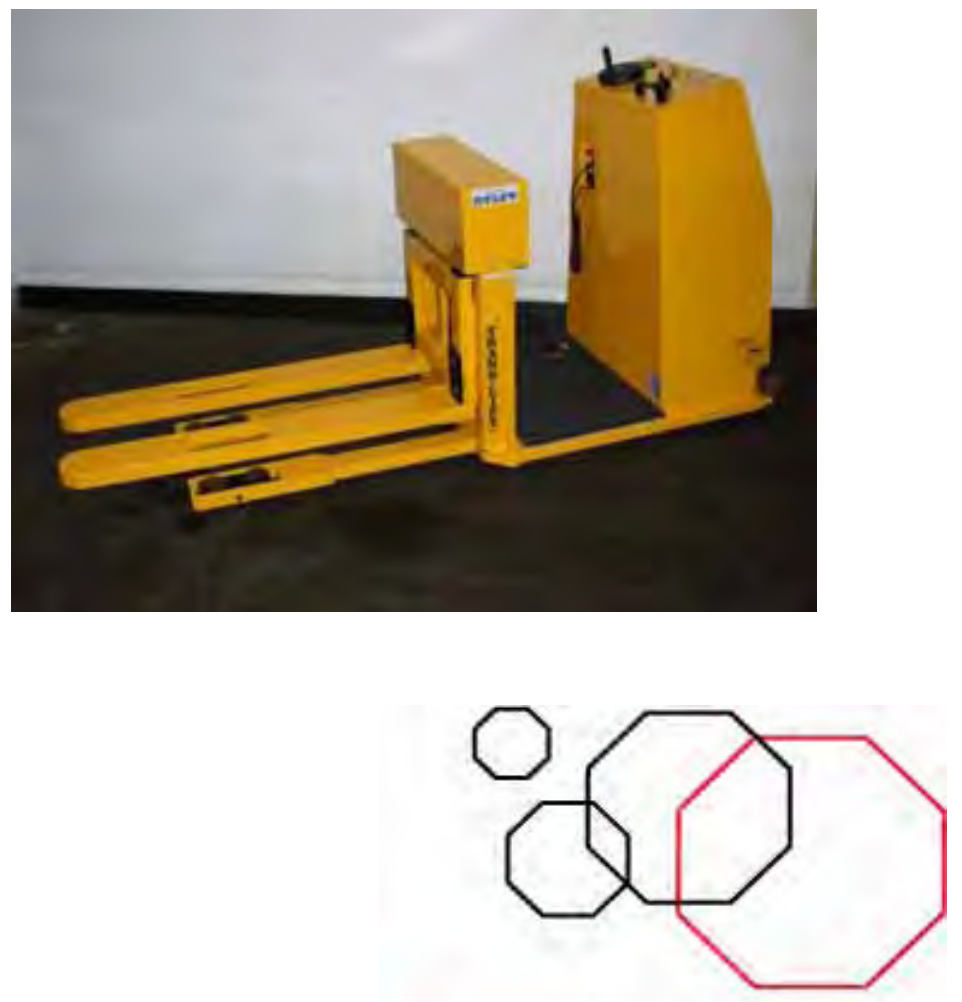


\section{Migatronic - case}

Migatronic a welding machine producer

Problems:

none...

Possibilities with FC:

- Create a new product range

- Enter new markets

- More turnover

- Less vulnerable
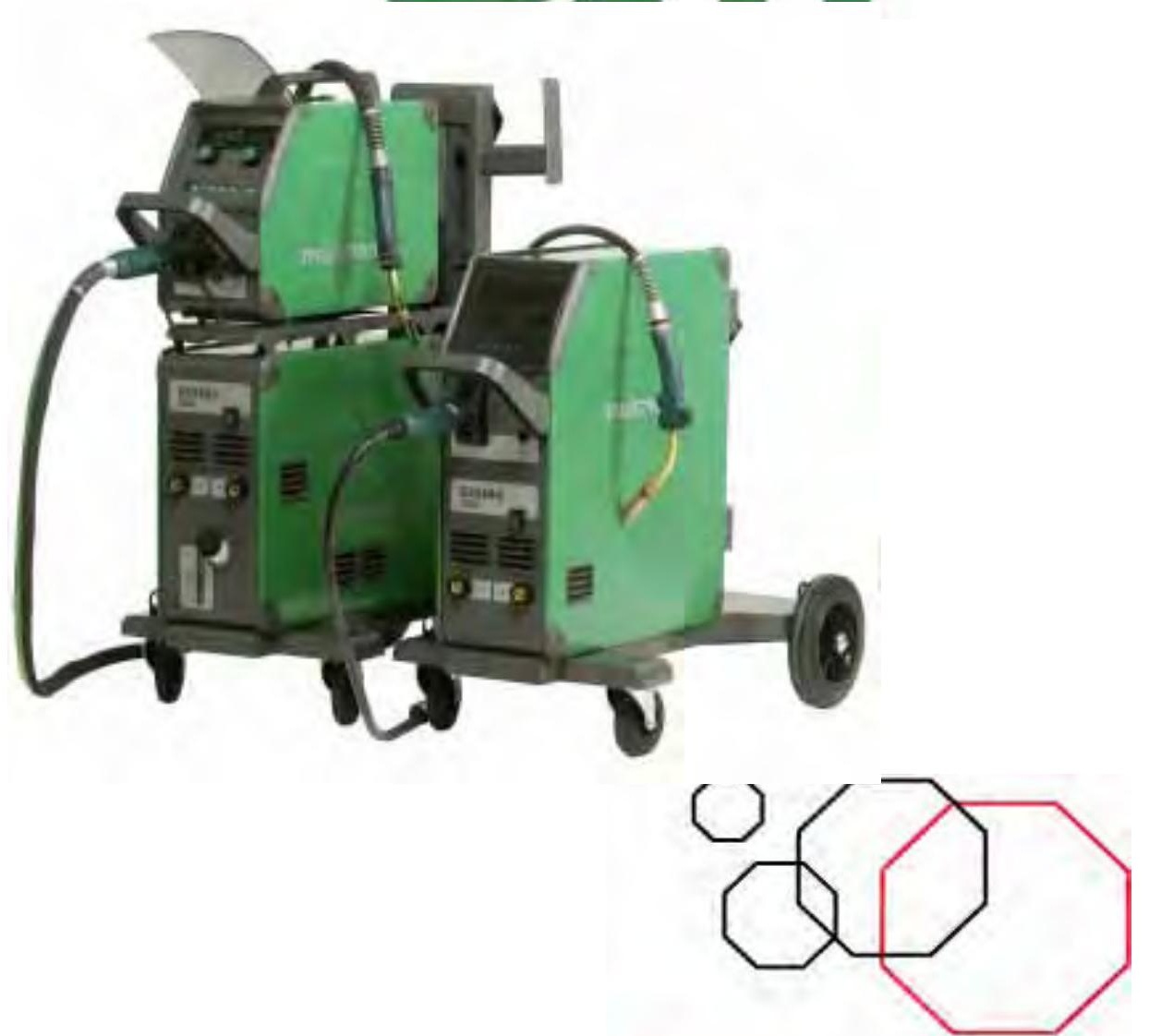


\section{Thank you!}

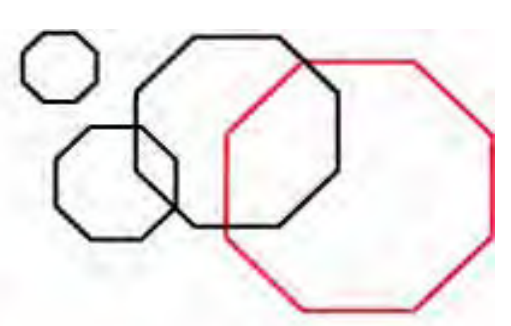




\section{Overview of U.S. DOE's Coal RD\&D Programs Clean and Secure Energy From Coal}

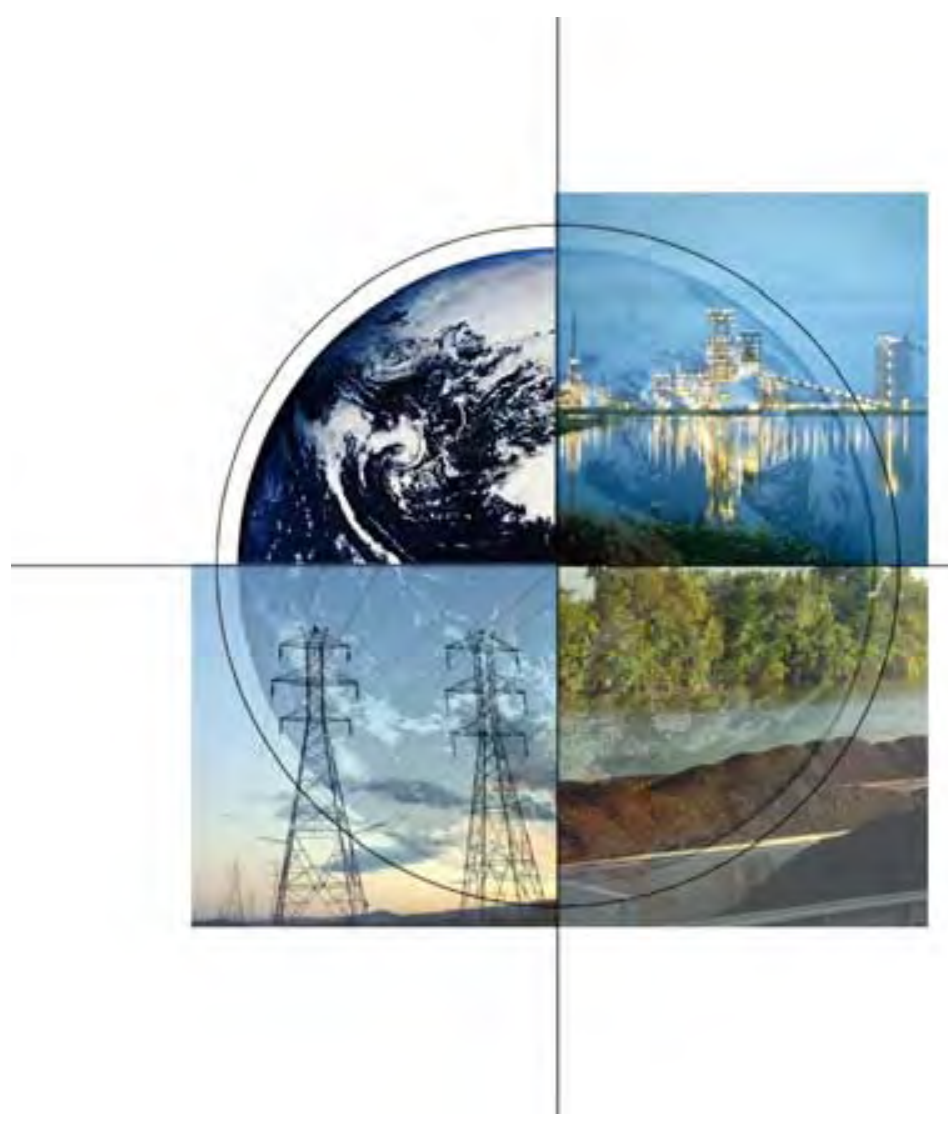

Scott M. Smouse International Coordination Team Leader National Energy Technology Laboratory

Risø International Energy Conference 2007 Copenhagen, Denmark 22-24 May 2007 


\section{Energy Demand Today}

\section{Energy Demand 2030}

\section{QBtu / Year 85\% Fossil Energy}

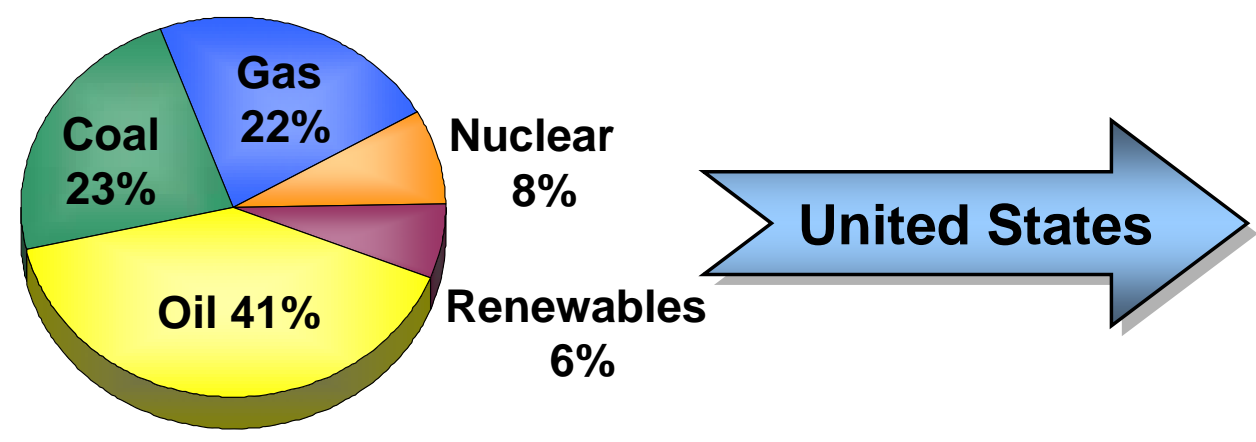

465 QBtu / Year 86\% Fossil Energy

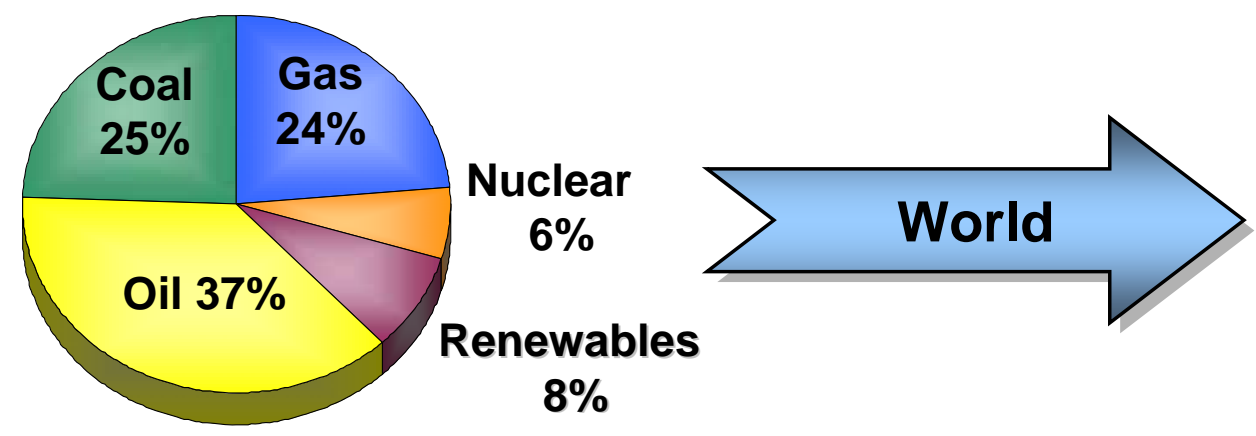

131 QBtu / Year 86\% Fossil Energy

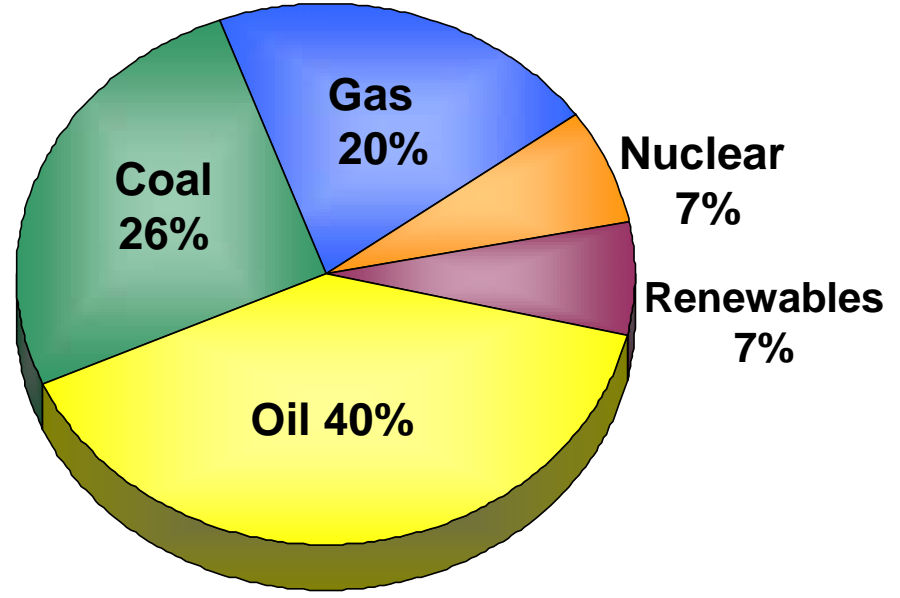

722 QBtu / Year 87\% Fossil Energy

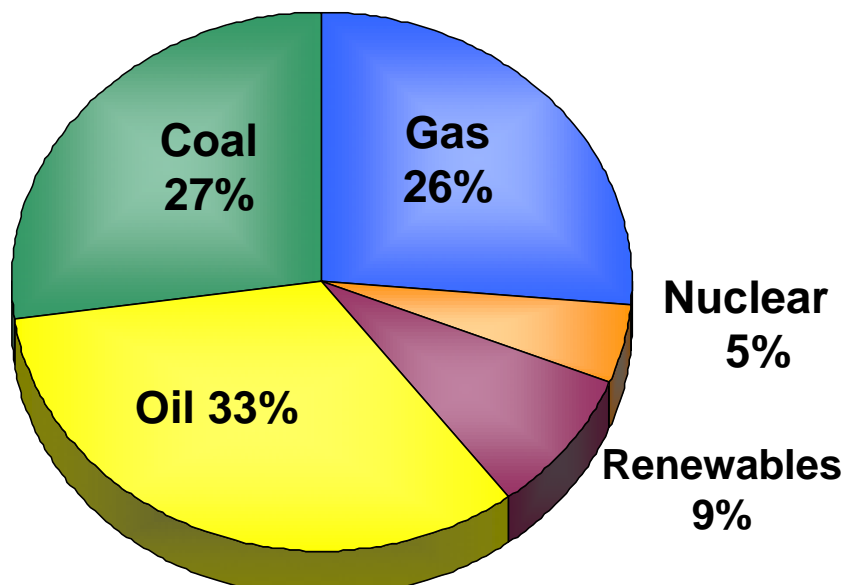




\section{U.S. Coal Utilization Outlook}

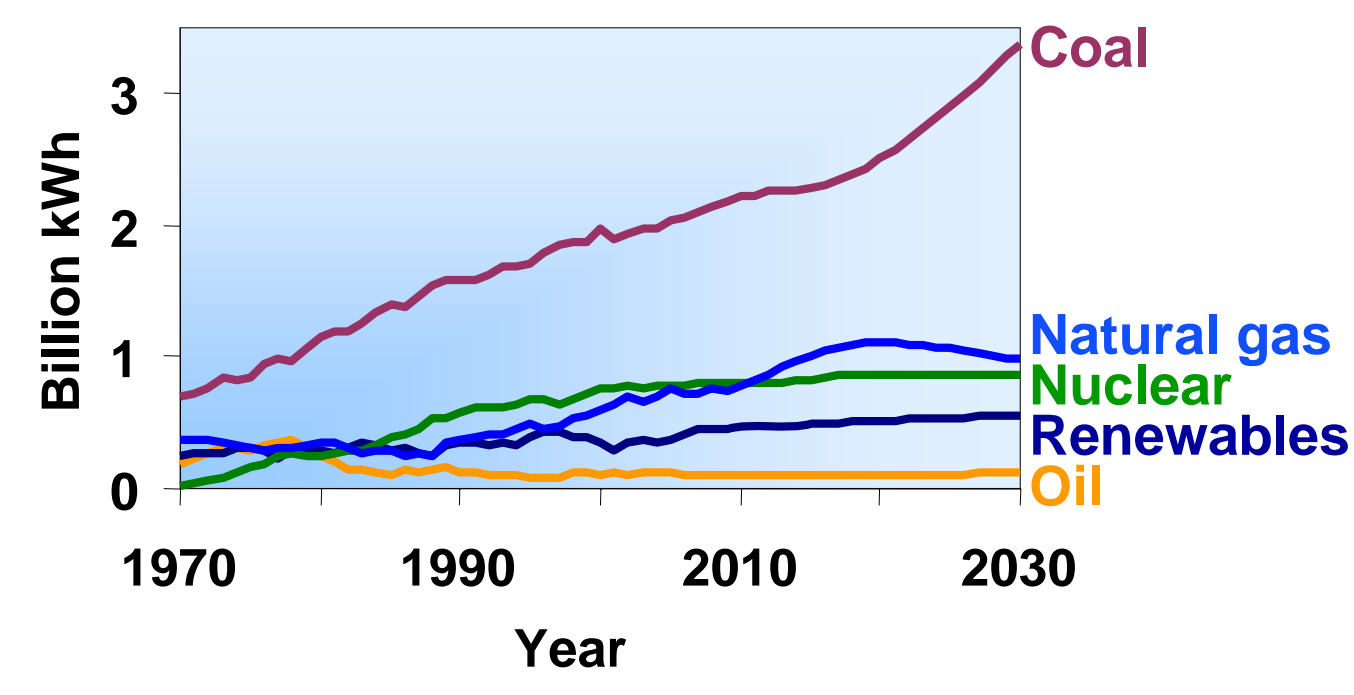

\section{Coal dominates electricity generation}




\section{0-Year Supply of Coal at Current Demand Levels}

\section{U.S. Fossil Fuel Reserves / Production Ratio}

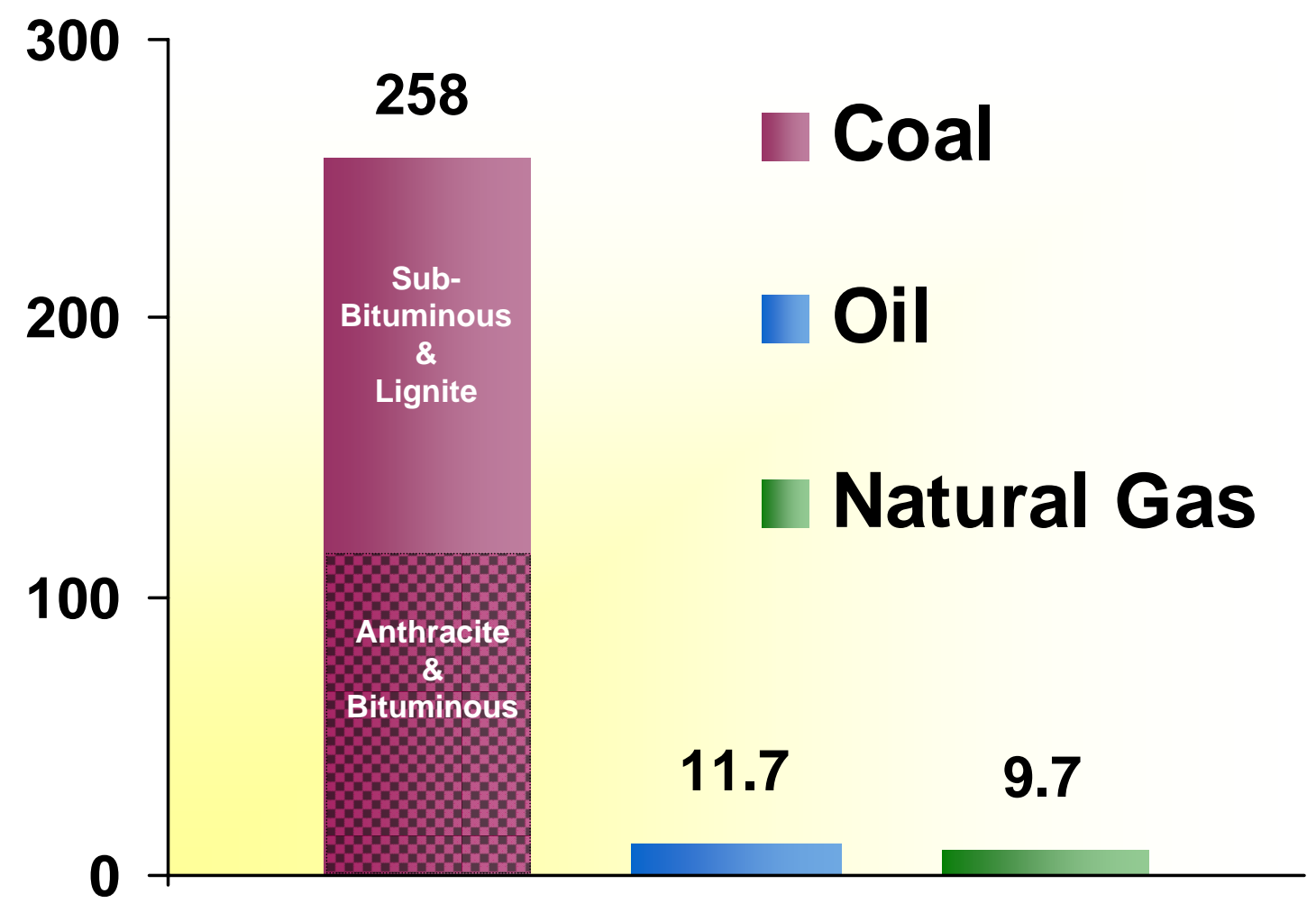




\section{Added GW - Double the 87 GW in DOE's EIA Annual Energy Outlook 2005}

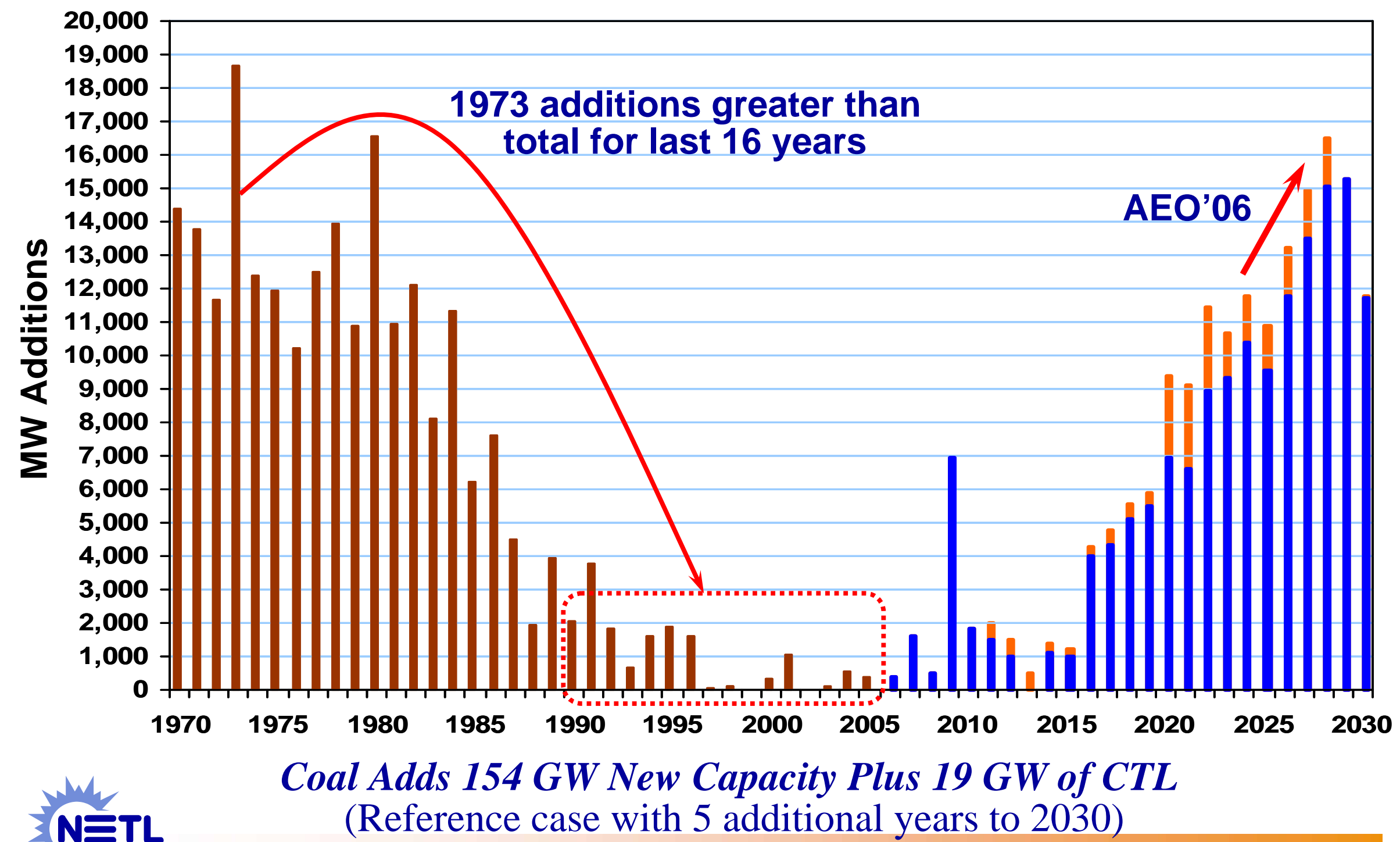




\section{DOE Strategic Plan}

1.1 Energy Diversity - Increase our energy options and reduce dependence on oil, thereby reducing vulnerability to disruption and increasing the flexibility of the market to meet U.S. needs.

1.2 Environmental Impacts of Energy - Improve the quality of the environment by reducing greenhouse gas emissions and environmental impacts to land, water, and air from energy production and use.

1.3 Energy Infrastructure - Create a more flexible, more reliable, and higher capacity U.S. energy infrastructure.

1.4 Energy Productivity - Cost-effectively improve the energy efficiency of the U.S. economy.

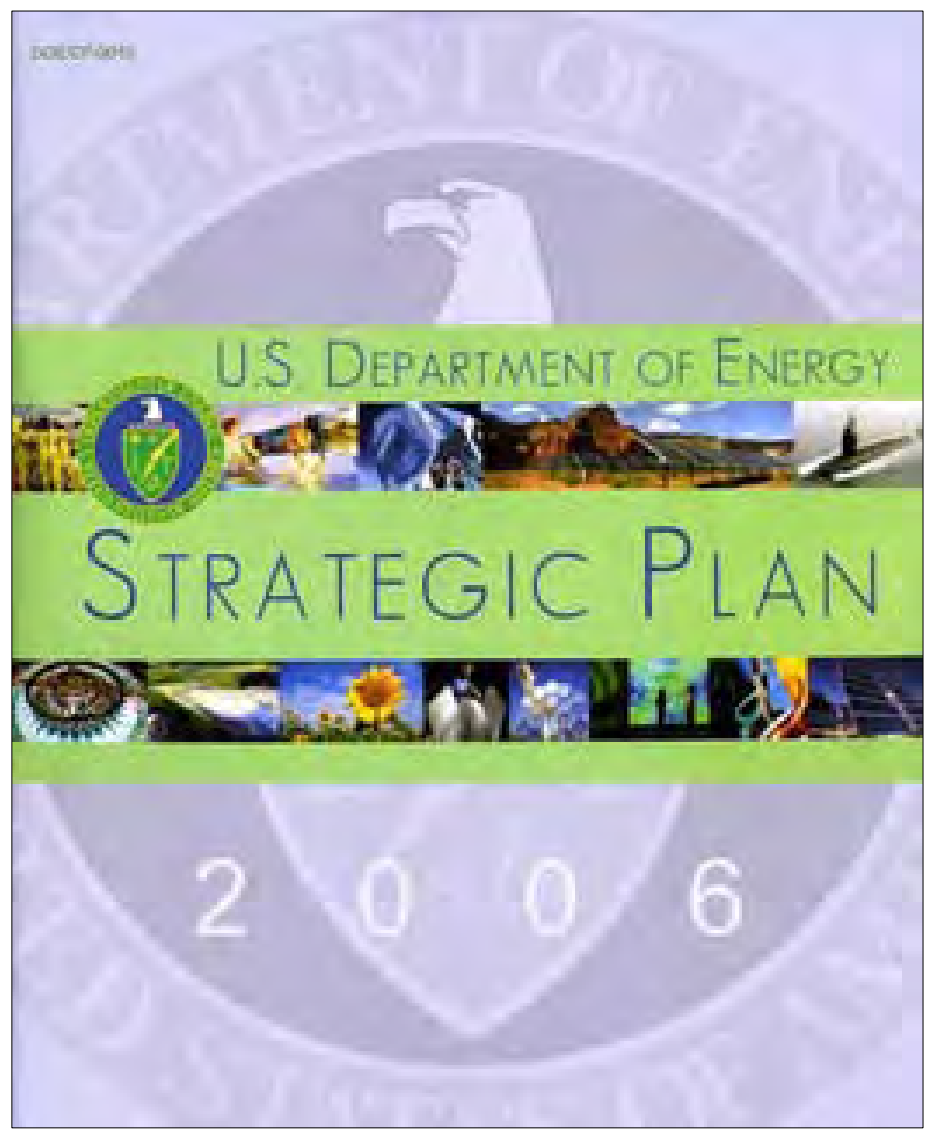




\section{R\&D Challenges for Coal Technology}

- "Near-zero" emissions

- $\mathrm{CO}_{2}$ management

- High efficiency

- Water use

- By-product utilization

- Flexible (feedstocks, products, siting)

- Cost competitive with other energy choices 


\section{Office of Fossil Energy's Coal \& Power Program}

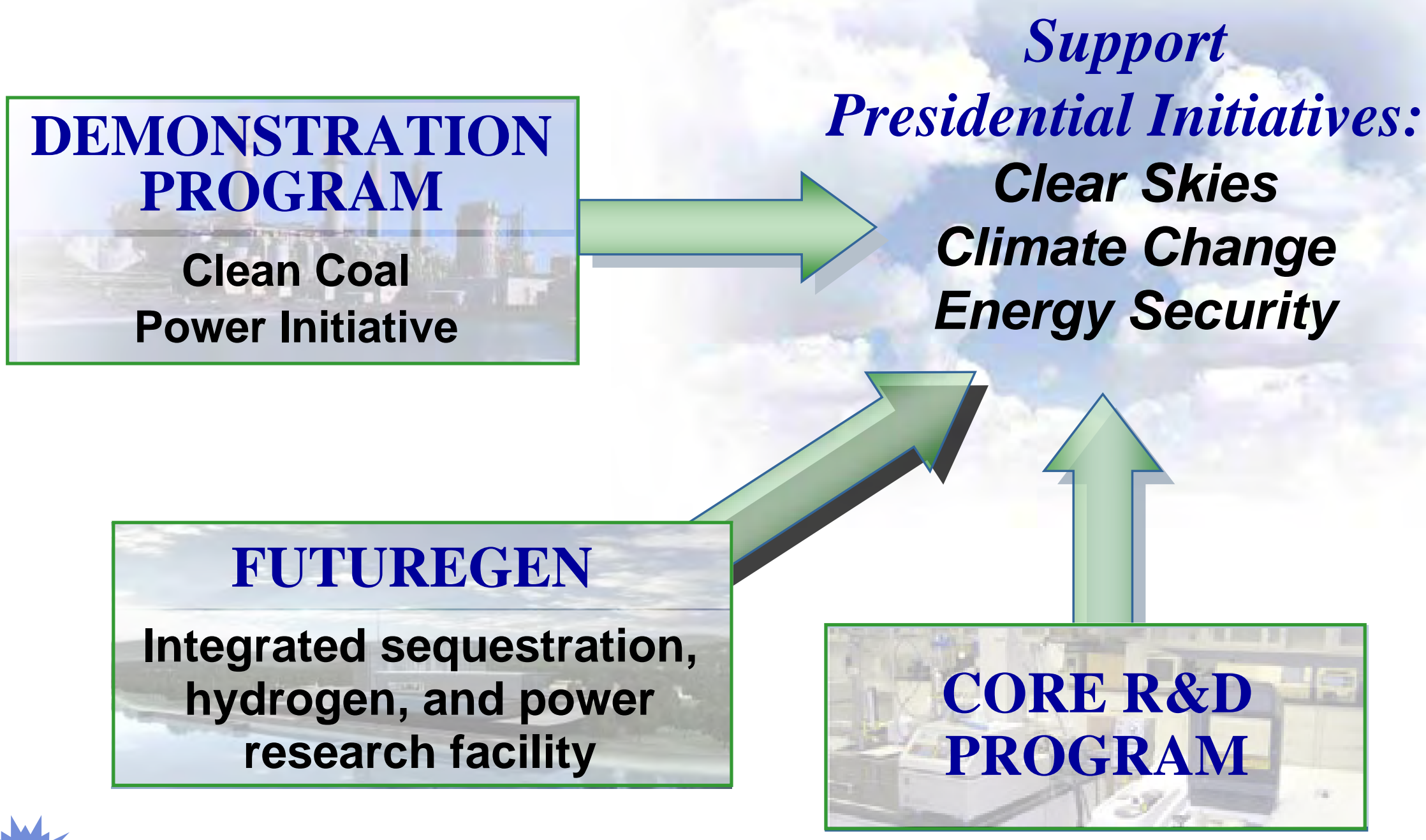




\section{Pathway to Clean and Secure Electricity from Coal}

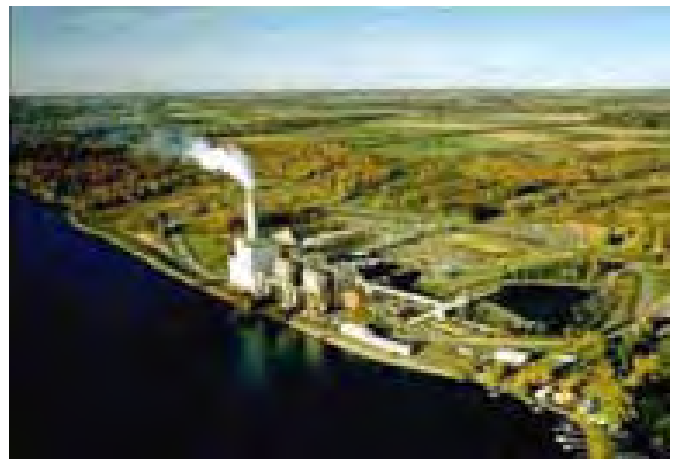

Existing Plants

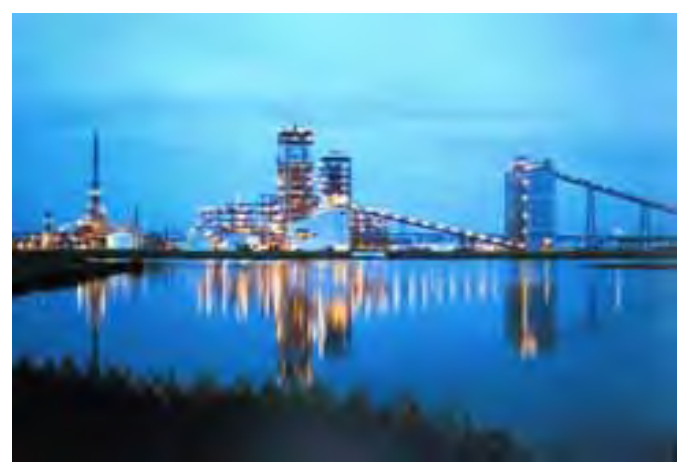

Clean Coal Successes

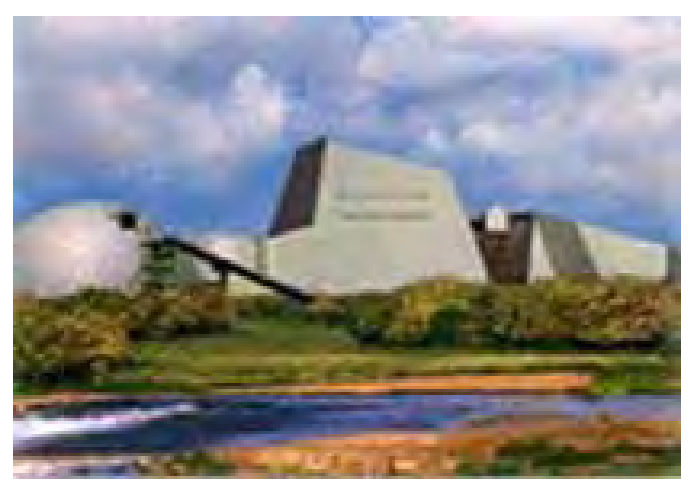

Near-Zero Emissions

Technology Research, Development \& Demonstration 


\section{DOE's Office of Fossil Energy Advanced Coal Power Systems Goals}

- 2010:

-45-50\% Efficiency (HHV)

$-99 \% \mathrm{SO}_{2}$ removal

$-\mathrm{NOx}<0.01 \mathrm{lb} / \mathrm{MM}$ Btu

$-90 \% \mathrm{Hg}$ removal

$-\$ 1,000 / k W(2002 \$)$

- 2012:

$-90 \% \mathrm{CO}_{2}$ capture

$-<10 \%$ increase in COE with carbon sequestration

- 2015

- Multi-product capability (e.g., power, liquid fuels, hydrogen, SNG)

$-50-60 \%$ efficiency (without carbon capture) 


\section{Coal \& Power Core R\&D Program}

- Innovations for Existing Plants

- Advanced Integrated Gasification Combined Cycle

- Hydrogen \& Syngas

- Carbon Sequestration

- Fuel Cells

- Advanced Research

- Advanced Turbines

Roadmap Developed for Each Program with Industry
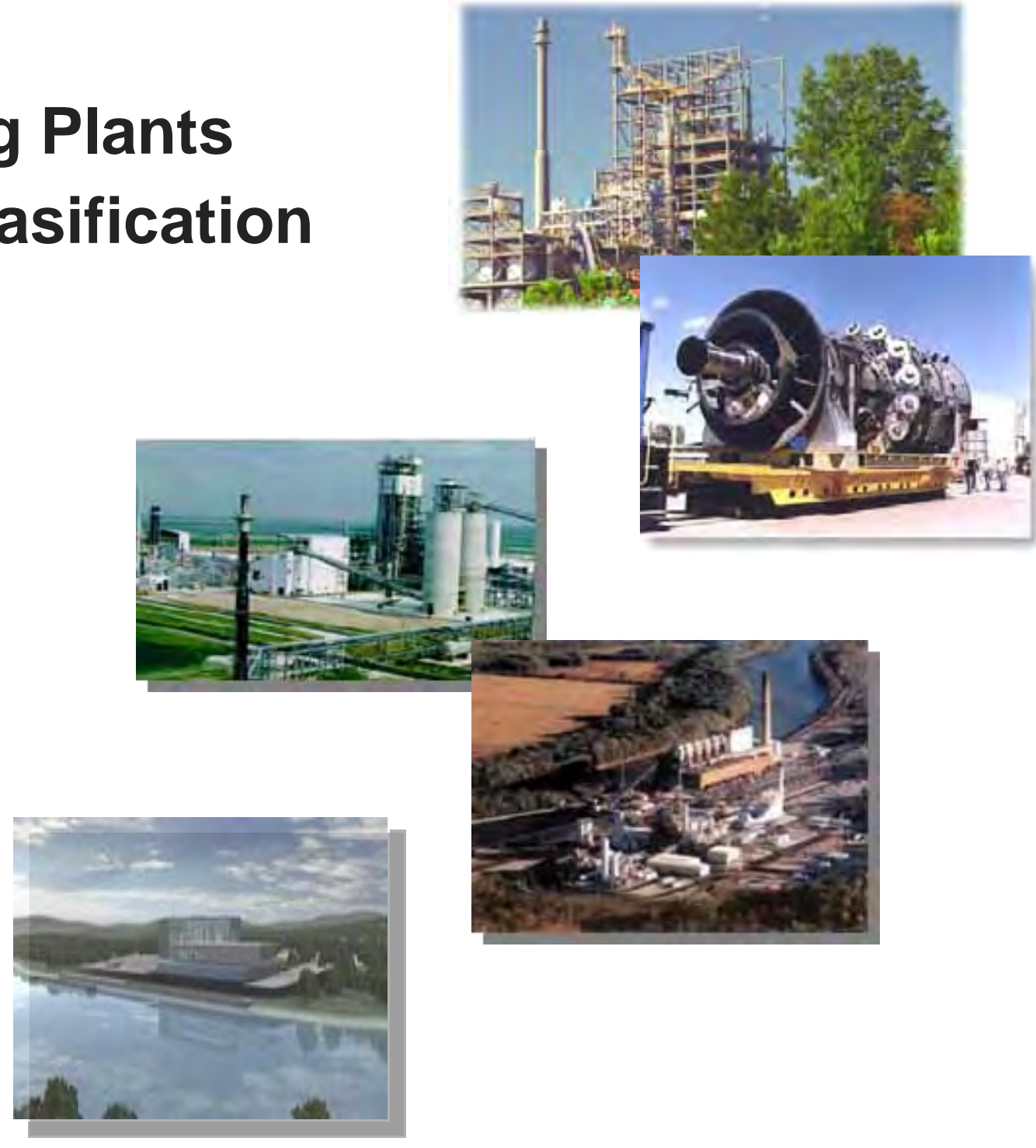


\section{Coal \& Power Program Addresses Both Near-Term and Long-Range Needs}

- Short-term: keep existing fleet in service; prepare for transition to near-zero-emission future

$-\mathrm{SO}_{2}, \mathrm{NO}_{x}, \mathrm{Hg}$

- Plant optimization and control

- Reduced carbon intensity

- Long-term: add near-zero emission energy plants

- IGCCs to market

- Advanced materials

- Ultra-high-efficiency hybrid systems

$-\mathrm{CO}_{2}$ capture and storage

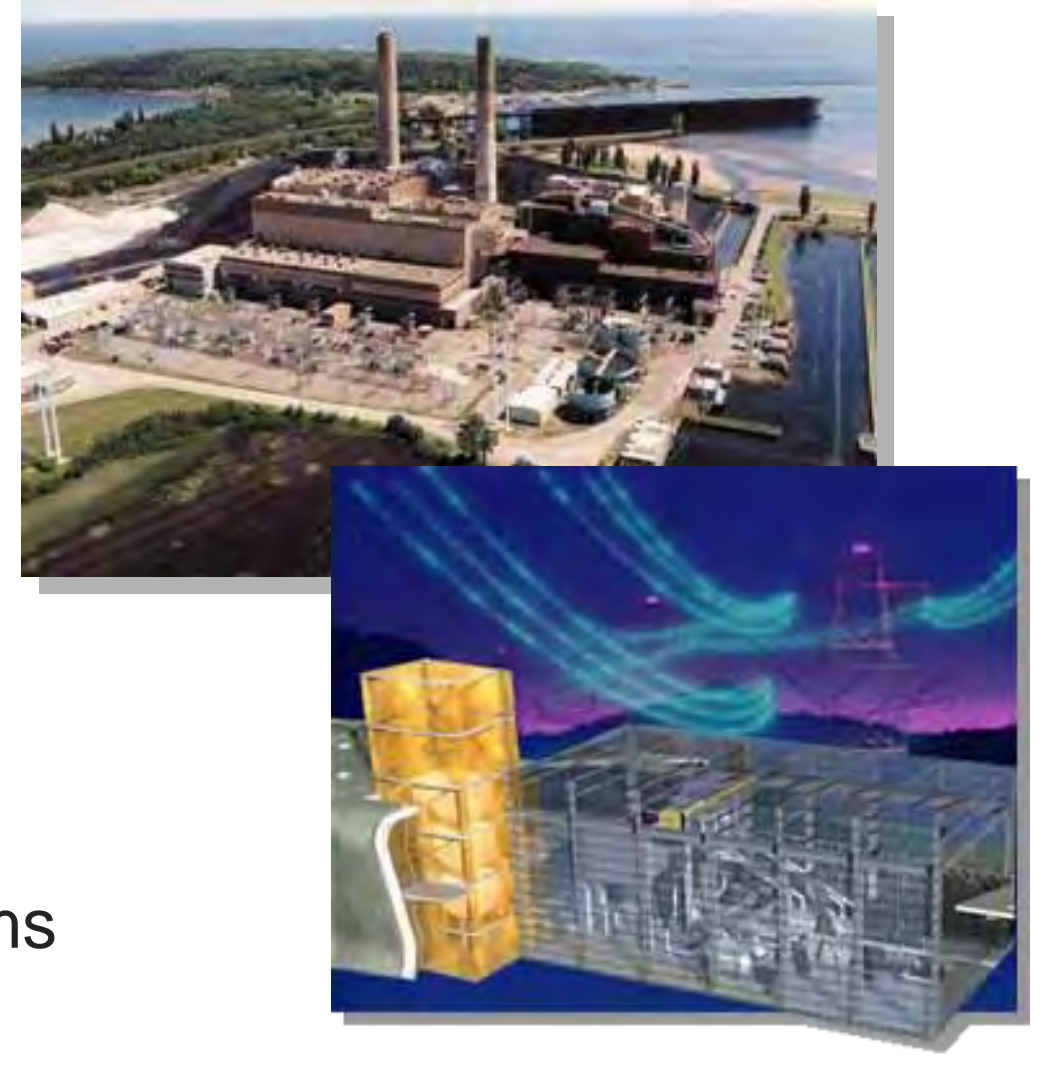




\section{Carbon Capture and Storage Opportunities Thousands of Years of Potential Storage Capacity Worldwide}

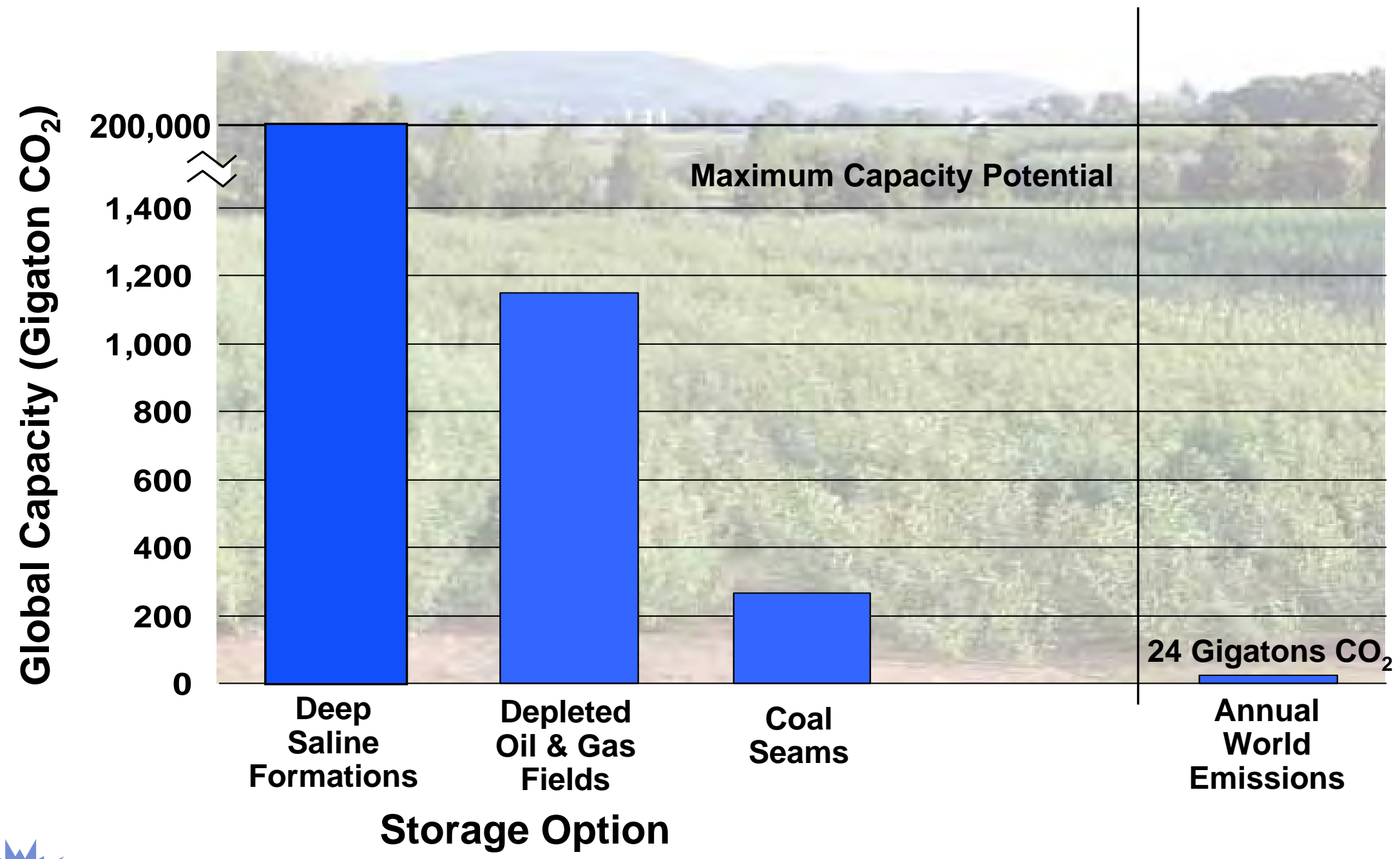




\section{DOE’s FY2006 Sequestration Program}

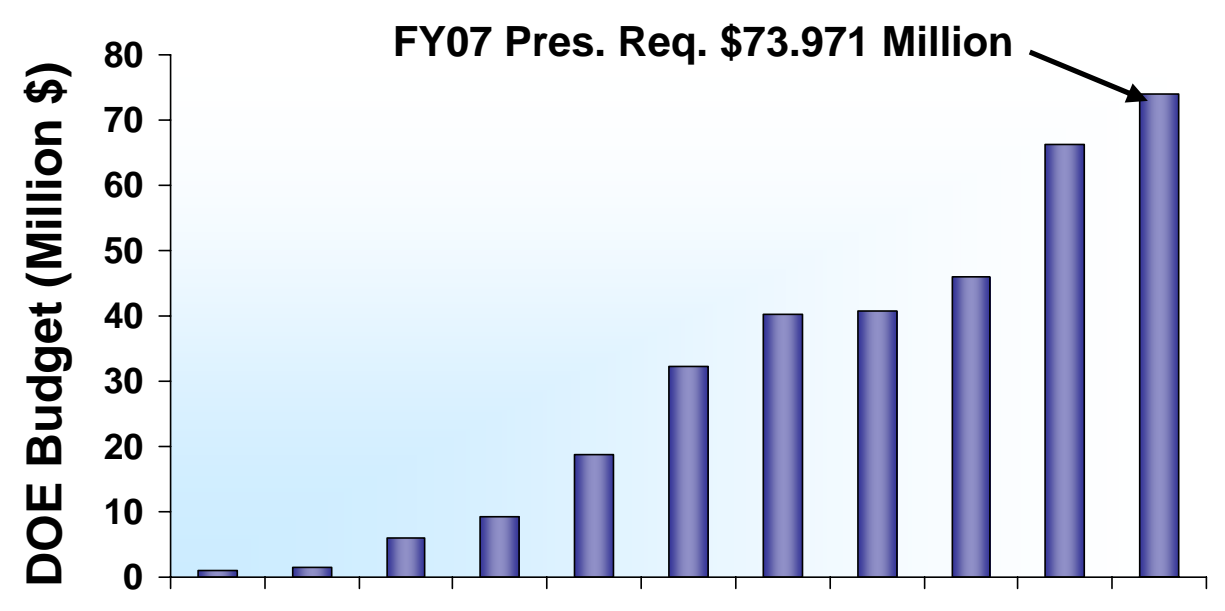

- Diverse research portfolio

70 R\&D Projects

19971998199920002001200220032004200520062007

Fiscal Year

Req

- Strong industry support

- 39\% cost share on projects

- Federal Investment to Date

\$260 Million

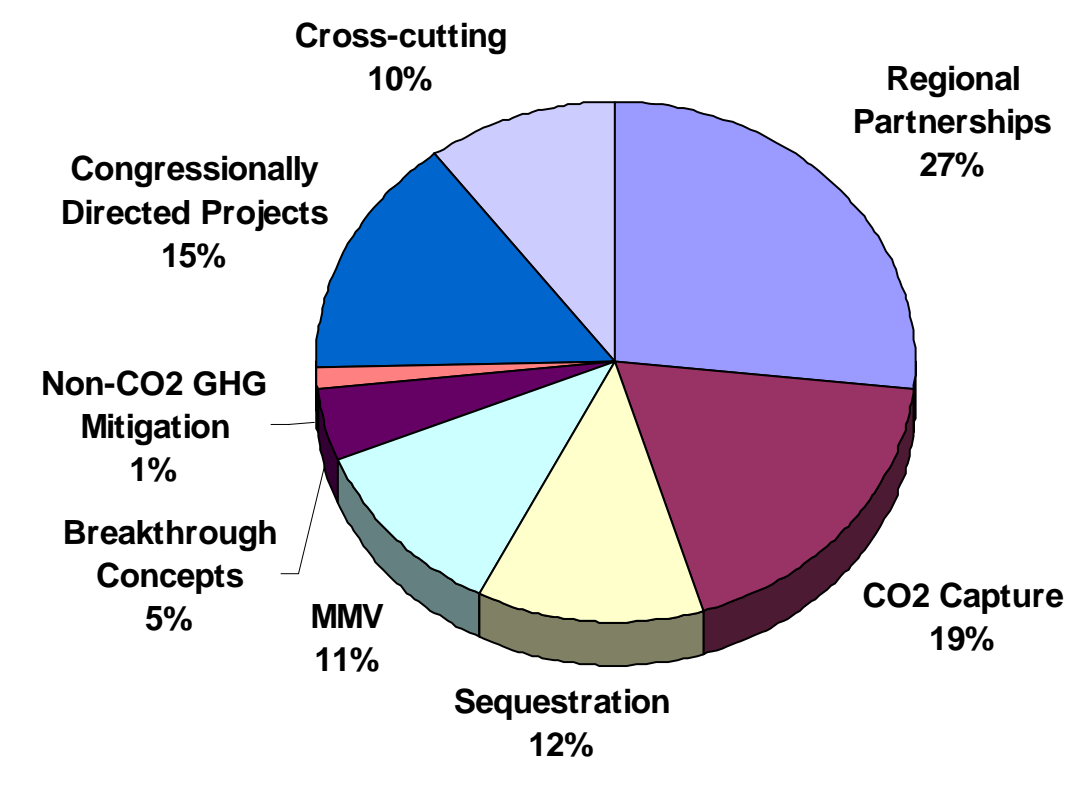

\section{FY2006 Budget}

Cross-cutting

$27 \%$ 


\section{Sequestration Program Goals Develop Technology Options for GHG Management}

- CCS R\&D Goals

- Options for IGCC and PC-based electricity generating technologies

- Sequestration/Storage R\&D Goals

- Predict $\mathrm{CO}_{2}$ storage capacity with $+/-30 \%$ accuracy

- Develop best practice reservoir management strategies that maximize $\mathrm{CO}_{2}$ trapping

Cost Performance Goals

\begin{tabular}{|l|c|c|}
\hline Year & $\begin{array}{c}\text { COE Penalty } \\
\text { IGCC Plants } \\
\text { (\% Increase) }\end{array}$ & $\begin{array}{c}\text { COE Penalty } \\
\text { PC Plants } \\
\text { (\% Increase) }\end{array}$ \\
\hline 2002 & 30 & 80 \\
\hline 2012 & 10 & 20 \\
\hline 2015 & $<10$ & 10 \\
\hline $2018^{*}$ & 0 & 0 \\
\hline
\end{tabular}

- Monitoring, Mitigation \& Verification

- Ability to verify $95 \%$ of stored $\mathrm{CO}_{2}$ ${ }^{*}$ Cost/Energy offset from sequestering $\mathrm{CO}_{2}$ with criteria pollutants $\mathrm{NOX}, \mathrm{SOx}, \mathrm{H}_{2} \mathrm{~S}$ (gasification)

$-\mathrm{CO}_{2}$ material balance to $>99 \%$ 


\section{Carbon Storage - Science is Growing}

\section{Understanding of storage mechanisms is critical}

to viability as a long-term option

- Physical Trapping

- Residual Phase Trapping

- Solution/Mineral Trapping

- Gas Adsorption
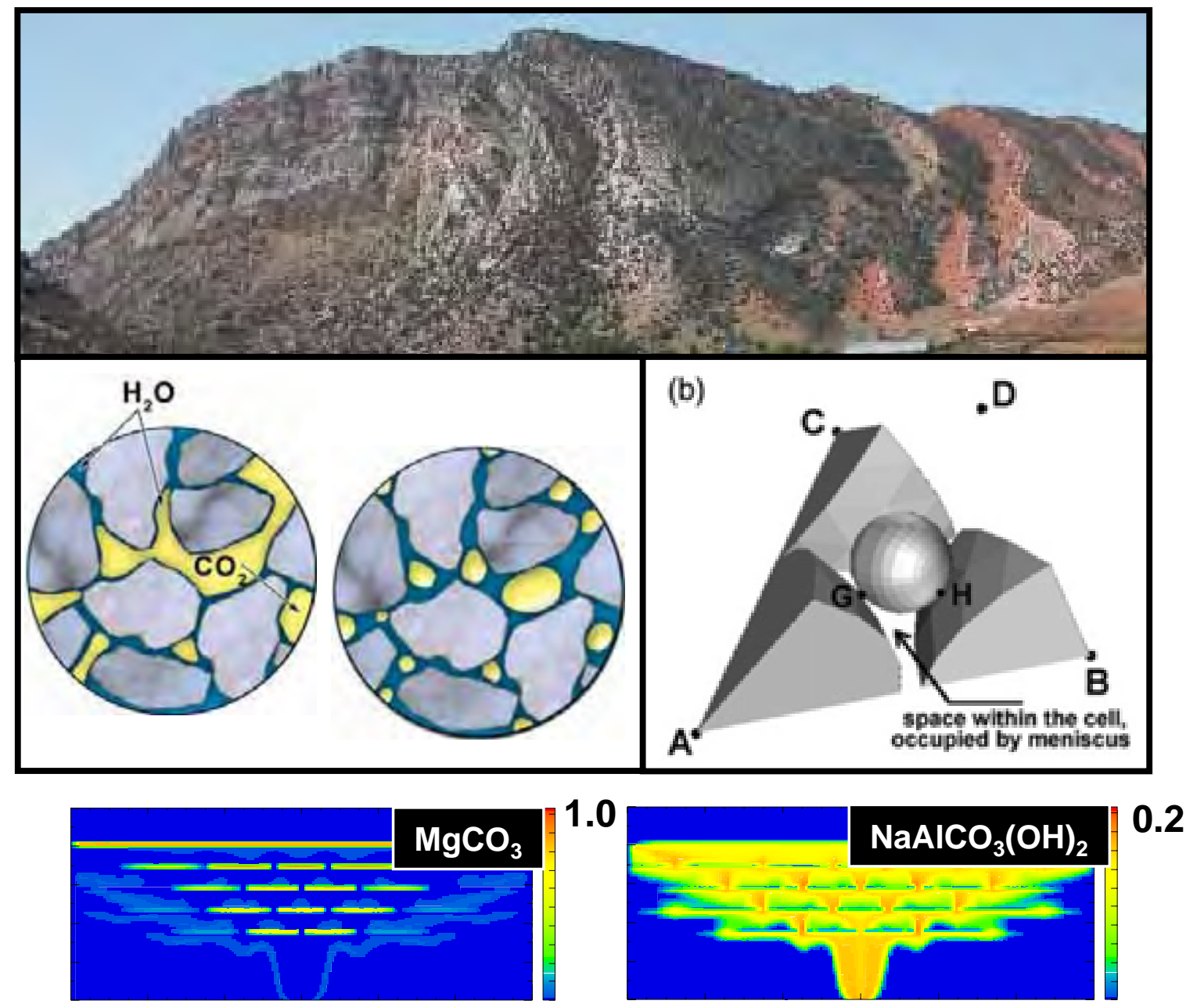


\section{Carbon Sequestration Regional Partnerships}

"Developing the Infrastructure for Wide-Scale Deployment"

Phase I (Characterization)

- 7 Partnerships (40 states)

- 24 months (2003-2005)

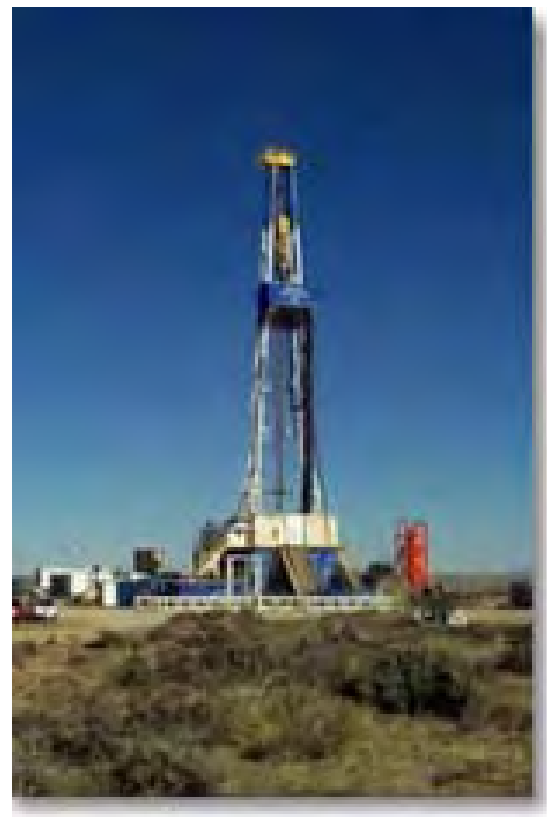




\section{Regional Carbon Sequestration Partnerships}

\section{Phase II Validation Tests - Injecting between 750 - 525,000 tons of $\mathrm{CO}_{2}$}

\section{Representing:}

- >300 Organizations

- 40 States

- 4 Canadian Provincess.

- 3 Indian Nations

- $34 \%$ cost share

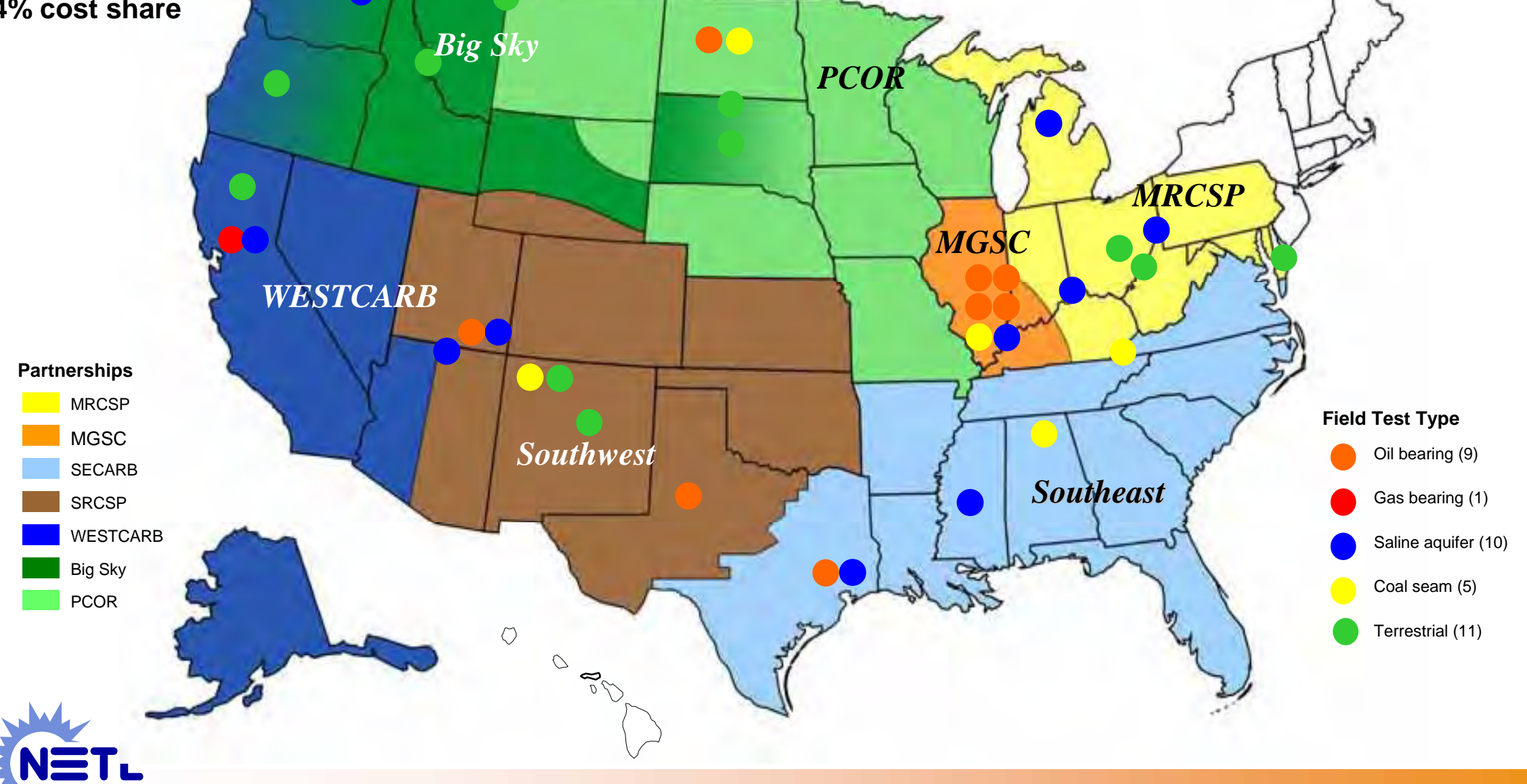




\section{Break-Through Capture Concepts}

\section{Ionic Liquids}

- $\mathrm{CO}_{2}$ is highly soluble in some ionic liquids

- Non-volatile liquid and high thermal stability

- Ability to capture $\mathrm{SO}_{2}$ with one solvent
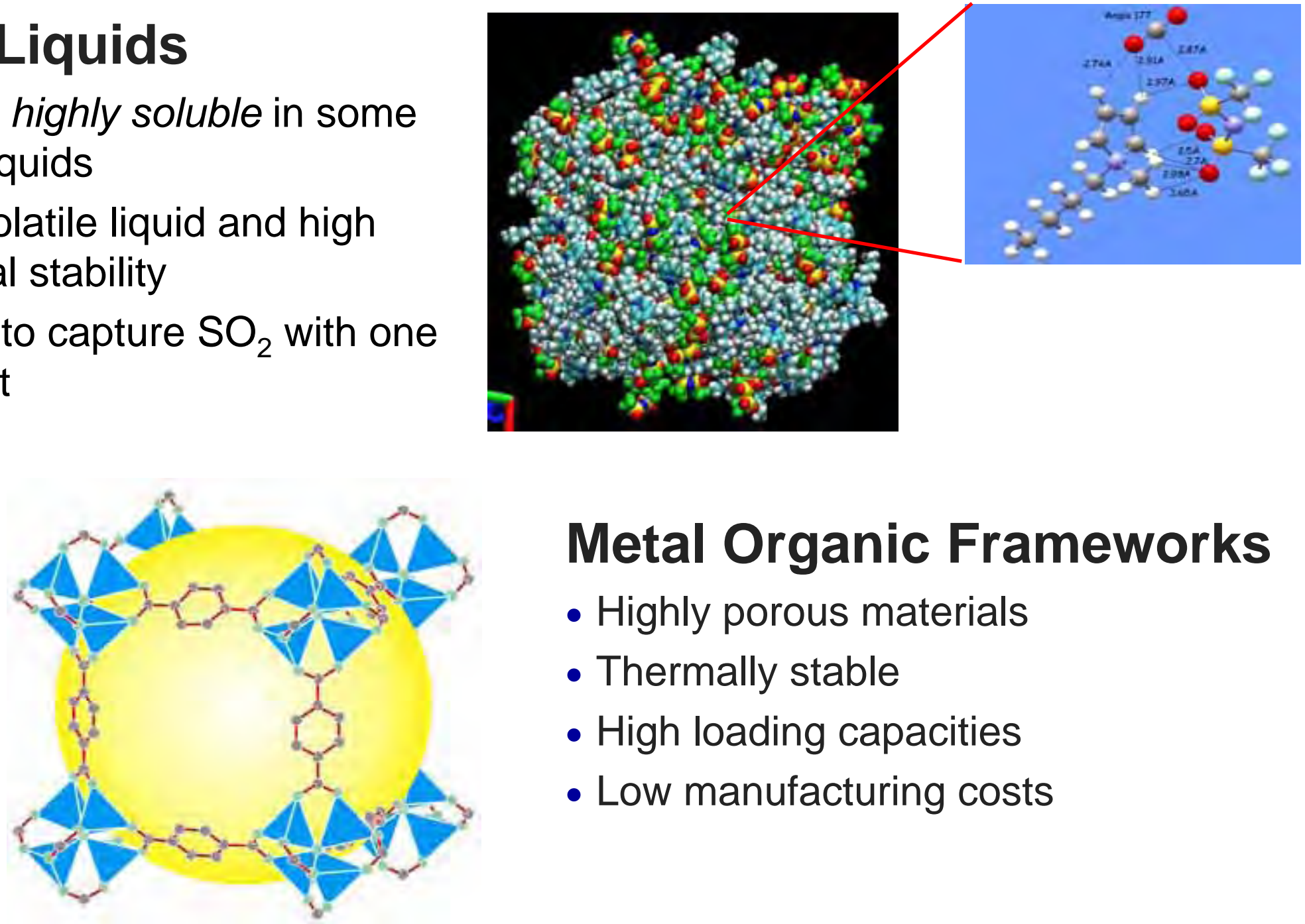

\section{Metal Organic Frameworks}

- Highly porous materials

- Thermally stable

- High loading capacities

- Low manufacturing costs 


\section{Break-Through Capture Concepts}

\section{Thermally Optimized Membranes}

- Order of magnitude higher selectivity than current polymers

- Selective from room temp to $400^{\circ} \mathrm{C}$

- Promising preliminary results
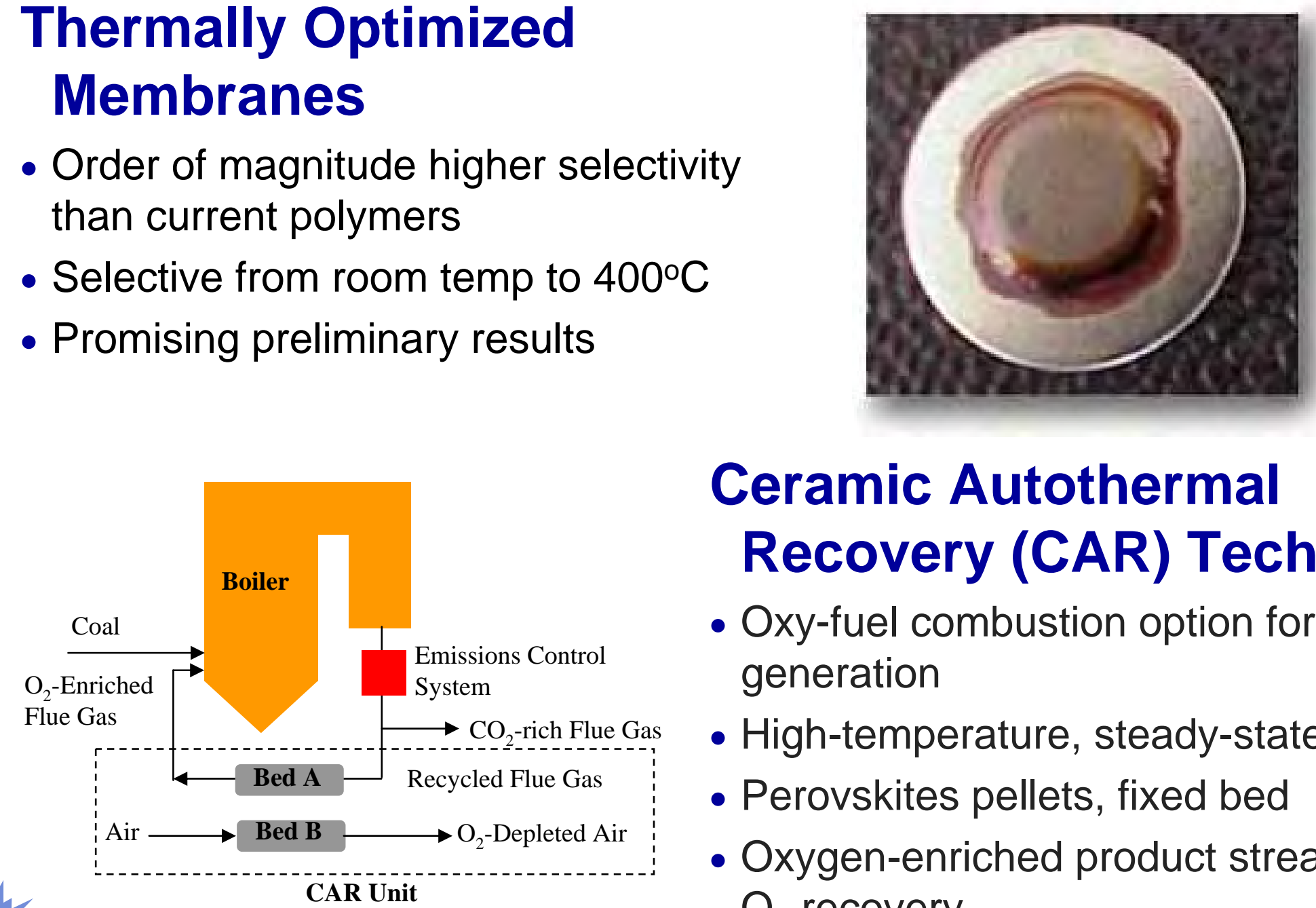

Ceramic Autothermal Recovery (CAR) Technology

- Oxy-fuel combustion option for power generation

- High-temperature, steady-state process

- Perovskites pellets, fixed bed

- Oxygen-enriched product stream, high $\mathrm{O}_{2}$ recovery 


\title{
Ongoing, Large-Scale $\mathrm{CO}_{2}$ Sequestration Projects
}

\author{
Weyburn $\mathrm{CO}_{2}$ EOR Project
}

- Pan Canadian Resources

- 200-mile $\mathrm{CO}_{2}$ pipeline from Dakota Gasification Plant

- Enhanced Oil Recovery in Canada

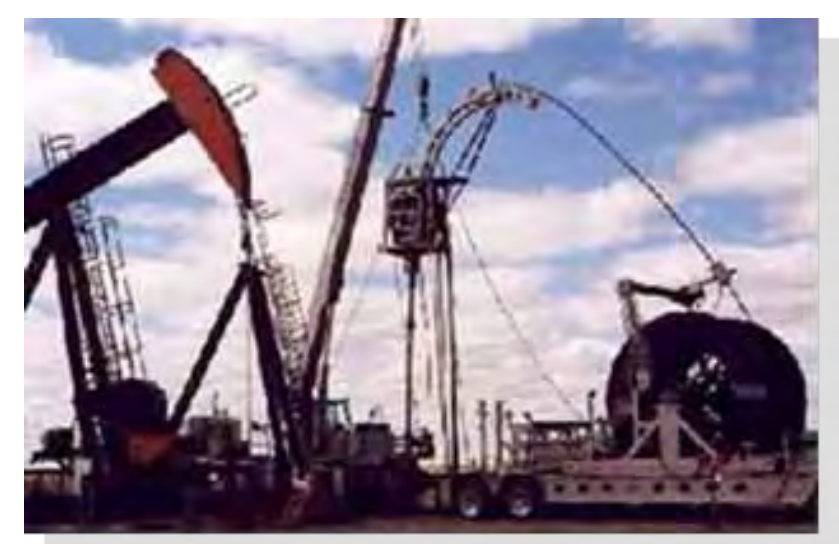

Sleipner North Sea Project

- Statoil

- $\mathrm{CO}_{2}$ sequestered - Utsira Formation

- Currently monitoring $\mathrm{CO}_{2}$ migration

- Separates $\mathrm{CO}_{2}$ from natural gas

- \$36-50/tonne $\mathrm{CO}_{2}$ tax

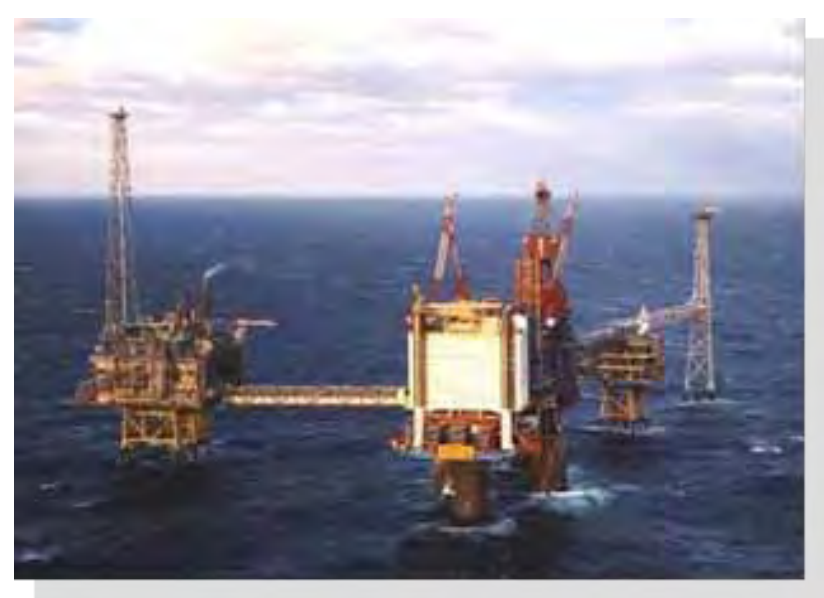




\section{DOE's Coal Demonstration Programs Implemented Through Competition}

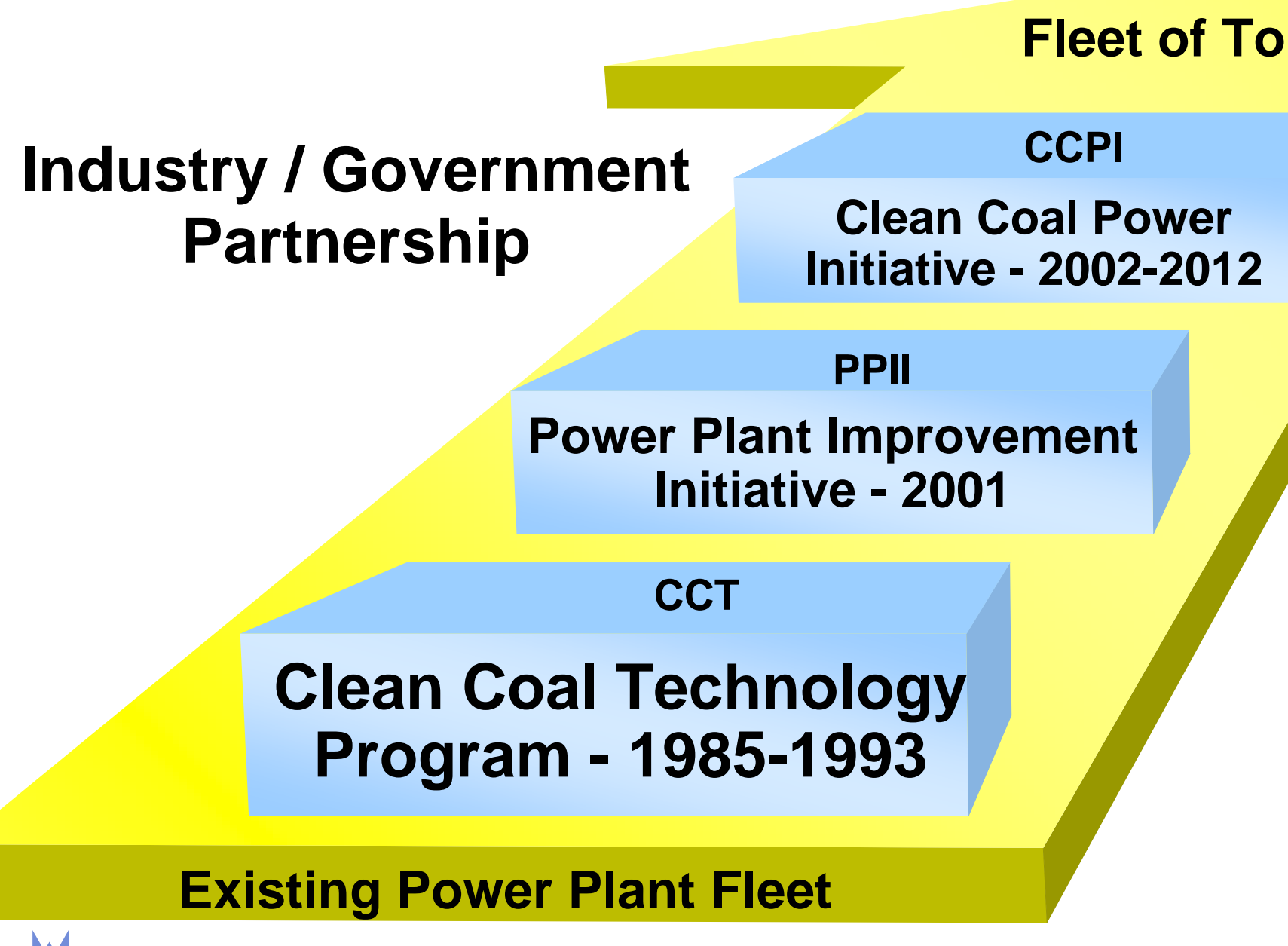

Minimum $50 \%$ NonFederal Cost Share

Repayment 


\section{IGCC Technology in Early Commercialization U.S. Coal-Fueled Plants}

- Wabash River

- 1996 Powerplant of Year Award*

- Achieved 95\% availability

- Tampa Electric

- 1997 Powerplant of Year Award*

- First dispatch power generator

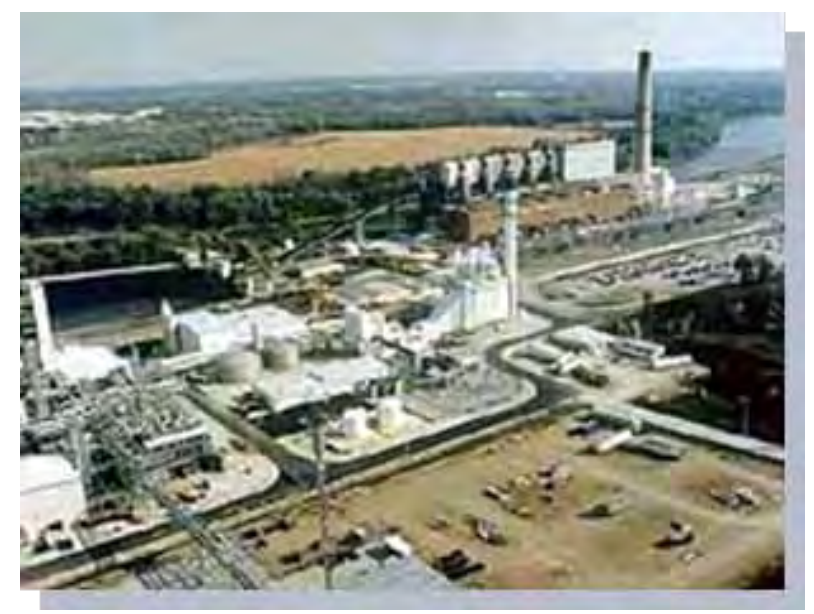

Nation's first commercial-scale

IGCC plants, each achieving

$>95 \%$ sulfur removal

$\geq 90 \% \mathrm{NO}_{\mathrm{x}}$ reduction

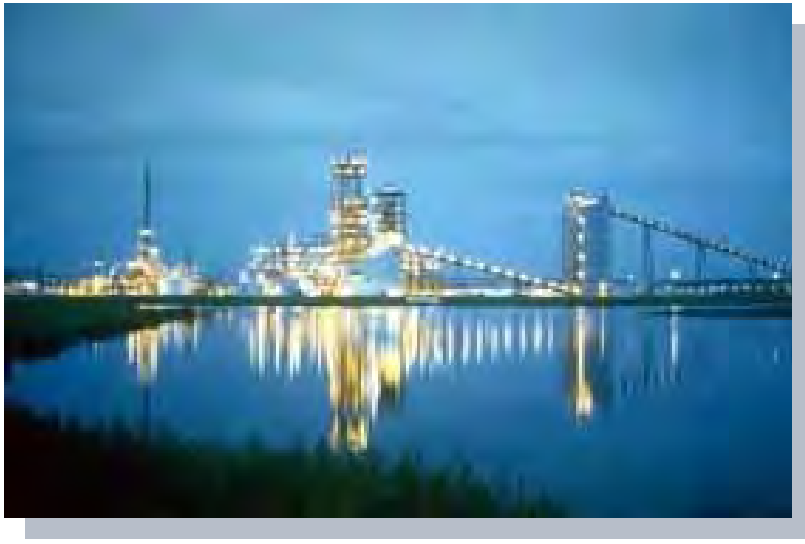




\section{Clean Coal Power Initiative}

- 10-year program

- 4 rounds of solicitations

- Drivers

- Overall

- Clear Skies Initiative

- Reduced carbon intensity

- Zero emissions technology target

- Energy/economic security

- Round 1 (Broad)

- Advanced coal-based power generation

- Efficiency, environmental \& economic improvements

- Round 2 (Prioritized)

- Gasification

- Hg control 


\section{CCPI Demonstration Projects Technologies, Locations and Cost Share}

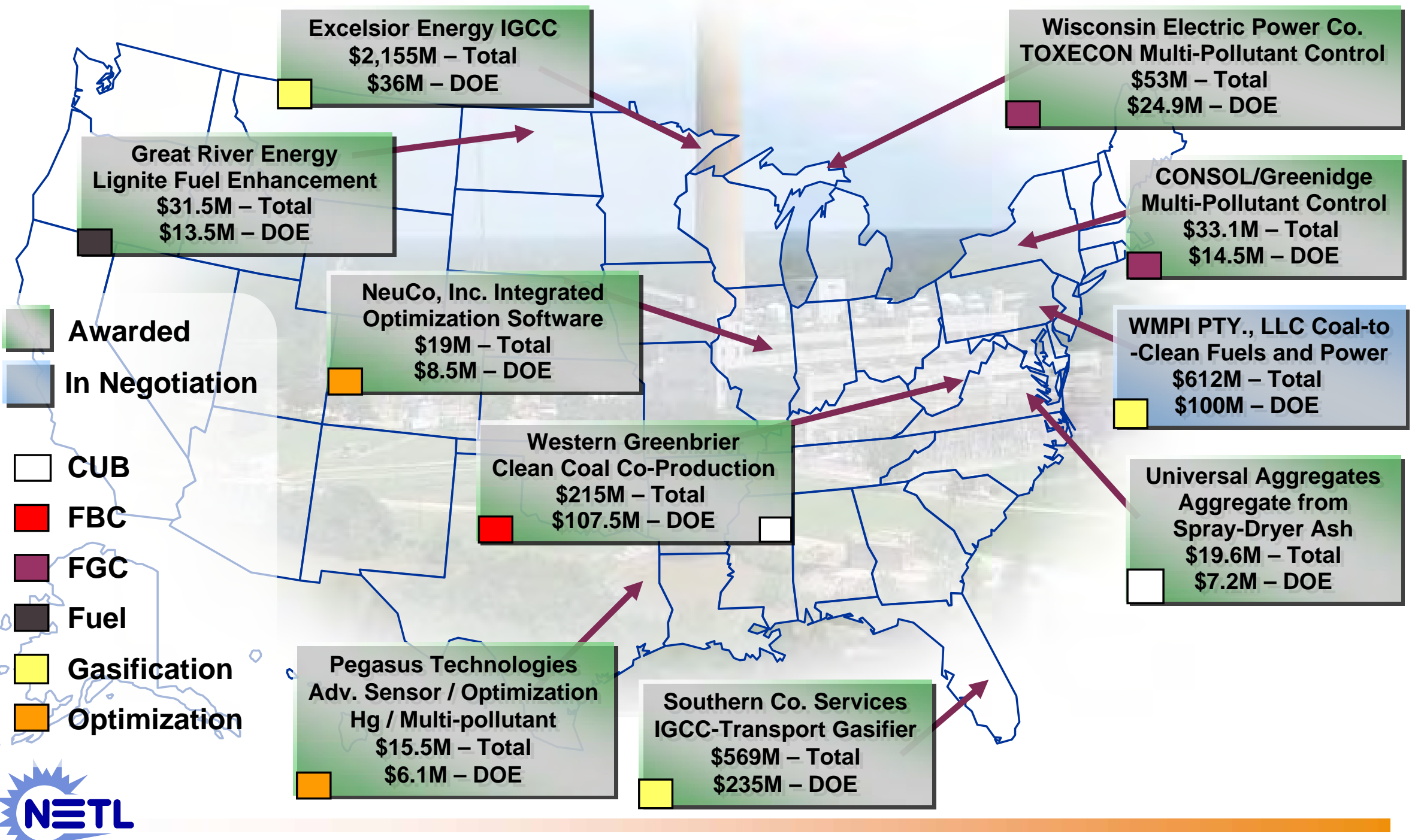




\section{FutureGen: A Global Partnership Effort}

One-billion dollar, 10-year project to create world's first coal-based, zero-emission electricity and hydrogen plant

\section{President Bush, 27 February 2003}

- Research platform to accelerate deployment of promising technologies

- Broad participation from mining and electricity sectors

- 12 member industry-led consortium with international collaboration

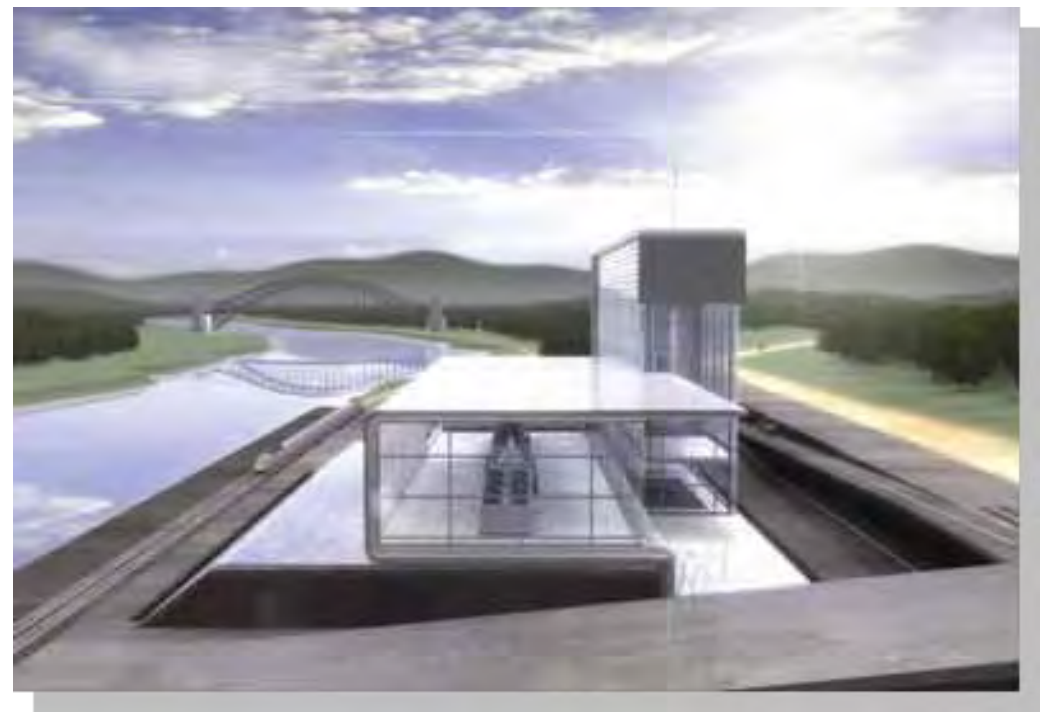




\section{FutureGen Concept}

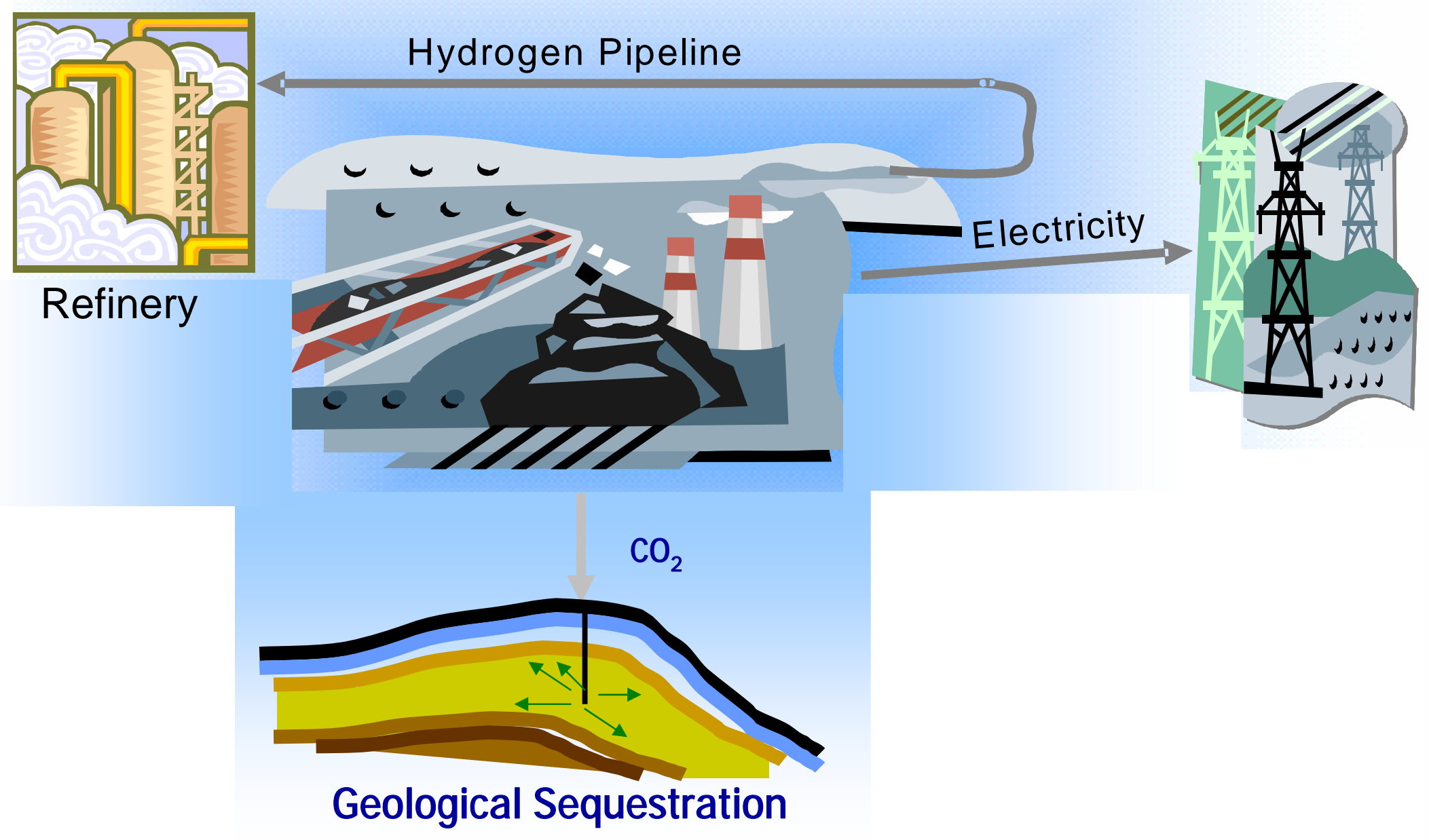

N 


\section{FutureGen: Integrating Function for Fossil Energy R\&D Program}
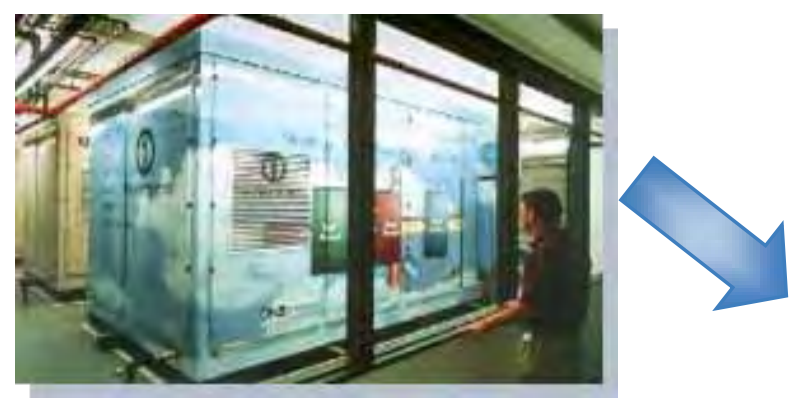

Fuel Cells

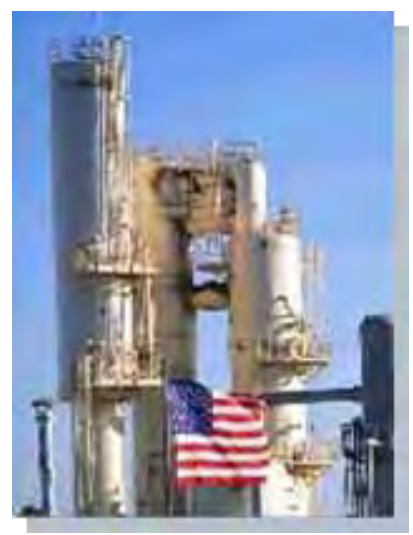

Gasification with Cleanup Separation N三TL
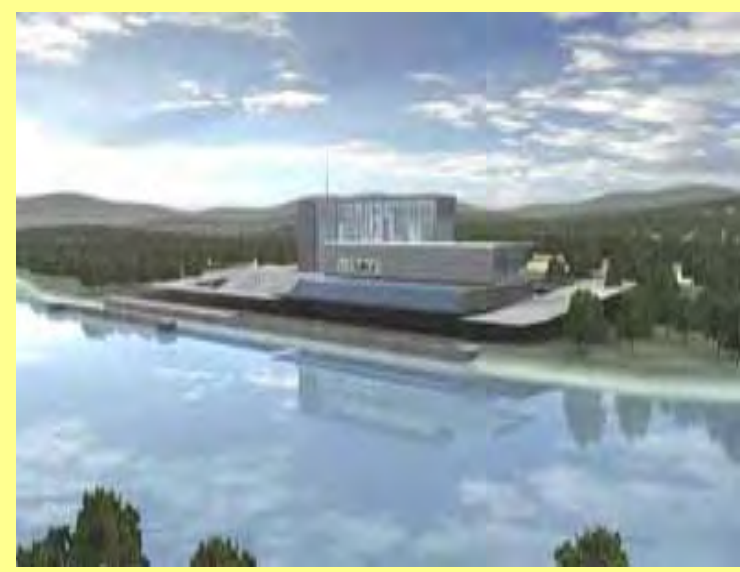

FutureGen

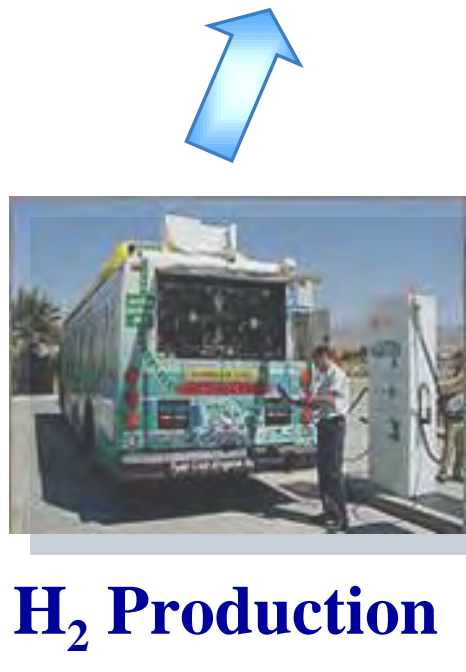

$\mathbf{H}_{2}$ Production

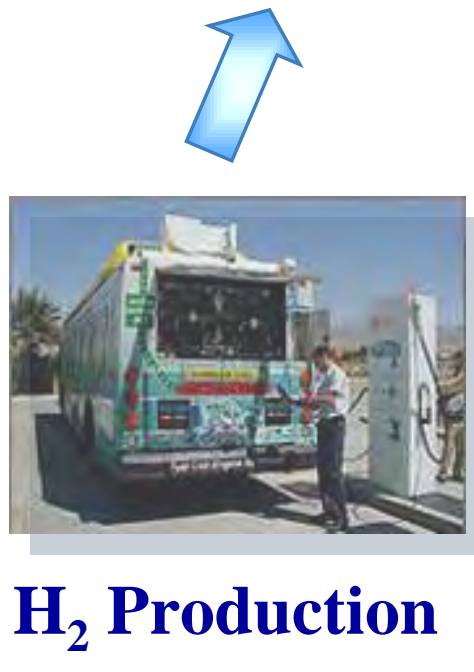

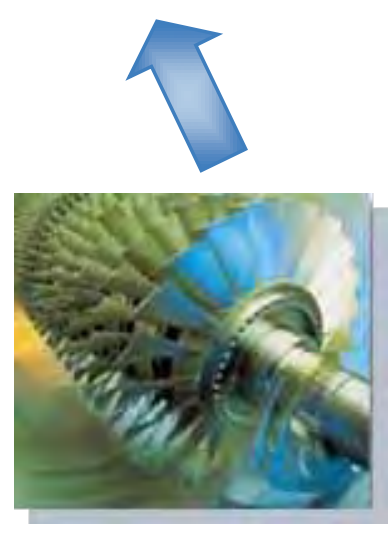

Optimized Turbines
Carbon Sequestration

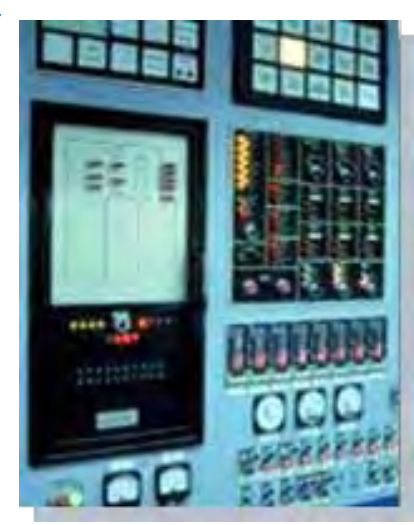

System Integration 


\section{FutureGen Project}

\section{Supporting FutureGen is Major Goal of FE's R\&D Programs}

- Industry-led project with government oversight \& international participation

- Signed Cooperative Agreement with DOE on 2 Dec. 2005

- Project structuring to Jan. 2007

- Design to July 2009

- Construction to July 2012

- Operations to July 2016

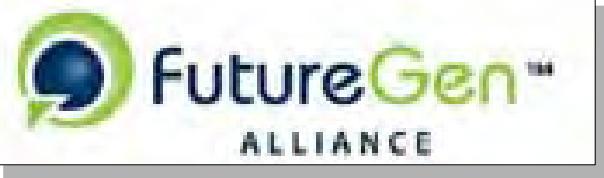

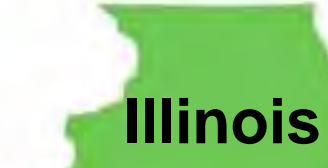

Tuscola

t

Mattoon

ALLIANCE

- Site monitoring to July 2018

- International Participation:

- India and South Korea signed Protocols of Intent to join

- China and Japan expressed strong interest in joining

- Industry will choose project site \& backbone technologies

- Down selected to 4 potential sites

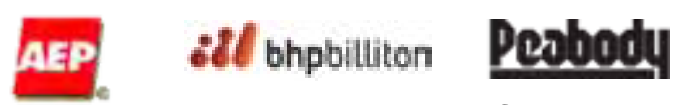

CONSOL ENERGY
(A) Anglo AMERICAN

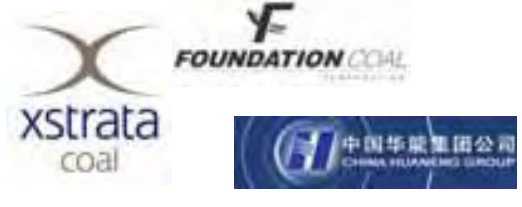

ppl

Texas 


\section{U.S. Government Commitment to Clean Energy From Coal}

FY 2006 Coal Program Funding

\begin{tabular}{|l|c|}
\hline \multicolumn{1}{|c|}{ Program } & Thousand \$ \\
\hline FutureGen & 17,820 \\
\hline $\begin{array}{l}\text { Clean Coal Power } \\
\text { Initiative }\end{array}$ & 49,500 \\
\hline $\begin{array}{l}\text { Innovations for } \\
\text { Existing Plants }\end{array}$ & 25,146 \\
\hline Gasification & 55,886 \\
\hline Turbines & 17,820 \\
\hline Sequestration & 66,330 \\
\hline Fuels & 28,710 \\
\hline Fuel Cells & 61,380 \\
\hline Advanced Research & 52,622 \\
\hline TOTAL COAL & 375,214 \\
\hline
\end{tabular}

\section{Historic and Continued U.S. Support}

- More than \$20 billion over past 30 years

- FutureGen: \$1 billion through 2018

- Carbon Sequestration: \$450 million through 2016 


\section{Energy Policy Act of 2005 (EPAct) and Coal}

\section{Seven areas directly affect coal-related technologies:}

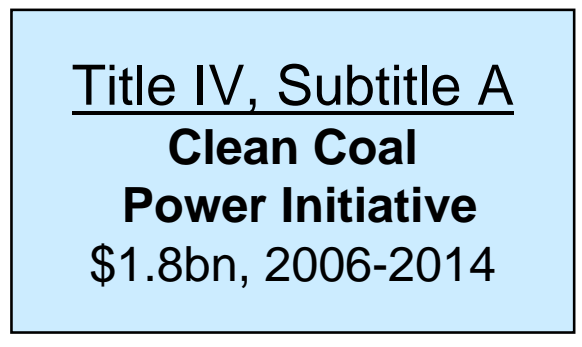

Title IV, Subtitle B
Clean Power Projects
Grants, Loans,
Loan Guarantees,
and Cost Sharing
\$ Indeterminate
$\underline{\text { Title IV, Subtitle C }}$ Coal and Related Programs Clean Air Coal Program \$3.0bn, 2007-2013

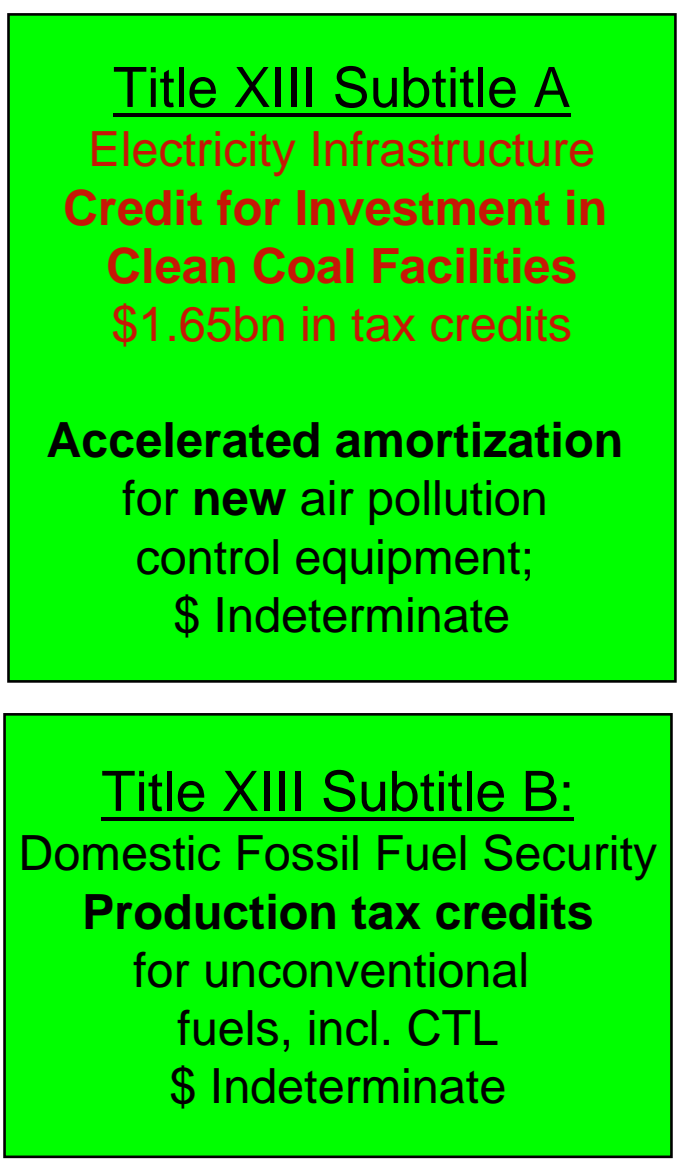

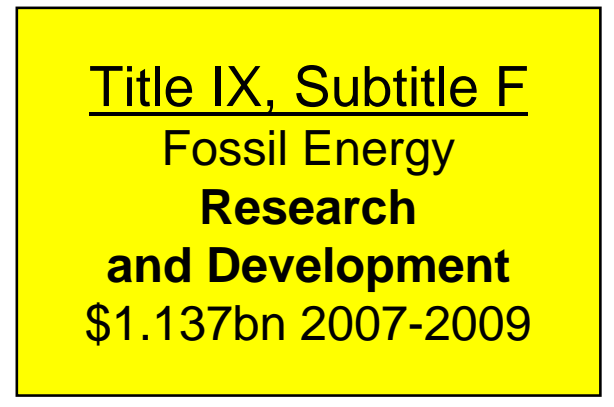

\begin{tabular}{|c|}
\hline Title XVII \\
Incentives for \\
Innovative \\
Technologies \\
Loan guarantees \\
for gasification projects \\
\$ Indeterminate \\
\hline
\end{tabular}




\section{Progress Towards Advanced Technology Implementation}

- Congressional Tax Credit Authorization of \$1.65 Billion

- 22 applications were received

- representing $\$ 27.7$ billion in proposed projects

- requesting $\$ 2.3$ billion in tax credits

- 18 IGCC and 4 adv. coal-based generation projects

- First Round Awards of Approximately \$1 Billion

\section{First Round Recipients Include:}

Duke Energy - Edwardsport IGCC Project, Edwardsport, IN

Tampa Electric Company, Polk County, FL

Southern Company - Mississippi Power

Company, Kemper County, MS

Duke Energy - Cliffside Modernization

Projects, Cleveland and Rutherford

County, NC
E.ON U.S., Louisville Gas and Electric and Kentucky Utilities Co., Bedford, KY

Carson Hydrogen Power, LLC - Carson Hydrogen Power Project, Carson, CA

TX Energy, LLC - Longview Gasification and Refueling Project, Longview, TX 
Suppor for sechinolegy developmenc is one of Governmentes ios to ensure a sustainatis. secure, and afiorolable energy iucure.

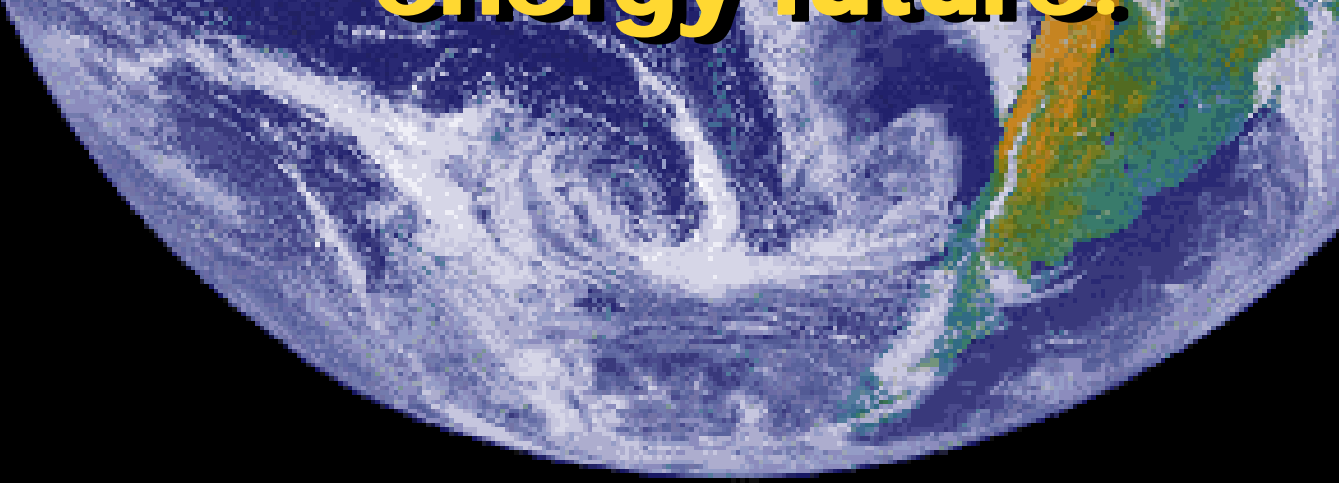




\section{Visit Our Websites}
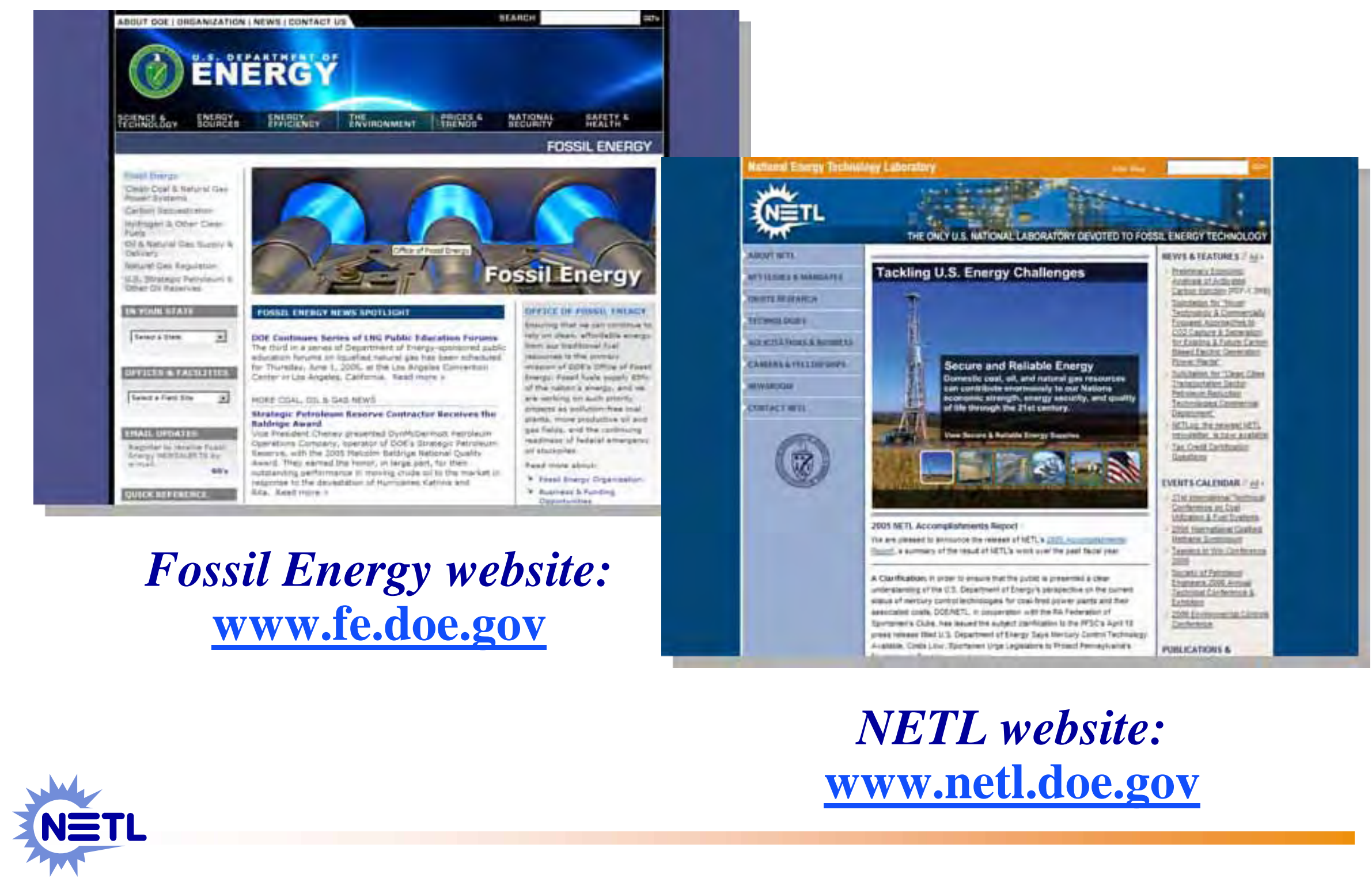

NETL website: www.netl.doe.gov 


\section{The UK Energy Research Atlas: A Tool for Prioritising and Planning Energy R\&D}

Risø I nternational Energy Conference 2007 Energy Solutions for Sustainable Development

$$
\text { 22-24 May } 2007
$$

J im Skea, Research Director 


\section{UK Energy Research Atlas}

- Why?

- What?

- Who and how?

- What next? 


\section{ENERGY RD\&D I N THE IEA}

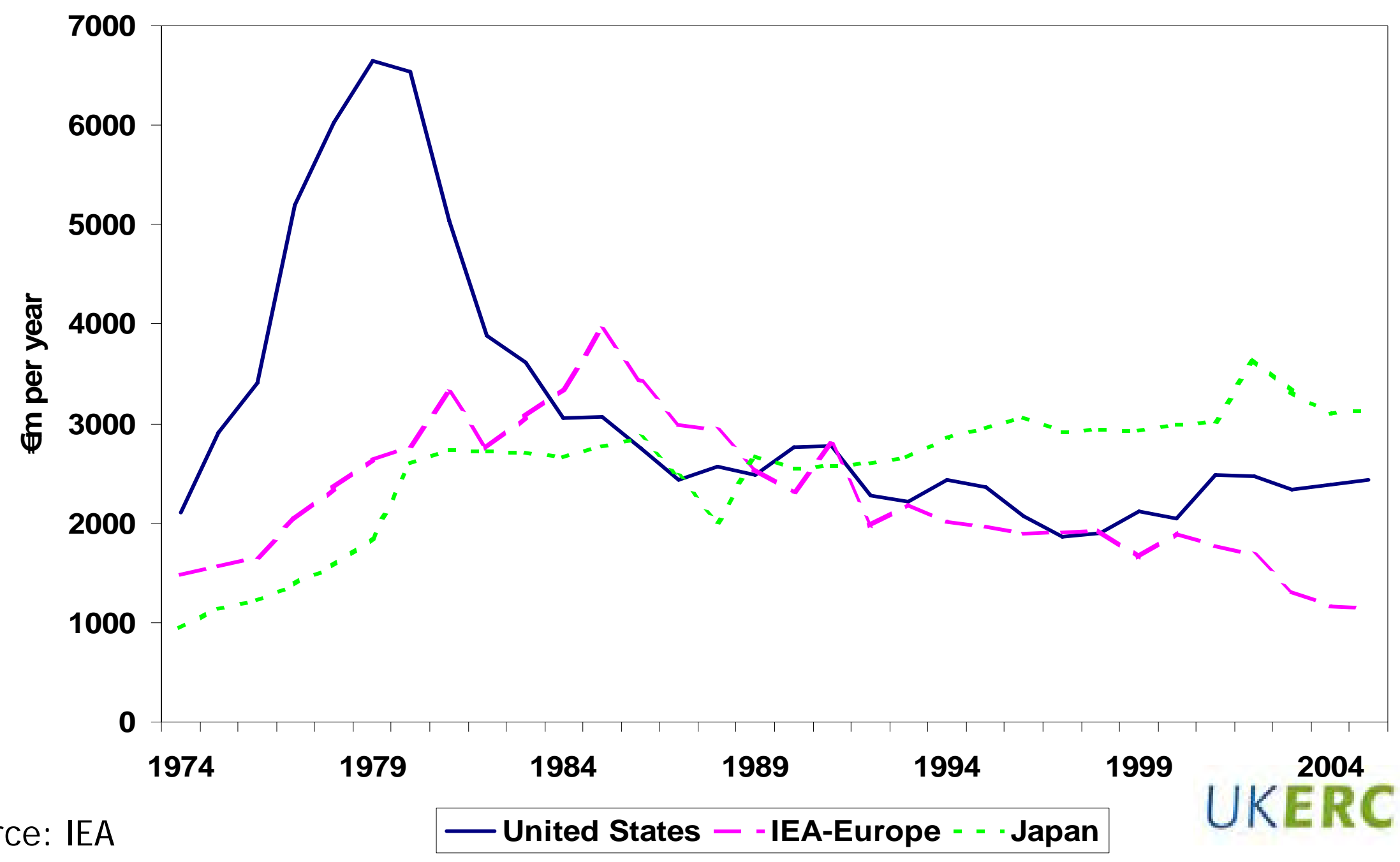




\section{UK ENERGY R\&D SI NCE 1992}

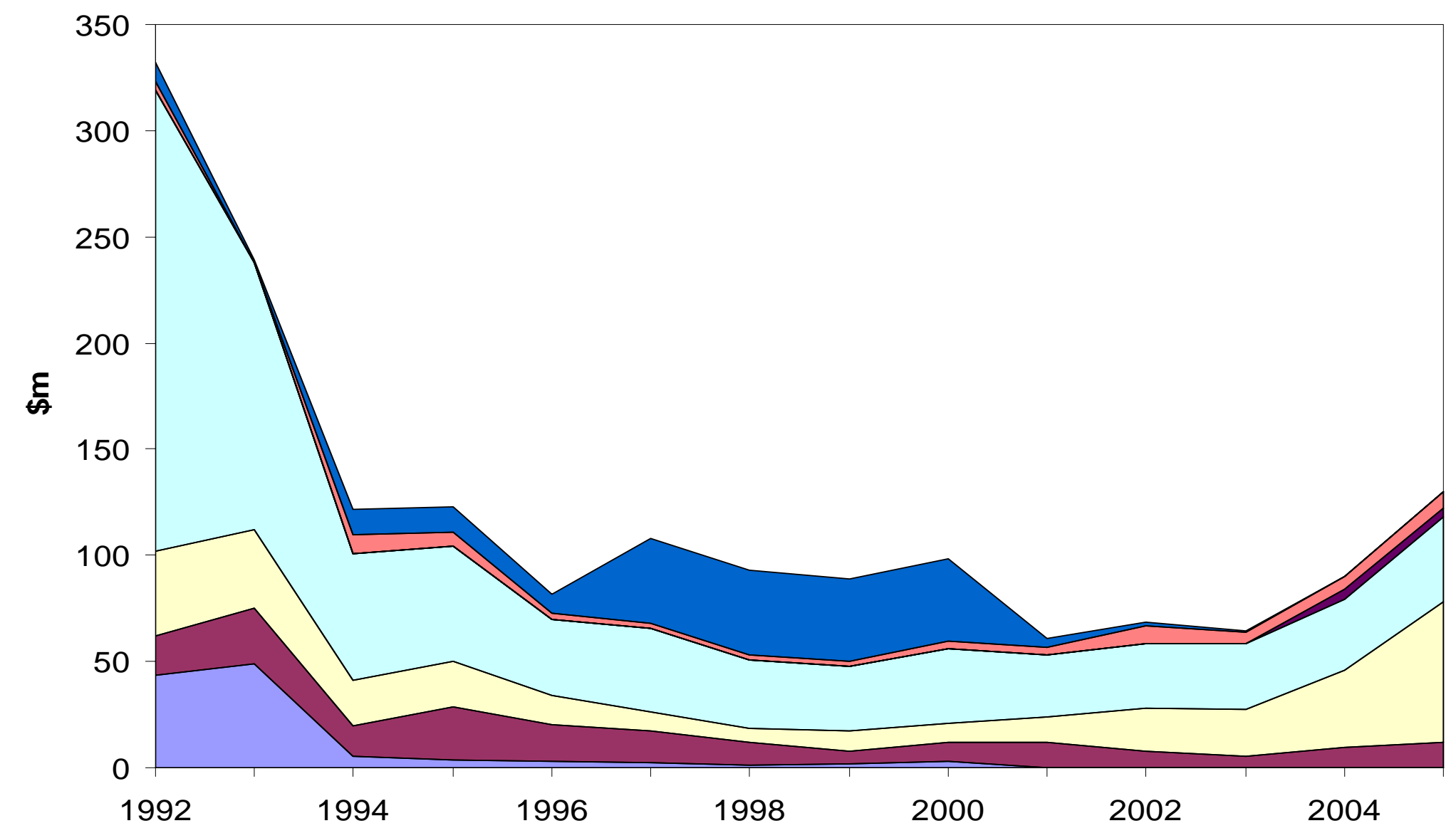

$\square$ Energy Efficiency $\quad \square$ Fossil $\quad \square$ Renewables $\quad \square$ Nuclear

$\square$ Hydrogen and Fuel Cell $\square$ Power and Storage $\quad \square$ Other 


\section{Scope}

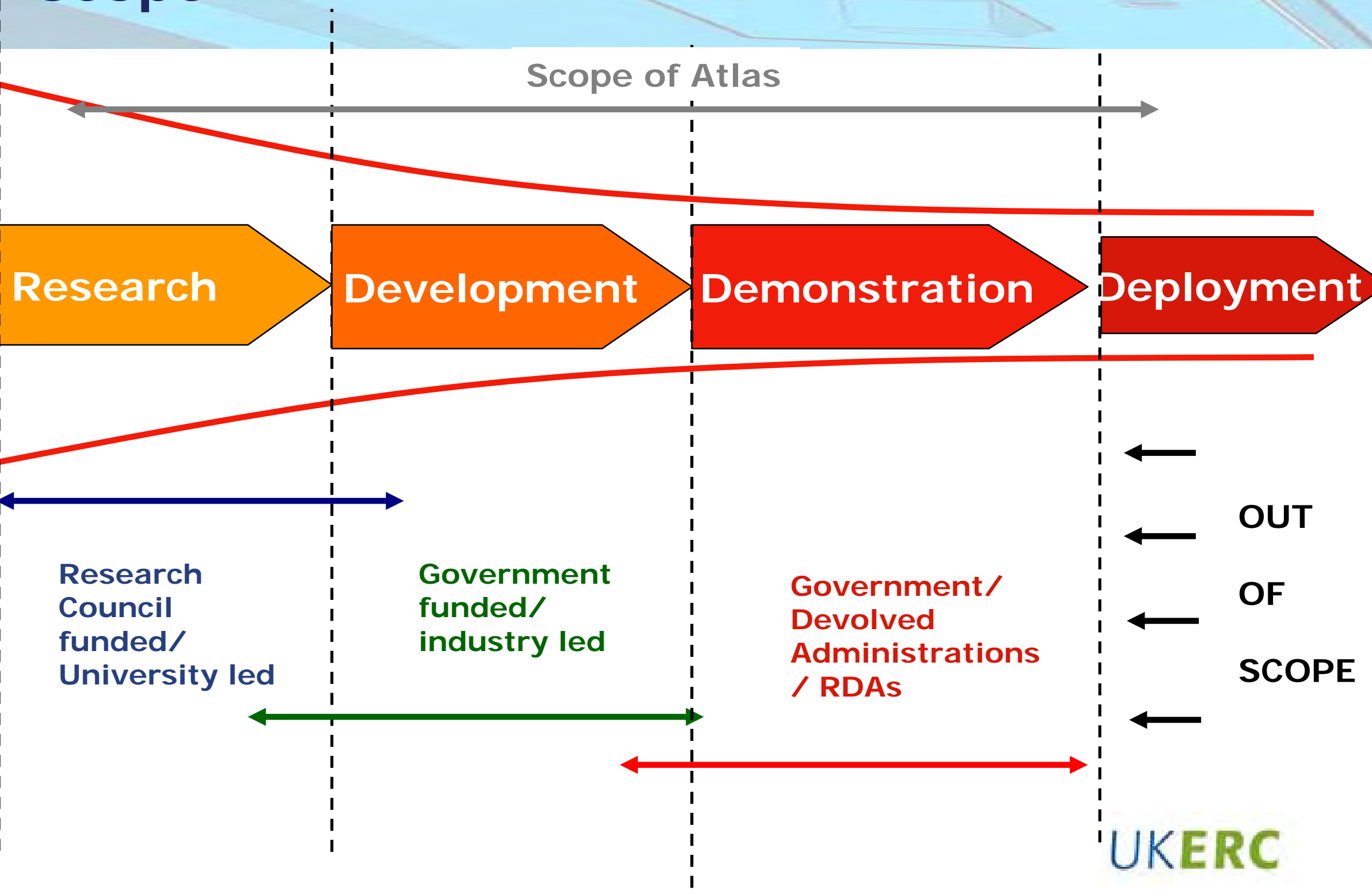




\section{ENERGY R\&D I N THE UK}

- Over-arching

- Energy Research Partnership, little resource. Thinks about the "big picture"

- University-led

- Research Councils Energy Programme (£70m pa), including UK Energy Research Centre ( $₫ 3 \mathrm{~m} \mathrm{pa}$ )

- Applied R\&D

- Department of Trade and Industry Technology Programme

- Various specific clean energy schemes

- Energy Technologies Institute, not yet up and running (up to $f 100 \mathrm{~m}$ pa, on target for $£ 60 \mathrm{~m}$ pa)

- Demonstration/Deployment

- Environmental Transformation Fund, not yet up and running, resources unclear 


\section{Why?}

- Evidence base

- Finding research partners/ providers

- Locating your own position

- Links along innovation chain

- UK and EU/ international links

\section{The first tool to show the live status of energy $R \& D$ in the UK}




\section{What?}

"an authoritative and comprehensive account of capabilities and unsolved research problems across the energy domain"

\section{Research} Landscape

characterising energy-related research activities and capabilities in the UK
Research Register an online, searchable database of energy-related awards and projects
Research Roadmaps

identifying the sequence of research problems to be overcome before new technologies can be commercially viable 


\section{EA R\&D Nomenclature}

- Energy demand

- Fossil fuels: oil, gas and coal

- Renewable energy sources

- Nuclear fission and fusion

- Hydrogen and fuel cells

- Other power and storage

- Other cross-cutting technologies and research 


\section{Accessing the Landscapes}

DUXERC Research Atlas: Landscape - Mozilla Firefox

Ele Edit Yew Go Bookmarks Iools Help

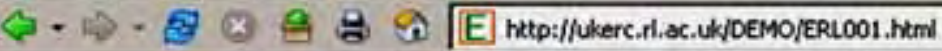

- LaNDSCAPE

b ROADMADS

P CONTACT

Guidance for landscape authora (PDF 42K)

\begin{tabular}{|l|}
\hline Area \\
\hline ENER GY EFFICIENCY
\end{tabular}

\section{Structure}

- Overview

- Capabilities Assessment

- Basic and Applied Strategic Research

- Applied Research

- Development and Demonstration Funding

- Research Facilities and other Assets

- Networks

- UK Participation in EU Activities

- International Initiatives

\begin{tabular}{|c|c|}
\hline & \multirow[b]{2}{*}{ Residential and Commercial } \\
\hline & \\
\hline & Transeart \\
\hline \multirow[t]{3}{*}{ L, GAS and COAL } & Oil and Gas \\
\hline & Coal \\
\hline & $\mathrm{CO} 2$ Capture and Storage \\
\hline \multirow[t]{7}{*}{ IY SOURCES } & Solar Energa \\
\hline & Wind Energy \\
\hline & Gesan Eneres \\
\hline & Bio-Eneray \\
\hline & Geothermal Energy \\
\hline & Hydropower \\
\hline & Other Renewables \\
\hline \multirow[t]{2}{*}{ and FUSION } & Puslear Fission \\
\hline & Nuslear Fusien \\
\hline \multirow[t]{2}{*}{ JEL CELLS } & Hudreaen \\
\hline & Eual celle \\
\hline \multirow[t]{3}{*}{ d STORAGE } & Electric pover conversion \\
\hline & Electricity transmistion and distribution \\
\hline & Energy storage \\
\hline \multirow{2}{*}{$\begin{array}{l}\text { TTING } \\
\text { RESEARCH }\end{array}$} & Energy sustem analyris \\
\hline & $\begin{array}{l}\text { Environmental, social and economic } \\
\text { impacts }\end{array}$ \\
\hline
\end{tabular}

7 (1) Go $\mathrm{Gl}$

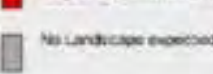

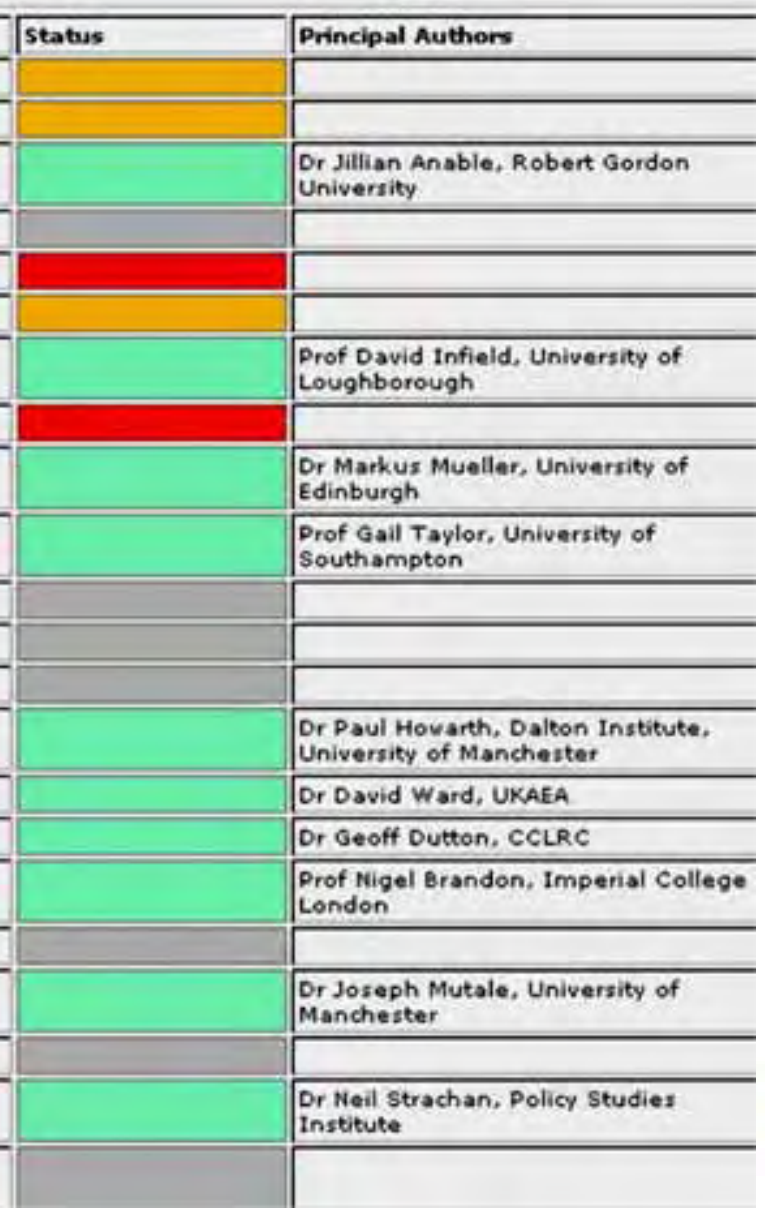




\section{Searching the Register}

\section{'UKERC Research Register : Public Access}

D UKERC HOME

D REGISTER HOME

P SEARCH THE REGISTER

P CATEGORYLIST

D RESEARCH atLas

V CONTACT REGISTER MANAGER

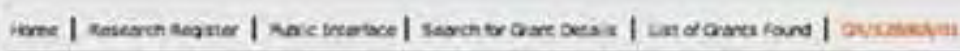

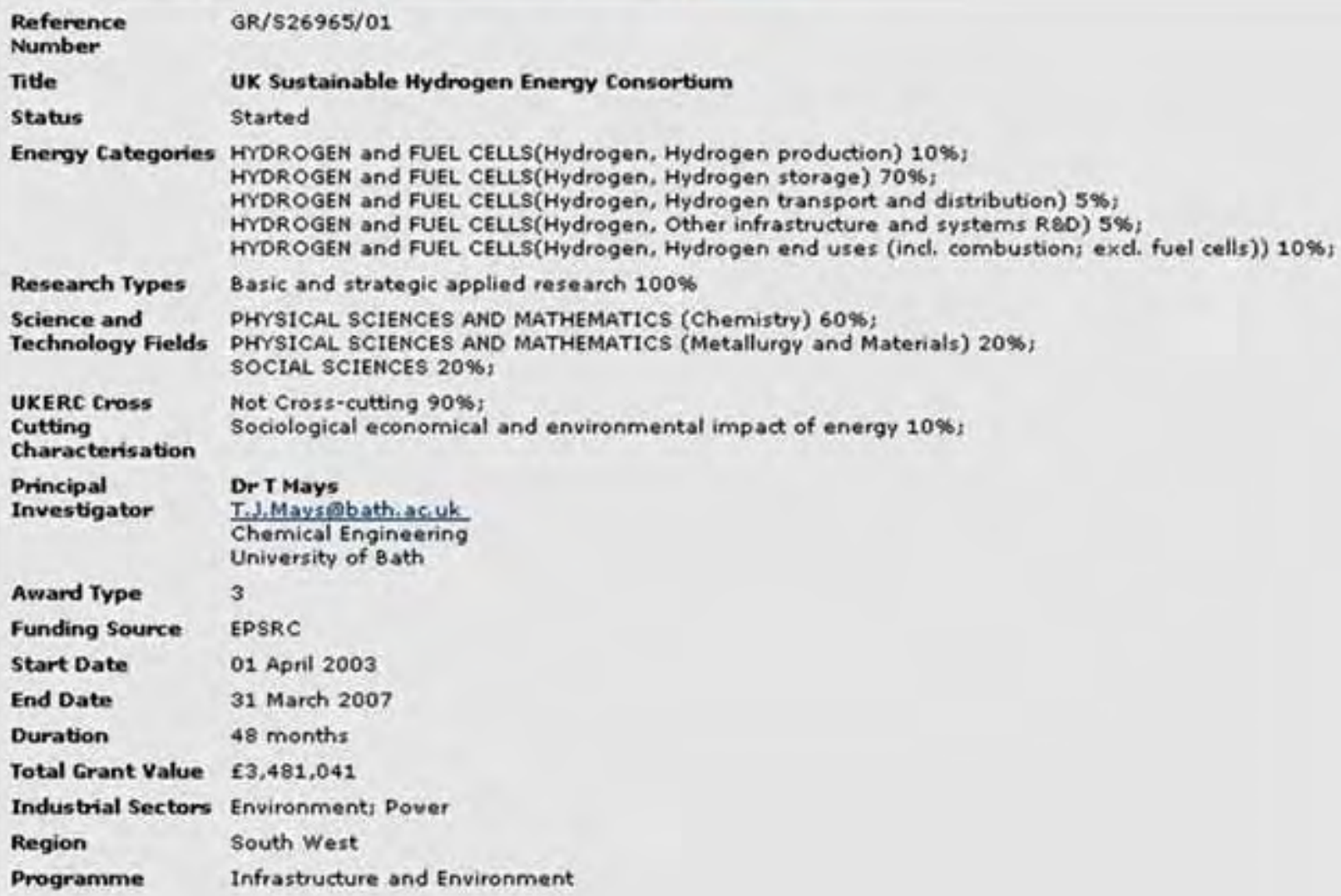

Investigators Principal Investigator Other Investigator
DrTMays, Chemical Engineering, University of Bath (99.98196)

Dr. R. Dinsdale, Sch of Applied Sciences, University of Glamorgan (0.001\%) Professor P. Fduards, Oxford Chemistry, University of Oxford $(0,001 \%)$ Pr I Gameson. School of Chemistry, University of Birmingham $(0.001 \%)$ Professer DM Grant, Sch of Mech, Materials, Manuf Eng \& Mgt, University of Nottingham 


\section{Technology Roadmap Characterisation}

\section{Bibliographic}

- weblink, geographical focus, abstract

Outputs

Architecture

- timescales, trends and drivers, enablers, performance targets, rd\&d mapping, critical assessment of capabilities

Process

- methods, stakeholder engagement, scale, re-visiting

Actions identified

- types, timescales, priorities, dependencies, responsibilities 


\section{Who Contributed and How?}

\section{UKERC researchers}

Rutherford Appleton Labs

\section{Partners:}

- UKAEA

- Dalton Institute

- Energy Helpline, UK National Contact Point

- British Coal Utilisation Research Association

\section{Atlas Advisory Group}

- UKERC plus Carbon Trust, DTI, Environmental Research Funders Forum, E.ON UK, EPSRC, Office of Science and Innovation 


\section{How It's Been Used}

- background information for presentations on the UK energy research

- information on local activities for regional development authorities etc

- evidence supporting criteria for the work programme of the new Energy Technologies Institute

- patterns of research activity for the International Science Panel on Renewable Energy

- identifying partners for establishing consortia for EU Framework Programme bids. 


\section{What Next?}

\section{The Research Atlas will never be finished....}

\section{I mmediate Tasks}

- Peer review/ community feedback

- Fill in missing Landscape/ roadmap sectors

- Synthesise existing roadmap information

- Content management system/ database development

\section{Longer Term}

- 6 monthly review cycle

- Enhance international dimension

- Private sector

- Address sectors not covered so far

- New UK-relevant roadmaps where the need exists 


\section{www. ukerc.ac. uk}




\section{E CN}

Energy research Centre of the Netherlands

European and global perspectives for CCS

Martine Uyterlinde, Heleen Groenenberg

Risø International Energy Conference, May 222007
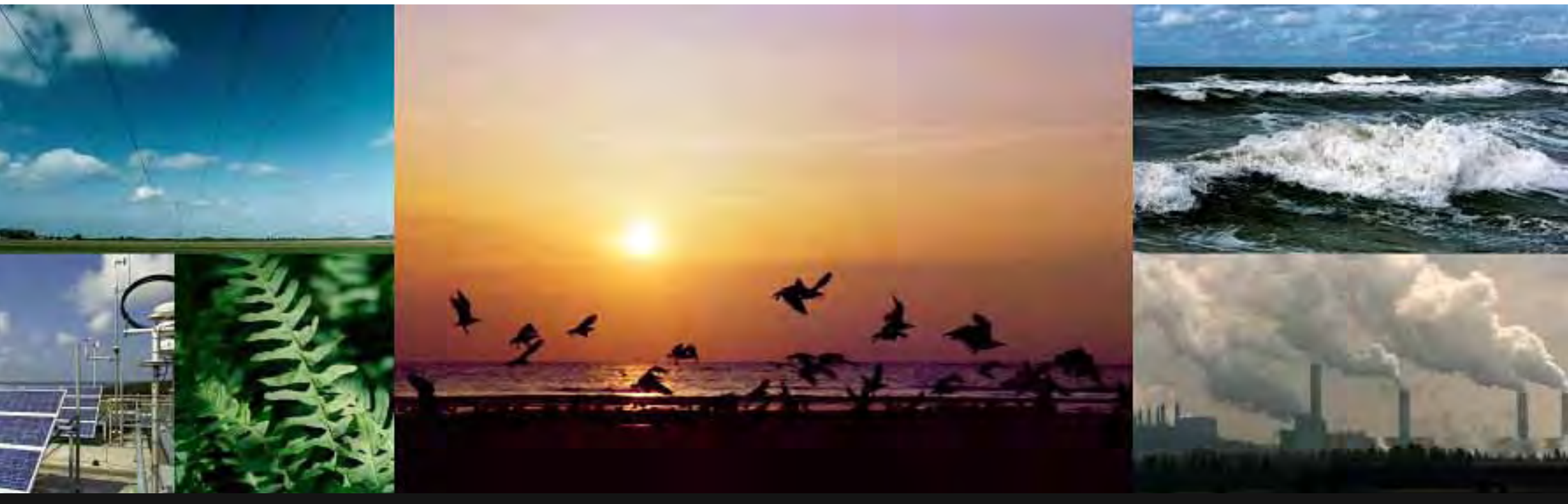


\section{Models and partners}

- MARKAL

ECN, Netherlands

- PRIMES/PROMETHEUS ICCS/NTUA, Greece

- MESSAGE

- POLES

- GMM

- PACE

- TIMES-EE, NEWAGE-W

IIASA, Austria

IPTS, Spain

PSI, Switzerland

ZEW, Germany

IER, Germany

- NEMESIS

ERASME, France

- ETP

- NEMS

IEA, France

DOE/EIA, US

- DNE21+

RITE, Japan

- AIM

NIES, Japan

- MAPLE

Natural Resources Canada 


\section{CASCADE-MINTS}

\begin{tabular}{|c|c|c|c|c|}
\hline & & down & Bot & up \\
\hline & Macro-economic & $\begin{array}{l}\text { Computable General } \\
\text { Equilibrium }\end{array}$ & $\begin{array}{c}\text { Energy System } \\
\text { Optimisation }\end{array}$ & $\begin{array}{l}\text { Integrated Energy } \\
\text { System simulation }\end{array}$ \\
\hline $\begin{array}{l}\text { Global, } \\
\text { US, Canada }\end{array}$ & & $\begin{array}{c}\text { AIM* }^{*} \\
\text { NEWAGE-W } \\
\text { PACE* }\end{array}$ & $\begin{array}{c}\text { DNE21+ } \\
\text { ETP } \\
\text { GMM } \\
\text { MESSAGE } \\
\text { PROM } \\
\text { (stod }\end{array}$ & $\begin{array}{l}\text { POLES } \\
\text { NEMS } \\
\text { MAPLE* } \\
\text { HEUS } \\
\text { stic) }\end{array}$ \\
\hline Europe & NEMESIS* & & $\begin{array}{l}\text { MARKAL Europe } \\
\text { TIMES-EE }\end{array}$ & PRIMES* \\
\hline
\end{tabular}




\section{$\mathrm{CO}_{2}$ capture and storage}

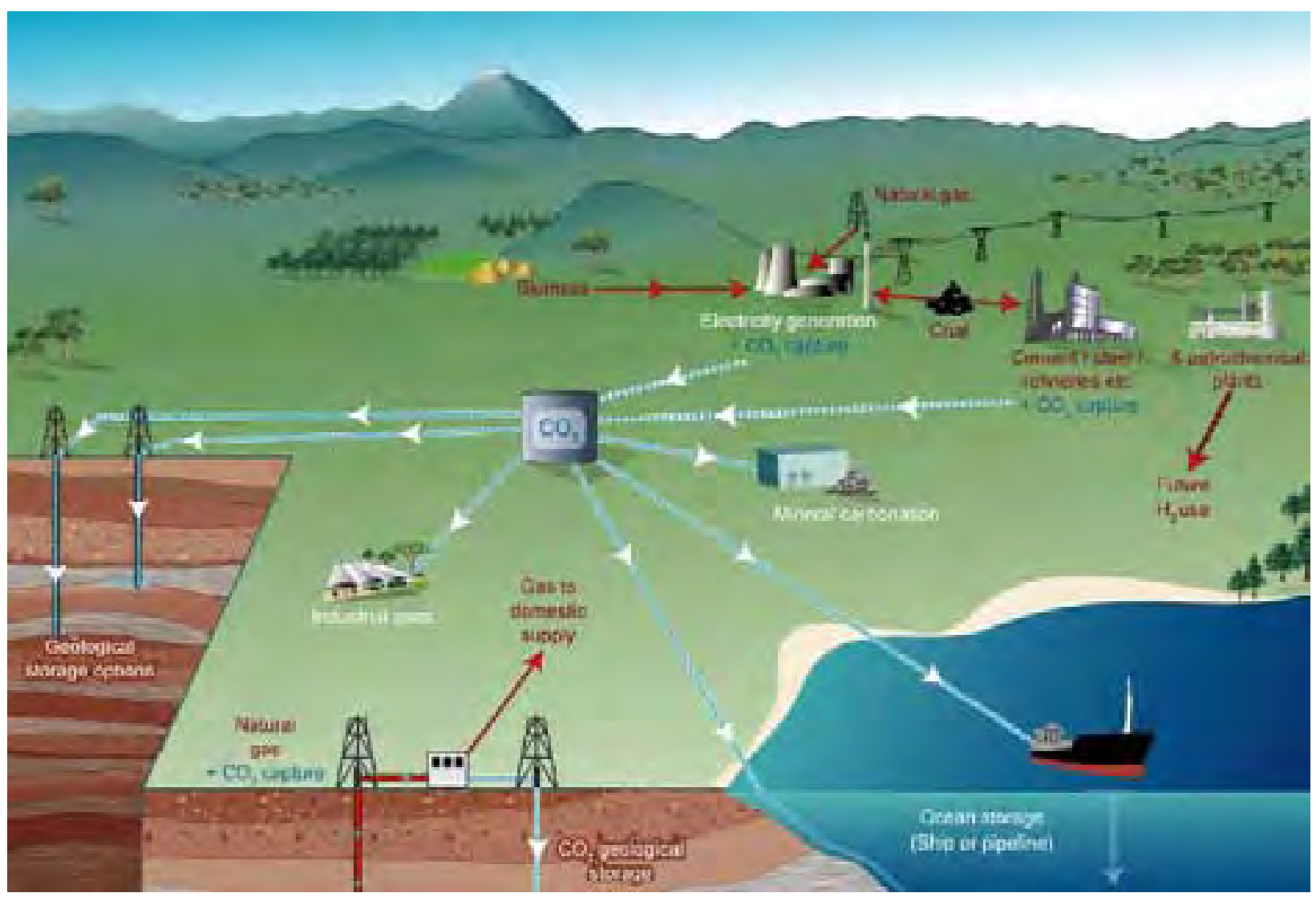

IPCC 2005 


\section{CCS in models}

- Post combustion (pulverized coal, NGCC)

- Pre combustion (IGCC, biomass gasification)

- No oxyfuel

- Some: $\mathrm{H}_{2}$, cement, cokes, ammonia

- Wide variety of storage options or

1 generic technology with infinite capacity 


\section{CCS in models (ctd.)}

Varying assumptions on:

- Investment costs

- O\&M costs

- Energy penalty

- Capture efficiency

- Learning rate
No assumptions on:

- Public acceptance

- Risks and safety regulations 


\section{Two policy approaches}

- CCS standards:

- $\mathrm{CO}_{2}$ capture obligation all new plants $>2015$

- not for peaking plants (<10 MW or utilisation < 20\%)

- not for small CHP

- $\mathrm{CO}_{2}$ emission cap:

- emission level same as CCS standards

- emissions trading only 


\section{$\mathrm{CO}_{2}$ emission cap}

- Emission level same as CCS standards

- Flexibility in technologies used

- Lower costs

- Lower penetration CCS

- More renewables and nuclear

- Shift to natural gas 


\section{CCS standards case}

[Gton CO2]

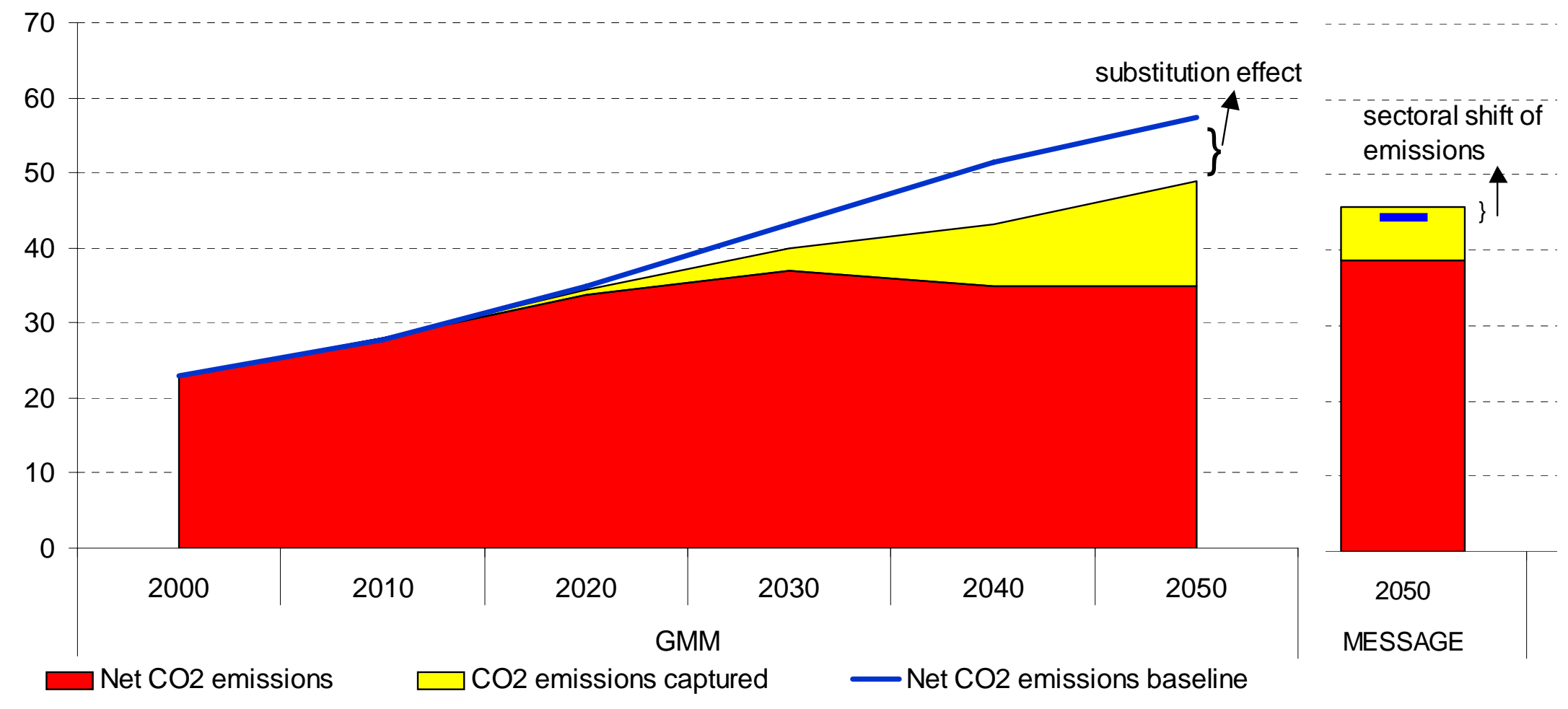




\section{CCS standards (ctd.)}

- $16-30 \%$ of global $\mathrm{CO}_{2}$ captured in 2050 (7-19 $\mathrm{GtCO}_{2}$ )

- $21-23 \%$ of total $\mathrm{CO}_{2}$ captured in Europe

- Variation due to differences in:

- projections primary energy mix

- assumptions technology learning

- future costs capture and renewables

- potentials renewables, constraints nuclear 


\section{CCS standards (ctd.)}

- Large capacities w/o CCS remain in system

- Peak gas capacity and renewables gain most

- Substitution effect: nuclear and renewables more competitive (> energy penalty)

- CCS may lead to leakage of emissions to other sectors (MESSAGE), e.g. biomass in power or more $\mathrm{H}_{2}$ from fossil fuels

- Coal-based CCS dominates, esp IGCC

- Biomass gasification negative emissions but high capital costs 


\section{$\mathrm{CO}_{2}$ storage capacity}

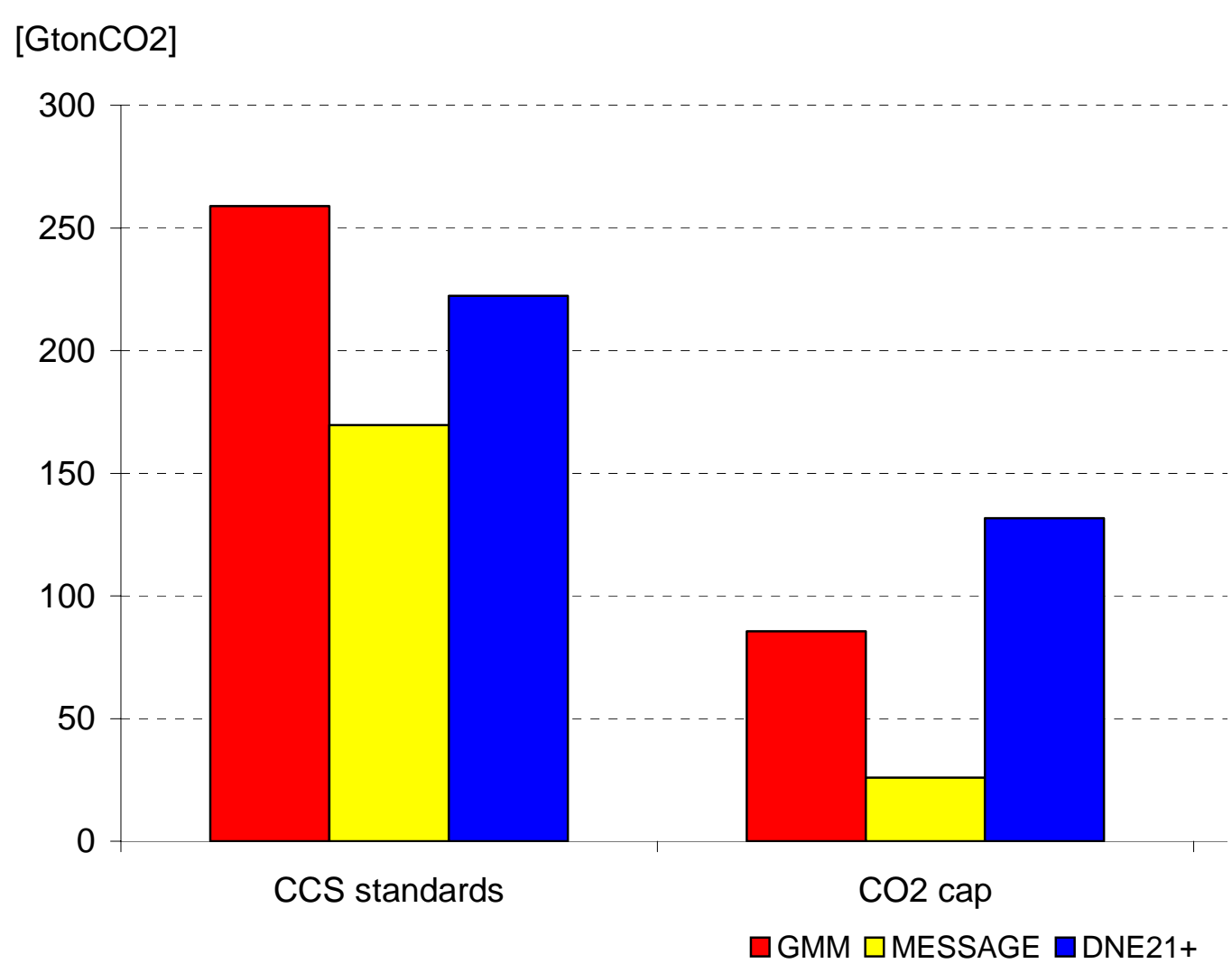

- IPCC 1995: 675-900 GtCO2 in depleted hydrocarbon fields 


\section{$\mathrm{CO}_{2}$ storage capacity (ctd.)}

[Mton]

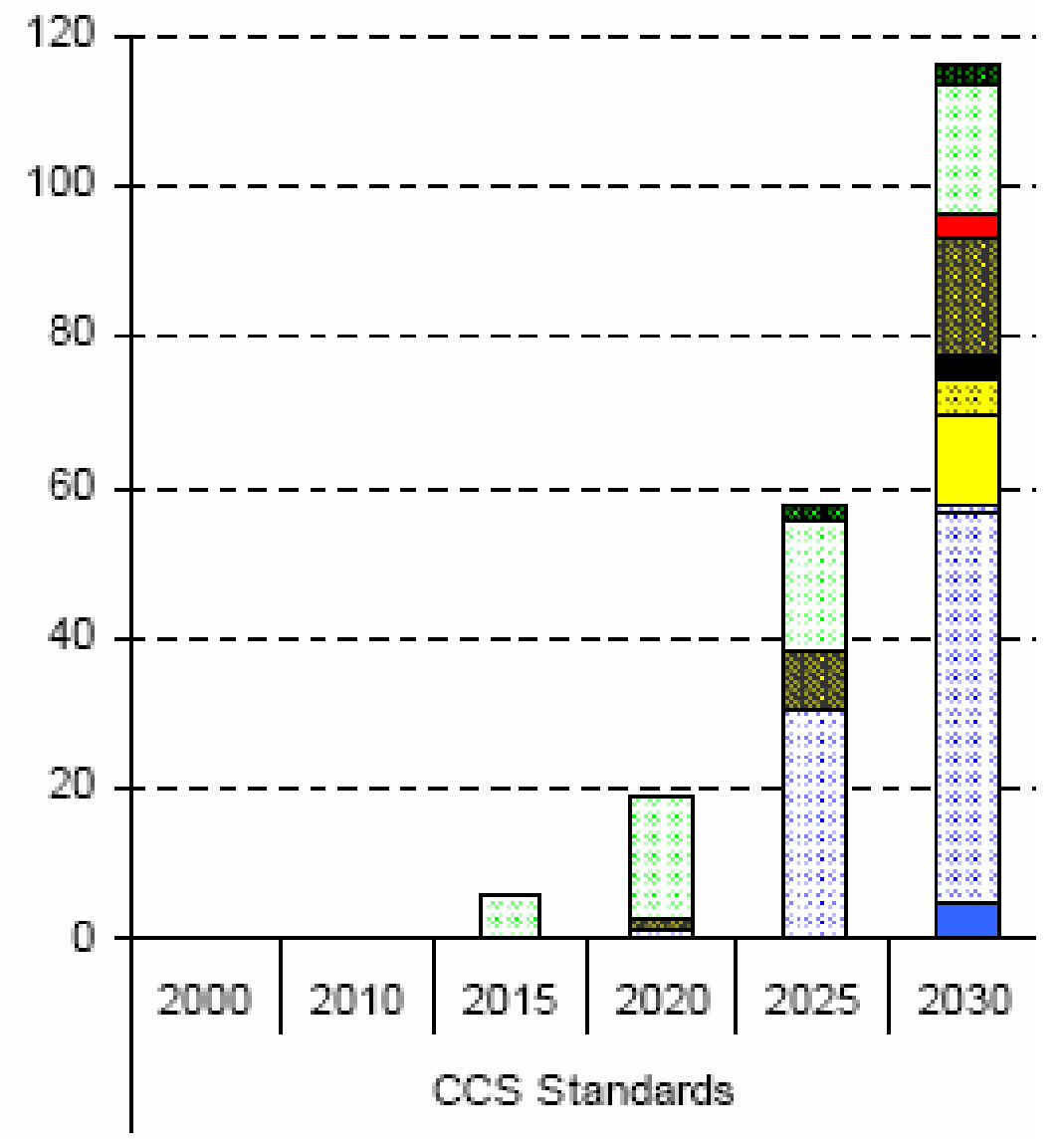

○ Slovenia

새 Hungary

$\square$ Poland

$\square$ Slovakia

○ Czech Republic

$\square$ Sweden

종 Spain

- Portugal

- Ovetherlands

$\square$ Italy

Oreece

Q Gemany

口Denmark

$\square$ Belgium

TIMES EE 


\section{EU Emissions Trading Scheme}

- Cost-effective instrument, however:

- Preference for low-cost abatement options

- Innovation market failure

- Need for complementary policies 


\section{Complementary incentives for CCS}

- CCS obligation

- Low-carbon portfolio standard + tradable certificates

- Public financial support

- Investment support

- Feed-in subsidies

- $\mathrm{CO}_{2}$ price guarantee 


\section{Interaction}

\section{complementary incentives $\leftrightarrow$ ETS (ctd)}
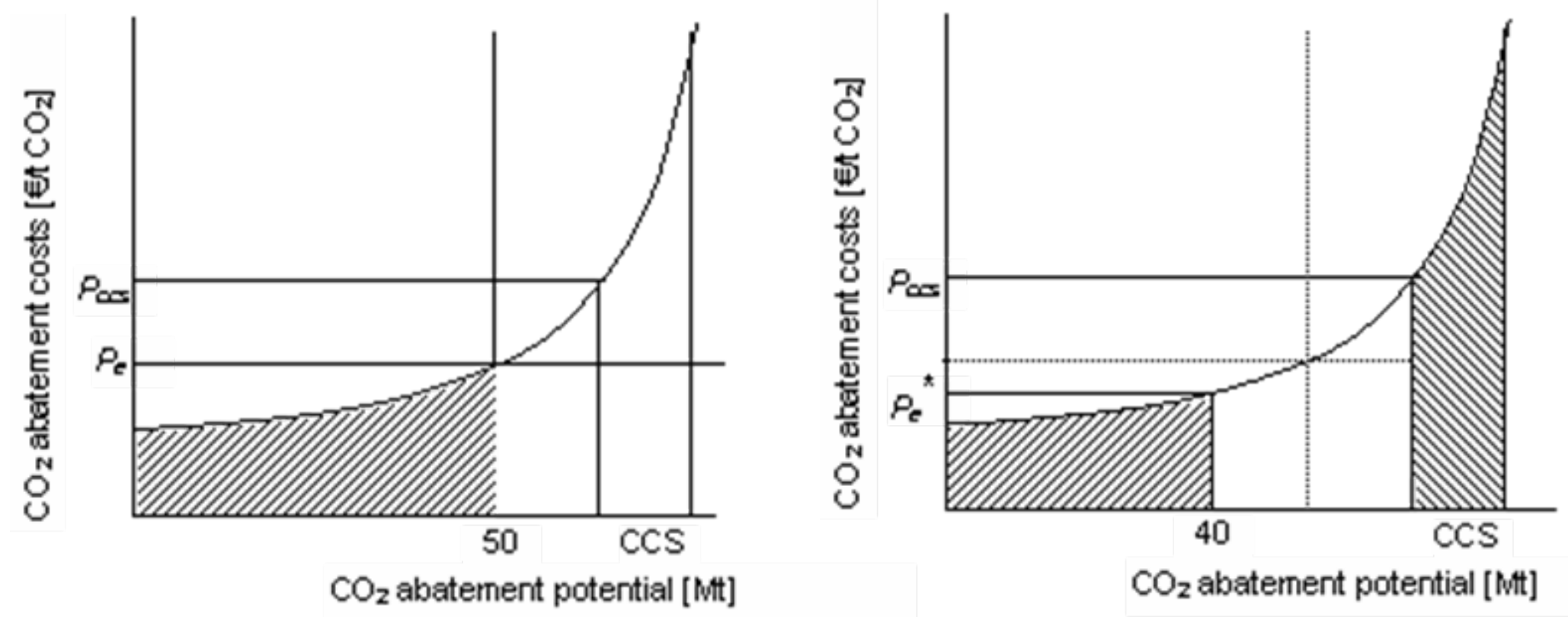

Any additional instrument will reduce demand for EUAs and lower $\mathrm{CO}_{2}$ market price unless cap is lowered accordingly 


\section{Interaction complementary incentives $\leftrightarrow$ ETS (ctd)}

- MS incentives small scope; less market impact

- Any additional instrument will reduce demand for EUAs and lower $\mathrm{CO}_{2}$ market price unless cap is lowered accordingly

$\rightarrow$ Lower cap in MS

$\rightarrow$ New entrants: no or limited allowances 


\section{Interactions \\ complementary incentives for CCS}

Renewable energy:

Diversion of resources + attention

$\rightarrow \%$ renewables contingent on CCS implemented

Innovation:

Cost reduction discouraged

$\rightarrow$ Obligation

Electricity market:

Technical reasons for placing CCS as baseload option, however O\&M cost lead to higher electricity price Security of energy supply:

CCS only contributes if gas prices spur a shift to coal, and $\mathrm{CO}_{2}$ prices are high enough for CCS 


\section{Conclusions}

- Up to $30 \%$ of global $\mathrm{CO}_{2}$ captured and stored in 2050

- Up to 22\% in Europe (slower growth power sector)

- Penetration renewables and nuclear accelerated if CCS is mandatory

- ETS cost-effective incentive for $\mathrm{CO}_{2}$ reduction, however market failures and low prices may hinder CCS deployment

- Interaction of complementary incentives with ETS requires cap adjustment 


\section{Thank you}

http://www.ecn.nl/en/ps/researchprogramme/energy-scenarios/cascade-mints/

The CASCADE MINTS project is funded by the EU under the Scientific Support to Policies priority of the Sixth RTD Framework Programme

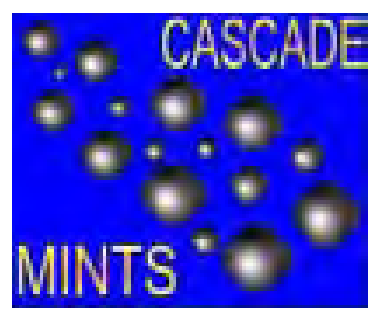

Martine Uyterlinde: uyterlinde@ecn.nl Heleen Groenenberg: groenenberg@ecn.nl 


\section{Solar Energy}

\section{Status and Perspectives}

\section{By Peter Ahm, Director, PA Energy A/S}

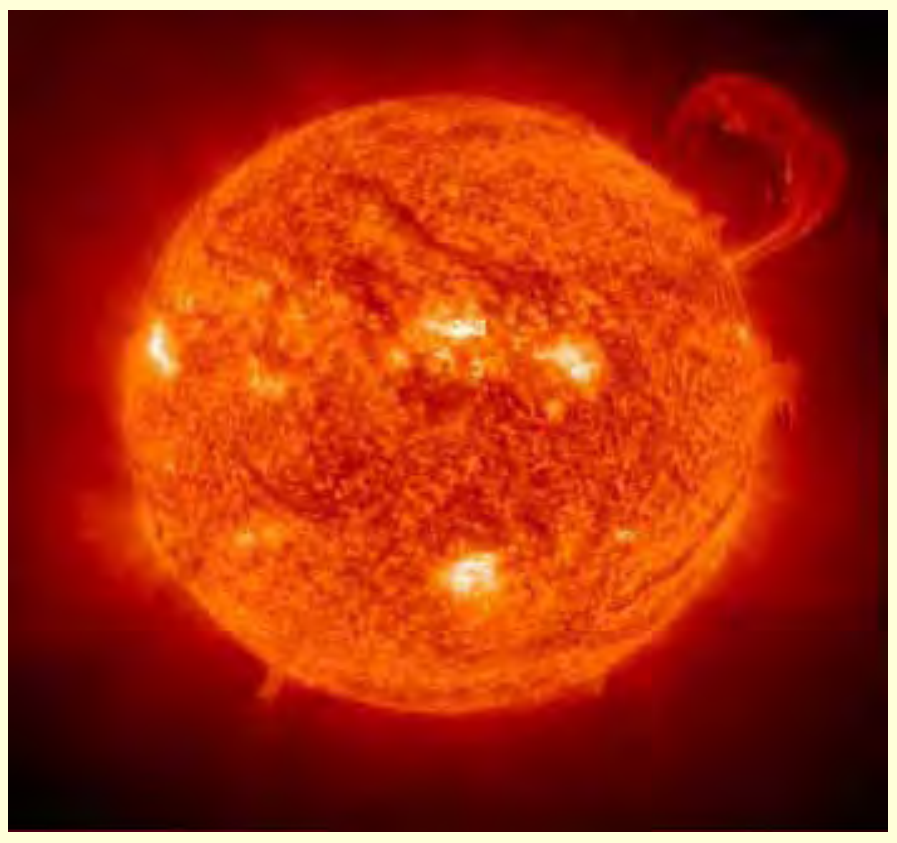




\section{The Potential for Solar Energy}

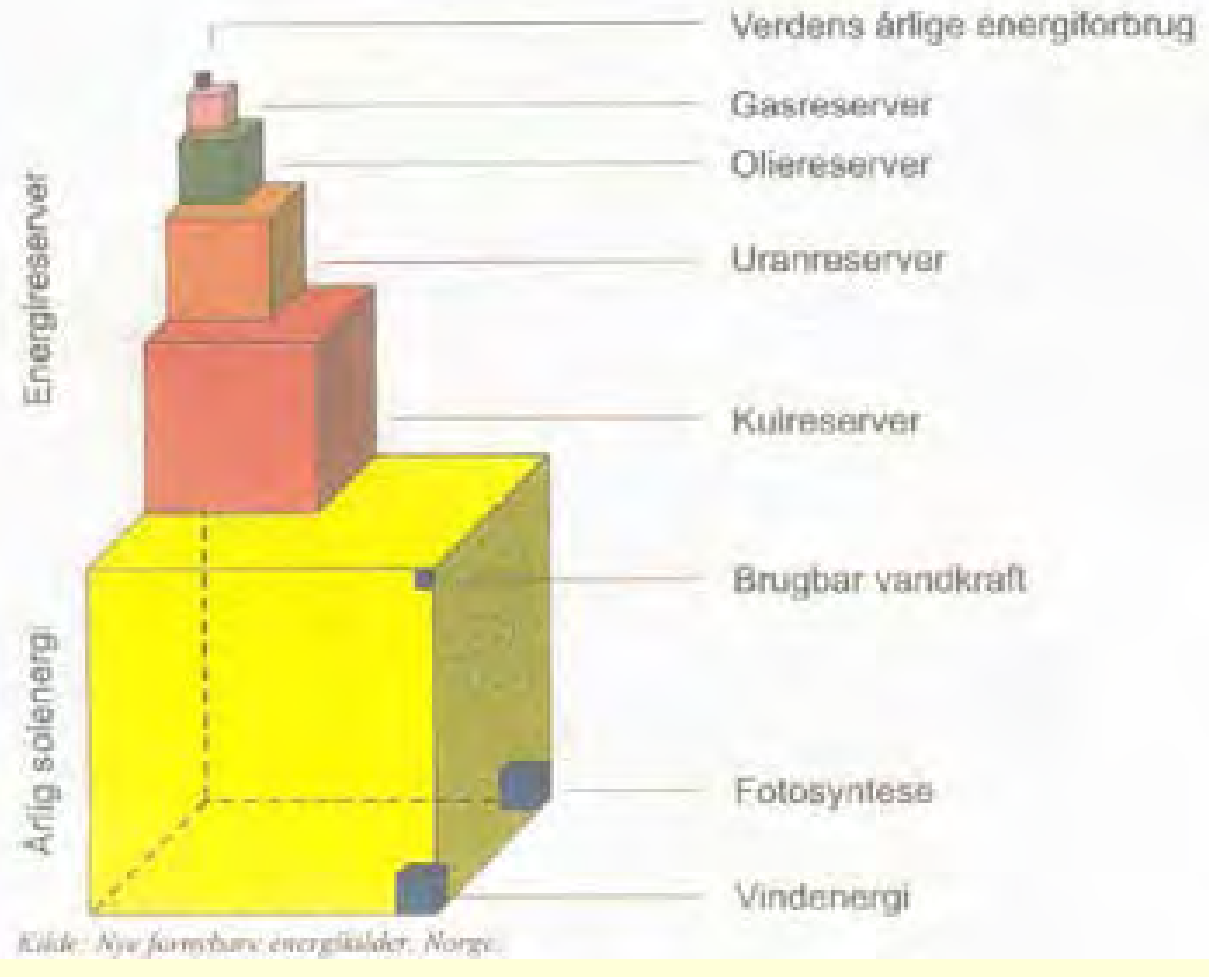

One hour's sunshine $\sim$ the global annual energy supply 


\section{Solar Energy}

\section{in the World Energy Supply}

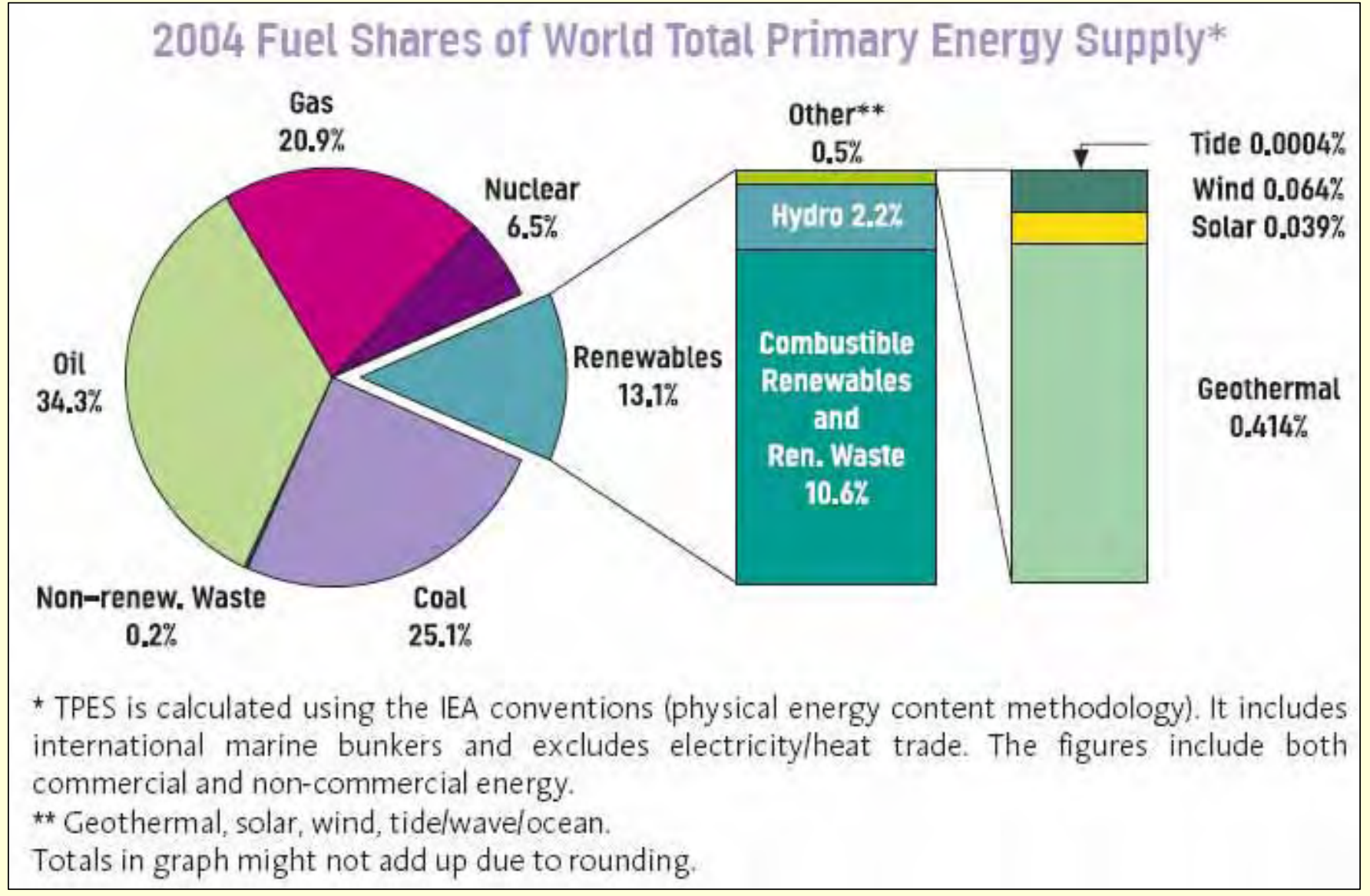

Source: IEA

Solar Energy - Status \& Perspectives 


\section{RE Characteristics}

\begin{tabular}{|c|c|c|c|}
\hline & $\begin{array}{c}\text { World electricity } \\
\text { production } \\
2003 \text { (TWh) }\end{array}$ & $\begin{array}{c}\text { Electricity } \\
\text { generation costs } \\
2003(€ \text { cents } / \mathrm{kWh})\end{array}$ & $\begin{array}{c}\text { World estimated technical } \\
\text { annual generation potential } \\
\text { (heat \& electricity) } \\
\left(\mathrm{x} 10^{3} \mathrm{TWh}\right)\end{array}$ \\
\hline Hydroelectricity & 3000 & $2-8$ & 14 \\
\hline Bio-energy & 175 & $5-6$ & $77-124$ \\
\hline Wind energy & 75 & $4-12$ & 178 \\
\hline Geothermal power & 50 & $2-10$ & 1400 \\
\hline Marine energy & 0.5 & {$[8-15]^{*}$} & No number available \\
\hline Solar thermal energy & 0.8 & $12-18$ & \\
\hline PV & 2,5 & $25-65$ & 440 \\
\hline Total & $\begin{array}{c}3300 \\
\text { Total electricity } \\
\text { consumption: } \\
15 \text { 000 }\end{array}$ & & $\begin{array}{c}>2100 \\
\text { Current global energy } \\
\text { consumption: } 110\end{array}$ \\
\hline
\end{tabular}

* estimated costs as no commercial plant is yet in production 


\section{RE Growth Rates}

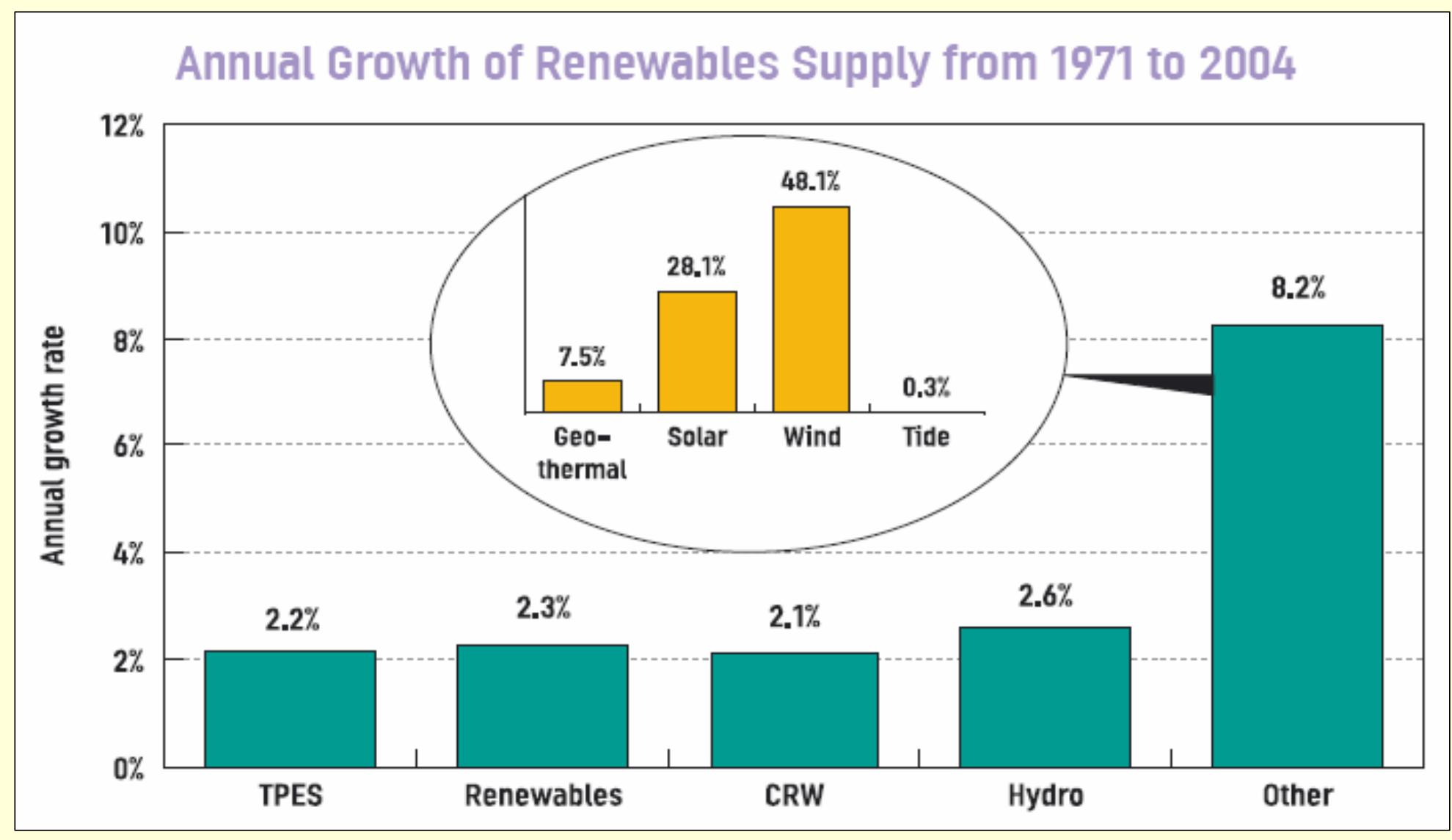

Solar Energy - Status \& Perspectives

PA Energy A/S 


\section{Solar Energy Technologies}

- Photovoltaics (PV) - electricity

- Solar Hot Water System (SHW)
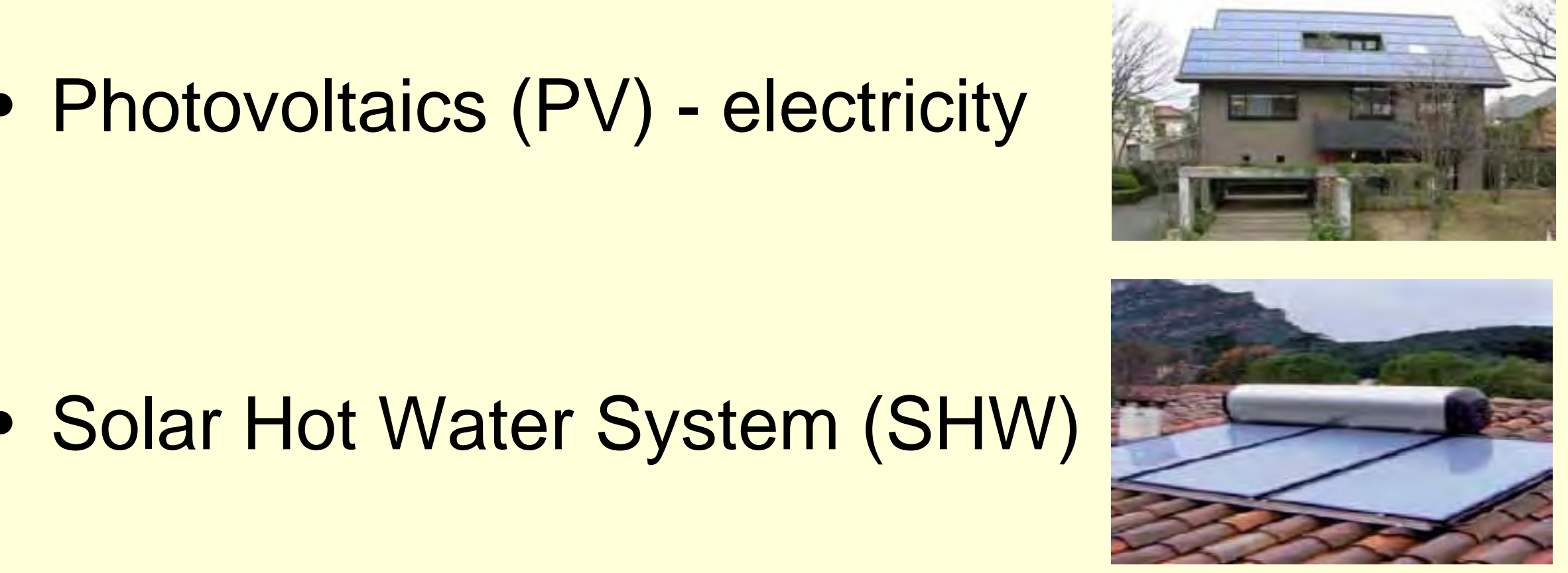

- Concentrated Solar Thermal (CST) - electricity

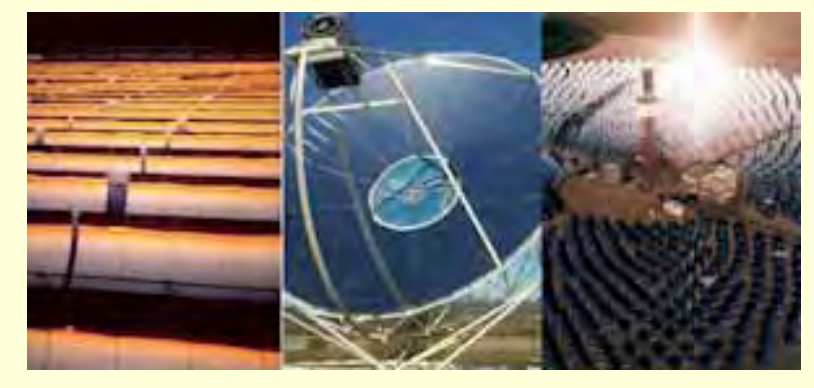




\section{Presentation: Focus on PV}

1. Status of technology

a) Technology development

b) Market development

2. Drivers \& trends in development

3. Challenges, or problems, facing progress 


\section{Generation PV's}

- Based on mono- og poly-crystalline $\mathrm{Si}$

- In $2006 \sim 90 \%$ of the market, poly-X alone

$>50 \%$

- Expected in 2015 to cover $>50 \%$ of the market

- Efficiency: 15-20\%

- The PV sector "work

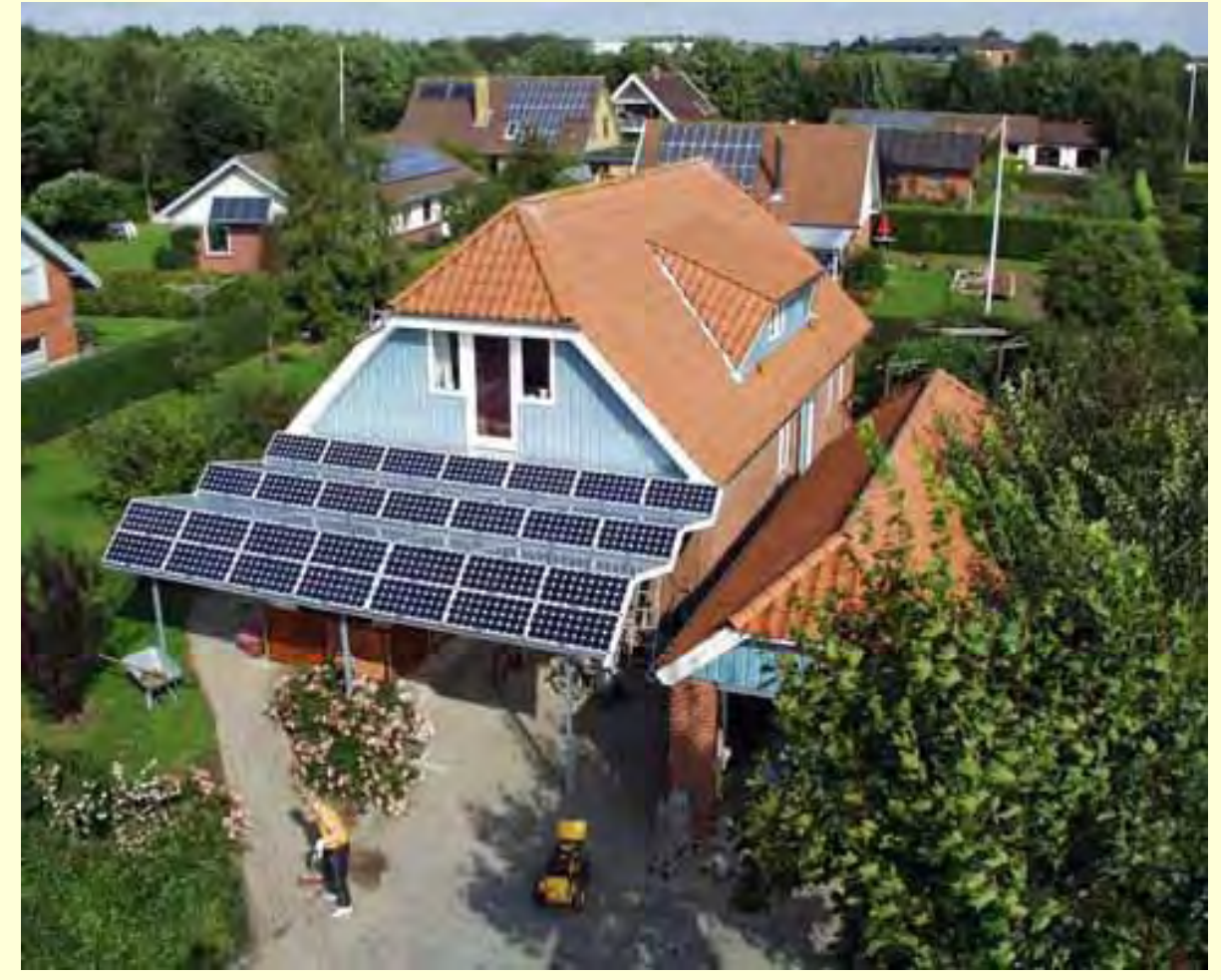
horse" 


\section{Generation PVs}

- Thinfilm types

- Si, CdT, CIS etc.

- Promising techology

- Potentially cheap

- Little materials

- Mass production

- Problem

- Manufacturing

- Stability

- Efficiency: 7- $15 \%$

- Time horizon: +2010

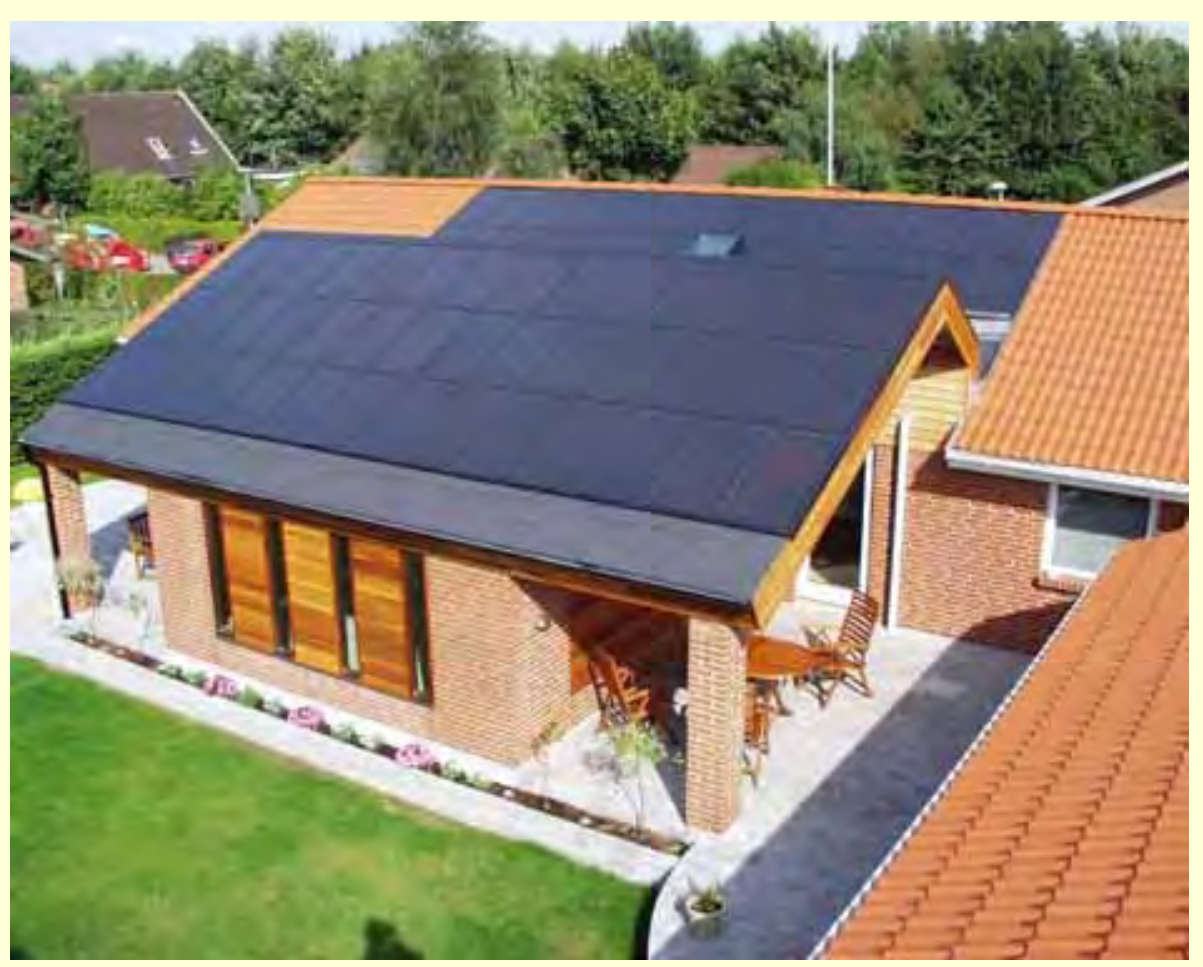




\section{Generation PVs}

- High-efficiency thinfilms

- stacked types: 30-60 $\%$ efficiency

- PEC types

- Polymer based types

- Time horizon: more than 15 years for commercial products (PEC on the market)

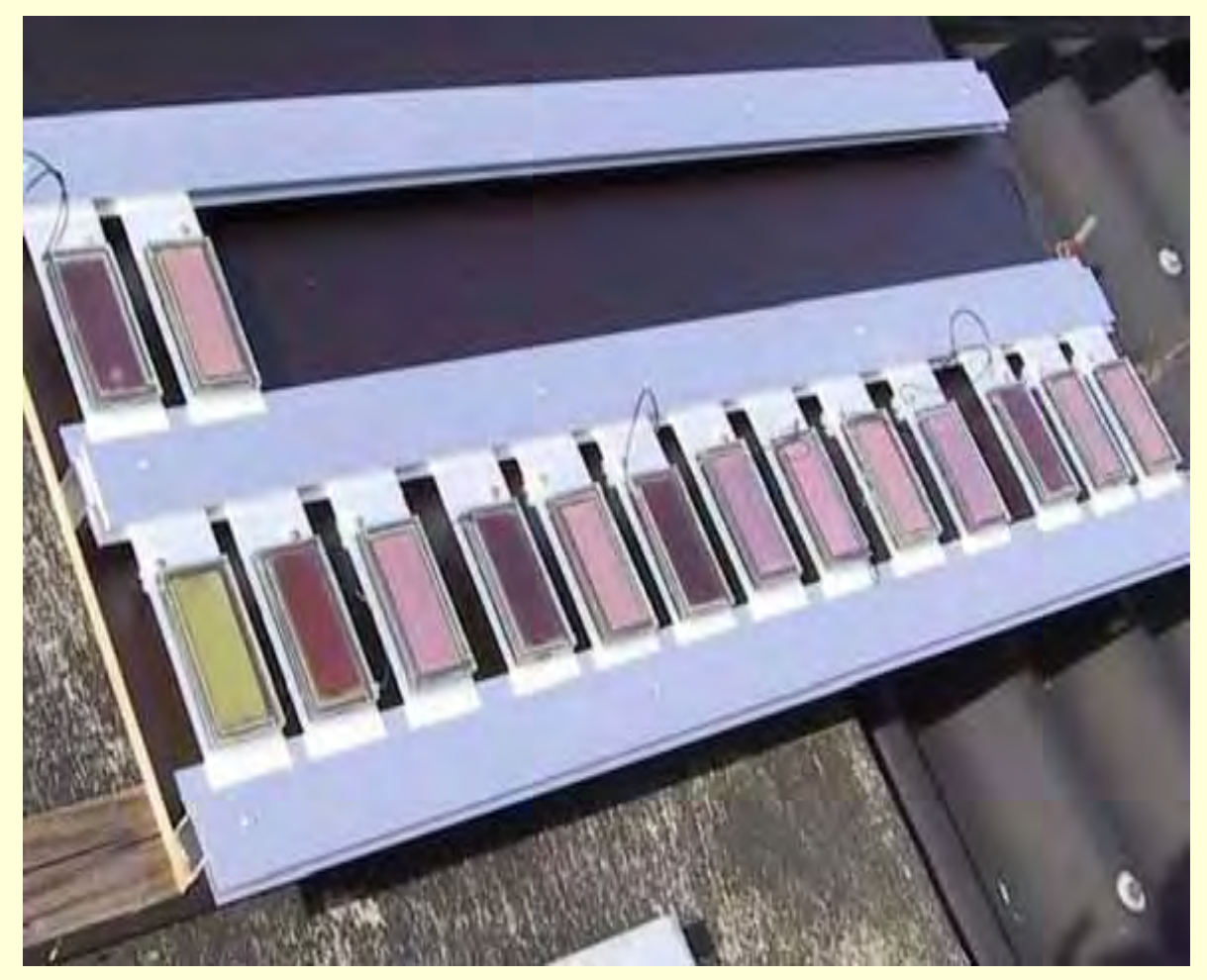




\section{PV Technology Trends}

Trends in market share per main PV technology

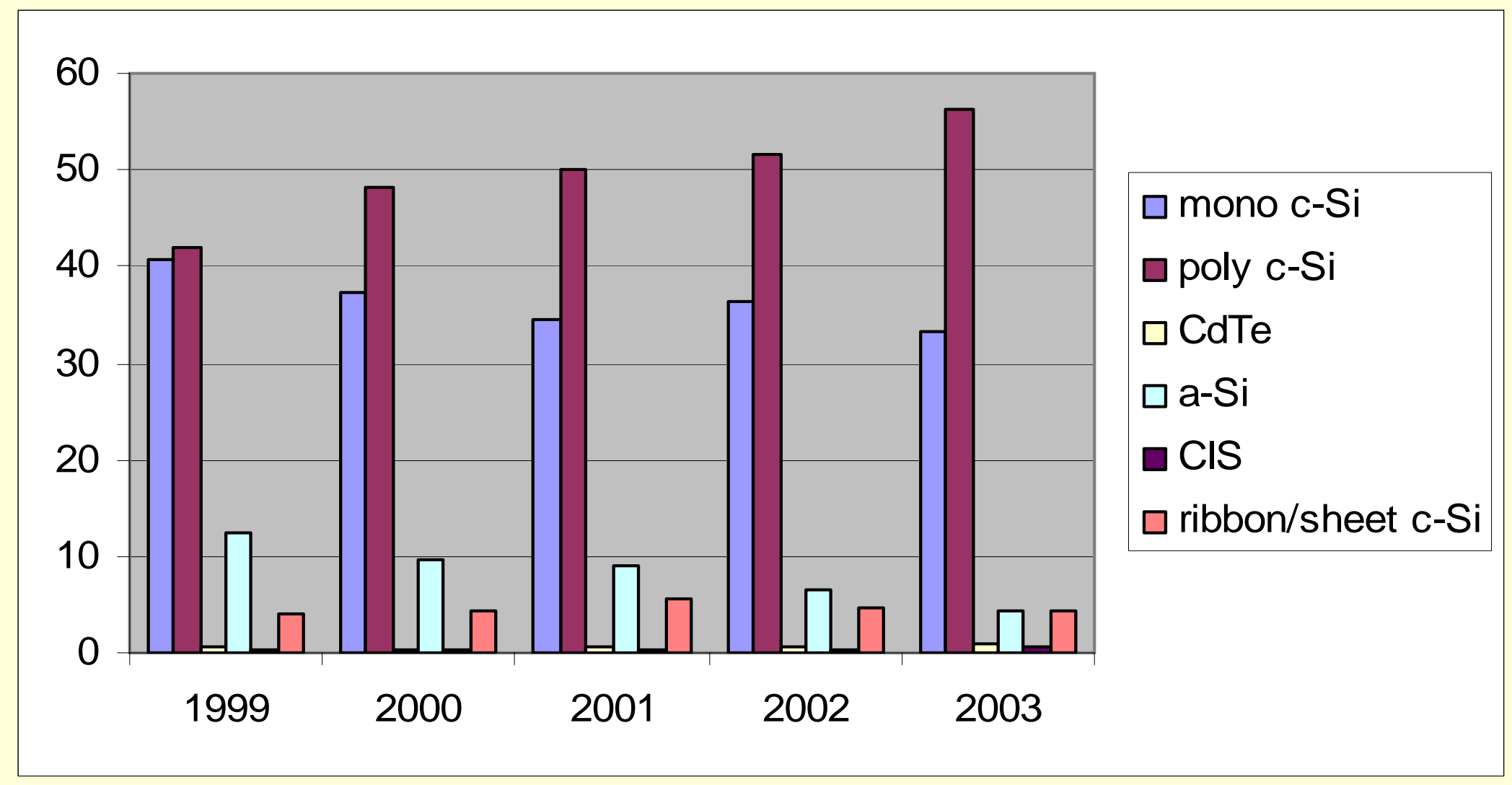




\section{Market Development 1}

- Annual growth rate since 2000 around $40 \%$

- Market value (global): >15 billion $€$ (as wind energy)

- Cell production in 2006: 2,5 GW

- Expected module production in 2010: 6-8 GW)

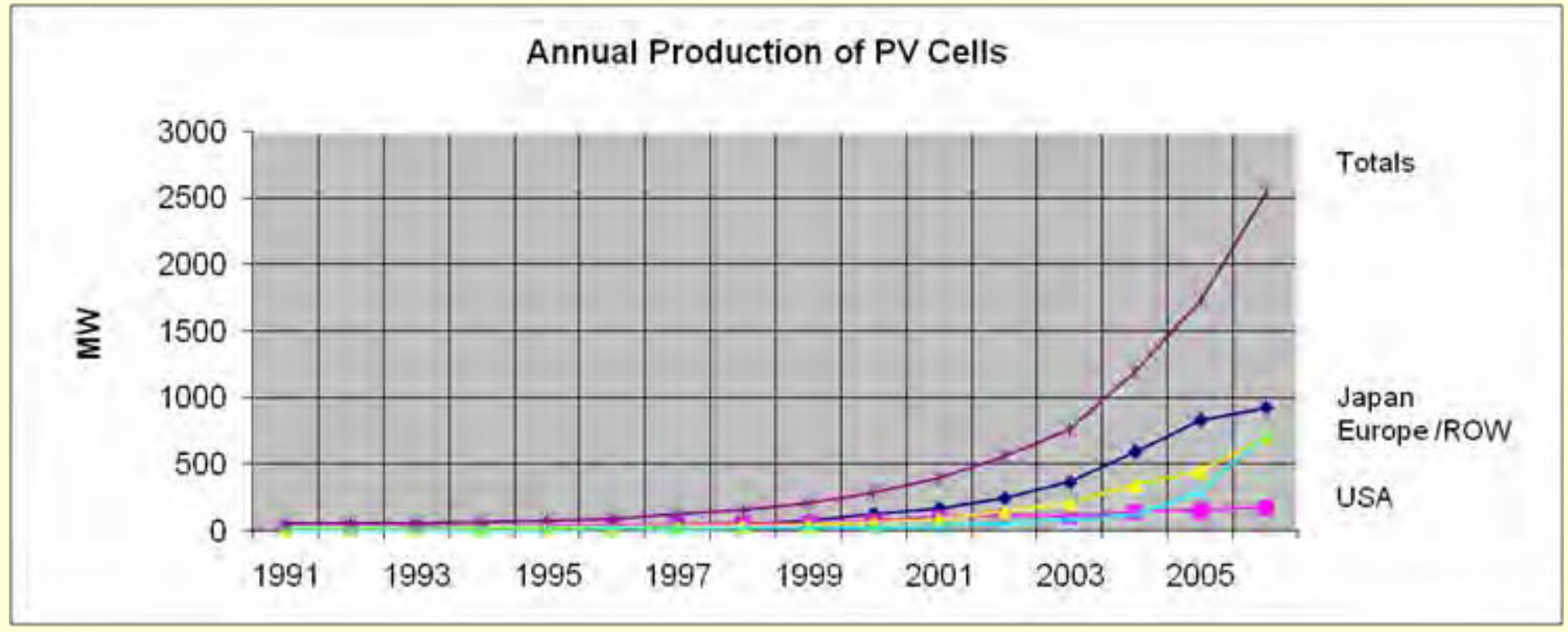

Solar Energy - Status \& Perspectives 


\section{Market Development 2 Annual growth rates in \%}

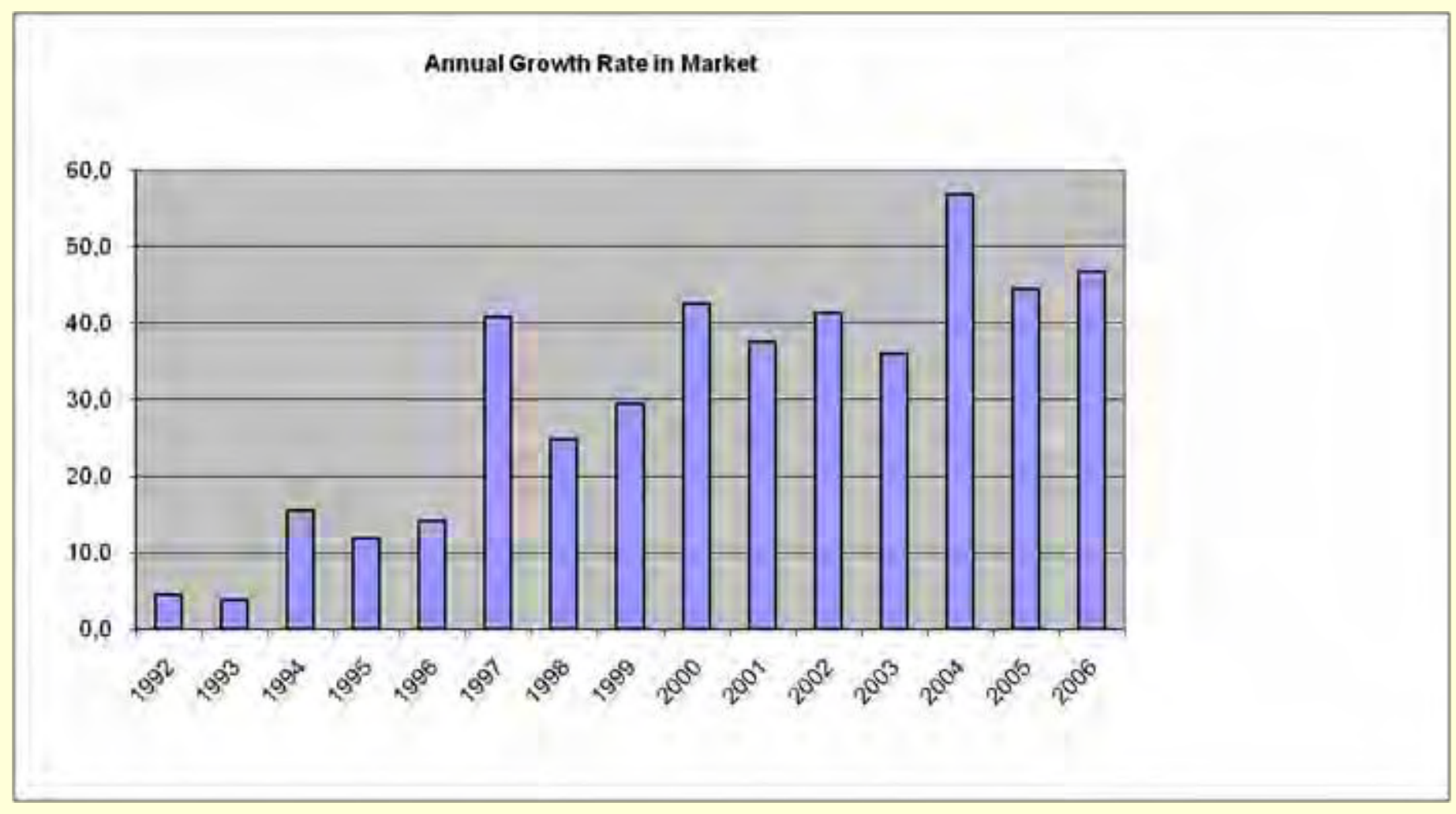




\section{Trends in Efficiency}

\section{Reported max. $\eta: 37$ \% (Emcore 2007)}

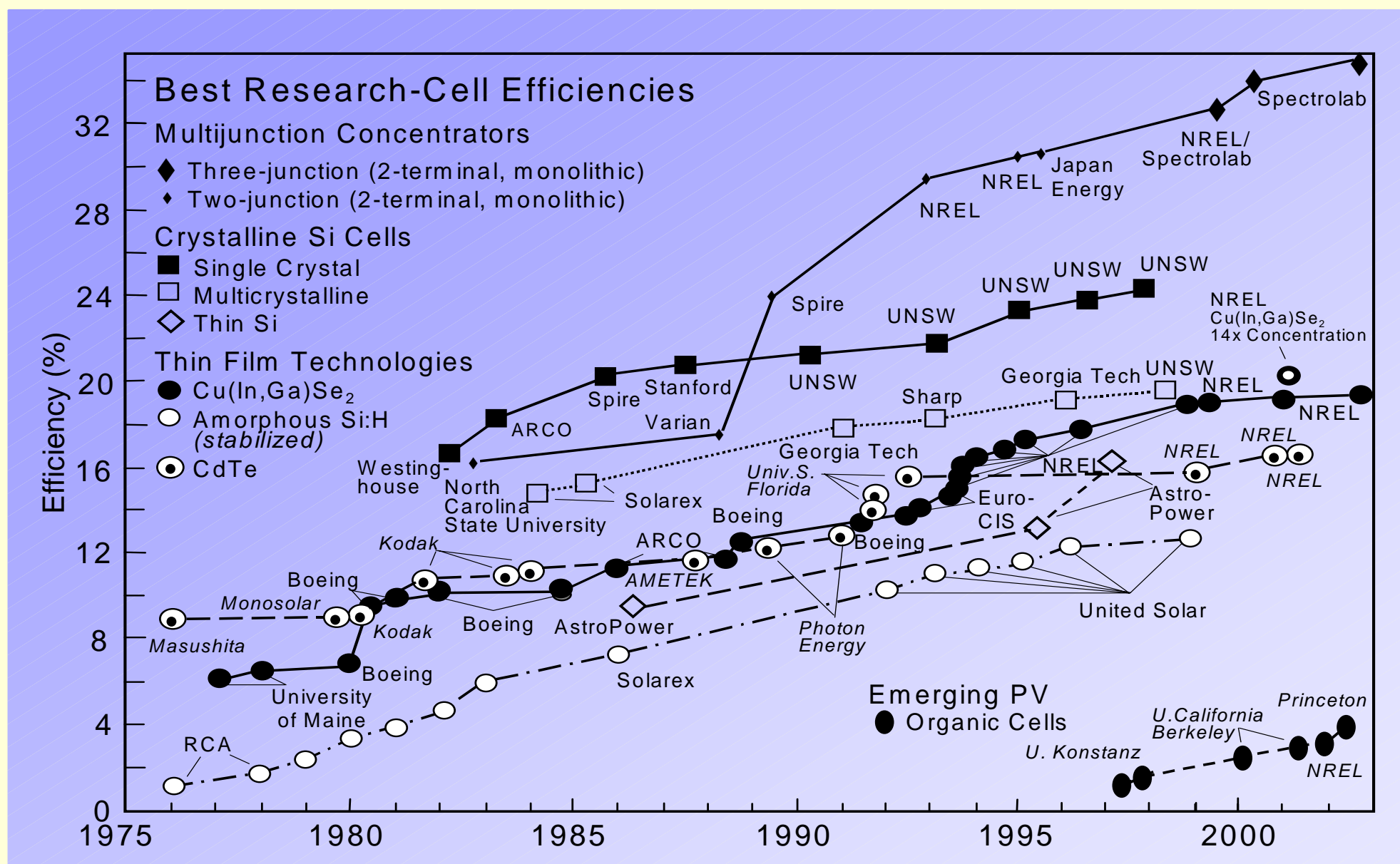

Solar Energy - Status \& Perspectives 


\section{Job Creation in Energy}

Table 3. Direct jobs in energy production.

\begin{tabular}{|c|c|c|}
\hline Sector & $\begin{array}{l}\text { Jobs. year } / \text { MTOE } \\
\text { (fuel production) }\end{array}$ & $\begin{array}{l}\text { Jobs - year / Terawatt-hour } \\
\text { (fuel production + power generation) }\end{array}$ \\
\hline Petroleuma & 396 & 260 \\
\hline Offshore oil ${ }^{a}$ & 450 & 265 \\
\hline Natural gas ${ }^{a}$ & 428 & 250 \\
\hline Coala & 925 & 370 \\
\hline Nuclear ${ }^{b}$ & 100 & 75 \\
\hline Wood energyc & & $733-1067$ \\
\hline Hydrod & & 250 \\
\hline Minihydroe & & 120 \\
\hline Wind & & $918^{(e)}-2,400^{(f)}$ \\
\hline Photovoltaics & & $29,580^{(e)}-107,000^{(e)}$ \\
\hline Bioenergy (from sugarcane) ${ }^{h}$ & & $3,711-5,392$ \\
\hline
\end{tabular}

Sources: (a) Grassi [1996]; (b) Electric Power International [1995] apud Grassi [1996] ${ }^{1}$; (c) Grassi [1996] ${ }^{2}$; (d) Carvalho and Szwarcz [2001]; (e) Perez [2001]; (f) IEA [2002b] $]^{3}$; (g) REPP [2OO1] ${ }^{4}$, IEA [2OO2b] ${ }^{5}$; (h)
UNICA [2003]

1500 people was the staff level for operation of a $1350 \mathrm{MW}$ nuclear power plant in the U.S., producing $9.45 \mathrm{TWh}$ yr (or $2.138 \mathrm{Mtoe} / \mathrm{yr}$ ) at efficiency of $38 \%$

electric generation based on herbaceous crops ( 5.5 direct jobs/ MWe) and on forestry crops ( 8 direct jobs/ Mwe), utilization $7,500 \mathrm{~h} / \mathrm{yr}$

3 world installed capacity for wind $17,300 \mathrm{MW}$, utilization $2,000 \mathrm{~h} / \mathrm{yr}$ and $4.8 \mathrm{jobs} / \mathrm{MW}$

4 including 12 different activities to construct, transport, install and service $1 \mathrm{MW}$ of PV (not included economies of scale between $2 \mathrm{~kW}$ and $1 \mathrm{MW}$ ), world installed PV capacity is $800 \mathrm{MW}$

5 utilization of $1,200 \mathrm{~h} / \mathrm{yr} ; 35.5 \mathrm{jobs} / \mathrm{MW}$ (included 15 different activities to manufacture, transport, install and service $1 \mathrm{MW}$ of wind power)

6 ethanol industry provides 33 direct jobs/ million liter in Brazil, where ethanol production in the $1992-2001$ period ranged between 10.6-15.4 billion liters/yr (LHV of ethanol $6,500 \mathrm{kcal} / \mathrm{kg}$ and density $0.8 \mathrm{~kg} / 1$ ); energy production comprised $7 \mathrm{Mtoe}$ of ethanol fuel, plus $9.6 \mathrm{TWh} / \mathrm{yr}$ of cogeneration (installed capacity $2,000 \mathrm{MW}$, utilization of $4,800 \mathrm{hours} / \mathrm{yr}$ ) 


\section{Trends in PV module prices}

Euro per W

$\rightarrow$ Japan $\leftrightharpoons$ Europa $\leftrightharpoons$ USA

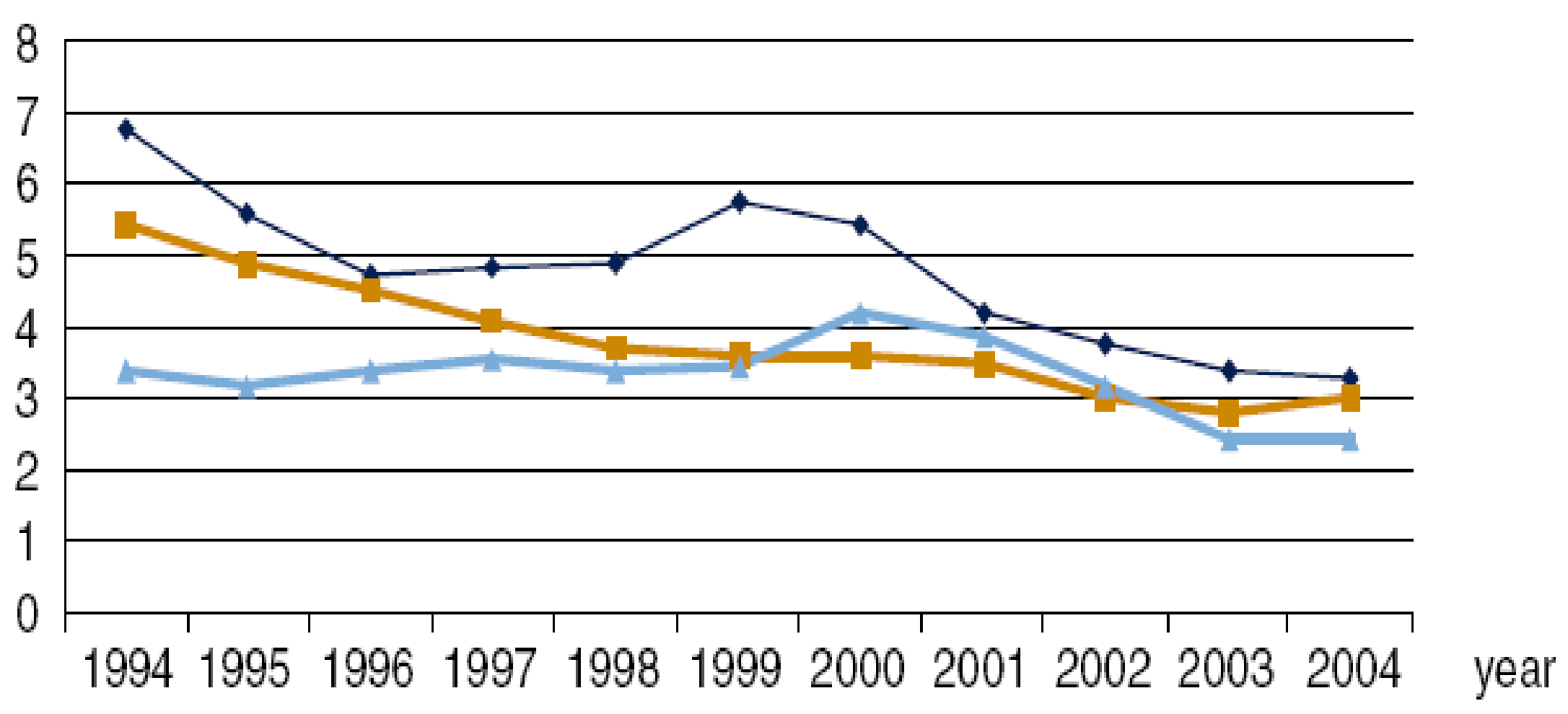




\section{PV Learning Curve}

[2001 \$]

Power Modules (1976-2001)

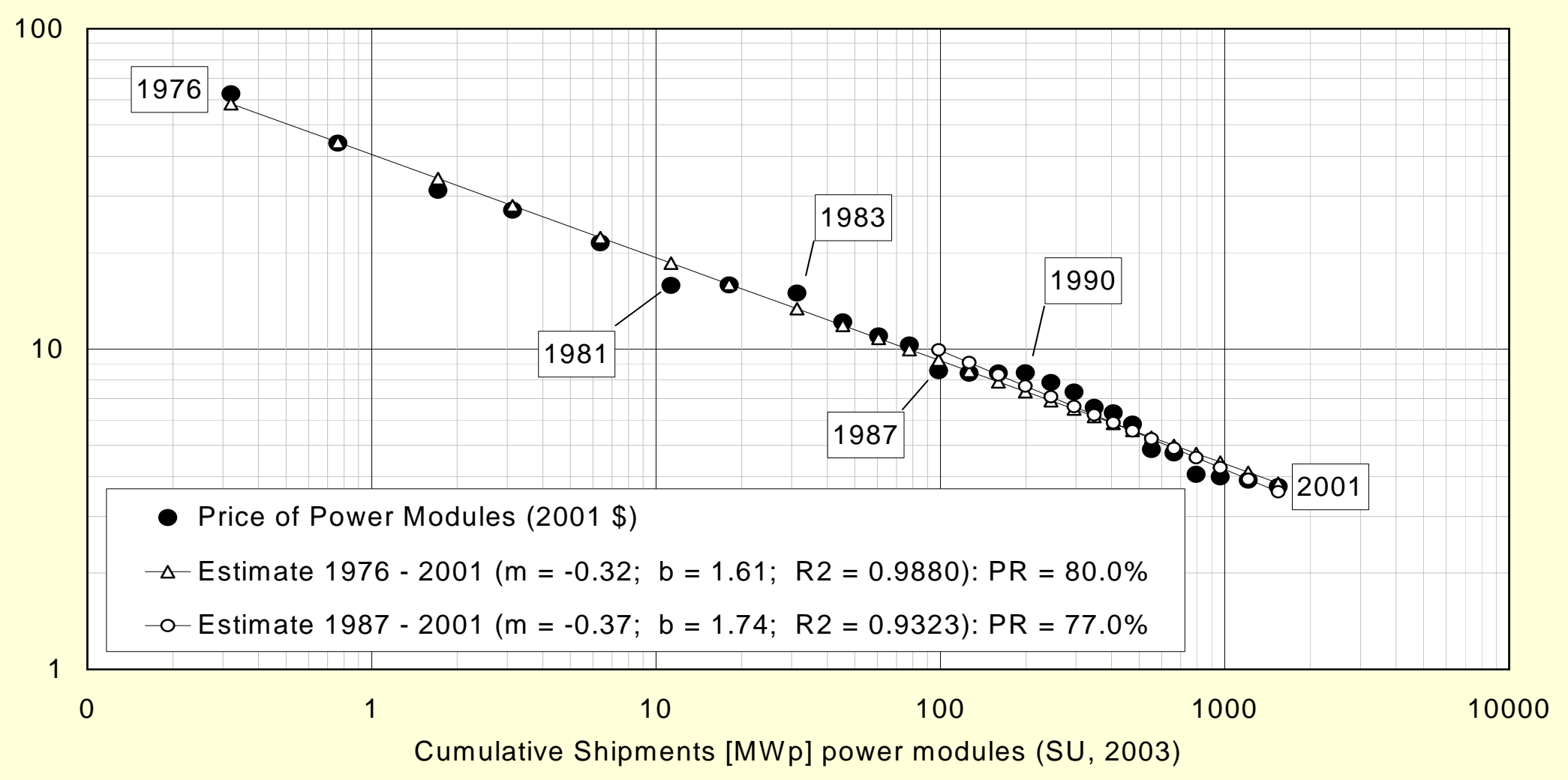

Solar Energy - Status \& Perspectives 


\section{Learning Curves - Energy Technologies}

- PV is special: technology generations known

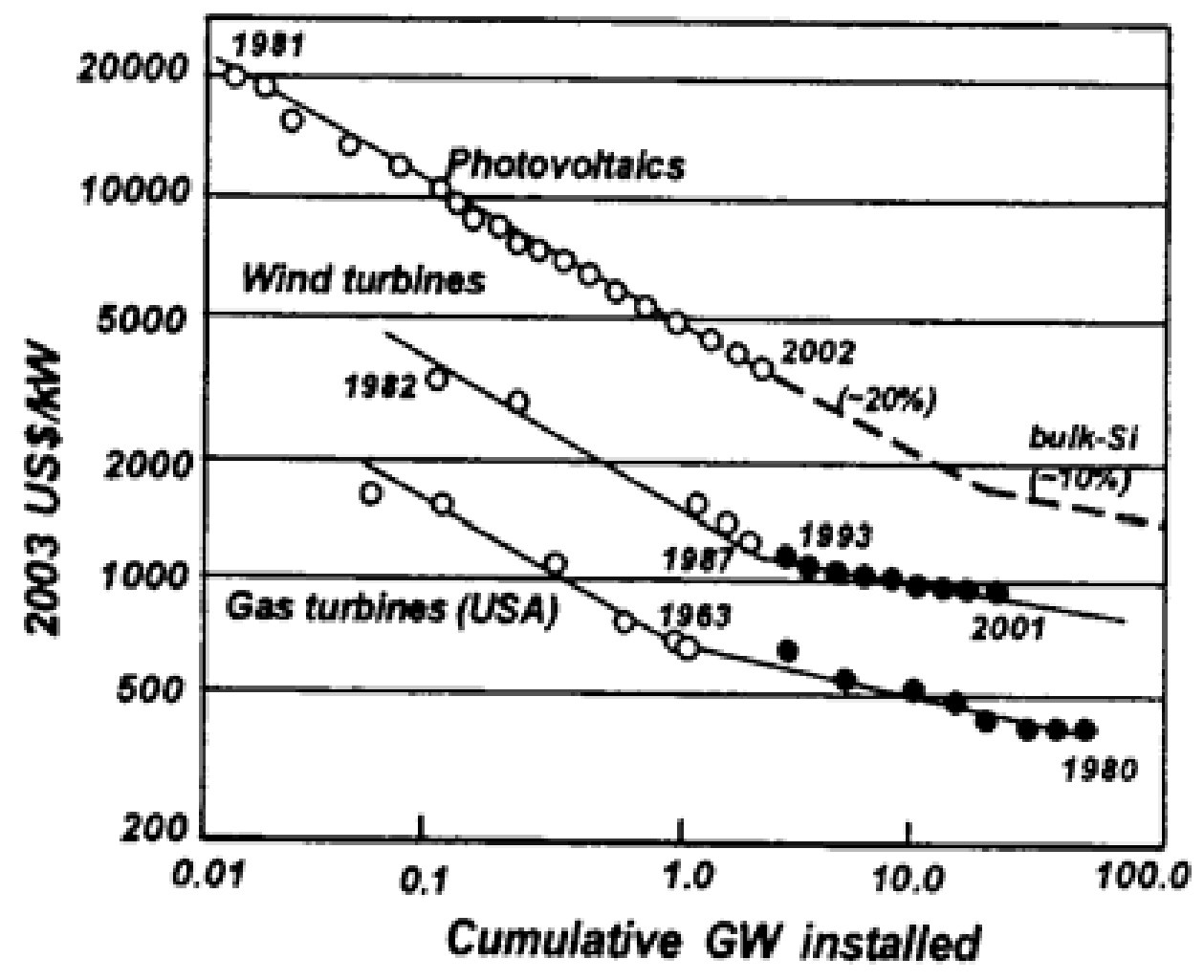




\section{When will PV be competitive?}

- IEA (Wene 2000) productionen of PV modules shall be increased by a factor 100 before competitiveness with fossil fuels (from $300 \mathrm{MW} / \mathrm{y}$ to $30 \mathrm{GW} / \mathrm{y}$ )

- With an annual average growth rate of 30 $\%$ this is achieved in 15 years (2015) 


\section{Competitiveness of market sectors}
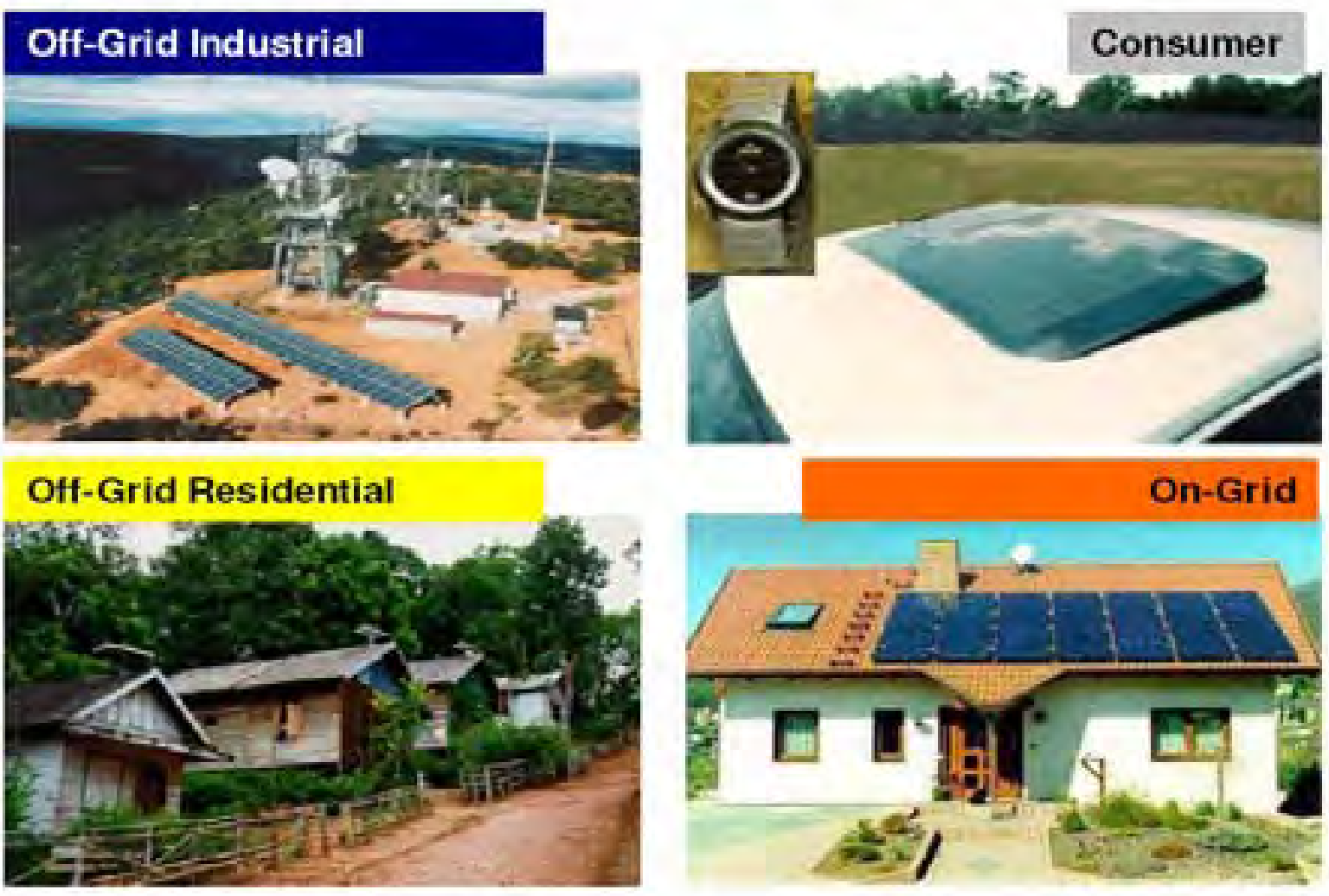

\section{Market Segments}

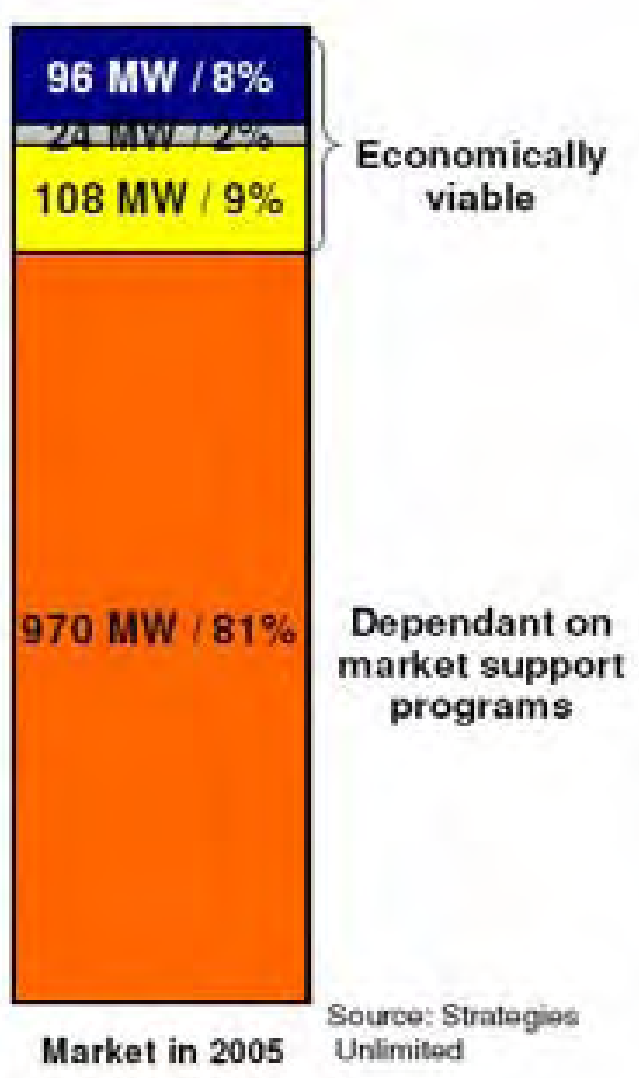

Solar Energy - Status \& Perspectives 


\section{Competitiveness of PV Solar Electricity}

- proven in the three segments:

- industrial off-grid

- consumer

- rural electrification

- coming soon in grid-connected systems

- First, in local replacement of peak tariff electricity in liberalized southern OECD countries (... 2010 ... 2015)

- Second, the same in more northern OECD countries (... 2020 ... 2025) 


\section{Competitiveness vs. grid power}
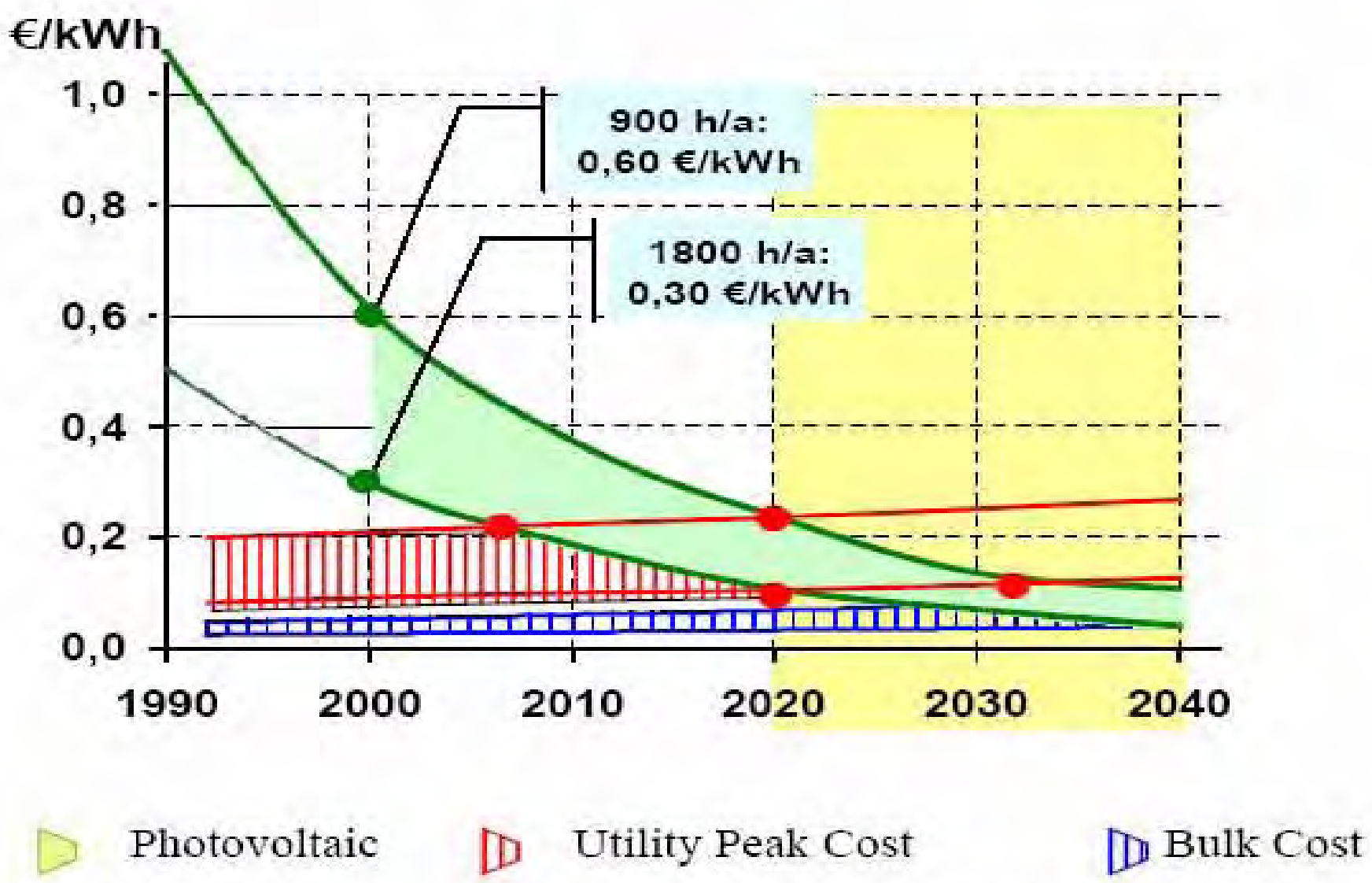

Source: EPIA towards an Effective Industrial Policy for PV.ppt/05.06.2004/Rapp@RWE Schott 
-Is there a necessity for 2nd and 3rd generation technologies to replace $\mathrm{c}-\mathrm{Si}$ wafer technology for module production cost below $1 € / \mathrm{W}$ ?

- No, but utilize new features of thin film and new concept cells to serve additional customer needs! 
Technology evolution

1) No $1 € / W$ limit for c-Si modules

\begin{tabular}{|l|c|c|}
\hline $\begin{array}{l}\text { Module full production } \\
\text { cost [€/W] }\end{array}$ & $\begin{array}{c}\text { MUSIC-FM } \\
\text { APAS-RENA } \\
\mathbf{( 1 9 9 7 )}\end{array}$ & $\begin{array}{c}\text { update } \\
\mathbf{( 2 0 0 2 )}\end{array}$ \\
\hline c-Si ribbon (e.g. EFG) & 0,7 & 0,6 \\
\hline multicryst./Cz-wafer & $0,9 / 1,1$ & $0,8 / 1,0$ \\
\hline thin-film (e.g. a-Si, CIS) & 0,7 & $\ldots$ \\
\hline
\end{tabular}




\section{Technology evolution EPIA Roadmap - c-Si technology}

\begin{tabular}{|l|c|c|c|}
\hline & $\mathbf{2 0 0 0}$ & $\mathbf{2 0 1 0}$ & $\mathbf{2 0 2 0}$ \\
\hline feedstock & 25 & 20 & $15 € / \mathrm{kg}$ \\
\hline wafer & 300 & 200 & $100 \mu \mathrm{m}$ \\
\hline cell & $14-17$ & $17-20$ & $19-22 \%$ \\
\hline module & \multicolumn{3}{|c|}{ long term stable, low cost/m² technology } \\
\hline
\end{tabular}

In the long run integrated manufacturing of thin wafers (100 $\mu \mathrm{m}$ or less) and subsequent cell and laminate making is probably the most effective route. 


\section{PV Technology forecast}

Figure 5: Possible Production by

Technologies in 2020 and 2030

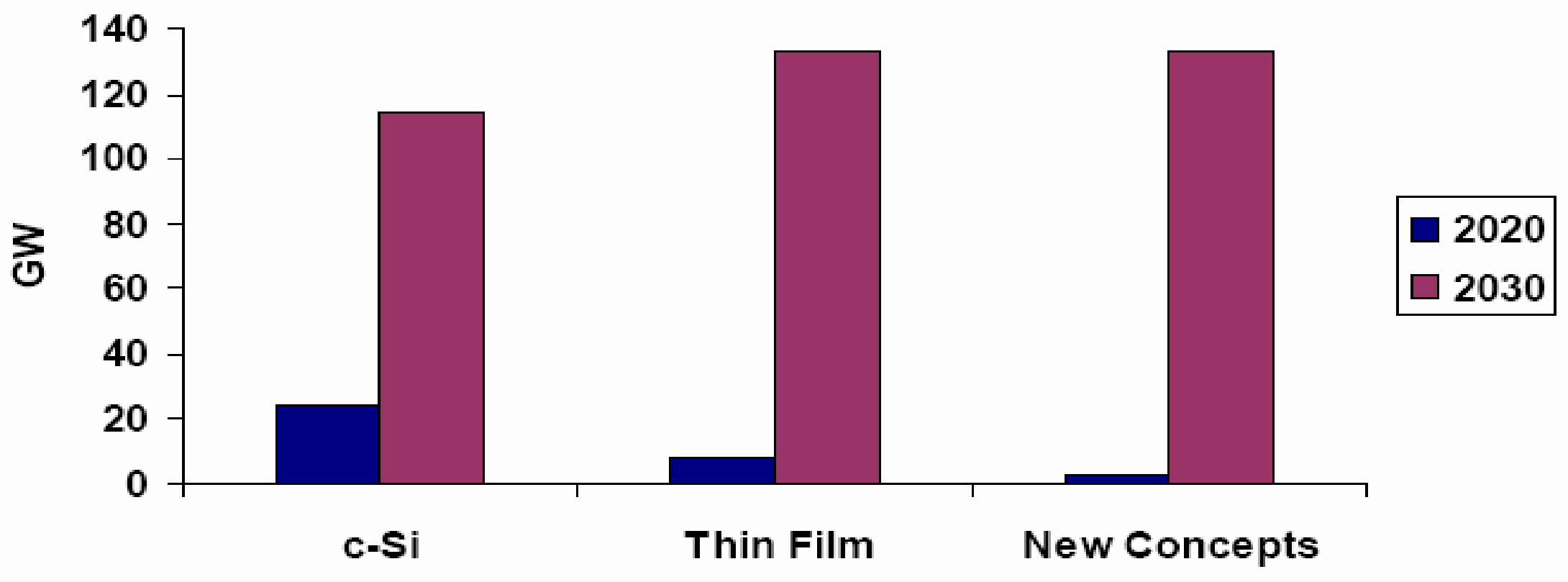

Source: Strategies Unlimited 


\section{Visions for PV 1}

Table 2. Key cost and investment assumptions of renewables. Source: IEA, 2006

\begin{tabular}{|llllllll|}
\hline & \multicolumn{3}{c}{ Learning } & \multicolumn{3}{c}{ Investment cost (S/kW) } & \multicolumn{3}{c|}{ Production cost (S/MWh) } \\
\hline & rate (\%) & $\mathbf{2 0 0 5}$ & $\mathbf{2 0 3 0}$ & $\mathbf{2 0 5 0}$ & 2005 & $\mathbf{2 0 3 0}$ & $\mathbf{2 0 5 0}$ \\
\hline Biomass & 5 & $1000-2500$ & $950-1900$ & $900-1800$ & $31-103$ & $30-96$ & $29-94$ \\
\hline Geothermal & 5 & $1700-5700$ & $1500-5000$ & $1400-4900$ & $33-97$ & $30-87$ & $29-84$ \\
\hline Large hydro & 5 & $1500-5500$ & $1500-5500$ & $1500-5300$ & $34-117$ & $34-115$ & $33-113$ \\
\hline Small hydro & 5 & 2500 & 2200 & 2000 & 56 & 52 & 49 \\
\hline Solar PV & 18 & $3750-3850$ & $1400-1500$ & $1000-1100$ & $178-542$ & $70-325$ & $<60-290$ \\
\hline Solar thermal & 5 & $2000-2300$ & $1700-1900$ & $1600-1800$ & $105-230$ & $87-190$ & $<60-175$ \\
\hline Tidal & 5 & 2900 & 2200 & 2100 & 122 & 94 & 90 \\
\hline Wind onshore & 5 & $900-1100$ & $800-900$ & $750-900$ & $42-221$ & $36-208$ & $35-205$ \\
\hline Wind offshore & 5 & $1500-2500$ & $1500-1900$ & $1400-1800$ & $66-217$ & $62-184$ & $60-180$ \\
\hline
\end{tabular}

Note: Using a $10 \%$ discount rate. The actual global range is wider as discount rates,

investment cost and fuel prices vary. Wind and solar include grid connection cost.

Learning rate implies percentage cost reduction for each doubling of installed capacity. 


\section{Visions for PV 2}

- Japan 2030:

- 52-82 GW installed

$-5-10 \mathrm{Yen} / \mathrm{kWh}$

- USA 2030:

-25 GW installed (10\% of electricity)

-150.000 new jobs

- EU 2010:

$-3 \mathrm{GW}$ installed (1\% of el.) - expect. > 6 GW 


\section{Visions for $\mathrm{PV} 3$}

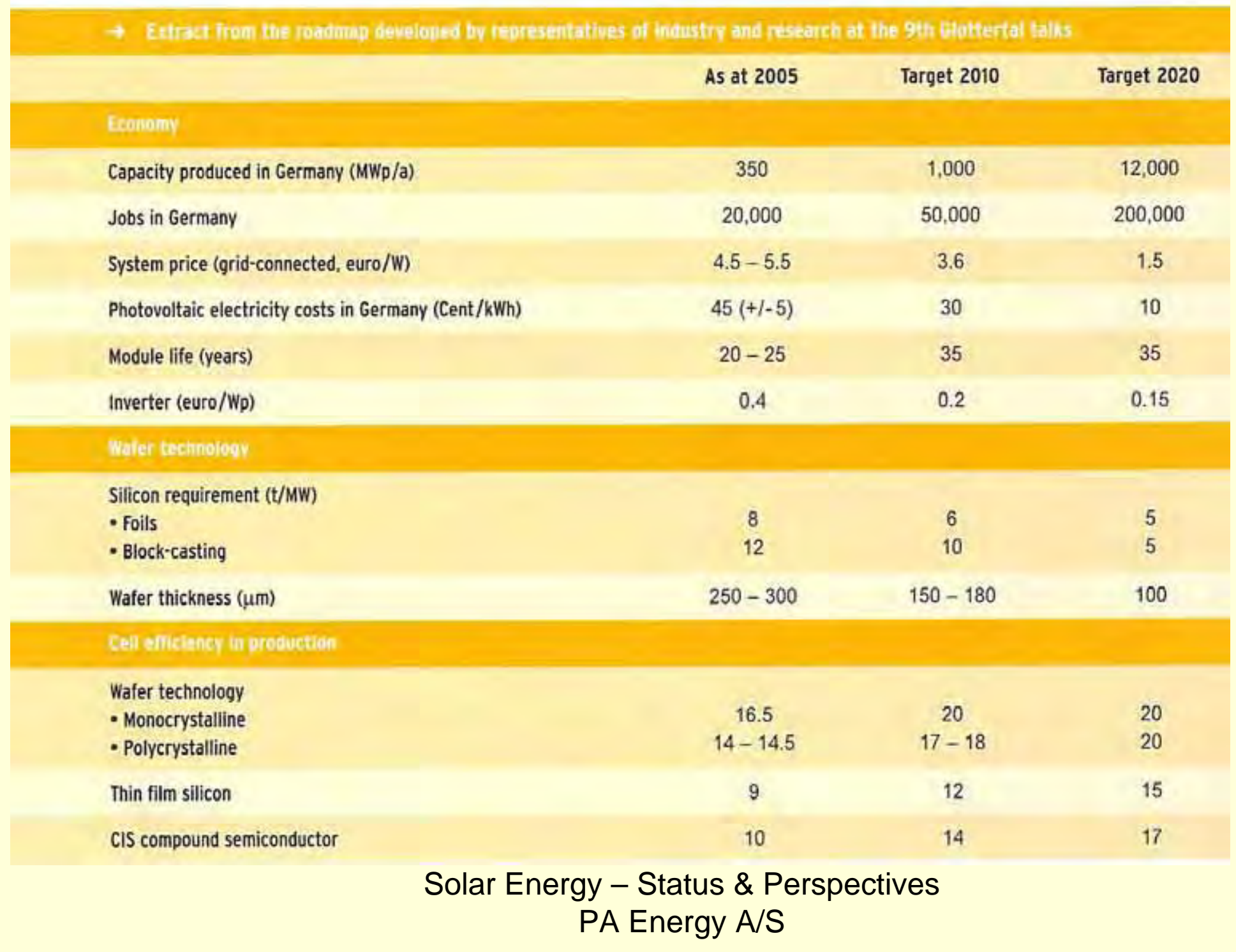




\section{Cost \& Prices \\ Price 2006: 0,5 US\$/kWh (OECD aver.)}

Levelized cost of solar power - 2006

US $\$ / \mathrm{kWh}$

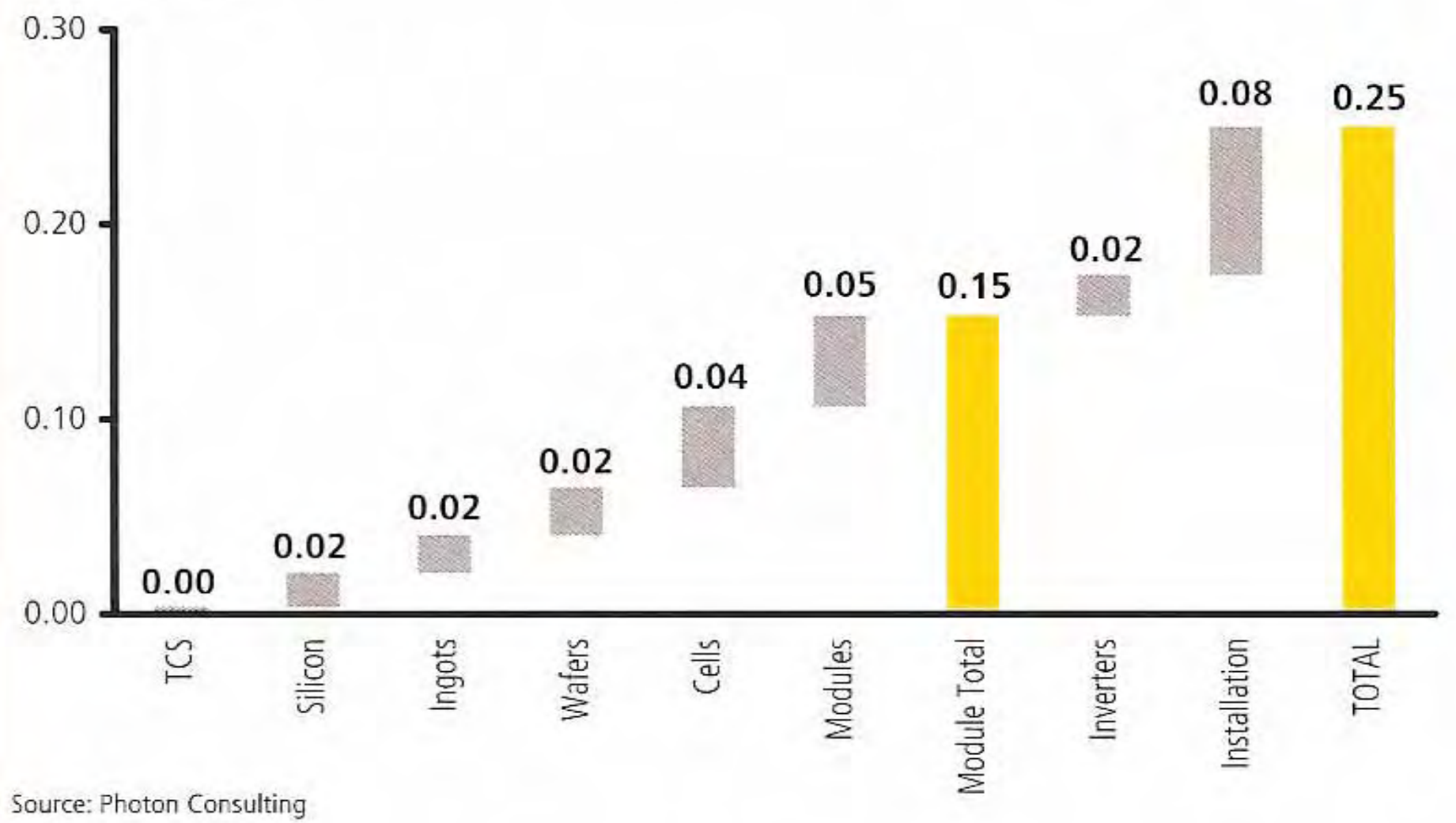




\section{Cost Reduction Drivers}

Cost reduction drivers through 2010

uss/kWh

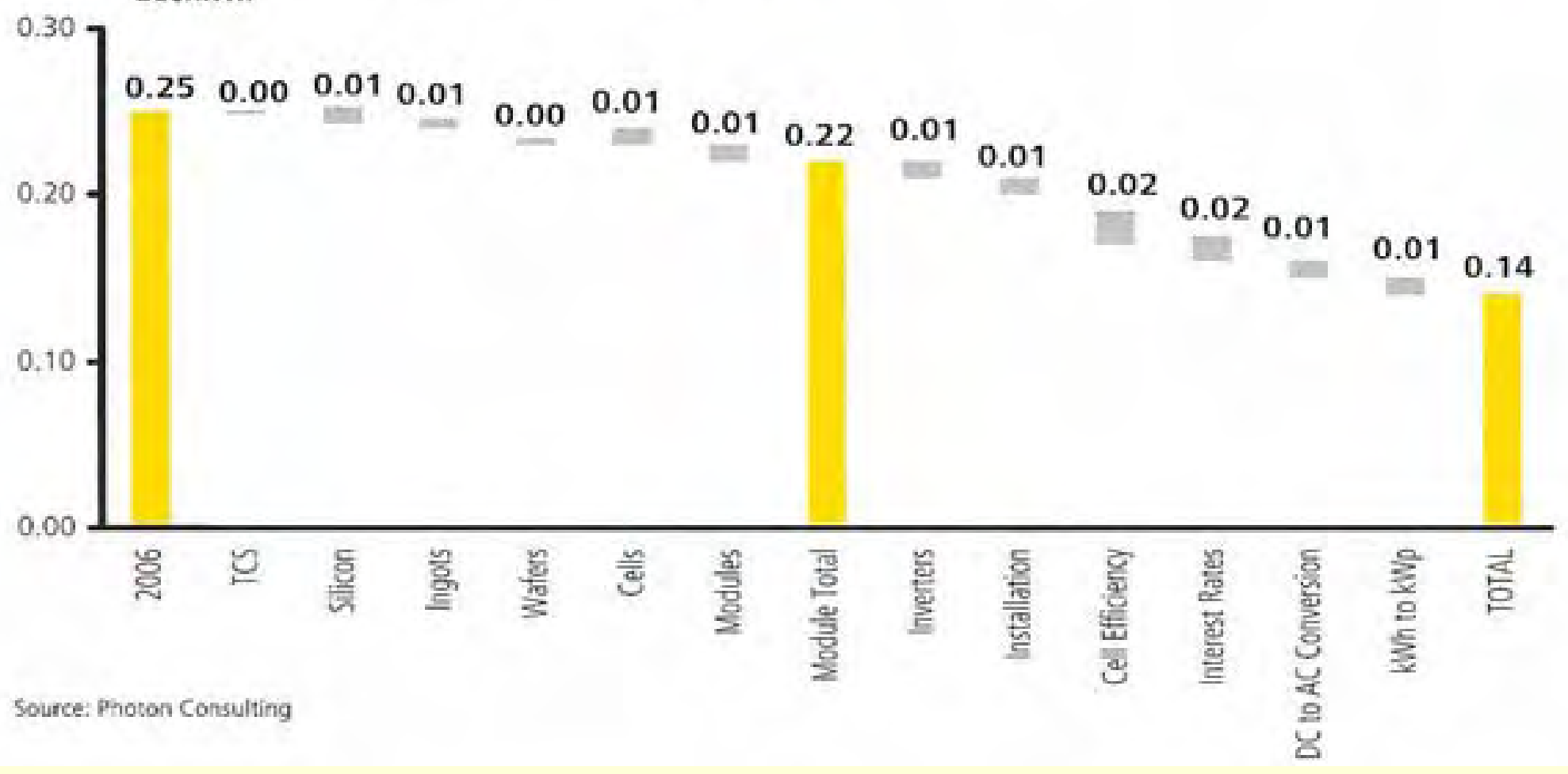

Solar Power - Status \& Perspectives 


\section{Technical Potential Solar}

Electricity: 323 km² (@ 360 TJ per km²)

Energy: $2260 \mathrm{~km}^{2}$ 


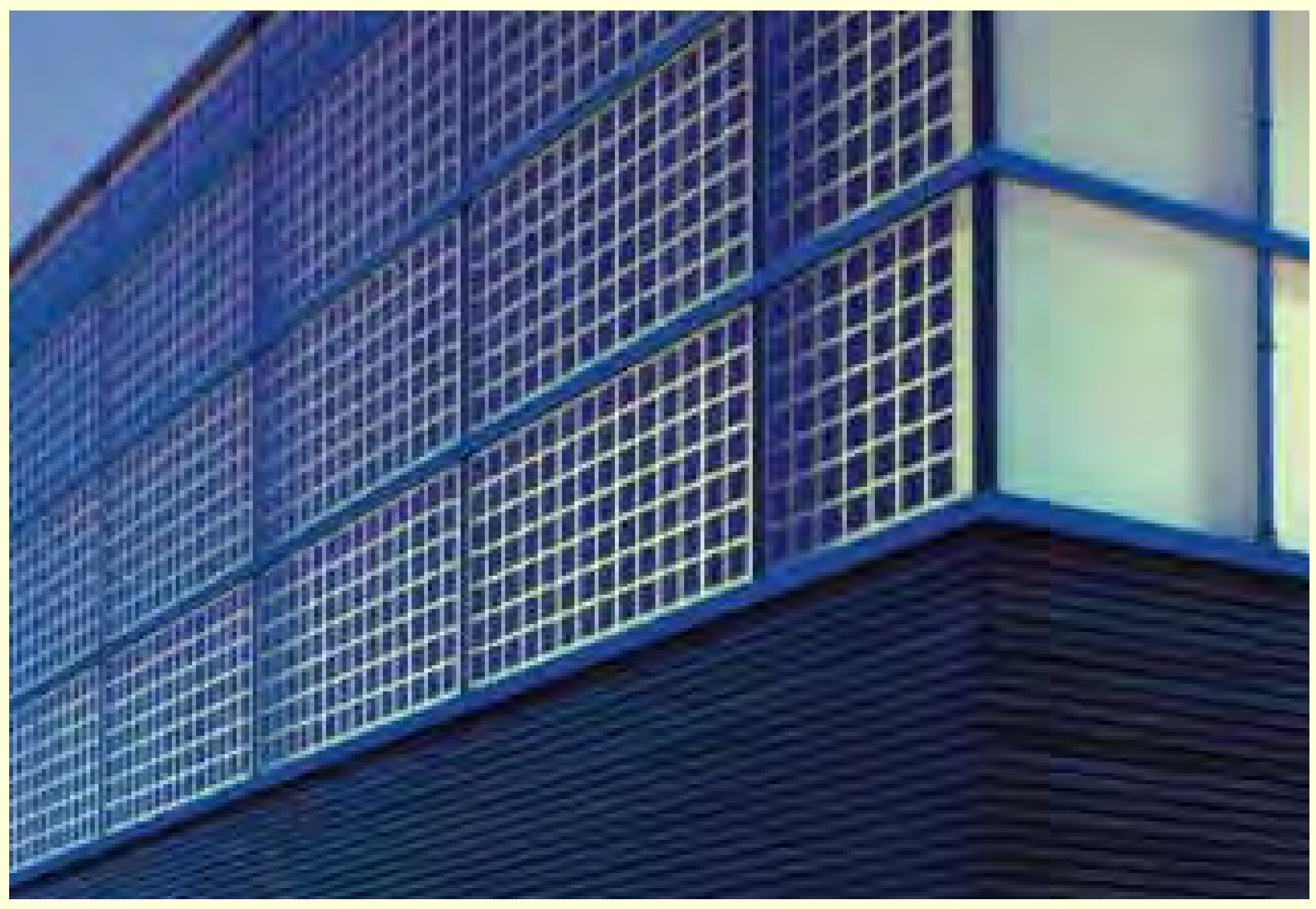

PV Aspects and Prospects 


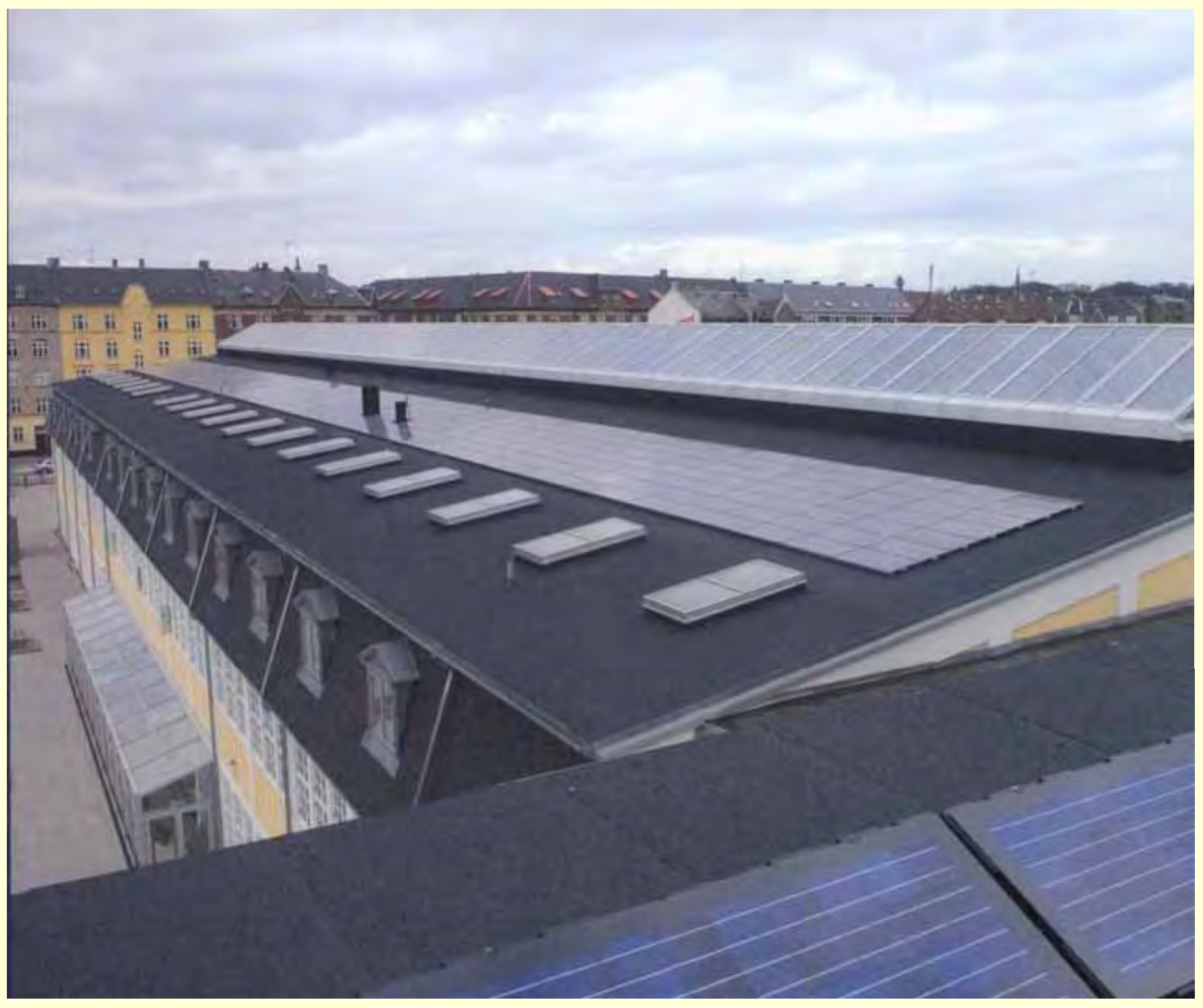

PV Aspects and Prospects 


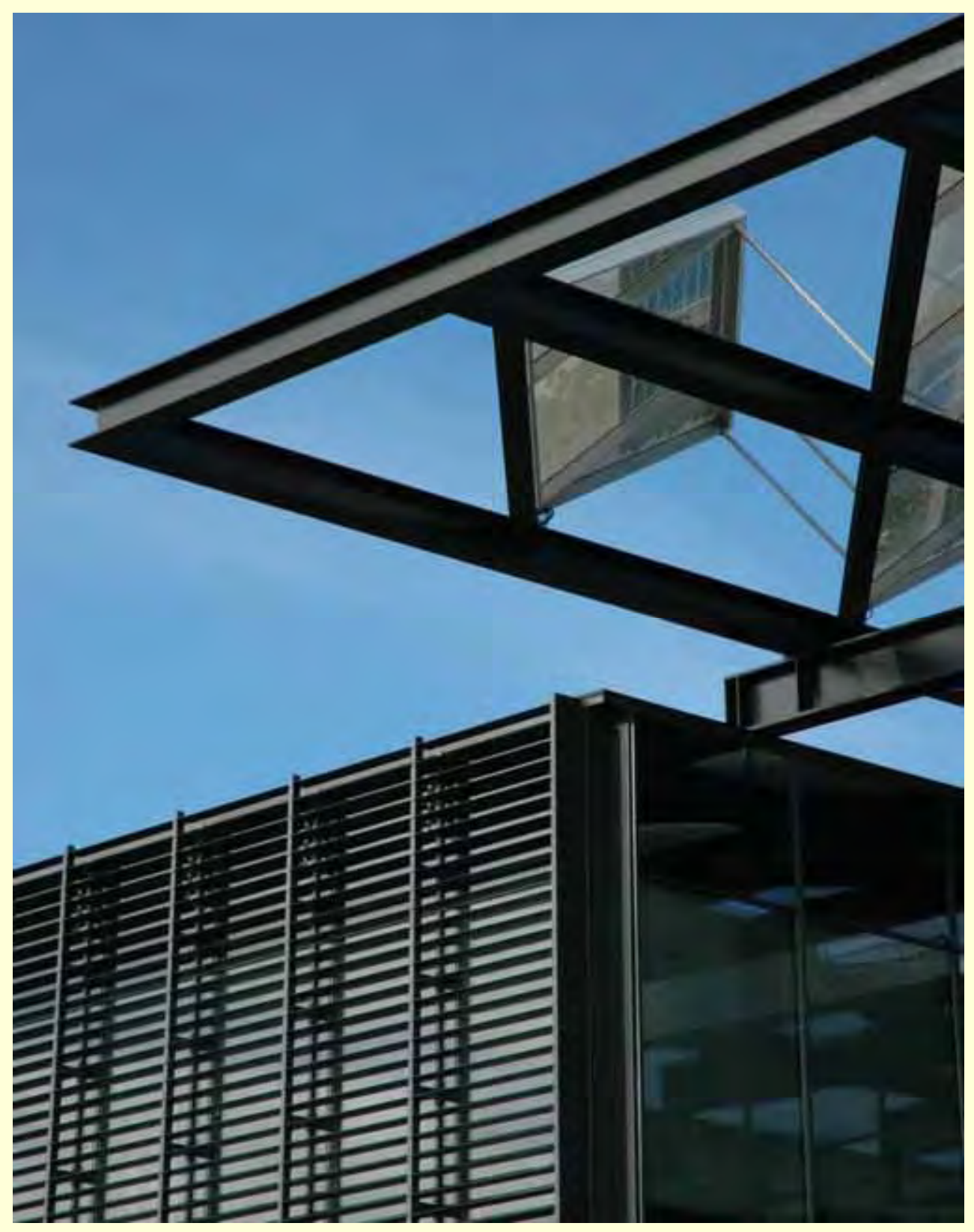

PV Aspects and Prospects 


\section{PV's in Transport?}

\section{Distance reached with 1 ha of energy crop/ PV gromd-mounted system}

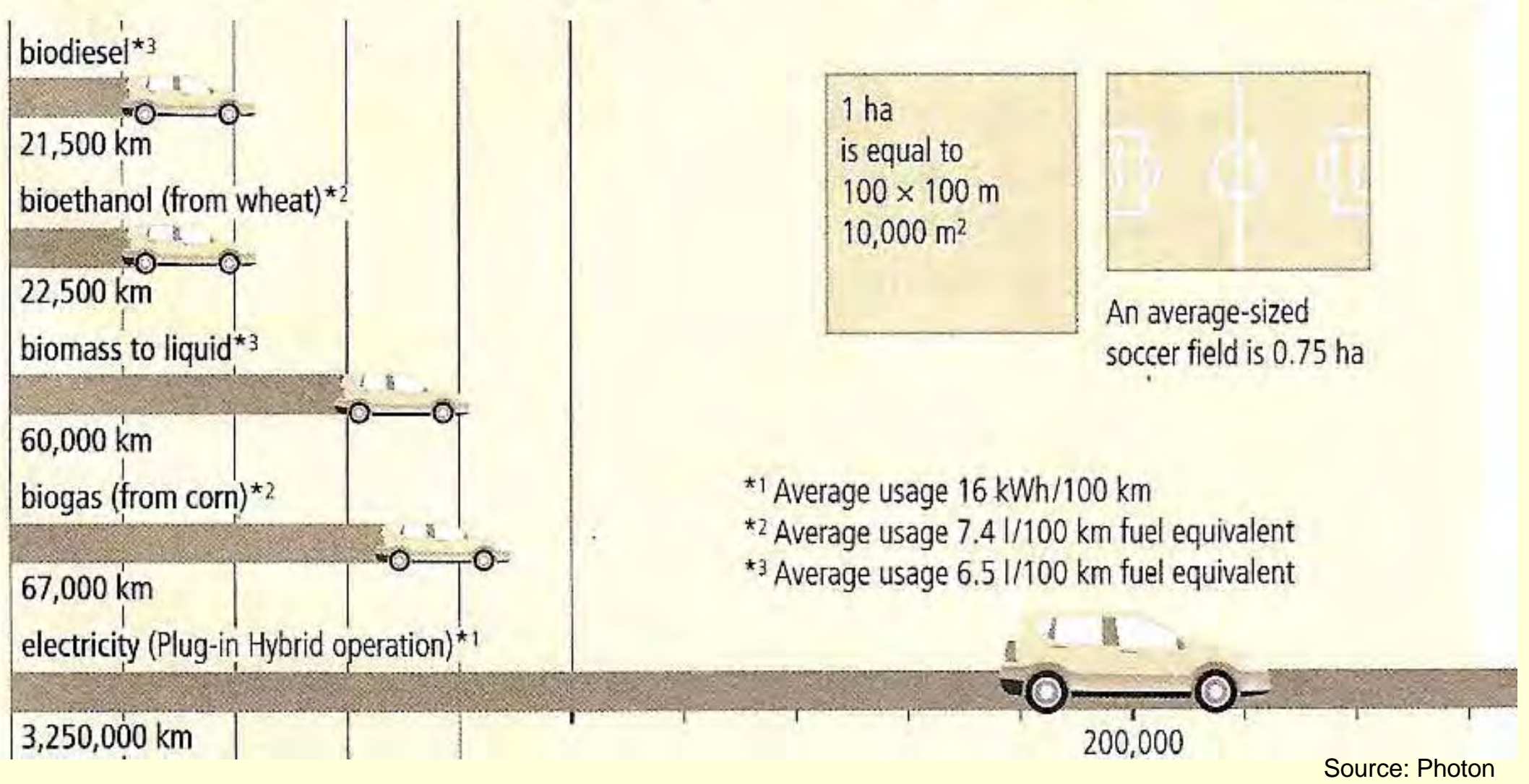

PV Aspects and Prospects 


\section{World Wide Access to Electricity}

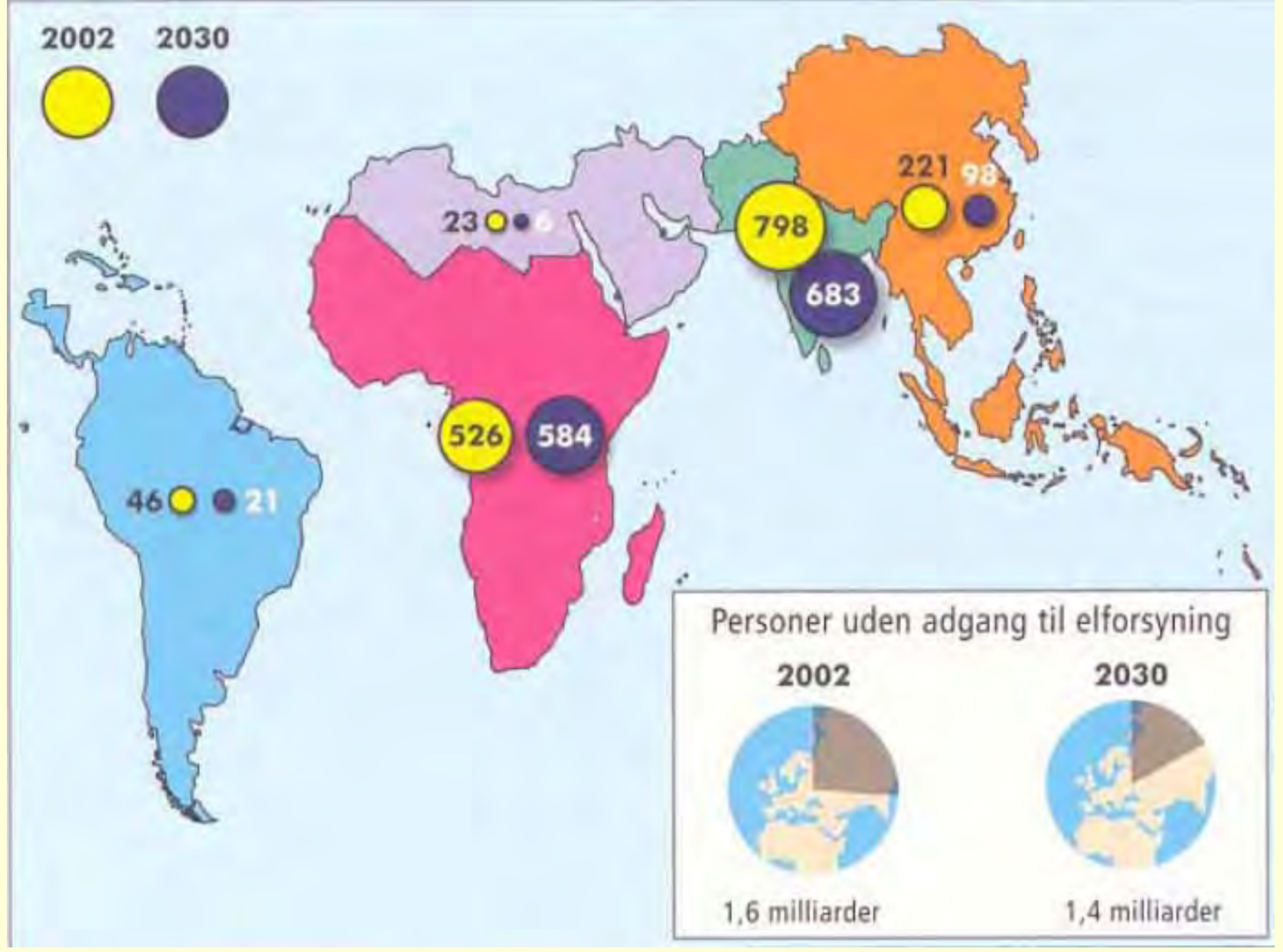

PV Aspects and Prospects 


\section{Developing Countries - "the dark locations"}
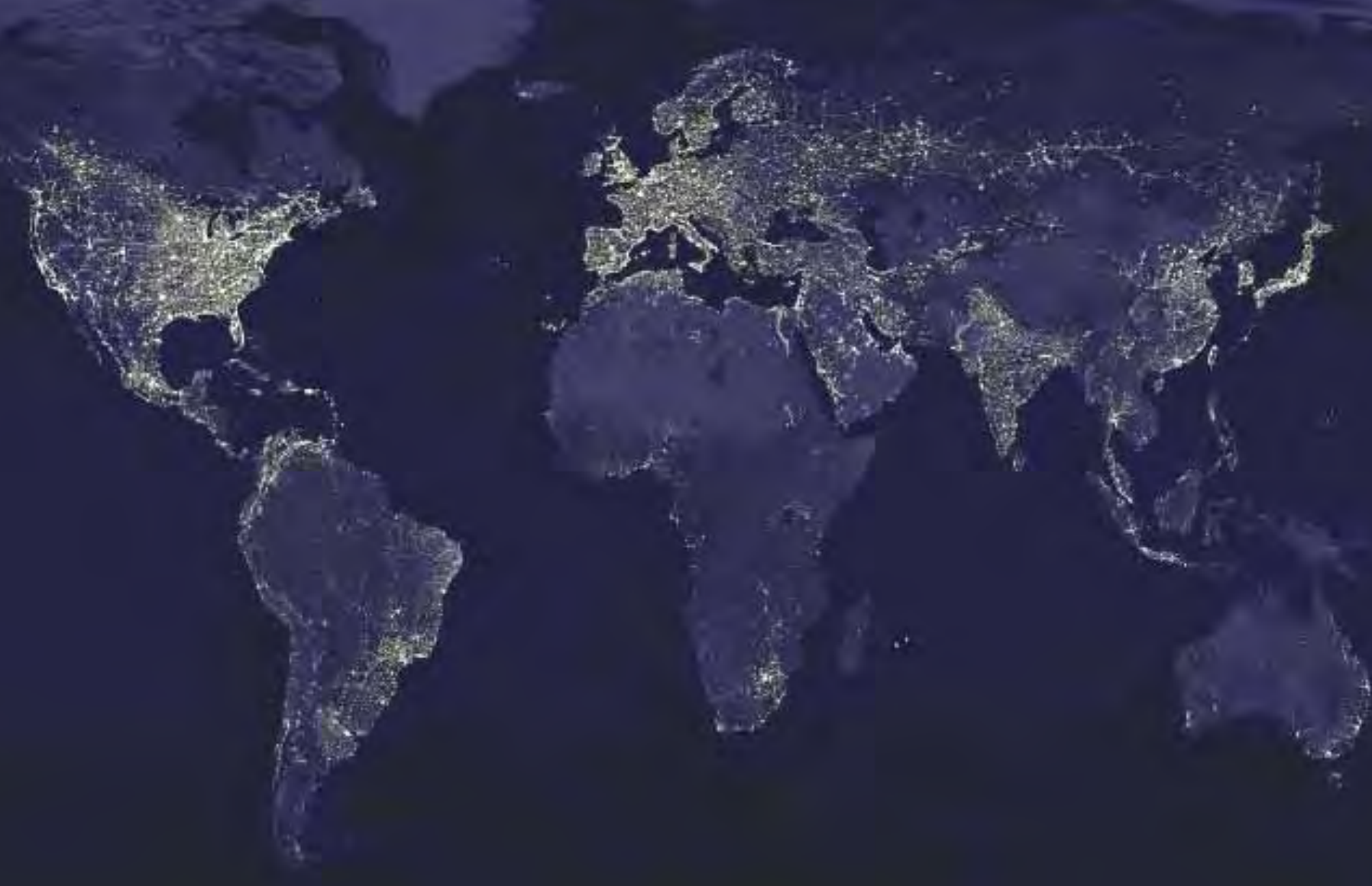


\section{Energy and Development - a new understanding}

- Access to energy and electricity does not create development but is a prerequisite for development. Energy is not only an individual sector, but:

- Energy and electricity is a precondition for efficiency in public sectors such as: health, education, water \& sanitation, good governance/ democracy

- Energy and electricity is a precondition for progress in poverty alleviation, equality, justice etc.

- Energy is a precondition in reaching the Millennium Development Goals 


\section{WBG Photovoltaic Projects}

\section{Serving $>1,43$ million $\mathrm{HH}+$ Facilities $\sim 7.5$ million persons}

$\sim 64 \mathrm{MWp} 31$ Countries Total Value: $\sim \mathbf{7 7 6}$ million

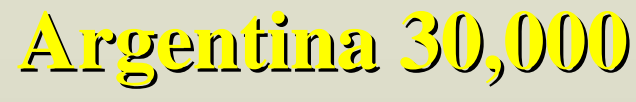

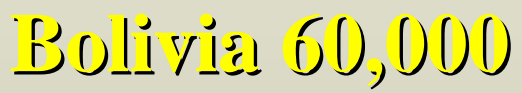
Fíc

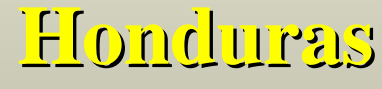

Domfinictan frep, 1 IYexico 1,000 IYIexico 30,000

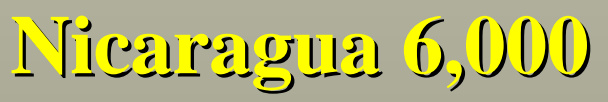
Includes projects completed, under implementation and preparation

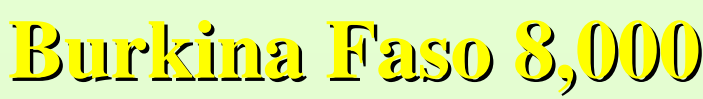
Cospe Vercle 1,500 Fithopies 0,300

$$
\text { Y.eny }
$$

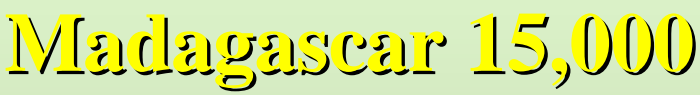

$$
\begin{aligned}
& \text { IVIs_li 10,000 } \\
& \text { Iy-ruscos }
\end{aligned}
$$

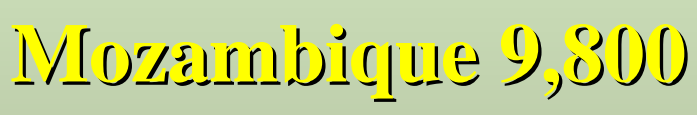

$$
\text { Senteg:al } 10,000
$$

Svarziland 2,000

Ugainda s0,000

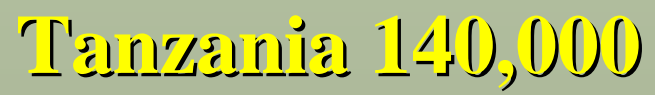

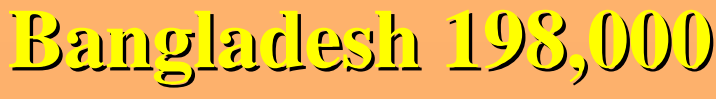
Ceicribudis 10,000 Chiną 400,000 Indlia $155,000+$ Indlonesial 8,500

$$
\text { Lsilos } 4,000
$$

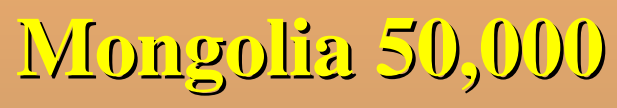
Pacificic Islandes 21,000 Philippines 135,000

$$
\text { PNG 2,500 }
$$

Srí Lamka 105,000 Vietnain 


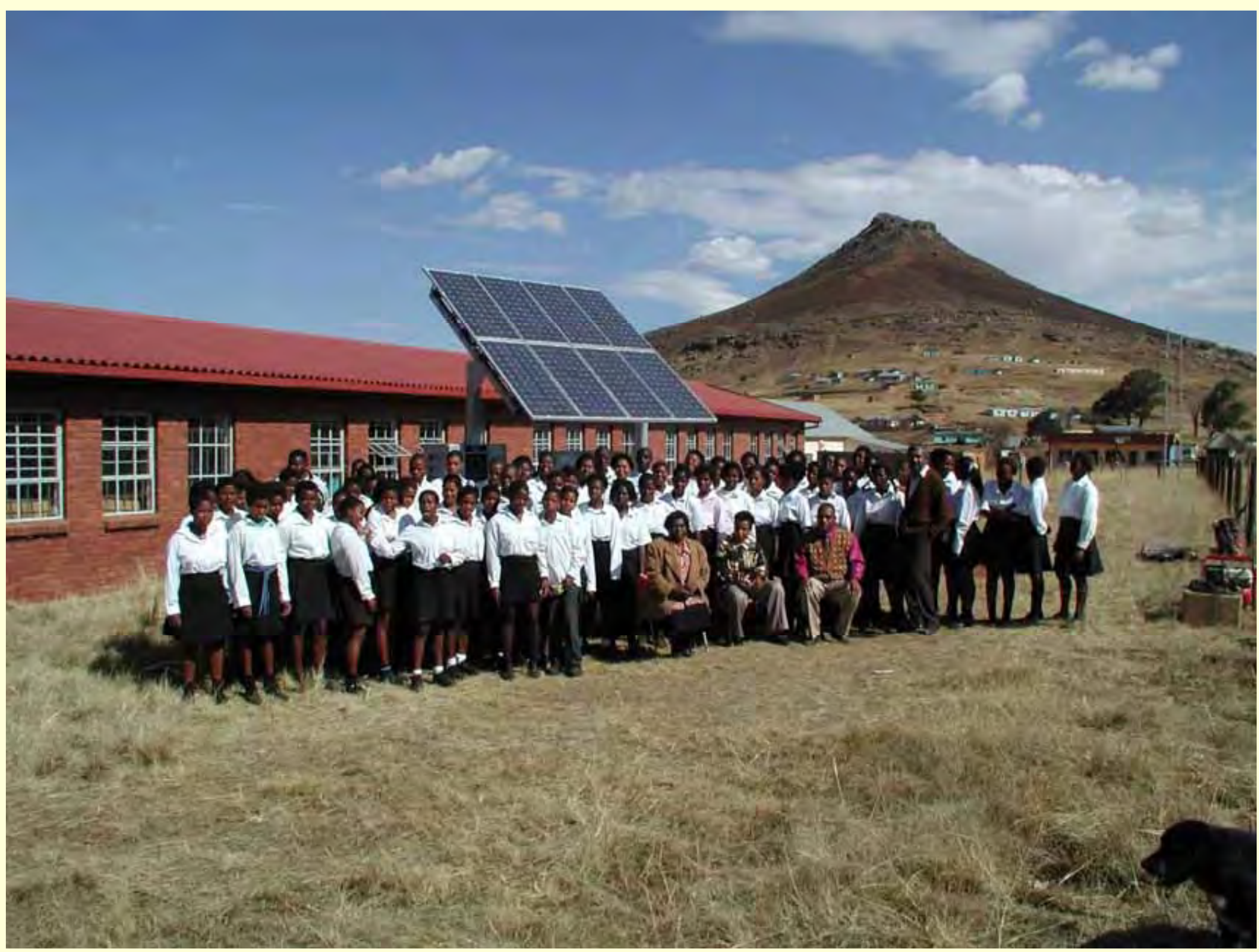

PV Aspects and Prospects 


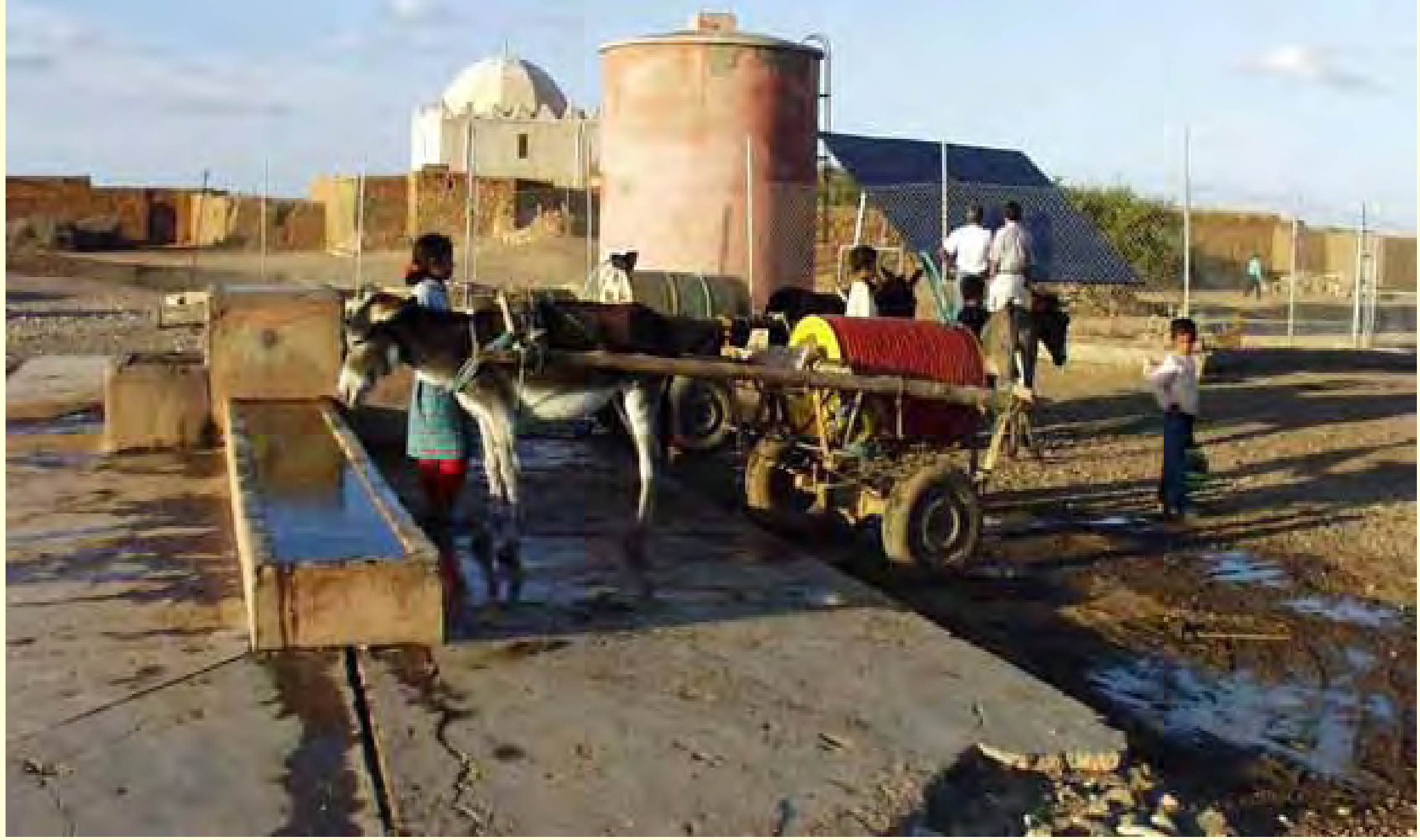




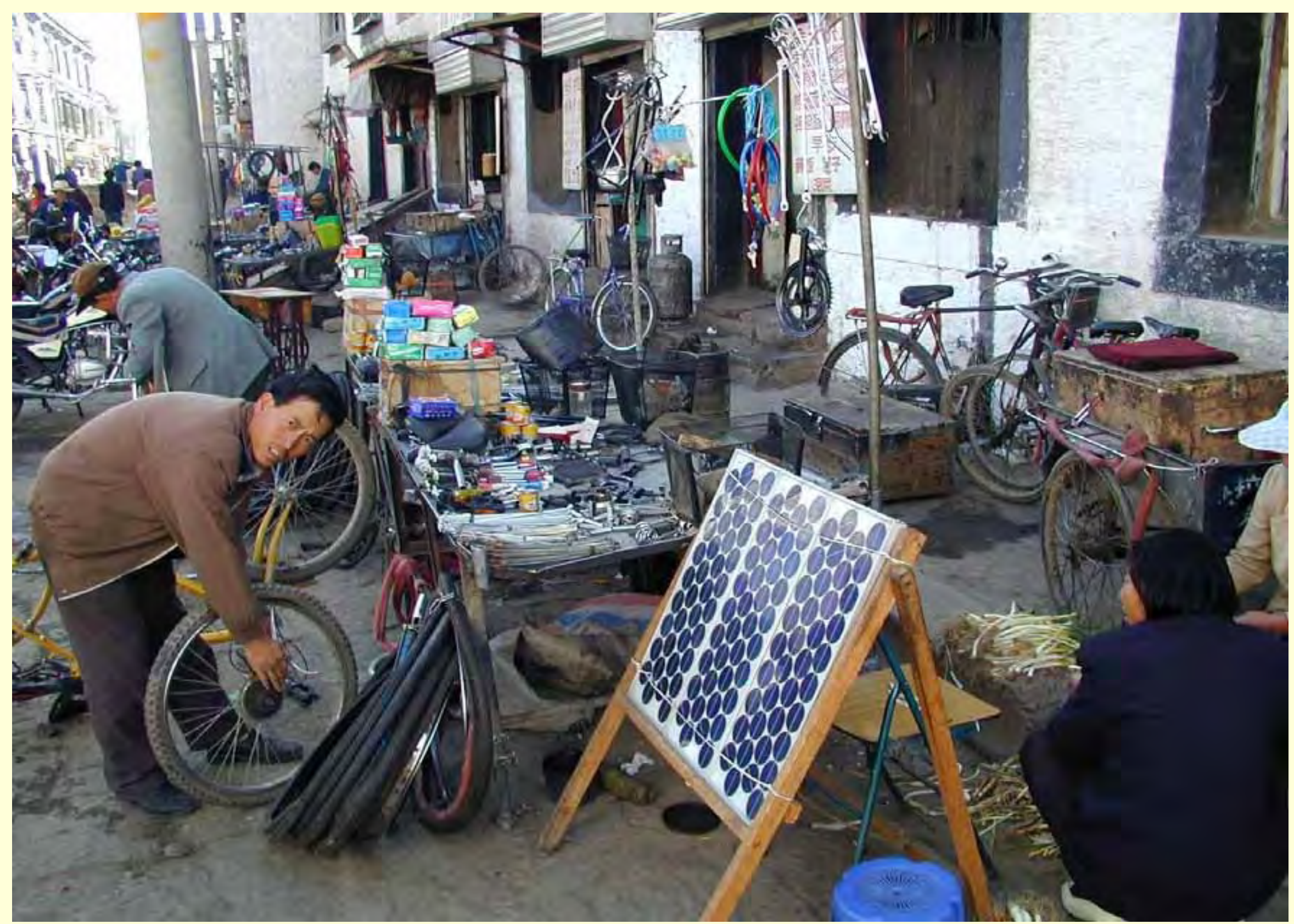




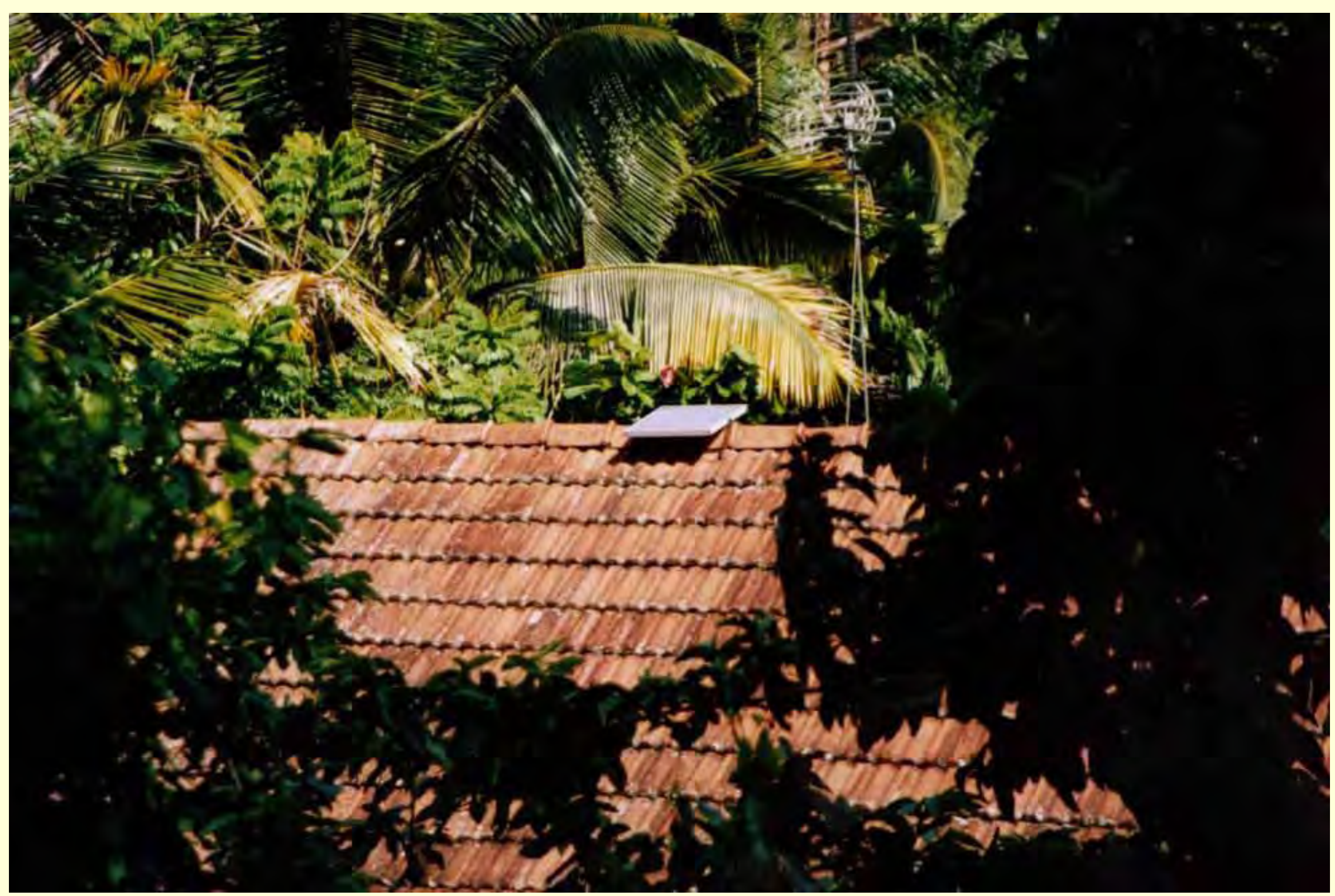




\section{Challenges for Solar Energy}

- In the industrialized world:

- To ensure ongoing market support until sustainable business level is reached

- Ongoing R\&D effort (not stop/go)

- Up-scale production to GW scale, volume a major cost reduction driver

- In the developing world:

- Develop financial structures and sustainable supply chains

- Increase donor-support for rural electrification 


\section{Solar Hot Water systems (SHW)}

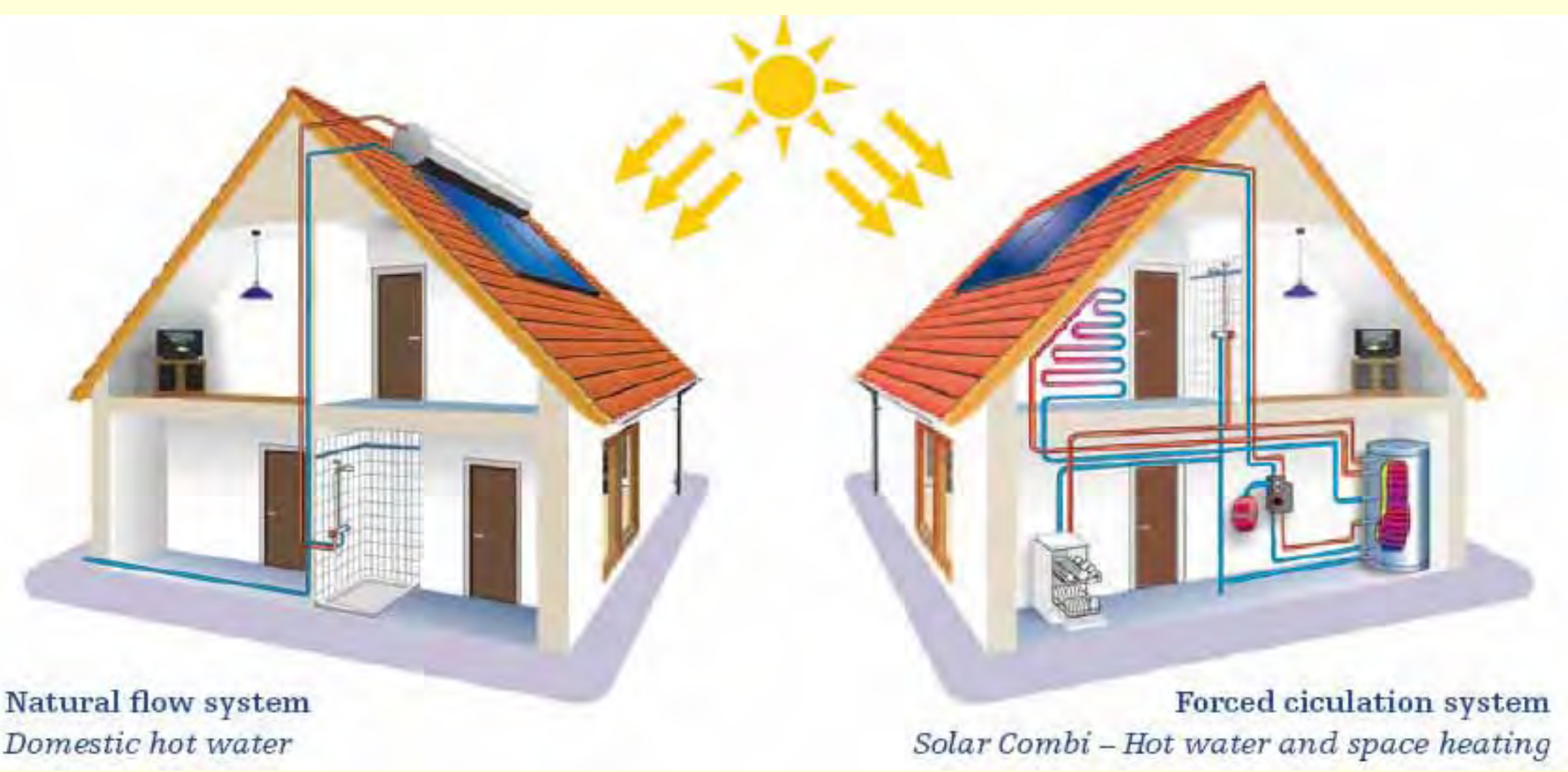




\section{Solar Heating Applications}

Solar cooling \& heating system: demand \& supply

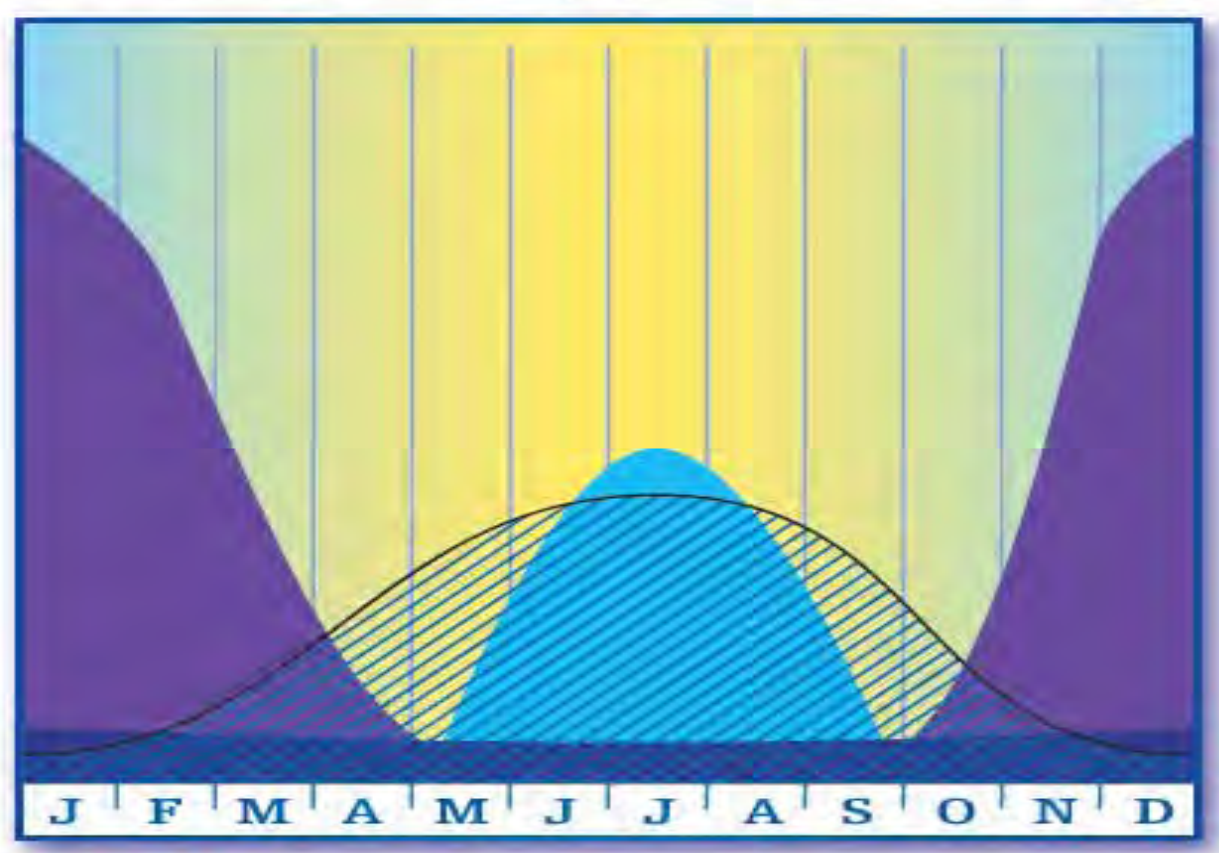

E212 solar collector yield

Domestic hot water demand

Space heating demand

cooling demand

Solar thermal can cover a substantial part of the heating and cooling demand in a typical central European building.

PV Aspects and Prospects 


\section{SHW Market}

Solar thermal market 2005

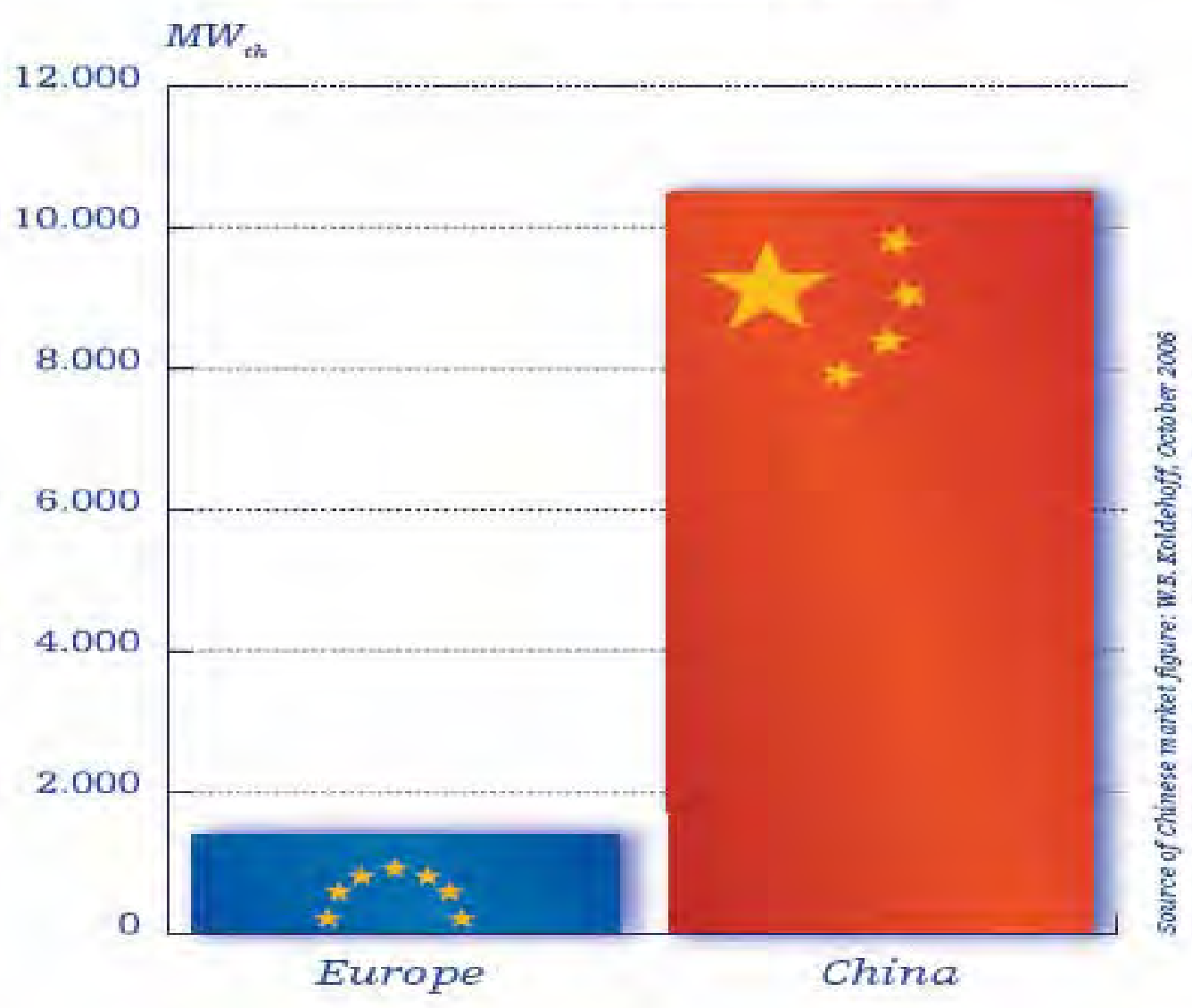

PV Aspects and Prospects 


\section{SHW installed capacity in EU}

Share of solar thermal market

(Newly installed capacity)

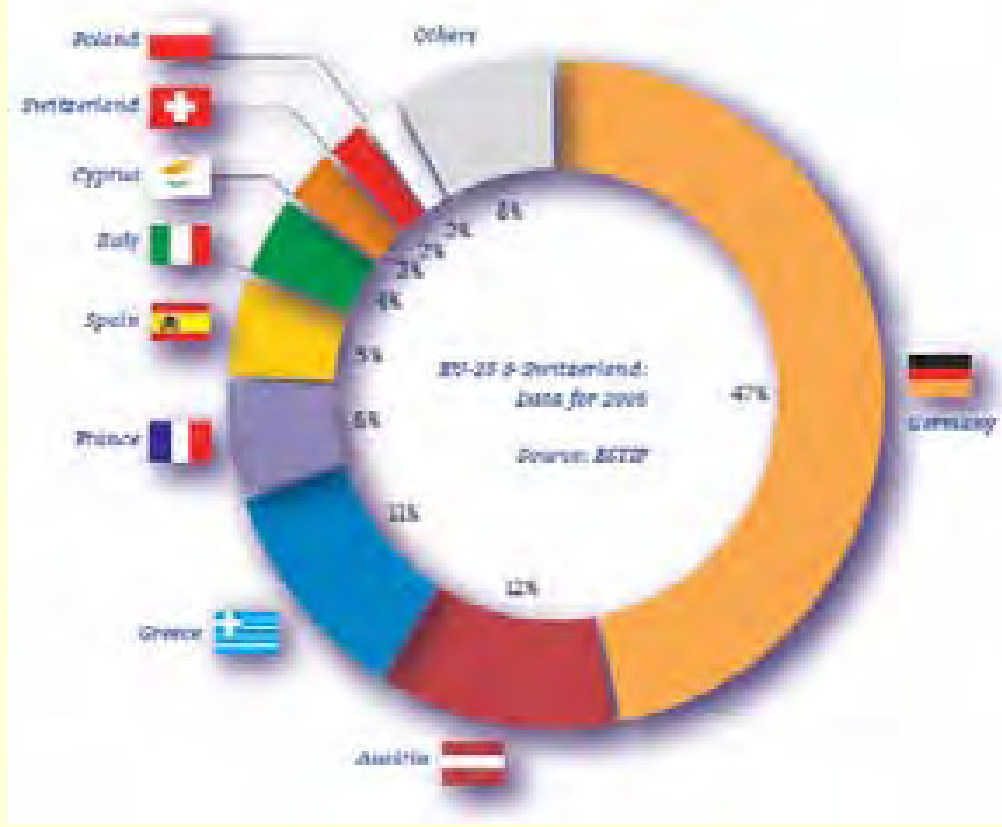

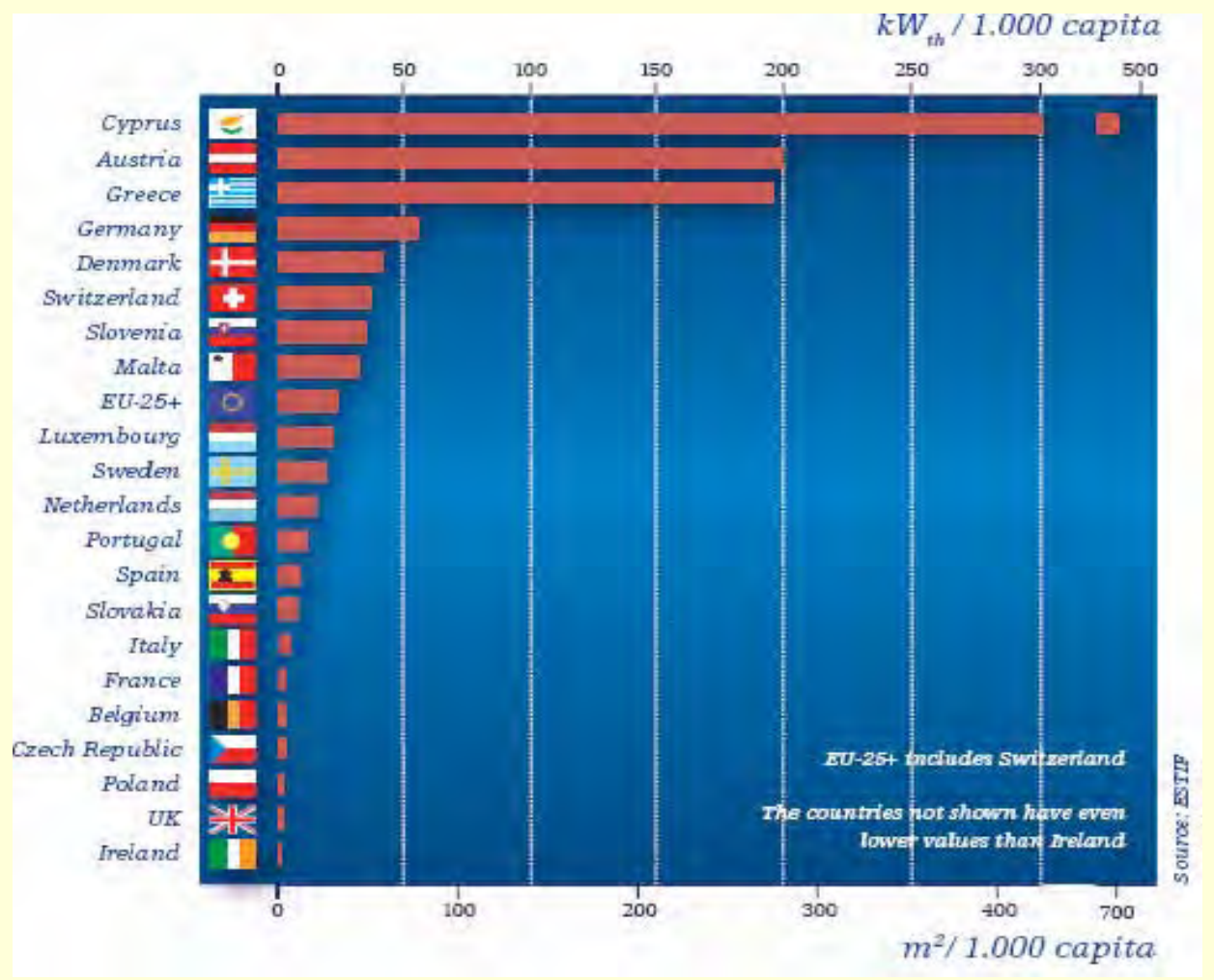




\section{Trends \& Policies}

Key national markets

$k W_{\text {th }} / 1.000$ capita

(Newly installed capacity per capita)

$\mathrm{m}^{2} / 1.000$ capita

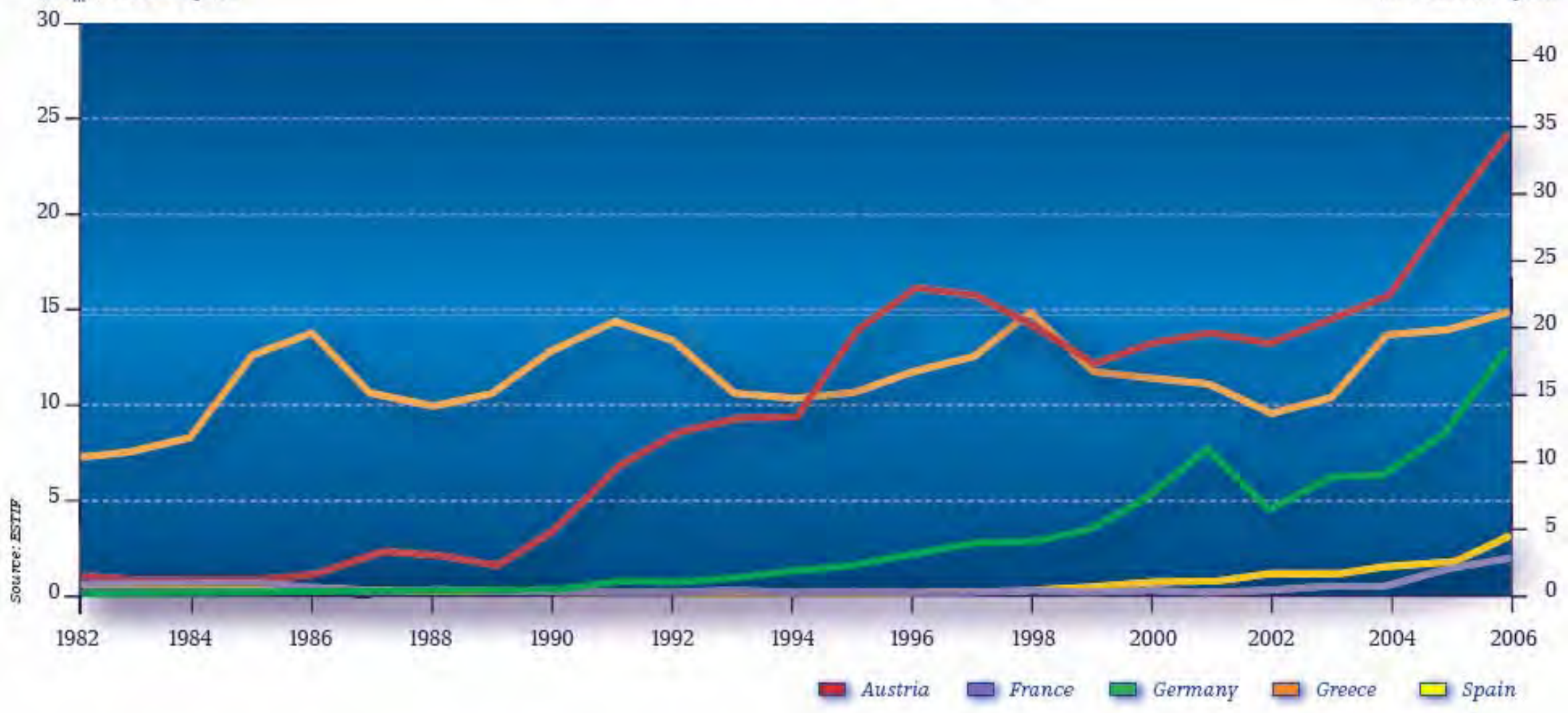

PV Aspects and Prospects 